\title{
La PEA Agropecuaria y su vinculación territorial
}

Cambios estructurales de la fuerza del trabajo en el actual contexto del capitalismo agrario avanzado. La Región Pampeana que rodea a la ciudad de Río Cuarto 
Universidad Nacional de La Plata

Facultad de Humanidades y Ciencias de la Educación

Tesis Doctoral en Geografía

La PEA Agropecuaria y su vinculación territorial.

Cambios estructurales de la fuerza del trabajo en el actual contexto del capitalismo agrario avanzado. La Región Pampeana que rodea a la ciudad de Río Cuarto

Autor: Ricardo Oscar Agüero

Directora: Dra. Ana Jofre Cabello

La Plata, República Argentina

Octubre de 2012 


\section{AGRADECIMIENTOS}

El haber logrado concluir, después de un largo tiempo, la presente tesis, se debe sin la menor duda al imprescindible, valioso y desinteresado apoyo brindado por amigos e instituciones universitarias como las que actualmente me acogen. En este sentido, va mi más profundo reconocimiento y gratitud:

- A mi directora de tesis, Dra. Ana Jofre, quien generosamente supo motivarme para que iniciase este emprendimiento y dirigirme luego con sabios criterios académicos y rigor crítico.

- A Rosana Rodeghiero, alma mater en la cotidiana e interminable tarea de desempeñar al mismo tiempo múltiples funciones, como transcriptora, correctora, compiladora y diagramadora de mi trabajo.

- A Marina Bustamante, antigua alumna y becaria, y actual discípula, por sus valiosos aportes de ideas, de evaluadora de contenidos y de correctora de redacción del presente escrito.

- A mis colaboradores alumnos y colegas de mi antiguo equipo de investigación sobre problemáticas rurales, Maira Puigomenech y Jorge Ramón González, quienes me acompañaron en diversos trabajos que sirvieron de precedentes a una serie de temas aquí nuevamente tratados, pero más desarrollados y articulados adecuadamente.

- A los colegas jóvenes de mi nuevo equipo de investigación y colaboradores especiales, Diego Zalazar, María de los Ángeles Galfioni, Rita Maldonado, Andrea Rivarola y Marcela Montero, quienes a través de meritorios aportes propios y sólida ayuda, contribuyeron en la elaboración de una serie de trabajos que precedieron a muchos de los contenidos tratados en la presente tesis.

- A mi querida familia, quienes con suma paciencia y a través de un silencioso apoyo, supieron tolerar mis prolongadas ausencias de cuerpo presente y no presente, a lo largo de los varios años que demandó mi tarea.

- A la Universidad Nacional de Río Cuarto, institución que me ofreció un inestimable apoyo logístico y económico que me permitió recorrer en profundidad el área de trabajo en que se basa mi tesis, como así también por el inapreciable apoyo que me brindó en recursos humanos y asesoramiento académico. 
- A la Universidad Nacional de La Plata, como institución de acogida de la presente tesis que, con su valioso asesoramiento y prestigio académico, me dio lugar a ingresar a la meritoria carrera de Doctorado en Geografía de la Facultad de Humanidades y Ciencias de la Educación.

- A los numerosos y anónimos agentes rurales entrevistados e instituciones de la región de estudio, como municipios, cooperativas agropecuarias, asociaciones gremiales rurales, agencias del INTA, entre otras, por la generosa y desinteresada información y conocimientos aportados a mi trabajo. 


\section{RESUMEN}

El propósito de este emprendimiento se centra en el análisis socio-territorial de la Población Económicamente Activa Agropecuaria (PEA Agropecuaria) que se desempeña en la región sur de la provincia de Córdoba, en el contexto de las transformaciones estructurales que se manifiestan en esta etapa del capitalismo agrario avanzado. Se parte de la idea de integrar todos los elementos de estudio en la realidad en que se insertan, procurando buscar la unidad de los fenómenos interactuantes. A tal fin, para desentrañar -en nuestro caso- el complejo mundo del trabajo rural, resulta clave enlazarlo a través de las variables témporoespaciales con la realidad económica del país y del mundo, a fin de construir un soporte explicativo sobre el desempeño y fluctuaciones de esta fuerza en el ámbito rural.

En concreto, esta investigación, luego de abocarse al desarrollo del marco teórico que la sustenta, despliega una mirada geo-histórica sobre la ocupación y el poblamiento del sur cordobés, seguido de un análisis demográfico de dicho espacio. A continuación, trata la dimensión cuantitativa y locacional de la PEA Agropecuaria, como así también la estructura agraria social y productiva, respectivamente. A su vez, dentro de los actores sociales que componen esta fuerza, se analiza en particular el perfil socio-económico de los productores, de los asalariados rurales, de los contratistas de servicio rurales y de las agroindustrias y acopiadoras en el papel de productores primarios, desde la perspectiva geográfica. Luego, se contempla el rol de la mujer trabajadora en el ámbito rural, las clases sociales que se manifiestan en el sector agropecuario y la incidencia de los factores culturales en el paisaje agrario. Por último, se desgranan algunas propuestas específicas a considerar y se deja planteado, a modo de reflexión final, si es válido retomar tradicionales caminos que proponían un reparto más igualitario de la riqueza agropecuaria.

En síntesis, esta investigación procura enriquecer, articular y amalgamar en un todo coherente los contenidos temáticos arriba nombrados, a fin de captar en su integralidad las problemáticas socio-territoriales de la fuerza laboral, dado que es esta "acción de nexo" el punto de interés central de la presente tesis.

Palabras clave: PEA Agropecuaria - Vinculación socio-territorial - Contexto capitalismo agrario avanzado - Región sur provincia de Córdoba 


\section{Abstract}

The purpose of this project is focused on the socio-spatial analysis of the Agricultural Economically Active Population (Agricultural PEA) who works in the southern region of the province of Cordoba, in the context of the structural changes that occur in this stage of advanced agrarian capitalism. The initial idea is to integrate all elements studied in the reality in which they are inserted, trying to seek unity of the interacting phenomena. For this purpose, to disembowel -in our case- the complex world of rural labor, is crucial to link it through temporal-spatial variables with the economic reality of the country and the world, in order to build a explaining support about performance and fluctuations of this force in rural areas.

Specifically, this research, after started tackling the development of the theoretical framework that supports it, displays a geo-historical view about occupation and settlement of the South of Cordoba, followed by a demographic analysis of the space. Then follows the quantitative and locational dimension of Agricultural PEA, as well as the social and productive agrarian structure. At the same time, within the social actors that compose this force, the socio-economic profile of farmers, rural workers, rural service contractors and agroindustries and collectors in the role of primary producers, is analyzed in particular from the geographical perspective. Later, it is contemplated the role of working women in rural areas, social classes that are manifested in the agricultural sector and the impact of cultural factors in the agricultural landscape. Finally, specific proposals to be consider are threshed and as a final thought, is raised if it is valid return to traditional paths that proposed a more equalitarian distribution of agricultural wealth.

In short, this research seeks to enrich, articulate and amalgamate into a coherent whole the thematic contents above named, to capture in its entirety the socio-territorial issues of the labor force, since this "action nexus" is the core interest of this thesis.

Keywords: Agricultural PEA - Socio-territorial linking - Advanced agrarian capitalism context - Province of Cordoba Southern region 


\section{ÍNDICES}

\section{Índice General}

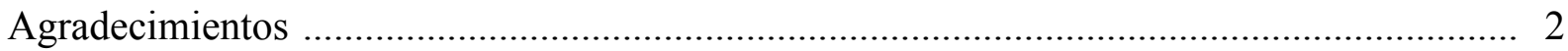

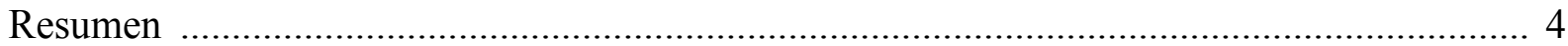

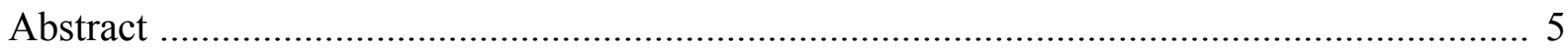

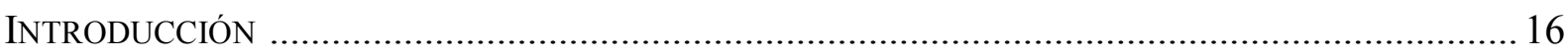

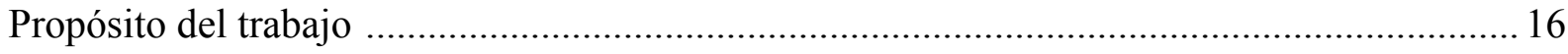

Delimitación del área de estudio y período de análisis ......................................................... 17

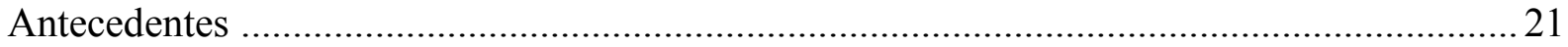

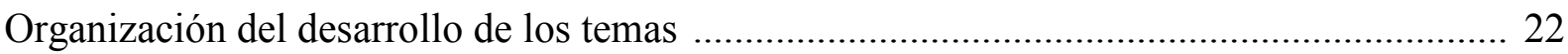

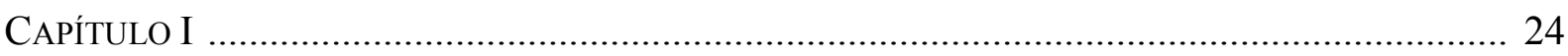

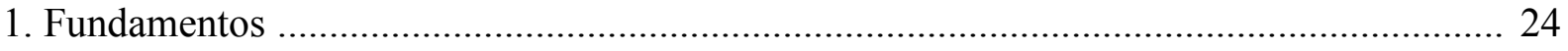

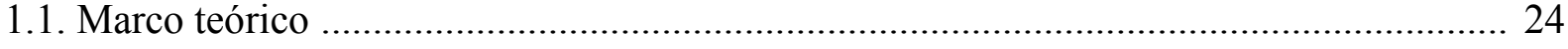

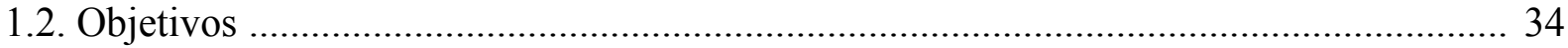

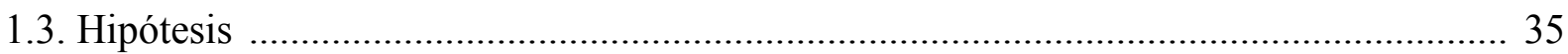

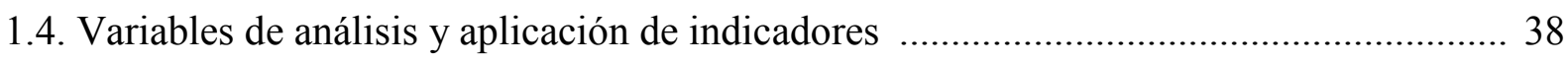

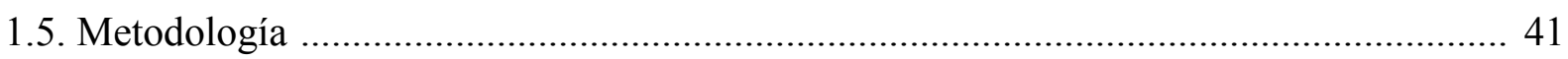

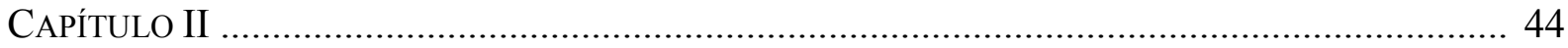

2. Una mirada geográfica sobre la ocupación y el poblamiento del sur de la provincia de

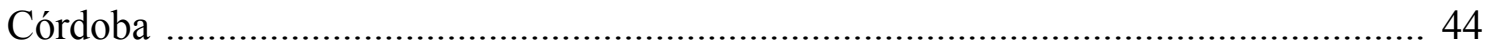

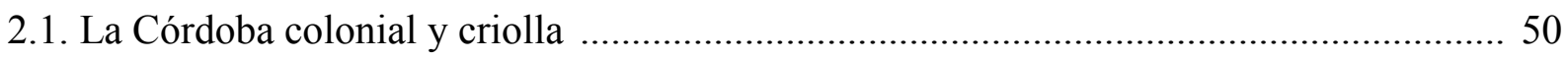

2.2. Acontecimientos significativos al inicio de la colonización agraria ............................... 54

2.3. Consolidación de la inmigración y colonización agraria en la llanura cordobesa ........... 58 
2.4. Evolución de la población por origen y nacionalidad, a nivel provincial, regional y de las colonias agrarias

2.5. El diseño ferroviario y su incidencia en la ocupación territorial ................................... 77

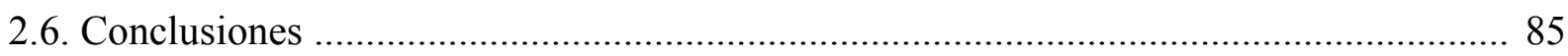

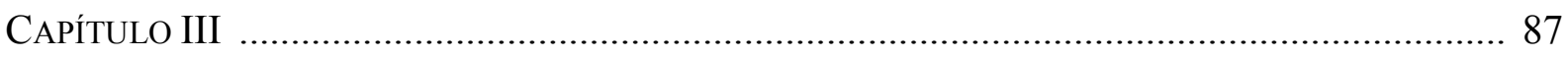

3. Evolución demográfica del Sur Cordobés …............................................................... 87

3.1. Caracterización demográfica y comparativa de la población rural y de la población urbana

3.1.1. Análisis a nivel de población total por sexo según condición urbana o rural de Argentina y provincia de Córdoba

3.1.2. Análisis de población total por sexo según condición urbana o rural del Sur Cordobés

3.1.3. Disminución íntercensal de "población rural agrupada" de los cuatro departamentos del Sur Cordobés

3.1.4. Población urbana y rural y de vivienda por zona rural de las diez localidades testigos con sus respectivas zonas rurales de influencia

3.2. El despoblamiento del campo y sus consecuencias

CAPÍtUlo IV 105

4. Dimensión cuantitativa y locacional de la PEA Agropecuaria 105

4.1. Conceptualización y caracterización de la PEA Agropecuaria 105

4.2. Evolución cuantitativa de la PEA Agropecuaria y de las categorías estadísticas asociadas a nivel país, de la provincia de Córdoba y de los cuatro departamentos que forman el sur cordobés

4.3. Magnitud y localización de la PEA Agropecuaria de las diez localidades testigos con sus respectivas zonas rurales de influencia del sur cordobés

4.3.1. Análisis cuantitativo y locacional de la PEA Agropecuaria

4.3.2. Análisis locacional de la PEA agropecuaria a través de encuestas y entrevistas sistematizadas

4.4. La incidencia de la PEA Agropecuaria y No Agropecuaria en la Población Rural Concentrada 
4.5. Cambios y problemáticas de la localización de la PEA Agropecuaria y sus implicancias territoriales

CAPÍtulo V 146

5. Análisis de la estructura agraria social y productiva del Sur Cordobés 146

5.1. Evolución de la estructura agraria fundiaria. Período 1969-2002 146

5.1.1. Caracterización de los establecimientos de acuerdo con la escala por tamaño de las explotaciones y su relación con el nivel económico de los productores

5.1.2. Variación intercensal en porcentaje en la cantidad, superficie y tamaño promedio de las explotaciones

5.1.3. Cantidad y superficie de las explotaciones agropecuarias por escala de extensión ... 152

5.1.4. Cantidad y superficie de las explotaciones agropecuarias, por tipo jurídico del productor

5.1.5. Distribución de la superficie de las explotaciones agropecuarias, por régimen de tenencia de la tierra, según departamento

5.1.6. Cantidad y superficie de las explotaciones agropecuarias, por régimen de tenencia de la tierra, según departamento

5.1.7. Síntesis de la problemática fundiaria 168

5.2. Cambios productivos en el quehacer agropecuario (1988-2009/10) 168

5.2.1. Análisis comparativo de los Censos Nacionales Agropecuarios de 1988 y 2002, sobre el tipo de uso de la tierra de las EAPs y de las superficies implantadas con cereales y oleaginosas, según departamentos involucrados

5.2.2. Análisis de los resultados de las campañas agrícolas de los principales cereales y oleaginosas (1988/1989-2009/2010), según registros del Ministerio de Agricultura, Ganadería y Alimentos de la provincia de Córdoba 181

5.2.3. Análisis de la evolución de la ganadería bovina en nuestra región de estudio 191

5.2.4. Consecuencias de los cambios productivos 196

CAPÍtUlo VI

6. Composición y articulación socio-económica, desde la perspectiva geográfica, de los principales actores sociales que componen la PEA Agropecuaria

6.1. Caracterización del perfil socio-económico de los productores agropecuarios 203 
6.1.1. Encuesta llevada a cabo a los productores en los centros urbanos. Año 1994 204

6.1.2. Encuesta llevada a cabo a los productores en las zonas rurales. Año 2002 ............... 210

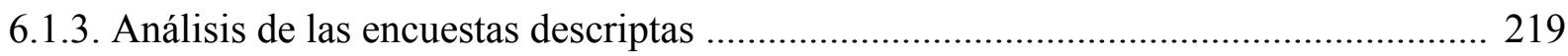

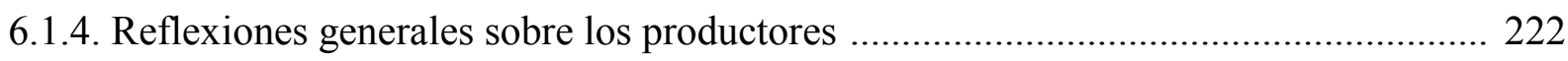

6.2. Caracterización del perfil socio-económico de los trabajadores rurales dependientes . 224

6.2.1. Resultado de las entrevistas a los trabajadores rurales en general ........................... 225

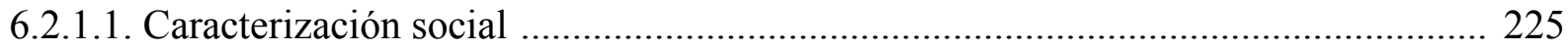

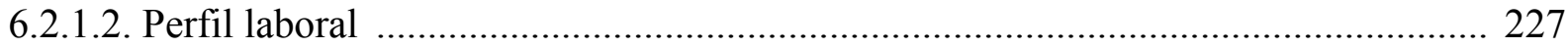

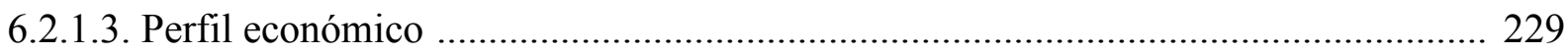

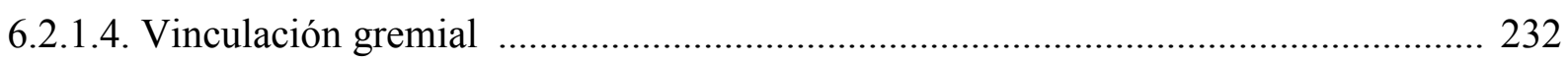

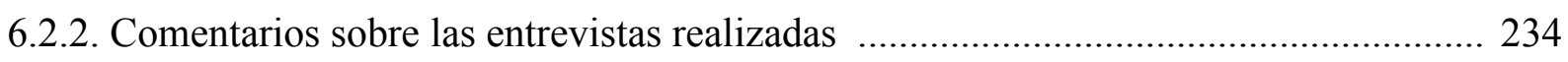

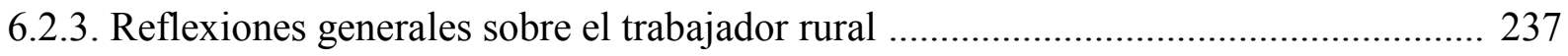

6.3. Caracterización del perfil socio-económico de los contratistas rurales ......................... 241

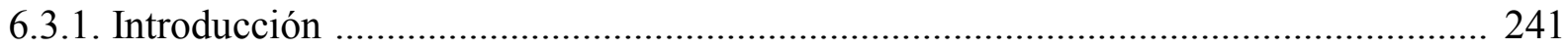

6.3.2. Análisis del desempeño de los contratistas de servicios .......................................... 247

6.3.2.1. La organización social del trabajo al interior de la empresa ................................. 247

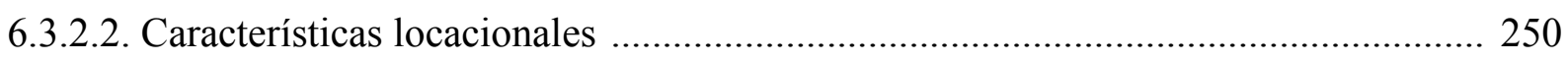

6.3.2.3. La dotación de recursos en equipamiento y manejo tecnológico .......................... 252

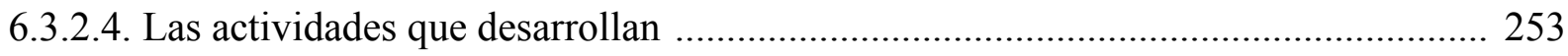

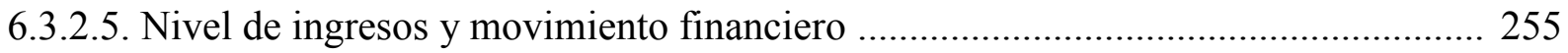

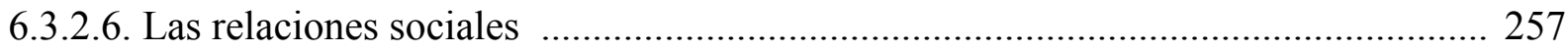

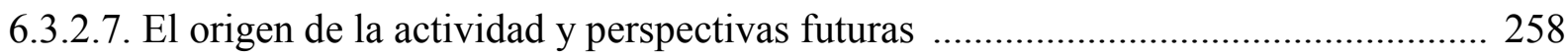

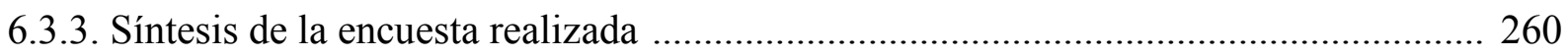

6.3.4. Opinión de los productores agropecuarios con respecto a la calidad de los servicios que les brindan los contratistas de servicios ........................................... 261

6.3.5. Análisis del desempeño de los contratistas de producción ....................................... 263

6.3.6. El gremio que nuclea a los contratistas rurales ....................................................... 266

6.3.7. Reflexiones generales sobre los contratistas rurales ............................................... 268

6.4. Caracterización económica de las agroindustrias y empresas agrocomerciales en relación con su injerencia en la explotación primaria agrícola ................................ 271

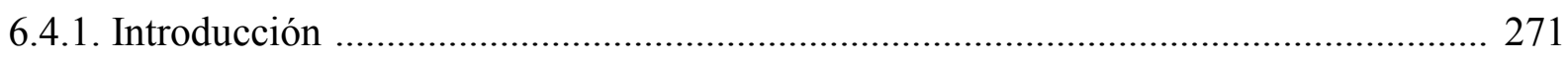

6.4.2. Formas de integración vertical hacia la actividad primaria de las agroindustrias y empresas agrocomerciales que se desempeñan en nuestro medio ............................ 273

6.4.2.1. Integración vertical directa (o propiamente dicha) ............................................ 273 
6.4.2.2. Integración vertical indirecta (o de acuerdo de partes)

6.4.2.3. Integración vertical asociativa

6.4.3. Características generales y desempeño en el proceso de integración vertical hacia atrás de algunas de las agroindustrias y agrocomercios más representativos de nuestro medio dedicados a la industrialización y comercialización de granos 276

6.4.3.1. Empresas agroindustriales de oleaginosas y cereales 277

6.4.3.2. Empresas agrocomerciales de acopio y comercialización de granos 279

6.4.4. Conclusiones sobre el desempeño de las empresas descriptas 281

6.5. Breves observaciones sobre los agentes rurales analizados en este capítulo 284

CAPÍtUlo VII 290

7. Aspectos laborales y socio-culturales específicos de los agentes rurales bajo estudio 290

7.1. El rol de la mujer en el ámbito rural 290

7.1.1. El papel de la mujer en las explotaciones agropecuarias y su evolución a través del tiempo 292

7.1.2. Estado de situación de la mujer 295

7.1.3. La influencia de la mujer en los cambios de localización y en el confort hogareño .. 298

7.1.4. El trabajo productivo de la mujer en las explotaciones ............................................ 300

7.1.5. El accionar político-gremial en defensa de las explotaciones familiares .................. 303

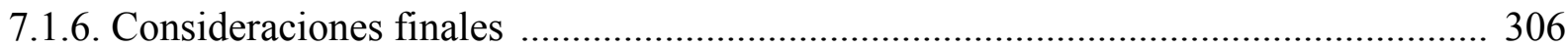

7.2. Las clases sociales del sector agropecuario, en relación con su inserción sociolaboral 307

7.2.1. Esquema cualitativo de la estratificación social de la PEA Agropecuaria del sur cordobés 310

7.2.2. Estratificación social de los productores rurales del sur cordobés 313

7.3. La dimensión cultural en el paisaje agrario 318

7.3.1. Breve descripción, a modo de marco referencial, de nuestro paisaje agrario 321

7.3.2. Las diferentes lógicas que se manifiestan en la configuración de nuestro paisaje agrario 
8.2. Problemáticas pendientes de profundizar provenientes del tratamiento de las hipótesis

8.3. Propuestas específicas a considerar

8.4. Reflexiones finales y sugerencia de fondo

Bibliografía

Bibliografía general 346

Fuentes documentales

Anexos

Anexo 1. Cuestionarios

1. Cuestionario de la encuesta a los productores agropecuarios que residen en los centros urbanos

2. Cuestionario de la entrevista a los asalariados rurales que residen en los centros urbanos

3. Cuestionario de entrevista a los agentes ligados que residen en los centros urbanos

4. Cuestionario de la encuesta a los productores agropecuarios que residen específicamente en las zonas rurales

5. Cuestionario de entrevista a los asalariados rurales (general)

6. Cuestionario de la encuesta a los contratistas de servicios

7. Cuestionario de entrevista a productores agropecuarios que hacen uso del servicio de contratistas

8. Cuestionario de entrevista a los directivos del gremio de contratistas denominado Federación Argentina de Contratistas de Máquinas Agrícolas (FACMA)

9. Cuestionario de entrevista a las Agroindustrias y Acopiadoras en la explotación primaria agrícola

Anexo 2. Cuadros

Cuadro $\mathrm{N}^{\mathrm{o}} 1$. Cantidad y superficie de las EAPs Agropecuarias por escala de extensión, en cifras y en porcentajes de los departamentos que constituyen la región sur de la provincia de Córdoba. Censos Nacionales Agropecuarios de 1969, 1988 y 2002 (versión completa)

Cuadro No 2. Resultados de las campañas agrícolas 1988/89-2009/10 de cereales y oleaginosas a nivel de provincia de Córdoba y del Sur Cordobés

Anexo 3. Dos ejemplos de cartografía digital empleada para la delimitación de las localidades con sus respectivas zonas rurales de influencia .............................................. 405

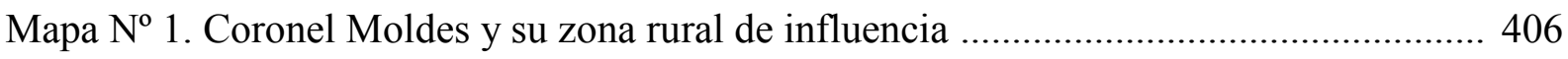

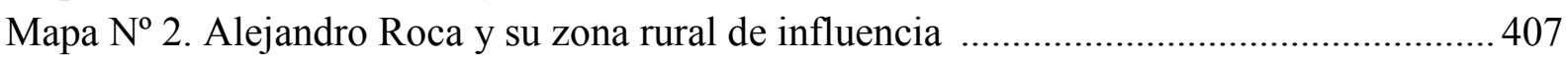




\section{Índice de mapas}

Mapa $\mathrm{N}^{\circ} 1$. Ubicación del área de estudio. Región sur de la provincia de Córdoba 19

Mapa $\mathrm{N}^{\mathrm{o}} 2$. Área rural de influencia de las diez localidades en estudio (provincia de

Córdoba, Argentina) 20

Mapa $\mathrm{N}^{\mathrm{0}}$ 3. Sur ampliado o Sur histórico ........................................................................... 45

Mapa No 4. Antiguo Departamento Río Cuarto. Año 1815 ................................................... 46

Mapa $\mathrm{N}^{\mathrm{0}}$ 5. Antiguo Departamento Tercero Abajo. Año 1815 …......................................... 47

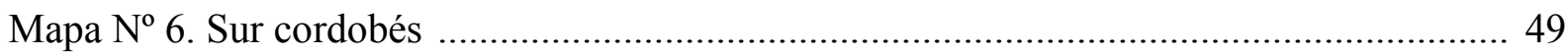

Mapa $\mathrm{N}^{\mathrm{o}}$ 7. Ocupación de la población colonial y criolla .................................................... 52

Mapa $\mathrm{N}^{\circ}$ 8. Estructura ferroviaria inicial de la provincia de Córdoba ................................. 79

Mapa $N^{0}$ 9. Diagrama ferroviario con realce de la región centro-sur provincial .................... 81

Mapa $\mathrm{N}^{\mathrm{o}}$ 10. Pequeños poblados de menos de 2.000 habitantes ....................................... 138

Mapa No 11. "Sur Cordobés" dentro de la Región Pampeana ............................................. 147

Mapa $\mathrm{N}^{\mathrm{o}}$ 12. Localización detallada del área de estudio ..................................................... 172

Mapa $\mathrm{N}^{\mathrm{o}}$ 13. Zonas rurales de influencia de las localidades de Berrotarán y Alcira

(Gigena)

\section{Índice de gráficos}

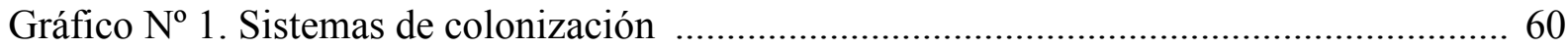

Gráfico $\mathrm{N}^{\mathrm{o}}$ 2. Población Económicamente Activa ….................................................... 105

Gráfico No 3. Conjunción Población Económicamente Activa .......................................... 106

Gráfico $N^{0}$ 4. Población rural ....................................................................................... 140

Gráfico $\mathrm{N}^{\mathrm{o}} 5$. Superficie sembrada de los totales de cereales y oleaginosas que predomina en cada año agrícola de la serie 1988/89-2009/10. Provincia de Córdoba

Gráfico $\mathrm{N}^{\mathrm{o}} 6$. Producción obtenida de los totales de cereales y oleaginosas que predomina en cada año agrícola de la serie 1988/89-2009/10. Provincia de Córdoba

Gráfico $\mathrm{N}^{\mathrm{o}} 7$. Superficie sembrada de los totales de cereales y oleaginosas que predomina en cada año agrícola de la serie 1988/89-2009/10. Región Sur de la provincia de Córdoba

Gráfico $\mathrm{N}^{\mathrm{0}}$ 8. Curva de tendencia de la superficie de maíz, soja y trigo en el período 1988-2009 en la Región Sur de la provincia de Córdoba

Gráfico $\mathrm{N}^{\mathrm{o}}$ 9. Producción obtenida de los totales de cereales y oleaginosas que predomina en cada año agrícola de la serie 1988/89-2009/10. Región Sur de la provincia de Córdoba

Gráfico $\mathrm{N}^{\mathrm{o}} 10$. Curva de tendencia de la producción de maíz, soja y trigo en el período 1988-2009 en la Región Sur de la provincia de Córdoba

Gráfico $\mathrm{N}^{\mathrm{o}} 11$. Clasificación de las diferentes formas y características de integración vertical "hacia atrás" (es decir, sobre la producción agropecuaria propiamente dicha), que emplean las agroindustrias y empresas agrocomerciales 


\section{Índice de cuadros}

Cuadro $\mathrm{N}^{\mathrm{o}}$ 1. Evolución numérica y demográfica de las colonias agrarias de la llanura cordobesa y de la Región Sur de la provincia

Cuadro N ${ }^{0} 2$. Distribución de colonias y campos colonizados en 1903 correspondientes a los actuales departamentos del sur de Córdoba

Cuadro No 3. Población de la provincia de Córdoba y de la Región Sur. 1795-2001 70

Cuadro No 4. Población total y extranjera por departamento de la Región Sur de la provincia de Córdoba. 1895-2001

Cuadro $\mathrm{N}^{\mathrm{o}} 5$. Población extranjera por nacionalidad de origen en la provincia de Córdoba. Censo Nacional 1895

Cuadro $\mathrm{N}^{\mathrm{o}}$ 6. Participación italiana en la población extranjera, por departamento, de la región sur de la provincia de Córdoba. Censo Nacional 1914

Cuadro $N^{0} 7$. Población por origen y nacionalidad de las colonias de la provincia de Córdoba. Año 1898

Cuadro $N^{o}$ 8. Población extranjera por nacionalidad de las Colonias del Sur de la provincia de Córdoba. 1898

Cuadro $N^{\circ}$ 9. Población por origen y nacionalidad de las colonias de la provincia de Córdoba. Año 1902

Cuadro $\mathrm{N}^{\mathrm{0}}$ 10. Población por origen de las colonias de los departamentos de la Región

Sur de la provincia de Córdoba. Año agrícola 1902-1903

Cuadro $\mathrm{N}^{\mathrm{o}} 11$. Población total en valores absolutos y porcentuales por sexo según condición urbana o rural a nivel país

Cuadro $\mathrm{N}^{\mathrm{o}} 12$. Población total en valores absolutos y porcentuales por sexo según condición urbana o rural a nivel de provincia de Córdoba

Cuadro $\mathrm{N}^{\mathrm{o}}$ 13. Provincia de Córdoba. Los cuatro departamentos que comprende el Sur Cordobés

Cuadro No 14. Disminución intercensal de Población Rural Agrupada de los cuatro departamentos del Sur Cordobés.

Cuadro $N^{0} 15$. Población Urbana, Rural y de Vivienda en zona rural de cada localidad testigo del Sur Cordobés

Cuadro No 16. Variación de la PEA Agropecuaria entre 1991 y 2001, a nivel país, provincia de Córdoba y de los cuatro departamentos de sur cordobés

Cuadro $\mathrm{N}^{\mathrm{0}}$ 17. Variación de la población en condición de ocupación en el sector agrícola según categoría ocupacional, entre 1991 y 2001, a nivel país, provincia de Córdoba y de los cuatro departamentos de sur cordobés

Cuadro $\mathrm{N}^{\circ}$ 18. Comparación del volumen de la PEA Rural y Urbana respecto de la PEA Agropecuaria y No Agropecuaria. 1991-2001

Cuadro No 19. Tamaño de la PEA Total a nivel de los "totales jurisdiccionales", "urbanos y rurales de las respectivas jurisdicciones", con sus correspondientes desagregaciones en PEA Agropecuaria y PEA No Agropecuaria. 1991 y 2001

Cuadro $N^{\circ}$ 20. Tamaño de la PEA Total a nivel de los "totales jurisdiccionales" de la "PEA Agropecuaria y No Agropecuaria de las respectivas jurisdicciones", con sus 
correspondientes desagregaciones en Total de la PEA Urbana y Total de la PEA Rural. 1991 y 2001

Cuadro $\mathrm{N}^{\mathrm{o}} 21$. Variación de la cantidad de personas que trabajan en las EAPs en forma permanente, entre 1988 y 2002, a nivel país y de provincia de Córdoba

Cuadro $N^{0} 22$. Totales y variación porcentual entre 1994 y 2000 de productores y explotaciones, más explotaciones compartidas y tamaño de las explotaciones correspondientes a datos del año 2000

Cuadro $\mathrm{N}^{\mathrm{o}} 23$. Totales y localización de los productores y PEA agropecuaria de los mismos

Cuadro $\mathrm{N}^{\mathrm{o}} 24$. Totales de la composición y localización de la PEA Agropecuaria de Productores. Datos de 1994 y 2000

Cuadro $\mathrm{N}^{\mathrm{o}} 25$. Totales y localización de la PEA agropecuaria

Cuadro No 26 . Totales y variación porcentual entre 1994 y 2000 de la PEA Agropecuaria

Cuadro No 27. Totales y localización del Núcleo Familiar de la PEA agropecuaria Datos de 2000

Cuadro $\mathrm{N}^{\circ} 28$. Totales del Núcleo Familiar y su relación con la fuerza laboral y familia dependiente de los productores y asalariados fijos - datos de 2000

Cuadro $N^{o} 29$. Incidencia del Núcleo Familiar de la PEA Agropecuaria que reside en los Centros Urbanos -en 1994 y 2000-

Cuadro $N^{\circ} 30$. Cuadro síntesis del total general y localización de la PEA Agropecuaria -datos de 1994 y 2000- y del Núcleo Familiar de la PEA Agropecuaria -datos 2000

Cuadro $\mathrm{N}^{\mathrm{o}} 31$. Poblaciones rurales de menos de 2.000 habitantes

Cuadro $\mathrm{N}^{\mathrm{o}} 32$. Variación intercensal en porcentaje en la cantidad, superficie y tamaño promedio de las explotaciones de los departamentos que constituyen la región sur de la provincia de Córdoba. Censos Nacionales Agropecuarios 1969, 1988 y 2002 . 151

Cuadro $\mathrm{N}^{\circ} 33$. Cantidad y superficie de las explotaciones agropecuarias por escala de extensión, en cifras y en porcentajes, de los departamentos que constituyen la región sur de la provincia de Córdoba. Censos Nacionales Agropecuarios de 1969, 1988 y 2002 (Versión Reducida)

Cuadro $\mathrm{N}^{\mathrm{o}} 34$. Cantidad y superficie de las explotaciones agropecuarias por escala de extensión, en cifras y en porcentajes, de los departamentos que constituyen la región sur de la provincia de Córdoba, Censos Nacionales Agropecuarios de 1969, 1988 y 2002

Cuadro $\mathrm{N}^{\mathrm{o}} 35$. Cantidad y superficie de las EAPs, por tipo jurídico del productor de los departamentos que constituyen la región sur de la provincia de Córdoba. CNAs 1988 y 2002

Cuadro $\mathrm{N}^{\mathrm{o}}$ 36. Córdoba. Distribución de la superficie de las EAPs, por régimen de tenencia de la tierra, de los departamentos que constituyen la región sur de la provincia de Córdoba. CNAs 1988 y 2002

Cuadro $N^{\circ} 37$. Cantidad y superficie de las EAPs, por régimen de tenencia de la tierra, según departamento. Censos Nacionales Agropecuarios de 1988 y 2002 
Cuadro $N^{o}$ 38. Superficie total de las EAPs, por tipo de uso de la tierra, según departamentos involucrados

Cuadro $N^{0}$ 39. Superficie implantada de las EAPs, por grupos de cultivo, según departamentos involucrados y período de ocupación, en ha

Cuadro $\mathrm{N}^{\circ}$ 40. Superficie implantada con cereales para grano, por cultivo, según departamentos involucrados y período de ocupación, en ha

Cuadro $N^{o} 41$. Superficie implantada con oleaginosas, por cultivo, según departamentos involucrados y período de ocupación, en ha

Cuadro $N^{o} 42-a$. Evolución de las superficies sembradas de granos en el período 2002/03-2009/10 en la Región Sur de la provincia de Córdoba

Cuadro $\mathrm{N}^{\mathrm{o}} 42-\mathrm{b}$. Evolución de las producciones obtenidas de granos en el período 2002/03-2009/10 en la Región Sur de la provincia de Córdoba

Cuadro $N^{0} 43$. Incidencia exclusiva de la soja. Superficie sembrada y producción, en relación con el total de los otros cultivos granarios, a nivel provincial y del Sur Cordobés. Serie 1988/89-2009/10

Cuadro $\mathrm{N}^{\mathrm{o}} 44$. Cantidad de EAPs con ganado bovino y número de cabezas, por escala de tamaño del rodeo, según departamentos involucrados

Cuadro $\mathrm{N}^{\circ}$ 45. Total de cabezas de ganado bovino, según departamentos involucrados ..... 194

Cuadro $\mathrm{N}^{\mathrm{o}}$ 46. Total de EAPs con ganado bovino, en relación al total de EAPs existentes, según departamentos involucrados

Cuadro $N^{\circ}$ 47. Distribución de la fuerza laboral y familia dependiente. 1994 208

Cuadro $\mathrm{N}^{\mathrm{0}}$ 48. Distribución de la fuerza laboral y familia dependiente. 2002 217

Cuadro $\mathrm{N}^{\circ} 49$. Tipología general de los contratistas rurales 242

Cuadro $\mathrm{N}^{\mathrm{o}}$ 50. Tiempos de trabajos de los cultivos de invierno y de verano 248

Cuadro $\mathrm{N}^{\mathrm{o}} 51$. Forma de pago por cultivo realizado 255

Cuadro $\mathrm{N}^{\mathrm{o}}$ 52. Aporte contratista. Aporte de labores de los contratistas agrícolas a la producción granaría argentina 268

Cuadro $N^{\circ}$ 53. Explotaciones que cuentan con huerta. Año 2002 ...................................... 294

Cuadro No 54. Estructura Familiar del Total del Núcleo Familiar. Año 2002 ..................... 295

Cuadro No 55. Estado Civil de la Mujer. Año 2002 ............................................................. 296

Cuadro $N^{0}$ 56. Máximo nivel de educación alcanzado. Año 2002 ...................................... 298

Cuadro $N^{0}$ 57. Fuerza laboral de las mujeres que viven en el campo. Año 2002 ................ 301

Cuadro $\mathrm{N}^{\circ}$ 58. PEA del sector agropecuario según clases y estratos sociales, observable en el sur cordobés

Cuadro $\mathrm{N}^{\mathrm{0}}$ 59. Estratificación social en base a la cantidad y superficie de las EAPs de los productores rurales del sur cordobés, de acuerdo con los Censos Nacionales Agropecuarios de 1969, 1988 y 2002 


\section{INTRODUCCIÓN}

\section{Propósito del trabajo}

El trabajo que aquí desarrollamos tiene como finalidad el estudio de manera integral de la Población Económicamente Activa (PEA) Agropecuaria, ${ }^{1}$ vinculada al territorio donde se desenvuelve, en el contexto de las transformaciones estructurales por las que atraviesa en esta etapa del capitalismo agrario avanzado. El área específica de trabajo comprende la Región Pampeana que rodea a la ciudad de Río Cuarto y que corresponde a un sector del sur de la provincia de Córdoba.

La presente indagación, que mantiene una continuidad temática con anteriores investigaciones que hemos realizado a través de una serie de proyectos de investigación, aprobados por la SeCyT de la Universidad Nacional de Río Cuarto, y que versan sobre aspectos parciales de la cuestión, pretende ahora, en cambio, profundizar e integrar en forma global las principales problemáticas que interactúan sobre la fuerza laboral, desde una perspectiva geográfica.

Es apropiado destacar que el interés por este tipo de cuestiones surge de observar -concretamente a raíz de los resultados del Censo Nacional de Población y Vivienda de 1991- la preocupación puesta de manifiesto por varias fuentes periodísticas, y por el público en general, sobre el despoblamiento acusado que venían sufriendo las áreas rurales y que se tomó como una de las causas principales, en ese momento, de un posible próximo estancamiento del campo o de una futura falta de aprovechamiento apropiado de las potencialidades del mismo, al quedar la tierra sin brazos para trabajarla.

Pero, como sabemos, este despoblamiento rural no produjo el efecto tan temido de que los campos quedasen sin trabajar, sino todo lo contrario, los mismos siguieron siendo explotados, pero ahora con mayor intensidad. La razón de este fenómeno consistió, como veremos más adelante -particularmente a partir de los últimos cuarenta años-en el cambio de

\footnotetext{
${ }^{1}$ Se entiende por dicha denominación, en primera instancia, a la Población Económicamente Activa que se desempeña en tareas agropecuarias, lo que a su vez implica precisar el concepto de PEA. Al respecto, la Organización Internacional del Trabajo (OIT) considera que "la PEA se define como el conjunto de todas las personas empleadas y desempleadas (con inclusión de aquellas que buscan trabajo por primera vez). Quedan comprendidos en esta definición los empleadores, los trabajadores por cuenta propia, los empleados, los obreros, los trabajadores familiares no remunerados, los miembros de las cooperativas de producción y los miembros de las fuerzas armadas" (OIT. 1986, 1920-2025 Población Económicamente Activa. Estimaciones: 1950-1980. Proyecciones: 1985-2025. Oficina Internacional del Trabajo. Ginebra).
} 
la "localización" de numerosos productores de las áreas rurales pampeanas que se desplazaron de sus establecimientos a los pueblos y ciudades intermedias de sus entornos inmediatos.

Explorar la magnitud, razones y consecuencias de este despoblamiento rural, y especialmente el traslado de la PEA agropecuaria a los centros urbanos, fue la inquietud inicial que nos impulsó a introducirnos en este tipo de análisis. Luego, progresivamente, fuimos avanzando sobre otros tópicos inherentes a la problemática laboral y que nos mostraban la gran complejidad en que está inserto el mundo del trabajo rural. Entre otros análisis, nos percatamos de que, para desentrañar su complejo entramado, resulta clave contextualizarlo a través de las variables témporo-espaciales con la realidad socio-económica evolutiva del país y del mundo, a fin de construir un soporte explicativo sobre el desempeño y fluctuaciones de esta fuerza en el ámbito rural.

En concreto, este trabajo centra su análisis en general en los aspectos locacionales y cuantitativos de la PEA agropecuaria, como así también sobre la estructura agraria social y productiva respectivamente. A su vez, dentro de los actores sociales que componen esta fuerza, analizamos en particular el perfil socio-económico de los productores, de los trabajadores dependientes rurales, de los contratistas de servicios rurales y de las agroindustrias y acopiadoras en el papel de productores primarios. Por último, contemplamos las clases sociales del sector agropecuario, como así también los factores culturales que inciden en la fuerza laboral y los efectos que generan sobre la misma.

En síntesis, esta investigación tiene como antecedente una serie de trabajos previos y procura, en esta instancia, enriquecerlos, articularlos y amalgamarlos en un todo coherente, a fin de captar en su integralidad las problemáticas socio-territoriales de la fuerza laboral, dado que es este nexo el punto de interés central de la presente tesis. Con esta investigación, buscamos, en resumidas cuentas, ayudar a comprender de la manera más apropiada los problemas del ámbito laboral rural de un espacio geográfico acotado de la llanura pampeana, a fin de contribuir a la búsqueda de soluciones a las cuestiones agropecuarias generales, que se manifiestan tanto a escalas regionales como a nivel nacional.

\section{Delimitación del área de estudio y período de análisis}

La delimitación areal de esta investigación se circunscribe principalmente a la Región Pampeana aledaña a la ciudad de Río Cuarto, con un radio de acción de $100 \mathrm{~km}$, aproximadamente, a partir de la misma, correspondiendo a los departamentos Río Cuarto y Juárez Celman, desde el punto de vista político-administrativo y estadístico. En un plano más 
genérico, el estudio también se extiende espacialmente a los departamentos vecinos de Presidente Roque Sáenz Peña y General Roca, totalizando la sumatoria de estos cuatro departamentos (ver Mapa $\mathrm{N}^{\mathrm{o}}$ 1) lo que se conoce como "sur cordobés". Este recorte territorial se ubica en parte en el extremo occidental de la pampa húmeda, con prolongación transicional hacia la pampa seca, cuyas características regionales formativas y específicas explicitamos en detalle en el capítulo siguiente de este trabajo. Dentro del primer espacio mencionado, la investigación se apoya principalmente en "diez centros urbanos testigos", con sus respectivas zonas rurales de influencia, ${ }^{2}$ con el fin de que sirvan de base operativa de los trabajos de campo (ver Mapa $\mathrm{N}^{\mathrm{o}}$ 2). El área elegida del sur cordobés tiene la ventaja, a su vez, de superponerse con el territorio donde se llevaron a cabo los proyectos de investigación anteriormente mencionados. Esta superposición supone que permite una captación más precisa de las problemáticas a analizar.

En lo que respecta al marco temporal que comprende esta investigación, abarca particularmente el período que se extiende entre 1980 y 2002, en razón de que pretende analizar básicamente la problemática de la PEA agropecuaria acaecida aproximadamente en los últimos veinte años del siglo pasado, correspondientes a una etapa de destacados sucesos en el desenvolvimiento agropecuario pampeano, "sin perjuicio de prolongar dicho período de estudio a tiempos más actuales", en la medida en que la información disponible y pertinencia temática lo permita o justifique. Especialmente interesa analizar este período por varias razones: por considerar, particularmente desde el advenimiento de la democracia, muy significativos y ricos los cambios en el aspecto del desempeño del trabajo rural, tecnológico y de las políticas macroeconómicas, con sus consecuentes repercusiones en el sector agropecuario; por ser relativamente actual y poder utilizar los datos del valioso material de los últimos censos nacionales, tanto agropecuarios como de población y vivienda, y poderle dar uso también a la información empírica recogida desde 1992 en las investigaciones realizadas en el área de estudio mencionada.

\footnotetext{
${ }^{2}$ Éstos son: Carril Norte: Alcira Gigena y Berrotarán; Carril Nordeste: General Cabrera y General Deheza; Carril Este: Ucacha y Alejandro Roca; Carril Sudoeste: Sampacho y Coronel Moldes; Carril Sur: Adelia María y Vicuña Mackenna. Corresponden a diez localidades significativas que conforman "Unidades territoriales" -el pueblo más su zona de influencia- que se sitúan en los departamentos Río Cuarto y Juárez Celman, sin abarcarlos en toda su extensión.
} 


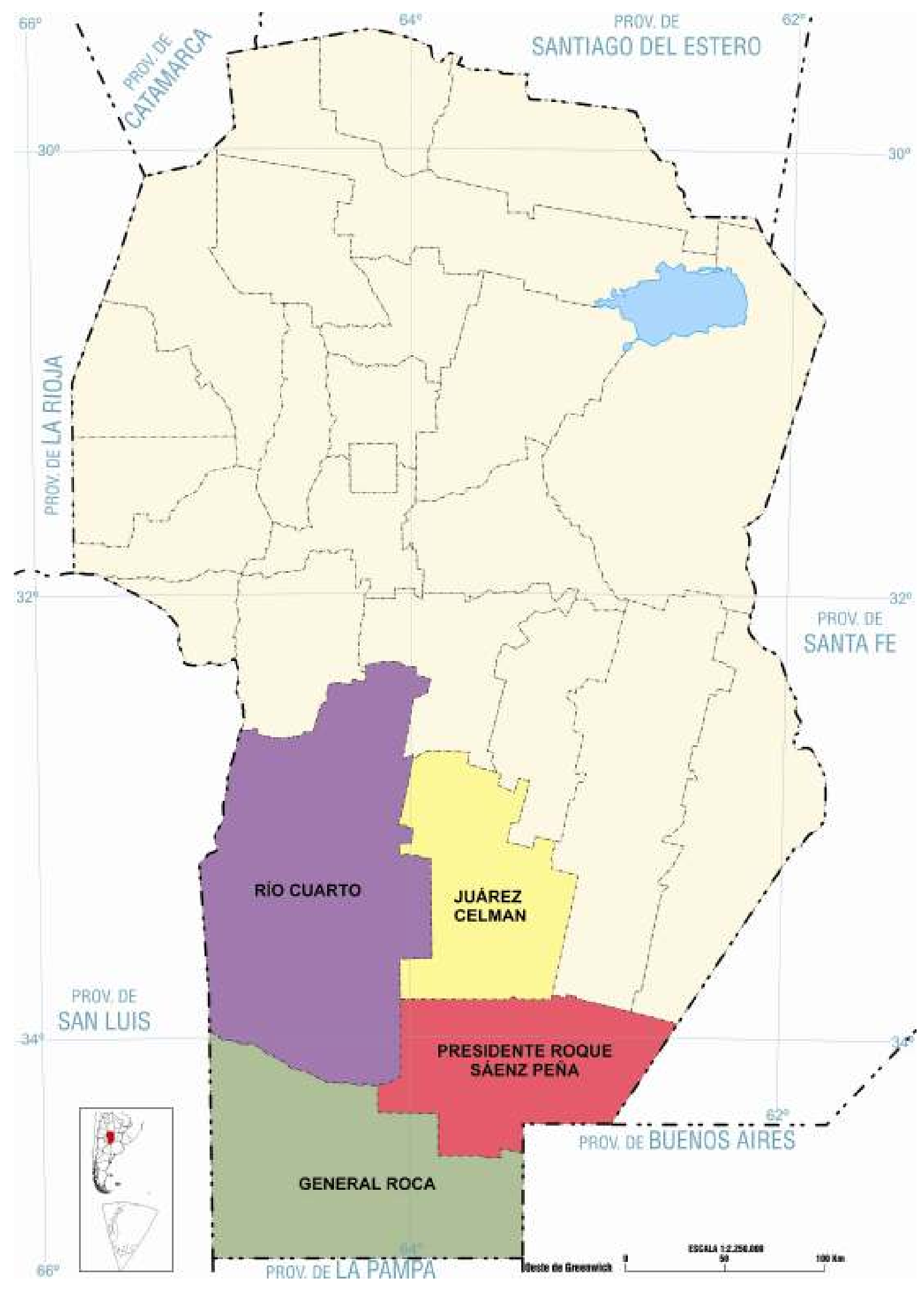

Mapa $\mathrm{N}^{\mathrm{o}}$ 1. Ubicación del área de estudio. Región sur de la provincia de Córdoba. 


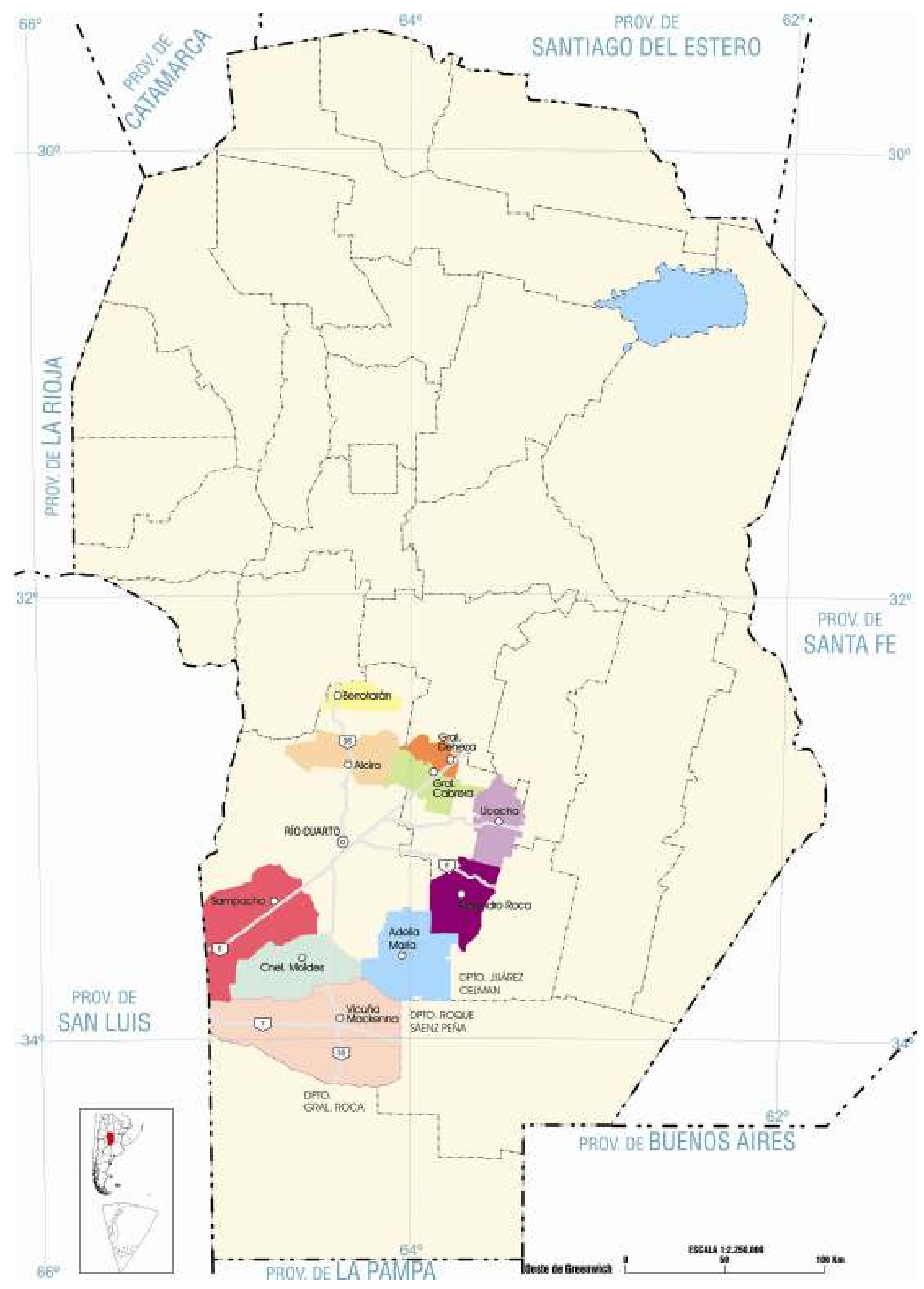

Mapa $\mathrm{N}^{\circ}$ 2: Área rural de influencia de las diez localidades en estudio (provincia de Córdoba, Argentina). 


\section{Antecedentes}

Los trabajos referidos específicamente a la fuerza laboral agropecuaria de nuestro país, en general, no son muy numerosos. Sobre todo, si los comparamos con el tratamiento de otras temáticas agrarias -especialmente de la Región Pampeana- que se pueden considerar como muy proficuos.

A pesar de ello, contamos con un conjunto de especialistas -S. Aparicio, R. Benencia, F. Forni, M. Manzanal, I. Llovet, G. Neiman, M.I. Tort, M. Lattuada, R. Hora, N. Giarraca, M. Teubal, G. Gutman, entre otros-, cuya producción científica sobre los agentes laborales rurales es de gran valor y utilidad. Particularmente, en los últimos años, se vienen desarrollando trabajos a nivel de diferentes regiones geográficas argentinas, bien sistematizados y con una información importante. También es válido mencionar a numerosos autores en cuya producción, sobre amplios y diversos problemas agrarios, figura el estudio de determinados actores sociales rurales. Entre ellos, podemos mencionar a O. Barsky, A. Pucciarelli, W. Ansaldi, E. Azcuy Ameghino, H. Giberti, G. Gori, E. Gallo, E. Basualdo, M. Khavisse, M. Murmis, N. Girbal de Blacha, sin que la lista -desde luego- se agote. Pero, si hacemos un recorrido amplio de la bibliografía sobre esta cuestión, vemos, por un lado, que la temática relacionada con problemáticas del trabajo fundamentalmente hace hincapié en agentes rurales específicos, sin integrar a la totalidad laboral que interactúa en un mismo espacio; y, por otro, se denota la insuficiencia de estudios concretos de casos, o sea, circunscriptos a territorios acotados, acompañados por la correspondiente labor empírica. Esta última carencia, inclusive, es reconocida por aquellos autores generalistas que desarrollan temas laborales agrarios a escala de una región geográfica o de todo el país, dado que para ellos la fuente básica de información se nutre de datos censales y estadísticos en general, faltándoles posiblemente la suficiente información específica que proviene del contacto directo con los actores sociales implicados, que sí se puede obtener en trabajos a nivel territorial más reducido.

En lo referente a nuestra área de estudio, se cuenta con muy poco material al respecto. Aparte de las indagaciones sobre la PEA agropecuaria que hemos venido realizando con el equipo integrante de los proyectos de investigación ya mencionados, subsidiados por la SeCyT de la Universidad Nacional de Río Cuarto, se pueden destacar interesantes publicaciones que atañen al sur cordobés -pero no referidas exclusivamente al tema laboral agropecuario y no siempre al espacio comprendido del mismo-, desde el punto de vista económico, sociológico y especialmente geográfico e histórico: M. Ríos, L. Achával, A. Terzaga, R. Ferrero, N. Cimminelli, J.L. de Imaz, R. Lucero Moriconi, J. Bialet Massé, A. 
Vitulo, Chañilao (J. Bustamante), A. Geymonat, S. Gutiérrez, A.H. Cantón, L. Formento, O. Prieto, que sirven para comprender el proceso evolutivo de ocupación de este territorio y para entender ciertas problemáticas parciales que involucran a las fuerzas del trabajo rural.

En síntesis, a nivel país, la bibliografía existente todavía no es suficiente, si bien contamos con valiosos libros y publicaciones que tratan concretamente la temática laboral rural, o que en algunas secciones de sus contenidos se refieren a la misma.

Es indudable que, en cuanto a los estudios de la PEA Agropecuaria en la Argentina, queda pendiente un sinnúmero de problemas por conocer, profundizar y dilucidar.

Cabe agregar, por último, que en la zona de estudio existen cuatro agencias del INTA, cuyos técnicos, en diversas circunstancias, han puesto sus conocimientos sobre el medio rural al servicio de la presente investigación.

\section{Organización del desarrollo de los temas}

La organización de los temas tratados en esta investigación consta primero de los fundamentos teórico-metodológicos que sustentan el emprendimiento, referidos ellos al marco conceptual, los objetivos y los pasos metodológicos que se pretende seguir. En segundo lugar, se vuelca una mirada geohistórica sobre la ocupación y poblamiento del área bajo estudio. Se describe la evolución territorial desde la Córdoba colonial y criolla hasta el ingreso y consolidación de la colonización agraria llevada a cabo en la llanura cordobesa. En tercer lugar, se trata, a nivel estadístico, la evolución demográfica del sur cordobés, diferenciando lo que corresponde a la población rural y a la población urbana. También se vuelcan los datos referidos a la evolución intercensal de la población urbana y rural y de vivienda, por zona rural de las diez localidades testigos con sus respectivas zonas rurales de influencia. En cuarto lugar, se penetra en el meollo de la tesis, al desarrollar, por una parte, la conceptualización y caracterización de la PEA Agropecuaria, y por otra, la sucesión de una serie de aspectos atinentes a la fuerza laboral, tales como evolución cuantitativa de la PEA Agropecuaria a nivel estadístico y análisis de la magnitud y localización de la PEA Agropecuaria de las diez localidades testigos con sus respectivas zonas rurales de influencia, en base a los datos recogidos en el trabajo de campo. En quinto lugar, se analiza, en primer término, la estructura agraria del sur cordobés, desde el punto de vista fundiario, donde se contempla la escala por tamaño de las EAPs, cantidad y superficie de las EAPs por tipo jurídico del productor y distribución de los establecimientos por régimen de tenecia de la tierra; en segundo término, la estructura agraria desde el punto de vista de los cambios productivos en el quehacer 
agropecuario, con especial énfasis en lo atinente al tipo de uso de la tierra de las EAPs y de las superficies implantadas de cereales y oleaginosas, con los resultados de las campañas agrícolas de los últimos veinte años. En sexto lugar, se desarrolla, desde la perspectiva geográfica y como parte fundamental del presente trabajo, la articulación socio-económica de los principales actores sociales que componen la PEA Agropecuaria. Se consideran al respecto los productores agropecuarios, los trabajadores rurales dependientes, los contratistas rurales y las agroindustrias con injerencia directa en la explotación primaria agrícola, básicamente mediante la aplicación de encuestas y entrevistas a los agentes implicados. En séptimo lugar, se tratan algunos aspectos laborales y socioculturales específicos de importancia significativa referidos a los actores rurales de nuestro estudio. Al respecto, se despliegan tres cuestiones, a saber: el análisis de las clases sociales del sector agropecuario en su faceta socio-ocupacional, la dimensión cultural en el paisaje agrario con las diferentes lógicas que intervienen en la configuración del mismo, y el rol de la mujer en el ámbito rural, con especial referencia en lo atinente a su trabajo productivo y al accionar político-gremial en defensa de las explotaciones familiares.

Por último, en el capítulo de cierre, se vuelcan las correspondientes conclusiones y algunas escuetas sugerencias sobre la realidad analizada. Aquí, finalmente, valiéndonos de las problemáticas consideradas de nuestra área de estudio, además de algunos aportes específicos, van a mediar reflexiones que invitan a pensar y repensar colectivamente estrategias de acción tendientes al logro de una mayor justicia y equidad socio-territorial para nuestro agro en general y, desde luego, para nuestro espacio rural en particular. 


\section{Capítulo I}

\section{Fundamentos}

\subsection{Marco teórico}

I

En este emprendimiento, partimos de la idea de que tiene que haber, en primera instancia, un "marco referencial" con respecto a qué es lo que queremos averiguar y por qué, en el sentido de la finalidad que se le busca a la investigación.

Al respecto, Lukacs es muy claro cuando afirma: "El conocimiento de los hechos no es posible como conocimiento de la 'realidad' más que en ese contexto que articula los hechos individuales de la vida social en una 'totalidad' como momentos del desarrollo social" (Lukacs, 1969:10). Tratamos, por lo tanto, de integrar todos los elementos de análisis y sus vinculaciones en el contexto que se insertan, tendientes a buscar la unidad de los fenómenos interactuantes.

Procuramos, también, respetar el criterio témporo-espacial en el estudio de los fenómenos y objetos geográficos, al considerar como inseparable e imprescindible la complementariedad analítica de estas dos dimensiones categoriales, y "ver el tiempo como simultaneidad, pues no hay ningún espacio en que el uso del tiempo sea idéntico para todos los hombres, empresas, instituciones" (Santos, 2000:134).

En el entendimiento de que el espacio geográfico actúa como receptor, activador, partícipe y reflejo de las acciones de la vida, pasamos a resaltar, algunas características y fenómenos que se observan y desarrollan en el mismo y que entendemos de vital importancia en el seguimiento de esta investigación.

Ante todo, tenemos en cuenta la existencia de una "espacialidad diferencial" sobre la cobertura terrestre, según una expresión conceptual feliz de Yves Lacoste (citado por Gómez Mendoza, 1982:146-147), a fin de poner en evidencia la infinidad de escalones socioeconómicos-territoriales que alternan en el espacio geográfico, donde no cabe duda de que "las relaciones de poder afectan la organización del espacio" (de Jong, 2009:278), estableciendo una serie de gradientes de calidad y afectación territorial.

Consideramos que "el intercambio de bienes y servicios (incluida la fuerza de trabajo) supone casi siempre cambios de ubicación" (Harvey, 2004:84). Este fluir define, por lo tanto, 
una red de movimientos de flujos de materialidades y personas, que pone en evidencia la permanente interacción social a nivel espacial.

En lo que respecta al análisis de la distribución territorial del trabajo, debemos recordar que la actual “...descansa sobre las divisiones territoriales del trabajo anteriores. Y la división social del trabajo no puede entenderse sin la explicación de la división territorial del trabajo, que depende, a su vez, de las formas geográficas heredadas" (Santos, 2000:119). Como vemos, la acción del trabajo imprime siempre sus huellas en el territorio, a veces visibles a modo de superposiciones truncas horizontales, y a veces totalmente borradas por el paso del tiempo, lo que da lugar y legitimidad, en nuestro caso, a enfocar las problemáticas laborales-territoriales, desde una perspectiva de unicidad conceptual.

Por otra parte, entendemos al espacio geográfico como una construcción social animada de una vitalidad cambiante, producto del accionar humano, pudiendo interpretarse, por lo tanto, que "es también el espacio de las ideas" (Chiozza, 2006:130). No cabe duda de que todo ámbito geográfico está acompañado por determinado basamento de ideas $\mathrm{y}$, cuando se produce, como bien dice E. Reclus, "el cambio del medio trae consigo forzosamente cambio de ideas, otra concepción de la naturaleza ambiente, otra manera de asociarse a las circunstancias, diferentes del medio anterior" (Reclus, 1975:171).

Nos parece importante contemplar también que la agricultura, si bien se rige por sus propias leyes, juntamente con la industria, como partes de un mismo encadenamiento dentro de una formación económica-social, “...tienden a un mismo fin siempre que no se las aísle sino que se las considere como eslabones comunes de un proceso global" (Kausky, 1970:11). Por otro lado, los problemas agropecuarios deben estar insertos en el marco de las cuestiones generales de la economía nacional, dado que los mismos “....son demasiado serios como para considerarlos sólo problemas sectoriales. Deben ser considerados problemas nacionales, su solución exige la participación activa del Estado...” (Giberti, 2009:15).

En lo atinente a la supuesta autonomía entre campo y ciudad, más allá de percibir sus contrastes “...tenemos que dar un paso más y ver sus interrelaciones y, a través de ellas, la configuración real de la crisis subyacente" (Williams, 2001:366). Se sabe que se ligan, en mayor o menor término, casi todos los fenómenos que se manifiestan en ambas esferas. Entendemos que toda manifestación de las problemáticas urbanas repercute también, de alguna manera, en el campo. Por lo tanto, el estudioso de las cuestiones rurales debe estar siempre atento, con su mirada extendida a la ciudad.

En esta investigación, asimismo, brindamos mucha importancia a la caracterización de las clases sociales de los agentes laborales que intervienen en el ámbito rural. Entendemos que 
las clases sociales, en su accionar sobre el territorio, trasladan sus características diferenciales sobre el mismo, dejando, de acuerdo con su capacidad económica, huellas tangibles y asimétricas en el espacio, como reflejo de su especificidad estructural. Consideramos, por tanto, que las clases sociales son, como bien lo especifica Lenin:

\footnotetext{
...grandes grupos de hombres que se diferencian entre sí por el lugar que ocupan en un sistema de producción social históricamente determinado, por las relaciones que se encuentran con respecto a los medios de producción (relaciones que en gran parte quedan establecidas y formuladas en las leyes), por el papel que desempeñan en la organización social del trabajo y, consiguientemente, por el modo y la proporción en que perciben la parte de riqueza social que disponen. Las clases son grupos humanos, uno de los cuales puede apropiarse el trabajo de otro, por ocupar puestos diferentes en un régimen determinado de economía social (Lenin, 1979:32),
}

y en el entendimiento de que las relaciones de producción se definen como el conjunto de relaciones económicas que se establecen entre las personas en el proceso de producción, vemos que existe en nuestra área de estudio una gran riqueza de vinculaciones y diversidad de subconjuntos de agentes laborales intervinientes entre sí que motivan su estudio.

Por último, detrás de toda esa maraña de problemas concurrentes de diversa índole en el espacio agropecuario, que dan lugar a muy diversos enfoques de análisis, como el que presentamos en esta instancia, lo real consiste en que lo primero que debemos tener en cuenta es que a la "tierra" se la debe considerar como un bien social y su función esencial, por sobre todas las cosas, es generar alimentos suficientes a la sociedad. R. Williams dice al respecto: "Los datos de la crisis de alimentos y población han sido amplia y adecuadamente difundidos. Para poder sobrevivir, tendremos que desarrollar y extender los trabajos agrícolas" (Williams, 2001:369). Y nosotros remarcamos al respecto, para mantener la vida y no para generar solamente negocios con criterios netamente comerciales y/o especulativos. En concreto, interpretamos que, cualquiera sea la línea de investigación sobre problemáticas del agro que se trabaje, la cuestión de la alimentación debe figurar como una preocupación constante, explícita o implícitamente incorporada en los análisis que se lleven a cabo.

\section{II}

Con respecto a la contextualización témporo-espacial de la presente investigación, la misma parte de la concepción de que los actores sociales y su vinculación territorial se desenvuelven dentro de un capitalismo agrario avanzado, en el cual predomina de manera hegemónica el modo de producción capitalista en todo el entorno pampeano, en combinación 
con otras formas no capitalistas precedentes (Pucciarelli, 1986), con una marcada tendencia de estas últimas a retirarse la de escena territorial mencionada.

Es palpable, en la Argentina en general y en el agro, por cierto, la persistencia de un capitalismo con carácter dependiente y monopólico que, a pesar de no estar tan subordinado exclusivamente como antes a los centros imperialistas -debido a que los centros de poder económico se han ampliado y resultan más ubicuos territorialmente-, sigue teniendo plena vigencia con los rasgos básicos que lo caracterizan.

En concreto, en el espacio pampeano -como decíamos- predomina un capitalismo avanzado pero no conformado independientemente, con un rápido y gran desarrollo de sus "fuerzas productivas", 1 pero asentado sobre pies de barro por su dependencia del capitalismo concentrado mandante.

En lo que respecta a los agentes laborales que forman parte de las fuerzas productivas, es observable desde hace tiempo, en el área pampeana, la consolidación de una burguesía agraria de tipo empresarial con rasgos capitalistas cada vez más acentuados, lo que no quiere decir que el trabajo familiar desaparezca, "pero se combina ahora [en un alto porcentaje] con la apropiación de plusvalía generada por el trabajador asalariado y con el propósito de extraer mayor rentabilidad al capital invertido en maquinaria y mano de obra" (Pucciarelli, 1986:50).

Desde el punto de vista geográfico, se debe tener muy en cuenta el desarrollo territorial desigual de la economía agraria argentina, con marcadas disimilitudes regionales en relación con el agro pampeano, diferentes realidades que no se pueden confundir. Y, a su vez, no se debe olvidar que el campo argentino en su integralidad está dentro de un circuito mayor de interrelaciones de poder socio-económico-espaciales, donde la autonomía en las decisiones se presentan limitadas o se relativizan.

Por otra parte, en el actual contexto que vive el país en relación con el campo, donde un cúmulo de problemas económicos y sociales agropecuarios continúa sin resolver, posiblemente el más grave de todos sea la "incertidumbre" por la que atraviesa el mundo rural en relación con su futuro. Las sucesivas políticas gubernamentales, con sus consecuencias, lejos de haber cuajado en una verdadera política de Estado, respecto de la función socioeconómica que debe cumplir el agro, son las que han generado esta indeterminación. No

\footnotetext{
Es interesante recordar la reflexión de C. Marx sobre la trascendencia de las "fuerzas productivas": "lo que distingue a las épocas económicas unas de otras no es lo que se hace, sino el cómo se hace, con qué instrumentos de trabajo se hace. Los instrumentos de trabajo no son solamente el barómetro indicador del desarrollo de la fuerza de trabajo del hombre, sino también el exponente de las condiciones sociales en que se trabaja" (Berisov et al., 1977:97).
} 
obstante, el campo sigue siendo el gran sostén -especialmente en los últimos años- del Estado, con los incrementos de la producción, las divisas que genera y la masa dineraria que aporta al tesoro nacional. Asimismo, la fuerza del trabajo rural en su totalidad, históricamente, se presenta muy estamentada -en claro perjuicio de los sectores más débiles-, quedando librada in-totum a su suerte, debiendo llevar a cabo su propia autorregulación y gestión de los múltiples requerimientos que necesita para producir. Éste es el sintético cuadro de posición general.

Con respecto a la situación del agro pampeano donde se desenvuelve esta investigación, vemos que está signado por profundos cambios estructurales que progresivamente vienen manifestándose desde hace treinta o cuarenta años, aproximadamente. Modificaciones que provienen de directrices macroeconómicas a diferente escala, tanto nacionales como internacionales, y que repercuten con particular fuerza en el área pampeana, por su fuerte inserción en el circuito capitalista productivo. Es así como las variables de las componentes del trabajo, la producción y la movilidad del capital circulante están sujetas a las fluctuaciones de la demanda y la oferta, resultantes de las políticas económicas que se digitan en los grandes centros de poder y que, inexorablemente, se trasladan a las economías agropecuarias pampeanas, dejándole muy poco margen de autonomía de decisión -exceptuando a las grandes corporaciones empresariales agropecuarias- al grueso de los actores que construyen esta fuente de riqueza.

Estas transformaciones se van a manifestar en diferentes planos, como por ejemplo: en el aspecto tecnológico productivo, con la modernización y acrecentamiento de un parque de maquinaria diversa y refinada, la difusión de semillas híbridas y de agroquímicos, la aplicación de una genética de avanzada en los rodeos y en el mayor uso del suelo, prácticas que no en todos los casos resultan exitosas; en el aspecto de manejo económico de las explotaciones y de gestión empresarial, que implica una mayor especialidad de las tareas y un ahorro de mano de obra, cuyo requisito perentorio de adquirir conocimientos de actualización empresarial, en combinación con la necesaria disponibilidad de capital, ponen en muchos casos en una frágil encrucijada a los pequeños productores; en el aspecto comunicacional donde, por un lado, los adelantos tecnológicos, como la incorporación de la telefonía celular, las computadoras, vehículos todo-terreno y TV satelital resultan sorprendentes y, por el otro -exceptuando el acondicionamiento de una relativamente densa red de rutas asfaltadas-, se carece todavía de caminos secundarios adecuados de acceso a los establecimientos. Corresponde destacar también los adelantos en el rubro del transporte de la producción que, a pesar de arrastrar especiales falencias, ha avanzado considerablemente. En suma, no obstante 
la persistencia de algunos déficit -no menores, en muchos casos-, los cambios positivos en la faceta de las comunicaciones se pueden considerar sustantivos.

En el fenómeno de los cambios locacionales de la fuerza de trabajo rural-que ha sido tema central de investigaciones anteriores, como ya se mencionó- del campo a los centros urbanos (Agüero et al., 1997, 2000; Agüero y González, 1998), motivado este "éxodo residencial radical" por la búsqueda de satisfacer expectativas familiares y/o un mayor confort de vida, pudo concretarse inicialmente por un relativo incremento en el bienestar económico de numerosos pequeños y medianos productores capitalizados. Por lo tanto, a diferencia de otros movimientos demográficos que respondían a la búsqueda de mejores condiciones económicas, en este caso fue a la inversa, justamente por atravesar esta franja de productores por una buena etapa económica. A su vez, estos movimientos campo-ciudad arrastraron también a cierta porción de asalariados permanentes.

En el aspecto del desempeño del trabajo rural, las transformaciones resultaron también muy importantes, donde la mecanización, los cambios de localización y las exigencias tecnológicas en general van a modificar sustancialmente el esquema laboral tradicional. Pero el cambio quizás más destacado se va a manifestar en aquellas explotaciones del área pampeana dedicadas a la actividad mixta o agrícola, con la introducción inicial del "contratista de servicios", ya sea para las labores de cosecha -principalmente- o de siembra (Llovet, 1991). Éste es un trabajador que se caracteriza por poseer un parque de maquinarias agrícolas destinadas a trabajar tierras de terceros, en labores parciales dentro del ciclo de la producción agrícola. Figura que más adelante se va a complejizar, al asumir muchas otras combinaciones de roles y funciones en las tareas inherentes al campo. En concreto, la aparición en escena de este agente va a producir la sustitución de tareas clásicas que antes correspondían a los productores.

En lo referente a los patrones culturales que posee el agro pampeano, vemos que la sociedad que lo compone no queda exenta del fenómeno de absorción de los nuevos códigos que dicta la globalización comunicacional, particularmente de parte de aquella PEA agropecuaria que sigue viviendo en el campo. Es notorio el esfuerzo que realiza por incorporar pautas de la vida doméstica semejantes a las que se practican en la ciudad. En suma, el campo está inundado de códigos de procedencia urbana, lo que no quiere decir que haya perdido su propio y rico bagaje de ideales, sentimientos y tradiciones -además de seguir evolucionando en su propia esencia-, que se desprende del plano de las representaciones culturales, ya que debemos recordar que los "lugares" siempre están cargados de sentido y de significaciones propias que los identifican (Claval, 1999). 
Como corolario de las transformaciones descriptas, y desde la perspectiva de su incidencia en la magnitud, composición y localización de la fuerza laboral agropecuaria, las repercusiones más notables que se observan son: el despoblamiento del campo, la disminución de las unidades productivas -aunque ahora todas ellas de mayor extensión-, con la consiguiente contracción de la PEA agropecuaria, la injerencia de nuevas fuerzas laborales despersonalizadas y con gran disponibilidad de capital, la ocupación de las explotaciones por un tiempo muy breve de parte de ciertos agentes, las modificaciones de las tareas en el manejo interno y de atención en la dirección de las explotaciones, la salida de la escena productiva de un porcentaje apreciable de pequeños productores, ya sea en calidad de "productores rentistas ocasionales" o por venta del establecimiento, al no poder adecuarse a los nuevos paradigmas tecnológico-económicos, la conversión de pequeños productores en empleados de las grandes empresas por pérdida de sus campos en manos de éstas, el desdibujamiento del asalariado rural tradicional y disminución sustantiva del mismo, la aparición de nuevas formas asociativas de defensa de las explotaciones familiares, aparte de otras muchas consecuencias más.

Por cierto que no todos los efectos de las transformaciones resultan negativos, pero los efectos positivos se derraman centralmente a nivel macroeconómico, beneficiándose básicamente, y mucho, las grandes concentraciones empresariales. En cambio, los actores sociales más débiles -asalariados y productores chicos- sufren las fluctuaciones y exigencias del mercado, que coyunturalmente pueden favorecerlos, pero que, a grandes rasgos, los obligan a una reconversión económica de sus explotaciones, en el caso de los pequeños productores, que en general resulta muy penosa y difícil de alcanzar por falta de capital suficiente y del necesario apoyo tecnológico.

En síntesis, las transformaciones generales que se observan en la economía agropecuaria pampeana, en los últimos tiempos y como expresión de los avances científicos y tecnológicos, se traducen en incrementos de la productividad laboral, de los índices de producción, de los volúmenes absolutos de producción y de la valorización de la tierra y, como contrapartida, en el debilitamiento económico o la exclusión social para amplias franjas de la fuerza del trabajo rural. Sin duda que este cuadro de situación está siempre supeditado a los vaivenes de la demanda internacional, y que es ésta, en última instancia, la que sujeta la economía agropecuaria pampeana a su arbitrio, al seguir oficiando de mercado regulador de su producción.

En lo atinente específicamente a las características y a la situación actual de la PEA agropecuaria en el área de estudio de esta investigación, se puede resumir de este modo: una 
injerencia progresiva de nuevas figuras laborales, como la proliferación desde hace varios años de grandes grupos empresariales, en muchos casos, con el aporte de capitales extrasectoriales, con continuidad en la actividad agropecuaria y, en otros casos, con duración acotada en la misma - pools de siembra-; la proliferación y consolidación de los contratistas en el desempeño de un doble rol: contratistas de servicios y contratistas capitalistas -en este caso, arriendan transitoriamente tierras y las trabajan por su cuenta-; la intromisión directa de las agroindustrias en la actividad agrícola, trabajando tierras propias y/o arrendadas o asociados a terceros; la proliferación insólita de productores chicos devenidos en "rentistas transitorios", al arrendar sus campos por períodos breves, generalmente a grupos empresariales, sin por ello haberse retirado en forma definitiva de las tareas agrícolas. Asimismo, se observa un cambio de situación de ciertos agentes laborales tradicionales, como el desdibujamiento en parte de los clásicos productores familiares, donde por un lado se detecta una consolidación capitalista de algunas explotaciones de pequeñas a medianas $\mathrm{y}$, en otros casos, el empobrecimiento, subordinación en su autonomía económica y, en varias circunstancias, exclusión de los pequeños productores del sistema.

Con respecto a las características del sector asalariado, además de su disminución general, ahora mucho más diferenciados internamente en cuanto a cualificación en su trabajo, aparecen nuevos trabajadores temporarios calificados, responsables generalmente del manejo de maquinaria agrícola, con ingresos salariales comparativamente altos. Como contrapartida, los asalariados temporarios tradicionales (bolseros, changarines, etc.), con un promedio de tiempo trabajado específicamente en quehaceres agrícolas que no superan los cuatro o cinco meses al año, viven en muchos casos en una pobreza acentuada a extrema, residiendo en una región de reconocida capacidad económica (Agüero, 1998). Por otra parte, se observa una marcada relocalización de la mano de obra dependiente, del campo a los centros urbanos y “...el mantenimiento o acrecentamiento de las condiciones de trabajo precario [...] en lo referente a la estabilidad y condiciones de trabajo" (Aparicio-Benencia, 1999:68).

Por último, a modo de síntesis de lo que en los capítulos siguientes explicitaremos en detalle, se puede decir que, de los agentes laborales que trabajan la tierra por su cuenta en el área de esta investigación, gozan de una presencia significativa los pequeños y medianos productores. Se detecta una baja predominancia del estanciero clásico, pero sí se observa una presencia importante del empresario capitalista y prácticamente la inexistencia del arrendatario tradicional. La denominación de chacarero como actor característico de otras épocas y lugares de la Región Pampeana no tiene vigencia actual en el área. El término 
generalizado que se utiliza -en el sur cordobés- para denominar a los agentes que trabajan la tierra por su cuenta -más allá del tamaño de las explotaciones- es el de "productor".

\section{III}

A modo de apreciación progresiva sobre la orientación geográfica epistemológica que se lleva a cabo en la presente investigación, podemos decir, en primer término, que se enmarca bajo un enfoque crítico sobre el actual desenvolvimiento del mundo dentro del maduro modo de producción capitalista imperante en el que la inequidad social, incentivada por el avasallante fenómeno de la globalización, se sigue incrementando sin cesar.

De acuerdo con lo anteriormente expresado, partimos de la base de que tiene que mediar en todo emprendimiento analítico un insoslayable posicionamiento ideológico del mundo, en el sentido de qué concepción del mismo se tiene, cómo se manifiesta y cómo debería ser, con el propósito - mediante la investigación pertinente- de ayudar a conocer mejor, y en lo posible contribuir a mejorar, las realidades imperantes.

El presente enfoque, conceptualmente, se apoya en el método dialéctico como base analítica, lo que implica un camino ascensional de superación de las inferencias "por el cual toda significación presupone una diferencia y una oposición y que en unión con ella da lugar a una significación de mayor nivel de integración" (Samaja, 1993:119). Pretende, por lo tanto, responder a un procedimiento sólido del análisis del objeto lógico que desemboque en una instancia superadora de las inferencias puestas en juego. Por otra parte, se debe resaltar, en última instancia, que "para el método dialéctico, el problema central es la transformación de la realidad" (Lukacs, 1969:4)

En el caso específico de esta indagación, procuramos analizar la evolución de los factores sociales intervinientes en el agro, con un interés dialéctico, respetando los progresos de las etapas históricas anteriores y considerando que

\footnotetext{
"la vía de la negación no significa en modo alguno la negación de todo lo existente; supone más bien la continuidad de aquello que está evolucionando. La negación de la sociedad capitalista por el socialismo no significa la abolición de la sociedad humana, sino la abolición de algunos elementos determinados de una de sus fases de evolución" (Kautsky, 1970:3)
}

La orientación que pretendemos impulsar apunta hacia una mirada política del espacio, asumiendo un posicionamiento crítico sobre las desigualdades socio-territoriales manifiestas, compartiendo la opinión de que "no existe ciencia objetiva, exenta de juicios de valor y 
políticamente neutra. Toda ciencia es ideológica, toda ciencia, y especialmente las ciencias sociales, sirven de algún propósito político" (Gómez Mendoza et al., 1982:143).

Asimismo, procuraremos no encorsetarnos en un posicionamiento teórico ideológico rígido y de consideración inmutable, dado que se entiende que "todo progreso, hecho dogma, se cambia gradualmente en obstáculo" (Reclus, 1975:87). En este mismo sentido, Gómez Mendoza et al. vuelcan su opinión final sobre los radicalismos geográficos -a los cuales nos adherimos-, diciendo: "parece necesario para toda perspectiva geográfica que se pretende radical y crítica basarse en la más radical y crítica aversión a codificaciones doctrinarias, a sistemas de entendimiento supuestamente autosuficientes y pretendidos monolitismos cognoscitivos" (Gómez Mendoza et al., 1982:153).

En suma, el enfoque geográfico que aquí implementamos, de posicionamiento crítico y armado analógico dialéctico, se proyecta desde una perspectiva humanista, entendiendo por tal paradigma la valorización de la sociedad humana como hacedora del espacio que la cobija, sin olvidar que coexisten entre sus propios miembros profundas desigualdades manifiestas. Esto requiere -para poner en práctica esta orientación- una reflexión crítica y una posición ideológica definida en el estudio de los saberes geográficos-como reafirmamos anteriormente-, a fin de procurar captar en toda su magnitud el complejo entramado de vivencias e intereses en esta realidad ecuménica.

La idea de esta visión consiste en comprender, en el plano de las interacciones de los seres humanos con su medio, los diferentes grados de conciencia, conocimientos, realizaciones y aspiraciones de los diversos grupos y estamentos sociales que conforman la humanidad.

En última instancia, a través del análisis geográfico, pretendemos colaborar en la desarticulación y el rompimiento del injusto orden social imperante y participar en la construcción equitativa de un cambio social humanizado, en armonía con el medio que sustenta a la sociedad.

Por último, así como Luis Franco se expresa diciendo que "toda incursión en el pasado que no lleva por finalidad esclarecer nuestro presente y el camino de salida hacia el futuro, no tiene razón de ser" (Franco, 1967:7), nosotros perseguimos la misma finalidad con el trabajo que aquí presentamos, es decir, conocer de la forma más cabal la realidad socioterritorial del área en cuestión y vislumbrar un camino de salida con progresiva tendencia hacia la obtención y de afianzamiento de una mayor justicia social territorial (Coccaro, 20032004). 


\subsection{Objetivos}

De acuerdo con la marcha impuesta en el Plan de Trabajo del proyecto de investigación inicial, unos pocos objetivos específicos originales sufrieron algún tipo de readecuación. Uno solo se cambió por imposibilidad operativa y material de cumplimentarlo y fue reemplazado por otro que hace referencia al marco geo-histórico de la región -anteriormente faltante-, y a su vez se modificó otro, con el fin de que sirva de cierre y sostén teórico de todo el trabajo emprendido. A continuación, se especifican los mismos.

\section{Objetivo general}

- Conformar un cuadro de situación explicativo que amalgame el cúmulo de aspectos que inciden en la PEA agropecuaria, de una manera lógicamente concatenada, a fin de poder arribar a la captación integral de las causas que interactúan entre las fuerzas laborales y el territorio que las acoge.

\section{Objetivos específicos}

- Indagar sobre la evolución geo-histórica de la ocupación y el poblamiento del territorio bajo estudio.

- Precisar la dinámica demográfica y las problemáticas de la localización de la PEA agropecuaria.

- Analizar las alteraciones espaciales que se están produciendo en el área de estudio, como consecuencia de las progresivas transformaciones socio-territoriales que se están llevando a cabo.

- Estudiar los perfiles socio-económicos de los diversos actores sociales que componen la PEA agropecuaria, con su correspondiente caracterización de clase social a la que pertenecen, con el propósito de detectar los diferentes niveles de vida y las tendencias económico-laborales de los mismos, en su vinculación con el territorio que los alberga.

- Indagar cómo inciden y se manifiestan la macro-política agropecuaria en el seno familiar de los asalariados y productores menos favorecidos, y las estrategias de sobrevivencia que desarrollan para adecuarse a las nuevas exigencias.

- Estudiar las relaciones que se establecen entre las nuevas modificaciones económicas agrícolas y las estrategias técnico-laborales que se emplean como producto de estos cambios. 
- Analizar las condiciones de reproducción de la fuerza del trabajo en los estamentos menos capitalizados y más desprotegidos de la escala laboral.

- Procurar captar las lógicas que interactúan -desde la perspectiva de la cultura- en el pensamiento del agente laboral y que dan lugar a la concreción de sus actos, es decir, cómo se imbrican en su accionar las pautas culturales con la actividad productiva.

- Detectar, en la medida de lo posible, las futuras tendencias hacia donde se orientarán las fuerzas político-económicas y laborales que regulan y conforman respectivamente la PEA agropecuaria.

- Arribar, por último, a la conformación de un marco teórico integrador que brinde sustento explicativo al desempeño territorial de los agentes laborales analizados y ayude -dentro de las posibilidades-, con los resultados del diagnóstico y el aporte de algunas sugerencias para el mejor conocimiento de las problemáticas laborales y el diseño de políticas públicas relacionadas con la actividad agropecuaria.

\subsection{Hipótesis}

A continuación, presentamos los planteos hipotéticos que sostienen este trabajo.

Básicamente, la hipótesis central que impulsa este proyecto se apoya en la concepción de que "la profundización de los cambios estructurales que se vienen manifestando en las actividades agropecuarias en nuestro país, y que son una consecuencia de los grandes lineamientos que emanan de los centros de poder económico mundiales y en menor término nacionales, seguirán engendrando - sin cambiar la distribución de poder- notables modificaciones sociales, económicas, políticas y culturales dentro del ámbito rural, especialmente el pampeano".

Con respecto a los actores implicados en esta propuesta, estos cambios, que ya se expresan en una readecuación de la PEA agropecuaria en lo atinente a sus roles laborales, a su capacidad de generar ingresos, a los cambios de localización y a su forma de vida en última instancia, por el momento, es de suponer que no alterarán la raíz de las estructuras de poder que digitan el quehacer del campo; es decir que no producirán transformaciones de fondo que impliquen equidad entre los agentes productivos ni un verdadero desarrollo social integral del agro, en el entendimiento de que este anhelo -que es imposible de lograr exclusivamente en forma sectorial- sólo se podrá alcanzar cuando la conjunción de las fuerzas provenientes de las bases del pueblo impongan una política de reversión del sistema imperante. 
Dentro de las limitaciones de la actual realidad agropecuaria argentina, es de presuponer que hasta que no se implemente una política real de defensa y crecimiento del agro, mediante un franco acuerdo entre todas las fuerzas que componen la burguesía nacional, el medio rural continuará mostrando un flanco de evidente debilidad de decisión, frente a las presiones, exigencias e injerencias provenientes de los ámbitos económicos externos. Y esta subordinación, como lógica consecuencia, seguirá repercutiendo negativamente en los sectores más desposeídos de la cadena laboral agropecuaria.

Si bien lo expresado hasta aquí es a nivel general, y considerando que las tendencias y suposiciones provisorias mencionadas tienen vigencia también para el área de estudio, nos interesa precisar, en el territorio de este análisis, ciertos supuestos más específicos -de acuerdo con las investigaciones anteriormente efectuadas- que inferimos ya se están manifestando o se pueden llegar a manifestar, sin perjuicio de que muchos de éstos eventualmente también sean válidos de aplicar en otros sectores de la Región Pampeana y/o en otros ámbitos rurales del país.

\section{Hipótesis derivadas}

En este sentido, pasamos a mencionar los supuestos más relevantes a nivel de nuestra área:

- Con respecto a la situación demográfica de la población rural, presuponemos una cierta estabilidad o una pausada disminución demográfica de la misma en el área de estudio, debido a que da la impresión de que el campo ha llegado a un punto de equilibrio en el sentido de que la actual población que alberga parece ser la imprescindible para que éste funcione.

- Con respecto a la situación locacional-laboral de los productores (especialmente los pequeños y medianos) y de los asalariados, presuponemos: un incremento del tiempo de dedicación en la atención de sus explotaciones por parte de los productores que viven en los centros urbanos, como una forma de preservar las mismas, y un quietismo locacional de los productores que siguen residiendo en las áreas rurales, como una estrategia de atender mejor sus campos; un incremento de la especialización laboral y de la tecnificación -más lento en los establecimientos menos capitalizados- en las explotaciones agropecuarias en general; una creciente dificultad por parte de varios pequeños y medianos productores - motivada por razones económicas o por albergar sus descendientes otras expectativas de vida- para lograr la continuidad de la reproducción generacional de la fuerza del trabajo en sus 
explotaciones; un incremento de la combinación a nivel familiar de trabajo ruralurbano en numerosos pequeños productores y asalariados -especialmente en los temporarios-, como una estrategia más de sobrevivencia; un achicamiento numérico progresivo de los asalariados tradicionales, particularmente de los permanentes, y un incremento de trabajadores temporarios calificados.

- Con respecto al desempeño socio-económico de los agentes productivos, inferimos: una única forma posible de permanencia en escena de los pequeños productores familiares -más allá de la coyuntura económica favorable del momento-podrá ser solamente factible a través de la optimización y el manejo más directo de las explotaciones (ante las dificultades para cumplir con la primera condición, es de suponer que, si no media una política de apoyo crediticio y de apoyo tecnológicoeconómico, inexorablemente tenderán a disminuir paulatinamente sus actividades productivas); una progresiva interdigitación de la actividad primaria con la secundaria, motivada por los avances económicos englobantes y crecientes de las agroindustrias; una pronunciada expansión de las grandes empresas agropecuarias y acusada injerencia de capitales extra-sectoriales en la explotación agropecuaria directa; una profundización en la tendencia de los grandes productores a fusionarse con el gran capital de origen urbano, despersonalizándose así la dirección de las grandes explotaciones y el consiguiente trasvasamiento del grueso de las ganancias hacia los grandes centros poblacionales.

- Con respecto a la situación económica de los pequeños y medianos agentes laborales, consideramos: una continuación en el desdibujamiento de un número apreciable de pequeños productores familiares, por auto-expulsión definitiva o transitoria del sistema o por pérdida de independencia en el manejo de sus explotaciones (subordinación económica); una progresiva consolidación económica de una apreciable cantidad de medianos productores que pudieron capitalizarse o están en condiciones de hacerlo y de alcanzar niveles de rentabilidad importantes, como así también de algunos pequeños productores que han logrado o están en condiciones de lograr alcanzar una creciente rentabilidad productiva en sus explotaciones (farmerización); una persistente disminución de la cantidad de actores sociales rurales que intervienen en la producción agropecuaria.

- Con respecto a los patrones culturales que inciden actualmente en la población del campo, inferimos una asimilación progresiva de los estilos de vida urbanos en el 
mundo rural, motivada por el incremento de las vinculaciones comunicacionales a nivel general.

\subsection{Variables de análisis y aplicación de indicadores}

- Con respecto a la situación demográfica de la población rural, tenemos en cuenta los siguientes indicadores, extraídos de los Censos Nacionales de Población y Vivienda de 1980, 1991 y 2001, como igualmente los obtenidos de encuestas a los agentes laborales y entrevistas laborales. Éstos son:

- Población total por sexo, según condición urbana o rural de Argentina y provincia de Córdoba.

- Población total por sexo, según condición urbana o rural de los cuatro departamentos que conforman el sur de Córdoba.

- Población rural concentrada de los cuatro departamentos del sur de Córdoba.

- Población urbana de cada localidad de los diez centros urbanos testigos.

- Población rural de la zona de influencia de cada localidad de los diez centros urbanos testigos, diferenciando la población dispersa y concentrada.

- Viviendas particulares ocupadas y desocupadas de cada zona rural de los diez centros urbanos testigos.

- Datos provenientes de la sección "Factores locacionales" de las encuestas efectuadas a los agentes laborales.

- Información proveniente de referentes claves.

- Con respecto a la situación locacional-laboral de los productores y de los asalariados rurales, los indicadores utilizados provienen de diferentes vertientes, como:

- Datos provenientes de los Censos Nacionales de Población y Vivienda 1991 y 2001:

- Totales de la PEA agropecuaria a nivel país, provincia de Córdoba y de los cuatro departamentos del sur de Córdoba.

- Datos provenientes de los Censos Nacionales Agropecuarios 1988 y 2002:

- Cantidad de personas que trabajan en las EAPs en forma permanente, según relación con el productor, a nivel provincia de Córdoba y de los departamentos del sur de Córdoba.

- Datos provenientes de las municipalidades de las diez localidades testigos: 

○ Listado de contribuyentes del "impuesto inmobiliario".
○ Listado de contribuyentes de la "guía animal".

- Datos provenientes de diversas organizaciones con vinculación rural:

- Información de las agencias de extensión del INTA.

○ Listado de asociaciones de cooperativas agropecuarias.

○ Listado de productores registrados en el SENASA.

- Listado de clientes de empresas consignatarias de ganado.

○ Listado de productores de las sociedades rurales.

- Datos provenientes de la sección "Estructura laboral" de las encuestas efectuadas a los agentes laborales.

- Informe de los delegados de las agencias regionales de la UATRE, sobre variación numérica de los asalariados rurales.

- Datos provenientes de informantes claves.

- Con respecto al desempeño socio-económico de los agentes productivos, donde procuramos indagar especialmente sobre la capacidad económica y situación social por la que atraviesa el campo de la región, los indicadores que utilizamos provienen de diferentes fuentes, como:

- Datos provenientes de los Censos Nacionales Agropecuarios 1988 y 2002:

- Tipos de uso de la tierra, a nivel provincial y del sur de Córdoba.

- Superficie implantada por grupos de cultivos, a nivel provincial y del sur de Córdoba.

- Cantidad de cabezas de ganado bovino, a nivel provincial y del sur de Córdoba.

- Datos provenientes de la Secretaría de Agricultura, Ganadería y Alimentación, Subsecretaría de Agricultura, de la provincia de Córdoba:

- Superficie sembrada de los totales de cereales y oleaginosas, período 1988-2010, de la provincia de Córdoba y del sur de Córdoba.

○ Producción obtenida de los totales de cereales y oleaginosas, períodos 1988-2010, de la provincia de Córdoba y del sur de Córdoba.

○ Total de cabezas de ganado bovino 2005-2010 de la provincia de Córdoba y del sur de Córdoba.

- Datos provenientes de las secciones "Estructura familiar" y "Estructura socioeconómica" de las encuestas efectuadas a los agentes laborales. 
- Información proveniente de diversas empresas acopiadoras y agroindustriales de la región.

- Información estadística general de la Secretaría de Agricultura y Ganadería de la Nación.

- Información periodística especializada en temas agropecuarios.

- Información especializada de las agencias de extensión del INTA de la región.

- Con respecto a la situación económica de los agentes laborales, cuya calibración es de vital importancia, acudimos a la utilización de diferentes indicadores, como:

- Datos fundiarios provenientes de los Censos Nacionales Agropecuarios 1988 y 2002: ○ Cantidad y superficie de las EAPs, por escala de extensión, a nivel provincial y del sur de Córdoba.

- Cantidad y superficie de las EAPs, por tipo jurídico del productor, a nivel provincial y del sur de Córdoba.

- Distribución y cantidad de las EAPs, por regímenes de tenencia de la tierra, a nivel provincial y del sur de Córdoba.

- Datos provenientes de las asociaciones gremiales de los agentes laborales:

- Información directa -y a través de publicaciones- proveniente de representantes de la Federación Agraria y de las Sociedades Rurales locales, dependientes de la Confederación Rural Argentina.

- Información directa -y a través de publicaciones- proveniente de representantes locales de la Unión Argentina de Trabajadores Rurales y Estibadores (UATRE).

○ Información directa -y a través de publicaciones- proveniente de representantes de la Federación Argentina de Contratistas de Maquinaria Agrícola (FACMA).

- Datos provenientes de la sección "Estructura socio-económica" de las encuestas efectuadas a los agentes laborales.

- Información brindada por referentes claves.

- Información aportada por las agencias de extensión del INTA de la región.

- Con respecto a los patrones culturales que inciden actualmente en la población del campo, los indicadores que utilizamos son los siguientes: 
- Datos provenientes de la sección "Estructura socio-económica", especialmente del ítem "Nivel educativo" del grupo familiar, de las encuestas efectuadas a los agentes laborales.

- Informes de becarios sobre las "materialidades culturales" observadas en los trabajos a su cargo, en el tratamiento de los paisajes agrarios de la región.

- Informes brindados por referentes claves.

- Publicaciones de diverso origen, que brindan algún tipo de referencia cultural -sobre tradiciones, vivencias, costumbres de uso- de la región.

\subsection{Metodología}

El presente proyecto consiste, básicamente, en un trabajo empírico, con un fuerte desarrollo en el plano de la investigación de campo, combinado con estudios sobre el tema y análisis teóricos, a fin de permitir la ampliación y comprensión más cabal de la micro-realidad que envuelve e incide en los fenómenos específicos que interactúan en el área de estudio.

En este sentido, en el esquema metodológico general de base dialéctica analógica -como ya especificamos más arriba-, seguimos una marcha deductiva, desde los marcos referenciales generales al análisis de los aspectos específicos que interactúan en la problemática del presente trabajo. Concomitantemente, en el desarrollo empírico de la investigación, aplicamos un procedimiento progresivo y ascendente, donde encadenamos los diversos fenómenos hasta obtener una vivencia integral de la realidad del área de estudio. Por último, en la búsqueda de las conexiones causales de fondo, que entendemos involucran a los fenómenos analizados empíricamente, prevalece un criterio globalizador, a fin de brindar una explicación a escala macro, más amplia y profunda de la realidad estudiada.

Se procuró proyectar las deducciones y conclusiones obtenidas de nuestra área de estudio, en términos comparativos, al resto de la Región Pampeana, tratando de detectar similitudes y diferencias entre ellas.

Las técnicas estadísticas empleadas y ya mencionadas - con el correspondiente apoyo informático- se basan en los Censos Nacionales de Población y Vivienda de 1980, 1991 y 2001, en los Censos Nacionales Agropecuarios de 1988 y 2002, en datos brindados por la Secretaría de Agricultura y Ganadería de la provincia de Córdoba, y en datos sistematizados de trabajos anteriores obtenidos desde 1992 hasta el año 2000, más información estadística de diferentes fuentes recogida a lo largo de la primera década del presente siglo XXI; las mismas 
permitieron recoger y procesar información demográfica, locacional, económica, laboral y en menor término, por insuficiencia de datos al respecto- social y cultural. Todas estas tareas se llevaron a cabo secuencial y paulatinamente, a medida que fuimos avanzando sobre cada problemática planteada.

El criterio analítico metodológico básico empleado en la investigación empírica continuó con el mismo lineamiento de trabajos anteriores, que consistió en apoyarse en las diez localidades testigos arriba mencionadas, con la idea de obtener de estas pequeñas "unidades territoriales", por una parte, información de detalle como producto de un contacto estrecho con el medio, y por otra, cubrir vacíos de datos que no figuran en los censos ni en las estadísticas oficiales en general. A su vez, cabe acotar que el método que se utilizó para delimitar el espacio rural de cada localidad, consistió en demarcarlo de acuerdo con el "sentido de pertenencia" de la población rural pertinente con el pueblo correspondiente, donde ésta ha establecido la mayor vinculación social y económica respectiva.

La "técnica de campo" desarrollada la utilizamos para obtener y procesar información de primera mano, en lo atinente a los aspectos locacionales, económicos, laborales, sociales y, particularmente, culturales, dado que de esta última dimensión prácticamente se carece de datos oficiales suficientes. Para ello, en primer lugar, llevamos a cabo una serie de encuestas por muestreo, con el propósito de obtener de los actores consultados la información arriba mencionada. Las encuestas abarcaron a casi todos los agentes laborales estudiados y el criterio que adoptamos, de acuerdo con el propósito del trabajo, se inscribe dentro del tipo que se conoce como "encuesta para fines científicos". Con respecto a la selección de la muestra, se optó, en base a nuestras posibilidades, por la forma no aleatoria del tipo de "muestra por cuotas" (Germani, s/f; López, 1978). También acudimos al empleo de "entrevistas sistematizadas" a personas representativas ligadas a las actividades agropecuarias, mediante la confección de diversos "cuestionarios de entrevista", que se adecuaron según las características específicas de los interlocutores a consultar. El objetivo central apuntó a obtener datos específicos e información particularmente vivencial, principalmente del universo que compone la PEA agropecuaria.

Asimismo, para el relevamiento de campo, elaboramos material cartográfico y guías estandarizadas, a fin de volcar en éstas lo observado directamente, la información provista por informantes claves y la documentación histórica recogida, información toda destinada a cuantificar y cualificar variables centrales que ayudaron a construir el marco estructural del trabajo. 
Con la información obtenida a través de las técnicas utilizadas, confeccionamos una base de datos que sirvió de insumo para la aplicación de ciertos programas computarizados que se requirieron en el desarrollo del trabajo. Con dicha información, realizamos también procedimientos apropiados, como volcarla en mapas temáticos, planillas y cuadros síntesis, que la transformaron en parámetros válidos para interpretar la realidad que se estudia.

En síntesis, lo que procuramos conseguir consistió en amalgamar los conocimientos obtenidos a nivel empírico con los provenientes de los estudios de gabinete sobre la temática y análisis teóricos, a fin de elaborar en forma adecuada la estructura y las conclusiones finales de la investigación. 


\section{Capítulo II}

\section{Una mirada geográfica sobre la ocupación y el poblamiento del sur de la provincia de}

\section{Córdoba}

Para centrar adecuadamente el territorio al que hace alusión el título arriba expuesto, conviene destacar que existen diferentes posicionamientos sobre las dimensiones de lo que se conoce como sur cordobés -aparte de los diversos criterios de regionalización existentes, en función del momento histórico al que uno se quiera referir. Es así como tenemos un amplio sur provincial o "sur ampliado", o "sur histórico" (Mapa $\mathrm{N}^{\mathrm{0}}$ 3), a partir del río Tercero hacia el sur y sin límites definidos en su extremo meridional, desde el período colonial hasta muy avanzada la segunda mitad del siglo XIX. La población, bajo el dominio de la colonia y luego bajo los gobiernos del período independiente, no se extenderá más allá del río Cuarto y, recién a fines de la década de 1860, se va a expandir muy lentamente hasta el río Quinto. Estos cursos fluviales servían de puntos de referencia y de apoyo a la frontera interna que atravesaba la provincia, apuntalada a lo largo de su recorrido por una línea de fortines. Más allá -en dirección al sur-, empezaba el dominio de las comunidades indígenas. Por lo tanto, el poder político efectivo de los gobiernos de turno llegaba solamente hasta estos ríos.

Después de la campaña del desierto de 1879, este amplio espacio que, desde 1815, estaba dividido políticamente en los departamentos Río Cuarto (Mapa $N^{o}$ 4) y Tercero Abajo (Mapa $\mathrm{N}^{\circ}$ 5), vemos que, en lo que respecta al viejo Dpto. Río Cuarto y las jurisdicciones que surgen de su fraccionamiento, se empiezan a diferenciar, por un lado, de los departamentos ubicados al este provincial -departamentos Unión y Marcos Juárez-, cuyas conexiones socio-económicas están más ligadas al corredor Rosario-Córdoba y con fuertes nexos con la provincia de Santa Fe, y por el otro, del sector norte de este amplio sur original -departamentos Tercero Arriba y General San Martín-, que va a quedar integrado al grupo de departamentos del centro provincial, cuyos vínculos están más ligados a la ciudad capital.

Con el paso del tiempo y hasta el presente, de acuerdo con nuestra caracterización, el sur de referencia original -"sur ampliado"- se contrae a un sur más restringido, actual "región sur" propiamente dicha de la provincia de Córdoba, o "sur cordobés", conformado por los siguientes cuatro departamentos: Río Cuarto, Juárez Celman, General Roca y Presidente 


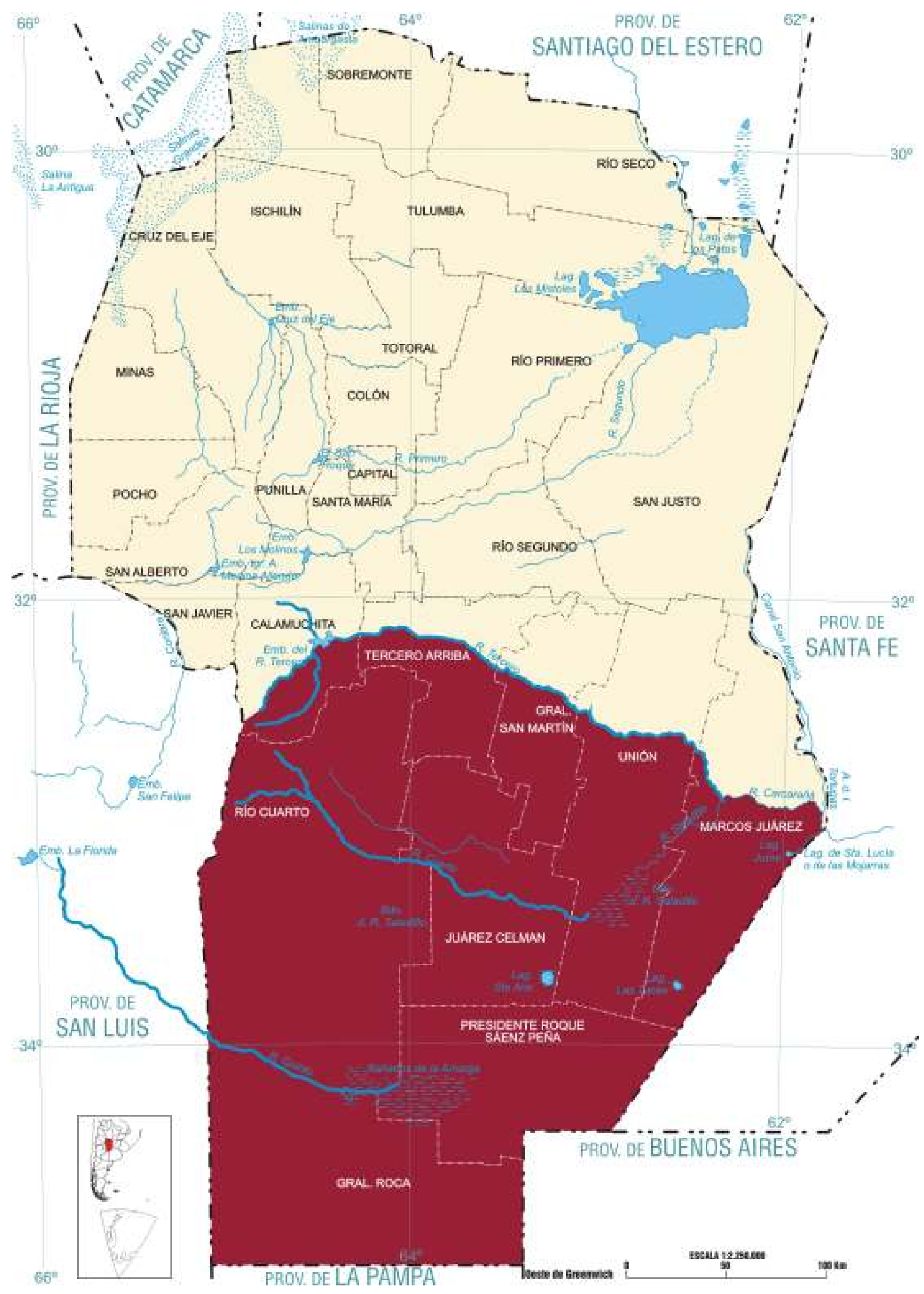

Mapa No 3. Sur ampliado o Sur histórico. 


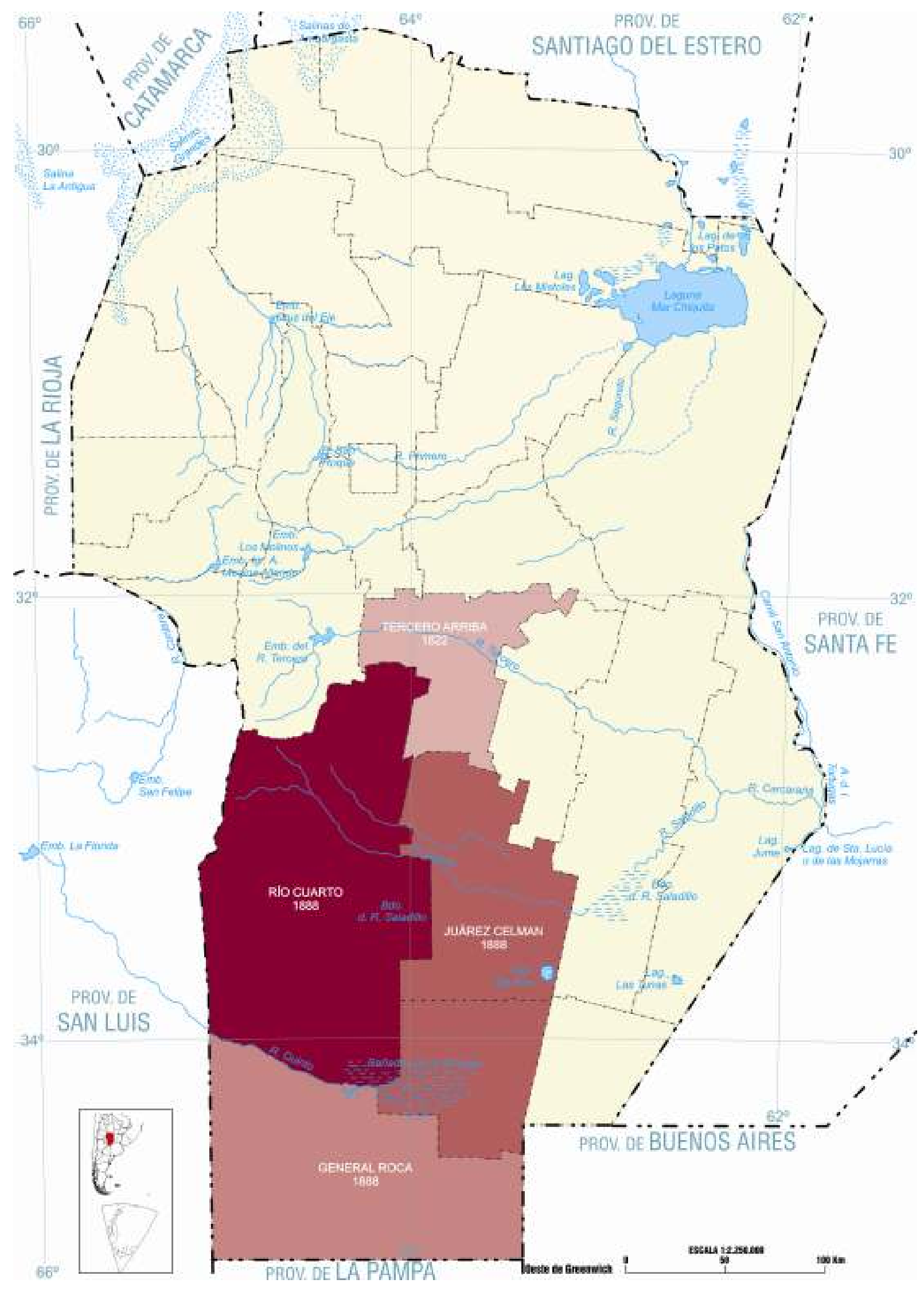

Mapa No 4. Antiguo Departamento Río Cuarto. Año 1815. 


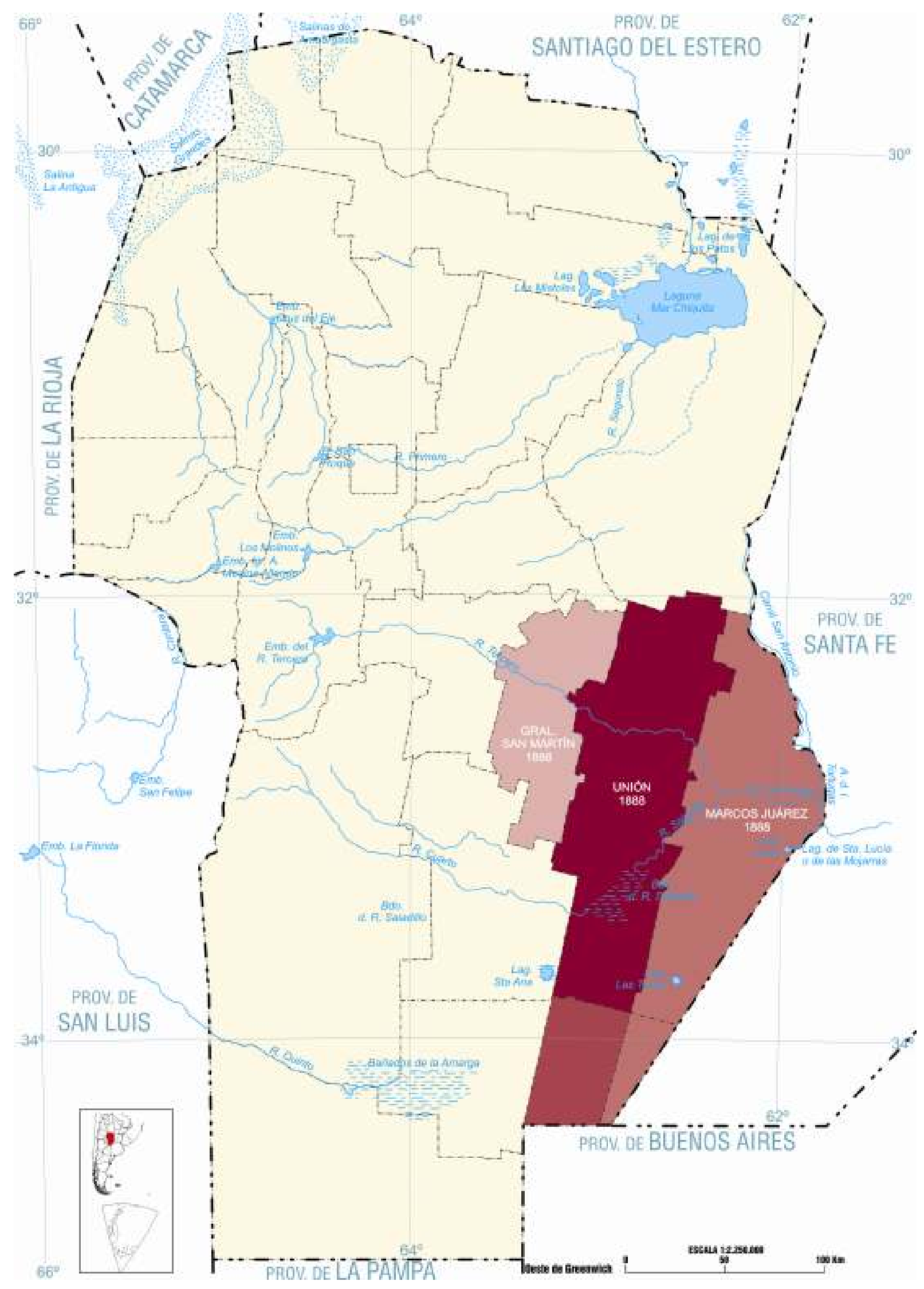

Mapa $N^{0}$ 5. Antiguo Departamento Tercero Abajo. Año 1815. 
Roque Sáenz Peña. Este último fue creado a partir de 1937, como producto del desmembramiento de porciones territoriales de cuatro departamentos que actualmente lo colindan (Mapa No 6). ${ }^{1}$

Si bien esta "región sur", constituida por los cuatro departamentos mencionados, cuyo principal pivote urbano es la ciudad de Río Cuarto, dista de una cohesión ajustadamente armónica -dado el accionar de fuerzas económicas dispersoras-, podemos decir que tiene ciertas características geográficas y productivas en común y que media una articulación en varios aspectos de su quehacer socio-económico.

En suma, en este análisis, se distingue: un "sur ampliado", con una extensión de casi la mitad de la provincia, correspondiente a una Córdoba del período hispano-criollo, y un sur restringido, más pequeño, actual "región sur" propiamente dicha o "sur cordobés", que se empieza a gestar a partir de la expulsión de los indígenas del territorio, pasando a ser ocupado por la clase terrateniente que amplía sus posesiones y por los inmigrantes colonizadores a continuación.

Origen y evolución de la formación política del sur de la provincia de Córdoba, en base a los límites actuales. El territorio provincial, a partir del río Tercero hacia el sur, que denominamos bajo el nombre genérico de "sur ampliado", estaba conformado por los antiguos departamentos Río Cuarto, al oeste, y Tercero Abajo, al este de dicho espacio meridional. El Dpto. Río Cuarto, en el año 1815 -fecha en la que coexistían doce jurisdicciones departamentales a nivel provincial-, comprendía, aparte del actual departamento homónimo, los territorios que hoy constituyen los departamentos General Roca, Juárez Celman, Tercero Arriba y parte de los departamentos General San Martín y Presidente Roque Sáenz Peña. De más está decir que un alto porcentaje de los espacios ubicados al sur de este viejo departamento estaban ocupados por grupos indígenas. En 1822, sufre el primer desmembramiento, al dar origen al Dpto. Tercero Arriba. Luego, en 1888, una ley provincial divide al Dpto. Río Cuarto en tres jurisdicciones: General Roca, Juárez Celman y el propio y actual Dpto. Río Cuarto (Mapa $\mathrm{N}^{\circ} 4$ ).

Por otro lado, el viejo Dpto. Tercero Abajo estuvo integrado antiguamente (1815) por los actuales departamentos General San Martín, Unión y Marcos Juárez. En el año 1860, va a sufrir una partición: el sector oriental del territorio pasa a denominarse Dpto. Unión y el occidental sigue conservando el antiguo nombre de Tercero Abajo, que con el tiempo va a pasar a denominarse General San Martín. Más adelante, en 1888, el Dpto. Unión va a ser dividido, a su vez, en dos partes; el sector occidental va a conservar su nombre y el oriental va a pasar a denominarse Marcos Juárez (Mapa No 5).

Por último, en 1937, por ley provincial, se va a crear el Dpto. Roque Sáenz Peña, con porciones territoriales desmembradas de los departamentos Juárez Celman -el mayor aportante-, General Roca, Unión y Marcos Juárez. Por consiguiente, a partir de ese año, quedan conformados, bajo nuestro criterio geográfico, los cuatro departamentos -Río Cuarto, Juárez Celman, General Roca y Presidente Roque Sáenz Peña- que constituyen actualmente la "región sur" de la provincia de Córdoba, o "sur cordobés" propiamente dicho (ver Mapa $\mathrm{N}^{\circ}$ 6). Con respecto a los otros departamentos arriba nombrados, entendemos, al igual que Terzaga (1963:171), que los departamentos Unión y Marcos Juárez, juntamente con el Dpto. San Justo, constituyen los "departamentos del este" provincial, y los departamentos Tercero Arriba y General San Martín, juntamente con otros departamentos que, en un sentido amplio, se disponen alrededor de la ciudad capital, constituyen los "departamentos del centro" provincial.

Asimismo, cabe especificar que, si bien parte de los territorios de los departamentos Tercero Arriba, General San Martín, Unión y Marcos Juárez desbordan hacia el norte del río Tercero (ver Mapa $\mathrm{N}^{\circ} 3$ ), desde el punto de vista político territorial, a dichos departamentos los incluimos de manera completa dentro del gran espacio que denominamos "sur ampliado". (Fuente: Información extraída del Atlas político de la provincia de Córdoba, editado por La Voz del Interior, 1998). 


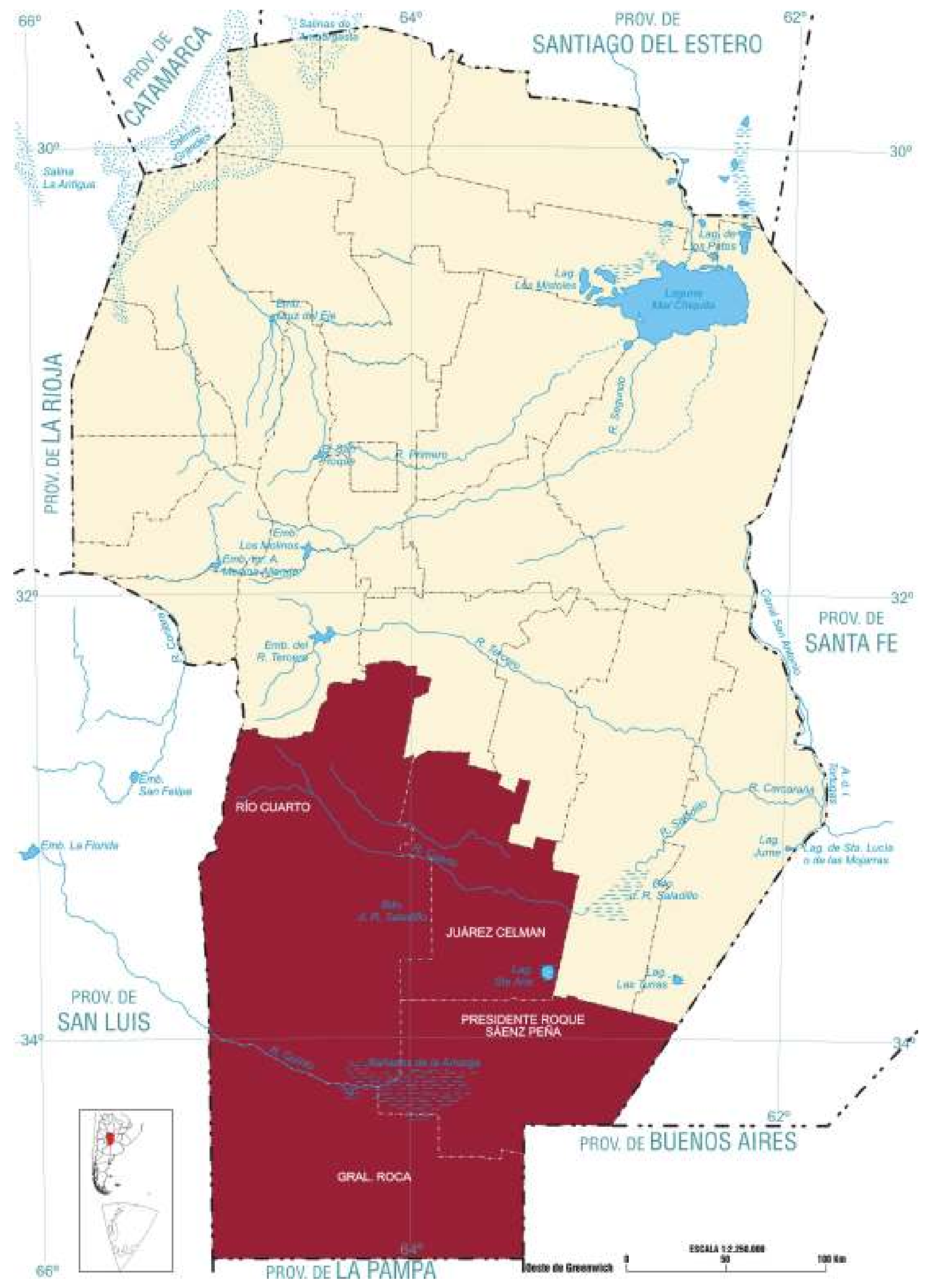

Mapa No 6. Sur cordobés. 
Una vez aclaradas las diferentes escalas en que se puede considerar el territorio que nos interesa, pasamos a analizar con cierto criterio cronológico los hechos y procesos de ocupación más destacables acaecidos en la "región sur", articulándolos con los entornos cercanos y/o lejanos, según la circunstancia del análisis así lo determine.

\subsection{La Córdoba colonial y criolla}

En la provincia de Córdoba, cuya esencia espiritual y económica, desde su fundación por la corriente colonizadora del norte, está representada históricamente por la ciudad capital, vemos que su población hispánica-criolla se asentó, básicamente, primero en la ciudad y sus alrededores, para luego, progresivamente, avanzar sobre el sector serrano, el norte provincial, siguiendo el camino real al Alto Perú, y la llanura circundante al núcleo fundacional. De modo tal que la población de origen europeo y aquella cruzada étnicamente con grupos nativos va a estar distribuida, durante la etapa colonial y hasta mediados de la segunda mitad del siglo XIX, principalmente en el norte, en el oeste serrano y en el centro -la capital y los departamentos “anejos", como se los llamaba- (Ferrero, 1978:19). ${ }^{2}$

El resto del espacio provincial, que corresponde a la llanura pampeana y que se extiende por todo el este y sur de la provincia, ocupando las dos terceras partes de la misma, va a acusar unos tímidos y saltuarios avances de poblaciones criollas a lo largo de los ríos Tercero y Cuarto, como así también hacia la laguna de Mar Chiquita, siguiendo el río Segundo, hasta la localidad de Villa Concepción del Tío. A lo largo de estos ríos, los avances mencionados se apuntalan militarmente mediante la fundación de fortines-pueblos, dando lugar a la conformación de una frontera interna que marca la zona de contacto y confrontación con los diferentes grupos indígenas.

En el este y noreste provincial, tienen presencia las parcialidades indígenas de procedencia chaqueña $\mathrm{y}$, hacia el sur del río Cuarto, la parcialidad indígena ranquelina, “...grupo de origen tehuelche, posteriormente araucanizado..." (Martínez Sarasola, 1992:213), es la que asume una fuerte presencia territorial. Estos grupos indígenas de la llanura, nómades y seminómades, cuyo modo de sustento tradicional se basaba en la caza y que, una vez convertidos en pueblos ecuestres, como por ejemplo los ranqueles, amplían su capacidad de acción para sobrevivir, apelando primero a la captura del ganado vacuno

\footnotetext{
2 No nos debemos olvidar de que la ocupación hispano-criolla de los espacios antes referidos se llevó a cabo principalmente sobre el hábitat del pueblo originario de los comechingones, comunidad sedentaria de aceptable grado de desarrollo civilizatorio que, al contacto y subordinación con el europeo, no pudo resistir esa situación y despareció como grupo étnico.
} 
mostrenco, luego a la práctica de una incipiente ganadería, como así también, según las circunstancias, al acaparamiento de los rodeos vacunos de la población criolla, se distinguen porque nunca se van a subordinar al "blanco" y van a asumir como reacción defensiva de su territorio el papel de pueblos guerreros, peleando desventajosamente, hasta el exterminio sistematizado de sus comunidades.

En este sentido, cabe la reflexión de Terzaga, cuando dice “...si estos pueblos no pudieron acaso haberse integrado en la sociedad y en la economía desarrollada por los criollos" (Terzaga, 1963:100). Es de lamentar -dado el grado de ductilidad social que demostró, por ejemplo, el grupo ranquelino, al absorber e incorporar los aspectos ventajosos que brindaba la "civilización" del momento- la falta de claridad y la mentalidad prejuiciosa de los gobiernos de esa época, por no haber intentado acordar una incorporación social progresiva de estas parcialidades indígenas, sin desalojarlas, y condenarlas al ostracismo. Pero, indudablemente, la ambición desmedida y encubierta del "blanco pudiente" por la incorporación de nuevas tierras a su patrimonio primaba sobre la posible política de integrar paulatinamente al "salvaje" - de acuerdo con la concepción de la época- a la comunidad nacional.

Por otra parte, queremos acotar que, cuando se trata de caracterizar la ocupación del espacio geográfico argentino, y en este caso la llanura cordobesa dentro de la Región Pampeana, aparece el término de "desierto", que hace referencia no a la aridez de sus tierras, sino a su vacío poblacional, a su falta de ocupación civilizada. Surge así y se instala el falso concepto de "espacios vacíos", como lugares carentes de población o, a lo sumo, ocupados por pueblos salvajes, que no merecen ser considerados como dueños de la tierra que pisan. Obviamente, este falso concepto representa un posicionamiento claramente etnocéntrico por parte de las fuerzas políticas dominantes de turno, que utilizan como excusa esta idea de "vacío espacial" de "tierras sin dueño civilizado", para ocuparlas a su arbitrio en el proceso de expansión territorial que dichas fuerzas han planeado llevar a cabo. Cabe recordar que éste fue el proceder de todos nuestros gobiernos independientes, antes y después de 1853, hasta la ocupación definitiva del "desierto", mediante la campaña militar de 1879. En este contexto, está inserta la llanura cordobesa y, por ende, el sur cordobés, espacio de análisis de este trabajo.

En esta Córdoba colonial y criolla, un aspecto de índole político-territorial interesante de destacar es la existencia, en su llanura, de la inestable y reducida franja espacial (Mapa $\mathrm{N}^{\mathrm{o}}$ 7) bajo el dominio relativo de los gobiernos respectivos, que permitía conectar el litoral con el centro - ciudad de Córdoba y zonas aledañas- y norte del país. Esta franja de tierra estaba 


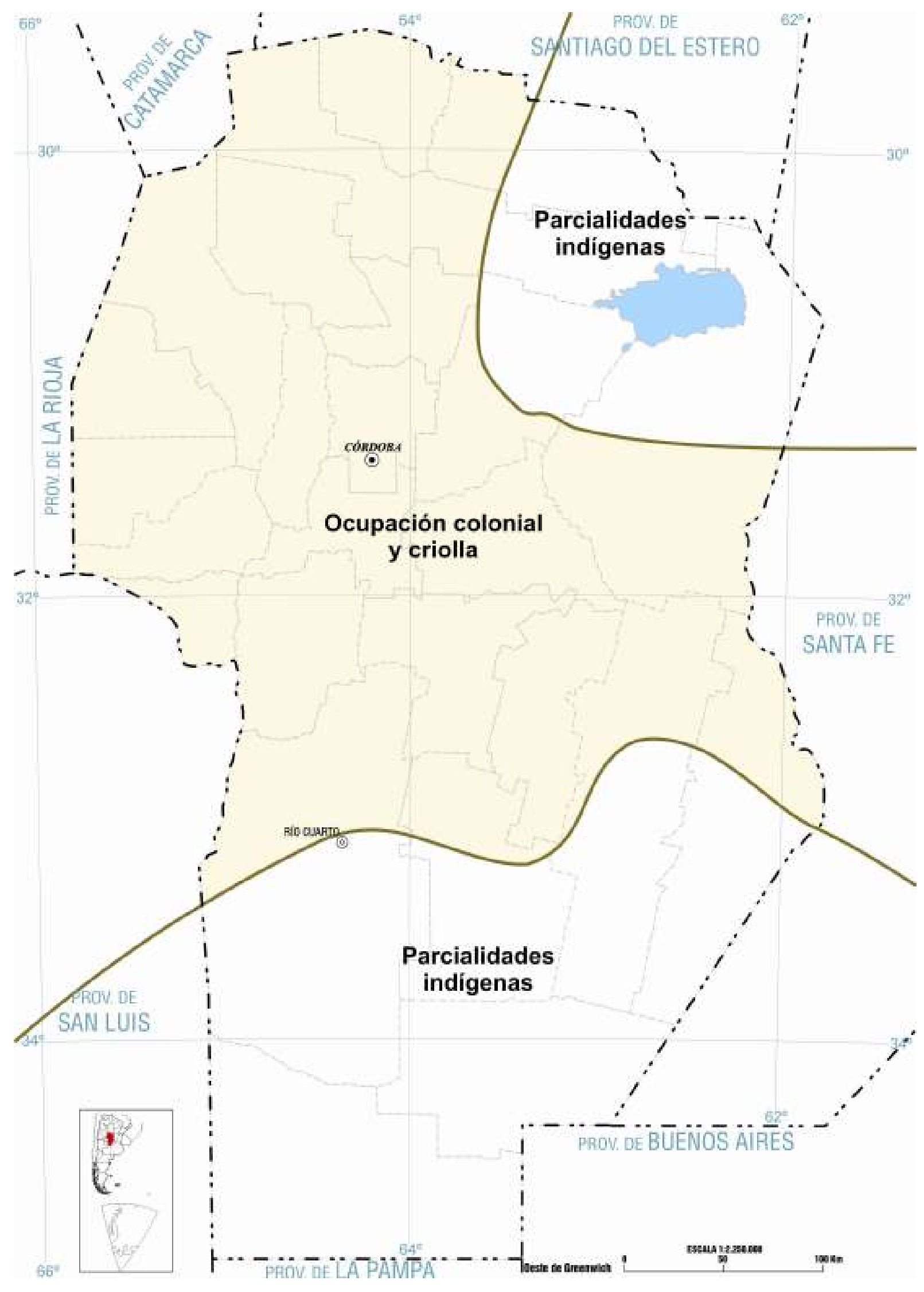

Mapa $\mathrm{N}^{\mathrm{o}} 7$. Ocupación de la población colonial y criolla. 
asediada al noreste por parcialidades indígenas -como ya lo dijimos- de procedencia chaqueña $\mathrm{y}$, hacia el sur, por parcialidades pertenecientes a los grupos ranqueles. La disposición de esta lonja de tierra, de ancho fluctuante, de acuerdo con cada momento histórico, indica, por un lado, la debilidad ocupacional de la planicie pampeana durante trescientos años y, por otro, la diferencia sustancial que media entre los dominios formales de la corona española y, luego, de los gobiernos patrios, expresadas en los mapas, y los dominios territoriales reales en manos de los mismos.

Esta reducida franja territorial "blanca", que conecta a escala nacional al litoral con el interior del país -en el caso de la llanura cordobesa- en su límite sur se mantiene de manera no consolidada, desde fines de la época colonial hasta muy avanzado el siglo XIX -siguiendo gran parte del curso del río Cuarto-, mediante el apuntalamiento -especialmente por obra del gobierno del Marqués de Sobre Monte- de fuertes como Achiras, Sampacho, Río Cuarto, La Carlota, etc.

En concreto, hasta las décadas de 1860-1870, aproximadamente, Córdoba conserva básicamente sus características criollas, pero progresivamente se empiezan a percibir ciertos cambios estructurales, en consonancia lógica con los nuevos sistemas socio-económicos que imponen los gobiernos centrales, a partir de la definitiva organización nacional.

La clásica economía cordobesa como proveedora del mercado interno, con producción de ganado mular y su industria artesanal de calidad reconocida (Ferrero, 1978), empieza a menguar de manera ostensible ante la competencia librecambista del litoral y el desplome de la demanda proveniente del Alto Perú -vigente ya desde hace tiempo-.

Básicamente, la población y los recursos económicos siguen concentrados en el norte, oeste y centro provincial, expandiéndose paulatinamente por el borde de la llanura cordobesa que se sitúa al este y sur de la capital, de modo que se va incrementando lentamente un avance demográfico territorial hacia estos puntos cardinales, mediante el asentamiento progresivo de estancias.

El "sur ampliado" de Córdoba, hasta fines de esta época, como dijimos más arriba, comprende toda la llanura que se extiende al sur del río Tercero, con frontera interna apoyada sobre el río Cuarto. La población criolla que, con base económica en la ganadería extensiva, se distribuye en la franja de tierra que media entre estos dos ríos, con un incipiente desplazamiento hacia el río Quinto, se localiza de manera muy dispersa, pero concentrada en muchos casos alrededor de los fortines, luego transformados -en ciertas circunstancias- en pequeños poblados. La población de todo este sur provincial va a reunir, para esta época, muy pocos habitantes (10.995), destacándose el viejo fuerte y Villa del Río Cuarto, de 5414 
habitantes (Cimminelli, 1999/2000), la única población del área que para la fecha (1869) se puede considerar como verdadero centro urbano.

\subsection{Acontecimientos significativos al inicio de la colonización agraria}

Un hecho de trascendencia capital se empieza a corporizar en el transcurso de la década de 1860, y no es otro que el tendido de la vía férrea Rosario-Córdoba. La gestación de este ferrocarril, denominado Central Argentino, se inicia mediante un acuerdo entre el gobierno de la Confederación Argentina y empresarios privados británicos, en 1855, pero dicho emprendimiento toma forma definitiva una vez consolidado el gobierno nacional, a partir de 1863. Es el primer tendido de vías férreas interprovincial que penetra en el interior del país y las acciones que desencadenan son múltiples. Es interesante resaltar que, en este convenio, se acordó un leonino contrato a favor de la empresa ejecutora, donde el Estado, como bien dice Scalabrini Ortiz (2006), tuvo que aportar ingentes recursos públicos. Valga como ejemplo el conocido otorgamiento por parte de las provincias de Córdoba y Santa Fe de una prima de una legua de tierra a cada lado de las vías y a lo largo de poco menos de cuatrocientos kilómetros, lo que implicó para el Ferrocarril Central Argentino un beneficio de 346.727 ha. a su favor.

En concreto, este ferrocarril penetra en territorio cordobés en 1863, llega a Villa María en 1867 y arriba por fin a Córdoba en 1870. Más allá del progreso, sesgado por los intereses especulativos que persigue la empresa, no cabe la menor duda de que su irrupción en la provincia representó objetivamente toda una revolución de múltiples efectos, tanto en el sentido de los medios de comunicación -recordar que su avance venía acompañado por el telégrafo-, como en el menor tiempo de recorrido e infinita mayor capacidad de carga en relación con el transporte de tracción a sangre, como así también en el sentido clásico de sembrador de poblaciones y asentamientos agrícolas a lo largo del recorrido de sus vías, con la lógica ventaja, a posteriori, de darle salida en sentido descendente a la producción que se generaba. Pero estas últimas transformaciones del accionar ferroviario como modificador del paisaje no se dio tempranamente en el caso del Ferrocarril Central Argentino. Tuvieron que pasar muchos años para que la inmigración, colonización y formación de pueblos se conformara a lo largo de sus vías. A pesar de que esta compañía contaba con una empresa subsidiaria, denominada “Compañía de tierras del Central Argentino", encargada de la colonización y venta de las tierras que gratuitamente, en su momento, le otorgó el gobierno, una serie de intereses especulativos particularmente orientados a la espera de un incremento cada vez mayor del valor de la tierra, desviaron por mucho tiempo la voluntad pobladora por 
parte de la compañía. De todos modos, queda claro que, a través de este ferrocarril, se empieza a abrir una brecha a la colonización agraria cordobesa.

Otro tanto pasó con el Ferrocarril Andino, como se explica a continuación. Un importante emprendimiento se empieza a pergeñar a partir del incipiente pueblo de Villa María, que consiste en considerar a éste como punta de rieles del tendido de una red ferroviaria que, pasando por Río Cuarto, Villa Mercedes y San Luis, llegara al corazón de la región de Cuyo, o sea, a Mendoza y San Juan. Dicha idea empieza a tomar forma y se inicia su construcción en 1871, pero con la particularidad de que este emprendimiento va a estar a cargo del Estado y su implementación dirigida y organizada -luego de algunas dubitacionestotalmente por ingenieros argentinos (Scalabrini Ortiz, 2006). Esta línea parte en diagonal hacia el sudoeste $\mathrm{y}$, al cruzar el río Tercero, va a ser el primer ferrocarril que ingresa propiamente al sur histórico cordobés. Vemos que, en un tiempo prudencial, llega a Río Cuarto en 1873, y a Villa Mercedes (San Luis) en 1875.

Aquí también se va a reproducir el fenómeno de que entre el tendido de vías y la formación de pueblos y colonias agrarias, van a mediar muchos años. En este caso, cuando se termina el tramo entre Villa María y Río Cuarto, solamente "se establecieron dos estaciones del ferrocarril, Dalmacio Vélez y General Cabrera, y durante muchos años la colonización no prosperó" (Lucero, 1999:105). Se deberá esperar hasta principios de la década de 1890 para percibir el verdadero poblamiento de esta franja de tierra orientada en diagonal hacia el sudoeste provincial. Es indudable que el tendido de una vía férrea no implica -a pesar de lo que creen algunos- que detrás del mismo, automáticamente, deviene el poblamiento y, por ende, la explotación inmediata de la tierra. Si bien el ferrocarril oficia de "punta de lanza" en el avance sobre el territorio, no cabe la menor duda de que debe mediar también una articulación entre poblamiento, disponibilidad de tierras y planes de colonización agraria, todos factores interactuantes en teoría, que no siempre se movilizan al unísono.

En los dos casos de referencia arriba citados -del Ferrocarril Central Argentino y Ferrocarril Andino-, más allá de los intereses específicos y factores coyunturales, que aletargaron la colonización a lo largo de sus vías, es indudable que incidió también la precariedad económica y la falta de experiencia colonizadora de parte de los gobiernos provinciales cordobeses de turno.

Paralelamente, al tiempo del avance ferroviario de estas dos líneas mencionadas -décadas de 1860 y 1870-, los gobiernos provinciales de Córdoba, un poco como reflejo del exitoso proceso colonizador santafesino -aunque este proceso distaba de ser perfecto-, iniciado a fines de 1850 , se disponen a emular esta experiencia apelando a la venta de tierras fiscales. Con 
este proceder, amén de procurar atraer la inmigración y el asentamiento de colonias agrícolas, se procura, asimismo, reunir fondos para paliar el déficit crónico de las arcas fiscales.

Son varias las propuestas de colonización que ofertan empresarios colonizadores al gobierno de Córdoba, sin poderse concretar cabalmente ninguna de ellas. En paralelo a esta situación, el gobierno provincial saca a remate tierras públicas en forma de "suertes" de estancias, en varias ocasiones. De modo tal que hay un crecimiento del latifundio -lo que implica una expansión de los ganaderos- en toda la periferia habitable de la llanura cordobesa. Estos nuevos latifundios se van a establecer especialmente en el sudeste provincial -antes del tendido ferroviario del Central Argentino-, siguiendo el río Tercero, donde estancieros porteños y británicos van a comprar grandes extensiones de tierra. Otra situación parecida pasa con las estancias riocuartenses, que empiezan a desplazarse hacia el río Quinto -décadas de 1870-1880 - mediante la compra de colosales extensiones de tierras públicas. Dentro de este grupo de terratenientes riocuartenses se destaca el que en su momento fue gobernador de Córdoba, don Ambrosio Olmos, cuyas seis estancias de la zona "totalizaban la fabulosa cifra de 300.000 ha" (Ferrero, 1978:153).

Por fin, el gobierno provincial, en procura de lograr una ocupación racional de la porción de la llanura pampeana que le corresponde, promulga lo que se conoce como "la primera ley de colonización", de 1871. Los aspectos centrales que establece son los siguientes:

- Dispone de 200 leguas fiscales para radicar la inmigración espontánea.

- Establece una ayuda oficial de cien pesos fuertes para semillas e instrumentos de labranza a cada colono.

- Las chacras se entregarán gratuitamente, con la única condición de residir tres años seguidos en ellas.

- Libera a los adjudicatarios de todo impuesto provincial por cinco años (Ferrero, 1978).

Si bien esta ley tendió a mejorar el orden y aprovechamiento de la tierra pública, el déficit crónico del tesoro provincial no ayudó como se esperaba al desarrollo colonizador.

No obstante, un año antes de la promulgación de la citada ley, o sea en 1870, se funda la primera colonia, Tortugas, en territorio cordobés, ${ }^{3}$ en el límite con la provincia de Santa $\mathrm{Fe}$, operación llevada a cabo por la Compañía de Tierras del Ferrocarril Central Argentino. Luego, en 1873, tiene lugar la fundación de la segunda colonia, Marengo Monferrati, en las

3 Años más tarde: "Un fallo de la Suprema Corte, en 1882, que fijó los límites entre ambas provincias, dejó luego gran parte de la colonia y la planta urbana al este del arroyo Tortugas, vale decir, en jurisdicción de Santa Fe" (Ferrero, 1978:49). 
cercanías de Villa María, y responde también a un emprendimiento particular con apoyo provincial. Por último, dentro de este período inicial, la provincia funda dos colonias oficiales: Sampacho, en 1875, al sudoeste de Río Cuarto, sobre la línea del Ferrocarril Andino, y Colonia Caroya, al norte de la ciudad de Córdoba, en el Departamento Colón. Más tarde, en 1877, debido a la imposibilidad por parte de la provincia de sostenerlas económicamente, pasan a jurisdicción nacional. Corresponde resaltar que, luego de una serie de avatares, que sus respectivos colonos lograron superar, se van a convertir en dos prósperos asentamientos agrícolas.

En suma, hasta 1876, "no había más que cuatro colonias, dos particulares y dos oficiales" (Ferrero, 1978:59) y, si bien el grueso de los inmigrantes pobladores eran de origen italiano, el aporte de extranjeros a la provincia era bien modesto.

Todavía en estos años transicionales de una Córdoba tradicional a otra gringa, va a persistir la influencia criolla en el quehacer provincial. Como bien lo puntualizan Terzaga (1963) y Ferrero (1978), dentro de la estructura social provincial, el sector dirigente va a estar en manos de una clase ganadera, dueña de la tierra en el sentido de grandes extensiones. A su vez, para la fecha de referencia, la oligarquía mandante responde a una orientación política liberal, con un criterio progresista de dar impulso a todos los factores económicos con que cuenta la provincia. Obviamente, en consonancia con la política nacional del momento, la riqueza potencial que se debe aprovechar pasa por la explotación agropecuaria de la llanura agraria cordobesa, ${ }^{4}$ acompañada por el poblamiento inmigratorio y el tendido ferroviario. Claro que la puesta en marcha de este propósito no es fácil de implementar, y en esas pruebas y errores del accionar político transcurren los años a que hacemos alusión.

Como contrapartida, en el otro extremo de la escala social, encontramos al criollo en el papel de peón de estancia, puestero, fortinero y, en el mejor de los casos, en el rol de pequeño productor serrano o dueño de un reducido rodeo en la llanura circundante. Por otra parte, la clase media -también predominantemente criolla- apenas se insinúa en los incipientes centros urbanos, aparte de la ciudad capital, de por sí escasamente poblada para la fecha -34500 habitantes en 1869-, representada por la pequeña burocracia, comerciantes y profesionales.

En suma, así era la llanura cordobesa en los años previos a la irrupción masiva de la colonización agraria. "Una mezcla de la Argentina tradicional y de las embrionarias formas capitalistas que se desplazaban desde el puerto hacia el interior" (Ferrero, 1978:35).

\footnotetext{
4 Las jurisdicciones políticas de la "llanura agraria cordobesa", según Ríos y Achával, correspondían a nueve departamentos que luego, con la creación, en 1937, del Dpto. Roque Sáenz Peña, llegan a diez. Éstos son: Río Segundo, Tercero Arriba, General San Martín, San Justo, Unión, Marcos Juárez, Río Cuarto, Juárez Celman, General Roca y Presidente Roque Sáenz Peña.
} 
Por último, resulta significativo destacar un aspecto de índole natural, que se atribuía a la llanura cordobesa. El mismo consistía - comenta Ferrero (1978)- en el concepto errado de la clase dirigente de la época - hasta principios de 1880- de considerar que la llanura provincial no podía ser cultivada sin riego - “tierra seca", le llamaban-. Sin duda, influyó la opinión del científico Burmeister, integrante de la "Academia de Ciencia de Córdoba", que descalificó esas tierras como aprovechables sin el aporte de riego. Pero posiblemente se deba tomar en cuenta también la influencia de la tradición del uso del riego para los cultivos de granos en las viejas áreas pobladas de las sierras y en el piedemonte respectivo.

En este sentido, es digno de resaltar - para la época- el desconocimiento geográfico general del territorio provincial, cuya acentuada falencia se prolongó hasta la aparición, en 1905, de la excelente Geografía de la provincia de Córdoba, de Manuel Ríos y Luis Achával, dos destacados ingenieros civiles a quienes el gobierno provincial les encomendó la elaboración de dicho tratado. Esta obra cubrió brillantemente los serios vacíos informativos atinentes a la provincia. A pesar de ello, siguió persistiendo en muchos aspectos el desconocimiento de espacios más restringidos, referidos sobre todo a los factores naturales, como el clima, el suelo y la topografía. A ello se sumaban las limitaciones e imperfecciones catastrales -superadas lentamente- que, en conjunto, se traducía, en muchos casos, en la asignación de tierras públicas por parte del gobierno, sin haber sido previamente exploradas y mensuradas debidamente, con las lógicas consecuencias litigiosas de superposición catastral de lotes de diferentes dueños y, en otros casos, la vaguedad en los límites perimetrales de los campos asignados.

\subsection{Consolidación de la inmigración y colonización agraria en la llanura cordobesa}

Como aclaramos al principio de este capítulo, para un análisis comprensible de nuestra área específica de trabajo -sur de la provincia de Córdoba-, hay que partir del estudio integral de la llanura cordobesa donde este "sur" se encuentra inserto.

Ahora bien, se puede decir que, a continuación de la etapa anteriormente considerada como de transición, se ingresa paulatinamente, a principios de la década de 1880 , en el período de consolidación del proceso migratorio y colonizador en la planicie agraria cordobesa, que se va a prolongar de manera sostenida hasta principios de la primera guerra mundial. En realidad, esta etapa se inicia con la acción militar conocida como Conquista del Desierto de 1879. Ésta -como se recordará- va a eliminar y echar a la población indígena de casi toda la Región Pampeana, hasta el límite norte de la Patagonia, para luego, años después, 
arrinconar en algunos valles andino-patagónicos a las pocas y diezmadas comunidades indígenas que lograron sobrevivir. En lo que a nuestro tema respecta, este operativo militar terminó de expulsar a la comunidad ranquelina del sur cordobés. El territorio que se incorpora al poder provincial se va a extender desde el río Quinto -donde desde 1870 se había establecido la nueva línea de frontera interna- hasta el paralelo de $35^{\circ}$ de latitud sur, que separa la provincia de Córdoba de La Pampa. Por lo tanto, a partir de 1879, el gobierno provincial dispone de toda la llanura que cae dentro de su jurisdicción para colonizarla. Ríos y Achával consideran al año 1883 -cuando después de muchos esfuerzos, se había logrado establecer cinco colonias en la provincia-: que "desde esa fecha data propiamente la colonización agrícola en el territorio de Córdoba" (Ríos y Achával, 1905:172, T. II), en coincidencia con el ingreso al país de una inmigración masiva de ultramar y con la intromisión progresiva de colonos santafesinos -en proceso expansivo de búsqueda de nuevas tierras-, de origen obviamente extranjero, en el sector oriental de la provincia de Córdoba.

Por otra parte, vemos que para esa época van a coexistir dos tendencias de ocupación territorial de la pradera cordobesa: una, con poblamiento de origen inmigratorio, ligada a la colonización y a la actividad predominantemente agrícola; la otra, con muy poco aporte poblacional, correspondiente a los grandes latifundios -en el sentido dado por sus grandes dimensiones parcelarias-. En este último caso, el trabajador de las estancias es de origen criollo.

En lo referente a los "sistemas de colonización" empleados en la provincia, se puede decir que fueron variando de acuerdo con las circunstancias socio-económico-políticas del momento, pero siempre tomando como punto de referencia el proceso colonizador iniciado en Santa Fe, que precedió en veinticinco años al de Córdoba.

En forma esquemática (Gráfico $\mathrm{N}^{\mathrm{o}}$ 1), podemos resumir los tipos de colonización implementados en: colonización oficial -nacional y provincial- y colonización privada, con el aporte, tanto en la primera como en la segunda, de la inmigración dirigida y espontánea. A su vez, el acceso a la tierra por parte del colono podía ser a nivel de: propietario -obviamente, la instancia que todos buscaban-, mediante el acceso gratuito a la misma, mediante la compra al contado o a través de la compra a plazos de las parcelas, en calidad de arrendatario y de mediero.

Luego, con el tiempo, surge una especie de subgrupo de la colonización privada, denominado "campos colonizados", pero que realmente no responde a esta categoría, dado que no está sujeta a una organización colónica ni se acogía a las leyes de colonización. Simplemente responde al fraccionamiento interno de parcelas que practicaba un terrateniente de su campo, arrendando las mismas a inmigrantes por un tiempo limitado de años, generalmente con la finalidad última y muy conocida de dejar alfalfado el predio antes de retirarse éste del mismo. No 
obstante, a los "campos colonizados", sin ser realmente colonias, se los tuvo en cuenta estadísticamente porque posiblemente, de algún modo, incorporaba inmigrantes al territorio y a la tarea agrícola.

\section{Gráfico $\mathbf{N}^{0}$ 1. Sistemas de colonización}

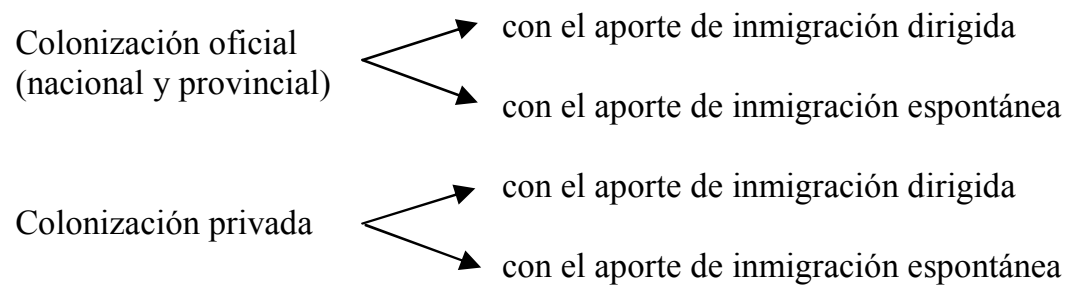

Acceso a la tierra por
parte de los colonos $\left\{\begin{array}{l}\bullet \text { propietarios } \\ \bullet \text { arrendatarios } \\ \bullet \text { medieros }\end{array}\right.$

Fuente: Elaboración propia.

Con relación a cómo se desempeñaron los distintos sistemas de colonización en nuestra llanura agraria, según Ferrero (1978), se puede considerar que, desde 1870 -fundación de Tortugas- hasta 1886, interactuaron tanto la colonización oficial como privada; luego, desde esta última fecha hasta fines de siglo, va a predominar la colonización privada mediante la venta a plazos de la tierra; por último, desde 1900 hasta 1914, se va a instaurar básicamente la colonización privada mediante el arrendamiento de la tierra.

La presente secuencia -esquemática, desde luego- está íntimamente relacionada con la disponibilidad de tierras públicas con que cuenta la provincia en cada momento histórico.

El autor arriba citado se refiere también al desprendimiento descontrolado de las tierras fiscales por parte de los diferentes gobiernos provinciales, durante la segunda mitad del siglo XIX. Con la venta de este bien público se cubrieron los déficit del tesoro, se pagaron favores políticos, se recompensó a militares y se ayudó en parte al proceso de colonización, pero de todos estos múltiples destinos del producto de la venta de tierras fiscales, quien realmente sacó provecho fue la clase dirigente y la oligarquía nacional y provincial -fusionada en los hechos-, que acapararon enormes extensiones de campos en muy pocas manos. En conclusión, hacia 1885, la provincia ya no disponía más de tierras públicas; las había malvendido a todas. Está claro, de acuerdo con las etapas arriba descriptas que, desde mediados de la década del 80 en adelante, en que ya no se cuenta más con tierras físcales, a medida que los campos se fueron encareciendo como producto de la demanda, los dueños de este factor económico, ya sean los terratenientes, compañías ferroviarias o bancos, comprendieron, con un criterio absolutamente especulativo, que el mejor negocio del 
momento era arrendar progresivamente la tierra, sacando el mayor provecho de la renta diferencial que ésta generaba. Especialmente en los departamentos del sur provincial, va a sobresalir esta modalidad de tenencia de la tierra.

Es muy interesante la apreciación de Ríos y Achával, de principios del siglo XX, de cómo se diferencia a simple vista un paisaje rural trabajado por propietarios de otro trabajado por arrendatarios. $\mathrm{Al}$ respecto, comentan:

...las colonias explotadas por arrendatarios sólo presentan como señales de labor la sementera lisa y desierta. No existen en ellas casas, ni árboles, ni ganado, ni indicio alguno revelador de trabajo del hombre permanentemente establecido en un punto del suelo (Ríos y Achával, 1905:178 T. II).

Acompaña, fortalece y apuntala esta etapa de expansión colonizadora la promulgación de dos leyes provinciales y otra a nivel nacional, conocida como Ley Avellaneda. La primera ley provincial, conocida también como Ley de Colonias, promulgada en 1886, es más específica y más completa que la de 1871. Establecía dos tipos de colonias: oficiales y privadas, contemplaba exenciones impositivas y desalentaba el arrendamiento. Más adelante, en 1896, se promulgó una nueva ley de colonias, que llenaba algunos vacíos y perfeccionaba ciertos atributos de la precedente (Cárcano, 1972). En el caso de las colonias oficiales provinciales que pasaron a formar parte de las colonias nacionales establecidas en Córdoba, estaban amparadas por la Ley Avellaneda, promulgada en 1876, bajo el mandato de dicho presidente. Cárcano destaca muy bien que esta ley nacional trata de ordenar un cúmulo importante de leyes y decretos precedentes -especialmente sobre la tierra pública-, sumamente inconexos entre sí y, a su vez, de reunir todas las variantes de sistemas de colonización practicadas hasta esa fecha en la Argentina (Cárcano, 1972). ${ }^{5}$

El presidente Avellaneda, que era un especialista en temas agrarios y admirador de los sistemas americanos, "era un sostenedor convencido y caluroso de la necesidad de levantar la república a base de pequeños propietarios" (Cárcano, 1972:151). De igual modo, las leyes provinciales anteriormente mencionadas procuran también, hasta cierto punto, brindar el apoyo y expansión de los pequeños productores y, si bien los logros alcanzados colaboraron en el afianzamiento colonizador, no pudieron evitar, al mismo tiempo, que la propiedad de la

\footnotetext{
Los sistemas autorizados de colonización de la Ley Avellaneda de 1876 se concretaban de esta forma:

a. Colonización directa por el Estado en territorios nacionales y en tierras cedidas por los gobiernos de las provincias.

b. Colonización indirecta, sirviéndose de empresas particulares en tierras ya mensuradas y divididas, o en lugares que no hubieran sido explorados.

c. Colonización por iniciativa individual.

d. Colonización por los gobiernos provinciales, estimulados por el gobierno de la nación.

e. Colonización por particulares amparados por el gobierno. (Fuente: Cárcano, 1971:154).
} 
tierra siguiera estando en muy pocas manos. Cabe, como ejemplo, destacar que, en plena vigencia de la Ley Avellaneda, continuó la venta despiadada de enormes extensiones de tierras públicas, en que el espíritu especulador se enseñoreó en esa instancia histórica.

Dentro de este proceso que venimos describiendo, está siempre pendiente como omisión grave de parte de la dirigencia de la época, la "no inclusión de la población criolla" - los paisanos- en el núcleo de los planes de colonización agraria. Si bien se los tuvo en cuenta en forma tangencial, como en el otorgamiento de tierras a la soldadesca, sin planificación alguna, en zonas generalmente de frontera o bajo el amparo de la "ley del hogar", de 1884, "introduciendo en cierta forma el homestead americano", que "estaba destinado a los habitantes pobres de la campaña, defensores de la frontera" (Cárcano, 1972:181), pero entregándoles siempre tierras en lugares remotos de los territorios nacionales vigentes en esos años. Lo cierto es que todas estas medidas no sirvieron para equiparar ni de lejos las oportunidades y ventajas que sí se le supo brindar a los inmigrantes de ultramar. Es muy claro el pensamiento de Bialet Massé al respecto cuando, con auténtica indignación sobre el mal estado de la población criolla, expresa que hay que "darle tierra de balde y todavía darle semilla y herramientas; son suyas, es el soberano de la tierra. Que se venda al que viene de fuera, pase; pero al dueño de casa hay que darle lo suyo" (Bialet Massé, 1986:122, T. I).

Se evidencian, así, los profundos prejuicios, por no decir posicionamientos racistas, que median en la dirigencia de esa generación, que si bien se consideraban criollos, entendían que su cepa respondía a una elite de estirpe hispana, diferente al mestizaje existente entre el paisanaje de nuestros campos. La excusa o argumento a esgrimir consistía en que esta población no sabía trabajar la tierra -a diferencia del inmigrante-, por ser eminentemente ecuestre, realidad esta última que era absolutamente cierta, pero que no quitaba que muchos de ellos tuviesen conocimientos rústicos de una agricultura tradicional, como bien lo manifiesta Bialet Massé, cuando expresa: "no se nos diga que el criollo no es agricultor, que no sabe, porque no es cierto; el que no sabe es el inmigrante extranjero" (Bialet Massé, 1986:122, T. I).

Los hechos, a través del tiempo, han demostrado que no hubo razón alguna para haber descalificado y dejado fuera del verdadero proceso de colonización agraria al criollo pobre, que tradicionalmente ha sobrevivido vendiendo su fuerza de trabajo. Adecuando las capacidades intrínsecas de su manejo de lo rural, con las actividades agrícolas extensivas, y mediante una paciente e inteligente política persuasiva, es de suponer que se podría haber sumado y hecho justicia a esta franja social. Pero la realidad de esa época determinó otra circunstancia. 
Lo que sí debe especificarse es que, por más que se hubiese incorporado a toda la población criolla al sistema de colonización -y esto no invalida la crítica precedente-, ésta habría sido numéricamente insuficiente para explotar las extensas praderas pampeanas. Además, como es de imaginar, estaba previsto que el paisano debía cubrir parte de la mano de obra que se requería en el avasallador avance agropecuario del momento.

En nuestro sur cordobés, al paisano criollo, en su rol de diestro peón de inmensas estancias, no le quedaba otra posibilidad que la de quedar encasillado de por vida en ese papel de dependencia laboral.

La evolución numérica de las colonias agrarias de la llanura cordobesa en general y su comparación con la región sur propiamente dicha se representa en el Cuadro $\mathrm{N}^{\circ} 1$. Como se puede observar, a partir del 80 del siglo XIX en adelante, la cantidad de colonias que se van asentando en la llanura se incrementa apreciablemente, para multiplicarse en forma notable en la década de 1890. Incide en este sentido la construcción de nuevas líneas férreas que se expanden por toda la planicie provincial, y que habían quedado estancadas a mediados de 1870. En el caso específico de los departamentos del sur y parte de los departamentos del este provincial, vemos que en un lapso aproximado de quince años se construye, a partir de 1886, al sur del río Cuarto, la línea principal del Ferrocarril Pacífico, que va de Rufino a Villa Mercedes (San Luis), pasando por los futuros pueblos de Laboulaye y Vicuña Mackenna, y en 1891 se termina la construcción de la línea que se extiende desde Villa María a Rufino, pasando por La Carlota, también perteneciente al Ferrocarril Pacífico. ${ }^{6}$

Para el mismo año 1891, el Ferrocarril Gran Sur, procedente de Villa ConstituciónVenado Tuerto, extiende sus vías hasta La Carlota, y unos pocos años antes (1888), el Ferrocarril Oeste de Santa Fe, procedente de Casilda, arriba a Cruz Alta, población ubicada en el límite interprovincial.

A pesar de que no siempre inmediatamente -como ya advertimos en páginas anterioresdetrás del trazado ferroviario surgen las colonias agrarias a su vera, en esta instancia, se puede decir que de manera fluida se fueron poblando los campos a un lado y otro de los rieles, en los actuales departamentos del este -Unión y Marcos Juárez-, colindantes con Santa Fe, con colonos procedentes, en su mayoría, de la vecina provincia. En cambio, según Ferrero (1978), en el sur provincial propiamente dicho, los resultados de la colonización a fines de siglo -1898- fueron más bien magros. Se contaba solamente con doce colonias entre oficiales y

6 Originalmente, la construcción de la línea Villa María-Rufino estuvo a cargo del "Ing. Giovanni Pelleschi y Cía."; luego, pasó a manos de la empresa "Villa María and Rufino Company" y, por último, se incorporó al Ferrocarril Pacífico. 
Cuadro $\mathbf{N}^{0}$ 1. Evolución numérica y demográfica de las colonias agrarias de la llanura cordobesa y de la Región Sur de la provincia

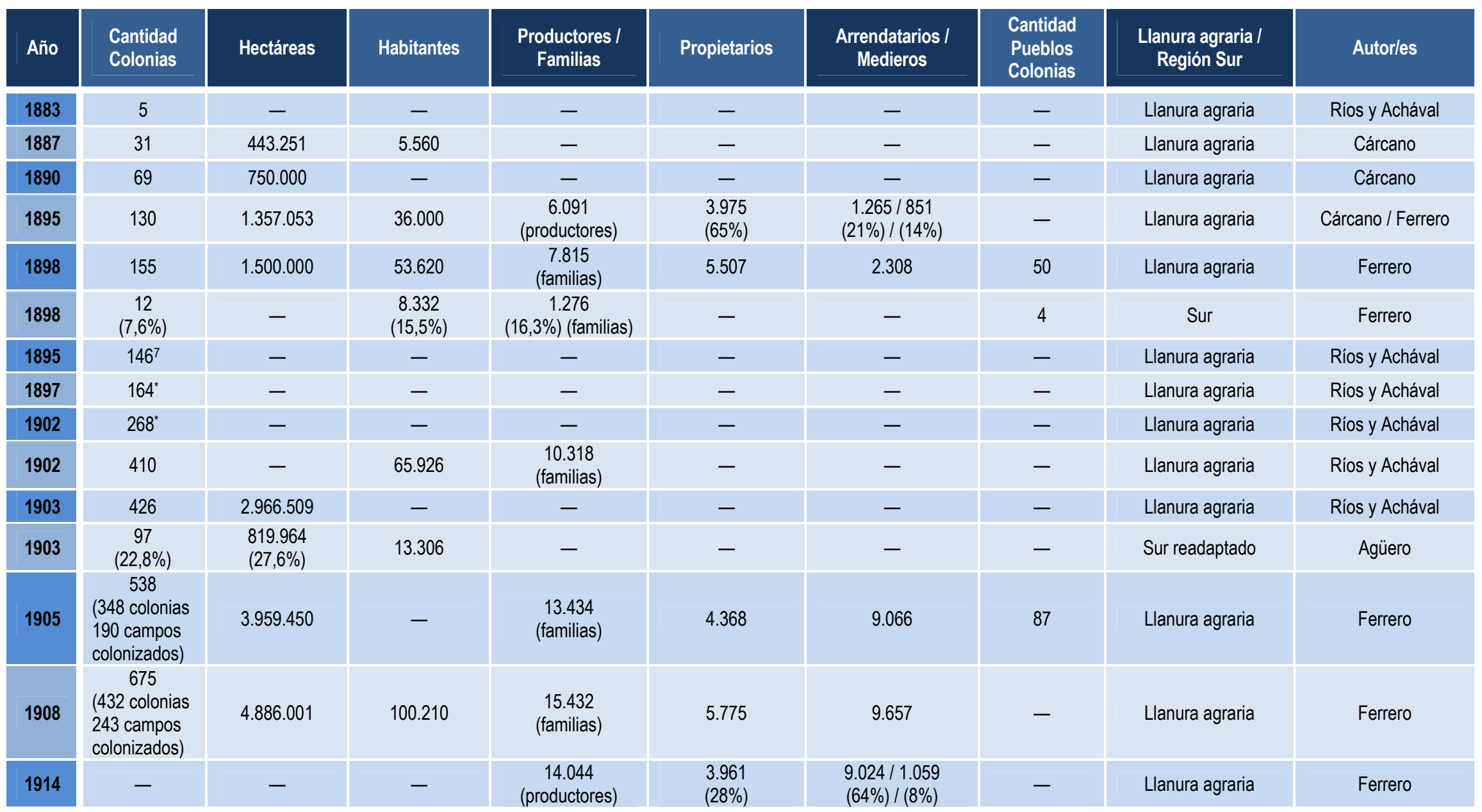

Fuente: Elaboración propia en base a los datos proporcionados por Ríos y Achával (1905), Ferrero (1978), Cárcano (1971). 
privadas, lo que representaba el 7,6\% del total de este tipo de establecimientos existentes en la provincia, y la población de colonos apenas alcanzaba el 15,5\% del total provincial. Evidentemente, todavía quedaban muchos espacios rurales sin ser aprovechados a través de la actividad colonizadora. La predominancia de una ganadería extensiva distribuida en inmensas estancias era enorme.

A partir de principios del siglo XX, es dable observar un crecimiento acentuadísimo del movimiento colonizador en la pampa cordobesa, en consonancia con un nuevo impulso de crecimiento ferroviario en la provincia. En el caso del sur cordobés, podemos mencionar el tramo terminado en 1901 por el Ferrocarril Pacífico, entre Rufino y Buena Esperanza (San Luis), pasando por Villa Huidobro; la prolongación de la línea del Ferrocarril Gran Sur, entre La Carlota y Río Cuarto, concluida en 1902, y la terminación, en 1903, del trayecto ferroviario Firmat-Corral de Bustos-Empalme Chucul-Río Cuarto, construido por el Ferrocarril Central Argentino. Por otra parte, en esta circunstancia, a diferencia de la anterior, sí se verifica un incremento notable de colonias en el sur de Córdoba. Es así como, previa readecuación de la procedencia geográfica de los datos recopilados por Ríos y Achával (1905, T. II), a mediados de 1903, de un total de 426 establecimientos entre colonias y campos colonizados en la llanura cordobesa, que ocupan casi tres millones de hectáreas, le corresponden al sur cordobés, conformado por el espacio que ocupan los actuales cuatro departamentos ya mencionados (Ver Cuadro $\mathrm{N}^{\mathrm{o}}$ 2), noventa y siete colonias y campos colonizados, lo que representa el $22,8 \%$ del total colonizado provincial, guarismo nada despreciable en comparación con el porcentaje obtenido en 1898, sobre todo si se tiene en cuenta que apenas habían transcurrido cinco años.

Cuadro $\mathbf{N}^{\circ}$ 2. Distribución de colonias y campos colonizados en 1903 correspondientes a los actuales departamentos del sur de Córdoba

\begin{tabular}{|l|c|}
\hline \multicolumn{1}{c|}{ Departamento } & Colonias y campos colonizados \\
\hline Juárez Celman & 28 \\
\hline Río Cuarto & 24 \\
\hline General Roca & 17 \\
\hline $\begin{array}{l}\text { Porción territorial ocupada actualmente por el Dpto. Presidente Roque } \\
\text { Sáenz Peña }\end{array}$ & 28 \\
\hline Total & 97 \\
\hline
\end{tabular}

Fuente: Readecuación de datos obtenidos por Ríos y Achával (1905, T. II), en 1903, de acuerdo con la nueva conformación político territorial del sur de Córdoba, a partir de 1937.

En el transcurrir del primer decenio del siglo XX, las colonias y campos colonizados en los departamentos agrarios de la provincia de Córdoba se siguieron incrementando 
sustancialmente $-1905,538$ colonias y campos colonizados; 1908, 675 colonias y campos colonizados- hasta 1914, e inclusive, pero ya con una intensidad menor, hasta un poco después de la finalización de la primera guerra mundial. Si bien carecemos de datos estadísticos después de 1903 del total del movimiento colonizador en el sur de Córdoba, sabemos - por información procedente de diferentes fuentes- que se fundaron numerosas y, en algunos casos, importantes colonias agrícolas, especialmente en el Dpto. Gral. Roca, distrito tradicionalmente ganadero, y en el futuro Dpto. Pte. Roque Sáenz Peña, al unísono del tendido de nuevas líneas férreas, que se extendieron por todos los extremos del territorio sureño, hasta el año 1914, básicamente.

Vemos así que, en el año 1906, el Ferrocarril Pacífico termina la construcción de la línea Vicuña Mackenna-Achiras y la línea Laboulaye-Villa Valeria, y poco tiempo después, prolonga los rieles que llegaban hasta Huinca Renancó, procedente de Bahía Blanca, hasta Villa Mercedes (San Luis). A su vez, el Ferrocarril Central Argentino extiende la línea que antes llegaba a Cruz Alta hasta Río Tercero, terminando de construir dicho trayecto en 1913. A continuación, en 1914, El Ferrocarril Central Argentino por fin termina de unir Río Cuarto con Córdoba, dos ciudades disociadas territorialmente, por diferentes intereses existentes a lo largo de su transcurrir histórico, como bien lo resalta Terzaga, al referirse a la tendencia centrífuga de Río Cuarto con respecto a la capital de la provincia, cuando expresa:

Una de esas razones radica en la configuración de las arterias útiles que atraviesan la provincia desde la época colonial. Viniendo desde Buenos Aires, una dirección conduce hacia el Alto Perú, y la otra derechamente hacia Chile, pasando por Cuyo. En el primer camino se encuentra la ciudad de Córdoba y en el segundo la de Río Cuarto. Semejante bifurcación de tránsito, de comercio, de intereses e influencias, significó también una divergencia entre ambas ciudades, desde el punto de vista de la geografía política (Terzaga, 1996:69).

Después de muchos años, el Ferrocarril Pacífico termina de construir, en 1929, la zigzagueante línea que une Laboulaye con Sampacho, convirtiéndose en el último trayecto ferroviario que se construye en la provincia de Córdoba.

Indudablemente, esta nueva proliferación de líneas férreas, a principios de siglo, coadyuvó eficazmente al incremento poblacional en general, como así también de nuevas colonias y pueblos, imprimiéndole un fuerte impulso socio-económico al postergado sur provincial, aprovechando el usufructo de su naturaleza potencialmente pródiga. Aparecen y se consolidan nuevos centros urbanos de gran dinamismo, al sur de la vieja frontera marcada por el río Cuarto, como Moldes, Adelia María, Vicuña Mackenna, Laboulaye, Huinca Renancó, Villa Huidobro, Villa Valeria, Mattaldi, entre otros más. 
No obstante, una realidad que no debemos perder de vista, a pesar de los éxitos del proceso colonizador -luego de un inicio lento y dificultoso-, con su significativa y consecuente expansión agrícola, es que la distribución de las tierras estuvo lejos de ser equitativa en su fraccionamiento. Siguieron predominando en forma abrumadora, especialmente en el sur provincial, las grandes estancias que se sucedían una detrás de otra, dejando pequeños intersticios de tierra ocupados por las colonias agrícolas y sus respectivos pueblos de referencia en algunos casos. Por otra parte, este fenómeno de asimetría distributiva de la tierra, que se manifestó en toda la Región Pampeana, en el caso de Córdoba, debemos recordar que la disponibilidad de tierras públicas, que tendría que haber sido la base de sustentación de la inmigración colonizadora, se había prácticamente agotado cuando justamente toma impulso el proceso colonizador. Además, como ya dijimos, no debemos confundir las verdaderas colonias agrícolas de los campos colonizados. Éstos eran, en realidad, grandes estancias con su superficie fraccionada en pequeñas parcelas, que servían de refugio provisorio al inmigrante pobre, mientras durase su contrato. Por lo tanto, por extensión, se incluye a estos agricultores en calidad de colonos, cuando realmente no lo eran. En suma, a pesar de que las estadísticas de la época incluían a esta categoría dentro del movimiento colonizador, porque de algún modo sostenían el flujo inmigratorio, en realidad lo que se manifiesta mediante este sistema expoliador es el tremendo peso que detenta el latifundio en esta etapa histórica. Dicho en otras palabras, cuando penetra el grueso de la inmigración colonizadora a la provincia, la tierra ya tenía dueño y el tamaño de las propiedades, en general, era de grandes dimensiones.

En lo que respecta a la forma como se fue proyectando el nuevo poblamiento en la llanura cordobesa, vemos que sufrió una especie de ocupación escalonada, que se introdujo por diferentes puntos cardinales. Antes de la irrupción del Ferrocarril Central Argentino en territorio cordobés -1866-, en todo el sudeste provincial, que luego iba a ser cruzado por esta línea, se asentaron -como ya dijimos- varias estancias de terratenientes porteños e ingleses, cuya actividad central consistía en la explotación de la ganadería ovina. Muchos años después -1886-, iba a ingresar por el flanco oriental de la provincia, procedente de la vecina Santa Fe, una fuerte oleada de colonos de origen inmigratorio, en búsqueda de nuevos espacios para cultivar, aprovechando el menor costo de la tierra. Cabe acotar que este flujo colonizador va a alternar y coexistir en los departamentos Unión y Marcos Juárez -exceptuando San Justo, donde todavía subsistían tierras públicas- con las estancias de grandes dimensiones arriba citadas, cuyas fechas de instalación son anteriores a la referida oleada colonizadora. También corresponde puntualizar que esta afluencia colonizadora de Santa Fe luego se va a derramar, a 
través del paso del tiempo, hacia el interior provincial, expandiéndose por toda la llanura cordobesa. Una vez despejado todo el sur provincial de la presencia indígena, dicho sur va a recibir la irrupción de estancieros cordobeses, que se van a desplazar desde el norte hacia el sur hasta el río Quinto, aproximadamente. Muchos de ellos, ya estaban aquerenciados desde muy antiguo en la frontera del río Cuarto.

Asimismo, las tierras del extremo sur, que pertenecen de forma plena al Dpto. Gral. Roca, van a ser adquiridas en su amplia mayoría por familias de la oligarquía terrateniente porteña, o sea, procedentes de Buenos Aires (Ferrero, 1978). Corresponde agregar que, paralelamente a la ocupación territorial desde los tres puntos cardinales mencionados, también ingresó a la provincia, como es de imaginar, una inmigración, tanto dirigida como espontánea, procedente directamente de Europa.

Por último, podemos remarcar que la característica y diferencia en la colonización del sur provincial respecto del resto de la llanura cordobesa, es que en dicho sur van a predominar -más que en otras zonas de la planicie provincial- las grandes propiedades dedicadas a la ganadería extensiva, poseedoras de un rodeo de inmensas proporciones. Éstas van a dejar un lugar limitado a la intromisión de la colonización agraria, dado que a los poderosos intereses terratenientes no les convenía la apertura agraria, salvo para alfalfar sus campos, razón por la cual, exceptuando las pocas colonias oficiales fundadas en su territorio, el tipo de colonización que va a predominar en el sur es la privada, mediante el sistema de arrendamiento y recurriendo básicamente a la inmigración espontánea.

Una característica de los grandes establecimientos fundados en el sur provincial es el grado de modernidad aplicado en el manejo de los mismos, donde se va a apelar a las mejores técnicas de explotación del momento, bajo criterios de racionalidad capitalista en todo el circuito productivo hasta la comercialización del producto, lo que no quita la coexistencia de estos campos modernos con latifundios en el sentido lato del término, o sea, con propiedades mal explotadas o sin explotar.

A medida que se flexibiliza la resistencia al ingreso pleno del proceso colonizador agrario y se produce la apertura a la inmigración en la llanura del sur, los cultivos que progresivamente se van a implantar son el trigo, el maíz y, especialmente, la alfalfa; esta última en los departamentos de Río Cuarto y Juárez Celman.

Toda esta actividad va a ser impulsada centralmente por el inmigrante colonizador, mayoritariamente de nacionalidad italiana o descendiente de primera generación de italianos, como lo analizaremos pormenorizadamente en el acápite siguiente. 
Finalmente, cabe acotar que el argentino que convive con el colono extranjero se ubica en los dos extremos de la escala social. Por un lado, los terratenientes, y por el otro, el paisano, en el papel de peón rural. Es justamente este criollo proletario el que le va a ayudar al colono a juntar la cosecha, especialmente cuando concluya la inmigración golondrina de ultramar.

\subsection{Evolución de la población por origen y nacionalidad, a nivel provincial, regional y de las colonias agrarias 8}

En el Cuadro $\mathrm{N}^{\mathrm{o}}$ 3, podemos apreciar la evolución del crecimiento poblacional a nivel provincial y del sur cordobés, desde fines del siglo XVIII hasta el último Censo Nacional de Población, de 2001. Se observa, desde el censo de Sobre Monte, de 1795, hasta el de la Confederación Argentina, de 1857, un lento crecimiento provincial, en que los diferentes avatares, como las guerras de la independencia y civiles por los que atravesó el país, más la desarticulación de la economía artesanal cordobesa, contribuyeron a este magro crecimiento demográfico. A partir de 1857, hasta 1869, se observa un incremento poblacional significativo. Pero es a partir del segundo Censo Nacional, de 1895 en adelante, especialmente hasta la década del 60 del siglo XX, que la población de la provincia sufre un incremento notable. Es que en este largo período de sesenta a setenta años se termina de ocupar el territorio provincial y la economía cordobesa construye y consolida su nuevo perfil agro-industrial, que la va a caracterizar a nivel nacional. A partir del censo de 1960, hasta el de 2001, su población sigue creciendo en forma significativa, pero de manera regular, sin acusar sobresaltos, a un promedio de 300.000 habitantes por década, hasta superar los tres millones de personas residentes en la provincia en el último censo mencionado.

En lo que respecta a la región sur, su crecimiento poblacional es más lento que a nivel provincial, y su peso demográfico en relación con el total de Córdoba fluctúa entre un $5 \%$ y $17 \%$, porcentaje más bien bajo, en comparación con las grandes dimensiones que detenta el sur cordobés. Este porcentaje poblacional regional del total provincial al que aludimos repunta notoriamente a partir del primer censo de 1869, hasta el tercero de 1914, en coincidencia con

8 En este acápite, cuando nos referimos a la población y sus magnitudes de la "región sur" de la provincia de Córdoba, nos limitamos, hasta las primeras décadas del siglo XX, al espacio comprendido por los tres departamentos que hasta esa época cubrían el grueso del territorio que hoy consideramos como el sur de Córdoba. Éstos eran: Río Cuarto, Juárez Celman y General Roca. Luego, a partir de 1937, cuando se crea el Dpto. Roque Sáenz Peña, este nuevo departamento pasa a integrar, juntamente con los tres nombrados más arriba -como lo aclaramos en párrafos anteriores-, de acuerdo con nuestro criterio, la actual "región sur" de Córdoba. 
la afluencia inmigratoria a la zona, particularmente con un salto acusado entre 1895 y 1914 . A partir de este hito, esta relación porcentual decrece siempre hasta 2001, dado que el crecimiento demográfico de la región es más bien lento, a diferencia de lo que sucede a nivel provincial, donde la expansión poblacional es mucho más acentuada y constante. En concreto, este ritmo pausado del sur cordobés, al no manifestarse dentro de su territorio actividades industriales de mano de obra intensiva, responde indudablemente al ritmo demográfico que emana de su contexto eminentemente agropecuario.

\begin{tabular}{|c|c|c|c|c|}
\hline Fuente & Año & $\begin{array}{l}\text { Provincia } \\
\text { Hab. }\end{array}$ & $\begin{array}{l}\text { Región Sur } \\
\text { Hab. }\end{array}$ & $\%$ del total provincial \\
\hline $\begin{array}{l}\text { Censo Gobernador } \\
\text { Sobre Monte }\end{array}$ & 1795 & 38.110 & 3.736 & $9,8 \%$ \\
\hline $\begin{array}{l}\text { Censo Gobernador } \\
\text { Bustos }\end{array}$ & 1822 & 76.219 & 4.883 & $6,4 \%$ \\
\hline $\begin{array}{l}\text { Censo Confederación } \\
\text { Argentina }\end{array}$ & 1857 & 137.079 & 6.543 & $4,8 \%$ \\
\hline $\begin{array}{l}\text { Primer Censo } \\
\text { Nacional }\end{array}$ & 1869 & 210.508 & 10.995 & $5,2 \%$ \\
\hline $\begin{array}{l}\text { Segundo Censo } \\
\text { Nacional }\end{array}$ & 1895 & 351.223 & 36.503 & $10,4 \%$ \\
\hline $\begin{array}{l}\text { Tercer Censo } \\
\text { Nacional }\end{array}$ & 1914 & 735.472 & 126.217 & $17,2 \%$ \\
\hline $\begin{array}{l}\text { Cuarto Censo } \\
\text { Nacional }\end{array}$ & 1947 & 1.497 .987 & 226.652 & $15,1 \%$ \\
\hline $\begin{array}{l}\text { Quinto Censo } \\
\text { Nacional }\end{array}$ & 1960 & 1.759 .997 & 237.677 & $13,5 \%$ \\
\hline Sexto Censo Nacional & 1970 & 2.073 .991 & 269.629 & $13,0 \%$ \\
\hline $\begin{array}{l}\text { Séptimo Censo } \\
\text { Nacional }\end{array}$ & 1980 & 2.407 .754 & 298.819 & $12,4 \%$ \\
\hline $\begin{array}{l}\text { Octavo Censo } \\
\text { Nacional }\end{array}$ & 1991 & 2.766 .693 & 336.727 & $12,2 \%$ \\
\hline $\begin{array}{l}\text { Noveno Censo } \\
\text { Nacional }\end{array}$ & 2001 & 3.066 .801 & 353.046 & $11,5 \%$ \\
\hline
\end{tabular}

Fuente: Elaboración propia en base a la información proveniente de Cimminelli (1999/2000), Terzaga (1963), Ríos y Achával (1905) y de los censos nacionales de población.

En la secuencia demográfica de los departamentos que conforma el sur provincial entre 1895 y 2001 (Cuadro N 4), observamos, en primer lugar, que solamente la población total de tres departamentos -Juárez Celman, General Roca y Presidente Roque Sáenz Peña- decrece entre 1947 y 1960, no así el Dpto. Río Cuarto, para luego remontar numéricamente, pero siempre con niveles de crecimiento, en general muy bajos. Un caso paradigmático se manifiesta en el Dpto. General Roca, que recién supera su población de 1947 en el censo de 1991. Por otra parte, es dable observar que los departamentos Presidente Roque Sáenz Peña y General Roca casi no han evolucionado poblacionalmente desde 1947 a 2001. Es indudable 
que en los tres departamentos arriba aludidos -y en otros también de la provincia-, como bien explica Terzaga, "el éxodo rural explica sin duda el decrecimiento intercensal [...] aunque no debe olvidarse que muchos de los efectos sociales y económicos de la disminución demográfica son compensados por la creciente mecanización de las labores agrícolas" (Terzaga, 1963:122). Cabe recordar que Terzaga se está refiriendo a la década de 1960.

Cuadro No 4. Población total y extranjera por departamento de la Región Sur de la provincia de Córdoba. 1895-2001

\begin{tabular}{|c|c|c|c|c|c|c|c|c|c|}
\hline \multirow{2}{*}{ Departamentos } & \multicolumn{3}{|c|}{1895} & \multicolumn{3}{|c|}{1914} & \multicolumn{3}{|c|}{1947} \\
\hline & Total & Extr. & $\%$ & Total & Extr. & $\%$ & Total & Extr. & $\%$ \\
\hline Juárez Celman & 7.923 & 1.237 & 15,6 & 35.192 & 9.953 & 28,3 & 38.743 & 3.898 & 10,1 \\
\hline Río Cuarto & 24.431 & 2.714 & 11,1 & 64.851 & 14.029 & 21,6 & 125.694 & 10.855 & 8,6 \\
\hline Gral. Roca & 4.149 & 455 & 10,9 & 26.174 & 8.484 & 32,4 & 32.128 & 3.441 & 10,7 \\
\hline Pte. R. S. Peña & - & - & - & - & - & - & 30.087 & 3.443 & 11,4 \\
\hline Total Depart. & 36.503 & 4.406 & 12,1 & 126.217 & 32.466 & 25,7 & 226.652 & 21.637 & 9,5 \\
\hline $\begin{array}{l}\% \text { del Total } \\
\text { Provincial }\end{array}$ & 10,4 & 12,4 & - & 17,2 & 21,5 & - & 15,1 & 15,9 & - \\
\hline Total Provincial & 351.223 & 35.547 & 10,1 & 735.472 & 151.242 & 20,6 & 1.497 .987 & 135.937 & 9,1 \\
\hline
\end{tabular}

\begin{tabular}{|c|c|c|c|c|c|c|c|c|c|c|c|c|}
\hline \multirow{2}{*}{ Departamentos } & \multicolumn{3}{|c|}{1960} & \multicolumn{3}{|c|}{1980} & \multicolumn{3}{|c|}{1991} & \multicolumn{3}{|c|}{2001} \\
\hline & Total & Extr. & $\%$ & Total & Extr. & $\%$ & Total & Extr. & $\%$ & Total & Extr. & $\%$ \\
\hline Juárez Celman & 38.715 & 2.207 & 5,7 & 45.565 & 802 & 1,8 & 51.490 & 393 & 0,8 & 55.348 & 328 & 0,6 \\
\hline Río Cuarto & 145.257 & 7.525 & 5,2 & 191.006 & 3.375 & 1,8 & 217.876 & 2.228 & 1,0 & 229.728 & 1.531 & 0,7 \\
\hline Gral. Roca & 25.522 & 1.530 & 6,0 & 29.787 & 457 & 1,5 & 32.866 & 236 & 0,7 & 33.323 & 125 & 0,4 \\
\hline Pte. R. S. Peña & 28.183 & 1.835 & 6,5 & 32.461 & 661 & 2,0 & 34.495 & 284 & 0,8 & 34.647 & 180 & 0,5 \\
\hline Total Depart. & 237.677 & 13.097 & 5,5 & 298.819 & 5.295 & 1,8 & 336.727 & 3.141 & 0,9 & 353.046 & 2.164 & 0,6 \\
\hline $\begin{array}{l}\% \text { del Total } \\
\text { Provincial }\end{array}$ & 13,5 & 12,2 & - & 12,4 & 8,6 & - & 12,2 & 7,2 & - & 11,5 & 5,5 & - \\
\hline Total Provincial & 1.759 .997 & 107.441 & 6,1 & 2.407 .754 & 61.807 & 2,6 & 2.766 .683 & 43.496 & 1,6 & 3.066 .801 & 39.561 & 1,3 \\
\hline
\end{tabular}

Fuente: Elaboración propia en base a datos aportados por Terzaga (1963), Lucero (1999), censos nacionales de población y Dirección de Estadísticas y Censos de la provincia de Córdoba.

En lo referente a la evolución de la población extranjera en el sur cordobés, vemos que la misma va a crecer de manera acusada desde 1895 hasta 1914, año en que el contingente de extranjeros alcanza a un cuarto de la población total de la región. En los años subsiguientes, decrece sostenidamente, al disminuir la afluencia inmigratoria y envejecer ésta en el área de referencia, fenómeno también observable a nivel provincial. 
Es interesante observar (Cuadro $\mathrm{N}^{\circ}$ 5) los datos sobre población extranjera por nacionalidad y origen de la provincia de Córdoba provistos por el Censo Nacional de Población de 1895 (Ríos y Achával, 1905:400, V. I). Vemos, en primer lugar, la predominancia abrumadora de italianos sobre el resto de los otros extranjeros. Le siguen de muy lejos la población de origen español, francés y alemán. También se destaca, dentro de la desagregación de la población extranjera, la diversidad -más allá del peso demográfico de los italianos- de países concurrentes afincados en la provincia, como asimismo la escasa relevancia numérica de habitantes de los países limítrofes, en comparación con la de los países europeos.

\section{Cuadro $N^{0}$ 5. Población extranjera por nacionalidad de origen en la provincia de Córdoba. Censo Nacional 1895}

\begin{tabular}{|l|c|c|}
\hline \multicolumn{1}{|c|}{ Origen } & Total & $\%$ \\
\hline Italianos & 22.230 & 62 \\
\hline Españoles & 5.442 & 15 \\
\hline Franceses & 2.747 & 8 \\
\hline Alemanes & 1.061 & 3 \\
\hline Austríacos & 993 & \\
\hline Otros europeos & 799 & \\
\hline Suizos & 722 & \\
\hline Ingleses & 465 & \\
\hline Uruguayos & 385 & \\
\hline Chilenos & 240 & \\
\hline Brasileños & 92 & \\
\hline Paraguayos & 69 & \\
\hline Norteamericanos & 31 & \\
\hline Otros americanos & 23 & \\
\hline Bolivianos & 18 \\
\hline Total población extranjera & 35.547 & \\
\hline & & \\
\hline
\end{tabular}

Fuente: Datos provenientes de Ríos y Achával (1905:400, V. I).

En este sentido, en el Cuadro $\mathrm{N}^{0} 6$, referente a la participación italiana dentro de la población extranjera afincada en los departamentos del sur en 1914, se destaca nuevamente el rol predominante de dicha comunidad, con un $61,4 \%$ del total foráneo. Asimismo, cabe acotar, de acuerdo con las interesantes observaciones de Lucero, en su libro La inmigración italiana en el sur de Córdoba, 1870-1920, el valioso rol que desempeñó la comunidad italiana en la región. El autor destaca varias características de los integrantes de esta nacionalidad, muchas de ellas no del todo conocidas. Vemos así que, aparte de resaltar la presencia masiva de italianos en todos los pueblos y áreas rurales del sur de Córdoba, pondera su capacidad de adaptación al medio en el que se instalaron a trabajar. Aclara también, de acuerdo con los 
informes provenientes del Censo Nacional de 1895, que la mayoría de los inmigrantes italianos que ingresaban al país por esa época declaraban saber leer y escribir. Dato que se contrapone con la idea generalizada de que los inmigrantes que en esos tiempos entraban a la Argentina eran mayoritariamente analfabetos. Aparte, especifica que los italianos no se establecían solamente en las áreas rurales, sino que también tenían presencia en las zonas urbanas de la región en una importante proporción -en 1914- del 31\% del total de connacionales. Recuerda al respecto que, aparte de ingresar agricultores de profesión, también arribaron muchos artesanos de diferentes especialidades, destacándose, entre otros, los albañiles y constructores de excelente formación. Asimismo, muchos peninsulares se dedicaron de manera exitosa a las actividades industriales y comerciales, en los pueblos que recién se iban formando. El autor da a conocer sobre una realidad poco conocida, que es la fuerte presencia de profesionales médicos y farmacéuticos de nacionalidad italiana que se instalaron en los centros urbanos de la región. También destaca el alto porcentaje de italianos propietarios de bienes raíces, lo que estaría indicando un aceptable -aunque no en predios de gran tamaño- acceso a la tierra por parte de una cantidad importante de connacionales. Asimismo, resalta la gran cantidad de sociedades de ayuda mutua creadas por los italianos en los diferentes pueblos del sur de Córdoba. Por último, con respecto a las regiones de origen de donde provenían los italianos que se establecieron en el sur provincial, el autor antes mencionado expresa: “...fue variado y diverso; si bien en algunas poblaciones los piamonteses fueron mayoría, en otras se observó una presencia de diversas regiones, y teniendo en cuenta los diferentes momentos de la colonización, esa presencia se diversificaba" (Lucero, 1999:19).

Cuadro $\mathrm{N}^{\circ}$ 6. Participación italiana en la población extranjera, por departamento, de la región sur de la provincia de Córdoba. Censo Nacional 1914

\begin{tabular}{|l|c|c|c|c|c|c|}
\hline \multicolumn{1}{|c|}{ Departamento } & Italianos & $\%$ & Otros Extranjeros & $\%$ & Población total & $\%$ \\
\hline Gral. Roca & 5.331 & 63,0 & 3.153 & 37,0 & 8.484 & 100 \\
\hline Río Cuarto & 8.297 & 59,0 & 5.732 & 41,0 & 14.029 & 100 \\
\hline Juárez Celman & 6.307 & 63,0 & 3.646 & 37,0 & 9.953 & 100 \\
\hline Total & 19.935 & 61,4 & 12.531 & 38,6 & 32.466 & 100 \\
\hline
\end{tabular}

Fuente: Datos provenientes de Lucero (1999:23).

Con respecto a la cantidad de población por origen y nacionalidad de las colonias de la provincia de Córdoba, para el año 1898 (Cuadro $N^{\circ}$ 7), vemos que estos establecimientos sumaban 155 y contaban con 53.620 habitantes en total, de acuerdo con los datos de Ríos y Achával. Se observa que dichas colonias contaban con una predominancia de población adulta 
extranjera, que demuestra la persistente mayoría de colonos de origen inmigratorio, pero con la particularidad de que entre la población infanto-juvenil sobresale una sorprendente predominancia de niños argentinos. Esto demuestra que los hijos del grueso de los colonos extranjeros, para la fecha, han nacido en la Argentina. Esto posiblemente se deba a que muchos de los matrimonios conformados por extranjeros ya se habían constituido en el país, y llevaban conviviendo una regular cantidad de años en el mismo. En síntesis, dado el gran peso demográfico de niños de origen argentino que, sumados a la pequeña cantidad de adultos de la misma nacionalidad, predomina por un margen reducido la población argentina en las colonias de referencia.

Cuadro $\mathrm{N}^{\circ}$ 7. Población por origen y nacionalidad de las colonias de la provincia de Córdoba. Año 1898

\begin{tabular}{|l|c|c|c|}
\hline \multicolumn{3}{|c|}{ Cantidad de habitantes de las colonias } & $\%$ \\
\hline \multirow{2}{*}{ Adultos } & Extranjeros & 24.746 & 46,2 \\
\hline \multirow{2}{*}{ Niños hasta 16 años } & Argentinos & 2.419 & 4,5 \\
\hline Total de habitantes de las colonias & Argentinos & 25.754 & 48,0 \\
\hline Total de extranjeros & Extranjeros & 701 & 1.3 \\
\hline Total de argentinos & 53.620 & 100 \\
\hline
\end{tabular}

Fuente: Elaboración propia en base a datos provenientes de Ríos y Achával (1905:405, V. I).

\begin{tabular}{|c|c|c|c|}
\hline \multicolumn{2}{|c|}{ Total de habitantes de las colonias } & \multicolumn{2}{|c|}{53.620} \\
\hline \multicolumn{2}{|c|}{ Total de familias de colonos } & \multicolumn{2}{|c|}{7.815} \\
\hline \multirow{8}{*}{$\begin{array}{l}\text { Cantidad de } \\
\text { familias por } \\
\text { nacionalidad }\end{array}$} & Italianas & 6.274 & $80,3 \%$ \\
\hline & Argentinas & 694 & $8,9 \%$ \\
\hline & Francesas & 304 & $3,9 \%$ \\
\hline & Alemanas & 162 & $2,1 \%$ \\
\hline & Españolas & 145 & $1,9 \%$ \\
\hline & Suizas & 115 & $1,5 \%$ \\
\hline & Belgas & 45 & \\
\hline & Judías rusas & 59 & \\
\hline
\end{tabular}

Asimismo, Ferrero, con los mismos datos sobre la población de las colonias de 1898, da a conocer los porcentajes de las familias colonizadoras por nacionalidad de origen. Aquí también, como es de imaginar, sobresalen de forma notoria las familias italianas que trabajan la tierra, seguidos de muy lejos por las familias argentinas, francesas, alemanas, españolas, etc. A su vez, se sabe que muchos de los miembros de las familias argentinas resultan ser descendientes de padres italianos. Al respecto, Ríos y Achával dicen: “La elevada proporción correspondiente a los italianos aparece más importante aún si se la considera que numerosas familias argentinas tienen ya por padres a hijos de colonos de esa nacionalidad" (Ríos y Achával, 1905:179, V. II). 
El mismo Ferrero, para el año 1898, brinda datos de la población colonizadora residente en la región sur de la provincia (Cuadro $\mathrm{N}^{0} 8$ ). Si bien el autor no precisa específicamente el espacio al que alude, remite, en primer lugar, que tanto la cantidad de población como de familias afincadas para ese año en el sur cordobés, corresponden a cifras muy modestas -el $15,5 \%$ y el $16,3 \%$, respectivamente-, en relación con sus totales a nivel provincial. Todavía el grueso inmigratorio no ha ingresado a este territorio. En cambio, el ingreso continuado de inmigrantes en los departamentos del este provincial es ya más que significativo para esa fecha. En segundo lugar, en lo que respecta a la distribución de familias colonizadoras por nacionalidad, vemos de manera recurrente la presencia acusadamente mayoritaria de italianos, seguido como siempre de muy lejos por argentinos, franceses, españoles, etc.

Cuadro No 8. Población extranjera por nacionalidad de las Colonias del Sur de la provincia de Córdoba. 1898

\begin{tabular}{|l|c|c|c|c|}
\hline & $\begin{array}{c}\text { Región Sur de la } \\
\text { provincia }\end{array}$ & $\%$ & $\begin{array}{c}\text { Provincia de } \\
\text { Córdoba }\end{array}$ & $\%$ \\
\hline Total de habitantes de las colonias & 8.332 & 15,5 & 53.620 & 100 \\
\hline Total de familias de las colonias & 1.276 & 16,3 & 7.815 & 100 \\
\hline
\end{tabular}

\begin{tabular}{|l|l|c|c|}
\hline \multirow{2}{*}{ Total de familias de colonos } & 1.276 & $100 \%$ \\
\hline \multirow{3}{*}{$\begin{array}{l}\text { Familias por } \\
\text { nacionalidad de }\end{array}$} & Italianas & 895 & $70,1 \%$ \\
\cline { 2 - 4 } origen & Argentinas & 161 & $12,6 \%$ \\
\cline { 2 - 4 } & Francesas & 90 & $7,1 \%$ \\
\cline { 2 - 4 } & Españolas & 66 & $5,2 \%$ \\
\cline { 2 - 4 } & Rusas & 34 & $2,7 \%$ \\
\cline { 2 - 4 } & Alemanas & 30 & $2,3 \%$ \\
\hline
\end{tabular}

Fuente: Datos provenientes de Ferrero (1978:112).

En el Cuadro No 9, con datos de Ríos y Achával, de 1902, referidos también a población colonizadora por origen y nacionalidad de la provincia de Córdoba, vemos que los porcentajes son similares a los del año 1898 (Cuadro $N^{0}$ 7), salvo un apreciable incremento absoluto de la población adulta extranjera y argentina, y una disminución no muy acusada de niños argentinos en términos relativos. En lo referente a la distribución de familias por nacionalidad, la misma también es muy similar al cuadro antes citado. Siguen predominando notoriamente las familias de origen peninsular, sobre el resto de otras procedencias.

Por último, en el Cuadro $\mathrm{N}^{\mathrm{o}}$ 10, con datos también de Ríos y Achával, de los años 1902-1903, donde figura la población por origen de los departamentos del sur cordobés, más el total de la población por origen de las colonias de los departamentos agrarios de la provincia, lamentablemente los datos de la población infanto-juvenil no están desagregados por nacionalidad, lo que nos obliga a limitarnos a analizar la población adulta solamente. En este sentido, vemos: 1) que el porcentaje de población adulta argentina en relación con el total 
Cuadro N 9. Población por origen y nacionalidad de las colonias de la provincia de Córdoba. Año 1902

\begin{tabular}{|l|c|c|c|}
\hline \multicolumn{3}{|c|}{ Cantidad de habitantes de las colonias } & $\%$ \\
\hline \multirow{2}{*}{ Adultos } & Extranjeros & 30.372 & 46,07 \\
\hline \multirow{2}{*}{ Niños } & Argentinos & 5.571 & 8,45 \\
\hline Total de habitantes de las colonias & 28.500 & 43,23 \\
\hline Total de extranjeros & Argentinos & 1.483 & 2,25 \\
\hline Total de argentinos & 65.926 & 100 \\
\hline
\end{tabular}

\begin{tabular}{|c|c|c|}
\hline \multicolumn{2}{|c|}{ Total de habitantes de las colonias } & 65.296 \\
\hline \multicolumn{2}{|c|}{ Total de familias de colonos } & 10.318 \\
\hline \multirow{10}{*}{$\begin{array}{l}\% \text { de familias por } \\
\text { nacionalidad }\end{array}$} & Italianas & $74,98 \%$ \\
\hline & Argentinas & $12,69 \%$ \\
\hline & Francesas & $2,62 \%$ \\
\hline & Españolas & $2,48 \%$ \\
\hline & Austríacas & $2,44 \%$ \\
\hline & Alemanas & $1,90 \%$ \\
\hline & Suizas & $1,74 \%$ \\
\hline & Rusas & $0,47 \%$ \\
\hline & Belgas & $0,40 \%$ \\
\hline & Diversas & $0,28 \%$ \\
\hline
\end{tabular}

Fuente: Elaboración propia en base a datos provenientes de Ríos y Achával (1905:179-181, V. I).

Cuadro $N^{\circ} 10$. Población por origen de las colonias de los departamentos de la Región Sur de la provincia de Córdoba. Año agrícola 1902-1903

\begin{tabular}{|c|c|c|c|c|c|c|c|c|}
\hline \multirow[b]{2}{*}{ Departamentos } & \multicolumn{4}{|c|}{ Adultos } & \multirow{2}{*}{$\begin{array}{c}\text { Niños } \\
\text { argentinos y } \\
\text { extranjeros } \\
\text { hasta } 16 \text { años }\end{array}$} & \multirow[b]{2}{*}{$\%$} & \multirow[b]{2}{*}{ Total } & \multirow[b]{2}{*}{$\%$} \\
\hline & Argentinos & $\%$ & $\begin{array}{c}\text { Extranjero } \\
s\end{array}$ & $\%$ & & & & \\
\hline Juárez Celman & 705 & 11,7 & 2.499 & 41,3 & 2.843 & 47,0 & 6.047 & 100 \\
\hline Río Cuarto & 1.973 & 34,0 & 1.692 & 29,1 & 2.140 & 36,9 & 5.805 & 100 \\
\hline Gral. Roca & 37 & 8,6 & 189 & 43,8 & 205 & 47,6 & 431 & 100 \\
\hline Total Depart. & 2.715 & 22,1 & 4.380 & 35,7 & 5.188 & 42,2 & 12.283 & 100 \\
\hline$\%$ del Total de los Dptos. Agrarios & 52,5 & - & 18,7 & - & 21,9 & - & 23,5 & - \\
\hline Total Dptos. Agrarios & 5.170 & 9,9 & 23.373 & 44,8 & 23.634 & 45,3 & 52.177 & 100 \\
\hline
\end{tabular}

Fuente: Elaboración propia en base a datos provenientes de Ríos y Achával (1905:191, V. II).

existente en los departamentos agrarios es muy elevado (52,5\%), lo que demuestra que todavía esta región -en términos comparativos con otras áreas provinciales- no está lo suficientemente poblada por la colonización agraria; 2) como contrapartida, el porcentaje de población adulta extranjera en relación con el total de los departamentos agrarios no es muy elevado $(18,7 \%)$; 3) la cantidad absoluta de adultos extranjeros, en comparación con los adultos argentinos, es notoriamente superior, en coincidencia con la tendencia general; 4) el total poblacional de los departamentos del sur, en relación con el total de toda la llanura agraria, es en este caso de 23,5\%, a diferencia de los guarismos de 1898 (Cuadro $\mathrm{N}^{\mathrm{o}}$ 8), significativamente superior, lo que está evidenciando un mayor ingreso para 1902-1903 de población colonizadora a la región sur cordobesa; 5) a pesar de la indivisibilidad estadística -en este caso- de la población infanto-juvenil por nacionalidad, es de suponer una gran 
predominancia de niños argentinos por los datos precedentes de que disponemos que, sumado a la población adulta de la misma nacionalidad, inferimos que la población argentina en general debe rondar por la mitad o un poco más del total de habitantes de las colonias de la región para esa fecha; 6) finalmente, a nivel de desagregación de los departamentos participantes, vemos que la población adulta argentina del Dpto. Río Cuarto, a diferencia de los otros departamentos, es moderadamente superior a la población adulta extranjera. Este hecho demuestra que este departamento, de cuña histórica más antigua y, por ende, más tradicionalista, resulta más refractario al ingreso extranjero que los otros que lo acompañan en la misma región.

\subsection{EI diseño ferroviario y su incidencia en la ocupación territorial}

Cabe aclarar en este acápite que, a fin de contextualizar de manera más integral el desempeño ferroviario en el espacio de nuestro estudio, incluimos en este análisis a toda el área centro-sur provincial, que llamamos -como se recordará- "sur ampliado" o "sur histórico", y que se extiende aproximadamente del río Tercero hasta el extremo meridional del territorio cordobés.

Dentro de este espacio que nos interesa, el accionar de las empresas ferroviarias privadas, con todas sus estrategias y desmesuras, no va a diferir de cómo se desempeñaron en el resto del país. Pero antes de entrar en el análisis de la actuación de dichas compañías, es conveniente observar, a nivel macro, cómo penetran las vías ferroviarias maestras en la provincia y cómo se entrecruzan dos criterios con intereses opuestos.

El primer ferrocarril que ingresa a la provincia de Córdoba -como ya se especificó- va a ser el famoso Central Argentino, compañía británica que une, a lo largo de cuatrocientos kilómetros, Rosario con la ciudad de Córdoba. Atraviesa el límite interprovincial en 1863, arriba a Villa María en 1867 y llega a la capital cordobesa en 1870. Obviamente, esta línea va a ser la punta de lanza de otras que, más adelante, se van a proyectar en la llanura cordobesa. A su vez, el gobierno nacional se hace cargo, mediante la creación de compañías estatales, del ferrocarril que -bajo el nombre de Central Norte- va a unir Córdoba con Tucumán, llegando a esta ciudad en 1876, y del ferrocarril -bajo el nombre de Andino- que, partiendo de Villa María rumbo al sudoeste y buscando la conexión con la región de Cuyo, va a llegar a Río Cuarto en 1873 y a Villa Mercedes (San Luis) en 1875.

Como se ve, estas dos empresas estatales van a resultar tributarias de la compañía del Central Argentino, lo que va a implicar una subordinación al capital británico de ese momento. 
Ya desde esa época, en el país, se evidencian dos tendencias sobre implementación ferroviaria claramente diferenciadas. Una, con criterio de integración nacional, que procura unir las diversas regiones del interior del país, tratando de fomentar el desarrollo económico de aquellos lugares más postergados, y la otra, con un criterio eminentemente especulativocomercial, procura abarcar en primer término la región pampeana bajo un diagramado radial con vértice en Buenos Aires, y en Rosario en menor proporción, y, en segundo término, penetrar en sectores de interés económico, específicos de las regiones correspondientes a las economías regionales, como Cuyo, Noroeste, Mesopotamia y Chaco oriental. Esta segunda tendencia era impulsada por las empresas ferroviarias privadas y por una parte significativa de la dirigencia política y de la oligarquía nacional, con intereses en común con las compañías extranjeras, a quienes no les interesaba realizar trazados de vías que cortasen el sistema radial, a fin de conectar entre sí, en el sentido norte-sur, localidades del interior de la llanura agraria, y menos que menos conectar entre sí las diferentes regiones del interior del país.

En el caso que nos compete, vemos que la primera estructura ferroviaria que se dibuja en el territorio provincial se circunscribe a un simple esqueleto con tres ramales: RosarioCórdoba, Córdoba-Tucumán y Villa María-Villa Mercedes, que atraviesa el mismo por el sudeste, norte y sudoeste (Mapa $\mathrm{N}^{\mathrm{o}} 8$ ).

Este diagramado ferroviario básico, que se inicia a mediados de 1860, va a perdurar durante más de veinte años, hasta 1886, que es cuando el Ferrocarril Pacífico -como ya se mencionó-, procedente de Buenos Aires-Rufino, atraviesa el lejano sur cordobés por Laboulaye, hasta arribar a Villa Mercedes (San Luis). Con respecto a esta compañía británica, es interesante rememorar a Scalabrini Ortiz (1966), cuando describe cómo esta compañía, en su afán de lucro, primero conspira contra el Ferrocarril Oeste, propiedad de la provincia de Buenos Aires, con el propósito de impedir que las vías de éste se prolonguen hasta Mendoza y luego hasta Chile y, en segundo lugar, contra el Central Argentino, mediante la compra del Ferrocarril Andino, a fin de desviar el tráfico de carga procedente de Mendoza y San Juan que transportaba el mismo hasta Villa María. Por lo tanto, el tramo Rufino-Laboulaye-Villa Mercedes del Ferrocarril Pacífico va a resultar ser la vía principal, succionadora del grueso del tráfico procedente de Cuyo.

Después de 1886, se manifiesta un nuevo avance en el tendido ferroviario hasta 1891, para luego decaer de manera abrupta. En este año de 1891, como ya especificamos en un acápite anterior, el Ferrocarril Gran Sur -que más adelante pasa a formar parte del Central Argentino- llegó hasta La Carlota y el Ferrocarril Pacífico terminó de unir el tramo entre Villa 


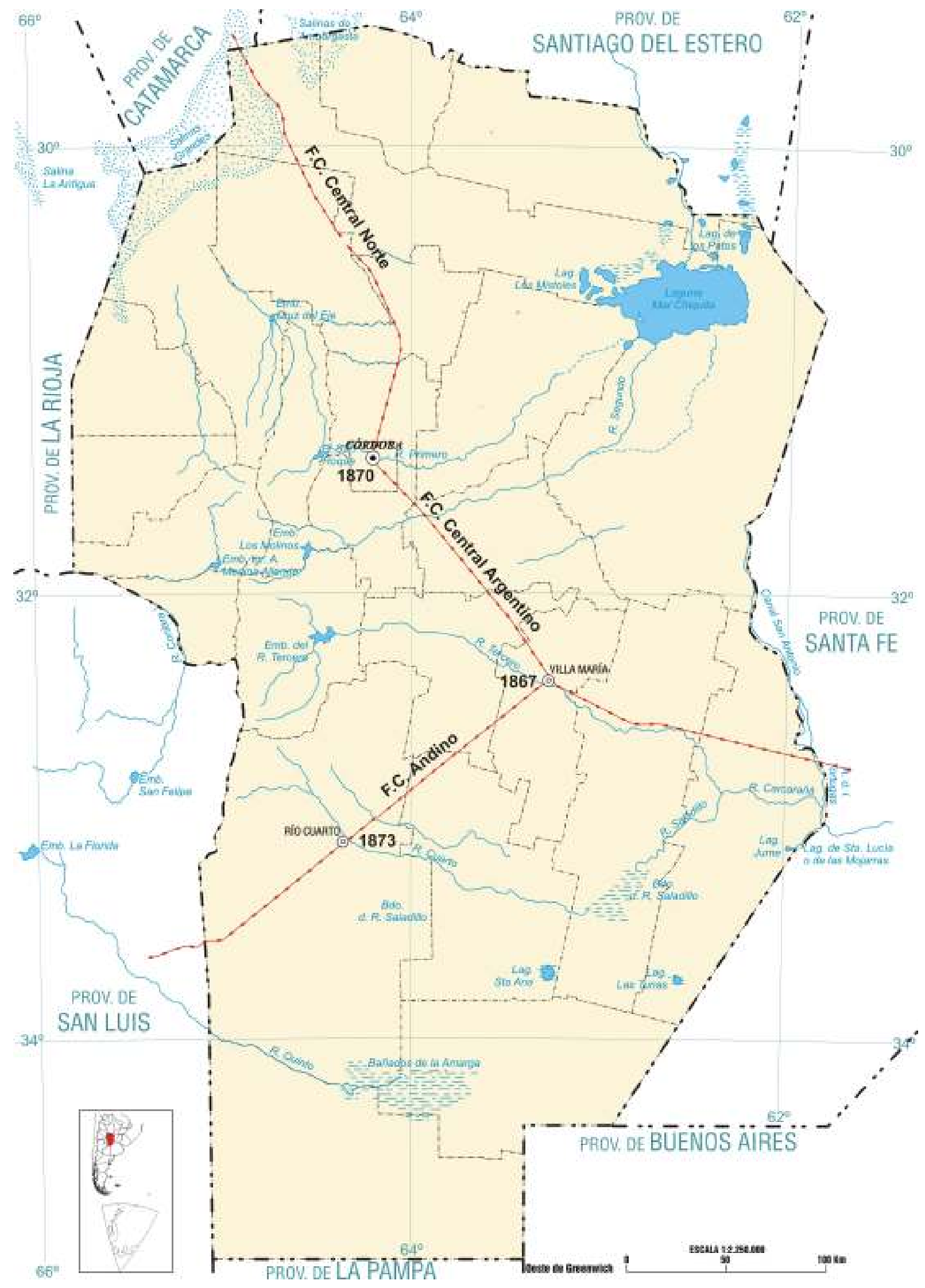

Mapa $\mathrm{N}^{\mathrm{o}}$ 8: Estructura ferroviaria inicial de la provincia de Córdoba. 
María y Rufino. Todavía no se insinuaba verdaderamente el entramado ferroviario, que se pondría de manifiesto años más tarde. Recién a fines del siglo XIX y principios del XX el tendido de vías toma nuevamente impulso y se construye febrilmente hasta 1914, quedando el "sur histórico" de la llanura cordobesa atravesado por numerosas vías, siendo una de las más importantes la prolongación del tendido ferroviario desde La Carlota hasta Río Cuarto, cuyo tramo se terminó de construir en 1902. A partir de 1914, queda establecido definitivamente el diseño ferroviario en el amplio espacio centro-sur de la provincia, desde el ramal principal Rosario-Córdoba del Central Argentino, que bordea el río Tercero hasta Villa María, para luego alejarse del río rumbo a la ciudad capital, hasta el ramal RufinoVilla Huidobro-Nueva Esperanza del Ferrocarril Pacífico, en el extremo meridional del territorio cordobés.

El diagramado que se conforma tiene las siguientes características (Mapa $\mathrm{N}^{\circ}$ 9):

- En todo este amplio espacio centro-sur van a construirse trece líneas férreas, ocho ramales en el sentido este-oeste, ${ }^{9}$ dos ramales en el sentido norte-sur ${ }^{10}$ y tres ramales en posición oblicua con respecto a los cuatro puntos cardinales. ${ }^{11}$

- Se observa que la línea del antiguo Ferrocarril Andino Villa María-Río Cuarto-Villa Mercedes, que corre en sentido noreste-sudoeste, oficia de colectora de seis ramales que convergen en la misma. ${ }^{12}$ En síntesis, la diagonal ferroviaria Villa María-Villa

9 Los ocho ramales en sentido este-oeste son:

- Rosario - Villa María - Córdoba (hasta Villa María corresponde el tramo ferroviario del límite norte del "sur ampliado cordobés")

- Casilda - Cruz Alta - Dalmacio Vélez Sarsfield - Río Tercero.

- Firmat - Corral de Bustos - Empalme Chucul - Río Cuarto.

- Venado Tuerto - La Carlota - Río Cuarto.

- Rufino - Laboulaye - Vicuña Mackenna - Villa Mercedes.

- Laboulaye - Sampacho (si bien, al principio, las vías no se orientan en sentido este-oeste, luego, al avanzar sobre el terreno, asumen esta orientación)

- Laboulaye - Villa Valeria (ídem)

- Rufino - Villa Huidobro - Nueva Esperanza.

10 Los dos ramales en sentido norte-sur son:

- Villa María - La Carlota - Rufino

- Río Cuarto - Córdoba.

11 Los tres ramales en posición oblicua son:

- Villa María - Río Cuarto - Villa Mercedes.

- Vicuña Mackenna - Sampacho - Achiras.

- Realicó - Huinca Renancó - Villa Huidobro - Villa Mercedes.

12 Los seis ramales que convergen a la línea Villa María - Río Cuarto - Villa Mercedes son:

- Casilda - Dalmacio Vélez Sarsfield - Río Tercero.

- Firmat - Empalme Chucul - Río Cuarto.

- Venado Tuerto - La Carlota - Río Cuarto.

- Río Cuarto - Córdoba.

- Laboulaye - Sampacho.

- Vicuña Mackenna - Sampacho - Achiras. 


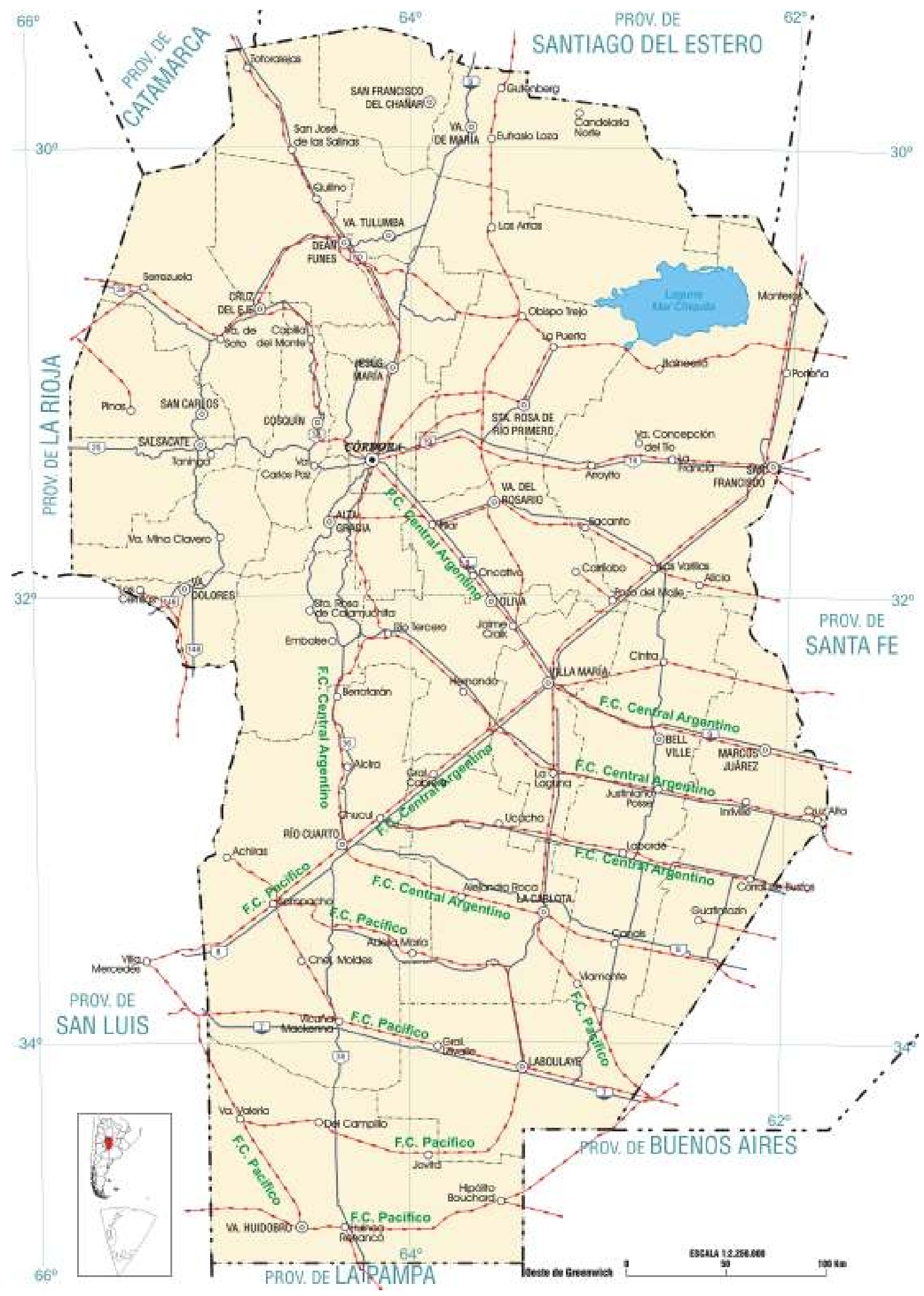

Mapa $\mathrm{N}^{\mathrm{o}}$ 9: Diagrama ferroviario con realce de la región centro-sur provincial.

Nota: A partir de 1947, el FF.CC. Central Argentino pasa a denominarse FF.CC. Bartolomé Mitre, y el FF.CC. Pacífico pasa a denominarse FF.CC. General San Martín. 
Mercedes sirve básicamente de soporte de los ramales que se despliegan en el sentido este-oeste por la llanura cordobesa.

- Otro aspecto a tener en cuenta es que, a partir de la línea principal de Ferrocarril Pacífico, Rufino-Laboulaye-Villa Mercedes, se desprenden cinco ramales de la misma compañía ${ }^{13}$ que, sumados a la vía principal, barren meticulosamente el territorio meridional profundo de la provincia, al sur del río Cuarto.

- En concreto, vemos que el entramado de vías del sur cordobés se va a apoyar en cuatro nudos ferroviarios: Villa María, Río Cuarto, Villa Mercedes y Rufino, que van a servir de dispersores-colectores del tráfico de trenes de toda esta amplia región.

En lo que respecta a las compañías ferroviarias intervinientes en el área de análisis, después de la concurrencia de varias empresas privadas británicas y una del Estado -Ferrocarril Andino-, al final se va a reducir a dos compañías privadas el reparto territorial del sector centro-sur cordobés. Al Ferrocarril Central Argentino le van a corresponder seis líneas $^{14}$ hacia el norte, a partir del trayecto Venado Tuerto-La Carlota-Río Cuarto, y al Ferrocarril Pacífico le van a corresponder ocho líneas ${ }^{15}$ hacia el sur del trayecto antes nombrado. $^{16}$

13 Los cinco ramales que se desprenden de la línea principal del Ferrocarril Pacífico Rufino - Laboulaye Vicuña Mackenna - Villa Mercedes son:

- Rufino - La Carlota - Villa María.

- Laboulaye - Sampacho.

- Laboulaye - Villa Valeria.

- Vicuña Mackenna - Sampacho - Achiras.

- Rufino - Villa Huidobro - Nueva Esperanza

14 Las seis líneas que le van a corresponder al Ferrocarril Central Argentino son:

- Venado Tuerto - La Carlota - Río Cuarto.

- Firmat - Empalme Chucul - Río Cuarto.

- Casilda - Dalmacio Vélez Sarsfield - Río Tercero.

- Rosario - Villa María - Córdoba.

- Río Cuarto - Córdoba.

- Río Cuarto - Villa María.

15 Las ocho líneas que le van a corresponder al Ferrocarril Pacífico son:

- Rufino - Laboulaye - Villa Mercedes.

- Rufino - La Carlota - Villa María (el único ramal que penetra en la zona del influencia del Ferrocarril Central Argentino).

- Laboulaye - Sampacho.

- Laboulaye - Villa Valeria.

- Vicuña Mackenna - Sampacho - Achiras.

- Rufino - Villa Huidobro - Nueva Esperanza.

- Río Cuarto - Villa Mercedes.

- Huinca Renancó - Villa Huidobro - Villa Mercedes (el tramo Realicó - Huinca Renancó le va a corresponder a otra empresa ferroviaria).

16 De las trece líneas ferroviarias arriba citadas que cruzan la llanura cordobesa, una de ellas, la correspondiente al recorrido Villa María - Río Cuarto - Villa Mercedes, del Ferrocarril Andino, cuando se vende, su trayecto se divide en dos partes: el tramo Río Cuarto - Villa Mercedes se incorpora al Ferrocarril Pacífico y el tramo Río Cuarto - Villa María se incorpora al Ferrocarril Central Argentino. 
Luego, cuando los ferrocarriles se nacionalizan, en 1947, el Ferrocarril Central Argentino pasa a constituir la empresa del Ferrocarril Bartolomé Mitre, y el Ferrocarril Pacífico se constituye en el Ferrocarril General San Martín.

En síntesis, el tendido ferroviario que se va a dibujar en el área centro-sur de la llanura cordobesa se caracteriza por la predominancia de carriles paralelos, dispuestos en sentido este-oeste, distanciados entre sí treinta y cinco, cuarenta y cinco, y cincuenta y siete kilómetros, como máximo, lo que significa que los puntos intermedios entre una línea ferroviaria y otra están alejados no más de veinte o veinticinco kilómetros, aproximadamente, de las mismas. Teóricamente, la influencia de las vías férreas barre el espacio circundante hasta cuatro o cinco leguas a cada costado de un ramal, donde se topa, a su vez, con el predominio proveniente de otro carril, que circula paralelamente al primero, no quedando, por lo tanto, casi puntos de la llanura fuera de la mayor o menor influencia del tren.

Esta disposición, a su vez, está matizada con una cantidad menor de trayectos ferroviarios en un sentido oblicuo y norte-sur -cinco en total, como ya se mencionó-, ubicados todos menos uno -Villa María-Rufino- en la periferia occidental de la pampa cordobesa, no alcanzando a conformarse, por consiguiente, al igual que en el resto de la red ferroviaria del país, una trama en forma de "enrejado en cuadrícula", lo que hubiese implicado una conexión "integral” entre el norte y sur provincial. Por cierto, la penetración de las vías férreas en la llanura pampeana, dispuesta de manera radial-que en la provincia de Córdoba se van a disponer paralelamente por la mayor distancia existente a la estación central de origen-, va a resultar ser una forma metódica de explotación racional de la planicie, bajo una orientación claramente agroexportadora. La porción pampeana de la provincia de Córdoba, naturalmente, no escapó a esta tendencia de usufructo asimétrico de los recursos territoriales, orquestado y proyectado por el capital británico, en connivencia con los gobiernos nacionales y la oligarquía del momento.

Ahora bien, no por ser muy conocido, deja de ser importante recordar el papel que cumplió el ferrocarril privado en manos británicas. Su desempeño, podría decirse, fue dual: por un lado positivo, favoreciendo claramente el poblamiento y expansión agrícola, en consonancia en este punto con la óptica inglesa, en que básicamente "se trazó para crear la producción agraria" (Ferrero, 1978:170); por el otro, en cambio, fue un auténtico expoliador de la riqueza que brindaba la tierra y de las oportunidades económicas en general que ofrecía el país. En este sentido, podemos destacar las enormes prebendas que recibió de parte del Estado argentino, ya sea mediante el capital garantido con el que contribuyó el gobierno para la concreción de los tendidos ferroviarios, capital que nunca fue reembolsado por las 
compañías favorecidas (Scalabrini Ortiz, 2006), ya mediante el otorgamiento de impresionantes extensiones de tierras aledañas a las vías, beneficio que recibieron a modo de prima, entre otros, el Ferrocarril Central Argentino y el Ferrocarril Gran Sur, que luego pasó a poder del Central Argentino.

Como retribución irónica por estas ventajas ofrecidas a las compañías privadas, cabe enumerar: la competencia desleal y destructora que oponían a las líneas férreas del Estado que coexistían con ellas en esa época, la falta de galpones y material rodante en muchas ocasiones, la fijación de tarifas desmesuradamente altas y arbitrarias, un trato irrespetuoso a los pasajeros (Bialet Massé, 1986) y una política ferroviaria en general orientada a desalentar y anular en lo posible a las economías regionales, especialmente si entraban en competencia directa con los intereses británicos.

Como si estas arbitrariedades de las compañías extranjeras fueran pocas, ante el incremento exponencial del valor de la tierra, debido al avance del ferrocarril en la llanura agraria, estas empresas obviamente resultaron ser las beneficiarias directas, además de especular hasta el infinito, con el propósito de otorgarle más valor a sus posesiones. Es justo también recordar que algunos grandes terratenientes, con la finalidad de incrementar el precio de sus tierras y extraerles mayor provecho, consiguieron que algunas compañías ferroviarias construyeran ramales que atravesaran sus campos, logrando de ese modo un alza del valor de sus propiedades, ya por demás extraordinario.

Por otra parte, estas compañías no querían la competencia de la red vial, oponiéndose a la construcción de caminos, sobre todo si brindaban otra alternativa de salida a la producción que ellos normalmente transportaban. Sobre este aspecto es interesante destacar, por ejemplo, que todavía en 1905 circulaban mensajerías en la llanura cordobesa, uniendo parajes donde el tren no llegaba con algunas de las estaciones ferroviarias cercanas más destacadas (Ríos y Achával, 1905).

En suma, a pesar de los excesos de lucro del ferrocarril de los primeros tiempos, no cabe la menor duda de que implicó un desarrollo -“unilateral por cierto" (Ferrero, 1978:168)- para Córdoba y el país todo. Por ejemplo, al sur de la línea Río Cuarto-La Carlota, prácticamente casi todas las colonias y pueblos tienen su origen a partir del tendido ferroviario. Cimminelli dice al respecto:

El proceso ordinario ha sido que, luego de la instalación del ferrocarril, el propietario de tierras aledañas a una estación ferroviaria solicita a las autoridades los beneficios de la ley de colonización de 1886, fundando una colonia en las cercanías. En ocasiones, el proceso parece haber sido inverso, es el propietario fundador de la colonia el que solicita a la compañía ferroviaria la instalación de una estación (Cimminelli, 1999/2000:113). 
No cabe la menor duda del efecto poblador del ferrocarril en el sur cordobés, como así también en toda la Región Pampeana. Lo que sí debe llamar a la reflexión es, si un agente de progreso tan poderoso como fue el ferrocarril privado pudo sembrar tantos beneficios, a pesar de que en su accionar arruinó a muchas "economías regionales" y "locales" pampeanas (por ejemplo, a molinos harineros ubicados en el interior), obteniendo al mismo tiempo ventajas extraordinarias más allá de lo imaginable, qué resultados nos habría brindado si dicho sistema ferroviario hubiese permanecido en todo momento en manos del Estado argentino. Cabe puntualizar que, en sus comienzos, las líneas férreas del Estado demostraron ser muy eficaces e integradoras a nivel nacional pero, en concreto, la nación no supo retenerlas y fueron absorbidas por las empresas extranjeras. Lo que pasó, Cuccorese lo especifica así: "Ahora bien ¿cuál fue la política ferroviaria seguida por la Argentina? En realidad, adelantamos, no hubo una politica definida. Variaba según las circunstancias" (Cuccorese, 1969:8).

\subsection{Conclusiones}

Como síntesis de lo expuesto en este capítulo, vemos que, con la ocupación de la llanura cordobesa y, por ende, de la región sur de la misma, último bastión de la colonización agraria, terminan de configurarse, en gran parte, los límites occidentales de la Región Pampeana, como un espacio con perfil definido en su forma de explotación agraria capitalista. En concreto, la diferencia del sur cordobés con el este provincial y la planicie santafesina es que la influencia inmigratoria y el asentamiento colonizador no fue tan acentuada y su estructura agraria fundiaria resultó menos parcelada. Estos factores en común dieron lugar a la supervivencia de algunos grandes latifundios, acompañada por la existencia de numerosas estancias de dimensiones más acotadas esparcidas por la zona y de una apreciable presencia de población de origen criollo en la composición demográfica de esta área.

Otra particularidad de la región sur, pero ahora con respecto a su relación con la ciudad capital de la provincia, es su prolongada desconexión temporal con la misma, como producto de su tradicional vinculación con el eje comercial oeste-este, Cuyo-Buenos Aires, reforzada a su vez esta ligazón con el advenimiento del ferrocarril, que cruzó por varios sectores dicho sur provincial. Situación vincular que, en la actualidad, se puede considerar morigerada, pero quizás no del todo zanjada.

Por otra parte, el propio espacio que encierra el sur cordobés no se manifiesta -a nivel provincial- como una unidad regional del todo cohesionada. El mismo trazado este-oeste de las vías férreas ya descripto, que surcaron el territorio, y la construcción de las posteriores 
rutas camineras que, paralelas a las vías, siguieron la misma orientación, determinaron un déficit en los intercambios de reciprocidad socio-económica en el sentido norte-sur en el espacio citado. Pero estas relaciones de vinculaciones incompletas, pero relaciones al fin, coadyuvaron de todos modos a la conformación de una estructura geográfica con varios rasgos compartidos de afinidad socio-territorial que caracterizan al sur cordobés.

Finalmente, a modo de reflexión y ampliando un poco la mirada sobre el fenómeno de la ocupación y colonización agraria de la llanura pampeana -donde, por cierto, está incluido nuestro espacio de estudio-, observamos que -exceptuando el esfuerzo de la colonización oficial y de ciertas medidas positivas implementadas por algunos gobernadores santafesinos, tendientes a una distribución equitativa de la tierra-, "prácticamente se desconoció la 'vía norteamericana' de desarrollo del capitalismo agrario. Predominó siempre el 'camino prusiano', es decir, el desarrollo económico subordinado a la gran propiedad terrateniente, a la que pagaba oneroso tributo" (Ferrero, 1978:120).

Lamentablemente, no se privilegió el acceso a la pequeña propiedad como política de Estado. Medidas por la buena senda hubo, como por ejemplo

El gobierno de Oroño (gobernador de Santa Fe, 1866) pudo servir de modelo a la nación en cuanto a gratuidad de la tierra entregada a los colonos y a la vigilancia de los intereses públicos vinculados a la propiedad territorial (Gori, 1971:86),

pero, como la historia lo demuestra, no se aprovechó de estas lecciones señeras. Primó la especulación de las tierras públicas y privadas para beneficios de las clases pudientes y como bien dice Gori: "Latifundio e inmigración son términos que se excluyen" y

...la verdadera colonización -aquella que entregaba gratuitamente la tierra en propiedad dividida en parcelas - fue cortada por intereses ya arraigados en el campo y, en su lugar, el régimen del arrendamiento o de la aparcería vino a replantearla, llamándose colonias a terrenos de propiedad privada entregados al trabajo de campesinos en situación de dependencia, arrendatarios o aparceros (Gori, 1971:99).

A su vez, Cárcano es claro cuando dice que los sistemas de colonización implementados en el país fueron muy heterogéneos y resultaron insuficientes para alcanzar una distribución racional y equitativa de la tierra en general, que beneficiase al pequeño agricultor (Cárcano, 1971). En suma, salvo escasos ejemplos, los colonos sufrieron la explotación bajo casi todos los sistemas de colonización.

Todos estos factores descriptos incidieron naturalmente también en nuestra región de interés, lo que dejó como resultado, aparte del proceso demográfico propio que la caracteriza, un tipo de ocupación poblacional y colonizadora similar a la de los otros sectores de la Región Pampeana, con su correspondiente saldo positivo y negativo como balance general. 


\section{Capítulo III}

\section{Evolución demográfica del Sur Cordobés}

\subsection{Caracterización demográfica y comparativa de la población rural y de la población urbana}

El propósito de este capítulo, entre otros cometidos, consiste en precisar el despoblamiento acentuado que vienen sufriendo desde hace décadas las áreas rurales del sur cordobés - pero limitado su análisis estadístico en esta circunstancia al período 1980-2001-, fenómeno que obviamente no es exclusivo de esta porción territorial del país.

Este proceso de desmantelamiento poblacional, que no implica que el campo se deje de trabajar -ya explicitado en la Introducción-, se expresa como un claro reflejo de un conjunto de factores político-económicos que han desencadenado profundas modificaciones socioterritoriales en el medio rural. La aplicación de nuevas tecnologías, de un manejo diferente de la explotación, la intromisión de grandes capitales de origen urbano tanto nacionales como extranjeros en las actividades agropecuarias, la aparición de nuevos agentes rurales, el peso cada vez más relevante de las agroindustrias en el manejo de la cadena productiva, las nuevas necesidades y aspiraciones de vida de los productores agropecuarios clásicos, las nuevas exigencias del mercado internacional cada vez más condicionantes, son algunos de los principales factores que han contribuido a la alteración aludida.

De los numerosos cambios que esta compleja dinámica ha producido en el medio rural, nos interesa, en esta instancia, como paso básico y previo a los análisis subsiguientes, tratar concretamente el despoblamiento rural en el área aludida, con la esperanza de captar más en detalle la serie de problemáticas y matices demográficos que conlleva este fenómeno.

No obstante, a fin de correlacionar articuladamente, nos ha parecido conveniente desde el punto de vista metodológico iniciar el análisis a partir de la escala territorial mayor a la menor, a fin de contextualizar debidamente el espacio elegido. De este modo, en forma sucinta, empezaremos por describir la evolución demográfica rural y urbana a nivel país conjuntamente con la provincia de Córdoba, para luego entrar precisamente en nuestra región de estudio, es decir, en el Sur Cordobés. Por ultimo, dentro de esta misma región, analizaremos a escala territorial todavía más reducida, las fluctuaciones demográficas de nuestras localidades testigos con sus respectivas zonas rurales de influencia, para luego desarrollar, al final, nuestra interpretación sobre algunas de las complejas causales que han interactuado en este proceso de despoblamiento rural. 
En suma, se procura arribar a un cuadro de situación que permita resaltar la magnitud del fenómeno de despoblamiento y las causales y consecuencias del mismo. Como agregado final, corresponde acotar que, para llevar a cabo esta tarea, nos hemos apoyado básicamente en la información proveniente de fuentes estadísticas, especialmente de los Censos de Población y Vivienda 1980, 1991 y 2001, como así también en los datos y vivencias recogidos en forma directa a través del trabajo de campo.

\subsubsection{Análisis a nivel de población total por sexo según condición urbana o rural de Argentina y provincia de Córdoba}

En el análisis estadístico de la evolución de la población urbana y rural de nuestro territorio de estudio, de acuerdo con los tres últimos Censos de Población y Vivienda, nos parece interesante, ante todo, iniciar la tarea de manera macro, tanto a nivel país como a nivel de la provincia de Córdoba, a fin de observar si los indicadores estadísticos guardan similitud o no, con la correspondientes a los cuatro departamentos que conforman el Sur Cordobés (Cuadro $\mathrm{N}^{\mathrm{o}} 11$ y Cuadro $\mathrm{N}^{\mathrm{o}} 12$ ).

Entrando en tema, vemos, en primer lugar, tanto a nivel país como de la provincia de Córdoba, un acentuado incremento de la población urbana en desmedro de población rural a lo largo de los tres censos, siendo los valores de la primera un poco más reducidos en la provincia de Córdoba. Particularmente, en las dos escalas territoriales se detecta una caída pronunciada de la población rural entre los censos de 1980 y 1991. Presumiblemente, en la década del '80, la mudanza voluntaria de parte de los productores agropecuarios por conveniencia personal del campo a los pueblos fue mucho más acentuada que en la década siguiente, aparte de otras circunstancias. Por otro lado, de acuerdo con los censos de 1991 y 2001, en los dos ámbitos territoriales, observamos que la "población rural dispersa" es mayoritaria con respecto a la "población rural agrupada", siendo esta diferencia muy pronunciada a nivel país, en cambio no es tan notoria en la provincia de Córdoba. Especialmente en ésta, el tramo entre agrupada y dispersa se ha acortado muchísimo en el año 2001.

Aquí caben, en general, las siguientes observaciones: por un lado, el predominio histórico de la población rural dispersa en Argentina -a diferencia de muchos lugares de los países andinos y del viejo mundo donde predomina la población rural concentrada- se debe tanto a razones de conformación socioeconómica de la sociedad como del uso del suelo, extensivo en nuestro caso, siendo especialmente destacable este tipo de distribución en la 
Región Pampeana; por otro, en provincia de Córdoba la incidencia de la pampa cordobesa, en consonancia con el resto de la llanura pampeana, indicaría que la disminución de la brecha entre población rural agrupada y dispersa se debe al pronunciado despoblamiento que vienen sufriendo los campos del sector llano de la provincia.

\section{Cuadro $\mathbf{N}^{\circ}$ 11. Población total en valores absolutos y porcentuales por sexo según condición urbana o} rural a nivel de país

\begin{tabular}{|c|c|c|c|c|}
\hline $\begin{array}{l}\text { República Argentina } \\
\text { Años 1980-1991-2001 }\end{array}$ & $\begin{array}{l}\text { Censo Nacional de Poblaci } \\
\text { Censo Nacional de Poblaci }\end{array}$ & $\begin{array}{l}\text { n y Vivienda } 1980 \text { y } 1991 \\
\text { n, Hogares y Viviendas } 20\end{array}$ & & \\
\hline Condición Urbana o Rural & Censo $1980 \quad \%$ & Censo $1991 \quad \%$ & Censo 2001 & $\%$ \\
\hline Población total & $\begin{array}{rr}27.947 .446 & 100 \% \\
100 \% & \end{array}$ & $\begin{array}{rr}32.615 .528 & 100 \% \\
100 \% & \end{array}$ & $\begin{array}{r}36.260 .130 \\
100 \%\end{array}$ & $100 \%$ \\
\hline Varones & $\begin{array}{r}13.755 .983 \\
49,2 \%\end{array}$ & $\begin{array}{r}15.937 .980 \\
48,9 \%\end{array}$ & $\begin{array}{r}17.659 .072 \\
48,7 \%\end{array}$ & \\
\hline Mujeres & $\begin{array}{r}14.191 .463 \\
50,8 \%\end{array}$ & $\begin{array}{r}16.677 .548 \\
51,2 \%\end{array}$ & $\begin{array}{r}18.601 .058 \\
51,3 \%\end{array}$ & \\
\hline Población Urbana (1) & $\begin{array}{r}23.192 .892 \\
100 \%\end{array}$ & $\begin{array}{r}28.436 .110 \\
100 \%\end{array}$ & $\begin{array}{r}32.431 .950 \\
100 \%\end{array}$ & $89,4 \%$ \\
\hline Varones & $\begin{array}{r}11.213 .938 \\
48,4 \%\end{array}$ & $\begin{array}{r}13.699 .016 \\
48,2 \%\end{array}$ & $\begin{array}{r}15.629 .299 \\
48,2 \%\end{array}$ & \\
\hline Mujeres & $\begin{array}{r}11.978 .954 \\
51,6 \%\end{array}$ & $\begin{array}{r}14.737 .094 \\
51,8 \%\end{array}$ & $\begin{array}{r}16.802 .651 \\
51,8 \%\end{array}$ & \\
\hline Población Rural (2) & $\begin{array}{r}4.754 .554 \\
100 \%\end{array}$ & $\begin{array}{r}4.179 .418 \\
100 \%\end{array}$ & $\begin{array}{r}3.826 .180 \\
100 \%\end{array}$ & $10,6 \%$ \\
\hline Varones & $\begin{array}{r}2.542 .045 \\
53,5 \%\end{array}$ & $\begin{array}{r}2.238 .964 \\
53,6 \%\end{array}$ & $\begin{array}{r}2.029 .773 \\
53 \%\end{array}$ & \\
\hline Mujeres & $\begin{array}{r}2.212 .509 \\
46,5 \%\end{array}$ & $\begin{array}{r}1.940 .454 \\
46,4 \%\end{array}$ & $\begin{array}{r}1.798 .407 \\
47 \%\end{array}$ & \\
\hline Población Rural Agrupada (3) & - & $\begin{array}{r}1.118 .092 \\
100 \%\end{array}$ & $\begin{array}{r}1.223 .533 \\
100 \%\end{array}$ & $3,4 \%$ \\
\hline Varones & - & - & $\begin{array}{r}620.099 \\
50,7 \%\end{array}$ & \\
\hline Mujeres & - & - & $\begin{array}{r}603.434 \\
49,3 \%\end{array}$ & \\
\hline Población Rural Dispersa ${ }^{(4)}$ & - & $\begin{array}{r}3.061 .326 \\
100 \%\end{array}$ & $\begin{array}{r}2.604 .647 \\
100 \%\end{array}$ & $7,2 \%$ \\
\hline Varones & - & - & $\begin{array}{r}1.409 .674 \\
54,1 \%\end{array}$ & \\
\hline Mujeres & - & - & $\begin{array}{r}1.194 .973 \\
45,9 \%\end{array}$ & \\
\hline
\end{tabular}

\section{Referencias}

(1) Se clasifica como urbana a la población en localidades de 2.000 y más habitantes.

(2) Se clasifica como rural a la población en localidades de menos de 2.000 habitantes o en campo abierto.

(3) Localidades de menos de 2.000 habitantes

(4) Campo abierto.

Fuente: Elaboración propia sobre la base de la información aportada por la Gerencia de Estadísticas y Censos del Gobierno de la Provincia de Córdoba.

A su vez, observamos que, en los censos de 1991 y 2001, los porcentajes de la "población rural agrupada" se mantienen casi iguales, tanto a nivel país como a nivel de la provincia de Córdoba, lo que aparentemente indicaría que la misma tiende a permanecer en las pequeñas localidades que habita, a pesar de que muchas de ellas -especialmente las de más reducidas dimensiones- se han vaciado notoriamente. 
Cuadro $\mathbf{N}^{\circ}$ 12. Población total en valores absolutos y porcentuales por sexo según condición urbana o rural a nivel de provincia de Córdoba

\begin{tabular}{|c|c|c|c|c|c|c|}
\hline $\begin{array}{l}\text { Provincia de Córdoba } \\
\text { Años 1980-1991-2001 }\end{array}$ & $\begin{array}{l}\text { Censo Nacional de } \\
\text { Censo Nacional de }\end{array}$ & $\begin{array}{l}\text { Poblaci } \\
\text { Poblaci }\end{array}$ & $\begin{array}{l}\text { n y Vivienda } 1980 \text { y } \\
\text { n, Hogares y Vivier }\end{array}$ & $\begin{array}{l}1991 \\
\text { das } 200 \\
\end{array}$ & & \\
\hline Condición Urbana o Rural & Censo 1980 & $\%$ & Censo 1991 & $\%$ & Censo 2001 & $\%$ \\
\hline Población total & $\begin{array}{r}2.407 .754 \\
100 \%\end{array}$ & $100 \%$ & $\begin{array}{r}2.766 .683 \\
100 \%\end{array}$ & $100 \%$ & $\begin{array}{r}3.066 .801 \\
100 \%\end{array}$ & $100 \%$ \\
\hline Varones & $\begin{array}{r}1.184 .813 \\
49,2 \%\end{array}$ & & $\begin{array}{r}1.349 .468 \\
48,8 \%\end{array}$ & & $\begin{array}{r}1.489 .403 \\
48,6 \%\end{array}$ & \\
\hline Mujeres & $\begin{array}{r}1.222 .941 \\
50,8 \%\end{array}$ & & $\begin{array}{r}1.417 .215 \\
51,2 \%\end{array}$ & & $\begin{array}{r}1.577 .398 \\
51,4 \%\end{array}$ & \\
\hline Población Urbana & $\begin{array}{r}1.943 .557 \\
100 \%\end{array}$ & $80,7 \%$ & $\begin{array}{r}2.380 .024 \\
100 \%\end{array}$ & $86 \%$ & $\begin{array}{r}2.721 .087 \\
100 \%\end{array}$ & $88,7 \%$ \\
\hline Varones & $\begin{array}{r}937.897 \\
48,3 \%\end{array}$ & & $\begin{array}{r}1.144 .083 \\
48,1 \%\end{array}$ & & $\begin{array}{r}1.307 .093 \\
48,0 \%\end{array}$ & \\
\hline Mujeres & $\begin{array}{r}1.005 .660 \\
51,7 \%\end{array}$ & & $\begin{array}{r}1.235 .941 \\
51,9 \%\end{array}$ & & $\begin{array}{r}1.413 .974 \\
52,0 \%\end{array}$ & \\
\hline Población Rural & $\begin{array}{r}464.197 \\
100 \%\end{array}$ & $19,3 \%$ & $\begin{array}{r}386.659 \\
100 \%\end{array}$ & $14 \%$ & $\begin{array}{r}345.734 \\
100 \%\end{array}$ & $11,3 \%$ \\
\hline Varones & $\begin{array}{r}246.916 \\
53,2 \%\end{array}$ & & $\begin{array}{r}205.385 \\
53,1 \%\end{array}$ & & $\begin{array}{r}182.310 \\
52,7 \%\end{array}$ & \\
\hline Mujeres & $\begin{array}{r}217.281 \\
46,8 \%\end{array}$ & & $\begin{array}{r}181.274 \\
46,9 \%\end{array}$ & & $\begin{array}{r}163.424 \\
47,3 \%\end{array}$ & \\
\hline Población Rural Agrupada & - & & $\begin{array}{r}147.550 \\
100 \%\end{array}$ & $5,3 \%$ & $\begin{array}{r}158.860 \\
100 \%\end{array}$ & $5,2 \%$ \\
\hline Varones & - & & $\begin{array}{l}74.216 \\
50.3 \%\end{array}$ & & $\begin{array}{r}79.742 \\
50,2 \%\end{array}$ & \\
\hline Mujeres & - & & $\begin{array}{r}73.334 \\
49.7 \%\end{array}$ & & $\begin{array}{r}79.118 \\
49,8 \%\end{array}$ & \\
\hline Población Rural Dispersa & - & & $\begin{array}{r}239.109 \\
100 \%\end{array}$ & $8,7 \%$ & $\begin{array}{r}186.874 \\
100 \%\end{array}$ & $6,1 \%$ \\
\hline Varones & - & & $\begin{array}{r}131.169 \\
54.9\end{array}$ & & $\begin{array}{r}102.568 \\
54,9 \%\end{array}$ & \\
\hline Mujeres & - & & $\begin{array}{r}107.940 \\
45.1 \%\end{array}$ & & $\begin{array}{l}84.306 \\
45,1 \%\end{array}$ & \\
\hline
\end{tabular}

Fuente: Elaboración propia sobre la base de la información aportada por la Gerencia de Estadísticas y Censos del Gobierno de la Provincia de Córdoba.

En relación con la distribución de la población por sexo en ambos espacios territoriales, la población femenina resulta mayoritaria tanto a nivel de población total como urbana, siendo más pronunciada su prevalencia en los ámbitos urbanos. Como contrapartida, la población masculina predomina netamente dentro de la población rural, siendo más pronunciado el gradiente entre varones y mujeres en la población rural que en la población urbana. Es obvio que se dé esta predominancia dado que el trabajo rural -por sus exigencias intrínsecasdemanda mayor cantidad de mano de obra masculina. Sobre todo, dentro de un esquema de agricultura capitalista prevaleciente y en franco ascenso, en desmedro de la agricultura familiar y/o de subsistencia, donde la mujer tenía mayor cabida como trabajadora rural. ${ }^{1}$

1 Sin perjuicio de observar, en muchas empresas agropecuarias familiares de la pampa cordobesa, la presencia creciente de la mujer -en calidad de esposa e hija- ligada al productor en las actividades rurales, especialmente en la faz organizativa, como complemento de refuerzo del que desempeña tradicionalmente el hombre. 
Se observa, asimismo, que los varones prevalecen más dentro de la población rural dispersa que en la agrupada, siendo la diferencia entre varones y mujeres mucho menor en esta última, lo que supone que los pequeños núcleos de población rural agrupada retienen más a la mujer que en el campo abierto, dado que las pequeñas localidades ofician, hasta cierto punto, como ámbito de asentamiento urbano.

\subsubsection{Análisis de población total por sexo según condición urbana o rural del Sur Cordobés}

Entramos ahora al análisis de los cuatro departamentos que comprende el Sur Cordobés (Cuadro $\mathrm{N}^{\mathrm{o}} 13$ ).

Lo primero que se observa es que el incremento de la población total de los cuatro departamentos en general, entre 1980 y 2001, dista de registrar guarismos importantes. Se puede decir que, en el período intercensal 1980-1991, acusó valores de incremento poblacional similares -aunque un poco mas bajos (12,7\%) - a la Argentina y a la provincia de Córdoba.

El mayor incremento se registra en los departamentos Juárez Celman y Río Cuarto. En el primero, por la atracción de población que genera la localización de una importante agroindustria en ese departamento y, en el segundo, por el peso intrínseco que representa la ciudad de Río Cuarto a nivel regional.

En cambio, en el período intercensal 1991-2001, el incremento de la población total en los cuatro departamentos se atenúa notablemente $(4,8 \%)$ y, si bien esta desaceleración también se observa a nivel país y de provincia de Córdoba, en el sur provincial es muchísimo más acentuado, lo que da que pensar que aparte de una disminución generalizada del crecimiento natural, hay un desplazamiento poblacional de la región hacia otros lugares del país, que determina que dicho aumento poblacional se suavice notablemente en comparación con el período intercensal anterior.

Por otra parte, la población urbana predomina en los tres censos analizados, especialmente en el Departamento Río Cuarto, por el peso que representa la ciudad del mismo nombre, y en el Departamento Presidente Roque Sáenz Peña, por el peso que le impone la ciudad de Laboulaye, que es el segundo centro urbano más poblado de la región sur. A su vez, se observa también un pronunciado incremento de la población urbana a lo largo de los tres censos, lo que implica como contrapartida una disminución acentuada de la población rural. 
Cuadro $\mathbf{N}^{\circ}$ 13. Provincia de Córdoba. Los cuatro departamentos que comprende el Sur Cordobés Población total en valores absolutos y en porcentuales por sexo según condición urbana o rural.

Años 1980-1991-2001.

Censo Nacional de Población y Vivienda 1980 y 1991.

Censo Nacional de Poblacion,

\begin{tabular}{|c|c|c|c|c|c|c|c|c|c|c|}
\hline \multirow{2}{*}{ Departamento } & \multirow{2}{*}{ Población Urbana y Rural } & \multicolumn{3}{|c|}{ Censo 1980} & \multicolumn{3}{|c|}{ Censo 1991} & \multicolumn{3}{|c|}{ Censo 2001} \\
\hline & & Total & Varones & Mujeres & Total & Varones & Mujeres & Total & Varones & Mujeres \\
\hline \multirow{10}{*}{ General Roca } & \multirow[t]{2}{*}{ Total } & 29.787 & 15.529 & 14.258 & 32.866 & 16.934 & 15.932 & 33.323 & 16.991 & 16.332 \\
\hline & & $100 \%$ & $\begin{array}{r}52,1 \% \\
100 \%\end{array}$ & $\begin{array}{r}47,9 \% \\
100 \%\end{array}$ & $100 \%$ & $\begin{array}{r}51,5 \% \\
100 \%\end{array}$ & $\begin{array}{r}48,5 \% \\
100 \%\end{array}$ & $100 \%$ & $\begin{array}{r}51 \% \\
100 \%\end{array}$ & $\begin{array}{r}49 \% \\
100 \%\end{array}$ \\
\hline & \multirow[t]{2}{*}{ Población Urbana } & 16.248 & 8.084 & 8.164 & 21.857 & 10.903 & 10.954 & 23.531 & 11.671 & 11.860 \\
\hline & & $54,5 \%$ & $52,1 \%$ & $57,3 \%$ & $66,5 \%$ & $64,4 \%$ & $68,8 \%$ & $70,6 \%$ & $68,7 \%$ & $72,6 \%$ \\
\hline & \multirow[t]{2}{*}{ Población Rural } & 13.539 & 7.445 & 6.094 & 11.009 & 6.031 & 4.978 & 9.792 & 5.320 & 4.472 \\
\hline & & $45,5 \%$ & $47,9 \%$ & $42,7 \%$ & $33,5 \%$ & $35,6 \%$ & $31,2 \%$ & $29,4 \%$ & $31,3 \%$ & $27,4 \%$ \\
\hline & \multirow{2}{*}{ Población Rural Agrupada } & 5.798 & 2.948 & 2.850 & 4.650 & 2.312 & 2.338 & 5.479 & 2.752 & 2.727 \\
\hline & & $19,5 \%$ & $19 \%$ & $20 \%$ & $14,1 \%$ & $13,6 \%$ & $14,7 \%$ & $16,5 \%$ & $16,2 \%$ & $16,7 \%$ \\
\hline & \multirow[t]{2}{*}{ Población Rural Dispersa } & 7.741 & 4.497 & 3.244 & 6.359 & 3.719 & 2.640 & 4.313 & 2.568 & 1.745 \\
\hline & & $26 \%$ & $28,9 \%$ & $22,7 \%$ & $19.4 \%$ & $22 \%$ & $16,5 \%$ & $12,9 \%$ & $15,1 \%$ & $10,7 \%$ \\
\hline \multirow{10}{*}{$\begin{array}{l}\text { Juárez } \\
\text { Celman }\end{array}$} & \multirow[t]{2}{*}{ Total } & 45.565 & 23.181 & 22.384 & 51.490 & 26.058 & 25.432 & 55.348 & 27.470 & 27.878 \\
\hline & & $100 \%$ & $\begin{array}{r}51 \% \\
100 \%\end{array}$ & $\begin{array}{r}49 \% \\
100 \%\end{array}$ & $100 \%$ & $\begin{array}{r}50,6 \% \\
100 \%\end{array}$ & $\begin{array}{r}49,4 \% \\
100 \%\end{array}$ & $100 \%$ & $\begin{array}{r}49,6 \% \\
100 \%\end{array}$ & $\begin{array}{r}50,4 \% \\
100 \%\end{array}$ \\
\hline & \multirow[t]{2}{*}{ Población Urbana } & 28.690 & 14.027 & 14.663 & 35.625 & 17.570 & 18.055 & 43.028 & 21.068 & 21.960 \\
\hline & & $63 \%$ & $60,5 \%$ & $65,5 \%$ & $69,2 \%$ & $67,4 \%$ & $71 \%$ & $77,7 \%$ & $76,7 \%$ & $78,8 \%$ \\
\hline & \multirow[t]{2}{*}{ Población Rural } & 16.875 & 9.154 & 7.721 & 15.865 & 8.488 & 7.377 & 12.320 & 6.402 & 5.918 \\
\hline & & $37 \%$ & $39,5 \%$ & $34,5 \%$ & $30,8 \%$ & $32,6 \%$ & $29 \%$ & $22,3 \%$ & $23,3 \%$ & $21,2 \%$ \\
\hline & \multirow{2}{*}{$\begin{array}{l}\text { Población Rural Agrupada } \\
\end{array}$} & 7.340 & 3.731 & 3.609 & 8.616 & 4.376 & 4.240 & 7.142 & 3.565 & 3.577 \\
\hline & & $16,1 \%$ & $16,1 \%$ & $16,1 \%$ & $16,7 \%$ & $16,8 \%$ & $16,7 \%$ & $12,9 \%$ & $13 \%$ & $12,8 \%$ \\
\hline & \multirow[t]{2}{*}{ Población Rural Dispersa } & 9.535 & 5.423 & 4.112 & 7.249 & 4.112 & 3.137 & 5.178 & 2.837 & 2.341 \\
\hline & & $20,9 \%$ & $23,4 \%$ & $18,4 \%$ & $14,1 \%$ & $15,8 \%$ & $12,3 \%$ & $9,4 \%$ & $10,3 \%$ & $8.4 \%$ \\
\hline
\end{tabular}


Cuadro N$^{\circ} 13$ (continuación)

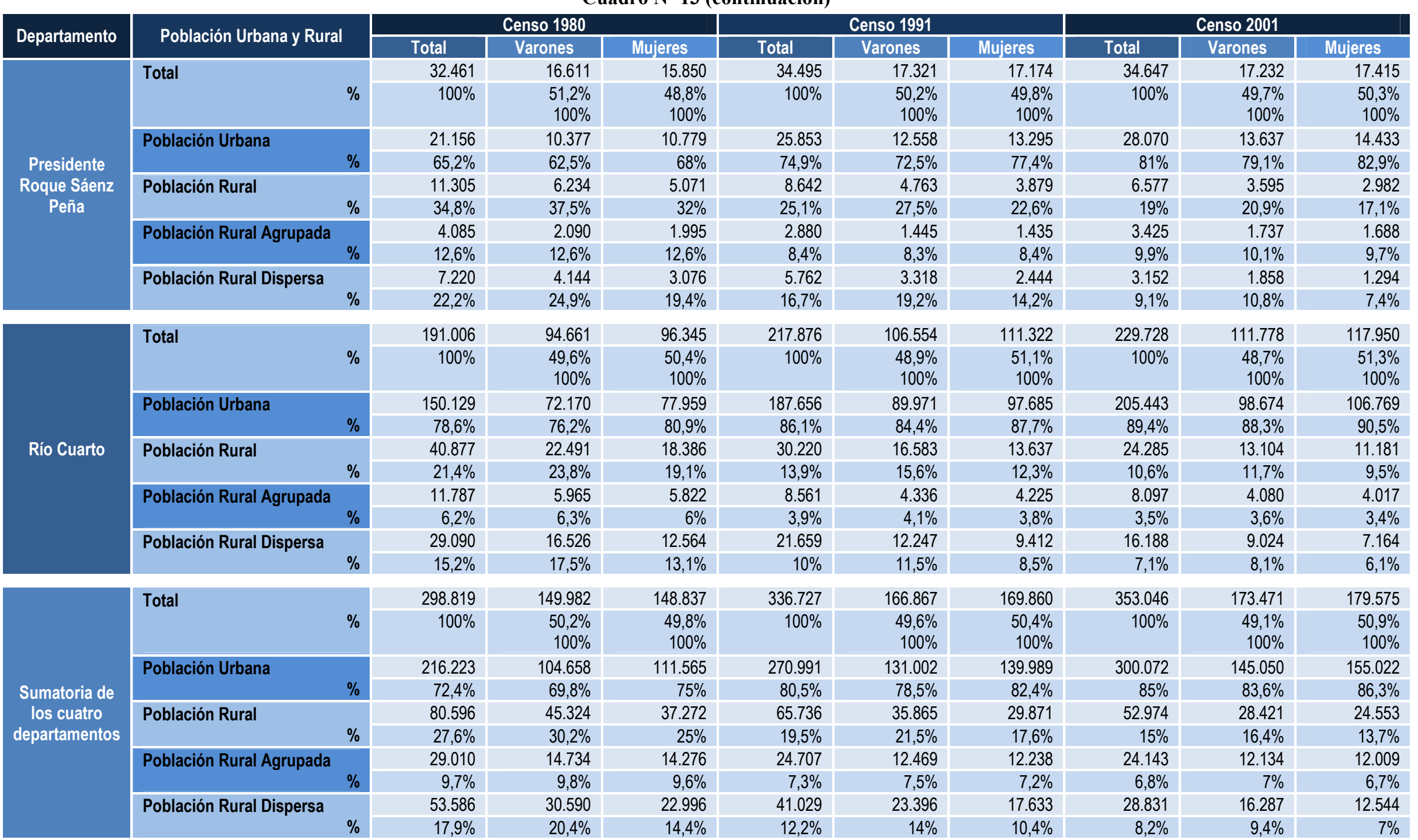
o

Fuente: Elaboración propia sobre la base de la información aportada por la Gerencia de Estadísticas y Censos del Gobierno de la Provincia de Córdoba. 
La caída poblacional de esta última es particularmente severa entre 1980 y 1991, para atenuarse luego en el periodo 1991-2001.

No cabe duda de que incidió al respecto, entre otros factores, el cambio en el modo de vida locacional de muchos productores -fenómeno que data aproximadamente de la década del '60-, que sin estar muchos de ellos acuciados económicamente, por razones de diversa índole, pero especialmente con el propósito de brindarles educación secundaria a sus hijos y en búsqueda de mayores comodidades en general -como se mencionó en el capítulo anterior-, se trasladaron a vivir a los centros urbanos más cercanos, sin abandonar la actividad agropecuaria, dado que los avances a nivel de infraestructura caminera, tecnológico y de manejo de las explotaciones así lo permitió.

En la década siguiente -como ya se dijo-, la disminución de la ruralidad se desacelera y da la impresión de que esta tendencia indica que el achicamiento de la población rural se está acercando a un límite a partir del cual ya no puede descender mucho más, dado que se supone que la poca gente que queda en el campo es la imprescindible para cubrir los requerimientos del mismo.

Con respecto a la distribución de la población rural en general, predomina la población rural dispersa, con una clara tendencia a acortarse la brecha entre agrupada y dispersa a lo largo de los tres censos analizados. No obstante, a nivel de desagregación departamental, vemos que ya en el censo de 2001, en los departamentos General Roca, Roque Sáenz Peña y Juárez Celman -inclusive en este ultimo a partir de 1991- la población rural agrupada supera a la dispersa, pero en el Departamento Río Cuarto sigue predominando fuertemente la dispersa con respecto a la agrupada; en el promedio general de los cuatro departamentos, prevalece, pero con escasa diferencia, la dispersa con relación a la agrupada.

En suma, es elocuente y profundo el despoblamiento a campo abierto; en cambio, se observa una mayor resistencia en la agrupada a mantener su caudal poblacional. Posiblemente, los núcleos poblacionales de menos de 2.000 habitantes, pero particularmente entre aquellos de 2.000 a 500 habitantes, sirven de anclaje a la población rural y contrarrestan, en parte, la fuga de la misma.

En lo referente a la distribución de la población total por sexo, en la sumatoria de los cuatro departamentos, observamos que, en el censo de 1980, predominan los varones, lo que indica, en términos comparativos, la fuerte ruralidad existente en ese año; pero, en los censos siguientes, la predominancia la pasa a ocupar la población femenina.

A nivel de desagregación departamental, vemos que en el Departamento General Roca prevalecen los varones a lo largo de los tres censos; en cambio, en los departamentos Juárez 
Celman y Presidente Roque Sáenz Peña, recién en el censo del 2001 pasan las mujeres a ser las predominantes. En el caso del Departamento Río Cuarto, por su mayor grado de urbanización, predomina la población total femenina en los tres censos. Por otra parte, dentro de la estructura de la población urbana, prevalecen siempre las mujeres, siendo notoria la diferencia en el Departamento Río Cuarto.

Con respecto a la población rural, si bien predominan los varones, la diferencia es mucho menor en la agrupada que en la dispersa. Inclusive en el censo de 1991, en el Departamento General Roca, y en el censo de 2001, en el departamento Juárez Celman, la población rural agrupada femenina supera por escaso margen a la masculina.

Por ultimo, dentro de la estructura de la población rural, tanto los varones como las mujeres, en general, predominan más dentro de la población rural dispersa que en la población rural agrupada. No obstante, en los departamentos General Roca y Juárez Celman, en el censo de 2001 -inclusive en este último, a partir del censo de 1991-, tanto la población masculina como la femenina va a prevalecer dentro de la población rural agrupada, lo que indica posiblemente, en estos casos, un acentuado desmantelamiento poblacional, en general, en el campo abierto.

Asimismo, las localidades de "población rural agrupada", todas sin excepción, comprendidas dentro de la franja de los 2.000 a 1.000 habitantes han incrementado su población a lo largo de los tres censos.

\subsubsection{Disminución íntercensal de "población rural agrupada" de los cuatro departamentos del Sur Cordobés}

A continuación, pasamos a analizar las pequeñas localidades del Sur Cordobés, comprendidas como "población rural agrupada" que, en algún periodo intercensal de los aquí estudiados, han sufrido una disminución en la cantidad de sus habitantes (Cuadro $\mathrm{N}^{\mathrm{o}}$ 14).

Cabe resaltar que todas las localidades de la región consideradas como centros urbanos (por contar con 2.000 o más habitantes) han acusado un incremento poblacional en el período que va de 1980 a 2001. Asimismo, todas -sin excepción- las localidades de población rural agrupada comprendidas dentro de la franja de $\operatorname{los} 2.000$ a 1.000 habitantes han incrementado su población a lo largo de los tres censos.

Remitiéndonos al Cuadro $\mathrm{N}^{\mathrm{o}} 14$, recién en la franja que va de los 1.000 a 500 habitantes, aparecen en el censo de 1980 dos localidades (Bengolea y Chaján) que han sufrido 
Cuadro No 14. Disminución intercensal de Población Rural Agrupada de los cuatro departamentos del Sur Cordobés

Años 1980-1991-2001

Censo Nacional de Población y Vivienda 1980 y 1991.

\begin{tabular}{|c|c|c|c|c|c|c|c|c|c|c|c|c|}
\hline \multirow[t]{2}{*}{ Departamento } & \multirow{2}{*}{$\begin{array}{c}\begin{array}{l}\text { Total de localidades del } \\
\text { departamento* }\end{array} \\
\text { Total } \\
\end{array}$} & \multicolumn{2}{|c|}{$\begin{array}{l}\text { Localidades de menos de } 2.000 \text { hab. } \\
\text { afectadas por disminución poblacional }\end{array}$} & Censo 1980 & \multirow{2}{*}{$\frac{\text { Censo } 1991}{\text { Total }}$} & \multirow{2}{*}{$\frac{\text { Censo } 2001}{\text { Total }}$} & \multirow[t]{2}{*}{ A } & \multirow[t]{2}{*}{ B } & \multirow[t]{2}{*}{ C } & \multirow[t]{2}{*}{ D } & \multirow[t]{2}{*}{$\mathbf{E}$} & \multirow[t]{2}{*}{$\mathbf{F}$} \\
\hline & & Total & Localidad & Total & & & & & & & & \\
\hline \multirow{4}{*}{ General Roca } & \multirow{4}{*}{14} & \multirow{4}{*}{4} & Villa Sarmiento & 299 & 207 & 332 & - & \multirow{4}{*}{3} & + & \multirow{4}{*}{1} & + & \multirow{4}{*}{2} \\
\hline & & & Pincen & 171 & 205 & 202 & + & & - & & + & \\
\hline & & & Onagoity & 104 & 72 & 74 & - & & + & & - & \\
\hline & & & Lecueder & 155 & 21 & 26 & - & & + & & - & \\
\hline \multirow{5}{*}{ Juárez Celman } & \multirow{5}{*}{17} & \multirow{5}{*}{5} & Bengolea & 635 & 825 & 812 & + & \multirow{5}{*}{2} & - & \multirow{5}{*}{3} & + & \multirow{5}{*}{3} \\
\hline & & & Los Cisnes & 464 & 487 & 469 & + & & - & & + & \\
\hline & & & El Rastreador & 104 & 72 & 83 & - & & + & & - & \\
\hline & & & Assunta & 98 & 80 & 58 & - & & - & & - & \\
\hline & & & Pacheco de Melo & 176 & (a) & 35 & $?$ & & $?$ & & - & \\
\hline \multirow{3}{*}{$\begin{array}{l}\text { Presidente Roque } \\
\text { Sáenz Peña }\end{array}$} & \multirow{3}{*}{10} & \multirow{3}{*}{3} & Rosales & 496 & 455 & 511 & - & \multirow{3}{*}{2} & + & \multirow{3}{*}{1} & + & \multirow{3}{*}{1} \\
\hline & & & Río Bamba & 58 & 97 & 88 & + & & - & & + & \\
\hline & & & Leguizamón & 87 & 35 & 57 & - & & + & & - & \\
\hline \multirow{9}{*}{ Río Cuarto } & & & Chaján & 513 & 484 & 634 & - & & + & & + & \\
\hline & & & Tosquitas & 383 & 378 & 382 & - & & + & & - & \\
\hline & & & Las Albahacas & 241 & 183 & 292 & - & & + & & + & \\
\hline & & & Suco & 301 & 290 & 291 & - & & + & & - & \\
\hline & 32 & 9 & Malena & 174 & 129 & 208 & - & 8 & + & 2 & + & 3 \\
\hline & & & Las Peñas & 209 & 148 & 139 & - & & - & & - & \\
\hline & & & Alpa Corral & 371 & 344 & 701 & - & & + & & + & \\
\hline & & & Villa El Chacay & 65 & 37 & 99 & - & & + & & + & \\
\hline & & & La Gilda & 48 & 80 & 70 & + & & - & & + & \\
\hline $\begin{array}{l}\text { otales de los cuatro } \\
\text { lepartamentos }\end{array}$ & 73 & 21 & & - & - & - & & 15 & & 7 & & 9 \\
\hline
\end{tabular}

Referencias: (a) El dato del censo de 1991 no es comparable por incluir población rural dispersa. A. Variación 1980-1991. En + o -

B. Total de localidades afectadas por la disminución de población entre 1980-1991

C. Variacion 1991-2001. En +o -.

D. Total de localidades afectadas por

E. Variación 1980-2001. En $+0-2$

F. Total de localidades afectadas por la disminución de población entre 1980-2001

Fuente: Elaboración propia sobre la base de la información aportada por la Gerencia de Estadísticas y Censos del Gobierno de la Provincia de Córdoba. 
algún tipo de perturbación poblacional negativa en uno de los dos periodos intercensales, pero entre los extremos de 1980-2001 han acusado un saldo poblacional positivo.

Es, desde luego, en la franja de menos de 500 habitantes, donde las pequeñas localidades han sufrido más las fluctuaciones negativas de población en los últimos tiempos. Podemos apreciar que es en el período intercensal 1980-1991 donde hubo mayor cantidad de localidades afectadas por disminución poblacional, quince de un total de veintiuna localidades, consideradas en el Cuadro $\mathrm{N}^{\mathrm{o}} 14$.

En cambio, en el período intercensal 1991-2001 esta cifra se achicó notablemente a siete localidades, lo que implica un repunte poblacional entre 1991 y 2001, en algunos casos de manera leve y en otros acentuada, de aquellas localidades que en el período anterior habían sufrido una disminución de habitantes. En concreto, en el periodo largo que va de 1980 a 2001, el total de localidades afectadas por disminución poblacional se va a limitar a nueve localidades, de las cuales dos mantienen su población casi igual entre los extremos de 1980 y 2001 (es el caso de Tosquita y Suco) y, de las siete restantes, podemos decir que en cuatro localidades la población ha disminuido abruptamente (es el caso de Lecueder, Assunta, Pacheco de Melo y Las Peñas).

En síntesis, lo que se colige es que, a diferencia de otras pequeñas localidades de distintas partes del país que tienden a extinguirse - problemática destacada por la geógrafa Marcela Benítez, en La Argentina que desaparece. Desintegración de comunidades rurales y poblados en vías de desaparición (1998)-, aparentemente en el Sur Cordobés este fenómeno no se manifiesta de manera acusada; es más, algunas localidades de menos de 2.000 habitantes, a lo largo de estos años, demográficamente se han revitalizado notoriamente. Pero lo observado hasta aquí, año 2001, quizás no concuerde con lo que pasa en la actualidad, ya que pueden haberse producido nuevas disminuciones en los pequeños pueblitos de la región.

\subsubsection{Población urbana y rural y de vivienda por zona rural de las diez localidades testigos con sus respectivas zonas rurales de influencia}

A continuación, siguiendo con el criterio de descender en la escala territorial, a fin de comparar y captar en detalle el fenómeno del despoblamiento rural en nuestra área de estudio, presentamos la evolución de la población urbana y rural y de la vivienda en zona rural, de acuerdo con los datos aportados por los censos de 1980, 1991 y 2001, de las diez localidades testigos con sus respectivas zonas rurales de influencia, que se encuentran en un radio de 100 km alrededor de la ciudad de Río Cuarto. Esencialmente, estas diez "unidades territoriales" 
(que incluye la localidad más su zona rural de influencia) se sitúan en los departamentos Río Cuarto y Juárez Celman, sin abarcarlos en toda su extensión (Cuadro No 15) (Mapa No 2).

Observamos, en primer lugar, un amplio predominio de la población urbana en relación con la población rural en todas las localidades estudiadas; a su vez, todas las localidades, a lo largo de los censos arriba citados, aumentaron su población -exceptuando Ucacha, que sufrió un pequeño reflujo entre 1991 y 2001-, siendo el incremento mayor en el primer período intercensal (1980-1991) que en el segundo, en consonancia con lo sucedido a nivel país y provincia de Córdoba. El incremento poblacional de las localidades entre los extremos de 1980-2001 -del 12\% al 81\%, con una media aproximada del 38,5\%- se puede considerar moderada en algunos casos, teniendo en cuenta que en los años transcurridos hubo un trasvasamiento poblacional significativo del campo a los pueblos cercanos, permitiendo interpretar, por consiguiente, que éstos drenaron población hacia otros centros urbanos de mayor jerarquía. En cambio, en otros, el incremento se puede considerar importante, especialmente en los casos de General Cabrera, General Deheza, Adelia María y Vicuña Mackenna, principalmente en las tres primeras localidades nombradas, donde se viene manifestando un acusado aumento de actividades agroindustriales y agrocomerciales.

En relación con la población de las zonas rurales de influencia de las localidades, observamos, en general, una caída demográfica importante en los dos períodos intercensales, manifestándose en forma pronunciada entre 1980 y 2001 -a excepción de las áreas rurales de Vicuña Mackenna y Sampacho, donde el peso de la ruralidad sigue teniendo relativa incidencia-, habiéndose agudizado este drenaje entre 1991 y 2001 en seis localidades de las diez estudiadas. En los casos de Adelia María, Sampacho y Vicuña Mackenna, cuentan respectivamente con uno -Monte de los Gauchos-, dos - Chaján y Suco- y tres -La Cautiva, Tosquita y Washington- centros poblados de menos de 2.000 habitantes en su entorno rural, en calidad de pueblitos subsidiarios que, de acuerdo con los criterios del INDEC, van a figurar como Población Rural Concentrada, motivo por el cual, en estos tres casos, desagregamos la Población Rural en Dispersa y Concentrada, a fin de diferenciar la incidencia de una y otra respectivamente, lo que va a dejar traslucir la disminución real de la Población Rural Dispersa, que es mucho más acentuada que los guarismos que se desprenden de la Concentrada, que inclusive se incrementó en el lapso estudiado.

En suma, el despoblamiento de las áreas rurales de las localidades consideradas es aproximadamente similar al del sur cordobés, en general, pero mucho más elevado que el promedio de despoblamiento de la provincia de Córdoba y del país. 
Cuadro $\mathrm{N}^{0}$ 15. Población Urbana, Rural y de Vivienda en zona rural de cada localidad testigo del Sur Cordobés

\begin{tabular}{|c|c|c|c|c|c|c|c|c|c|c|c|c|c|c|c|c|c|c|c|c|c|c|}
\hline \multirow{4}{*}{ 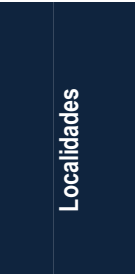 } & \multirow{4}{*}{ 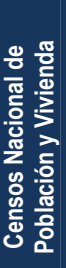 } & \multirow{2}{*}{\multicolumn{3}{|c|}{$\begin{array}{l}\text { Población urbana de cada } \\
\text { localidad }\end{array}$}} & \multirow{2}{*}{\multicolumn{3}{|c|}{$\begin{array}{l}\text { Población rural de la zona } \\
\text { de influencia de c/localidad }\end{array}$}} & \multicolumn{6}{|c|}{ Desagregación de la población rural } & \multirow{2}{*}{\multicolumn{3}{|c|}{$\begin{array}{l}\text { Total de Población } \\
\text { (pobl. urbana + pobl. rural) } \\
\text { (unidades territoriales) }\end{array}$}} & \multirow{4}{*}{ 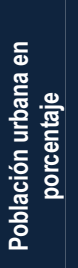 } & \multirow{4}{*}{ 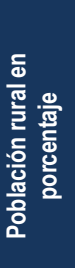 } & \multirow{2}{*}{\multicolumn{4}{|c|}{$\begin{array}{l}\text { Viviendas en las zonas rurales de } \\
\text { los Censos Nacionales } 1991 \text { y } 2001\end{array}$}} \\
\hline & & & & & & & & \multicolumn{3}{|c|}{ Población dispersa } & \multicolumn{3}{|c|}{ Población concentrada* } & & & & & & & & & \\
\hline & & \multirow{2}{*}{ 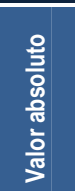 } & \multicolumn{2}{|c|}{ Variación en \% } & \multirow{2}{*}{$\begin{array}{l}\text { 을 } \\
\text { 응 } \\
\text { 응 } \\
\text { 흥 }\end{array}$} & \multicolumn{2}{|c|}{ Variación en \% } & \multirow{2}{*}{ 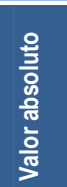 } & \multicolumn{2}{|c|}{ Variación en \% } & \multirow{2}{*}{ 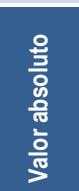 } & \multicolumn{2}{|c|}{ Variación en \% } & \multirow{2}{*}{$\begin{array}{l}\text { 을 } \\
\frac{0}{0} \\
\frac{0}{10} \\
\frac{0}{00}\end{array}$} & \multicolumn{2}{|c|}{ Variación en \% } & & & & & Desoc & pados \\
\hline & & & $\begin{array}{l}\bar{\delta} \\
\text { \% } \\
\text { \% } \\
\%\end{array}$ & $\begin{array}{l}\bar{్} \\
\text { ळ. } \\
\text { \% }\end{array}$ & & 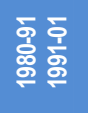 & $\begin{array}{l}\bar{\varnothing} \\
\text { 。ัे } \\
\text { \% }\end{array}$ & & $\begin{array}{l}\text { 훙후 } \\
\text { \% 융 }\end{array}$ & $\begin{array}{l}\bar{\zeta} \\
\text { ळ. } \\
\text { ळ }\end{array}$ & & 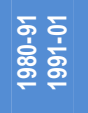 & $\begin{array}{l}\text { 훙 } \\
\text { ळ } \\
\text { \% }\end{array}$ & & $\begin{array}{l}\overline{\$} \\
\text { \% } \\
\text { \% }\end{array}$ & $\begin{array}{l}\text { 훙 } \\
\text { \% }\end{array}$ & & & 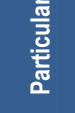 & $\begin{array}{l}\text { 응 } \\
\text { oํㄹㅇ } \\
\text { o }\end{array}$ & 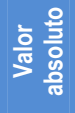 & 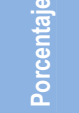 \\
\hline & 1980 & 7.252 & & & 1.164 & & & & & & & & & 8.416 & & & $86,2 \%$ & $13,8 \%$ & & & & \\
\hline Gral. & 1991 & 8.894 & $+22,6 \%$ & & 1.105 & $-5,1 \%$ & & & & & & & & 9.999 & $+18,8 \%$ & & $88,9 \%$ & $11,1 \%$ & 370 & 297 & 73 & $19,7 \%$ \\
\hline & 2001 & 10.351 & $+16,4 \%$ & $+42,7 \%$ & 724 & $-34,5 \%$ & $-37,8 \%$ & & & & & & & 11.075 & $+10,8 \%$ & $+31,6 \%$ & $93,5 \%$ & $6,5 \%$ & 370 & 240 & 130 & $35,1 \%$ \\
\hline & 1980 & 5.248 & & & 1.045 & & & & & & & & & 6.293 & & & $83,4 \%$ & $16,6 \%$ & & & & \\
\hline Gral. & 1991 & 6.935 & $+46,5 \%$ & & 1.518 & $+45,3 \%$ & & & & & & & & 8.453 & $+34,3 \%$ & & $83,5 \%$ & $16,5 \%$ & 519 & 387 & 132 & $25,4 \%$ \\
\hline & 2001 & 9.391 & $+24 \%$ & $+81,7 \%$ & 670 & $-55,9 \%$ & $-35,9 \%$ & & & & & & & 10.061 & $+19,0 \%$ & $+59,9 \%$ & $93,4 \%$ & $6,6 \%$ & 323 & 204 & 119 & $36,8 \%$ \\
\hline & 1980 & 6.627 & & & 2.353 & & & & & & & & & 8.980 & & & $74,1 \%$ & $25,9 \%$ & & & & \\
\hline Coronel & 1991 & 7.653 & $+14,4 \%$ & & 1.719 & $-26,9 \%$ & & & & & & & & 9.372 & $+4,4 \%$ & & $81,7 \%$ & $18,3 \%$ & 670 & 472 & 198 & $29,5 \%$ \\
\hline & 2001 & 8.019 & $+5,3 \%$ & $+20,5 \%$ & 1.178 & $-31,5 \%$ & $-49,9 \%$ & & & & & & & 9.197 & $-1,9 \%$ & $+2,4 \%$ & $87,3 \%$ & $12,7 \%$ & 652 & 384 & 268 & $41,1 \%$ \\
\hline & 1980 & 5.666 & & & 4.503 & & & 3.087 & & & $1.436^{(1)}$ & & & 10.169 & & & $55,7 \%$ & $44,3 \%$ & & & & \\
\hline $\begin{array}{l}\text { Vicuna } \\
\text { Mackenna }\end{array}$ & 1991 & 7.181 & $+26,7 \%$ & & 4.195 & $-6,8 \%$ & & 2.643 & $-13,8 \%$ & & 1.552 & $+8,1 \%$ & & 11.376 & $+11,9 \%$ & & $63,1 \%$ & $36,9 \%$ & 1.571 & 1.183 & 388 & $24,7 \%$ \\
\hline & 2001 & 8.836 & $+25,2 \%$ & $+58,7 \%$ & 3.370 & $-19,7 \%$ & $-25,2 \%$ & 1.756 & $-33,6 \%$ & $-42,7 \%$ & 1.614 & $+4,0 \%$ & $+12,4 \%$ & 12.206 & $+7,3 \%$ & $+20,0 \%$ & $72,7 \%$ & $27,3 \%$ & 1.596 & 1.101 & 495 & $31,0 \%$ \\
\hline & 1980 & 6.467 & & & 3.655 & & & 2.841 & & & $814(2)$ & & & 10.122 & & & $63,9 \%$ & $36,1 \%$ & & & & \\
\hline Sampacho & 1991 & 7.160 & $+10,7 \%$ & & 2.942 & $-19,5 \%$ & & 2.188 & $-23,7 \%$ & & 774 & $-4,9 \%$ & & 10.102 & $-0,2 \%$ & & $70,9 \%$ & $29,1 \%$ & 1.125 & 843 & 282 & $25,0 \%$ \\
\hline & 2001 & 7.237 & $+1,1 \%$ & $+11,9 \%$ & 2.652 & $-9,9 \%$ & $-27,7 \%$ & 1.725 & $-20,4 \%$ & $-39,3 \%$ & 927 & $+19,8 \%$ & $+13,9 \%$ & 9.889 & $-2,1 \%$ & $-2,7 \%$ & $73,2 \%$ & $26,8 \%$ & 1.213 & 894 & 319 & $26,3 \%$ \\
\hline Berrotarán & 1980 & 4.962 & & & 825 & & & & & & & & & 5.787 & & & $85,7 \%$ & $14,3 \%$ & & & & \\
\hline (área pampeana & 1991 & 6.187 & $+24,7 \%$ & & 485 & $-41,2 \%$ & & & & & & & & 6.672 & $+15,3 \%$ & & $92,7 \%$ & $7,3 \%$ & 207 & 149 & 58 & $28,0 \%$ \\
\hline exclusivamente) & 2001 & 6.441 & $+4,1 \%$ & $+29,8 \%$ & 365 & $-24,7 \%$ & $-55,8 \%$ & & & & & & & 6.806 & $+2,0 \%$ & $+17,6 \%$ & $94,6 \%$ & $5,4 \%$ & 199 & 127 & 72 & $36,2 \%$ \\
\hline & 1980 & 3.987 & & & 2.074 & & & 1.796 & & & $278^{(3)}$ & & & 6.061 & & & $65,8 \%$ & $34,2 \%$ & & & & \\
\hline Adella & 1991 & 5.251 & $+32,8 \%$ & & 1.613 & $-22,2 \%$ & & 1.237 & $-31,1 \%$ & & 376 & $+35,3 \%$ & & 6.864 & $+13,2 \%$ & & $76,6 \%$ & $23,4 \%$ & 679 & 458 & 221 & $32,5 \%$ \\
\hline & 2001 & 6.358 & $+21,5 \%$ & $+61,4 \%$ & 1.452 & $-10,0 \%$ & $-30,0 \%$ & 960 & $-22,4 \%$ & $-46,5 \%$ & 492 & $+30,9 \%$ & $+77,0 \%$ & 7.810 & $+13,8 \%$ & $+28,9 \%$ & $81,6 \%$ & $18,4 \%$ & 705 & 474 & 231 & $32,8 \%$ \\
\hline & 1980 & 4.312 & & & 2.066 & & & & & & & & & 6.378 & & & $67,6 \%$ & $32,4 \%$ & & & & \\
\hline $\begin{array}{l}\text { Alcira } \\
\text { Gigen }\end{array}$ & 1991 & 4.948 & $+14,7 \%$ & & 1.227 & $-40,6 \%$ & & & & & & & & 6.175 & $-3,2 \%$ & & $80,1 \%$ & $19,9 \%$ & 455 & 332 & 123 & $27,0 \%$ \\
\hline & 2001 & 5.486 & $+10,9 \%$ & $+27,2 \%$ & 824 & $-32,5 \%$ & $-60,1 \%$ & & & & & & & 6.310 & $+2,2 \%$ & $-1,1 \%$ & $86,9 \%$ & $13,1 \%$ & 461 & 302 & 159 & $34,5 \%$ \\
\hline & 1980 & 4.036 & & & 1.257 & & & & & & & & & 5.293 & & & $76,3 \%$ & $23,7 \%$ & & & & \\
\hline Ucacha & 1991 & 4.777 & $+18,4 \%$ & & 1.014 & $-19,3 \%$ & & & & & & & & 5.791 & $+9,4 \%$ & & $82,5 \%$ & $17,5 \%$ & 408 & 284 & 124 & $30,4 \%$ \\
\hline & 2001 & 4.751 & $-0,5 \%$ & $+17,7 \%$ & 767 & $-24,4 \%$ & $-39,0 \%$ & & & & & & & 5.518 & $-4,7 \%$ & $+4,3 \%$ & $86,1 \%$ & $13,9 \%$ & 408 & 282 & 126 & $30,9 \%$ \\
\hline & 1980 & 3.297 & & & 1.510 & & & & & & & & & 4.807 & & & $70,0 \%$ & $30,0 \%$ & & & & \\
\hline $\begin{array}{l}\text { Alejandiro } \\
\text { Roca }\end{array}$ & 1991 & 3.791 & $+14,2 \%$ & & 1.130 & $-25,2 \%$ & & & & & & & & 4.921 & $+2,4 \%$ & & $78,1 \%$ & $21,9 \%$ & 482 & 312 & 170 & $35,3 \%$ \\
\hline & 2001 & 4.642 & $+17,4 \%$ & $+34 \%$ & 674 & $-40,4 \%$ & $-55,4 \%$ & & & & & & & 5.316 & $+8,0 \%$ & $+10,6 \%$ & $87,5 \%$ & $12,5 \%$ & 420 & 270 & 150 & $35,7 \%$ \\
\hline
\end{tabular}

Referencias: * Corresponde a la sumatoria de los pequeños centros poblados de menos de 2.000 habitantes.

1).Washington, Tosquita y La Cautiva - (2) Chaján y Suco - (3) Monte de los Gauchos.

Fuente: Elaboración propia sobre la base de los Censos Nacionales de Población y Vivienda 1980, 1991 y 2001, de donde se obtuvieron los valores resumidos de población rural y de vivienda, provenientes de la sumatoria de los datos de los radios censales del área bajo estudio, provistos por la Dirección Provincial de Estadísticas y Censos de la Provincia de Córdoba. 
Ahora, si consideramos la evolución de la población de las "unidades territoriales", que -como dijimos- comprenden las localidades más sus respectivas zonas rurales de influencia -en concreto, población urbana más población rural-, veremos que las que cuentan con más habitantes son aquellas unidades territoriales que corresponden a Vicuña Mackenna, Sampacho, General Cabrera y General Deheza. En las dos primeras incide principalmente el alto peso relativo de su población rural, y en las dos últimas incide básicamente el peso que tiene la población urbana. Entre los extremos de 1980 y 2001, el mayor incremento poblacional a nivel de unidades territoriales va a corresponder a General Deheza y General Cabrera, por la misma causa anteriormente nombrada. Obviamente, en las unidades territoriales, los aumentos poblacionales intercensales van a ser menores -y en algunos casos negativos- que los de la población urbana, por el contrapeso que representa la población rural en franco retroceso. Queda claro que el entorno rural de las localidades estudiadas, al igual que muchas otras de la llanura pampeana, se ha ido vaciando progresivamente de habitantes.

Como resultado de este fenómeno, los porcentuales de población urbana de las respectivas unidades territoriales, en general, son muy altos y similares a los que detenta la provincia de Córdoba.

Por otra parte, como consecuencia del desmantelamiento de la población rural, es muy interesante apreciar el alto índice de viviendas desocupadas que se observan en las áreas rurales de las localidades estudiadas y que fluctúa entre el $26 \%$ y el $41 \%$ en el último censo, habiéndose incrementado significativamente entre el último y penúltimo censo en seis áreas rurales; en cambio, en las cuatro restantes se ha mantenido más o menos constante. Es dable considerar que estos valores pueden presentar un cierto margen de error, ya que en el acto censal pueden haber mediado situaciones coyunturales - ej.: familias ampliadas (parte de la misma vive en el campo y la otra parte en el pueblo) y productores que viven en el campo, pero que a su vez tienen casa en el pueblo- que determinaron que en ese momento no hubiese gente en algunas viviendas que normalmente están ocupadas permanentemente. Corresponde puntualizar que varias de estas viviendas desocupadas pertenecen a productores que viven en los pueblos y que son usadas parcialmente cuando los mismos se trasladan a trabajar sus respectivas explotaciones. Es pertinente resaltar que muchas de estas viviendas desocupadas han sido muy confortables y bien equipadas y que, debido al abandono que sufren, paulatinamente se van degradando. Queda claro que el alto porcentaje de viviendas desocupadas existentes constituye un contundente testimonio más del despoblamiento que viene acusando el campo desde hace muchos años. 


\subsection{EI despoblamiento del campo y sus consecuencias}

De acuerdo con todo lo expuesto hasta aquí, entendemos que la evolución demográfica, en general, y el despoblamiento del campo, en particular, observado en nuestra área de estudio, no difiere mayormente con respecto a la provincia de Córdoba y, en líneas amplias, con el resto del país. No obstante, si bien conserva similitudes demográficas muy próximas en relación con las escalas territoriales mayores, en determinados casos se detectan diferencias de cierta relevancia en algunos indicadores de población.

Es así como, a nivel comparativo, a lo largo de los tres censos observamos lo siguiente:

- Un incremento de la población total del Sur Cordobés menor que a nivel país y de provincia de Córdoba, lo que supone -como sugerimos anteriormente- un desplazamiento de cierto porcentaje de la población de la región hacia otros puntos del país.

- Una disminución más acentuada de la población rural en comparación con el país y la provincia.

- Dentro de la estructura de la población total, un mayor porcentaje de población rural con respecto a las dos escalas territoriales mayores, debido al fuerte peso histórico de las actividades rurales en la región sur de la provincia.

- Una predominancia relativamente similar de la población rural dispersa con respecto a la agrupada, tanto en la región sur como en los otros dos ámbitos territoriales mayores.

- Una tendencia de la población rural agrupada de mantener relativamente su caudal poblacional en las tres escalas territoriales analizadas.

- Dentro del total poblacional del Sur Cordobés, vemos -a diferencia del nivel nacional y provincial- que los varones predominan en el censo de 1980, para luego asumir la mayoría la población femenina en los dos censos siguientes, pero a su vez dicha diferencia en menor proporción que a nivel nacional y provincial.

- Las pequeñas localidades del Sur Cordobés, y particularmente las que poseen menos de 500 habitantes, posiblemente no han sufrido un drenaje tan acusado como otras localidades similares del resto del país.

Cabe resaltar que las observaciones censales arriba expresadas de similitudes y diferencias que acusa el Sur Cordobés, se reafirman en el análisis demográfico, a menor escala territorial, de las diez localidades testigos con sus respectivas zonas rurales de influencia. 
Por lo tanto, la diferencia sustancial en términos demográficos del Sur Cordobés, con respecto al país y la provincia, es que en aquél, a pesar de una mayor ruralidad dentro de la estructura interna de la población total, se manifiesta un despoblamiento rural mucho más marcado y profundo a lo largo de los tres censos. Dicha caída de la población rural del Sur Cordobés se asemeja bastante, posiblemente, a lo que también le acontece al resto de la Región Pampeana. Por lo tanto -más allá de las coyunturas económicas favorables o no-, es de pensar que un área evolucionada agrícolamente como es ésta, donde por sus adelantos tecnológicos y mayor disponibilidad de capital se prescinde de un mayor número de trabajadores rurales, y donde se impone un mecanismo más acentuado de explotación de los campos comandado desde los centros urbanos, ha de producir, como consecuencia, un ritmo de exclusión demográfica rural mucho más relevante que en algunas otras regiones del país.

En líneas generales, como todo fenómeno de magnitud y de intensidad persistente, se supone que los causales del despoblamiento no son simples ni acotados a hechos puntuales, sino que más bien responden a sucesivas motivaciones que han producido, simultánea y escalonadamente, según el contexto histórico, dicho vaciamiento poblacional.

Dentro de la tendencia mundial del incremento de la población urbana en desmedro de la rural, de la que obviamente el país, la provincia de Córdoba y nuestra región de análisis no escapan, en esta última se pueden detectar causales específicas que seguramente son muy similares a las que se manifestaron y se manifiestan en el resto de la Región Pampeana. En este sentido, podemos destacar de manera muy sucinta las principales motivaciones del abandono del campo como lugar de residencia. Éstas son:

- Como ya lo mencionamos, el desplazamiento de pequeños productores familiares y medianos productores del campo a los pueblos o ciudades intermedias cercanas, a partir de la década del ' 60 y ' 70 -en un contexto para los nombrados de relativa bonanza económica-, tuvo como principal motivación brindarle educación secundaria a sus hijos y, a su vez, acceder a las comodidades y a la sociabilidad de los centros urbanos. Este movimiento campo-ciudad coincide con la creación de escuelas de enseñanza media en las principales localidades a partir de mediados del siglo pasado en nuestra región de análisis.

Cabe acotar que a raíz de este desplazamiento, que fue de gran significación en el área de estudio, los productores que se habrían trasladado a los pueblos y que obviamente seguían trabajando sus campos, pasaron a poseer doble vivienda. La casa del pueblo como residencia familiar, y la de la explotación como residencia de 
tránsito, es decir, la pasan a utilizar parcialmente cuando realizan sus tareas agropecuarias.

- El desprendimiento definitivo de las explotaciones por parte de un apreciable número de pequeños productores, ya sea por falta de rentabilidad de sus campos o por no poder pagar las deudas contraídas. Este abandono de los campos en los últimos tiempos se manifiesta particularmente a fines de la década del '70 y en ciertos periodos de las dos décadas siguientes, en que un conjunto de factores adversos, como créditos usurarios, alta inflación generalizada, caída de los precios de los productos agrícolas, entre otros factores, no pudieron ser afrontados por los eslabones más débiles de la cadena productiva agropecuaria. En estos casos, los agentes que se retiran de la escena productiva representan una pérdida absoluta de productores agropecuarios. Además, debe agregarse -en los últimos tiempos- el desprendimiento transitorio de sus tierras y su consecuente traslado a los centros urbanos de un número también apreciable de pequeños productores, tentados por los altos precios coyunturales de los alquileres rurales.

- La tercera razón importante del abandono del campo como lugar de residencia, y quizás la más trascendente, deviene de la dinámica generalizada de los últimos tiempos de la ventaja especulativa de explotar la tierra en gran escala, es decir, en grandes unidades de producción. Esto implica que tal gran concentración de las explotaciones - gracias al ingreso de las nuevas tecnologías y de grandes capitalesagudiza el despoblamiento del campo, fenómeno que ya viene manifestándose desde hace varios años atrás, además de generar una gran disminución numérica de productores agropecuarios y, por arrastre, de asalariados rurales,

Con respecto a las consecuencias socio-territoriales que acarrea el vaciamiento rural, algunas son perceptibles a simple vista, como el observar casas e instalaciones abandonadas, alambrados de las parcelas caídos, caminos vecinales descuidados, el no avistaje de personas a lo largo de grandes extensiones y el deterioro en muchos casos del ambiente natural, por falta de cuidado y del control estrecho de la mano del hombre.

Asimismo, se suma otra consecuencia, quizás no tan perceptible pero bastante más significativa, y que atañe a la actual estructura agraria fundiaria. Ésta consiste -en razón de la reaparición de grandes explotaciones, con la consecuente menor participación de personas en el ámbito rural-, en una utilización menos racional, desde el punto de vista socio-productivo, es decir distributivo, de lo que puede brindar la tierra cuando se interactivan todas sus potencialidades sociales y naturales. 
En síntesis, no obstante los problemas que representa contar con un campo semivacío de personas, posiblemente el centro de la cuestión no pase intrínsecamente por el despoblamiento en sí, ya que técnicamente -aunque con ciertas desventajas ineludibles, ya que no cabe la menor duda de que si el campo está habitado, el mismo se aprovecha mejor- las explotaciones pueden ser comandadas medianamente bien desde las localidades urbanas más cercanas, sino que, básicamente, los campos se sigan trabajando adecuadamente en toda su extensión, con la participación efectiva de la fuerza laboral rural que toda la vida ha trabajado los mismos. Como reflexión final, en relación con la región de nuestro estudio, da la impresión de que el despoblamiento rural está llegando a un punto a partir del cual es difícil que sustantivamente avance más, debido a que, presumiblemente, las personas que siguen viviendo en el medio rural, por una parte, resultan ser la mano de obra imprescindible para el cuidado básico que requiere el campo y, por otra, el contar en la actualidad con productores que, al disponer de un buen pasar económico y poseer viviendas con apreciables comodidades, semejantes en muchos casos a las urbanas, han podico afianzar sólidamente su residencia permanente en el medio rural. 


\section{Capítulo IV}

\section{Dimensión cuantitativa y locacional de la PEA Agropecuaria}

\subsection{Conceptualización y caracterización de la PEA Agropecuaria}

Antes de entrar en la caracterización genérica de los actores laborales que intervienen en el agro, entendemos que resulta oportuno enmarcar en forma debida el objeto de estudio: la PEA Agropecuaria en el contexto de las fuerzas laborales que interactúan tanto en las áreas rurales como en los centros urbanos (Agüero, González, Puigdomenech, 1999). A nivel de apreciación conceptual y a fin de destacar adecuadamente la "diferencia entre PEA Rural y PEA Agropecuaria", se puede empezar diciendo que tanto los términos PEA Rural como PEA Urbana hacen referencia al asentamiento o residencia de la PEA, y PEA Agropecuaria y PEA No Agropecuaria a la actividad económica prevaleciente dentro de la PEA (Gráfico № 2).

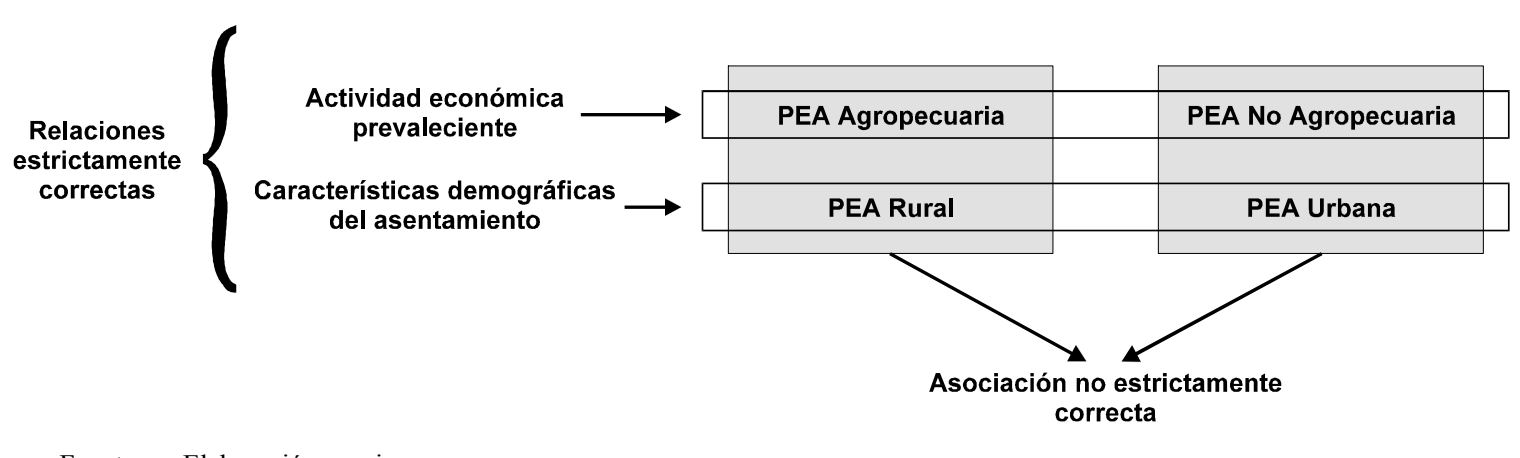

Fuente: Elaboración propia.

A su vez hay que considerar que la PEA Agropecuaria no vive exclusivamente en las áreas rurales (asentamientos con menos de 2000 habitantes para Argentina) y que la residencia de la PEA No Agropecuaria no se circunscribe solamente a las áreas urbanas (2000 o más habitantes). No obstante, se suelen usar como sinónimos respectivamente para estos agregados las expresiones PEA Rural y PEA Urbana, “con una definición implícita de ruralurbano basada no ya en las características demográficas del asentamiento sino en las actividades económicas prevalecientes" (Torrado, 1992:118). Si bien esta asociación terminológica se suele emplear debido a la fuerza de la costumbre, debe quedar en claro que no es estrictamente correcta.

En forma ampliada, se representa en el Gráfico $\mathrm{N}^{\mathrm{o}} 3$ la conjunción de la dupla PEA Rural-PEA Urbana y PEA Agropecuaria-PEA No Agropecuaria con sus respectivas implicancias, desagregaciones y vinculaciones. Partiendo de la población rural y urbana, por 
entender que las PEAs respectivas son un desprendimiento de aquéllas, se distinguen en forma esquemática cuatro instancias:

1) Lugar de residencia: aquí se observa una PEA Agropecuaria residiendo en los centros urbanos y una PEA No Agropecuaria viviendo en las áreas rurales.

2) Lugar de trabajo, área rural: esta instancia va a englobar la PEA Agropecuaria y la PEA No Agropecuaria que reside en las áreas rurales más la PEA Agropecuaria asentada en las áreas urbanas.

3) Lugar de trabajo, centro urbano: esta instancia va a involucrar la PEA No Agropecuaria que reside en las áreas rurales y que trabaja en la ciudad, más la PEA No Agropecuaria propiamente dicha que reside en los centros urbanos.

4) Actividad económica prevaleciente: ésta se superpone a las dos áreas de asentamiento.

En suma, caben estas conceptualizaciones a fin de despejar algunos aspectos confusos que se observan en cierto material estadístico. Es así como se suele asociar a la Población Rural y su correspondiente fuerza laboral como la única abocada a las tareas rurales, cuando queda claro que un porcentaje apreciable de la PEA Agropecuaria proviene de los centros urbanos. Además este tipo de asociación desestima a la PEA No Agropecuaria inserta en la Población Rural, que por otro lado es importante. En última instancia, se confunde lugar de residencia con actividad laboral, situación ésta que hay que tratar de evitar.

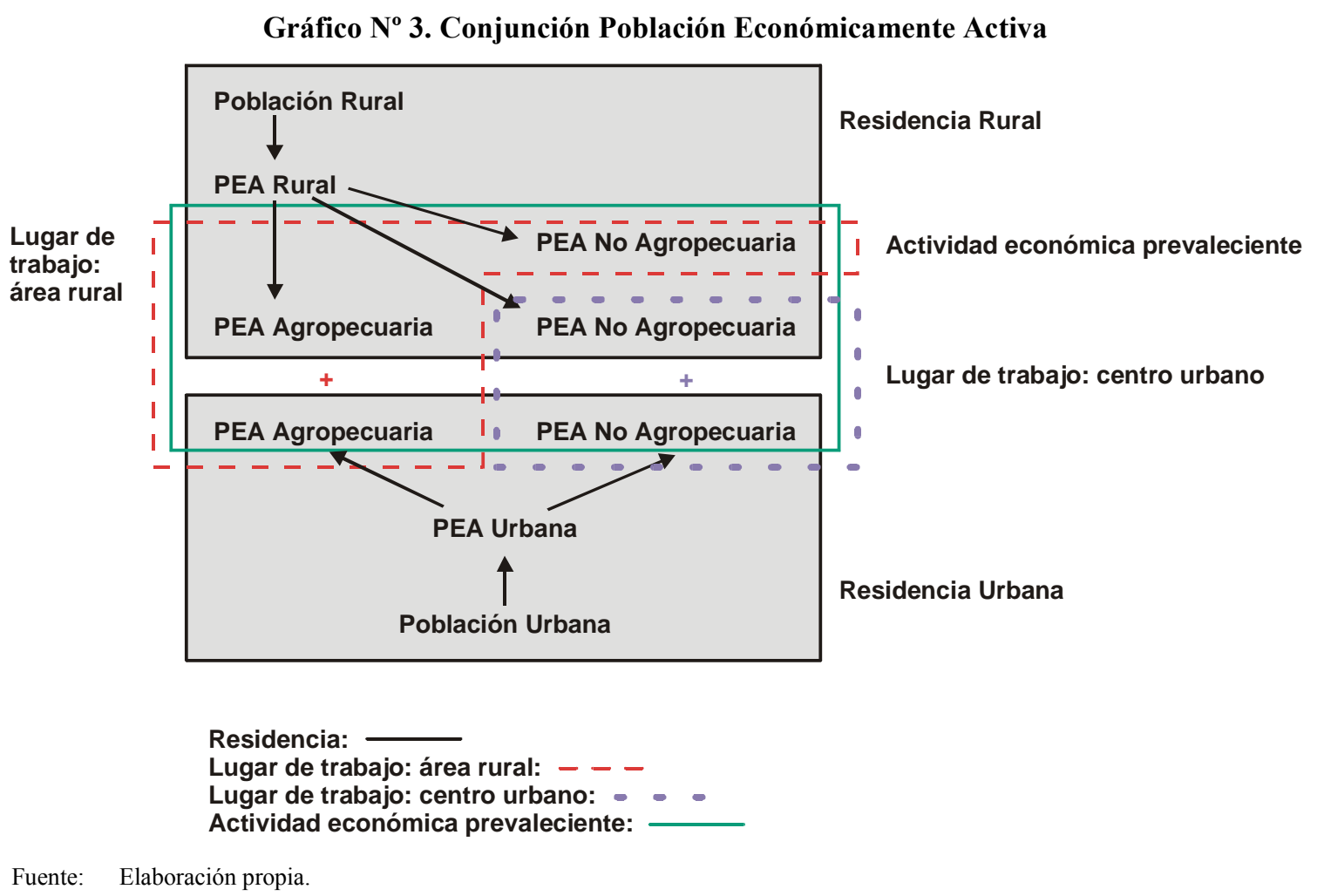


Por último, cabe resaltar que el propósito de incluir de manera genérica toda la fuerza laboral ocupada y desocupada sin diferenciarla dentro de la PEA Agropecuaria, parte de la dificultad de distinguirla en el ámbito del trabajo rural -lo que no resulta, en cambio, tan así en el ámbito urbano-, debido al ritmo estacional del mismo.

\subsection{Evolución cuantitativa de la PEA Agropecuaria y de las categorías estadísticas asociadas a nivel país, de la provincia de Córdoba y de los cuatro departamentos que forman el sur cordobés}

En este acápite, nos proponemos desarrollar, a nivel estadístico, el papel que ocupa la PEA Agropecuaria en el conjunto del total de la fuerza laboral, en base a las variaciones que ha sufrido la misma entre 1991 y 2001, según los Censos Nacionales de Población y Vivienda respectivos. Todo ello, de manera comparativa, a nivel de país, de provincia y de los cuatro departamentos del sur cordobés.

Es conveniente aclarar que los guarismos de la PEA Agropecuaria y sus valores asociados que utilizamos los consideramos con un criterio amplio y flexible, ya que cabe recordar que, a nivel censal, tales categorías estadísticas - las referidas a la PEA- no existen como tales, sino que hay que construirlas con datos provenientes de otras fuentes de recopilación censal, que pueden no reflejar estrictamente los valores de la PEA en sus tres variantes: total, agropecuaria y no agropecuaria.

Por último, a modo de agregado informativo, en esta sección volcamos los datos de los Censos Nacionales Agropecuarios de 1988 y 2002, de las personas que trabajan en las explotaciones (EAPs) en forma permanente, de las mismas jurisdicciones arriba nombradas. Si bien el universo informativo de esta procedencia está lejos de involucrar a toda la fuerza laboral agropecuaria, además de emplear una metodología diferente de la que se emplea en los Censos Nacionales de Población y Vivienda, nos sirve, no obstante, de punto de referencia para conocer la evolución de la fuerza laboral que se desempeña de manera continua en los establecimientos rurales.

A continuación, y ya entrando en tema propiamente dicho, podemos apreciar, en el Cuadro $\mathrm{N}^{\mathrm{o}} 16$, la variación de la PEA Agropecuaria en los tres niveles jurisdiccionales mencionados, entre 1991 y 2001. Vemos que, en general, la disminución de la PEA Agropecuaria es de alrededor de un $30 \%$ en promedio. Porcentaje más que elocuente, que refleja el vaciamiento de la fuerza del trabajo rural que viene sufriendo el agro y tendencia 
que coincide de manera amplia con otras observaciones similares llevadas a cabo por nosotros, en otras partes de este trabajo.

Cuadro No 16. Variación de la PEA Agropecuaria entre 1991 y 2001, a nivel país, provincia de Córdoba y de los cuatro departamentos de sur cordobés

\begin{tabular}{|c|c|c|c|c|c|c|c|}
$\begin{array}{c}\text { Año de } \\
\text { relevamiento } \\
\text { censal }\end{array}$ & $\begin{array}{c}\text { Total del } \\
\text { país }\end{array}$ & $\begin{array}{c}\text { Provincia } \\
\text { de Córdoba }\end{array}$ & Río Cuarto & $\begin{array}{c}\text { Juárez } \\
\text { Celman }\end{array}$ & $\begin{array}{c}\text { Presidente } \\
\text { Roque Sáenz } \\
\text { Peña }\end{array}$ & $\begin{array}{c}\text { General } \\
\text { Roca }\end{array}$ & $\begin{array}{c}\text { Sumatoria de } \\
\text { los cuatro } \\
\text { departamentos }\end{array}$ \\
\hline 1991 & 1.347 .393 & 131.816 & 14.798 & 6.669 & 4.629 & 4.771 & 30.867 \\
\hline 2001 & 897.507 & 94.319 & 10.375 & 4.383 & 2.761 & 3.847 & 21.366 \\
\hline $\begin{array}{c}\text { Variación } \\
\text { absoluta }\end{array}$ & -449.886 & -37.497 & -4.423 & -2.286 & -1.868 & -924 & -9.501 \\
Variación \% & $-33,4 \%$ & $-28,4 \%$ & $-29,9 \%$ & $-34,3 \%$ & $-40,4 \%$ & $-19,4 \%$ & $-30,8 \%$ \\
\hline
\end{tabular}

Fuente: Elaboración propia en base a la información brindada por las áreas agropecuarias y socio-demográficas de la Dirección General de Estadística y Censos, Secretaría General de la Gobernación de la Provincia de Córdoba.

Por otro lado, en el Cuadro $\mathrm{N}^{0} 17$, figura la población agropecuaria por categoría ocupacional. En el mismo, se observan las siguientes características:

- En consonancia con lo descripto en el Cuadro $N^{\circ} 16$, se detecta, entre 1991 y 2001, una caída total de los valores absolutos de todas las categorías ocupacionales que conforman el activo laboral agropecuario.

- Dentro del mismo año -o sea, en sentido horizontal-, tanto de 1991 como de 2001, vemos en la desagregación de las categorías ocupacionales que, en todas las jurisdicciones analizadas, detenta el primer lugar la categoría "Obrero, empleado", con porcentajes promedios que giran alrededor del 50\%. Le sigue, en segundo lugar, el rubro "Trabajador por cuenta propia", con ciertos desfasajes en el orden arriba mencionado en algunos departamentos del sur cordobés, pero que en la sumatoria de los mismos vuelve a ocupar cuantitativamente el segundo lugar. El tercer puesto -exceptuando la jurisdicción del "Total del país"-, en general, corresponde a la categoría "Patrón", con porcentajes no muy significativos, quedando ubicado en último lugar el rubro correspondiente al "Trabajador familiar". Vemos que, en este tipo de desagregación, hay una clara predominancia de la categoría "Obrero, empleado". Asimismo, en este cuadro, es interesante observar que, presumiblemente, la sumatoria de las categorías de "Patrón" y gran parte de "Trabajador por cuenta propia”, corresponden, en una escala mucho más abarcativa, a la que figura bajo el rubro de "Productor" en el Cuadro 21, que contiene la cantidad de personas que trabajan en las EAPs en forma permanente.

- Entre un año y otro -o sea, en sentido vertical- se observa, en la columna de "Obrero, empleado", un incremento relativo intercensal apreciable a lo largo de todas las jurisdicciones consideradas. También se observa una disminución relativa suave y constante de los porcentuales, en los casos de las columnas del "Trabajador por cuenta 
propia" y del "Patrón". En cambio, se manifiesta una disminución relativa muy pronunciada en la categoría de "Trabajador familiar". Esto último se explica en parte debido a que muchos hijos de productores rurales se orientan hacia trabajos urbanos o prosiguen estudios superiores que los alejan de las tareas del campo.

Cuadro $\mathbf{N}^{0}$ 17. Variación de la población en condición de ocupación en el sector agrícola según categoría ocupacional, entre 1991 y 2001, a nivel país, provincia de Córdoba y de los cuatro departamentos de sur cordobés

\begin{tabular}{|c|c|c|c|c|c|c|c|}
\hline \multirow[b]{2}{*}{ Jurisdicciones } & \multirow[b]{2}{*}{ Años } & \multirow{2}{*}{\begin{tabular}{|c|} 
Población \\
agropecuaria \\
total ocupada
\end{tabular}} & \multicolumn{5}{|c|}{ Categoría ocupacional } \\
\hline & & & $\begin{array}{l}\text { Obrero, } \\
\text { empleado }\end{array}$ & $\begin{array}{l}\text { Trabajador por } \\
\text { cuenta propia }\end{array}$ & Patrón & $\begin{array}{l}\text { Trabajador } \\
\text { familiar }\end{array}$ & Ignorado \\
\hline \multirow{2}{*}{ Total del país } & 1991 & $\begin{array}{c}1.347 .393 \\
100 \%\end{array}$ & $\begin{array}{c}610.414 \\
45,3 \%\end{array}$ & $\begin{array}{c}362.403 \\
26,9 \%\end{array}$ & $\begin{array}{c}130.182 \\
9,7 \%\end{array}$ & $\begin{array}{c}242.343 \\
17,9 \%\end{array}$ & $\begin{array}{l}2.051 \\
0,2 \%\end{array}$ \\
\hline & 2001 & $\begin{array}{c}897.507 \\
100 \%\end{array}$ & $\begin{array}{c}490.561 \\
54,6 \%\end{array}$ & $\begin{array}{c}220.515 \\
24,6 \%\end{array}$ & $\begin{array}{c}80.650 \\
9 \%\end{array}$ & $\begin{array}{c}105.781 \\
11,8 \%\end{array}$ & - \\
\hline \multirow{2}{*}{$\begin{array}{l}\text { Provincia de } \\
\text { Córdoba }\end{array}$} & 1991 & $\begin{array}{c}131.816 \\
100 \%\end{array}$ & $\begin{array}{l}55.077 \\
41,8 \%\end{array}$ & $\begin{array}{l}34.534 \\
26,2 \%\end{array}$ & $\begin{array}{c}19.742 \\
15 \%\end{array}$ & $\begin{array}{c}22.291 \\
17 \%\end{array}$ & 172 \\
\hline & 2001 & $\begin{array}{l}94.319 \\
100 \%\end{array}$ & $\begin{array}{c}49.079 \\
52 \%\end{array}$ & $\begin{array}{l}22.256 \\
23,6 \%\end{array}$ & $\begin{array}{l}12.714 \\
13,5 \%\end{array}$ & $\begin{array}{l}10.270 \\
10,9 \%\end{array}$ & 一 \\
\hline \multirow{2}{*}{ Río Cuarto } & 1991 & $\begin{array}{l}14.798 \\
100 \%\end{array}$ & $\begin{array}{l}6.068 \\
41 \%\end{array}$ & $\begin{array}{l}3.645 \\
24,6 \%\end{array}$ & $\begin{array}{l}2.574 \\
17,4 \%\end{array}$ & $\begin{array}{c}2.500 \\
17 \%\end{array}$ & 11 \\
\hline & 2001 & $\begin{array}{c}10.375 \\
100 \%\end{array}$ & $\begin{array}{l}5.011 \\
48,3 \%\end{array}$ & $\begin{array}{c}2.694 \\
26 \%\end{array}$ & $\begin{array}{r}1.640 \\
15,8 \%\end{array}$ & $\begin{array}{l}1.030 \\
9,9 \%\end{array}$ & 一 \\
\hline \multirow{2}{*}{ Juárez Celman } & 1991 & $\begin{array}{l}6.669 \\
100 \%\end{array}$ & $\begin{array}{l}3.614 \\
54,2 \%\end{array}$ & $\begin{array}{c}1.122 \\
16,8 \%\end{array}$ & $\begin{array}{c}1.212 \\
18,2 \%\end{array}$ & $\begin{array}{c}721 \\
10,8 \%\end{array}$ & - \\
\hline & 2001 & $\begin{array}{l}4.383 \\
100 \%\end{array}$ & $\begin{array}{l}2.627 \\
59,9 \%\end{array}$ & $\begin{array}{c}699 \\
15,9 \%\end{array}$ & $\begin{array}{c}731 \\
16,7 \%\end{array}$ & $\begin{array}{c}326 \\
7,5 \%\end{array}$ & 一 \\
\hline \multirow{2}{*}{$\begin{array}{c}\text { Presidente Roque } \\
\text { Sáenz Peña }\end{array}$} & 1991 & $\begin{array}{l}4.629 \\
100 \%\end{array}$ & $\begin{array}{l}2.294 \\
49,6 \%\end{array}$ & $\begin{array}{c}955 \\
20,6 \%\end{array}$ & $\begin{array}{c}679 \\
14,7 \%\end{array}$ & $\begin{array}{c}697 \\
15,1 \%\end{array}$ & 4 \\
\hline & 2001 & $\begin{array}{l}2.761 \\
100 \%\end{array}$ & $\begin{array}{l}1.675 \\
60,7 \%\end{array}$ & $\begin{array}{c}426 \\
15,4 \%\end{array}$ & $\begin{array}{c}462 \\
16,7 \%\end{array}$ & $\begin{array}{c}198 \\
7,2 \%\end{array}$ & 一 \\
\hline \multirow{2}{*}{ General Roca } & 1991 & $\begin{array}{l}4.771 \\
100 \%\end{array}$ & $\begin{array}{l}2.756 \\
57,8 \%\end{array}$ & $\begin{array}{c}723 \\
15,2 \%\end{array}$ & $\begin{array}{c}817 \\
17,7 \%\end{array}$ & $\begin{array}{c}474 \\
9,9 \%\end{array}$ & 1 \\
\hline & 2001 & $\begin{array}{l}3.847 \\
100 \%\end{array}$ & $\begin{array}{l}2.453 \\
63,8 \%\end{array}$ & $\begin{array}{c}504 \\
13,1 \%\end{array}$ & $\begin{array}{c}631 \\
16,4 \%\end{array}$ & $\begin{array}{l}259 \\
6,7 \%\end{array}$ & 一 \\
\hline \multirow{2}{*}{$\begin{array}{c}\text { Sumatoria de los } \\
\text { cuatro } \\
\text { departamentos }\end{array}$} & 1991 & $\begin{array}{c}30.867 \\
100 \%\end{array}$ & $\begin{array}{l}14.732 \\
47,8 \%\end{array}$ & $\begin{array}{l}6.445 \\
20,9 \%\end{array}$ & $\begin{array}{l}5.282 \\
17,1 \%\end{array}$ & $\begin{array}{l}4.392 \\
14,2 \%\end{array}$ & 15 \\
\hline & 2001 & $\begin{array}{c}21.366 \\
100 \%\end{array}$ & $\begin{array}{l}11.766 \\
55,1 \%\end{array}$ & $\begin{array}{l}4.323 \\
20,2 \%\end{array}$ & $\begin{array}{l}3.464 \\
16,2 \%\end{array}$ & $\begin{array}{l}1.813 \\
8,5 \%\end{array}$ & - \\
\hline
\end{tabular}

Fuente: Elaboración propia en base a la información brindada por las áreas agropecuarias y socio-demográficas de la Dirección General de Estadística y Censos, Secretaría General de la Gobernación de la Provincia de Córdoba.

A continuación, en el Cuadro $\mathrm{N}^{\mathrm{o}} 18$, comparamos la incidencia del volumen de la PEA Rural y Urbana con respecto a la PEA Agropecuaria y No Agropecuaria. Así, vemos que:

- Lo primero que resalta es que, si bien en las zonas rurales -donde se asienta la PEA Rural- predomina en todas las jurisdicciones la PEA Agropecuaria -excepto en la provincia de Córdoba en 2001-, no obstante, se manifiesta con una presencia importante la PEA No Agropecuaria, con un incremento porcentual firme en términos relativos entre 1991 y 2001. Como contrapartida, hay un achicamiento porcentual relativo entre un escalón temporal y otro de la PEA Agropecuaria. Esta presencia destacada de la PEA No Agropecuaria en las zonas rurales de referencia, a pesar de la disminución 
pronunciada de la población rural en general, se presupone que se debe a que la misma persiste con mayor éxito que la PEA Agropecuaria, dentro de la Población Rural agrupada (localidades de menos de 2.000 habitantes).

- En cambio, en las áreas urbanas -donde se asiente la PEA Urbana-, el volumen de la PEA Agropecuaria es muy limitado, en general, pero con cierto realce en los departamentos del sur cordobés, en comparación a nivel de provincia y de nación. Esta PEA Agropecuaria, a su vez, sufre una disminución porcentual en términos relativos entre 1991 y 2001, no así, desde luego, la PEA No Agropecuaria. En suma, no es correcto considerar a la mano de obra con residencia rural como exclusivamente agropecuaria, como igualmente a la fuerza de trabajo con residencia urbana -a pesar de que es acusadamente mayoritaria- como exclusivamente no agropecuaria, especialmente en los casos de los departamentos del sur provincial.

Cuadro N 18. Comparación del volumen de la PEA Rural y Urbana respecto de la PEA Agropecuaria y No Agropecuaria. 1991-2001

\begin{tabular}{|c|c|c|c|c|c|c|c|}
\hline \multirow[b]{2}{*}{ Jurisdicción } & \multirow[b]{2}{*}{ Años } & \multicolumn{3}{|c|}{ PEA Rural } & \multicolumn{3}{|c|}{ PEA Urbana } \\
\hline & & Total & $\begin{array}{c}\text { PEA } \\
\text { Agropecuaria }\end{array}$ & $\begin{array}{c}\text { PEA No } \\
\text { Agropecuaria }\end{array}$ & Total & $\begin{array}{c}\text { PEA } \\
\text { Agropecuaria }\end{array}$ & $\begin{array}{c}\text { PEA No } \\
\text { Agropecuaria }\end{array}$ \\
\hline \multirow{2}{*}{ Total del país } & 1991 & $\begin{array}{c}1.657 .743 \\
100 \%\end{array}$ & $\begin{array}{c}962.741 \\
58,1 \%\end{array}$ & $\begin{array}{c}695.002 \\
41,9 \%\end{array}$ & $\begin{array}{c}10.710 .585 \\
100 \%\end{array}$ & $\begin{array}{c}384.652 \\
3,6 \%\end{array}$ & $\begin{array}{c}10.325 .933 \\
96,4 \%\end{array}$ \\
\hline & 2001 & $\begin{array}{c}1.099 .247 \\
100 \%\end{array}$ & $\begin{array}{l}569.925 \\
51,8 \%\end{array}$ & $\begin{array}{c}529.322 \\
48,2 \%\end{array}$ & $\begin{array}{c}9.813 .940 \\
100 \%\end{array}$ & $\begin{array}{c}327.582 \\
3,3 \%\end{array}$ & $\begin{array}{c}9.486 .358 \\
96,7 \%\end{array}$ \\
\hline \multirow{2}{*}{$\begin{array}{l}\text { Provincia de } \\
\text { Córdoba }\end{array}$} & 1991 & $\begin{array}{c}166.027 \\
100 \%\end{array}$ & $\begin{array}{l}87.289 \\
52,6 \%\end{array}$ & $\begin{array}{l}78.738 \\
47,4 \%\end{array}$ & $\begin{array}{c}910.790 \\
100 \%\end{array}$ & $\begin{array}{c}44.527 \\
4,9 \%\end{array}$ & $\begin{array}{c}866.263 \\
95,1 \%\end{array}$ \\
\hline & 2001 & $\begin{array}{c}118.494 \\
100 \%\end{array}$ & $\begin{array}{l}55.488 \\
46,8 \%\end{array}$ & $\begin{array}{l}63.006 \\
53,2 \%\end{array}$ & $\begin{array}{c}906.830 \\
100 \%\end{array}$ & $\begin{array}{c}38.831 \\
4,3 \%\end{array}$ & $\begin{array}{c}867.999 \\
95,7 \%\end{array}$ \\
\hline \multirow{2}{*}{ Río Cuarto } & 1991 & $\begin{array}{c}14.217 \\
100 \%\end{array}$ & $\begin{array}{l}9.532 \\
67 \%\end{array}$ & $\begin{array}{l}4.685 \\
33 \%\end{array}$ & $\begin{array}{c}72.238 \\
100 \%\end{array}$ & $\begin{array}{l}5.266 \\
7,3 \%\end{array}$ & $\begin{array}{l}66.972 \\
92,7 \%\end{array}$ \\
\hline & 2001 & $\begin{array}{l}8.958 \\
100 \%\end{array}$ & $\begin{array}{l}5.550 \\
62 \%\end{array}$ & $\begin{array}{l}3.408 \\
38 \%\end{array}$ & $\begin{array}{c}67.772 \\
100 \%\end{array}$ & $\begin{array}{l}4.825 \\
7.7 \%\end{array}$ & $\begin{array}{l}62.942 \\
92,3 \%\end{array}$ \\
\hline \multirow{2}{*}{$\begin{array}{l}\text { Juárez } \\
\text { Celman }\end{array}$} & 1991 & $\begin{array}{l}7.196 \\
100 \%\end{array}$ & $\begin{array}{l}4.098 \\
56,9 \%\end{array}$ & $\begin{array}{l}3.098 \\
44,1 \%\end{array}$ & $\begin{array}{c}14.529 \\
100 \%\end{array}$ & $\begin{array}{l}2.571 \\
17,7 \%\end{array}$ & $\begin{array}{l}11.958 \\
82,3 \%\end{array}$ \\
\hline & 2001 & $\begin{array}{l}4.602 \\
100 \%\end{array}$ & $\begin{array}{l}2.387 \\
51,9 \%\end{array}$ & $\begin{array}{l}2.215 \\
48,1 \%\end{array}$ & $\begin{array}{l}15.311 \\
100 \%\end{array}$ & $\begin{array}{l}1.996 \\
13 \%\end{array}$ & $\begin{array}{c}13.315 \\
87 \%\end{array}$ \\
\hline \multirow{2}{*}{$\begin{array}{c}\text { Presidente } \\
\text { Roque Sáenz } \\
\text { Peña }\end{array}$} & 1991 & $\begin{array}{l}2.943 \\
100 \%\end{array}$ & $\begin{array}{r}1.570 \\
53,3 \%\end{array}$ & $\begin{array}{r}1.373 \\
46,7 \%\end{array}$ & $\begin{array}{c}11.520 \\
100 \%\end{array}$ & $\begin{array}{l}3.059 \\
26,6 \%\end{array}$ & $\begin{array}{l}8.461 \\
73,4 \%\end{array}$ \\
\hline & 2001 & $\begin{array}{l}2.602 \\
100 \%\end{array}$ & $\begin{array}{l}1.604 \\
61,6 \%\end{array}$ & $\begin{array}{c}998 \\
38,4 \%\end{array}$ & $\begin{array}{l}9.305 \\
100 \%\end{array}$ & $\begin{array}{l}1.157 \\
12,4 \%\end{array}$ & $\begin{array}{l}8.148 \\
87,6 \%\end{array}$ \\
\hline \multirow{2}{*}{ General Roca } & 1991 & $\begin{array}{l}5.011 \\
100 \%\end{array}$ & $\begin{array}{l}3.032 \\
60,5 \%\end{array}$ & $\begin{array}{r}1.979 \\
39.5 \%\end{array}$ & $\begin{array}{l}8.579 \\
100 \%\end{array}$ & $\begin{array}{r}1.739 \\
20,3 \%\end{array}$ & $\begin{array}{l}6.840 \\
79,7 \%\end{array}$ \\
\hline & 2001 & $\begin{array}{l}3.960 \\
100 \%\end{array}$ & $\begin{array}{l}2.190 \\
55,3 \%\end{array}$ & $\begin{array}{r}1.770 \\
44,7 \%\end{array}$ & $\begin{array}{l}8.167 \\
100 \%\end{array}$ & $\begin{array}{l}1.657 \\
20,3 \%\end{array}$ & $\begin{array}{l}6.510 \\
79,7 \%\end{array}$ \\
\hline \multirow{2}{*}{$\begin{array}{l}\text { Sumatoria de } \\
\text { los cuatro } \\
\text { departamentos }\end{array}$} & 1991 & $\begin{array}{c}29.367 \\
100 \%\end{array}$ & $\begin{array}{l}18.232 \\
62,1 \%\end{array}$ & $\begin{array}{l}11.135 \\
37,9 \%\end{array}$ & $\begin{array}{c}106.866 \\
100 \%\end{array}$ & $\begin{array}{l}12.635 \\
11,8 \%\end{array}$ & $\begin{array}{l}94.231 \\
88,2 \%\end{array}$ \\
\hline & 2001 & $\begin{array}{c}20.122 \\
100 \%\end{array}$ & $\begin{array}{l}11.731 \\
58,3 \%\end{array}$ & $\begin{array}{l}8.391 \\
41,7 \%\end{array}$ & $\begin{array}{c}100.555 \\
100 \%\end{array}$ & $\begin{array}{l}9.635 \\
9,6 \%\end{array}$ & $\begin{array}{l}90.920 \\
90,4 \%\end{array}$ \\
\hline
\end{tabular}

Fuente: Elaboración propia en base a la información brindada por las áreas agropecuarias y socio-demográficas de la Dirección General de Estadística y Censos, Secretaría General de la Gobernación de la Provincia de Córdoba.

En el Cuadro $\mathrm{N}^{\mathrm{o}}$ 19, queremos resaltar básicamente la visualización del tamaño de la "PEA Total" a nivel de los totales jurisdiccionales y, en menor término, urbanos y rurales de 
las respectivas jurisdicciones, con sus correspondientes desagregaciones en PEA Agropecuaria y PEA No Agropecuaria.

Cuadro No 19. Tamaño de la PEA Total a nivel de los "totales jurisdiccionales", "urbanos y rurales de las respectivas jurisdicciones", con sus correspondientes desagregaciones en PEA Agropecuaria y PEA No Agropecuaria. 1991 y 2001

\begin{tabular}{|c|c|c|c|c|c|c|c|c|c|}
\hline \multirow{2}{*}{ Jurisdicción } & \multirow{2}{*}{ Años } & \multicolumn{2}{|c|}{ PEA Total } & \multicolumn{3}{|c|}{ PEA Agropecuaria } & \multicolumn{3}{|c|}{ PEA No Agropecuaria } \\
\hline & & Cantidad & $\%$ & Cantidad & 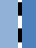 & $\%$ & Cantidad & & $\%$ \\
\hline \multirow{2}{*}{ Total del país } & 1991 & 12.368 .328 & i $100 \%$ & 1.347 .393 & I & $10,9 \%$ & 11.020 .935 & I & $89,1 \%$ \\
\hline & 2001 & 10.913.187 & $100 \%$ & 897.507 & $!$ & $8,2 \%$ & 10.015 .680 & ! & $91,8 \%$ \\
\hline \multirow{2}{*}{ Total PEA Urbana } & 1991 & 10.710 .585 & $100 \%$ & 384.652 & i & $3,6 \%$ & 10.325 .933 & I & $96,4 \%$ \\
\hline & 2001 & 9.813 .940 & $100 \%$ & 327.582 & $!$ & $3,3 \%$ & 9.486 .358 & ! & $96,7 \%$ \\
\hline \multirow{2}{*}{ Total PEA Rural } & 1991 & 1.657 .743 & $100 \%$ & 962.741 & i & $58,1 \%$ & 695.002 & I & $41,9 \%$ \\
\hline & 2001 & 1.099 .247 & ! $100 \%$ & 569.925 & $!$ & $51,8 \%$ & 529.322 & $!$ & $48,2 \%$ \\
\hline \multirow{2}{*}{$\begin{array}{l}\text { Provincia de } \\
\text { Córdoba }\end{array}$} & 1991 & 1.076 .817 & I $100 \%$ & 131.816 & I & $12,2 \%$ & 945.001 & , & $87,8 \%$ \\
\hline & 2001 & 1.025 .324 & $100 \%$ & 94.319 & ! & $9,2 \%$ & 931.005 & ! & $90,8 \%$ \\
\hline \multirow{2}{*}{ Total PEA Urbana } & 1991 & 910.790 & I $100 \%$ & 44.527 & i & $4,9 \%$ & 866.263 & 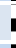 & $95,1 \%$ \\
\hline & 2001 & 906.830 & $100 \%$ & 38.831 & $!$ & $4,3 \%$ & 867.999 & $!$ & $95,7 \%$ \\
\hline \multirow{2}{*}{ Total PEA Rural } & 1991 & 166.027 & $100 \%$ & 87.289 & i & $52,6 \%$ & 78.738 & 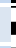 & $47,4 \%$ \\
\hline & 2001 & 118.494 & $100 \%$ & 55.488 & ! & $46,8 \%$ & 63.006 & ! & $58,2 \%$ \\
\hline \multirow{2}{*}{ Río Cuarto } & 1991 & 86.455 & I $100 \%$ & 14.798 & I & $17,1 \%$ & 71.657 & I & $82,9 \%$ \\
\hline & 2001 & 76.730 & $100 \%$ & 10.375 & i & $13,5 \%$ & 66.355 & 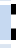 & $86,5 \%$ \\
\hline \multirow{2}{*}{ Total PEA Urbana } & 1991 & 72.238 & I $100 \%$ & 5.266 & i & $7,3 \%$ & 66.972 & I & $92,7 \%$ \\
\hline & 2001 & 67.772 & $100 \%$ & 4.825 & ! & $7,7 \%$ & 62.947 & 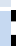 & $92,3 \%$ \\
\hline \multirow{2}{*}{ Total PEA Rural } & 1991 & 14.217 & I $100 \%$ & 9.532 & 1 & $67 \%$ & 4.685 & I & $33 \%$ \\
\hline & 2001 & 8.958 & $100 \%$ & 5.550 & ! & $62 \%$ & 3.408 & 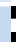 & $38 \%$ \\
\hline \multirow{2}{*}{ Juárez Celman } & 1991 & 21.725 & $100 \%$ & 6.669 & $!$ & $30,7 \%$ & 15.056 & ! & $69,3 \%$ \\
\hline & 2001 & 19.913 & $100 \%$ & 4.383 & i & $22 \%$ & 15.530 & I & $78 \%$ \\
\hline \multirow{2}{*}{ Total PEA Urbana } & 1991 & 14.529 & I $100 \%$ & 2.571 & i & $17,7 \%$ & 11.958 & 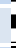 & $82,3 \%$ \\
\hline & 2001 & 15.311 & $100 \%$ & 1.996 & $i$ & $13 \%$ & 13.315 & i & $87 \%$ \\
\hline \multirow{2}{*}{ Total PEA Rural } & 1991 & 7.196 & I $100 \%$ & 4.098 & I & $56,9 \%$ & 3.098 & I & $44,1 \%$ \\
\hline & 2001 & 4.602 & $100 \%$ & 2.387 & i & $51,9 \%$ & 2.215 & ; & $48,1 \%$ \\
\hline \multirow{2}{*}{$\begin{array}{l}\text { Presidente Roque } \\
\text { Sáenz Peña }\end{array}$} & 1991 & 14.463 & $100 \%$ & 4.629 & $!$ & $32 \%$ & 9.834 & I & $68 \%$ \\
\hline & 2001 & 11.907 & $100 \%$ & 2.761 & i & $23,2 \%$ & 9.146 & 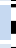 & $76,8 \%$ \\
\hline \multirow{2}{*}{ Total PEA Urbana } & 1991 & 11.520 & $100 \%$ & 3.059 & ! & $26,6 \%$ & 8.461 & ! & $73,4 \%$ \\
\hline & 2001 & 9.305 & $100 \%$ & 1.157 & i & $12,4 \%$ & 8.148 & 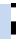 & $87,6 \%$ \\
\hline \multirow{2}{*}{ Total PEA Rural } & 1991 & 2.943 & $100 \%$ & 1.570 & $!$ & 53,3 & 1.373 & ! & $46,7 \%$ \\
\hline & 2001 & 2.602 & $100 \%$ & 1.604 & i & $61,6 \%$ & 998 & 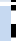 & $37,4 \%$ \\
\hline \multirow{2}{*}{ General Roca } & 1991 & 13.590 & $100 \%$ & 4.771 & ! & $31,1 \%$ & 8.819 & ! & $64,9 \%$ \\
\hline & 2001 & 12.127 & I $100 \%$ & 3.847 & i & $31,7 \%$ & 8.280 & 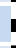 & $68,3 \%$ \\
\hline \multirow{2}{*}{ Total PEA Urbana } & 1991 & 8.579 & $100 \%$ & 1.739 & $!$ & $20,3 \%$ & 6.840 & 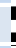 & $79,7 \%$ \\
\hline & 2001 & 8.167 & $100 \%$ & 1.657 & i & $20,3 \%$ & 6.510 & 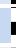 & $79,7 \%$ \\
\hline Total PFA Rural & 1991 & 5.011 & $100 \%$ & 3.032 & $!$ & $60,5 \%$ & 1.979 & $!$ & $39,5 \%$ \\
\hline I Otal PEA Rural & 2001 & 3.960 & $100 \%$ & 2.190 & i & $55,3 \%$ & 1.770 & 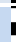 & $44,7 \%$ \\
\hline Sumatoria de los & 1991 & 136.233 & $100 \%$ & 30.867 & i & $22,7 \%$ & 105.366 & i & $77,3 \%$ \\
\hline cuatro departamentos & 2001 & 120.677 & I $100 \%$ & 21.366 & I & $17,7 \%$ & 99.311 & i & $82,3 \%$ \\
\hline & 1991 & 106.866 & $100 \%$ & 12.635 & i & $11,8 \%$ & 94.231 & ! & $88,2 \%$ \\
\hline Iotal PEA Urbana & 2001 & 100.555 & $100 \%$ & 9.635 & I & $9,6 \%$ & 90.920 & I & $90,4 \%$ \\
\hline & 1991 & 29.367 & $100 \%$ & 18.232 & ! & $62,1 \%$ & 11.135 & ! & $37,9 \%$ \\
\hline al PEA & 2001 & 20.122 & I $100 \%$ & 11.731 & i & $58,3 \%$ & 8.391 & 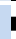 & $41,7 \%$ \\
\hline
\end{tabular}

Fuente: Elaboración propia en base a la información brindada por las áreas agropecuarias y socio-demográficas de la Dirección General de Estadística y Censos, Secretaría General de la Gobernación de la Provincia de Córdoba.

En este sentido, observamos: 
- Con respecto a los "totales jurisdiccionales", tanto a nivel país como de provincia de Córdoba, la PEA Agropecuaria en relación con la No Agropecuaria, en los dos años analizados, va a oscilar entre un $8 \%$ y un $12 \%$, con un decrecimiento apreciable en términos relativos -aparte de absolutos-. En cambio, en lo que respecta a los departamentos del sur cordobés, la presencia de la PEA Agropecuaria en relación con la No Agropecuaria es mucho más significativa, oscilando en la síntesis de los cuatro departamentos entre un $23 \%$ en 1991 y un $18 \%$ en 2001, en consonancia con un área geográfica eminentemente agropecuaria. Está claro que los reducidos porcentajes de la PEA Agropecuaria con respecto a la PEA Total guarda un cierto paralelismo con el peso porcentual del Producto Bruto Interno (PBI) del sector primario en la economía general.

- Se vuelca también en el cuadro, para el cotejo comparativo, la PEA Total Urbana y Rural de las jurisdicciones respectivas, con su correspondiente desagregación en PEA Agropecuaria y No Agropecuaria, con la evolución de los resultados ya descriptos en el cuadro anterior.

Por su parte, en el Cuadro $\mathrm{N}^{\circ} 20$, destacamos cómo se distribuye la PEA Total, Agropecuaria y No Agropecuaria, a nivel jurisdiccional, en las áreas urbanas como rurales. Aquí, cabe resaltar lo siguiente:

- Una incidencia porcentual en general muy elevada de la PEA Urbana, que se incrementa en 2001, en relación con la PEA Rural, en todas las PEAs totales jurisdiccionales, con cierta disminución obvia de los porcentuales de la PEA Urbana, en los departamentos del sur provincial. Cabe agregar que esta diferenciación estadística entre totales urbanos y rurales guarda una correlación aproximativa con la distribución porcentual de la población urbana y rural en las mismas áreas de referencia.

- En todas las jurisdicciones, en general, es dable observar un incremento intercensal en valores relativos bastante notable de la PEA Agropecuaria, como así también, pero en menor proporción, de la PEA No Agropecuaria, en el total de la PEA Urbana. Como contrapartida, va a disminuir porcentualmente -como así también obviamente en términos absolutos- la PEA Agropecuaria y No Agropecuaria, en el total de la PEA Rural. En estos casos, es interesante discernir que si bien la PEA Agropecuaria disminuye en sí misma en términos absolutos como relativos, como así también en comparación con la PEA No Agropecuaria, vemos que dentro de la disminución general de la misma, tanto en el medio rural como urbano, tiende más a persistir en este último ámbito. Dicho de otro modo, dentro del achicamiento general intercensal de la PEA Agropecuaria, lo que queda de la misma tiende a concentrarse más en los centros urbanos. 
Cuadro No 20. Tamaño de la PEA Total a nivel de los "totales jurisdiccionales" de la "PEA Agropecuaria y No Agropecuaria de las respectivas jurisdicciones", con sus correspondientes desagregaciones en Total de la PEA Urbana y Total de la PEA Rural. 1991 y 2001

\begin{tabular}{|c|c|c|c|c|c|c|c|c|c|}
\hline & \multirow{2}{*}{ Jurisdicción } & \multirow{2}{*}{ Años } & \multicolumn{3}{|c|}{ Totales } & \multicolumn{2}{|c|}{$\begin{array}{c}\text { Total de la PEA } \\
\text { Urbana }\end{array}$} & \multicolumn{2}{|c|}{ Total de la PEA Rural } \\
\hline & & & Cantidad & & $\%$ & Cantidad & $\%$ & Cantidad & $\%$ \\
\hline \multirow{6}{*}{ 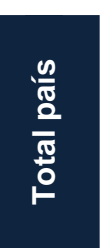 } & \multirow{2}{*}{ PEA Total } & 1991 & 12.368 .328 & ! & $100 \%$ & 10.710 .585 & $86,6 \%$ & 1.657 .473 & $13,4 \%$ \\
\hline & & 2001 & 10.913 .187 & I & $100 \%$ & 9.813 .940 & $89,9 \%$ & 1.099 .247 & $10,1 \%$ \\
\hline & \multirow{2}{*}{$\begin{array}{c}\text { PEA } \\
\text { Agropecuaria }\end{array}$} & 1991 & 1.347 .393 & 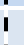 & $100 \%$ & 384.652 & $28,5 \%$ & 962.741 & $71,5 \%$ \\
\hline & & 2001 & 897.507 & i & $100 \%$ & 327.582 & $36,5 \%$ & 569.925 & $63,5 \%$ \\
\hline & \multirow{2}{*}{$\begin{array}{c}\text { PEA No } \\
\text { Agropecuaria }\end{array}$} & 1991 & 11.020 .935 & ! & $100 \%$ & 10.325 .933 & I $93,7 \%$ & 695.002 & I $6,3 \%$ \\
\hline & & 2001 & 10.015 .680 & ' & $100 \%$ & 9.486 .358 & $94,7 \%$ & 529.322 & $5,3 \%$ \\
\hline \multirow{6}{*}{ 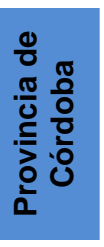 } & \multirow{2}{*}{ PEA Total } & 1991 & 1.076 .817 & $!$ & $100 \%$ & 910.790 & $84,6 \%$ & 166.027 & $15,4 \%$ \\
\hline & & 2001 & 1.025 .324 & I & $100 \%$ & 906.830 & $88,4 \%$ & 118.494 & $11,6 \%$ \\
\hline & \multirow{2}{*}{$\begin{array}{c}\text { PEA } \\
\text { Agropecuaria }\end{array}$} & 1991 & 131.816 & ! & $100 \%$ & 44.527 & $33,8 \%$ & 87.289 & $66,2 \%$ \\
\hline & & 2001 & 94.319 & 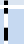 & $100 \%$ & 38.831 & $41,2 \%$ & 55.488 & $58,8 \%$ \\
\hline & \multirow{2}{*}{$\begin{array}{c}\text { PEA No } \\
\text { Agropecuaria }\end{array}$} & 1991 & 945.001 & ! & $100 \%$ & 866.263 & $91,7 \%$ & 78.738 & I $8,3 \%$ \\
\hline & & 2001 & 931.005 & ; & $100 \%$ & 867.999 & $93,2 \%$ & 63.006 & : $6,8 \%$ \\
\hline \multirow{6}{*}{ 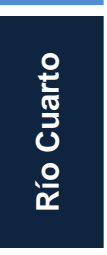 } & \multirow{2}{*}{ PEA Total } & 1991 & 86.455 & 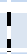 & $100 \%$ & 72.238 & $83,6 \%$ & 14.217 & $16,4 \%$ \\
\hline & & 2001 & 76.730 & 1 & $100 \%$ & 67.772 & $88,3 \%$ & 8.958 & $11,7 \%$ \\
\hline & \multirow{2}{*}{$\begin{array}{c}\text { PEA } \\
\text { Agropecuaria } \\
\end{array}$} & 1991 & 14.798 & I & $100 \%$ & 5.266 & $35,6 \%$ & 9.532 & $64,4 \%$ \\
\hline & & 2001 & 10.375 & i & $100 \%$ & 4.825 & $46,5 \%$ & 5.550 & $53,5 \%$ \\
\hline & \multirow{2}{*}{$\begin{array}{c}\text { PEA No } \\
\text { Agropecuaria }\end{array}$} & 1991 & 71.657 & $!$ & $100 \%$ & 66.972 & $93,5 \%$ & 4.685 & $6,5 \%$ \\
\hline & & 2001 & 66.355 & I & $100 \%$ & 62.947 & $94,9 \%$ & 3.408 & $5,1 \%$ \\
\hline \multirow{6}{*}{ 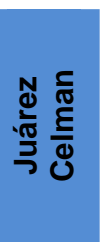 } & \multirow{2}{*}{ PEA Total } & 1991 & 21.725 & ' & $100 \%$ & 14.529 & $66,9 \%$ & 7.196 & $33,1 \%$ \\
\hline & & 2001 & 19.913 & 1 & $100 \%$ & 15.311 & I $76,9 \%$ & 4.602 & I $23,1 \%$ \\
\hline & \multirow{2}{*}{$\begin{array}{c}\text { PEA } \\
\text { Agropecuaria }\end{array}$} & 1991 & 6.669 & 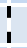 & $100 \%$ & 2.571 & $38,6 \%$ & 4.098 & $61,4 \%$ \\
\hline & & 2001 & 4.383 & I & $100 \%$ & 1.996 & I $45,6 \%$ & 2.387 & I $54,4 \%$ \\
\hline & \multirow{2}{*}{$\begin{array}{c}\text { PEA No } \\
\text { Agropecuaria }\end{array}$} & 1991 & 15.056 & ! & $100 \%$ & 11.958 & $79,4 \%$ & 3.098 & $20,6 \%$ \\
\hline & & 2001 & 15.530 & I & $100 \%$ & 13.315 & - $85,7 \%$ & 2.215 & I $14,3 \%$ \\
\hline \multirow{6}{*}{ 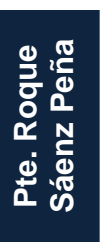 } & & 1991 & 14.463 & 1 & $100 \%$ & 11.520 & $79,7 \%$ & 2.943 & $20,3 \%$ \\
\hline & PEA I otal & 2001 & 11.907 & ! & $100 \%$ & 9.305 & $78,1 \%$ & 2.602 & I $21,9 \%$ \\
\hline & $\overline{\text { PEA }}$ & 1991 & 4.629 & i & $100 \%$ & 3.059 & $66,1 \%$ & 1.570 & $33,9 \%$ \\
\hline & Agropecuaria & 2001 & 2.761 & i & $100 \%$ & 1.157 & I $41,9 \%$ & 1.604 & I $58,1 \%$ \\
\hline & PEA No & 1991 & 9.834 & 1 & $100 \%$ & 8.461 & $86 \%$ & 1.373 & $14 \%$ \\
\hline & Agrope & 2001 & 9.146 & i & $100 \%$ & 8.148 & I $89,1 \%$ & 998 & I $10,9 \%$ \\
\hline & PEA & 1991 & 13.590 & I & $100 \%$ & 8.579 & $63,1 \%$ & 5.011 & ; $36,9 \%$ \\
\hline & PEA & 2001 & 12.127 & I & $100 \%$ & 8.167 & $67,3 \%$ & 3.960 & $32,7 \%$ \\
\hline 핑 유 & PEA & 1991 & 4.771 & 1 & $100 \%$ & 1.739 & $36,4 \%$ & 3.032 & $63,6 \%$ \\
\hline 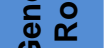 & Agropecuaria & 2001 & 3.847 & $!$ & $100 \%$ & 1.657 & $43,1 \%$ & 2.190 & ! $56,9 \%$ \\
\hline & PEA No & 1991 & 8.819 & ; & $100 \%$ & 6.840 & $77,6 \%$ & 1.979 & $22,4 \%$ \\
\hline & Agropecuaria & 2001 & 8.280 & ! & $100 \%$ & 6.510 & ! $79,6 \%$ & 1.770 & ! $21,4 \%$ \\
\hline & PEA & 1991 & 136.233 & I & $100 \%$ & 106.866 & I $78,4 \%$ & 29.367 & $21,6 \%$ \\
\hline 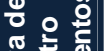 & PEA Total & 2001 & 120.677 & & $100 \%$ & 100.555 & $83,3 \%$ & 20.122 & $16,7 \%$ \\
\hline - & PEA & 1991 & 30.867 & I & $100 \%$ & 12.635 & I $40,9 \%$ & 18.232 & I $59,1 \%$ \\
\hline$E 0$ & Agropecuaria & 2001 & 21.366 & 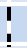 & $100 \%$ & 9.635 & $45,1 \%$ & 11.731 & $54,9 \%$ \\
\hline 응 으 웡 & PEA No & 1991 & 105.366 & I & $100 \%$ & 94.231 & $89,4 \%$ & 11.135 & $10,6 \%$ \\
\hline & Agropecuaria & 2001 & 99.311 & ! & $100 \%$ & 90.920 & ! $91,6 \%$ & 8.391 & ! $8,4 \%$ \\
\hline
\end{tabular}

Fuente: Elaboración propia en base a la información brindada por las áreas agropecuarias y socio-demográficas de la Dirección General de Estadística y Censos, Secretaría General de la Gobernación de la Provincia de Córdoba.

Por último, en el Cuadro $\mathrm{N}^{\mathrm{o}} 21$, como habíamos especificado al principio de este acápite, se vuelcan los datos de los Censos Agropecuarios de 1988 y 2002 de las personas que trabajan en forma permanente en las EAPs. Todo ello referido, en términos comparativos, a 
nivel país y provincia de Córdoba, y en menor término, a nivel de los departamentos del sur cordobés, por disponer solamente de los datos del Censo de 2002.

Vemos así que:

- Del total de personas que trabajan en forma permanente en las EAPs, tanto a nivel país como de provincia, el mayor porcentaje en los dos censos corresponde a los "Productores", luego le siguen los "No familiares del productor" y, por último, los "Familiares del productor". Con la característica en valores relativos de un incremento intercensal significativo en el rubro de "Productores", en correspondencia con una suave disminución porcentual a nivel país en la categoría "Familiares del productor", pero acusadamente fuerte esa disminución a nivel de provincia. En cambio, en el ítem "No familiares del productor", se va a manifestar una acusada disminución porcentual a nivel país y un leve incremento de los valores porcentuales a nivel provincia.

- Respecto de los valores porcentuales del Censo de 2002 de los departamentos del sur provincial -exceptuando Río Cuarto-, vemos que sigue un orden diferente al arriba descripto. Observamos que el mayor porcentaje corresponde a los "No familiares del productor", seguido por el de los "Productores", y terminando por los "Familiares del productor". No cabe duda de que, en general, la mayor dimensión de las EAPs de los departamentos del sur cordobés determina, en términos comparativos, una mayor disponibilidad de personal dependiente.

Cuadro $\mathbf{N}^{0}$ 21. Variación de la cantidad de personas que trabajan en las EAPs en forma permanente, entre 1988 y 2002, a nivel país y de provincia de Córdoba

\begin{tabular}{|c|c|c|c|c|c|c|c|c|c|c|}
\hline \multirow[t]{2}{*}{ Jurisdicciones } & \multirow[t]{2}{*}{ Años } & \multicolumn{3}{|c|}{$\begin{array}{l}\text { Total de personas que } \\
\text { trabajan en las EAPs } \\
\text { en forma permanente }\end{array}$} & \multicolumn{2}{|c|}{ Productor } & \multicolumn{2}{|c|}{$\begin{array}{c}\text { Familiares del } \\
\text { productor }\end{array}$} & \multicolumn{2}{|c|}{$\begin{array}{l}\text { No familiares del } \\
\text { productor }\end{array}$} \\
\hline & & Cantidad & i & $\%$ & Cantidad & $\%$ & Cantidad & $\%$ & Cantidad & \\
\hline \multirow{2}{*}{ Total del país } & 1988 & 939.822 & I & $100 \%$ & 340.745 & $36,3 \%$ & 258.433 & I $27,5 \%$ & 340.644 & I $36,2 \%$ \\
\hline & 2002 & 775.296 & I & $100 \%$ & 340.735 & $43,9 \%$ & 204.664 & $26,4 \%$ & 229.847 & $29,7 \%$ \\
\hline \multirow{2}{*}{$\begin{array}{l}\text { Provincia de } \\
\text { Córdoba }\end{array}$} & 1988 & 102.325 & i & $100 \%$ & 41.391 & $40,5 \%$ & 22.349 & I $21,8 \%$ & 38.585 & $37,7 \%$ \\
\hline & 2002 & 63.128 & ! & $100 \%$ & 29.829 & $47,2 \%$ & 8.877 & $14,1 \%$ & 24.422 & $38,7 \%$ \\
\hline \multirow{2}{*}{ Río Cuarto } & 1988 & $\mathrm{~S} / \mathrm{D}$ & I & & $S / D$ & 1 & $S / D$ & I & $\mathrm{S} / \mathrm{D}$ & I \\
\hline & 2002 & 6.222 & ! & $100 \%$ & 3.185 & $51,2 \%$ & 628 & $10,1 \%$ & 2.409 & $38,7 \%$ \\
\hline \multirow{2}{*}{ Juárez Celman } & 1988 & $S / D$ & , & & $S / D$ & I & $\mathrm{S} / \mathrm{D}$ & I & $S / D$ & I \\
\hline & 2002 & 3.083 & ! & $100 \%$ & 985 & $31,9 \%$ & 413 & $13,4 \%$ & 1.685 & $54,7 \%$ \\
\hline \multirow{2}{*}{$\begin{array}{l}\text { Presidente Roque } \\
\text { Sáenz Peña }\end{array}$} & 1988 & $S / D$ & i & & $S / D$ & i & $S / D$ & I & $S / D$ & I \\
\hline & 2002 & 2.345 & ! & $100 \%$ & 974 & $41,6 \%$ & 240 & $10.2 \%$ & 1.131 & $48,2 \%$ \\
\hline \multirow{2}{*}{ General Roca } & 1988 & $S / D$ & 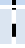 & & S/D & 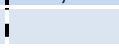 & S/D & i & $S / D$ & i \\
\hline & 2002 & 3.032 & ! & $100 \%$ & 1.173 & $38,7 \%$ & 182 & $6 \%$ & 1.677 & $55,3 \%$ \\
\hline \multirow{2}{*}{$\begin{array}{l}\text { Sumatoria de los } \\
\text { cuatro departamentos }\end{array}$} & 1988 & $S / D$ & 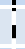 & & $S / D$ & 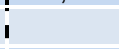 & $S / D$ & i & $S / D$ & i \\
\hline & 2002 & 14.682 & ! & $100 \%$ & 6.317 & $43 \%$ & 1.463 & $10 \%$ & 6.902 & $47 \%$ \\
\hline
\end{tabular}

Fuente: Elaboración propia en base a la información brindada por los Censos Nacionales Agropecuarios de 1988 y 2002.

En suma, reiteramos que los datos arriba vertidos sobre la mano de obra permanente empleada en las EAPs no involucra, desde luego, a toda la fuerza laboral rural, como sí 
pretende englobar, en cambio, los datos de la PEA Agropecuaria, pero no obstante, sirven para conocer, como un aporte estadístico más, las diferentes variantes de fuerzas del trabajo que concurren en las tareas agropecuarias.

A continuación, pasamos a tratar el tema de la magnitud y localización de la PEA Agropecuaria en base a los trabajos de campo realizados en nuestra área de estudio.

\subsection{Magnitud y localización de la PEA Agropecuaria de las diez localidades testigos con sus respectivas zonas rurales de influencia del sur cordobés}

En esta instancia, dentro de las múltiples vertientes que nos interesa analizar de la PEA Agropecuaria, nos limitamos centralmente a exponer los resultados de la incidencia de su “magnitud” y "localización” y sus consecuencias socio-espaciales entre los años 1994 y 2000 -fechas en las que se relevaron los datos de base-, en función de los trabajos de campo llevados a cabo a tal efecto en las diez localidades testigos, con sus respectivas zonas rurales de influencia -definidas como "unidades territoriales"- correspondientes, a fin de acercarnos con mayor profundidad al conocimiento de las problemáticas arriba mencionadas en dichas áreas y contribuir, a su vez, mediante el aporte de datos y de la comparación, a la captación más cabal de las fluctuaciones cuantitativas y de la localización de la PEA Agropecuaria en la Región Pampeana en general.

Es pertinente recordar que, para la obtención de "información específica propia", las técnicas de campo empleadas al respecto fueron:

a) Para la recopilación de datos cuantitativos sobre los totales y la localización de la PEA Agropecuaria de cada localidad con su entorno rural, los mismos se extrajeron de los listados de los padrones municipales de contribuyentes -especialmente para la recopilación de información de la fuerza laboral que vive en los centros urbanos-, de los productores que figuran en la oficina de guía animal -especialmente para detectar a los agentes que residen en el campo-, de las cooperativas, de las asociaciones gremiales de los productores y asalariados rurales, entre otros.

b) Para la recopilación de datos cuali-cuantitativos de los actores involucrados, atinentes a la obtención de información particular -referida a diferentes aspectos de su desenvolvimiento integral- y vivencial, se acudió -como se informó en páginas anteriores-a entrevistas a referentes claves y a la ejecución de una "encuesta" por muestreo.

A continuación, pasamos a describir en detalle la valoración cuantitativa y locacional de la fuerza laboral existente en las "unidades territoriales" mencionadas. 


\subsubsection{Análisis cuantitativo y locacional de la PEA Agropecuaria}

En lo referente al Cuadro $\mathrm{N}^{\circ} 22$, donde se comparan "totales generales y variaciones porcentuales de productores y explotaciones, más explotaciones compartidas y tamaño de la explotación", es dable observar lo siguiente:

- Una caída abrupta entre los dos años mencionados del 33,43\% del total de los productores contabilizados en el área de estudio, como así también del total de explotaciones con un porcentaje casi igual al anterior del $33,42 \%$, como producto del arrendamiento (especialmente del tipo accidental) a agentes que incluyen en una sola explotación varias explotaciones preexistentes de menor tamaño y de la retirada definitiva de productores de la escena productiva. De acuerdo con los datos del Censo Nacional Agropecuario del año 2002, la caída porcentual de explotaciones es mucho mayor. Vemos así que el descenso entre 1994 y 2000, en comparación con el censo aludido, guarda proporcionalidad en los guarismos descendentes.

- Un porcentaje del $12,9 \%$ de explotaciones "compartidas"1 del total de explotaciones, que explica por qué la cifra de los establecimientos es menor que la de los productores. También se detecta un porcentaje del 25,36\% de productores del total que comparten explotaciones, lo que indica valores muy altos de participación entre los mismos. Este último dato rompe un poco la idea de la predominancia del productor individual a cargo de la explotación.

- En lo que respecta a la distribución por tamaño de las explotaciones del total de las mismas, vemos que prevalecen las Pequeñas Explotaciones (P.E.) con el 43,5\%, seguido por las Mediana Explotaciones (M.E.) con el 37,2\% y por último las Grandes Explotaciones (G.E.) con el 19,3\%. Queda claro que en el área de trabajo predominan numéricamente las P.E. y M.E., lo que no quiere decir que esta supremacía se traduzca de igual forma en relación con la superficie que ocupan. ${ }^{2}$

Con respecto al análisis de los "totales y localización de los Productores y PEA Agropecuaria de los mismos" (Cuadro No 23), es dable destacar los siguientes aspectos:

- La mayoría de los productores en 1994 viven en los centros urbanos -exceptuando Vicuña Mackenna, Sampacho y Adelia María-, ubicándose el promedio total de los mismos en un $60 \%$. (Es pertinente precisar que en los ítems

\footnotetext{
Explotaciones "compartidas" son aquellas en las cuales la titularidad del establecimiento, formalmente o de hecho, es compartida por más de un productor (jefe de explotación).

2 Los criterios y parámetros que utilizamos para distinguir los diferentes tamaños de las explotaciones se explicitan más adelante, en el capítulo V.
} 
Cuadro $N^{\circ}$ 22. Totales y variación porcentual entre 1994 y 2000 de productores y explotaciones, más explotaciones compartidas y tamaño de las explotaciones correspondientes a datos del año 2000

\begin{tabular}{|c|c|c|c|c|c|c|c|c|c|c|}
\hline $\begin{array}{l}\text { Localidad + zona } \\
\text { rural de } \\
\text { influencia }\end{array}$ & $\begin{array}{c}\text { Fechas de } \\
\text { levantamiento de } \\
\text { datos }\end{array}$ & Total & $\begin{array}{l}\text { ctores y } \\
\%\end{array}$ & Total & $\begin{array}{l}\text { ciones y } \\
\%\end{array}$ & $\begin{array}{l}\text { Explotaciones compartidas con el } \\
\text { total de productores. Datos de } \\
2000\end{array}$ & $\begin{array}{l}\text { \% de explotaciones } \\
\text { compartidas del total de } \\
\text { explotaciones. Datos de } 2000\end{array}$ & $\begin{array}{l}\% \text { de productores que } \\
\text { comparten explot. del total de } \\
\text { productores. Datos de } 2000\end{array}$ & \multicolumn{2}{|c|}{$\begin{array}{l}\text { Tamaño de las } \\
\text { explotaciones en \%. Datos } \\
\text { de } 2000\end{array}$} \\
\hline $\begin{array}{l}\text { General } \\
\text { Cabrera }\end{array}$ & $\begin{array}{l}1994 \\
2000\end{array}$ & $\begin{array}{l}233 \\
117\end{array}$ & $-49,79 \%$ & $\begin{array}{l}200 \\
97\end{array}$ & $-51,50 \%$ & 19 explot. con 39 prod. & $19,59 \%$ & $33,33 \%$ & $\begin{array}{l}\text { Pequeñas: } \\
\text { Medianas: } \\
\text { Grandes: }\end{array}$ & $\begin{array}{l}39,2 \% \\
34,0 \% \\
26,8 \%\end{array}$ \\
\hline $\begin{array}{l}\text { General } \\
\text { Deheza }\end{array}$ & $\begin{array}{l}1994 \\
2000\end{array}$ & $\begin{array}{l}191 \\
156\end{array}$ & $-18,32 \%$ & $\begin{array}{l}164 \\
126\end{array}$ & $-23,17 \%$ & 19 explot. con 49 prod. & $15,08 \%$ & $31,41 \%$ & $\begin{array}{l}\text { Pequeñas: } \\
\text { Medianas: } \\
\text { Grandes: }\end{array}$ & $\begin{array}{r}56,3 \% \\
38,9 \% \\
4,8 \%\end{array}$ \\
\hline $\begin{array}{l}\text { Coronel } \\
\text { Moldes }\end{array}$ & $\begin{array}{l}1994 \\
2000\end{array}$ & $\begin{array}{l}513 \\
314\end{array}$ & $-38,79 \%$ & $\begin{array}{l}440 \\
240\end{array}$ & $-40,91 \%$ & 44 explot. con 98 prod. & $16,92 \%$ & $31,21 \%$ & $\begin{array}{l}\text { Pequeñas: } \\
\text { Medianas: } \\
\text { Grandes: }\end{array}$ & $\begin{array}{l}39,3 \% \\
38,0 \% \\
22,7 \%\end{array}$ \\
\hline $\begin{array}{c}\text { Vicuña } \\
\text { Mackenna }\end{array}$ & $\begin{array}{l}1994 \\
2000\end{array}$ & $\begin{array}{l}500 \\
385\end{array}$ & $-23,00 \%$ & $\begin{array}{l}426 \\
350\end{array}$ & $-18,22 \%$ & 30 explot. con 65 prod. & $8,57 \%$ & $16,88 \%$ & $\begin{array}{l}\text { Pequeñas: } \\
\text { Medianas: } \\
\text { Grandes: }\end{array}$ & $\begin{array}{l}32,6 \% \\
42,3 \% \\
25,1 \%\end{array}$ \\
\hline Sampacho & $\begin{array}{l}1994 \\
2000\end{array}$ & $\begin{array}{l}523 \\
348\end{array}$ & $-33,46 \%$ & $\begin{array}{l}448 \\
328\end{array}$ & $-26,79 \%$ & 18 explot. con 38 prod. & $5,49 \%$ & $10 ., 92 \%$ & $\begin{array}{l}\text { Pequeñas: } \\
\text { Medianas: } \\
\text { Grandes: }\end{array}$ & $\begin{array}{r}55,8 \% \\
34,8 \% \\
9,4 \%\end{array}$ \\
\hline $\begin{array}{l}\text { Berrotarán (área } \\
\text { pampeana } \\
\text { exclusivamente) }\end{array}$ & $\begin{array}{l}1994 \\
2000\end{array}$ & $\begin{array}{l}152 \\
117\end{array}$ & $-23,03 \%$ & $\begin{array}{l}130 \\
87\end{array}$ & $-33,08 \%$ & 19 explot. con 49 prod. & $21,84 \%$ & $41,88 \%$ & $\begin{array}{l}\text { Pequeñas: } \\
\text { Medianas: } \\
\text { Grandes: }\end{array}$ & $\begin{array}{l}31,0 \% \\
57,5 \% \\
11,5 \%\end{array}$ \\
\hline $\begin{array}{l}\text { Adelia } \\
\text { María }\end{array}$ & $\begin{array}{l}1994 \\
2000\end{array}$ & $\begin{array}{l}400 \\
221\end{array}$ & $-44,75 \%$ & $\begin{array}{l}343 \\
190\end{array}$ & $-44,61 \%$ & 23 explot. con 54 prod. & $12,11 \%$ & $24,43 \%$ & $\begin{array}{l}\text { Pequeñas: } \\
\text { Medianas: } \\
\text { Grandes: }\end{array}$ & $\begin{array}{l}45,2 \% \\
37,9 \% \\
16,9 \%\end{array}$ \\
\hline $\begin{array}{l}\text { Alcira } \\
\text { Gigena }\end{array}$ & $\begin{array}{l}1994 \\
2000\end{array}$ & $\begin{array}{l}446 \\
292\end{array}$ & $-34,53 \%$ & $\begin{array}{l}382 \\
235\end{array}$ & $-38,48 \%$ & 46 explot. con 103 prod. & $19,57 \%$ & $35,27 \%$ & $\begin{array}{l}\text { Pequeñas: } \\
\text { Medianas: } \\
\text { Grandes: }\end{array}$ & $\begin{array}{l}41,3 \% \\
40,4 \% \\
18,3 \%\end{array}$ \\
\hline Ucacha & $\begin{array}{l}1994 \\
2000\end{array}$ & $\begin{array}{l}225 \\
152\end{array}$ & $-32,45 \%$ & $\begin{array}{l}193 \\
120\end{array}$ & $-37,82 \%$ & 20 explot. con 52 prod. & $16,66 \%$ & $34,21 \%$ & $\begin{array}{l}\text { Pequeñas: } \\
\text { Medianas: } \\
\text { Grandes: }\end{array}$ & $\begin{array}{l}29,2 \% \\
36,7 \% \\
34,1 \%\end{array}$ \\
\hline Alejandro Roca & $\begin{array}{l}1994 \\
2000\end{array}$ & $\begin{array}{l}200 \\
150\end{array}$ & $-25,00 \%$ & $\begin{array}{l}171 \\
137\end{array}$ & $-19,88 \%$ & 11 explot. con 24 prod. & $8,03 \%$ & $16,00 \%$ & $\begin{array}{l}\text { Pequeñas: } \\
\text { Medianas: } \\
\text { Grandes: }\end{array}$ & $\begin{array}{l}65,5 \% \\
11,5 \% \\
23,0 \%\end{array}$ \\
\hline $\begin{array}{c}\text { Totales } \\
\text { Generales }\end{array}$ & $\begin{array}{l}1994 \\
2000\end{array}$ & $\begin{array}{l}3383 \\
2252\end{array}$ & $-33,43 \%$ & $\begin{array}{l}2899 \\
1930\end{array}$ & $-33,42 \%$ & 249 explot. con 571 prod. & $12.90 \%$ & $25,36 \%$ & $\begin{array}{l}\text { Pequeñas: } \\
\text { Medianas: } \\
\text { Grandes: }\end{array}$ & $\begin{array}{l}43,5 \% \\
37,2 \% \\
19,3 \%\end{array}$ \\
\hline
\end{tabular}

Fuente: Elaboración propia en base a datos obtenidos del padrón de contribuyentes municipales, oficinas de guía animal municipales, cooperativas agropecuarias, sociedades rurales locales, SENASA. 
Cuadro $\mathbf{N}^{\circ}$ 23. Totales y localización de los productores y PEA agropecuaria de los mismos

\begin{tabular}{|c|c|c|c|c|c|c|c|c|c|c|c|c|c|c|c|c|c|c|}
\hline \multirow[b]{3}{*}{$\begin{array}{c}\text { Localidades + } \\
\text { zona rural de } \\
\text { influencia }\end{array}$} & \multicolumn{10}{|c|}{ Productores } & \multicolumn{8}{|c|}{ PEA Agropecuaria de los Productores } \\
\hline & \multicolumn{5}{|c|}{ Datos de 1994} & \multicolumn{5}{|c|}{ Datos de 2000} & \multicolumn{4}{|c|}{ Datos de 1994} & \multicolumn{4}{|c|}{ Datos de 2000} \\
\hline & 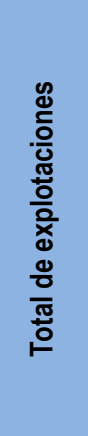 & 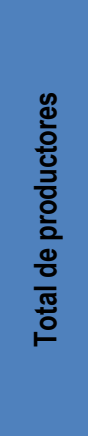 & 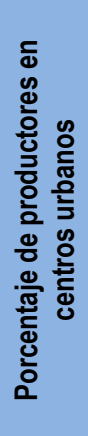 & 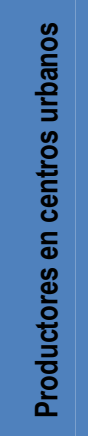 & 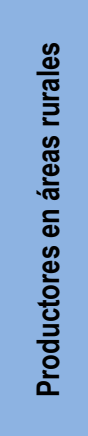 & 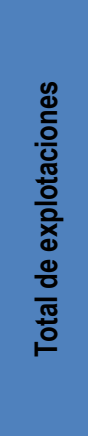 & 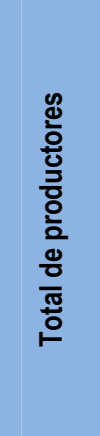 & 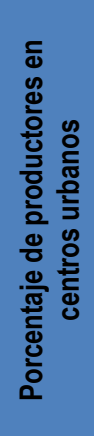 & 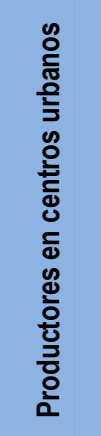 & 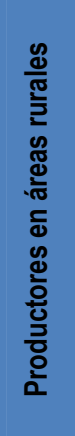 & 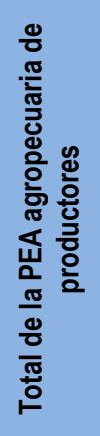 & 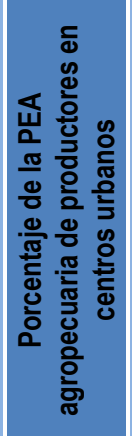 & 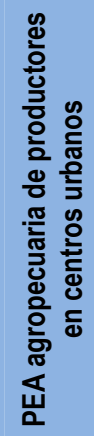 & 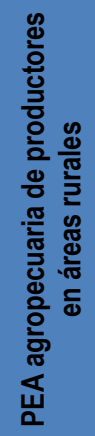 & 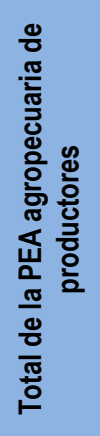 & 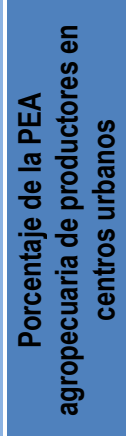 & 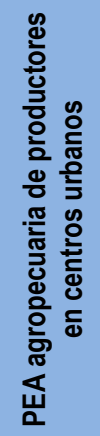 & 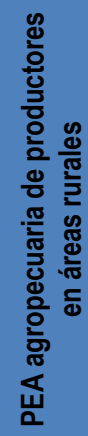 \\
\hline Gral. Cabrera & 200 & 233 & 73,81 & 172 & 61 & 97 & 117 & 63,24 & 74 & 43 & 297 & 62,62 & 186 & 111 & 178 & 56,17 & 100 & 78 \\
\hline Gral. Deheza & 164 & 191 & 70,15 & 134 & 57 & 126 & 156 & 61,53 & 96 & 60 & 249 & 60,24 & 150 & 99 & 213 & 51,17 & 109 & 104 \\
\hline Coronel Moldes & 440 & 513 & 79,92 & 410 & 103 & 260 & 314 & 79,93 & 251 & 63 & 811 & 56,84 & 461 & 350 & 486 & 55,96 & 272 & 214 \\
\hline $\begin{array}{c}\text { Vicuña } \\
\text { Mackenna }\end{array}$ & 428 & 500 & 42,00 & 210 & 290 & 350 & 385 & 62,59 & 241 & 144 & 714 & 33,47 & 239 & 475 & 521 & 54,70 & 285 & 236 \\
\hline Sampacho & 448 & 523 & 35.37 & 185 & 338 & 328 & 348 & 55,74 & 194 & 154 & 889 & 24,40 & 217 & 672 & 532 & 42,48 & 226 & 306 \\
\hline $\begin{array}{l}\text { Berrotarán } \\
\text { (área pampeana } \\
\text { exclusivamente) }\end{array}$ & 130 & 152 & 75,00 & 114 & 38 & 87 & 117 & 66,66 & 78 & 39 & 204 & 63,72 & 130 & 74 & 172 & 55,81 & 96 & 76 \\
\hline Adelia María & 343 & 400 & 48,25 & 193 & 207 & 190 & 221 & 62,44 & 138 & 83 & 686 & 31,34 & 215 & 471 & 351 & 46,15 & 162 & 189 \\
\hline Alcira Gigena & 382 & 446 & 65,00 & 290 & 156 & 235 & 292 & 58,56 & 171 & 121 & 563 & 58,08 & 327 & 236 & 370 & 50,54 & 187 & 183 \\
\hline Ucacha & 193 & 225 & 80,00 & 180 & 45 & 120 & 152 & 71,71 & 109 & 43 & 346 & 70,23 & 243 & 103 & 231 & 57,57 & 133 & 98 \\
\hline Alejandro Roca & 171 & 200 & 68,50 & 137 & 63 & 137 & 150 & 68,66 & 103 & 47 & 296 & 55,06 & 163 & 133 & 209 & 52,63 & 110 & 99 \\
\hline Totales & 2.899 & 3.383 & 59,85 & 2.025 & 1.358 & 1.930 & 2.252 & 64,60 & 1.455 & 797 & 5.055 & 46,11 & 2.331 & 2.724 & 3.263 & 51,48 & 1.680 & 1.583 \\
\hline
\end{tabular}

Fuente: Elaboración propia en base a los datos obtenidos del padrón de contribuyentes municipales, oficinas de guía animal municipales, cooperativas agropecuarias, sociedades rurales locales, SENASA. 
"Centros Urbanos" se incluyen los que viven en el pueblo cabecera del área rural, más los que residen en otras localidades urbanas).

- En el año 2000, en todas las unidades territoriales, la mayoría de los productores viven en los centros urbanos, fluctuando entre un $56 \%$ y $80 \%$, con un promedio general de casi el 65\%, superior en 5 puntos al promedio de 1994. Esto nos está indicando un continuo drenaje de jefes de explotaciones del campo hacia los centros urbanos. Es dable observar que en cinco unidades territoriales el porcentaje de urbanización de los productores es menor que con respecto a 1994. Esto se debe a que en el proceso de disminución de productores entre 1994 y 2000, proporcionalmente disminuyeron más los productores que viven en los centros urbanos que los que residen en el campo.

- Cabe acotar que tanto en 1994 como en 2000 -en base a datos que no figuran en el cuadro pertinente-, dentro del total de Productores que residen en los centros urbanos, un porcentaje reducido pero no desestimable - del 8,6\% en 1994 y del 7,8\% en 2000desempeñan al mismo tiempo una actividad urbana aparte de la específica rural.

- En 1994, en el grueso de las unidades territoriales, la mayoría de la PEA Agropecuaria de los Productores (que comprende al productor más los integrantes del grupo familiar que trabajan con él) reside en los centros urbanos, exceptuando las tres unidades territoriales anteriormente nombradas, con una fluctuación porcentual de entre el 55\% y 70\%, pero el porcentaje total de la PEA Agropecuaria urbanizada se limita al $46 \%$.

- En 2000 también la mayoría de la PEA Agropecuaria de los Productores vive en los centros urbanos, exceptuando Sampacho y Adelia María, pero en un porcentaje menor que la de 1994, por la misma razón de que la PEA Agropecuaria que reside en los centros urbanos en 2000, proporcionalmente disminuye más que la que vive en el campo. No obstante el porcentaje del total de la PEA Agropecuaria urbanizada supera el 50\%, ubicándose casi en el 52\%.

Es interesante resaltar del Cuadro $\mathrm{N}^{\mathrm{0}} 24$, referido a los "Totales y localización de la composición de la PEA Agropecuaria de Productores", el papel limitado como fuerza laboral de los familiares de los productores.

Por un lado, observamos en los centros urbanos, tanto en 1994 como en 2000 -con valores muy similares- una escasa participación de los familiares que acompañan en el trabajo 
Cuadro No 24. Totales de la composición y localización de la PEA Agropecuaria de Productores. Datos de 1994 y 2000

\begin{tabular}{|c|c|c|c|c|c|c|c|c|c|c|}
\hline \multirow[b]{2}{*}{$\begin{array}{l}\text { Localidades + } \\
\text { zona rural de } \\
\text { influencia }\end{array}$} & \multirow[b]{2}{*}{$\begin{array}{l}\text { Fecha de } \\
\text { levantamiento } \\
\text { de datos }\end{array}$} & \multicolumn{3}{|c|}{ Centros urbanos } & \multicolumn{3}{|c|}{ Áreas rurales } & \multicolumn{3}{|c|}{ Totales generales } \\
\hline & & PEA total & Productor & $\begin{array}{l}\text { Familiar del } \\
\text { Productor }\end{array}$ & PEA total & Productor & $\begin{array}{l}\text { Familiar del } \\
\text { Productor }\end{array}$ & $\begin{array}{l}\text { PEA total } \\
\text { general }\end{array}$ & $\begin{array}{l}\text { Productor } \\
\text { totales } \\
\text { generales }\end{array}$ & $\begin{array}{l}\text { Familiares del } \\
\text { Productor } \\
\text { totales } \\
\text { generales }\end{array}$ \\
\hline General & 1994 & 186 & 172 & 14 & 111 & 61 & 50 & 297 & 233 & 64 \\
\hline Cabrera & 2000 & 100 & 74 & 26 & 78 & 43 & 35 & 178 & 117 & 61 \\
\hline \multirow{2}{*}{$\begin{array}{l}\text { General } \\
\text { Deheza }\end{array}$} & 1994 & 150 & 134 & 16 & 99 & 57 & 42 & 249 & 191 & 58 \\
\hline & 2000 & 109 & 96 & 13 & 104 & 60 & 44 & 213 & 156 & 57 \\
\hline \multirow{2}{*}{$\begin{array}{l}\text { Coronel } \\
\text { Moldes }\end{array}$} & 1994 & 461 & 410 & 51 & 350 & 103 & 247 & 811 & 513 & 298 \\
\hline & 2000 & 272 & 251 & 21 & 214 & 63 & 151 & 486 & 314 & 172 \\
\hline \multirow{2}{*}{$\begin{array}{l}\text { Vicuña } \\
\text { Mackenna }\end{array}$} & 1994 & 239 & 210 & 29 & 475 & 290 & 185 & 714 & 500 & 214 \\
\hline & 2000 & 285 & 241 & 34 & 236 & 144 & 92 & 521 & 385 & 136 \\
\hline \multirow{2}{*}{ Sampacho } & 1994 & 217 & 185 & 32 & 672 & 338 & 334 & 889 & 523 & 366 \\
\hline & 2000 & 226 & 194 & 32 & 306 & 154 & 152 & 532 & 346 & 184 \\
\hline \multirow{2}{*}{ Berrotarán } & 1994 & 130 & 114 & 16 & 74 & 38 & 36 & 204 & 152 & 52 \\
\hline & 2000 & 96 & 78 & 18 & 76 & 39 & 37 & 172 & 117 & 55 \\
\hline \multirow{2}{*}{ Adelia María } & 1994 & 215 & 193 & 22 & 471 & 207 & 264 & 686 & 400 & 286 \\
\hline & 2000 & 162 & 138 & 24 & 189 & 83 & 106 & 351 & 221 & 130 \\
\hline \multirow{2}{*}{ Alcira (Gigena) } & 1994 & 327 & 290 & 37 & 236 & 156 & 80 & 563 & 446 & 117 \\
\hline & 2000 & 187 & 171 & 16 & 183 & 121 & 62 & 370 & 292 & 78 \\
\hline \multirow{2}{*}{ Ucacha } & 1994 & 243 & 180 & 63 & 103 & 45 & 58 & 346 & 225 & 121 \\
\hline & 2000 & 133 & 109 & 24 & 98 & 43 & 55 & 231 & 152 & 79 \\
\hline \multirow{2}{*}{$\begin{array}{l}\text { Alejandro } \\
\text { Roca }\end{array}$} & 1994 & 163 & 137 & 26 & 133 & 63 & 70 & 296 & 200 & 96 \\
\hline & 2000 & 110 & 103 & 7 & 99 & 47 & 38 & 209 & 150 & 59 \\
\hline \multirow{4}{*}{$\begin{array}{l}\text { Totales } \\
\text { generales }\end{array}$} & \multirow{2}{*}{1994} & 2331 & 2025 & 306 & 2724 & 1358 & 1366 & 5055 & 3383 & 1672 \\
\hline & & $100 \%$ & $86,87 \%$ & $13.13 \%$ & $100 \%$ & $49,85 \%$ & $50,15 \%$ & $100 \%$ & $66.92 \%$ & $33,08 \%$ \\
\hline & \multirow{2}{*}{2000} & 1680 & 1455 & 225 & 1583 & 797 & 786 & 3263 & 2252 & 1011 \\
\hline & & $100 \%$ & $86,61 \%$ & $13,39 \%$ & $100 \%$ & $50,35 \%$ & $49,65 \%$ & $100 \%$ & $69,02 \%$ & $30,98 \%$ \\
\hline
\end{tabular}

Fuente: Elaboración propia en base a los datos obtenidos del padrón de contribuyentes municipales, oficinas de guía animal municipales, cooperativas agropecuarias, sociedades rurales locales, SENASA. 
al productor. En cambio, en las áreas rurales, la participación familiar es muchísimo mayor, rondando el $50 \%$ de la PEA total de dichas áreas.

Con respecto a los totales generales de la PEA Agropecuaria de los Productores, el peso del trabajador familiar en 1994 se circunscribe a un tercio de la fuerza laboral de los productores, bajando esa relación a un $31 \%$ en 2000. En concreto, el bajo porcentaje de trabajadores familiares en el primer caso, se debe a que una alta proporción de productores que viven en los centros urbanos son los únicos que trabajan en las explotaciones, en cambio, los que residen en el campo, generalmente, cuentan con un sólido apoyo familiar.

En el Cuadro $\mathrm{N}^{\mathrm{o}}$ 25, que versa sobre los “Totales y localización de la PEA Agropecuaria", aclaramos que aquí se considera a toda la fuerza laboral que participa en las tareas rurales: Asalariados ${ }^{3}$ : Fijos y Temporarios, Agentes Ligados ${ }^{4}$ y Productores $^{5}$, y los familiares que acompañan en el trabajo a los titulares de cada una de estas categorías.

Los aspectos a señalar son:

- Una disminución entre 1994 y 2000 -no figura en el cuadro- del 36\% del total general de la PEA Agropecuaria, de un 31\% del total de la PEA Agropecuaria que vive en los centros urbanos y de un $40,1 \%$ de la que reside en las áreas rurales. Esto está en consonancia con las disminuciones señaladas en el anteúltimo cuadro.

- En la "Sección PEA Agropecuaria de 1994", en primer lugar prevalece el total de la PEA Agropecuaria que reside en las áreas rurales con un 58\%. En segundo lugar, dentro de esta misma área, prevalecen los Productores (en el campo, en general, no viven los asalariados temporarios) sobre los Asalariados Fijos, con un 52\%. En tercer lugar, en los centros urbanos primero figura la PEA de los Productores con un 63\%, luego los Asalariados -dentro de éstos sobresalen notoriamente los temporarios-y

3 Consideramos "asalariados rurales" -o trabajadores rurales dependientes- a los trabajadores dependientes del agro que prestan un servicio a cambio de una remuneración determinada, en virtud de un acuerdo de trabajo.

4 Los "agentes ligados" representan aquella fuerza laboral que no está a cargo en forma exclusiva de la explotación ni interviene en el ciclo completo de la producción, pero que presta un servicio directo al agro mediante el desempeño de un oficio o profesión en calidad de trabajadores por cuenta propia. Ej.: contratistas de servicios, fumigadores, alambradores, veterinarios, etc.

5 A modo de aproximación conceptual, consideramos "productores" a todos aquellos actores sociales que trabajan la tierra por su cuenta, pudiendo ser propietarios o arrendatarios, sea en calidad de productores familiares que no explotan mano de obra asalariada, permanente o temporaria, y que participan de un régimen de explotación capitalista, lo que implica poseer diferentes grados de capitalización -en tierras, infraestructura edilicia, maquinaria y capital circulante- destinando el total de su producción al circuito comercial y orientando su producción hacia la obtención de la mayor tasa de ganancia. Dentro de este sector, consideramos a todo el agro que va del pequeño productor capitalizado, que se vale o no de la mano de obra asalariada, hasta los grupos que integran grandes sociedades empresariales agropecuarias, no contemplando en esta categoría al sector campesino y minifundista, debido a "la ausencia... [por parte de éstos] de una acumulación sistemática de capital, a causa de restricciones estructurales que lo impiden” (Manzanal, 1993:23). 
Cuadro $\mathrm{N}^{\circ}$ 25: Totales y localización de la PEA agropecuaria

\begin{tabular}{|c|c|c|c|c|c|c|c|c|c|c|c|c|c|c|c|c|c|c|c|c|}
\hline \multirow{3}{*}{$\begin{array}{c}\text { Localidades } \\
\text { + zona rural } \\
\text { de } \\
\text { influencia }\end{array}$} & \multicolumn{10}{|c|}{ PEA Agropecuaria - Datos de 1994} & \multicolumn{10}{|c|}{ PEA Agropecuaria - Datos de 2000} \\
\hline & \multicolumn{6}{|c|}{ Centros urbanos } & \multicolumn{3}{|c|}{ Áreas rurales } & \multirow[b]{2}{*}{ 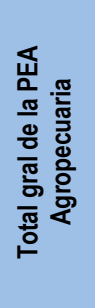 } & \multicolumn{6}{|c|}{ Centros urbanos } & \multicolumn{3}{|c|}{ Áreas rurales } & \multirow[b]{2}{*}{ 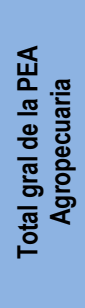 } \\
\hline & 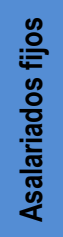 & 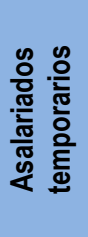 & 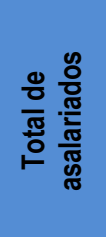 & 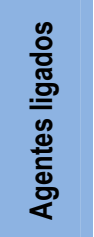 & 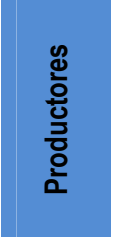 & 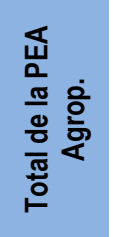 & 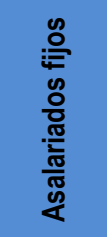 & 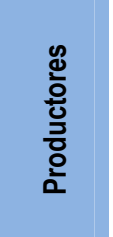 & 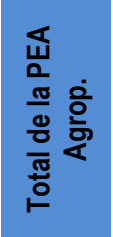 & & 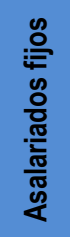 & 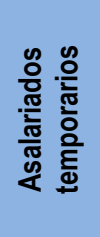 & 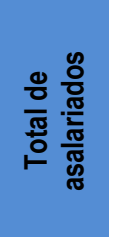 & 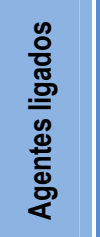 & 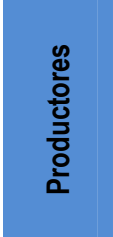 & $\begin{array}{l}\frac{\pi}{4} \\
\frac{\pi}{0} \\
\frac{0}{0} \\
\frac{\pi}{0} \\
\frac{\pi}{0}\end{array}$ & $\begin{array}{l}\stackrel{0}{0} \\
\frac{0}{6} \\
\frac{0}{0} \\
\frac{0}{\frac{\pi}{2}} \\
\frac{\pi}{0} \\
\frac{0}{0}\end{array}$ & 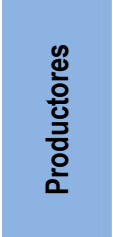 & 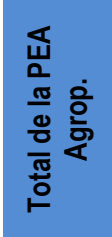 & \\
\hline Gral. Cabrera & 44 & 100 & 144 & 7 & 186 & 337 & 260 & 111 & 371 & 708 & 15 & 42 & 57 & 7 & 100 & 164 & 103 & 78 & 181 & 345 \\
\hline Gral. Deheza & 38 & 103 & 141 & 35 & 150 & 326 & 128 & 99 & 227 & 553 & 5 & 70 & 75 & 35 & 109 & 219 & 68 & 104 & 172 & 391 \\
\hline $\begin{array}{l}\text { Coronel } \\
\text { Moldes }\end{array}$ & 43 & 120 & 163 & 30 & 461 & 654 & 662 & 350 & 1.012 & 1.666 & 11 & 71 & 82 & 30 & 272 & 384 & 333 & 214 & 547 & 931 \\
\hline $\begin{array}{c}\text { Vicuña } \\
\text { Mackenna }\end{array}$ & 33 & 20 & 53 & 22 & 239 & 314 & 226 & 475 & 701 & 1.015 & 62 & 24 & 86 & 22 & 285 & 393 & 367 & 236 & 603 & 996 \\
\hline Sampacho & 52 & 60 & 112 & 9 & 217 & 338 & 125 & 672 & 797 & 1.135 & 20 & 69 & 89 & 9 & 226 & 324 & 99 & 306 & 405 & 729 \\
\hline $\begin{array}{l}\text { Berrotarán } \\
\text { (área pampeana } \\
\text { exclusivamente) }\end{array}$ & 58 & 60 & 118 & 9 & 130 & 257 & 56 & 74 & 130 & 387 & 8 & 36 & 44 & 9 & 96 & 149 & 21 & 76 & 97 & 246 \\
\hline Adelia María & 18 & 48 & 66 & 30 & 215 & 311 & 153 & 471 & 624 & 935 & 38 & 35 & 73 & 30 & 162 & 265 & 169 & 189 & 358 & 623 \\
\hline Alcira Gigena & 41 & 88 & 129 & 41 & 327 & 497 & 262 & 236 & 498 & 995 & 15 & 49 & 64 & 41 & 187 & 292 & 130 & 183 & 313 & 605 \\
\hline Ucacha & 75 & 105 & 180 & 29 & 243 & 452 & 478 & 103 & 581 & 1.033 & 11 & 59 & 70 & 29 & 133 & 232 & 186 & 98 & 284 & 516 \\
\hline $\begin{array}{c}\text { Alejandro } \\
\text { Roca }\end{array}$ & 51 & 10 & 61 & 20 & 163 & 244 & 151 & 133 & 284 & 528 & 21 & 8 & 29 & 20 & 110 & 159 & 72 & 99 & 171 & 330 \\
\hline Totales & 453 & 714 & 1.167 & 232 & 2.331 & 3.730 & 2.501 & 2.724 & 5.225 & 8.955 & 206 & 463 & 669 & 232 & 1.680 & 2.581 & 1.548 & 1.583 & 3.131 & 5.712 \\
\hline Porcentuales & & & $31,28 \%$ & $6,22 \%$ & $62,50 \%$ & $41,65 \%$ & $47,87 \%$ & $52,13 \%$ & $58,35 \%$ & $100 \%$ & & & $25,92 \%$ & $8,99 \%$ & $65,09 \%$ & $45,19 \%$ & $49,44 \%$ & $50,56 \%$ & $54,81 \%$ & $100 \%$ \\
\hline
\end{tabular}

Fuente: Elaboración propia en base a los datos obtenidos del padrón de contribuyentes municipales, oficinas de guía animal municipales, cooperativas agropecuarias, sociedades rurales locales, SENASA, gremio de asalariados rurales. 
por último vienen con un reducido $6 \%$ los Agentes Ligados, porcentaje que resulta coherente con las funciones complementarias que presta esta categoría. (Esta franja la consideramos como que reside básicamente en las localidades. En el caso de los contratistas rurales, tomamos solamente en cuenta a aquellos que exclusivamente se dedican a prestar servicios a terceros).

- En la "Sección PEA Agropecuaria de 2000", en primer lugar, también prevalece la PEA Agropecuaria que vive en las áreas rurales, con un 55\%, que marca en comparación con 1994 una paulatina tendencia hacia la urbanización de la PEA Agropecuaria. En segundo lugar, dentro de esta área, apenas sobresale la PEA de los Productores con un 50,5\%. En tercer lugar, en los centros urbanos primero figura la PEA de los Productores con un 65\%, seguido por los Asalariados con un 26\% (cuya disminución en comparación con los guarismos de 1994 es muy pronunciada) y por último con un $9 \%$ los Agentes Ligados.

En relación, básicamente, con los "totales generales y variaciones porcentuales de la PEA Agropecuaria" (Cuadro No 26), los aspectos relevantes a señalar son:

- Una disminución considerable del 35,45\% del total de la PEA Agropecuaria de los productores (productor más familiar que trabaja con el mismo) entre los dos años de referencia.

- Una disminución también acusada del 39,56\% del total de la PEA Agropecuaria de los asalariados entre los años citados. Si desagregamos esta fuerza laboral, comprobamos que esta merma es todavía mayor en los empleados fijos $(40,62 \%)$ que en los temporarios $(35,15 \%)$. Esta diferencia se explicaría debido a que los procesos de eficientización del campo afectan más a los primeros que a los últimos, ya que siempre el productor demanda algún tipo de tareas transitorias.

- En lo que respecta a la PEA Agropecuaria de los agentes ligados, en nuestros registros figura sin variación numérica entre los años analizados.

- Por último, la caída del total general de la PEA Agropecuaria, o sea la sumatoria de todas las fuerzas laborales intervinientes, es del 36,21\% entre los años referidos.

- Si consideramos la distribución porcentual de los guarismos de los diferentes agentes laborales de un mismo año -no figuran en el cuadro-, vemos que a la PEA Agropecuaria en el año 1994 le corresponde un 56,5\% a los productores, un 41\% a los asalariados y un 2,5\% a los agentes ligados; y al año 2000 le corresponde un $57 \%$ 
a los productores, un $39 \%$ a los asalariados y un $4 \%$ a los agentes ligados. En una palabra, no se manifiestan modificaciones sustanciales.

Cuadro No 26. Totales y variación porcentual entre 1994 y 2000 de la PEA Agropecuaria

\begin{tabular}{|c|c|c|c|c|c|c|c|c|c|c|c|c|c|}
\hline \multirow[b]{2}{*}{$\begin{array}{l}\text { Localidad } \\
\text { + zona } \\
\text { rural de } \\
\text { influencia }\end{array}$} & \multirow[b]{2}{*}{$\begin{array}{l}\text { Fechas de } \\
\text { levantamiento } \\
\text { de datos }\end{array}$} & \multirow{2}{*}{\multicolumn{2}{|c|}{\begin{tabular}{|c|} 
Total de la PEA \\
Agropecuaria \\
de los \\
productores y \\
variación $\%$
\end{tabular}}} & \multicolumn{6}{|c|}{ PEA Agropecuaria de los asalariados } & \multirow{2}{*}{\multicolumn{2}{|c|}{$\begin{array}{l}\text { Total de la PEA } \\
\text { Agropecuaria de los } \\
\text { agentes ligados y } \\
\text { variación \% }\end{array}$}} & \multirow{2}{*}{\multicolumn{2}{|c|}{$\begin{array}{c}\text { Total General } \\
\text { de la PEA } \\
\text { Agropecuaria y } \\
\text { variación } \%\end{array}$}} \\
\hline & & & & & $\begin{array}{l}\text { e la PEA } \\
\text { de los } \\
\text { iados y } \\
\text { ción } \%\end{array}$ & $\begin{array}{r}\text { PEA } \\
\text { asala } \\
\text { ve }\end{array}$ & $\begin{array}{l}\text { op. de los } \\
\text { los fijos y } \\
\text { :ión \% }\end{array}$ & & $\begin{array}{l}\text { p. de los } \\
\text { iados } \\
\text { rales y } \\
\text { ión \% }\end{array}$ & & & & \\
\hline \multirow{2}{*}{$\begin{array}{l}\text { General } \\
\text { Cabrera }\end{array}$} & 1994 & 297 & & 404 & & 304 & & 100 & & 7 & & 708 & \\
\hline & 2000 & 178 & $-40,07 \%$ & 160 & $-60,40 \%$ & 118 & $-61,18 \%$ & 42 & $-58,00 \%$ & 7 & $0,00 \%$ & 345 & $-51,27 \%$ \\
\hline \multirow{2}{*}{$\begin{array}{l}\text { General } \\
\text { Deheza }\end{array}$} & 1994 & 249 & & 269 & & 166 & & 103 & & 35 & & 553 & \\
\hline & 2000 & 213 & $-14,46 \%$ & 143 & $-46,84 \%$ & 73 & $-56,02 \%$ & 70 & $-32,04 \%$ & 35 & $0,00 \%$ & 391 & $-29,30^{\circ}$ \\
\hline \multirow{2}{*}{$\begin{array}{l}\text { Coronel } \\
\text { Moldes }\end{array}$} & 1994 & 811 & & 825 & & 705 & & 120 & & 30 & & 1666 & \\
\hline & 2000 & 486 & $-40,07 \%$ & 415 & $-49,70 \%$ & 344 & $-51,21 \%$ & 71 & $-40,83 \%$ & 30 & $0,00 \%$ & 931 & $-44,12$ \\
\hline \multirow{2}{*}{$\begin{array}{l}\text { Vicuña } \\
\text { Mackenna }\end{array}$} & 1994 & 714 & & 279 & & 259 & & 20 & & 22 & & 1015 & \\
\hline & 2000 & 521 & $-27,03 \%$ & 453 & $+62,37 \%$ & 429 & $+65,64 \%$ & 24 & $+20,00 \%$ & 22 & $0,00 \%$ & 996 & $-1,879$ \\
\hline \multirow{2}{*}{ Sampacho } & 1994 & 889 & & 237 & & 177 & & 60 & & 9 & & 1135 & \\
\hline & 2000 & 532 & $-40,14 \%$ & 188 & $-20,68 \%$ & 119 & $-32,77 \%$ & 69 & $+15,00 \%$ & 9 & $0,00 \%$ & 729 & $-35,77$ \\
\hline \multirow{2}{*}{$\begin{array}{l}\text { Berrotarán } \\
\text { (área pampeana } \\
\text { exclusivamente) }\end{array}$} & 1994 & 204 & & 174 & & 114 & & 60 & & 9 & & 387 & \\
\hline & 2000 & 172 & $-15,69 \%$ & 65 & $-62,64 \%$ & 29 & $-74,56 \%$ & 36 & $-40,00 \%$ & 9 & $0,00 \%$ & 246 & $-36,43$ \\
\hline \multirow{2}{*}{$\begin{array}{l}\text { Adelia } \\
\text { María }\end{array}$} & 1994 & 686 & & 219 & & 171 & & 48 & & 30 & & 935 & \\
\hline & 2000 & 351 & $-48,83 \%$ & 242 & $+10,50 \%$ & 207 & $+21,05 \%$ & 35 & $-27,08 \%$ & 30 & $0,00 \%$ & 623 & $-33,370$ \\
\hline \multirow{2}{*}{$\begin{array}{l}\text { Alcira } \\
\text { Gigena }\end{array}$} & 1994 & 563 & & 391 & & 303 & & 88 & & 41 & & 995 & \\
\hline & 2000 & 370 & $-34,28 \%$ & 194 & $-50,38 \%$ & 145 & $-52,15 \%$ & 49 & $-44,32 \%$ & 41 & $0,00 \%$ & 605 & $-39,20 \%$ \\
\hline \multirow{2}{*}{ Ucacha } & 1994 & 346 & & 658 & & 553 & & 105 & & 29 & & 1033 & \\
\hline & 2000 & 231 & $-21,96 \%$ & 256 & $-61,09 \%$ & 197 & $-64,38 \%$ & 59 & $-43,81 \%$ & 29 & $0,00 \%$ & 516 & $-50,05 \%$ \\
\hline \multirow{2}{*}{$\begin{array}{l}\text { Alejandro } \\
\text { Roca }\end{array}$} & 1994 & 296 & & 212 & & 202 & & 10 & & 20 & & 528 & \\
\hline & 2000 & 209 & $-29,39 \%$ & 101 & $-52,36 \%$ & 93 & $-53,96 \%$ & 8 & $-20,00 \%$ & 20 & $0,00 \%$ & 330 & $-37,50^{\circ}$ \\
\hline \multirow{2}{*}{$\begin{array}{l}\text { Totales } \\
\text { Generales }\end{array}$} & 1994 & 5055 & & 3668 & & 2954 & & 714 & & 232 & & 8955 & \\
\hline & 2000 & 3263 & $\%$ & 2217 & $-39,56 \%$ & 1754 & -4 & 463 & $\%$ & 232 & $0.00 \%$ & 57 & $-36,2$ \\
\hline
\end{tabular}

Fuente: Elaboración propia en base a los datos obtenidos del padrón de contribuyentes municipales, oficinas de guía animal municipales, cooperativas agropecuarias, sociedades rurales locales, SENASA, gremio de asalariados rurales.

El Cuadro $\mathrm{N}^{\mathrm{o}} 27$ trata los "totales y localización del Núcleo Familiar" de la PEA Agropecuaria”, referido exclusivamente al año 2000, por carecer de los datos equivalentes correspondientes al año 1994. Los aspectos sobresalientes son éstos:

- En la distribución de los totales generales del NF de la PEA Agropecuaria, el 59,5\% le corresponde al NF de los Productores, el 36,5\% al de los Asalariados y un 4\% al de los Agentes Ligados. Vemos así que la preponderancia del NF de los Productores es contundente.

6 El Núcleo Familiar (NF) de una familia agropecuaria está constituido por la PEA Agropecuaria más la PEA No Agropecuaria más la Familia Dependiente de la misma. 
Cuadro No 27: Totales y localización del Núcleo Familiar de la PEA agropecuaria - Datos de 2000

\begin{tabular}{|c|c|c|c|c|c|c|c|c|c|c|c|c|c|}
\hline \multirow{4}{*}{ 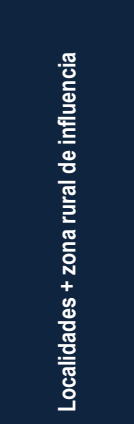 } & \multirow[b]{4}{*}{ 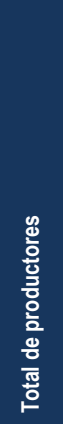 } & \multicolumn{3}{|c|}{ NF Productores } & \multicolumn{5}{|c|}{ NF Asalariados } & \multirow{3}{*}{ 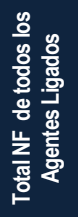 } & \multirow{3}{*}{ 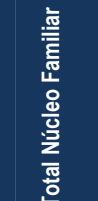 } & \multirow{3}{*}{ 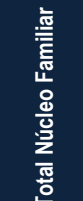 } & \\
\hline & & \multirow{3}{*}{ 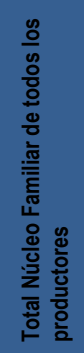 } & \multicolumn{2}{|c|}{ Residencia } & \multicolumn{3}{|c|}{ Asalariados Fijos } & \multirow{3}{*}{$\begin{array}{l}\text { Núcleo } \\
\text { Familiar } \\
\text { Temp. }\end{array}$} & \multirow{3}{*}{ 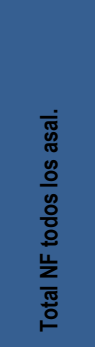 } & & & & \\
\hline & & & \multirow[b]{2}{*}{ 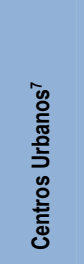 } & \multirow[b]{2}{*}{ 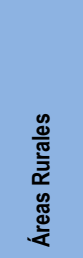 } & \multirow[b]{2}{*}{ 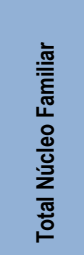 } & \multicolumn{2}{|c|}{ Residencia } & & & & & & 歖 \\
\hline & & & & & & 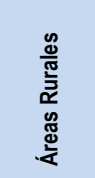 & $\begin{array}{l}\frac{0}{0} \\
\frac{0}{3} \\
\frac{3}{2}\end{array}$ & & & 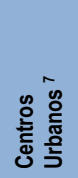 & 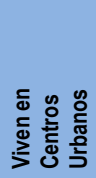 & 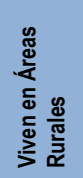 & 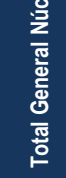 \\
\hline $\begin{array}{l}\text { Gral. } \\
\text { Cabrera }\end{array}$ & 117 & 473 & 282 & 191 & 259 & 199 & 60 & 105 & 364 & 16 & 463 & 390 & 853 \\
\hline Gral. Deheza & 156 & 622 & 333 & 289 & 232 & 217 & 15 & 175 & 407 & 86 & 609 & 506 & 1.115 \\
\hline $\begin{array}{l}\text { Coronel } \\
\text { Moldes }\end{array}$ & 314 & 1.241 & 807 & 434 & 704 & 676 & 28 & 176 & 880 & 75 & 1.086 & 1.110 & 2.196 \\
\hline $\begin{array}{c}\text { Vicuña } \\
\text { Mackenna }\end{array}$ & 385 & 1.348 & 831 & 517 & 1.127 & 821 & 306 & 60 & 1.187 & 55 & 1.252 & 1.338 & 2.590 \\
\hline Sampacho & 348 & 1.330 & 597 & 733 & 321 & 261 & 60 & 171 & 492 & 21 & 849 & 994 & 1.843 \\
\hline $\begin{array}{l}\text { Berrotarán } \\
\text { (área pampeana } \\
\text { exclusivamente) }\end{array}$ & 117 & 397 & 256 & 141 & 91 & 70 & 21 & 90 & 181 & 20 & 387 & 211 & 598 \\
\hline Adelia María & 221 & 910 & 492 & 418 & 430 & 354 & 76 & 86 & 516 & 76 & 730 & 772 & 1.502 \\
\hline $\begin{array}{c}\text { Alcira } \\
\text { Gigena }\end{array}$ & 292 & 1.060 & 555 & 505 & 302 & 262 & 40 & 121 & 423 & 101 & 817 & 767 & 1.584 \\
\hline Ucacha & 152 & 576 & 371 & 205 & 357 & 333 & 24 & 146 & 503 & 71 & 612 & 538 & 1.150 \\
\hline $\begin{array}{l}\text { Alejandro } \\
\text { Roca }\end{array}$ & 150 & 568 & 341 & 227 & 253 & 178 & 75 & 20 & 273 & 49 & 485 & 405 & 890 \\
\hline Totales & 2.252 & 8.525 & 4.865 & 3.660 & 4.076 & 3.371 & 705 & 1.150 & 5.226 & 570 & 7.290 & 7.031 & 14.321 \\
\hline Porcentuales & & $59,53 \%$ & $57,07 \%$ & $42,93 \%$ & $78,00 \%$ & $(64,50 \%)$ & $(13,50 \%)$ & $22,00 \%$ & $36,49 \%$ & $3,98 \%$ & $50,90 \%$ & $49,10 \%$ & $10 c$ \\
\hline
\end{tabular}

Fuente: Elaboración propia en base a los datos obtenidos del padrón de contribuyentes municipales, oficinas de guía animal municipales, cooperativas agropecuarias, sociedades rurales locales, SENASA, gremio de asalariados rurales.

- Con respecto, básicamente, a la franja del NF de los Productores, la mayoría vive en los centros urbanos con un 57\%, correspondiéndole al NF que vive en las áreas rurales un $43 \%$.

- En la franja del NF de los Asalariados, se distribuye en un 78\% para los fijos -desagregados en un $64,5 \%$ con residencia en las áreas rurales y un $13,5 \%$ en los pueblos-y en un 22\% para los temporarios (que consideramos que viven solamente en los pueblos). Vemos, a su vez, que si se sumara el NF de los Asalariados Fijos que viven en el pueblo más el de los Temporarios, la cifra total va a ser del $35,5 \%$, siendo este guarismo notoriamente inferior al NF de los Asalariados Fijos que residen en las áreas rurales, que como ya se dijo, es del 64,5\%. Dicho de otro modo, la mayoría del

Centros urbanos: a los que residen en el pueblo testigo más los que residen en otras localidades. 
NF de los Asalariados sigue residiendo en el campo. Parecería que esta franja es la última en permanecer en el mismo, por ser la que menos opción tiene de cambiar de lugar, y porque su localización rural se convierte en varios casos en muy necesaria, cuando los Productores pasan a vivir en los centros urbanos.

- Por último, queda el NF de los Agentes Ligados que viven exclusivamente en los pueblos, con un escaso $4 \%$ como ya lo mencionamos anteriormente.

- En suma, el total del NF de la PEA Agropecuaria que reside en los centros urbanos es escasamente superior con un $51 \%$ al que vive en las áreas rurales. Esto se debe básicamente a la preponderancia del NF de los Productores -reforzado por el de los Agentes Ligados- que residen en los centros urbanos, que contrabalancea el fuerte peso que ejerce al NF de los Asalariados Fijos que residen en las áreas rurales.

Todos estos guarismos responden al año 2000, pero por el fuerte despoblamiento rural que se ha seguido manifestando en los años siguientes, es de suponer que en la actualidad se haya incrementado sustancialmente el total del NF de la PEA Agropecuaria que reside en los centros urbanos.

Con respecto, básicamente, a los "totales del Núcleo Familiar y su relación con la fuerza laboral y Familia Dependiente de los Productores y Asalariados Fijos" (Cuadro No 28), es dable observar los siguientes aspectos:

- El total de la PEA de los Productores representa el 41,56\% del total del NF y el de la Familia Dependiente el 58,44\%. Diferencia no muy acusada entre la fuerza laboral familiar y la Familia Dependiente. Si desagregamos el total de la PEA mencionada en PEA Agropecuaria y PEA No Agropecuaria, los porcentajes se distribuyen en un $38,28 \%$ para la primera y un $3,28 \%$ para la segunda, lo que quiere decir que la PEA Agropecuaria disminuye unos puntos y aparece una PEA No Agropecuaria con un pequeño porcentaje en su haber, representado por algunos familiares de los Productores que trabajan generalmente en tareas urbanas.

- El total de la PEA de los Asalariados Fijos, representa el 43,35\% del total del NF y el de la Familia Dependiente el 56,65\%. La PEA No Agropecuaria de estos agentes es mínima y la relación de su PEA Agropecuaria con respecto a la de los Productores es apreciablemente superior, lo que nos está diciendo que en los Asalariados hay una mayor colaboración de sus familiares en el trabajo rural. Se aclara que los datos se circunscriben a los Asalariados Fijos por carecer de la suficiente información de los temporarios. 
Cuadro $\mathbf{N}^{\circ}$ 28. Totales del Núcleo Familiar y su relación con la fuerza laboral y familia dependiente de los productores y asalariados fijos - datos de 2000

\begin{tabular}{|c|c|c|c|c|c|c|c|c|c|c|c|}
\hline \multirow{3}{*}{$\begin{array}{l}\text { Localidad + } \\
\text { zona rural de } \\
\text { influencia }\end{array}$} & \multicolumn{6}{|c|}{ Productores } & \multicolumn{5}{|c|}{ Asalariados Fijos } \\
\hline & \multirow[b]{2}{*}{$\begin{array}{l}\text { Total de } \\
\text { productores }\end{array}$} & \multirow{2}{*}{$\begin{array}{l}\text { Total } \\
\text { del } \\
\text { Núcleo } \\
\text { Familiar }\end{array}$} & \multicolumn{4}{|c|}{ Fuerza laboral y familia dependiente } & \multirow{2}{*}{$\begin{array}{l}\text { Total } \\
\text { del } \\
\text { Núcleo } \\
\text { Familiar }\end{array}$} & \multicolumn{4}{|c|}{ Fuerza laboral y familia dependiente } \\
\hline & & & $\begin{array}{l}\text { Total } \\
\text { de la } \\
\text { PEA }\end{array}$ & $\begin{array}{l}\text { PEA } \\
\text { Agrop. }\end{array}$ & $\begin{array}{l}\text { PEA } \\
\text { No } \\
\text { Agrop. }\end{array}$ & $\begin{array}{l}\text { Familia } \\
\text { Depend. }\end{array}$ & & $\begin{array}{l}\text { Total } \\
\text { de la } \\
\text { PEA }\end{array}$ & $\begin{array}{c}\text { PEA } \\
\text { Agrop. }\end{array}$ & $\begin{array}{l}\text { PEA } \\
\text { No } \\
\text { Agrop. }\end{array}$ & $\begin{array}{l}\text { Familia } \\
\text { Depend. }\end{array}$ \\
\hline $\begin{array}{l}\text { General } \\
\text { Cabrera }\end{array}$ & 117 & 473 & 178 & 178 & - & 295 & 259 & 118 & 118 & - & 141 \\
\hline $\begin{array}{l}\text { General } \\
\text { Deheza }\end{array}$ & 156 & 622 & 225 & 213 & 12 & 397 & 232 & 73 & 73 & - & 159 \\
\hline $\begin{array}{l}\text { Coronel } \\
\text { Moldes }\end{array}$ & 314 & 1241 & 530 & 486 & 44 & 711 & 704 & 346 & 344 & 2 & 358 \\
\hline $\begin{array}{c}\text { Vicuña } \\
\text { Mackenna }\end{array}$ & 385 & 1348 & 551 & 521 & 30 & 797 & 1127 & 429 & 429 & - & 698 \\
\hline Sampacho & 348 & 1330 & 566 & 532 & 34 & 764 & 321 & 120 & 119 & 1 & 201 \\
\hline $\begin{array}{l}\text { Berrotarán } \\
\text { (área pampeana } \\
\text { exclusivamente) }\end{array}$ & 117 & 397 & 182 & 172 & 10 & 215 & 91 & 29 & 29 & - & 62 \\
\hline Adelia María & 221 & 910 & 389 & 351 & 38 & 521 & 430 & 210 & 207 & 3 & 220 \\
\hline $\begin{array}{l}\text { Alcira } \\
\text { (Gigena) }\end{array}$ & 292 & 1060 & 452 & 370 & 82 & 608 & 302 & 148 & 145 & 3 & 154 \\
\hline Ucacha & 152 & 576 & 252 & 231 & 21 & 324 & 357 & 197 & 197 & - & 160 \\
\hline $\begin{array}{l}\text { Alejandro } \\
\text { Roca }\end{array}$ & 150 & 568 & 218 & 209 & 9 & 350 & 253 & 97 & 93 & 4 & 156 \\
\hline $\begin{array}{l}\text { Totales } \\
\text { Generales }\end{array}$ & 2252 & 8525 & 3543 & 3263 & 280 & 4982 & 4076 & 1767 & 1754 & 13 & 2309 \\
\hline Porcentuales & & $100 \%$ & $41,56 \%$ & $(38,28 \%)$ & $(3,28 \%)$ & $58,44 \%$ & $100 \%$ & $43,35 \%$ & $(43,03 \%)$ & $(0,32 \%)$ & $56,65 \%$ \\
\hline
\end{tabular}

Fuente: Elaboración propia en base a los datos obtenidos del padrón de contribuyentes municipales, oficinas de guía animal municipales, cooperativas agropecuarias, sociedades rurales locales, SENASA, gremio de asalariados rurales.

El objetivo del Cuadro No 29 sobre "La incidencia del NF de la PEA Agropecuaria que reside en los centros urbanos", en 1994 y 2000, es el de ajustar y valorar debidamente el peso demográfico del NF de toda la fuerza laboral agropecuaria que vive en los pueblos testigos, en relación con el total de la población urbana de los mismos, y comparar aproximativamente, el peso demográfico de toda la PEA Agropecuaria que reside en dichos pueblos. Corresponde aclarar que las cifras que figuran en las columnas del NF de la PEA Agropecuaria que reside en los pueblos son menores que las de los "centros urbanos", por ejemplo del Cuadro 27, porque no contabiliza la fuerza laboral agropecuaria -con su correspondiente Familia Dependiente- que trabaja en las áreas rurales de los respectivos pueblos testigos, pero que viven en otras localidades. 
Cuadro No 29: Incidencia del Núcleo Familiar de la PEA Agropecuaria que reside en los Centros Urbanos -en 1994 y 2000-

\begin{tabular}{|c|c|c|c|c|c|c|c|c|}
\hline 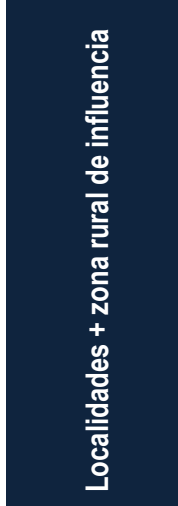 & 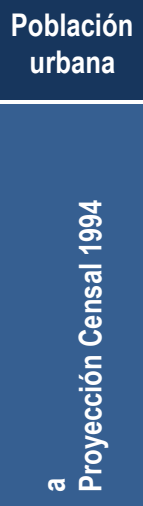 & 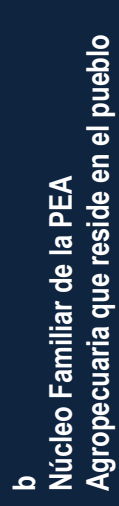 & 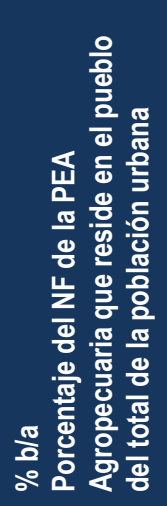 & 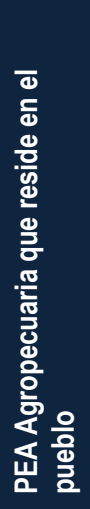 & 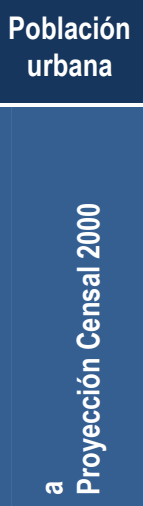 & 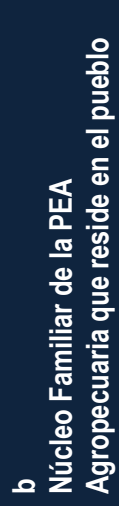 & 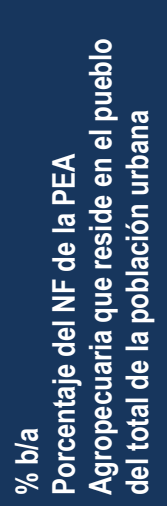 & 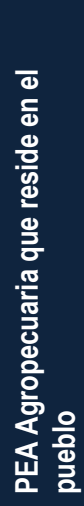 \\
\hline $\begin{array}{l}\text { Gral. } \\
\text { Cabrera }\end{array}$ & 9.516 & 987 & $10,37 \%$ & 337 & 10.287 & 439 & $4,27 \%$ & 164 \\
\hline Gral. Deheza & 8.592 & 986 & $11,47 \%$ & 326 & 9.132 & 609 & $6,67 \%$ & 219 \\
\hline $\begin{array}{l}\text { Coronel } \\
\text { Moldes }\end{array}$ & 7.967 & 1.811 & $22,73 \%$ & 654 & 8.341 & 1.034 & $12,40 \%$ & 384 \\
\hline $\begin{array}{l}\text { Vicuña } \\
\text { Mackenna }\end{array}$ & 7.684 & 799 & $10,39 \%$ & 314 & 8.556 & 861 & $10,06 \%$ & 393 \\
\hline Sampacho & 7.365 & 959 & $13,02 \%$ & 338 & 7.648 & 732 & $9,57 \%$ & 324 \\
\hline $\begin{array}{l}\text { Berrotarán } \\
\text { (área pampeana } \\
\text { exclusivamente) }\end{array}$ & 6.355 & 749 & $11,78 \%$ & 257 & 6.625 & 347 & $5,24 \%$ & 149 \\
\hline Adelia María & 5.742 & 822 & $14,31 \%$ & 311 & 6.217 & 631 & $10,15 \%$ & 265 \\
\hline $\begin{array}{l}\text { Alcira } \\
\text { Gigena }\end{array}$ & 5.075 & 1.365 & $26,89 \%$ & 497 & 5.523 & 747 & $13,53 \%$ & 292 \\
\hline Ucacha & 5.007 & 1.345 & $26,86 \%$ & 452 & 5.062 & 535 & $10,57 \%$ & 232 \\
\hline $\begin{array}{c}\text { Alejandro } \\
\text { Roca }\end{array}$ & 4.265 & 805 & $18,87 \%$ & 244 & 4.619 & 368 & $7,97 \%$ & 159 \\
\hline $\begin{array}{c}\text { Totales y } \\
\text { Porcentuales }\end{array}$ & 67.568 & 10.628 & $15,73 \%$ & 3.730 & 72.010 & 6.303 & $8,75 \%$ & 2.581 \\
\hline
\end{tabular}

Fuente: Elaboración propia en base a los datos obtenidos del padrón de contribuyentes municipales, oficinas de guía animal municipales, cooperativas agropecuarias, sociedades rurales locales, SENASA, gremio de asalariados rurales.

Los aspectos a considerar son los siguientes:

- Tanto en 1994 como en 2000 los totales porcentuales del NF de la PEA Agropecuaria que reside en el pueblo del total de la población urbana, es sumamente bajo -fluctúan entre un 10\% y un 27\%-, acentuándose notoriamente en 2000 -entre $4 \%$ y $12 \%$-. Estos guarismos nos están indicando que el peso demográfico de toda la población que depende "estrictamente" de las actividades agropecuarias dista sobremanera de ser mayoría en el contexto demográfico general de los pueblos 
estudiados, quedando demostrado por otro lado que la amplia mayoría de la población de las localidades aludidas depende de las actividades específicamente urbanas. Esto no quita que el producto económico que generan las actividades del campo se permeen hacia el grueso de las actividades urbanas, pero de manera indirecta.

- El descenso brusco de los totales del 15,73\% de la relación b/a de 1994 con respecto al $8,75 \%$ de 2000 , se debe a la disminución pronunciada en 2000 del NF de la PEA Agropecuaria que reside en el pueblo, cuya variación negativa va a ser de un $41 \%$ con respecto a 1994, cuya diferencia, a su vez, se agudiza más al incrementarse naturalmente la población urbana en general en dicho lapso. Esto nos está señalando que no solamente disminuye la PEA Agropecuaria en las áreas rurales sino que ésta también disminuye en los pueblos, como fenómeno de contracción general de toda la fuerza laboral rural en el área de estudio.

- Por último, en la Sección de 1994 y de 2000, se adosa una columna donde figura la PEA Agropecuaria que reside en el pueblo. Si bien no podemos compararla en cifras con la PEA Urbana de las respectivas localidades por carecer de esta información, por los reducidos guarismos que se expresan, se puede deducir aproximativamente en base a los totales poblacionales de dichas localidades, la poca incidencia que tienen en comparación con la PEA Urbana de los pueblos.

Por último, en el Cuadro $\mathrm{N}^{\circ} 30$, correspondiente al "Cuadro síntesis del total general y localización de la PEA Agropecuaria -datos 1994 y 2000- y del núcleo familiar de la PEA Agropecuaria -datos 2000-“, 8 sintetizamos los totales y la localización de las variables centrales que hemos estado considerando. Los aspectos destacables son los siguientes:

En la sección correspondiente a 1994, del total general de la PEA Agropecuaria, prevalece el total de la PEA Agropecuaria que vive en las áreas rurales, con un 58,35\%, correspondiéndole a la que vive en los centros urbanos un 41,65\%. En la sección de 2000, estos guarismos se suavizan, en el sentido de que el total de la PEA Agropecuaria que vive en las áreas rurales decae a un 54,81\% y, como contrapartida, la fuerza laboral que reside en los centros urbanos alcanza el 45,19\%. La diferencia, no obstante, de los agentes laborales que siguen viviendo en el campo es todavía significativa en 2000, a pesar de la preponderancia de la PEA Agropecuaria de los Productores que residen en los centros urbanos. Esto se debe, como se recordará, a la persistencia de la PEA Agropecuaria de los Asalariados Fijos que

8 Se carece en este último caso de la información necesaria para construir un cuadro equivalente para 1994. 
Cuadro No 30. Cuadro síntesis del total general y localización de la PEA Agropecuaria -datos de 1994 y 2000 - y del Núcleo Familiar de la PEA Agropecuaria - datos 2000-

\begin{tabular}{|c|c|c|c|c|c|c|c|c|c|}
\hline \multirow[b]{2}{*}{ Localidades } & \multicolumn{3}{|c|}{$\begin{array}{l}\text { Totales PEA Agropecuaria. Datos } \\
\qquad 1994\end{array}$} & \multicolumn{3}{|c|}{$\begin{array}{l}\text { Totales PEA Agropecuaria. Datos } \\
2000\end{array}$} & \multicolumn{3}{|c|}{$\begin{array}{c}\text { Totales NF de la PEA Agropecuaria } \\
\text { Datos } 2000\end{array}$} \\
\hline & 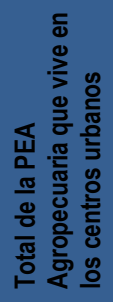 & 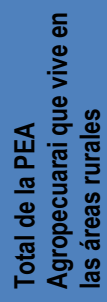 & 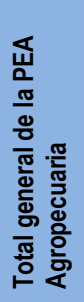 & 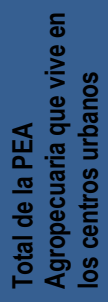 & 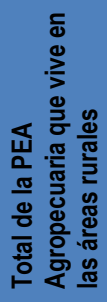 & 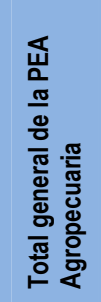 & 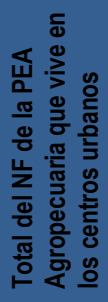 & 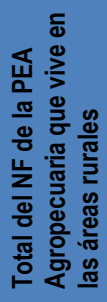 & 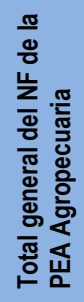 \\
\hline General Cabrera & 337 & 371 & 708 & 164 & 181 & 345 & 463 & 390 & 853 \\
\hline General Deheza & 326 & 227 & 553 & 219 & 172 & 391 & 609 & 506 & 1115 \\
\hline Coronel Moldes & 654 & 1012 & 1666 & 384 & 547 & 931 & 1086 & 1110 & 2196 \\
\hline Vicuña Mackenna & 314 & 701 & 1015 & 393 & 603 & 996 & 1252 & 1338 & 2590 \\
\hline Sampacho & 338 & 797 & 1135 & 324 & 405 & 729 & 849 & 994 & 1843 \\
\hline Berrotarán & 257 & 130 & 387 & 149 & 97 & 246 & 387 & 211 & 598 \\
\hline Adelia María & 311 & 624 & 935 & 265 & 358 & 623 & 730 & 772 & 1502 \\
\hline Alcira (Gigena) & 497 & 498 & 995 & 292 & 313 & 605 & 817 & 767 & 1584 \\
\hline Ucacha & 452 & 581 & 1033 & 232 & 284 & 516 & 612 & 538 & 1150 \\
\hline Alejandro Roca & 244 & 284 & 528 & 159 & 171 & 330 & 485 & 405 & 890 \\
\hline \multirow{2}{*}{$\begin{array}{l}\text { Totales y } \\
\text { Porcentuales }\end{array}$} & 3730 & 5225 & 8955 & 2581 & 3131 & 5712 & 7290 & 7031 & 14321 \\
\hline & $41,65 \%$ & $58,35 \%$ & $100 \%$ & $45,19 \%$ & $54,81 \%$ & $100 \%$ & $50,90 \%$ & $49,10 \%$ & $100 \%$ \\
\hline $\begin{array}{l}\text { Disminución PEA } \\
\text { Agropecuaria } 2000 \\
\text { con respecto a } \\
\text { PEA Agropecuaria } \\
1994\end{array}$ & - & - & - & $-30,80 \%$ & $-40,1 \%$ & $-36,21 \%$ & - & - & - \\
\hline
\end{tabular}

Fuente: Elaboración propia en base a los datos obtenidos del padrón de contribuyentes municipales, oficinas de guía animal municipales, cooperativas agropecuarias, sociedades rurales locales, SENASA, gremio de asalariados rurales.

siguen viviendo en las áreas rurales, más el peso numérico todavía significativo de la PEA Agropecuaria de los Productores que residen en el mismo lugar, lo que determina que continúe prevaleciendo el total de la PEA Agropecuaria que vive en el campo. A su vez, cabe acotar que, además de las diferencias porcentuales en la localización de la fuerza laboral, se debe tener presente -como ya se manifestó más arriba- que la disminución del total de la PEA Agropecuaria que reside en los centros urbanos en dicho lapso tuvo una retracción del 30,8\%, la del total de la PEA Agropecuaria que vive en el campo de un 40,1\% y la del total general de la PEA Agropecuaria de un 36,21\%, toda una disminución de la fuerza laboral rural generalizada, que se supone se ha seguido acentuando en los años subsiguientes.

Por último, para el año 2000, del total general del NF de la PEA Agropuecuaria, apenas va a prevalecer el total del NF de la PEA Agropecuaria que vive en los centros urbanos, con un 51\%. Aquí la diferencia a favor de los centros urbanos se debe básicamente al peso numérico de la Familia Dependiente que arrastra la PEA Agropecuaria de los Productores que 
residen en los pueblos. Debe quedar en claro que los últimos guarismos mencionados responden al año 2000, en cambio es de suponer que en la actualidad los indicadores de localización de la PEA Agropecuaria tiendan a desplazarse y convertirse en mayoría en los centros urbanos, y los indicadores del NF de la PEA Agropecuaria a incrementar su presencia en los mismos.

\subsubsection{Análisis locacional de la PEA agropecuaria a través de encuestas y entrevistas sistematizadas}

La recopilación de datos sobre este punto proviene, básicamente, de dos grupos encuestas - mencionadas en páginas anteriores- que se llevaron a cabo en dos momentos y ámbitos diferentes, juntamente con dos entrevistas sistematizadas. La primera encuesta concluyó en 1994 y estuvo orientada al relevamiento de los productores -con datos breves sobre los asalariados permanentes y temporarios proveniente de información vertida por sus empleadores- que residen en los diez centros urbanos del área de estudio, acompañada por entrevistas sistematizadas efectuadas a los asalariados y agentes ligados, con igual tipo de residencia. La segunda concluyó en 2002 y estuvo dirigida al relevamiento de los productores -con la obtención de datos sobre los asalariados fijos a través de la información vertida por sus empleadores- que viven en las zonas rurales de las diez localidades consideradas en la investigación. En 2008, concluyó una entrevista masiva llevada a cabo a los asalariados en general, que viven tanto en los pueblos como en las áreas rurales.

El cuestionario de las encuestas se estructuró en cuatro secciones -y las entrevistas de forma similar-:

1. "Características específicas relacionadas con los cambios de localización", para los agentes que viven en el pueblo, y "Motivos, expectativas y características de localización en la zona rural”, para los que viven en las áreas rurales.

2. Estructura familiar y otras variables sociales.

3. Perfil económico.

4. Perfil laboral.

De acuerdo con el propósito de este capítulo, nos limitamos, en esta instancia, solamente a exponer los resultados de los fenómenos de localización proveniente de las encuestas y entrevistas mencionadas. 
Con referencia a la "encuesta de 1994, efectuada a la categoría laboral Productores que residen en los centros urbanos" ${ }^{9}$, se llevaron a cabo 105 encuestas distribuidas proporcionalmente en función de la cantidad de productores que residen en cada pueblo y trabajan en sus respectivas zonas rurales.

Al respecto, podemos decir:

- Con relación a la "procedencia" de los productores, la amplia mayoría ha vivido anteriormente en el campo (82\%), sin desestimar por ello un pequeño porcentaje que ha nacido o procede de centros urbanos. Con respecto a la procedencia rural de sus padres, este porcentaje se eleva al $89 \%$.

- El traslado a las localidades predominantemente se llevó a cabo en las décadas del '70 (38,9\%) y el' $80(44,5 \%)$.

- Entre las "causas" que motivaron dicho traslado, la "educativa" (específicamente acceso a la enseñanza media) ocupa el primer lugar (41\%), seguida en forma muy distante por la atracción de las "comodidades urbanas" (13\%), por una "combinación de razones" (11\%), "por motivos de salud" (8\%), "por ceder la vivienda a los hijos" $(8 \%)$, etc.

- En la mayoría de los casos la situación familiar, en la fecha del traslado, atravesaba por un buen momento económico (75\%). Esta circunstancia -de acuerdo con las décadas de traslado anteriormente mencionadas- coincide con un período de sostenida expansión agrícola en la Región Pampeana, por lo menos hasta mediados de la década del ochenta, que es cuando se inicia un retroceso económico en el agro pampeano (Barsky y Gelman, 2001).

- La amplia mayoría de los que proceden de áreas rurales siente deseos personales de volver a vivir en el campo (67\%), lo que indica, más allá de las posibilidades reales de poder concretar esta aspiración, un íntimo apego a la vida rural, cuando en general no están en condiciones de cumplir con este anhelo por varios motivos.

- El grueso de los entrevistados se siente cómodo de vivir en el pueblo (72\%), lo que no obligadamente se contradice con lo anteriormente expresado.

\footnotetext{
Corresponde precisar que los productores que se encuestaron, tanto en los centros urbanos como en las áreas rurales, pertenecían proporcionalmente a todos los niveles económicos, pero limitado al tipo jurídico: "persona física", "sociedad de hecho" y sociedades formales conformadas por pocos socios y con permanencia en la actividad productiva.

Básicamente, se procuró encuestar, por razones operativas, a los "productores individuales" y aquellos agrupados en "un reducido número de personas", más allá del tamaño de los establecimientos que explotan. No se consideró, por lo tanto, en esta oportunidad, a las grandes sociedades agropecuarias, generalmente anónimas y de compleja estructura composicional.
} 
- Casi todos son propietarios de las viviendas que habitan en el pueblo (90\%) y la calidad de la construcción de las mismas ${ }^{10}$ es buena (76\%), e inclusive en algunos casos muy buena $(11 \%)$.

- Casi todos también poseen casa en el campo (92\%) y en la mayoría de éstas vive alguien en forma permanente (73\%), preferentemente ocupada por empleados (59\%) e hijos (31\%). El estado de mantenimiento de la casa de campo en general fluctúa entre aceptable y bueno (79\%). Asimismo, se detecta un porcentaje no desestimable de viviendas desocupadas (27\%).

Con respecto a las entrevistas de 1994, llevadas a cabo a los asalariados y agentes ligados que también viven en los centros urbanos, pasamos a analizar lo siguiente:

- En la categoría laboral: Asalariados -se entrevistaron temporarios y permanentes-, podemos observar:

- La mayoría de los asalariados ha vivido anteriormente en el campo y en relación con los años de traslado al pueblo, éste se llevó a cabo entre las décadas del ' 70 y el ' 80 .

- Entre las razones que motivaron dicho traslado, se destacan las "educativas" (43\%) y “por problemas económicos” (29\%).

○ En la mayoría de los que proceden de áreas rurales prevalece el deseo personal de volver a vivir en el campo, pero a su vez en general se sienten cómodos viviendo en el pueblo.

○ En relación con la pertenencia de sus viviendas, todos son propietarios $(100 \%)$ y la calidad de las mismas fluctúa entre regular (57\%) y aceptable (43\%).

- En la categoría laboral: Agentes Ligados -se entrevistaron básicamente "contratistas de servicios"- se detectan estas variables:

o Prácticamente todos los entrevistados acusan una procedencia rural y el traslado del campo a la localidad se produjo especialmente en las décadas del '70 y el '80.

10 El criterio que hemos utilizado para "calificar" las viviendas de forma macro se basa en la calidad de los materiales de la construcción y del estado de conservación de las mismas, de acuerdo con la siguiente escala básica:

- Vivienda precaria: piso de tierra o de cemento, paredes de adobe o similares, techos de paja, chapa o similar, sanitarios incompletos.

- Vivienda regular: piso de baldosa rústica, paredes de ladrillo sin revocar, techo de chapa o similar, sanitarios básicos, mal estado de conservación de la misma.

- Vivienda buena: piso de baldosa o similar, paredes de material revocado, techo de hormigón armado, de machimbre o similar, sanitarios completos, buen estado de conservación de la misma.

- Vivienda muy buena: al igual que la escala anterior pero la construcción provista con materiales de mejor calidad, en muy buen estado de conservación y de mayores dimensiones que las viviendas estándar. 
○ Entre las razones que motivaron dicho traslado predomina el ítem "otras causas" -lo que da a entender que las razones son muy variadas-, seguido por las “educativas" y por "problemas económicos".

○ La situación económica familiar en el momento del traslado se reparte entre regular y buena.

○ Casi todos están conformes con la vida en el pueblo.

o Prácticamente todos son propietarios de las viviendas que habitan y con respecto a la construcción de las mismas, predominan las de calidad buena.

- Con respecto a la "encuesta de 2002, efectuada a la categoría laboral Productores y llevada a cabo específicamente en las áreas rurales", en esta tarea, se levantaron 132 entrevistas, distribuidas también proporcionalmente en función de la cantidad de productores que residen en cada zona rural.

Las variables más destacadas son:

- En lo referente a la procedencia de los productores, la mayoría nació en la explotación (41\%) o en la zona rural donde se encuentra su actual predio (29\%). En relación con los padres de los productores, el 34,7\% nació en la zona rural, el 9,1\% en la explotación y el 33,9\% fuera de la zona rural (pero en territorio argentino). El resto son de origen extranjero, correspondiendo a la nacionalidad italiana el 15,7\% y a la nacionalidad española el 6,6\%. En relación con la procedencia extranjera de sus abuelos, la amplia mayoría proviene de Italia (73,8\%), en menor medida de España $(9,8 \%) \mathrm{y}$, por último, de Austria $(1,6 \%),{ }^{11}$ correspondiendo a los nacidos en Argentina el 14,8\%.

- En los casos de los productores que no nacieron en los establecimientos, la fecha en que se trasladaron a vivir a la explotación, ya sea por parte del actual productor o por sus ascendientes, varía de la década del '30 a la del '60, pero con especial énfasis durante las décadas del ' 40 y el ' 50.

- Entre las razones que motivaron la localización en la explotación por parte del actual productor, la predominante recae en la de "seguir ligado al lugar donde se nació o donde se vive desde hace tiempo" (64,7\%); en mucha menor proporción por “oportunidad comercial de compra de la propiedad" (18,9\%), seguido por razones de "herencia" $(11,5 \%)$ y por "facilidades de compra de parte de antiguos arrendatarios" $(4,9 \%)$.

11 Como caso singular, muchos de los inmigrantes que se instalaron en las colonias de Sampacho -una de las primeras en fundarse en la provincia de Córdoba- eran de nacionalidad austríaca. 
- Hay conformidad en general con la vida que se lleva a cabo en la explotación $(89,4 \%)$, quedando circunscriptos a un $9,1 \%$ los que están más o menos conformes, y casi todos piensan seguir residiendo en la misma (96,2\%).

- El 100\% de los encuestados viven permanentemente en la explotación y casi todos se proveen de sus necesidades cotidianas en el pueblo testigo (92,4\%), en cuya zona de influencia se encuentra ubicado el predio. El 51,5\% de los productores cuenta con un vehículo para desplazarse y el 48,5\%, con dos o más vehículos.

- La calidad de las viviendas fluctúa entre buena (67,9\%) y regular (30,7\%), y el tamaño de sus casas ${ }^{12}$ en general varía entre mediano $(42,9 \%)$ y grande $(54,3 \%)$. A su vez, el estado de mantenimiento de las mismas oscila entre aceptable (40\%) y bueno $(57,1 \%)$.

- La gran mayoría de las viviendas cuenta con electricidad de red (80,2\%), el 17\% de ellas posee generador propio y el 2,8\% no están electrificadas; casi todas cuentan con acceso telefónico $(92,8 \%)$. Casi todas, también, están provistas de aparatos de televisión $(94,2 \%)$.

- Muchos productores cuentan con una segunda vivienda en la explotación (45,5\%), generalmente ocupada por los empleados $(63,3 \%)$. A su vez, es significativa la proporción de productores que poseen casa en el pueblo $(46,2 \%)$, que puede estar habitada por familiares o no, y se la frecuenta de acuerdo con las necesidades del caso, pero no por ello abandonan su domicilio rural.

- En síntesis, con respecto a las comodidades de las viviendas del campo, se puede decir que en general están provistas de un confort y de una tecnología comunicacional que fluctúa de bastante aceptable a muy buena.

Con referencia a la "entrevista sistematizada y masiva de 2008 -se entrevistaron cincuenta y dos agentes-, efectuada a los Asalariados que viven tanto en los centros urbanos como en el campo", podemos decir lo siguiente:

En relación con los asalariados que residen en los pueblos, vemos que el grueso proviene de parajes rurales de la zona, al igual que sus padres y abuelos, y en el caso especialmente de los temporarios, varios de ellos han nacido en el mismo pueblo, dado que este tipo de trabajador, casi en su totalidad, vive en los centros urbanos. El traslado del campo

12 El criterio básico utilizado para determinar el tamaño de las viviendas se centró en la cantidad de habitaciones de que disponen las mismas, del modo siguiente:

- Vivienda pequeña: una habitación.

- Vivienda mediana: dos habitaciones.

- Vivienda grande: tres o más habitaciones. 
al pueblo data, en general, de las décadas del '80 y '90, motivado por razones de tipo laboral y educativo -de los hijos-, entre otras.

En el caso de los "asalariados que viven en el campo" -prácticamente todos permanentes-, también ellos, como sus antecesores, son oriundos de la zona, habiéndose establecido en las EAPs donde ahora trabajan dentro de un arco temporal que fluctúa entre cuatro y veinticinco años anteriores a la fecha de 2008. Las razones de residir en dichos establecimientos son diversas, como la posibilidad de acceder a sueldos adecuados, condiciones de vida aceptables, buen trato y, en menor medida, el no tener hijos en edad escolar, entre otras. ${ }^{13}$

Cabe acotar que la mayoría de los apellidos de los asalariados mencionados son de origen español; esta realidad nos está indicando la clara procedencia criolla de este sector del trabajo rural.

Por otra parte, todos los asalariados que viven en los pueblos están conformes con residir en los mismos. En cambio, en el caso de los trabajadores que viven en las EAPs, si bien también, en general, están conformes con habitar en ellas, algunos albergan la esperanza de mudarse del actual lugar, en búsqueda de mejores condiciones de trabajo.

En lo referente a la situación habitacional, podemos aseverar que los "trabajadores permanentes" que viven en los pueblos, generalmente cuentan con vivienda propia, casi siempre de calidad aceptable a regular y de tamaño medio (dos o tres habitaciones), en tanto que los permanentes que viven en el campo residen normalmente en una vivienda aparte de la del patrón, contando éstas generalmente con servicio eléctrico de red; además, muchos de ellos cuentan con vivienda propia en el pueblo, frecuentándola -cuando no está alquilada-los fines de semana generalmente. La circunstancia de que varios de los trabajadores permanentes que residen en el campo con sus familias cuenten con viviendas propias en los pueblos no es un hecho menor, ya que esta realidad nos está indicando que la verdadera residencia de los mismos son los pequeños centros urbanos y que, por razones de trabajo, van a vivir al campo. Es dable destacar que gran parte de las viviendas rurales ocupadas por dichos empleados se encuentran en inaceptables condiciones de habitabilidad; la excepción la constituyen las viviendas de las estancias visitadas en la zona rural de Del Campillo, de calidad notablemente superior.

En cuanto a los "trabajadores temporarios", la totalidad de los entrevistados declararon ser propietarios de sus viviendas urbanas, de condiciones humildes pero aceptables, ubicadas

13 Es interesante señalar, como un dato complementario, que la distancia promedio de las EAPs donde residen los trabajadores permanentes entrevistados al pueblo más cercano ronda entre los 10 y $15 \mathrm{~km}$. Esta situación está relacionada con la dificultad de acceder de manera fluida por parte de los hijos de los asalariados a los colegios de los pueblos, ya que no siempre son suficientes las escuelas rurales. 
juntamente con las de los permanentes, generalmente del otro lado de la vía -entiéndase, a espaldas del sector urbano principal del pueblo, dividido tradicionalmente por la vía férrea que lo atraviesa-, en casitas prolijas de material, donde no se ve el rancho criollo.

En suma, los fenómenos sobre la cuestión de la localización que expresan las encuestas y entrevistas arriba descriptas, son similares -por lo que sabemos-, de manera general, a los que se observan en otros sectores del espacio pampeano.

El peso de atracción de los centros urbanos, para todos los tipos de agentes laborales, es innegable. Muchos de los que actualmente viven en una aglomeración, ya sea en tiempos cercanos o lejanos, han acusado un traslado del campo al pueblo. También las razones de dicho desplazamiento, en la mayoría de los casos, se debe a causalidades similares. La calidad y confort de las viviendas, en general, tanto de los productores que residen en los pueblos como los que residen en el campo, se pueden considerar que abarcan toda la escala, que va de aceptable a muy buena, según los niveles económicos de los implicados. Estas cualidades no se manifiestan así en el caso de los trabajadores dependientes, si bien predomina su condición de propietarios de sus viviendas, lo real es que persisten muchas viviendas cuya calidad fluctúa de regular a precaria -a pesar de que muchas, dentro de su simpleza, pueden considerarse como aceptables- al igual que varias de las que habitan los asalariados permanentes en las EAPs donde se desempeñan.

\subsection{La incidencia de la PEA Agropecuaria y No Agropecuaria en la Población Rural Concentrada}

En este punto, queremos destacar la incidencia de la fuerza laboral, tanto rural como urbana, que reside en un conjunto de pequeños poblados de menos de 2000 habitantes -todos ubicados en el área de la presente investigación (Mapa $\mathrm{N}^{\mathrm{o}} 10$ )-, cuyos análisis y resultados lo llevaron a cabo exitosamente un grupo de becarios de investigación, dependientes de la SeCyT de la UNRC, cuya temática central consistió en el estudio de la PEA Rural Concentrada.

Los poblados y los becarios asignados al análisis de los mismos fueron los siguientes:

- Chaján y Suco, becarias: Andrea Rivarola y Verónica Marincioni. ${ }^{14}$

14 Rivarola, A. 1999. "Estudio de la PEA Rural concentrada en base al análisis de un centro poblacional de menos de 2.000 habitantes. El caso de Suco". Informe de Beca de Ayudantía de la SeCyT, UNRC, realizado a través del Dpto. de Geografía, Facultad de Ciencias Humanas. Director: Ricardo Agüero.

Marincioni, V. 1999. "Estudio de la PEA Rural concentrada en base al análisis de un centro poblacional de menos de 2.000 habitantes. El caso de Chaján". Informe de Beca de Ayudantía de la ScCyT, UNRC, realizado a través del Dpto. de Geografía, Facultad de Ciencias Humanas. Director: Ricardo Agüero. 


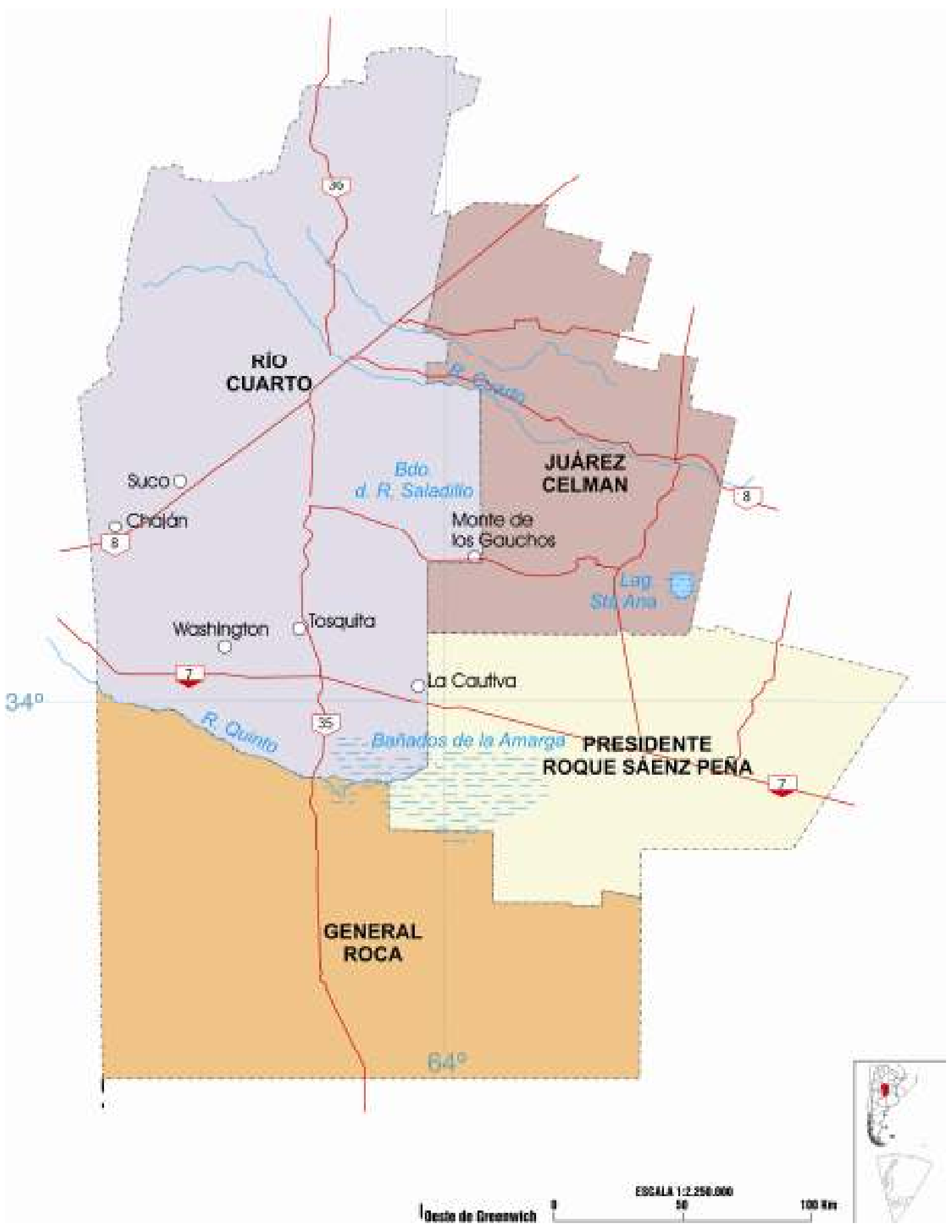

Mapa $\mathrm{N}^{\circ} 10$. Pequeños poblados de menos de 2.000 habitantes. 
- Washington, Tosquita, La Cautiva y Monte de los Gauchos, becarios: Marina Bustamante y Diego Zalazar. ${ }^{15}$

La idea clave de dichos emprendimientos consistió en caracterizar los pequeños centros poblacionales básicamente por sus funciones laborales predominantes, en el sentido de si prevalece la PEA Agropecuaria o la No Agropecuaria y, en segundo término, analizar el desenvolvimiento general de la composición socio-económico-laboral que se manifiesta en los mismos.

Con respecto al primer aspecto de lo antedicho, que es lo que aquí nos interesa desarrollar, partió de la inquietud de indagar si en las localidades de menos de 2000 habitantes, categorizadas por el INDEC como Población Rural Concentrada, las mismas se comportan como simples aglomeraciones de personas básicamente dedicadas a los trabajos rurales, o si se desenvuelven como pequeños centros urbanos por su finalidad y predominancia de tareas no agropecuarias que desarrollan sus habitantes, o si se desenvuelven también en forma combinada como centros rurales-urbanos, por el equilibrio porcentual relativo existente entre las tareas no agropecuarias y agropecuarias que desarrollan los habitantes aludidos.

La investigación emprendida por los becarios se aboca, por consiguiente, en constatar qué peso demográfico tiene tanto la fuerza laboral del campo como la fuerza laboral urbana en los pequeños centros poblados considerados rurales, dado que generalmente se desconoce o se desestima el peso de esta fuerza en los mismos.

Resulta conveniente, por lo tanto, desarrollar un breve análisis teórico sobre los "tipos de PEA Rural" que existen, dado el alto grado de complejidad que encierra esta fuerza laboral aparentemente uniforme. Así, debemos recordar que de la Población Rural se desprende una Población Rural Concentrada (la que vive agrupada en un conglomerado de viviendas de menos de 2000 habitantes) y una Población Rural Dispersa (que vive a campo abierto). Éstas, a su vez, conforman una PEA Rural Concentrada y una PEA Rural Dispersa. Por último, cada

15 Bustamante, M. y D. Zalazar. 2001. "Estudio de la PEA Rural concentrada en base al análisis de un centro poblacional de menos de 2.000 habitantes. El caso de La Cautiva”. Informe de Beca de Ayudantía de la SeCyT, UNRC, realizado a través del Dpto. de Geografía, Facultad de Ciencias Humanas. Director: Ricardo Agüero.

Zalazar, D. y M. Bustamante. 2001. "Estudio de la PEA Rural concentrada en base al análisis de un centro poblacional de menos de 2.000 habitantes. El caso de Washington y Tosquita". Informe de Beca de Ayudantía de la SeCyT, UNRC, realizado a través del Dpto. de Geografía, Facultad de Ciencias Humanas. Director: Ricardo Agüero.

Zalazar, D. y M. Bustamante. 2001. "Estudio de la PEA Rural concentrada en base al análisis de un centro poblacional de menos de 2.000 habitantes. El caso de Monte de los Gauchos". Informe de Beca de Ayudantía de la SeCyT, UNRC, realizado a través del Dpto. de Geografía, Facultad de Ciencias Humanas. Director: Ricardo Agüero. 
una de ellas se desdobla en una PEA Agropecuaria y una PEA No Agropecuaria (de acuerdo con la problemática que aquí se trata, en esta instancia no se consideró el desdoblamiento de la PEA Rural Dispersa en PEA Agropecuaria y No Agropecuaria) (Gráfico 4).

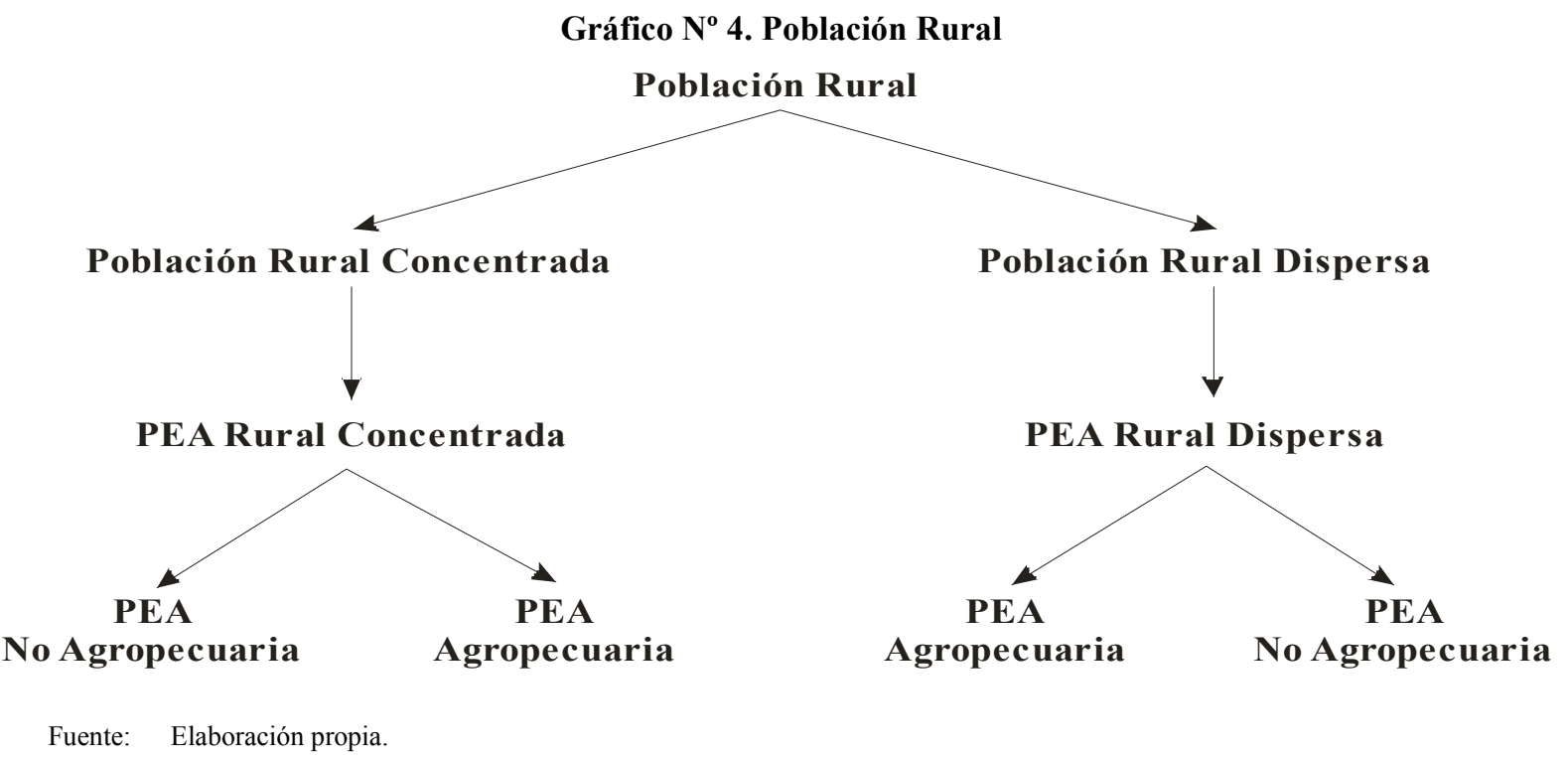

Pero esta clasificación se complica, según la intensidad con que participe la PEA No Agropecuaria en la PEA Rural Concentrada, de modo tal que, en un supuesto caso, cuando en un pequeño poblado de menos de 2000 habitantes llega a predominar la PEA No Agropecuaria sobre el total de la fuerza laboral, ésta intrínsecamente se asemeja a una estructura composicional laboral comparable a un centro urbano, de acuerdo con el criterio de la geografía clásica, que considera: "Para dar una definición de ciudad [este término es equivalente a centro urbano para nosotros] tendremos que basarnos en las actividades de sus habitantes, que deben ser precisamente no agrícolas" (Derruau, 1965:562). Dicho de otro modo, para que una aglomeración sea contemplada como urbana, además de contar con una cantidad de población representativa y de una cierta estructura edilicia, debe predominar sobre el total de la fuerza laboral el trabajo de consistencia urbana.

Cabe aclarar que, desde el punto de vista metodológico formal, estas mediaciones explicitadas no afectan el corte estadístico oficial entre Población Urbana y Rural, dado que el INDEC establece taxativamente que todo agrupamiento menor de 2000 habitantes entra en la categoría de población rural concentrada. Pero sí es importante, en un plano teóricoconceptual, el análisis de estas mediaciones, porque señalan, entre otras cosas, lo discutible que resulta el criterio demográfico cuantitativo. Es por eso que, en el estudio de los pequeños poblados -exceptuando los casos de muy reducidas dimensiones-, resulta de sumo interés explorar la incidencia de la PEA No Agropecuaria en su estructura poblacional, porque desde 
el punto de vista geográfico -como se decía- si llegan a predominar las actividades laborales urbanas en algunos de ellos se asemejan y aproximan, por sus funciones -sin perder su condición de poblados rurales por su exigüidad demográfica-, a la categoría de centros urbanos propiamente dichos, dado que esas actividades les imprimen en su tejido poblacional una dinámica urbana -contextualizada en una transferencia hacia el plano social, económico y cultural-que es diferente a la dinámica rural.

A fin de cotejar la problemática planteada conceptualmente con la realidad emanada de los resultados, pasamos a volcar exclusivamente - entre otra gran cantidad de datos recogidoslos datos de la distribución de la PEA por sus funciones laborales, en las pequeñas poblaciones estudiadas por los becarios arriba aludidos (Cuadro $\mathrm{N}^{\mathrm{o}} 31$ ).

\begin{tabular}{|c|c|c|c|}
\hline Localidades & Población & PEA Agropecuaria & PEA No Agropecuaria \\
\hline La Cautiva & 646 (año 2000) & $52,2 \%$ & $47,8 \%$ \\
\hline Washington & 521 (año 2000) & $50 \%$ & $50 \%$ \\
\hline Monte de los Gauchos & 520 (año 2000) & $35 \%$ & $65 \%$ \\
\hline Chaján & 604 (año 1999) & $36,5 \%$ & $63,5 \%$ \\
\hline Suco & 290 (año 1999) & $35,8 \%$ & $64,2 \%$ \\
\hline Tosquita & 314 (año 2000) & $38,7 \%$ & $61,3 \%$ \\
\hline
\end{tabular}

Fuente: Elaborado por Andrea Rivarola y Verónica Marincioni (1999); Marina Bustamante y Diego Zalazar (2001).

Vemos así que, en cuatro poblados, predomina notoriamente la fuerza laboral urbana y, en los dos restantes, si bien no predomina, ronda o se acerca al 50\%. En concreto, la PEA No Agropecuaria tiene una presencia significativa en los poblados estudiados de menos de 2.000 habitantes, quedando en claro que éstos distan mucho de representar meras aglomeraciones de trabajadores casi exclusivamente rurales. Por otra parte, es de suponer que en aquellos poblados más grandes -entre 1000 y 2000 habitantes- que no figuran en ninguno de los ejemplos dados, el peso de las tareas urbanas ha de sobresalir de manera más notoria.

Por último, la relevancia de la PEA No Agropecuaria en los ejemplos arriba expuestos, sirve para entender, desde el punto de vista estadístico, tanto a nivel país como provincial, por qué dentro de la distribución territorial de la PEA general, tiene particular relevancia la PEA No Agropecuaria que reside en las áreas rurales. Sin la menor duda, esta realidad se debe al peso numérico no desestimable que acusa la PEA No Agropecuaria inserta en la PEA Rural Concentrada, o sea, la que reside en poblados de menos de 2000 habitantes, y que se diferencia de la PEA No Agropecuaria inserta dentro de la PEA Rural Dispersa, dado que aquí su peso numérico en términos comparativos resulta insignificante. 


\subsection{Cambios y problemáticas de la localización de la PEA Agropecuaria y sus implicancias territoriales}

A modo de cierre de este capítulo, la idea aquí es limitarnos a resaltar los aspectos más sobresalientes y exponer algunas reflexiones sobre las problemáticas estudiadas de manera muy sintética, por interpretar que las especificaciones sobre la distribución locacional de la población que nos interesa figuran en detalle en los cuadros y en los análisis precedentes.

En este sentido, de acuerdo con los datos obtenidos, cabe destacar, en primer lugar, la impresión de que el drenaje de la fuerza laboral procedente del campo ya no se limita solamente a un cambio de localización campo-centro urbano como en otros tiempos, sino que incluye también una pérdida de la fuerza laboral agropecuaria, que se direcciona tanto hacia las actividades urbanas como a ocupar un rol pasivo (vivir del alquiler de las explotaciones). Este movimiento es coincidente con la disminución de las explotaciones y de los productores que nosotros detectamos entre 1994 y 2000, reforzado con los datos del último Censo Nacional Agropecuario de 2002, que acusa para la provincia de Córdoba una disminución del $37,7 \%$ de establecimientos, en relación con el censo anterior de 1988.

Corresponde alertar que seguramente esta disminución de explotaciones y productores no es equivalente estrictamente a un incremento similar en la concentración de la propiedad de la tierra, sino que estas pérdidas se asocian, en parte, más bien a un "proceso de concentración del capital" (Barsky, 2003:19). Esto se debe a que numerosos propietarios arriendan a terceros sus campos y pasan a vivir de rentas. Por lo tanto, lo que sí se ha concentrado (o sea, disminuido) son las unidades de producción agropecuaria que ahora sí son manejadas por menos titulares abocados a la explotación rural, que no obligadamente tienen que ser propietarios de los predios.

Con respecto a la distribución campo-ciudad de la PEA Agropecuaria, si bien en nuestra información de 2000 estaban repartidos en forma relativamente pareja -no así en el caso de los productores titulares que viven predominantemente en los centros urbanos-, es de suponer que en la actualidad el mayor porcentaje de la misma se localice mayoritariamente en las localidades, dado que el flujo campo-ciudad observable continuó a partir de ese año, pero posiblemente con tendencia a disminuir por agotamiento demográfico. Pero a su vez se debe advertir que no solamente disminuye numéricamente esta fuerza a nivel general, sino que también lo hace aquella que se localiza en los centros urbanos. Por cierto que dentro de su composición laboral, la mayor retracción se manifiesta en los Asalariados Fijos, seguidos por los Temporarios y luego aquellos Productores más vulnerables de la cadena productiva. 
En lo referente al desplazamiento del campo al pueblo -como ya nos referimos en el capítulo anterior- por parte de un gran número de productores, entre las décadas del '60, '70 y parte del '80, se debió en gran medida a la inquietud de brindar una mejor educación a los hijos, como también por la atracción de gozar de las comodidades urbanas, pero corresponde destacar que este desplazamiento se pudo concretar fundamentalmente por la situación de relativa bonanza económica por la que atravesaban estos sectores, circunstancia muy diferente de lo que representa un traslado por dificultades económicas.

En relación con el nivel de vida de los productores que residen en los pueblos, de acuerdo con lo que traslucen las "encuestas", se puede considerar en general como aceptable, pero, en caso de revertirse la actual bonanza del campo, quizás este bienestar ya no sea tan así para algunos pequeños productores, al tener que contemplar los gastos que representa el permanente traslado a sus establecimientos, el mantenimiento de una doble vivienda, y la pérdida de productividad por la insuficiente atención horaria que se le destina a las explotaciones, entre otras razones.

Sobre la situación de los asalariados rurales temporarios que residen predominantemente en las localidades, se la puede considerar como de extrema precariedad, por la discontinuidad laboral y los bajos ingresos que perciben.

En lo concerniente al total de la población que subsiste directamente del campo y reside en los pueblos, vemos que demográficamente no es significativa, lo que no quita que la difusión económica que esta actividad genera represente el sostén básico de supervivencia de las localidades.

Con respecto a los productores que residen en el campo, vemos que sus condiciones de vida en general han mejorado sustancialmente, aunque todavía sufren de cierto aislamiento por el estado deficiente de los caminos vecinales y por la falta de un sistema organizado de transporte que traslade a los adolescentes a las escuelas de nivel medio, ubicadas en los pueblos. Este último problema todavía se torna más dificultoso para los Asalariados Fijos, lo que motiva, en muchos casos, que la familia tenga que vivir en el pueblo y el asalariado residir durante los días laborales en la explotación.

Dentro del contexto de despoblamiento y disminución específica de la PEA Rural -como remarcamos en páginas anteriores-, vemos que se están produciendo al mismo tiempo profundas transformaciones socio-territoriales. Al vacío poblacional lo acompañan campos con viviendas desocupadas, alambrados caídos, caminos abandonados, desaparición de escuelas y almacenes rurales, entre otros indicadores. Pero debemos alertar que lo observado no implica que proliferen los campos abandonados. Éstos se siguen trabajando en general, 
pero reconfigurados a una escala de manejo de explotación de mayor tamaño, lo que quiere decir que las dimensiones de ciertos establecimientos en la actualidad pueden absorber la superficie de varias pequeñas explotaciones que hasta no hace mucho estaban en actividad. Por otro lado, el desplazamiento de la población rural a los pueblos - no toda, porque parte de ella se traslada a centros urbanos mayores- también ha producido dificultades de tipo urbano, porque las localidades - por su reducido tamaño y limitada capacidad de gestión- no están siempre en condiciones de receptar esa afluencia poblacional.

Como síntesis de este análisis, a las tendencias que venimos observando en relación con la problemática locacional las podemos desdoblar en relación con los dos ámbitos donde reside el productor, que viene a ser el actor principal de todos los agentes rurales que conforman la PEA Agropecuaria y el que moviliza en su accionar a toda esta fuerza laboral. En este sentido, por la información recopilada, podemos inferir que, con respecto a los Productores que todavía viven en el campo, su tendencia es seguir residiendo en el mismo, tanto por vocación de arraigo al lugar como también para tener un control más directo de la explotación y de ese modo asegurar su permanencia en las actividades rurales. En lo que concierne a los Productores que viven en los pueblos y en el caso de los más vulnerables, presumiblemente -más allá de la actual bonanza agrícola- una de las opciones de supervivencia dentro del sistema pase por poner en práctica una atención más estrecha y personalizada en sus establecimientos, a fin de intensificar la producción, tendencia que se empieza a observar pero que no implica cambio de localización, salvo en algunos pocos casos en que se insinuó una leve tendencia al repoblamiento de las explotaciones. ${ }^{16}$

En suma, da la impresión de que se ha llegado o se está llegando a un punto de agotamiento en lo atinente al desplazamiento campo-ciudad de los productores y en menor término, quizás, en el caso de los Asalariados Fijos.

Terminando, cabe expresar que la cuestión central no pasa tanto por los cambios de localización de la PEA Agropecuaria, aunque puede producir significativos inconvenientes, sino por la disminución numérica de la misma, ya que obviamente esta contracción representa la surgencia de múltiples problemas. Asimismo, tenemos en claro que el fenómeno de la localización que nos preocupa actúa como reflejo de los procesos socio-económicos generales

16 Cabe recordar que, en la segunda mitad de la década del 90 -cuando estábamos en plena tarea de relevamiento zonal de lo que aquí, en parte, se informa-, la situación económica del campo atravesaba por momentos difíciles. Es en esas circunstancias que surgió toda una corriente de opinión entre los productores implicados de "volver al campo", como una estrategia de sobrevivencia a fin de no desaparecer de la escena productiva. Tendencia que no cristalizó -salvo en muy pocos casos-, dado que resultó más que difícil revertir la situación de localización, ya que, en su momento, representó todo un progreso el cambio de lugar de residencia. 
que se desencadenan en las áreas rurales, no obstante, tiene la virtud de servir de indicador -entre otros- para adentrarse en las causales de muchas de las problemáticas rurales y particularmente de la fuerza laboral agropecuaria, que es el foco de nuestro interés.

Por último, si bien en este estudio tenemos en claro que los factores de localización devienen principalmente de la evolución de los procesos económicos generales, también interpretamos que una "política específica orientada a impulsar básicamente la localización más adecuada", como una primera aproximación, se puede convertir en una alternativa válida dentro de marcos de decisión más reducidos -por ejemplo, a escala familiar o grupal- de nuevas estrategias de sobrevivencia en el sentido más amplio del concepto (Agüero et al., 2003-2004). 


\section{Capítulo V}

\section{Análisis de la estructura agraria social y productiva del Sur Cordobés}

\subsection{Evolución de la estructura agraria fundiaria. Período 1969-2002}

El propósito de esta primera parte del presente capítulo consiste en analizar básicamente la evolución y principales características de la estructura agraria fundiaria del sur cordobés, a lo largo de los tres censos nacionales agropecuarios de 1969, 1988 y 2002. Como se recordará, el espacio bajo estudio es de grandes dimensiones; los cuatro departamentos que lo conforman totalizan una superficie de $48.180 \mathrm{~km}^{2}$ y corresponde a casi un tercio de la superficie de la provincia. Se ubica casi en su totalidad en el extremo occidental de la llanura pampeana -excepto una estrecha franja situada al oeste del Departamento Río Cuarto, que pertenece al faldeo oriental de las Sierras de Comechingones- y abarca parte de la pampa húmeda y subhúmeda de la misma (Mapa $\mathrm{N}^{\mathrm{o}}$ 11). En general, es un territorio de buenos campos, bien dotado por los factores naturales, de aceptables a buenos rendimientos agropecuarios, aunque con ciertos sectores proclives a las inundaciones y a la erosión hídrica. La idea, en esta oportunidad, consiste en avanzar en la profundización específica de las variables centrales referidas a la "cantidad y superficie de las explotaciones agropecuarias por escala de extensión", al "régimen de tenencia de la tierra" y al "tipo jurídico del productor". Cabe acotar que con respecto a estas dos últimas variables, limitamos nuestro análisis solamente a los censos de 1988 y 2002, debido a las dificultades de compatibilizar las mismas con las existentes en el censo de 1969.

Si bien este tipo de investigación no es nuevo, ya que a lo largo del tiempo se detectan numerosos y valiosos trabajos sobre estructura agraria, especialmente del área pampeana (Cárcano, 1972; Flichman, 1982; Gaignard,1989; Pucciarelli, 1993; Barsky, 1991, 1997, entre algunos de los principales autores que han tratado el tema), los mismos mayormente se refieren en general a todo el espacio pampeano y, a su vez, por obvias cuestiones temporales, no incorporan los datos del último censo del año 2002. Es por ello que, considerando las limitaciones y generalidades arriba expuestas -más la necesidad de brindar conocimiento de la distribución fundiaria, para la mayor comprensión de la dinámica socioeconómica de la fuerza laboral-, hemos interpretado como pertinente y válido un estudio de las variables centrales anteriormente mencionadas, referidas al sur cordobés. ${ }^{1}$

\footnotetext{
1 En esta oportunidad, analizamos en forma integral los cuatro departamentos que conforman el Sur Cordobés.
} 


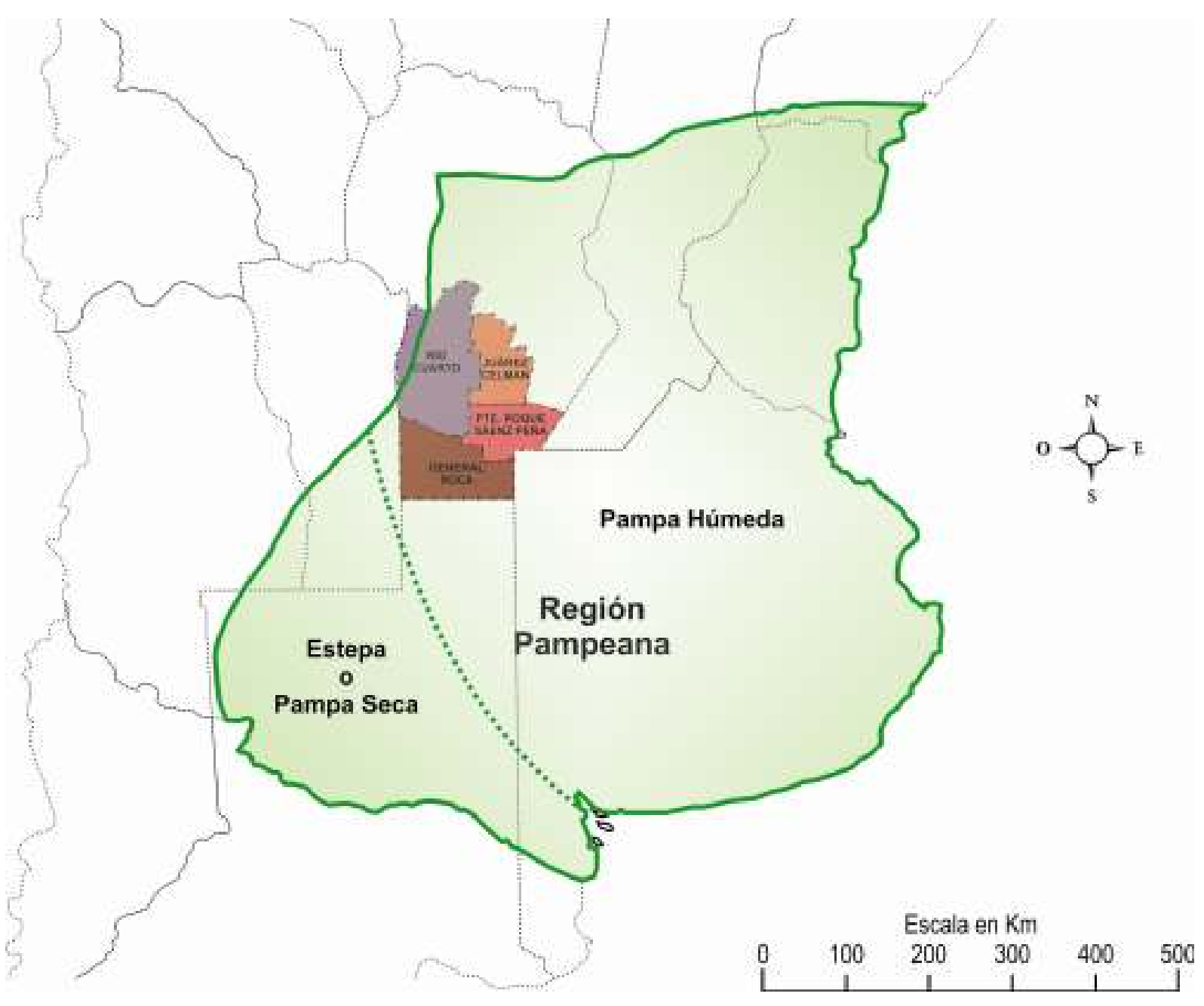

Mapa N 11. "Sur Cordobés” dentro de la Región Pampeana.

En este sentido, en el área aludida, al igual que en el resto de la Región Pampeana, son varias las señales que indican cambios estructurales socio-económicos de gran magnitud en el quehacer agropecuario. Es así como se observa a través del trabajo de campo, con el simple deambular y alternar con los que realizan las tareas rurales, una clara tendencia a la concentración de la tierra -que no es equivalente obligadamente a una concentración de la propiedad-, un despoblamiento rural profundo acompañado por modificaciones significativas del paisaje agrario, el empleo de una tecnificación arrolladora en las medianas y grandes explotaciones, un incremento sustantivo en la producción de granos, la intromisión de capitales de gran magnitud procedentes de fuera del área, cambios agudos -soja mediante- en el uso de la tierra, un uso intensivo y no controlado en muchos casos del suelo, una modificación profunda de los actores sociales intervinientes en el agro, donde -dentro de un lapso temporal amplio- son muchos los que han perdido y pierden y menos los que ganan, un bienestar insoslayable en los últimos años de aquellos productores que han quedado bien 
pertrechados dentro del sistema, como igualmente un mayor confort de vida en general de aquellos escasos productores que siguen persistiendo en habitar a campo traviesa, entre otros varios aspectos más a considerar.

Todo ello conforma un cuadro de situación que, si bien resulta difícil de discernir a priori, dentro de todas estas alteraciones, cuáles son los aspectos positivos y negativos y el saldo correspondiente, lo concreto y comprobable, más allá de la bonanza por la que atraviesa el campo aprovechable para aquellos que han quedado y son dueños de los bienes de producción, es que en este reparto asimétricamente fructífero muchos agentes productivos se han perdido en el camino y, por lo tanto, son cada vez menos los actores sociales intervinientes en la explotación agropecuaria.

De esta realidad percibida en forma empírica, de por sí altamente compleja, en esta circunstancia nos limitamos al análisis de la estructura agraria fundiaria en nuestra zona de trabajo, con el propósito de contribuir a la mejor comprensión, desde el ángulo de los cambios sufridos en la posesión de la tierra, del cúmulo de fenómenos intervinientes en nuestro ámbito rural, teniendo muy en claro que las herramientas que utilizamos contribuyen de manera limitada a despejar algunas de las problemáticas interactuantes en nuestra región de estudio.

Por último, cabe agregar que la tarea desarrollada en este acápite ha consistido básicamente en un trabajo de gabinete y la metodología empleada se ha circunscripto generalmente al análisis estadístico, apoyado complementariamente por observaciones directas de la región y datos de primera mano, recogidos en trabajos de campo que venimos realizando desde hace tiempo.

\subsubsection{Caracterización de los establecimientos de acuerdo con la escala por tamaño de las} explotaciones y su relación con el nivel económico de los productores ${ }^{2}$

Nos parece oportuno, antes de entrar en el análisis pormenorizado de las variables centrales arriba citadas, especificar la "escala por tamaño" de los establecimientos, en función del tipo de explotación extensiva, con alguna tendencia a semi-intensiva, y su relación con el nivel económico de los productores imperante en el área de trabajo, a los fines de caracterizar debidamente los establecimientos de acuerdo con su tamaño, promediando las diferencias del caso. En forma esquemática, podemos expresar:

2 En esta sección, nos hemos apoyado en gran parte en las observaciones elaboradas por G. Flichman -pero actualizadas por nosotros, de acuerdo con nuestra realidad, al momento de la confección de este trabajo-, en lo referente a la clasificación de los establecimientos de acuerdo con su tamaño (Flichman, 1982). 
- Pequeñas explotaciones: hasta 200 ó 300 ha (tendiendo a incrementarse hacia el tope en el extremo sur de la provincia), partiendo de un piso areal que ronda entre las 25 y 50 ha (superficies menores a éstas responden en general a un uso variado de aprovechamiento no vasto, como por ejemplo de granjas y huertas de uso intensivo, que se localizan principalmente en los cinturones verdes de los centros urbanos). Son trabajadas obviamente por "pequeños productores" en forma personal con un fuerte apoyo familiar. Emplean ocasionalmente asalariados transitorios. Su acceso a las nuevas tecnologías imperantes es limitado, como así también su capacidad para llevar a cabo prácticas culturales relacionadas con la rotación de suelos.

- Medianas explotaciones: de 200 ó 300 ha a 500 ha. También en este caso las explotaciones son trabajadas personalmente por el productor $\mathrm{y}$, si bien también colabora la familia, sus tareas productivas requieren de una mayor presencia del trabajador transitorio y en menor término del trabajador asalariado permanente. Aquél hace uso de varios adelantos tecnológicos y posee un nivel aceptable de mecanización. Cuenta con cierta capacidad de gestión para impulsar prácticas productivas alternativas en su establecimiento. En muchos casos éste es manejado con criterio empresarial. En términos esquemáticos, en este estrato en general se ubican los "medianos productores".

- Medianas-grandes explotaciones: de 500 ha a 1.000 ha. El productor de este estrato posee un gran dinamismo económico y la función laboral que desempeña es más bien de organizador. Su establecimiento es trabajado principalmente por asalariados, tanto permanentes como transitorios. La intervención de estos últimos está regulada de acuerdo con los requerimientos de las diferentes etapas del ciclo agrícola. El aporte laboral familiar es mucho más reducido. Posee buen nivel de mecanización y se vale plenamente de los adelantos tecnológicos y del asesoramiento profesional. El papel que desempeña es el de un verdadero “capitalista agrario" (Flichman, 1982:117). Cuenta con un nivel de capitalización general importante. Invierte fuertes sumas en insumos y en diferentes prácticas agropecuarias para incrementar la producción por hectárea, y obtiene altos rendimientos por unidad de superficie. El tipo de gestión es netamente empresarial. En forma simplificada, se los denomina también "medianosgrandes productores".

- Grandes explotaciones: más de 1.000 ha. Aquí se conjuga una variada gama de diferentes agentes productivos y de niveles de tamaños de explotaciones, que van de terratenientes capitalistas tradicionales a grandes sociedades empresariales, y de 
campos que superan holgadamente las 2.500 y 5.000 ha. El trabajo se realiza a través de la contratación de personal asalariado. El aprovechamiento económico es más extensivo, de menor desembolso relativo de capital que los estratos de explotaciones anteriores $\mathrm{y}$, por ende, de menor rendimiento por hectárea, pero gracias a las extensas superficies trabajadas, el nivel de rentabilidad es satisfactorio. Por lo tanto, no obligadamente se invierten grandes sumas en maquinarias y en nuevas tecnologías, aunque últimamente hay una fuerte tendencia a incrementar este tipo de inversiones. Las labores están muy bien organizadas y se desenvuelven bajo criterios claramente empresariales (Agüero et al., 2005).

De acuerdo con lo anteriormente vertido, corresponde acotar, por una parte, que si bien es sabido que no se puede circunscribir la importancia económica de una explotación en base exclusivamente a su tamaño, ya que entran en juego otros factores como nivel de tecnificación y capital disponible, entre otros, para definir la capacidad productiva de un establecimiento, lo cierto es que en nuestra región, más allá de algunos desfasajes entre tamaño y rendimiento productivo, la jerarquía de las explotaciones se adecuan en general a las escalas arriba descriptas, debido a que en cada estrato se manifiesta de manera bastante uniforme la misma capacidad económica. Por otra, resulta también pertinente precisar que, debido al incremento generalizado de la superficie de las explotaciones, más las exigencias de contar con una sólida disponibilidad económica para producir, desde hace un tiempo se insinúa el criterio de considerar como válido el corrimiento hacia adelante de todas las escalas por tamaño de los establecimientos.

\subsubsection{Variación intercensal en porcentaje en la cantidad, superficie y tamaño promedio de}

\section{las explotaciones}

De acuerdo con el Censo Nacional Agropecuario de 2002, el total de las explotaciones de los cuatro departamentos implicados es de 6.095 unidades, que representa el 23,24\% del total provincial. A su vez, el total de la superficie de las explotaciones de los cuatro departamentos asciende a 3.873.709,3 ha y representa el 31,64\% del total provincial. Todo ello representa cifras bastante elocuentes de la importancia del espacio considerado.

Con respecto a la variación intercensal 1969-1988-2002 (Cuadro $\mathrm{N}^{\mathrm{o}}$ 32) de la "cantidad" de explotaciones, dentro de lo abrumadoramente negativo de como se manifiesta, en la desagregación en porcentaje observamos que la disminución en el período 1969-1988 es más pronunciada a nivel provincial que la del total de los cuatro departamentos considerados, 
disminuyendo los valores negativos a nivel departamental a medida que nos desplazamos hacia el extremo sur de la provincia.

Cuadro $N^{0}$ 32. Variación intercensal en porcentaje en la cantidad, superficie y tamaño promedio de las explotaciones de los departamentos que constituyen la región sur de la provincia de Córdoba. Censos Nacionales Agropecuarios 1969, 1988 y 2002

\begin{tabular}{|c|c|c|c|c|c|c|c|c|c|c|}
\hline \multirow[b]{2}{*}{ Departamento } & \multirow[b]{2}{*}{$\begin{array}{c}\text { Censo } \\
\text { Nacional } \\
\text { Agropecuario }\end{array}$} & \multirow[b]{2}{*}{$\begin{array}{l}\text { Cantidad de } \\
\text { explotaciones }\end{array}$} & \multicolumn{2}{|c|}{ Variación en \% } & \multirow[b]{2}{*}{$\begin{array}{l}\text { Superficie de } \\
\text { las } \\
\text { explotaciones }\end{array}$} & \multicolumn{2}{|c|}{ Variación en \% } & \multirow[b]{2}{*}{$\begin{array}{c}\text { Tamaño } \\
\text { promedio de } \\
\text { las } \\
\text { explotaciones } \\
\text { ha }\end{array}$} & \multicolumn{2}{|c|}{ Variación en \% } \\
\hline & & & $\begin{array}{c}1969- \\
1988 \\
1988- \\
2002\end{array}$ & $\begin{array}{l}1969- \\
2002\end{array}$ & & \begin{tabular}{r|}
$1969-$ \\
1988 \\
$1988-$ \\
2002
\end{tabular} & $\begin{array}{l}1969- \\
2002\end{array}$ & & $\begin{array}{c}1969- \\
1988 \\
1988- \\
2002\end{array}$ & $\begin{array}{l}1969- \\
2002\end{array}$ \\
\hline \multirow{3}{*}{$\begin{array}{l}\text { Provincia de } \\
\text { Córdoba }\end{array}$} & 1969 & 57.826 & & & 14.207 .230 & & & 245,7 & & \\
\hline & 1988 & 40.061 & $-30,7 \%$ & & 13.724 .885 & $-3,4 \%$ & & 342,6 & $+39,4 \%$ & \\
\hline & 2002 & 25.620 & $-36,0 \%$ & $-55,7 \%$ & $12.244 .257,8$ & $-10,8 \%$ & $-13,8 \%$ & 477,9 & $+39,5 \%$ & $+94,5 \%$ \\
\hline \multirow{3}{*}{ Río Cuarto } & 1969 & 6.040 & & & 1.819 .171 & & & 301,2 & & \\
\hline & 1988 & 4.580 & $-24,2 \%$ & & 1.703 .378 & $-6,4 \%$ & & 371,9 & $+23,5 \%$ & \\
\hline & 2002 & 2.984 & $-34,8 \%$ & $-50,6 \%$ & 1.468.291,2 & $-13,8 \%$ & $-19,3 \%$ & 492,1 & $+32,3 \%$ & $+63,4 \%$ \\
\hline \multirow{3}{*}{ Juárez Celman } & 1969 & 2.060 & & & 787.375 & & & 382,2 & & \\
\hline & 1988 & 1.653 & $-19,8 \%$ & & 737.576 & $-6,3 \%$ & & 446,2 & $+16,7 \%$ & \\
\hline & 2002 & 962 & $-41,8 \%$ & $-53,3 \%$ & $746.631,5$ & $+1,2 \%$ & $-5,2 \%$ & 776,1 & $+73,9 \%$ & $+103,1 \%$ \\
\hline \multirow{3}{*}{$\begin{array}{l}\text { Pte. Roque } \\
\text { Sáenz Peña }\end{array}$} & 1969 & 1.653 & & & 808.482 & & & 489,1 & & \\
\hline & 1988 & 1.350 & $-18,3 \%$ & & $782.565,5$ & $-3,2 \%$ & & 579,7 & $+18,5 \%$ & \\
\hline & 2002 & 961 & $-28,8 \%$ & $-41,9 \%$ & $606.634,9$ & $-22,5 \%$ & $-25,0 \%$ & 631,3 & $+8,9 \%$ & $+29,1 \%$ \\
\hline \multirow{3}{*}{ General Roca } & 1969 & 1.797 & & & 1.211 .829 & & & 674,4 & & \\
\hline & 1988 & 1.556 & $-13,4 \%$ & & 1.188 .890 & $-1,9 \%$ & & 764,1 & $+13.3 \%$ & \\
\hline & 2002 & 1.188 & $-23,7 \%$ & $-33,9 \%$ & $1.052 .151,7$ & $-11,5 \%$ & $-13,2 \%$ & 885,6 & $+15,9 \%$ & $+31,3 \%$ \\
\hline \multirow{3}{*}{$\begin{array}{l}\text { Sumatoria de } \\
\text { los cuatro } \\
\text { departamentos }\end{array}$} & 1969 & 11.550 & & & 4.626 .857 & & & 400,6 & & \\
\hline & 1988 & 9.139 & $-20,9 \%$ & & $4.412 .409,5$ & $-4,6 \%$ & & 482,8 & $+20,5 \%$ & \\
\hline & 2002 & 6.095 & $-33,3 \%$ & $-47,2 \%$ & $3.873 .709,3$ & $-12,2 \%$ & $-16,3 \%$ & 635,5 & $+31,6 \%$ & $+58,6 \%$ \\
\hline
\end{tabular}

Fuente: Elaboración propia en base de la información aportada por los CNAs 1969, 1988 y 2002.

A su vez, la disminución en la cantidad de explotaciones en el período 1988-2002 es sustancialmente superior al período anterior -con valores negativos menos abruptos en los departamentos Presidente Roque Sáenz Peña y General Roca-. Esta realidad refleja sin la menor duda los cimbronazos económicos acaecidos durante la década del '90, cuando se entronizó el eficientismo económico en la producción agropecuaria en general.

Si consideramos el período 1969-2002, los porcentajes negativos resultan espectaculares, superando el 50\% a nivel provincial y también en los departamentos Río Cuarto y Juárez Celman, atenuándose los valores porcentuales negativos en los 
departamentos del extremo sur provincial. En concreto, los porcentajes aludidos demuestran el alto grado de concentración progresiva de las explotaciones, o sea, mayor tamaño y menor cantidad de las mismas -lo que no implica igual concentración de la propiedad-, como resultado de la expansión de las directrices capitalistas en el agro pampeano del sur cordobés, siendo aparentemente menos dinámicos estos cambios estructurales -por lo que reflejan los porcentajes- en los departamentos Presidente Roque Sáenz Peña y General Roca, debido posiblemente al mayor tamaño preexistente de sus explotaciones.

Lo anteriormente descripto se refleja obviamente en un incremente sustancial en el "tamaño promedio" de las explotaciones en los períodos censales considerados, siendo en general más acentuado en el último período (1988-2002).

El crecimiento en el tamaño promedio de las explotaciones entre 1969 y 2002 es, desde luego, muy alto, pero exceptuando el Dpto. Juárez Celman -que supera el 100\%-, en el resto de los departamentos implicados los valores son inferiores al promedio provincial, que es del 94,5\%. Esto posiblemente se debe a que tradicionalmente los campos del sur cordobés, en general, son de mayor tamaño que en otras áreas de la provincia; por lo tanto, el efecto de los cambios estructurales en el incremento del tamaño de las explotaciones, en comparación con el resto de la provincia, no ha repercutido tanto.

En relación con la variación intercensal de la "superficie" de las explotaciones, observamos en general que, si bien la disminución acaecida es apreciable tanto a nivel departamental como provincial, dista de asemejarse a los valores de las otras variables. La justificación de dicha disminución es difícil de explicar.

\subsubsection{Cantidad y superficie de las explotaciones agropecuarias por escala de extensión}

En relación específicamente con la "cantidad y superficie de las explotaciones por escala de extensión" de los cuatro departamentos nombrados más el de la provincia de Córdoba, con fines comparativos y considerando los tres últimos censos aludidos, podemos decir, de acuerdo con el Cuadro $\mathrm{N}^{\mathrm{o}} 33$, que corresponde a la "versión escalar reducida", que:

- El mayor porcentaje de la "cantidad" total de explotaciones en los tres censos se ubica en el Dpto. Río Cuarto, al igual que a nivel provincial, en la escala "hasta 200 ha", 
Cuadro $\mathrm{N}^{\circ}$ 33. Cantidad y superficie de las explotaciones agropecuarias por escala de extensión, en cifras y en porcentajes, de los departamentos que constituyen la

\begin{tabular}{|c|c|c|c|c|c|c|c|c|c|c|c|c|c|c|c|}
\hline \multirow[b]{2}{*}{ Dpto. } & \multirow[b]{2}{*}{ CNA } & \multicolumn{2}{|c|}{ Total } & \multicolumn{4}{|c|}{ Hasta 200 ha } & \multicolumn{4}{|c|}{ De 200,1 a 1000 ha } & \multicolumn{4}{|c|}{ Más de 1000 ha } \\
\hline & & $\begin{array}{l}\text { Cant. de } \\
\text { Expl. }\end{array}$ & Sup. ha & $\begin{array}{c}\text { Cant. de } \\
\text { Expl. }\end{array}$ & $\begin{array}{c}\% \text { del } \\
\text { total }\end{array}$ & Sup. ha & $\begin{array}{l}\% \text { del } \\
\text { total }\end{array}$ & $\begin{array}{l}\text { Cant. de } \\
\text { Expl. }\end{array}$ & $\begin{array}{l}\% \text { del } \\
\text { total }\end{array}$ & Sup. ha & $\begin{array}{l}\% \text { del } \\
\text { total }\end{array}$ & $\begin{array}{l}\text { Cant. de } \\
\text { Expl. }\end{array}$ & $\begin{array}{l}\% \text { del } \\
\text { total }\end{array}$ & Sup. ha & $\%$ del total \\
\hline \multirow{3}{*}{$\begin{array}{l}\text { Prov. de } \\
\text { Córdoba }\end{array}$} & 1969 & 57.826 & 14.207 .230 & 41.418 & 71,83 & 3.100 .857 & 21,82 & 14.359 & 24,83 & 5.554 .146 & 39,10 & 2.043 & 3,54 & 5.552 .246 & 39,08 \\
\hline & 1988 & 40.061 & $13.724 .885,5$ & 23.611 & 58,94 & 2.027 .320 & 14,77 & 14.075 & 35,13 & 5.843 .103 & 42,57 & 2.375 & 5,93 & 5.854 .459 & 42,66 \\
\hline & 2002 & 25.620 & $12.244 .257,8$ & 12.743 & 49,74 & $1.121 .904,9$ & 9,16 & 10.298 & 40,19 & $4.627 .330,3$ & 37,79 & 2.579 & 10,07 & $6.495 .022,6$ & 53,05 \\
\hline \multirow{3}{*}{ Río Cuarto } & 1969 & 6.040 & 1.819 .171 & 3.864 & 63,97 & 350.960 & 19,29 & 1.897 & 31,41 & 725.770 & 39,90 & 279 & 4,62 & 742.438 & 40,81 \\
\hline & 1988 & 4.580 & 1.703 .378 & 2.383 & 52,03 & 236.720 & 13,90 & 1.902 & 41,53 & 778.502 & 45,70 & 285 & 6,44 & 688.153 & 40,40 \\
\hline & 2002 & 2.984 & $1.468 .291,2$ & 1.332 & 44,64 & $134.677,5$ & 9,17 & 1.328 & 44,50 & $537.138,6$ & 39,03 & 324 & 10,86 & $760.475,1$ & 51,80 \\
\hline \multirow{3}{*}{$\begin{array}{l}\text { Juárez } \\
\text { Celman }\end{array}$} & 1969 & 2.060 & 787.375 & 1.251 & 60,73 & 123.706 & 15,71 & 691 & 33,54 & 271.763 & 34,51 & 118 & 5,73 & 391.905 & 49,78 \\
\hline & 1988 & 1.653 & 737.576 & 797 & 48,21 & 83.815 & 11,36 & 700 & 42,35 & 303.208 & 41,11 & * & 9,44 & * & 47,53 \\
\hline & 2002 & 962 & $746.631,5$ & 366 & 38,04 & $37.370,1$ & 5,01 & 427 & 44,39 & $196.604,3$ & 26,33 & 169 & 17,57 & $512.657,1$ & 68,66 \\
\hline \multirow{3}{*}{$\begin{array}{l}\text { Pte. } \\
\text { Roque } \\
\text { Sáenz } \\
\text { Peña }\end{array}$} & 1969 & 1.653 & 808.482 & 811 & 49,06 & 85.181 & 10,54 & 698 & 42,23 & 285.584 & 35,32 & 144 & 8,71 & 437.713 & 54,14 \\
\hline & 1988 & 1.350 & $782.565,2$ & 519 & 38,44 & 61.889 & 7,91 & 660 & 48,88 & 284.636 & 36,38 & * & 12,68 & * & 55,71 \\
\hline & 2002 & 961 & $606.634,9$ & 360 & 37,46 & $41.923,9$ & 6,91 & 455 & 47,36 & $204.065,6$ & 33,64 & 146 & 15,19 & $360.645,4$ & 59,45 \\
\hline \multirow{3}{*}{$\begin{array}{c}\text { General } \\
\text { Roca }\end{array}$} & 1969 & 1.797 & 1.211 .829 & 776 & 43,18 & 68.813 & 5,68 & 766 & 42,63 & 337.980 & 27,89 & 255 & 14,19 & 805.034 & 66,43 \\
\hline & 1988 & 1.556 & 1.188 .890 & 565 & 36,31 & 55.684 & 4,68 & 713 & 45,82 & 324.406 & 27,29 & 278 & 17,87 & 808.834 & 68,03 \\
\hline & 2002 & 1.188 & $1.052 .151,7$ & 354 & 29,80 & $36.042,2$ & 3,43 & 575 & 48,40 & $264.076,5$ & 25,10 & 259 & 21,80 & 752.033 & 71,47 \\
\hline
\end{tabular}

* No figuran los valores en cifras, por existir un desfasaje numérico entre los totales departamentales y en la escala de extensión.

Fuente: Elaboración propia en base a la información aportada por los CNAs de 1969, 1988 y 2002. 
que responde obviamente a los pequeños establecimientos, con una disminución apreciable y progresiva entre 1969 y 2002.

- En el Dpto. Juárez Celman el mayor porcentaje de la "cantidad" total de las explotaciones corresponde a la escala "hasta 200 ha" solamente en los censos de 1969 y 1988, y en los departamentos Presidente Roque Sáenz Peña y General Roca en el censo de 1969.

En cambio, en esta franja, la "superficie" que ocupan los cuatro departamentos del total de explotaciones a lo largo de los tres censos es más bien reducida, también con una disminución considerable entre los extremos censales.

- En la escala “de 200,1 a 1.000 ha”, que responde esquemáticamente a las medianas explotaciones (200,1 a $500 \mathrm{ha})$ y medianas-grandes explotaciones (500,1 a $1.000 \mathrm{ha})$, el porcentaje de la "cantidad" de establecimientos en los departamentos Río Cuarto y Juárez Celman, al igual que a nivel provincial, entre 1969 y 2002, se va a incrementar notablemente. Inclusive en el Dpto. Juárez Celman, en el último censo de 2002, el mayor porcentaje de la cantidad total de explotaciones se va a ubicar en esta franja. En cambio, este incremento es más bien pausado en los departamentos Presidente Roque Sáenz Peña y General Roca. No obstante, a partir de los censos de 1988 y 2002 el mayor porcentaje en la cantidad total de explotaciones en estos dos últimos departamentos se va a situar en esta escala.

Con respecto a la "superficie" que ocupan las explotaciones del total, se observa en todos los departamentos menos en el de General Roca, al igual que a nivel provincial, un incremento interesante en general entre los censos de 1969 y 1988, a tal punto que el mayor porcentaje de superficie del total de las explotaciones en el censo de 1988 se va a ubicar en esta franja en el Dpto. Río Cuarto. Pero, de acuerdo con los resultados del censo de 2002, esta tendencia positiva se va a invertir notablemente tanto en los departamentos Río Cuarto y Juárez Celman -en este último de manera muy acentuada-, como a nivel provincial, manifestándose en forma menos acusada en los departamentos Presidente Roque Sáenz Peña y General Roca.

- En la escala "de más de 1.000,1 ha", donde están involucradas las grandes $(1.000,1 \mathrm{a}$ 2.500 ha) y muy grandes explotaciones (de más de 2.500 ha, e inclusive de más de 10.000 ha), la "cantidad" de establecimientos en los cuatro departamentos, como así también a nivel provincial -dentro de los reducidos valores porcentuales en términos 
comparativos- va a sufrir de manera ascendente entre los censos de 1969, 1988 y 2002 un incremento más que apreciable.

En relación con el total de la "superficie" que ocupan las explotaciones, exceptuando el Dpto. Río Cuarto en el censo de 1988, en todos los departamentos en los tres censos, el mayor porcentaje del total de la superficie de las explotaciones se va a ubicar en esta franja. Por otra parte, en los censos correspondientes a 1969 y 1988, tanto en el Dpto. Río Cuarto y Juárez Celman como a nivel provincial el porcentaje de la superficie de las explotaciones en esta escala no supera el 50\% del total, e inclusive en los dos departamentos citados sus porcentajes entre 1969 y 1988 disminuyeron levemente. En cambio, en los departamentos Presidente Roque Sáenz Peña y General Roca, los porcentajes de la superficie del total de las explotaciones desde 1969 estuvieron siempre por encima del 50\%, e inclusive en el Dpto. General Roca por encima del $60 \%$.

A partir del censo de 2002 cabe destacar el fuerte incremento que se va a registrar en el porcentaje de la superficie de las explotaciones, que va a superar en los cuatro departamentos el 50\%, al igual que a nivel provincial, resultando especialmente muy elevados estos porcentajes en los departamentos Juárez Celman y General Roca, que llegaron al $68,7 \%$ y $71,5 \%$, respectivamente.

Hasta aquí hemos analizado la cantidad y superficie de las explotaciones en tres columnas por escala de extensión, en la "versión reducida", con el propósito de diferenciar de manera sintética y esquemática la incidencia en cada una de ellas de las pequeñas, medianas y grandes explotaciones. Ahora, si contemplamos la "versión ampliada", donde figura una mayor cantidad de fraccionamientos de la escala de extensión que la arriba utilizada (Cuadro $\mathrm{N}^{\mathrm{o}} 34$ ), se comprueba:

- Con respecto al censo de 1969:

- En la "versión ampliada", el mayor porcentaje de la "cantidad" total de las explotaciones se ubica en los cuatro departamentos, al igual que a nivel provincial, en la escala de " 25,1 a 200 ha".

- En la "versión ampliada", el mayor porcentaje de "superficie" del total que ocupan las explotaciones se ubica, en todos los casos -los cuatro departamentos y la provincia- en el segmento de "más de 2.500 ha".

- Con respecto al censo de 1988:

- En la "versión ampliada", el mayor porcentaje de la "cantidad" total de las explotaciones se ubica en tres de los departamentos -Río Cuarto, Juárez Celman y 
Cuadro $\mathrm{N}^{\circ}$ 34. Cantidad y superficie de las explotaciones agropecuarias por escala de extensión, en cifras y en porcentajes, de los departamentos que constituyen la región sur de la provincia de Córdoba, Censos Nacionales Agropecuarios de 1969, 1988 y 2002 (versión ampliada)

\begin{tabular}{|c|c|c|c|c|c|c|c|c|c|c|c|c|c|c|c|c|c|c|c|c|c|c|c|c|c|c|c|}
\hline \multirow{2}{*}{ Dpto. } & \multirow{2}{*}{ CNA } & \multicolumn{2}{|c|}{ Total } & \multicolumn{4}{|c|}{ Hasta 25 ha } & \multicolumn{4}{|c|}{ De 25,1 a 200 ha } & \multicolumn{4}{|c|}{$\begin{array}{l}\text { De 200,1 a } 400 \text { ha } \\
\text { (CNA A } 969) \\
\text { De 200,1 a 500 ha } \\
\text { (CNA 1988 y 2002) }\end{array}$} & \multicolumn{4}{|c|}{$\begin{array}{l}\text { De 400,1 a } 1000 \mathrm{ha} \\
\text { (CNA } 1969) \\
\text { De 500,1 a 1000 ha } \\
\text { (CNA 1988 y 2002) }\end{array}$} & \multicolumn{4}{|c|}{ De 1000,1 a 2500 ha } & \multicolumn{4}{|c|}{ Más de 2500 ha } \\
\hline & & 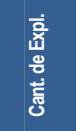 & 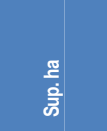 & 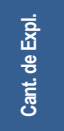 & $\frac{\overline{\mathrm{g}}}{\mathrm{g}}$ & $\begin{array}{l}\frac{\mathrm{g}}{2} \\
\frac{\mathrm{c}}{\mathrm{c}}\end{array}$ & $\begin{array}{l}\text { 푱 } \\
\frac{\mathrm{g}}{\mathrm{g}} \\
\frac{\mathrm{g}}{\circ}\end{array}$ & 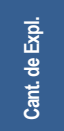 & $\begin{array}{l}\frac{\overline{\mathrm{g}}}{\mathrm{s}} \\
\frac{\mathrm{g}}{\mathrm{g}} \\
\frac{\mathrm{g}}{\circ}\end{array}$ & $\frac{\mathrm{g}}{\frac{\mathrm{g}}{\mathrm{g}}}$ & 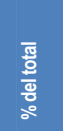 & 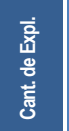 & $\begin{array}{l}\frac{\bar{y}}{\mathrm{~g}} \\
\frac{\mathrm{g}}{\mathrm{g}} \\
\frac{0}{\circ}\end{array}$ & 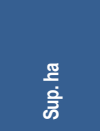 & 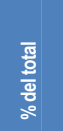 & 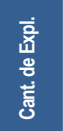 & $\begin{array}{l}\text { 퐁 } \\
\frac{\mathrm{s}}{\mathrm{g}} \\
\frac{\mathrm{g}}{\circ}\end{array}$ & $\begin{array}{l}\frac{\mathrm{g}}{2} \\
\frac{\mathrm{o}}{\overline{2}}\end{array}$ & 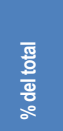 & 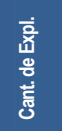 & $\begin{array}{l}\frac{\mathrm{g}}{\mathrm{g}} \\
\frac{\mathrm{g}}{\mathrm{g}} \\
\frac{\mathrm{o}}{\circ}\end{array}$ & 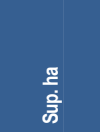 & 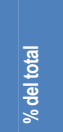 & 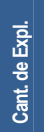 & 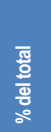 & 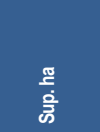 & 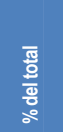 \\
\hline \multirow{3}{*}{$\begin{array}{l}\text { Prov. de } \\
\text { Córdoba }\end{array}$} & 1969 & 57.826 & 14.207 .230 & 12.717 & 21,99 & 120.351 & 0,85 & 28.701 & 49,64 & 2.980 .506 & 20,98 & 9.633 & 16,66 & 2.719 .536 & 19,14 & 4.726 & 8,17 & 2.834 .610 & 19,95 & 1.407 & 2,44 & 2.159 .390 & 15,20 & 636 & 1,10 & 3.392 .853 & 23,88 \\
\hline & 1988 & 40.061 & $13.724 .885,5$ & 5.149 & 12,85 & 58.944 & 0,43 & 18.462 & 46,09 & 1.968 .376 & 14,34 & 10.423 & 26,02 & 3.302 .001 & 24,06 & 3.652 & 9,12 & 2.541 .102 & 18,51 & 1.737 & 4,33 & 2.628 .913 & 19,16 & 638 & 1,59 & 3.225 .546 & 23,50 \\
\hline & 2002 & 25.620 & $12.244 .257,8$ & 2.700 & 10,54 & $29.265,9$ & 0,24 & 10.043 & 39,20 & 1.092 .639 & 8,92 & 6.964 & 27,18 & $2.273 .460,6$ & 18,57 & 3.334 & 13,01 & $2.353 .869,7$ & 19,22 & 1.872 & 7,31 & $2.825 .344,3$ & 23,08 & 707 & 2,76 & $3.669 .678,3$ & 29,97 \\
\hline \multirow{3}{*}{$\begin{array}{c}\text { Rio } \\
\text { Cuarto }\end{array}$} & 1969 & $\begin{array}{c}6.040 \\
10,44 \%\end{array}$ & $\begin{array}{c}1.819 .171 \\
12,80 \%\end{array}$ & 902 & 14,93 & 9.206 & 0,51 & 2.962 & 49,04 & 341.754 & 18,79 & 1.296 & 21,46 & 363.609 & 19,98 & 601 & 9,95 & 362.161 & 19,91 & 192 & 3,18 & 283.102 & 15,56 & 87 & 1,44 & 459.336 & 25,25 \\
\hline & 1988 & $\begin{array}{r}4.580 \\
11,43 \%\end{array}$ & $\begin{array}{l}1.703 .378 \\
12,41 \%\end{array}$ & 334 & 7,29 & 4.065 & 0,24 & 2.049 & 44,74 & 232.655 & 13,66 & 1.415 & 30,90 & 444.930 & 26,12 & 487 & 10,63 & 333.572 & 19,58 & 213 & 4,65 & 320.054 & 18,79 & 82 & 1,79 & 368.099 & 21,61 \\
\hline & 2002 & $\begin{array}{c}2.984 \\
11,65 \%\end{array}$ & $\begin{array}{c}1.468 .291,2 \\
11,99 \%\end{array}$ & 179 & 6,00 & $2.272,7$ & 0,15 & 1.153 & 38,64 & $132.404,8$ & 9,02 & 947 & 31,73 & $308.815,6$ & 21,03 & 381 & 12,77 & 264.323 & 18,0 & 234 & 7,84 & $354.109,5$ & 24,12 & 90 & 3,02 & $406.365,6$ & 27,68 \\
\hline \multirow{3}{*}{$\begin{array}{l}\text { Juárez } \\
\text { Celman }\end{array}$} & 1969 & $\begin{array}{l}2.060 \\
3,56 \%\end{array}$ & $\begin{array}{c}787.375 \\
5,54 \%\end{array}$ & 190 & 9,22 & 2.061 & 0,26 & 1.061 & 51,51 & 121.645 & 15,45 & 457 & 22,18 & 128.956 & 16,38 & 234 & 11,36 & 142.806 & 18,14 & 69 & 3,35 & 107.789 & 13,69 & 49 & 2,38 & 284.116 & 36,08 \\
\hline & 1988 & $\begin{array}{l}1.653 \\
4,13 \%\end{array}$ & $\begin{array}{c}737.576 \\
5,37 \%\end{array}$ & 66 & 3,99 & 888 & 0,12 & 731 & 44,22 & 82.927 & 11,24 & 486 & 29,40 & 154.679 & 20,97 & 214 & 12,95 & 148.529 & 20,14 & * & $\frac{\text { Más d }}{9,44}$ & $\frac{1000,1 \mathrm{Has}}{*}$ & 47,53 & & & & \\
\hline & 2002 & $\begin{array}{c}962 \\
3,75 \%\end{array}$ & $\begin{array}{c}746.631,5 \\
6,10 \%\end{array}$ & 41 & 4,26 & 546,3 & 0,07 & 325 & 33,78 & $36.823,8$ & 4,93 & 277 & 28,80 & $89.747,8$ & 12,02 & 150 & 15,59 & $106.856,5$ & 14,31 & 124 & 12,89 & $185.052,3$ & 24,79 & 45 & 4,68 & $327.604,3$ & 43,88 \\
\hline \multirow{3}{*}{$\begin{array}{l}\text { Pte. } \\
\text { Roque } \\
\text { Sáenz } \\
\text { Peña }\end{array}$} & 1969 & $\begin{array}{l}1.653 \\
2,86 \%\end{array}$ & $\begin{array}{c}808.482 \\
5,69 \%\end{array}$ & 119 & 7,20 & 1.163 & 0,14 & 692 & 41,86 & 84.018 & 10,39 & 437 & 26,44 & 128.119 & 15,85 & 261 & 15,79 & 157.465 & 19,48 & 88 & 5,32 & 135.541 & 16,76 & 56 & 3,39 & 302.172 & 37,38 \\
\hline & 1988 & $\begin{array}{l}1.350 \\
3,37 \%\end{array}$ & $\begin{array}{c}782.565,2 \\
5,70 \%\end{array}$ & 36 & 2,66 & 460 & 0,06 & 483 & 35,78 & 61.429 & 7,85 & 460 & 34,07 & 146.384 & 18,71 & 200 & 14,81 & 138.252 & 17,67 & * & $\frac{\text { Más d }}{12,68}$ & $\frac{1000,1 \mathrm{Has}}{*}$ & 55,71 & & & & \\
\hline & 2002 & $\begin{array}{c}961 \\
3,75 \%\end{array}$ & $\begin{array}{c}6006.634,9 \\
4,95 \%\end{array}$ & 24 & 2,50 & 277,3 & 0,05 & 336 & 34,96 & $41.646,6$ & 6,86 & 304 & 31,64 & 97.979 & 16,15 & 151 & 15,71 & $106.086,6$ & 17,49 & 109 & 11,34 & $167.505,6$ & 27,61 & 37 & 3,85 & $193.139,8$ & 31,84 \\
\hline \multirow{3}{*}{$\begin{array}{l}\text { General } \\
\text { Roca }\end{array}$} & 1969 & $\begin{array}{l}1.797 \\
3,11 \%\end{array}$ & $\begin{array}{c}1.211 .829 \\
8,53 \%\end{array}$ & 223 & 12,41 & 2.032 & 0,17 & 553 & 30,77 & 66.781 & 5,51 & 431 & 23,98 & 127.294 & 10,50 & 335 & 18,64 & 210.685 & 17,38 & 162 & 9,02 & 264.969 & 21,87 & 93 & 5,18 & 540.065 & 44,57 \\
\hline & 1988 & $\begin{array}{l}1.556 \\
3,88 \%\end{array}$ & $\begin{array}{c}1.188 .890 \\
8,66 \%^{\circ}\end{array}$ & 106 & 6,81 & 1.109 & 0,09 & 459 & 29,50 & 54.539 & 4,59 & 462 & 29,69 & 148.452 & 12,49 & 251 & 16,13 & 175.954 & 14,80 & 174 & 11,18 & 272.876 & 22,95 & 104 & 6,69 & 535.958 & 45,08 \\
\hline & 2002 & $\begin{array}{l}1.188 \\
4,64 \%\end{array}$ & $\begin{array}{c}1.052 .151,7 \\
8,59 \%\end{array}$ & 50 & 4,21 & 565 & 0,05 & 304 & 25,59 & $35.477,2$ & 3,37 & 371 & 31,23 & $120.504,5$ & 11,46 & 204 & 17,17 & 143.572 & 13,65 & 162 & 13,64 & 254.865 & 24,22 & 97 & 8,16 & 497.168 & 47,25 \\
\hline \multirow{3}{*}{$\begin{array}{l}\text { Sumatoria } \\
\text { de los } \\
\text { cuatro } \\
\text { dptos. }\end{array}$} & 1969 & $\begin{array}{l}11.550 \\
19,97 \%\end{array}$ & $\begin{array}{c}4.626 .857 \\
32,57 \%^{\circ}\end{array}$ & & & & & & & & & & & & & & & & & & & & & & & & \\
\hline & 1988 & $\begin{array}{c}9.139 \\
22,81 \%\end{array}$ & $\begin{array}{c}4.412 .409,5 \\
32,15 \%^{\circ}\end{array}$ & & & & & & & & & & & & & & & & & & & & & & & & \\
\hline & 2002 & $\begin{array}{c}6.095 \\
23,79 \%\end{array}$ & $\begin{array}{c}3.873 .709,3 \\
31,64 \%\end{array}$ & & & & & & & & & & & & & & & & & & & & & & & & \\
\hline
\end{tabular}

* No figuran los valores en cifras, por existir un desfasaje numérico entre los totales departamentales y en la escala de extensión.

Del total provincial.

Fuente: Elaboración propia en base a la información aportada por los CNAs de 1969, 1988 y 2002 
Presidente Roque Sáenz Peña-, al igual que a nivel provincial, en el segmento de “25,1 a 200 ha”; en cambio, en el Dpto. General Roca, se sitúa en la escala de “200,1 a 500 ha”.

- En la "versión ampliada", el mayor porcentaje de "superficie" del total que ocupan las explotaciones, tanto en el Dpto. Río Cuarto como a nivel provincial, se ubica en el segmento de "200,1 a 500 ha", lo que indica una morigeración en el tamaño general de las explotaciones, en relación con el censo anterior. En cambio, en los departamentos Juárez Celman y Presidente Roque Sáenz Peña se sitúa en la escala de "1.000,1 a 2.500 ha". y en el Dpto. General Roca, en el segmento de "más de 2.500 ha".

- Con respecto al censo de 2002:

- En la "versión ampliada", el mayor porcentaje de la "cantidad" total de las explotaciones se ubica también en tres de los departamentos -Río Cuarto, Juárez Celman y Presidente Roque Sáenz Peña-, al igual que a nivel provincial, en el segmento de "25,1 a 500 ha", y en el Dpto. General Roca en la escala de "200,1 a 500 ha".

- En la "versión ampliada", el mayor porcentaje de "superficie" del total que ocupan las explotaciones se sitúa en los cuatro departamentos, al igual que a nivel provincial, en la escala de "más de 2.500 ha", lo que indica claramente una nivelación generalizada en el incremento acentuado del tamaño de las explotaciones.

En suma, en relación con la cantidad y superficie de las explotaciones, podemos puntualizar lo siguiente:

- La disminución es progresiva y significativa a lo largo de los tres censos de la "cantidad" de explotaciones "hasta 200 ha", en los cuatro departamentos, como a nivel provincial; dicha diferencia porcentual se traslada en gran parte a la franja intermedia de "200,1 a 1.000 ha" y, por carácter transitivo, repercute también en el incremento de la cantidad de explotaciones en las escalas superiores de "más de 1.000 ha".

La disminución porcentual de la "superficie" de las explotaciones "hasta 200 ha" -que también es muy acentuada- se traslada en general hacia las franjas intermedias de "200,1 a 1.000 ha", pero acotadas entre los censos de 1969 y 1988. La disminución de la superficie de las explotaciones "hasta 200 ha" en el censo de 2002 
da la impresión de que ya no incide mayormente en las escalas inmediatas superiores de " 200,1 a 1.000 ha".

- La "cantidad" de explotaciones en las escalas intermedias de "200,1 a 1.000 ha" en los departamentos aludidos, como igualmente a nivel provincial, a lo largo de los tres censos, marca un relevante incremento de las mismas en estos estratos. A tal punto esto es así que, si desagregamos las escalas intermedias de acuerdo con la "versión completa" que brindan los censos, ${ }^{3}$ se comprueba que, a partir del censo de 1988, el mayor porcentaje de la cantidad total de las explotaciones de los cuatro departamentos, como igualmente a nivel provincial, se ubica en el segmento de “200,1 a 500 ha”, o sea, en la categoría tendiente a medianas explotaciones.

El incremento en la "superficie" de las explotaciones en casi todos los departamentos -menos en el Dpto. General Roca-, al igual que a nivel provincial, se observa entre los censos de 1969 y 1988, para luego disminuir en el censo de 2002, inclusive a valores inferiores al censo de 1969, lo que indica claramente un desplazamiento de la superficie de las explotaciones de estas franjas en el censo de 2002 hacia las escalas superiores de "más de 1.000,1 ha".

- El incremento sostenido en la "cantidad" de explotaciones en las escalas superiores de "más de 1.000,1 ha" -aunque los porcentajes en términos comparativos sean reducidos- en todos los departamentos, al igual que a nivel provincial, a lo largo de los tres censos y que se enfatiza particularmente en el censo de 2002, está indicando una sostenida injerencia de las grandes explotaciones en el sur cordobés.

Con respecto a la incidencia de la "superficie" de las explotaciones en las escalas de “más de 1.000,1 ha", corresponde destacar que en los censos de 1969 y 1988, en los departamentos Río Cuarto y Juárez Celman, al igual que a nivel provincial, si bien son relevantes los porcentajes de la superficie de las explotaciones que ocupan esta franja con respecto al total, los mismos no son mayoritarios en el sentido de que no superan el 50\% del total, lo que quiere decir que entre los años citados, a lo largo de todas las escalas, la distribución en la superficie de las explotaciones estuvo más equitativamente repartida. Pero es en el censo de 2002 que esta distribución relativamente equitativa se altera profundamente, al igual que a nivel provincial, superando en esta franja la superficie de las explotaciones el $50 \%$ del total. Cabe resaltar que este incremento especialmente se da en forma desmesurada en el Dpto.

3 La "versión completa" de todos los fraccionamientos de la escala de extensión que utilizan los censos, por razones de espacio, figura solamente en el Anexo, como Cuadro $\mathrm{N}^{\circ} 1$. 
Juárez Celman. En cambio -como ya lo expresáramos-, en los departamentos Presidente Roque Sáenz Peña y General Roca, dada la predominancia permanente de campos de gran extensión, la superficie de las explotaciones en este segmento, a lo largo de los tres censos, siempre estuvo holgadamente por encima del 50\% del total, siendo muy notoria esta predominancia en el Dpto. General Roca.

El impacto del incremento generalizado de las "superficies" de las explotaciones en el censo de 2002 se pone de manifiesto al observar en la "versión completa" que en todos los departamentos, al igual que a nivel provincial, el mayor porcentaje de superficie del total que ocupan las explotaciones se ubica en el segmento de "1.000,1 a 2.500 ha", o sea, en la categoría de grandes explotaciones.

En resumidas cuentas, el mayor porcentaje del total de las dos variables referidas tiende a concentrarse entre los censos de 1969 y 1988 hacia el centro de la escala de extensión. En cambio, entre los censos de 1988 y 2002, si bien el mayor porcentaje de la "cantidad" total de explotaciones se sigue incrementando en el centro de la escala de extensión, el mayor porcentaje de "superficie" del total que ocupan las explotaciones se incrementa significativamente en el extremo de mayores dimensiones en la escala de extensión, acompañado también por un incremento no desestimable en la "cantidad" de explotaciones. De acuerdo con esta última tendencia que acusa el censo de 2002, queda en evidencia que la orientación predominante apunta hacia un aumento progresivo y acentuado de la superficie de las explotaciones en general.

\subsubsection{Cantidad y superficie de las explotaciones agropecuarias, por tipo jurídico del productor}

A nivel evolutivo y comparativo, podemos resaltar las siguientes características (Cuadro $\left.\mathrm{N}^{\mathrm{o}} 35\right)$ :

- En los censos de 1988 y 2002 el "tipo jurídico del productor" que va a predominar en cantidad de explotaciones, en los cuatro departamentos implicados, al igual que a nivel provincial, corresponde a la categoría de "persona física", representada por valores que en todos los casos están por encima del 60\%, lo que deja traslucir la relevancia histórica de la propiedad individual en la apropiación de la tierra. Le sigue luego la categoría "sociedad de hecho", con una disminución porcentual no desestimable entre los censos de 1988 y 2002. No obstante este decrecimiento, resulta relevante esta categoría en nuestra área de estudio, donde se pone de manifiesto 
Cuadro $N^{\circ} 35$. Cantidad y superficie de las EAPs, por tipo jurídico del productor de los departamentos que constituyen la región sur de la provincia de Córdoba. CNAs 1988 y 2002

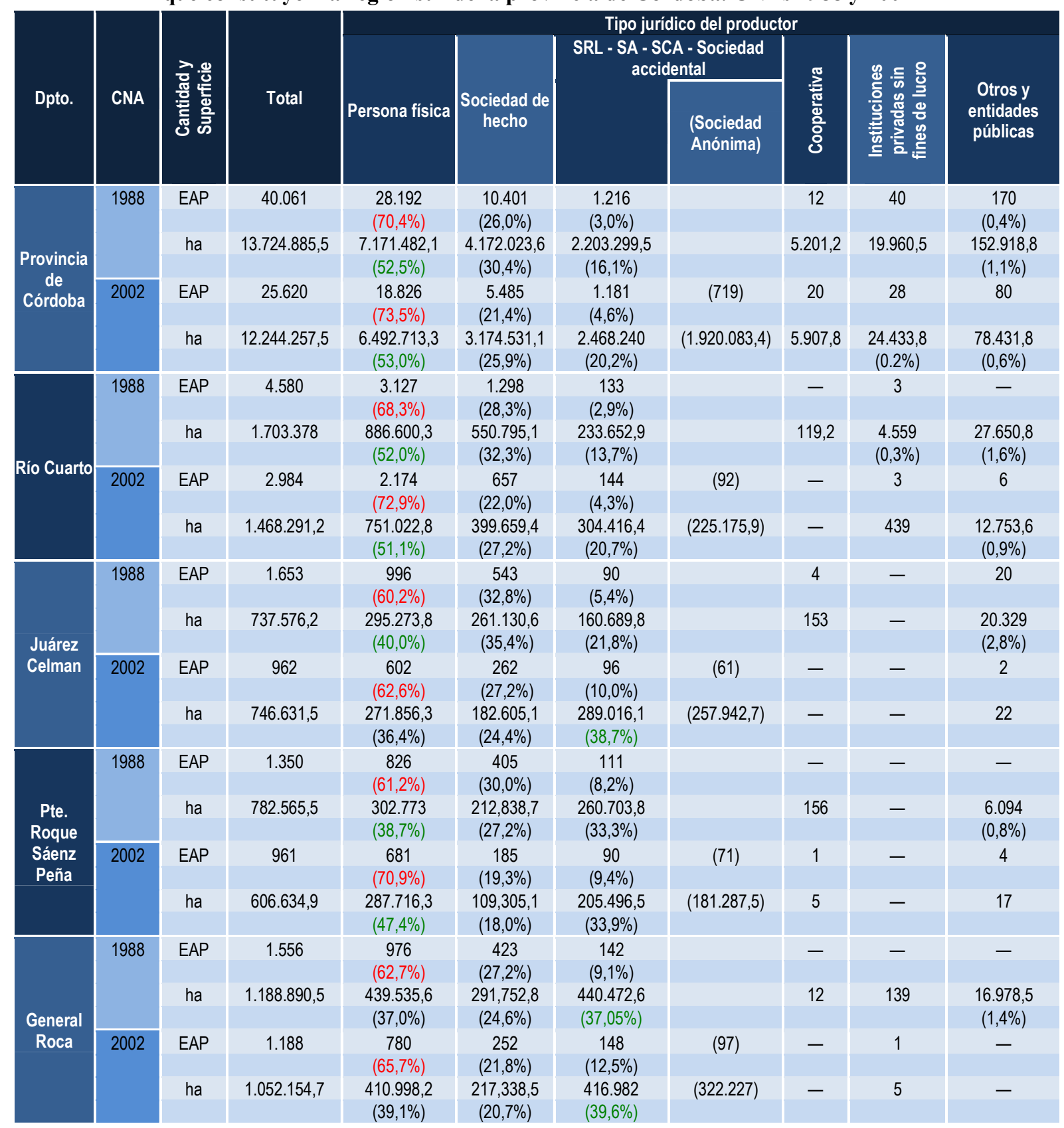

Fuente: Elaboración propia en base a la información aportada por los CNAs de 1988 y 2002.

que numerosas explotaciones están compartidas por más de un productor con su correspondiente familia. Aquí corresponde acotar que esta realidad demuestra que es incorrecto -como se desliza en muchos análisis- equiparar como situación equivalente cantidad de establecimientos con cantidad de productores, como también se torna muy difícil equiparar en forma lineal los diferentes tamaños de las explotaciones con pequeños, medianos y grandes productores, según la escala de las dimensiones areales de los establecimientos. 
A continuación le sigue la categoría "sociedades formalmente constituidas" (SRL, SCA, SA, Sociedad Accidental), con valores porcentuales bajos -entre el 3\% y el $12 \%$-, pero que se incrementan entre los dos censos. Dentro de esta categoría es interesante destacar el peso numérico que tiene la figura jurídica correspondiente a las sociedades anónimas, en el censo de 2002. Vemos que en todos los casos predomina ampliamente sobre los otros tipos de sociedades. Esta realidad nos estaría señalando la intromisión progresiva del gran capital de diferente procedencia en las actividades agropecuarias de la región.

Por último, los valores porcentuales de los tipos jurídicos restantes que contemplan los censos aludidos, se pueden considerar residuales.

- En casi todos los departamentos, al igual que a nivel provincial, en los dos censos, va a predominar en "superficie" ocupada -menos en los departamentos General Roca y Juárez Celman solamente en el censo de 2002- la categoría de "persona física", con valores que fluctúan entre el 39\% y el 52\%, lo que indica -a diferencia de los altos porcentajes que acusa la cantidad de explotaciones- que la superficie de la tierra ocupada está más repartida entre las otras categorías. En cambio, en los departamentos Juárez Celman -solamente en el censo de 2002- y General Roca, van a ocupar el primer lugar en superficie las "sociedades formalmente constituidas". Esto se debe a que sobresalen en estas dos jurisdicciones grandes establecimientos conformados bajo la figura jurídica de sociedades de diferente tipo.

En segundo lugar le sigue la categoría "sociedad de hecho" en los departamentos Río Cuarto y Juárez Celman -solamente en el censo de 1988-, al igual que a nivel provincial. En cambio, este posicionamiento en el Dpto. Presidente Roque Sáenz Peña lo van a ocupar las "sociedades formalmente constituidas", dado que también en esta jurisdicción es relevante la presencia de grandes establecimientos conformados por diversos tipos de sociedades. Asimismo, el segundo lugar en superficie ocupada, por la alteración del orden de los valores arriba descriptos, le corresponde en lo departamentos General Roca y Juárez Celman -solamente en el censo de 2002- a la categoría "persona física".

A continuación, en tercer lugar, le sigue la categoría "sociedad formalmente constituida" en los departamentos Río Cuarto y Juárez Celman -solamente en el censo de 1988-, al igual que a nivel provincial. En cambio, en los departamentos Presidente Roque Sáenz Peña, General Roca y Juárez Celman -solamente en el censo de 2002- el tercer lugar es ocupado por la categoría "sociedad de hecho". 
En síntesis, podemos decir que en el Dpto. Río Cuarto y en el Dpto. Juárez Celman, solamente hasta el censo de 1988, al igual que a nivel provincial, se observa de acuerdo con el orden descendente en los porcentajes de las superficies ocupadas, una tradicional distribución de los tipos jurídicos del productor, en concordancia con la forma como ha sido apropiada la tierra en términos históricos. En cambio, en los otros departamentos se evidencia una alteración del anterior orden mencionado, dada la injerencia de grandes sociedades en las superficies ocupadas, focalizadas sobre todo en establecimientos de grandes dimensiones.

Otro aspecto importante a destacar es el papel descollante de las sociedades anónimas dentro de las "sociedades formalmente constituidas", perceptible a partir del censo de 2002, donde se detecta una supremacía abrumadora tanto en cantidad como en superficie ocupada sobre las otras figuras jurídicas societales, lo que marca -como ya se dijo- el avance progresivo de un capitalismo avanzado en el quehacer agropecuario.

A continuación, pasamos a analizar la "tenencia de la tierra" en nuestra región, desde dos puntos de vista.

\subsubsection{Distribución de la superficie de las explotaciones agropecuarias, por régimen de} tenencia de la tierra, según departamento

Al respecto, podemos decir lo siguiente (Cuadro $\mathrm{N}^{\mathrm{o}} 36$ ):

- El primer lugar en la distribución de la superficie por tenencia de la tierra en todos los departamentos, al igual que a nivel provincial, en los dos censos, corresponde en forma abrumadora - como es de imaginar- a las tierras en propiedad, con porcentajes muy altos, que fluctúan entre el $56 \%$ y el $82 \%$. Se observa, en general, un decrecimiento intercensal en superficie bastante pronunciado, especialmente notorio en el Dpto. Juárez Celman.

- El segundo lugar en la distribución de la superficie por tenencia de la tierra, en los dos censos, en todos los departamentos, al igual que a nivel provincial, corresponde a las tierras en arrendamiento, con porcentajes que varían entre el $14 \%$ y el $25 \%$. Aquí se observa, en general, un crecimiento intercensal bastante importante, excepto en el caso del Dpto. Juárez Celman que, a la inversa, sufre un pequeño descenso.

- El tercer lugar en la distribución de la superficie por tenencia de la tierra, en los dos censos, en todos los departamentos - excepto en el Dpto. General Roca en el censo de 1988-, al igual que a nivel provincial, corresponde a las "tierras en contrato accidental", con porcentajes en general muy reducidos, excepto en el Dpto. Juárez 
Celman que, aparte de sobresalir sus guarismos del resto, acusa un incremento enorme entre los censos de 1988 y 2002. Es evidente, en este caso, que ha habido un traslado básicamente de "tierras en propiedad" a este régimen de tenencia de la tierra.

- El último lugar en la distribución de la superficie por tenencia de la tierra, en los dos censos, en todos los departamentos, al igual que a nivel provincial, le corresponde a las "tierras en aparcería”, con valores mínimos, seguido por los otros regímenes que figuran en el cuadro, con porcentajes en general declaradamente residuales.

Cuadro $N^{0}$ 36. Córdoba. Distribución de la superficie de las EAPs, por régimen de tenencia de la tierra, de los departamentos que constituyen la región sur de la provincia de Córdoba. CNAs 1988 y 2002

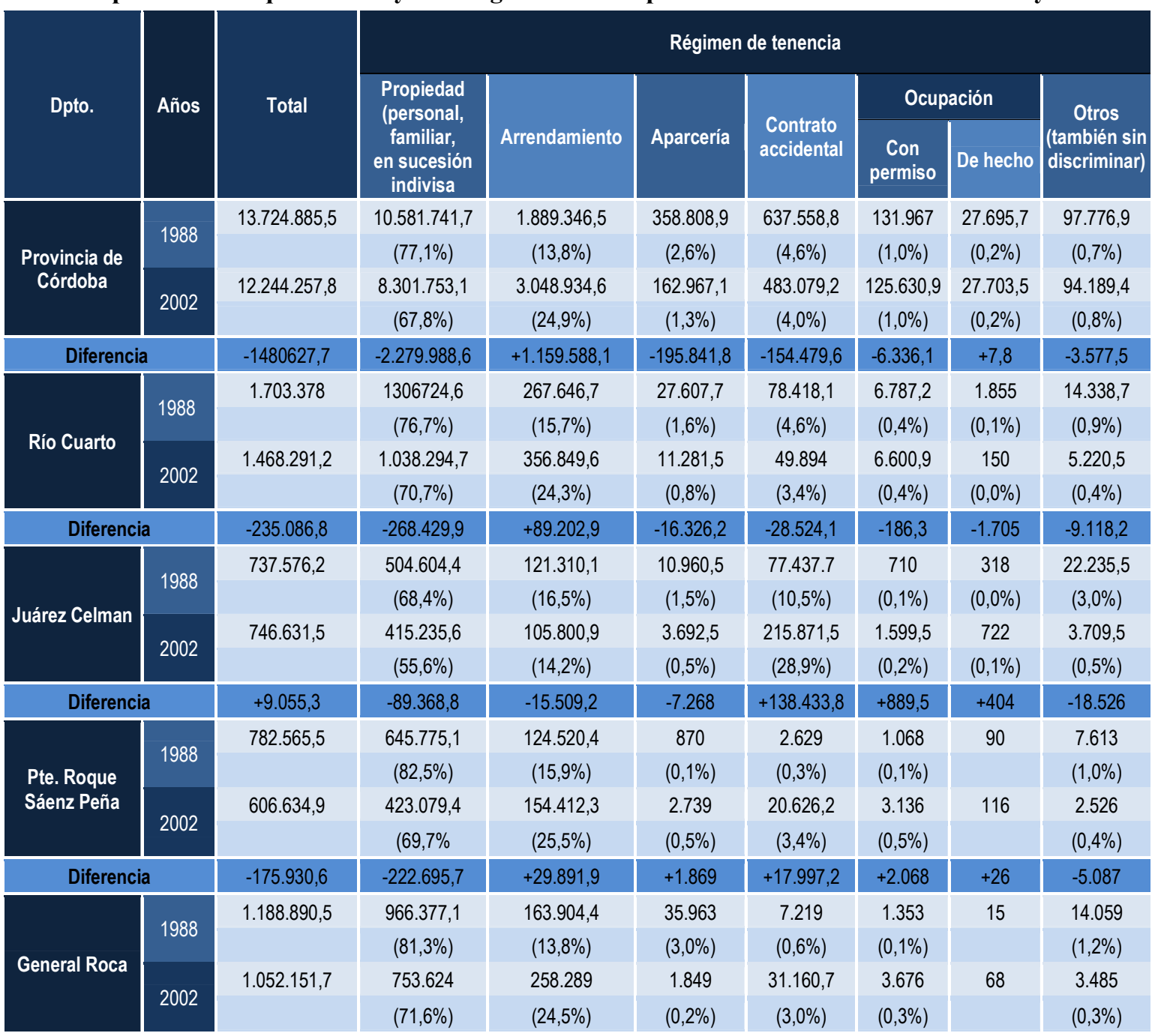

Fuente: Elaboración propia en base a la información aportada por los CNAs de 1988 y 2002.

En suma, se observa entre los censos de 1988 y 2002 -excepto en el Dpto. Juárez Celman- un traslado significativo de la "tierra en propiedad" a las "tierras en arrendamiento", de modo tal que éstas acusan un incremento muy importante, no solamente en valores porcentuales, sino también en valores absolutos, a pesar de la disminución generalizada de los 
totales de la superficie de las explotaciones. Esta circunstancia estaría reafirmando la gran movilidad en la demanda de alquileres de tierra observable desde hace tiempo, y la preferencia por arrendar más que por comprar campos.

Por otra parte, llama la atención, en general, la escasa representatividad numérica de las "tierras en contrato accidental", que no coincide en absoluto con la información de campo que nosotros venimos recogiendo desde hace tiempo.

Con respecto al crecimiento inusitado de "tierras en contrato accidental" en el Dpto. Juárez Celman, posiblemente esta realidad esté demostrando, entre otros factores, la fuerte incidencia de una poderosa agroindustria de la zona, con la dinámica generalizada de adquirir tierras en alquiler o a través de interpósitas personas para trabajarla en plazos breves.

\subsubsection{Cantidad y superficie de las explotaciones agropecuarias, por régimen de tenencia de la tierra, según departamento}

En relación con este enfoque de análisis sobre el régimen de tenencia de la tierra, podemos expresar lo siguiente (Cuadro $\mathrm{N}^{\mathrm{o}} 37$ ):

- El primer lugar en los dos censos, en todos los departamentos, al igual que a nivel provincial, tanto en "cantidad" como en "superficie" de los establecimientos, corresponde a las "EAPs con toda su tierra en propiedad", con porcentajes en cantidad de explotaciones que fluctúan entre el $46 \%$ y el $67 \%$ y en superficie entre el $38 \%$ y el $68 \%$. Se observa, a su vez, en las dos variables un decrecimiento intercensal apreciable, pero más acentuado en superficie de las explotaciones.

- El segundo lugar en los dos censos, en todos los departamentos -excepto en el Dpto. Juárez Celman en el censo de 2002 en superficie de las explotaciones-, al igual que a nivel provincial, tanto en "cantidad" como en "superficie" de los establecimientos, corresponde a las "EAPs que combinan tierras en propiedad con arrendamiento", con porcentajes en cantidad de explotaciones que varían entre el $14 \%$ y el $29 \%$ y en superficie entre el $18 \%$ y el $39 \%$. Asimismo, se observa en las dos variables un incremento intercensal considerable, especialmente apreciable en superficie de las explotaciones. En cambio, el segundo lugar en el censo de 2002 en el Dpto. Juárez Celman, en superficie de los establecimientos, corresponde a las "EAPs que combinan tierras en propiedad con contrato accidental", con un porcentaje muy considerable. 
Cuadro No 37: Cantidad y superficie de las EAPs, por régimen de tenencia de la tierra, según departamento. Censos Nacionales Agropecuarios de 1988 y 2002

\begin{tabular}{|c|c|c|c|c|c|c|c|c|c|c|c|c|c|c|c|}
\hline \multirow[b]{2}{*}{ Dpto. } & \multirow[b]{2}{*}{ CNA } & \multirow{2}{*}{$\begin{array}{l}\text { Cantidad } \\
\text { Superficie }\end{array}$} & \multirow[b]{2}{*}{ Total } & \multicolumn{6}{|c|}{ EAPs con toda su tierra en } & \multicolumn{5}{|c|}{ EAPs que combinan tierra en propiedad con } & \multirow{2}{*}{$\begin{array}{l}\text { Otras combinaciones } \\
\text { sin tierra en propiedad }\end{array}$} \\
\hline & & & & Propiedad & Arrendamiento & Aparcería & $\begin{array}{l}\text { Contrato } \\
\text { accidental }\end{array}$ & Ocupación & Otros & Arrendamiento & Aparcería & $\begin{array}{c}\text { Contrato } \\
\text { accidental }\end{array}$ & Ocupación & $\begin{array}{c}\text { Otras } \\
\text { combinaciones }\end{array}$ & \\
\hline \multirow{12}{*}{$\begin{array}{c}\text { Provincia } \\
\text { de } \\
\text { Córdoba }\end{array}$} & \multirow{4}{*}{1988} & \multirow{2}{*}{$\begin{array}{c}\text { EAP }(342,6 \\
\text { prom) }\end{array}$} & \multirow{2}{*}{40.061} & 24.796 & 2.706 & 621 & 923 & 593 & 93 & 5.593 & 1.008 & 2.096 & 444 & 841 & 347 \\
\hline & & & & $(61,9 \%)$ & $(6,7 \%)$ & $(1,6 \%)$ & $(2,3 \%)$ & $(1,5 \%)$ & $(0,2 \%)$ & $(14 \%)$ & $(2,5 \%)$ & $(5,2 \%)$ & $(1,1 \%)$ & $(2,1 \%)$ & $(0,9 \%)$ \\
\hline & & \multirow{2}{*}{ ha } & \multirow{2}{*}{$13.724,885,5$} & $8.318 .669,7$ & $725.034,9$ & $126.587,2$ & $197.086,8$ & $91.863,2$ & $84.665,3$ & $2.448 .553,5$ & $358.368,8$ & $727.958,1$ & $119,227,3$ & $410.545,5$ & $116.326,2$ \\
\hline & & & & $(60,6 \%)$ & $(5,3 \%)$ & $(0,9 \%)$ & $(1,4 \%)$ & $(0,7 \%)$ & $(0,6 \%)$ & $(17,8 \%)$ & $(2,6 \%)$ & $(5,4 \%)$ & $(0,9 \%)$ & $(3,0 \%)$ & $(0,8 \%)$ \\
\hline & \multirow{4}{*}{2002} & \multirow{2}{*}{$\begin{array}{l}\text { EAP }(477,9 \\
\text { prom) }\end{array}$} & \multirow{2}{*}{25.620} & 13.836 & 2.968 & 175 & 260 & 460 & 135 & 5.948 & 297 & 535 & 292 & 516 & 198 \\
\hline & & & & $(54,0 \%)$ & $(11,6 \%)$ & $(0,7 \%)$ & $(1,0 \%)$ & $(1,8 \%)$ & $(0,5 \%)$ & $(23,2 \%)$ & $(1,2 \%)$ & $(2,1 \%)$ & $(1,1 \%)$ & $(2,0 \%)$ & $(0,8 \%)$ \\
\hline & & \multirow{2}{*}{ ha } & \multirow{2}{*}{$12.244 .257,8$} & $5.929 .534,2$ & 1.121.021,1 & $62.459,7$ & $93.038,7$ & 98.218 & $56.193,3$ & $3.604 .259,5$ & $140.509,3$ & $515.770,3$ & $90.953,6$ & $422,852,6$ & $109.447,5$ \\
\hline & & & & $(48,4 \%)$ & $(9,2 \%)$ & $(0,5 \%)$ & $(0,8 \%)$ & $(0,8 \%)$ & $(0,5 \%)$ & $(29,4 \%)$ & $(1,1 \%)$ & $(4,2 \%)$ & $(0,7 \%)$ & $(3,5 \%)$ & $(0,9 \%)$ \\
\hline & \multirow{2}{*}{\multicolumn{2}{|c|}{ Diferencia EAP }} & -14.441 & -10.960 & +262 & -446 & -663 & -133 & +42 & +355 & -711 & -1.561 & -152 & -325 & -149 \\
\hline & & & $(-36,0 \%)$ & $(-44,2 \%)$ & $(+9,7 \%)$ & $(-71,8 \%)$ & $(-71,8 \%)$ & $(-22,4 \%)$ & $(+45,2 \%)$ & $(+6,3 \%)$ & $(-70,5 \%)$ & $(-74,5 \%)$ & $(-34,2 \%)$ & $(-38,6 \%)$ & $(-42,9 \%)$ \\
\hline & \multirow{2}{*}{\multicolumn{2}{|c|}{ Diferencia ha }} & $-1.480 .627,7$ & $-2.389 .135,5$ & $+395.986,2$ & $64.127,5$ & $-104.048,1$ & $+6.354,8$ & -28.472 & +1.155 .706 & $-217.859,5$ & $-212.187,8$ & $-28.273,7$ & $+12.308,1$ & $-6.878,7$ \\
\hline & & & $(-10,8 \%)$ & $(-28,7 \%)$ & $(+54,6 \%)$ & $(-51,0 \%)$ & $(-52,8 \%)$ & $(+6,91 \%)$ & $(-33,6 \%)$ & $(+47,2 \%)$ & $(-60,8 \%)$ & $(-29,1 \%)$ & $(-23,7 \%)$ & $(+3,0 \%)$ & $(-5,91 \%)$ \\
\hline \multirow{12}{*}{ Río Cuarto } & \multirow{4}{*}{1988} & EAP $(372 \mathrm{prom})$ & 4580 & 2.607 & 369 & 36 & 128 & 19 & 14 & 852 & 86 & 283 & 32 & 119 & 35 \\
\hline & & CAF (JIL piOII) & 4.000 & $(59,9 \%)$ & $(8,0 \%)$ & $(0,8 \%)$ & $(2,8 \%)$ & $(0,4 \%)$ & $(0,3 \%)$ & $(18,6 \%)$ & $(1,9 \%)$ & $(6,2 \%)$ & $(0,7 \%)$ & $(2,6 \%)$ & $(0,8 \%)$ \\
\hline & & $h_{3}$ & 1703.378 & $955.862,6$ & $93.966,7$ & $7,258,1$ & $25.295,2$ & $1.572,2$ & 12.611 & $381.018,9$ & $36.280,5$ & $106.202,8$ & $9.774,5 \%$ & $61.650,7$ & $11.854,8$ \\
\hline & & na & 1.103 .518 & $(56,1 \%)$ & $(5,5 \%)$ & $(0,4 \%)$ & $(1,5 \%)$ & $(0,1 \%)$ & $(0,8 \%)$ & $(22,4 \%)$ & $(2,1 \%)$ & $(6,2 \%)$ & $(0,6 \%)$ & $(3,6 \%)$ & $(0,7 \%)$ \\
\hline & & EAP (492 prom) & 2984 & 1.569 & 307 & 8 & 30 & 24 & 6 & 852 & 20 & 70 & 24 & 52 & 22 \\
\hline & 2002 & 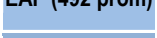 & 2.004 & $(52,6 \%)$ & $(10,3 \%)$ & $(0,3 \%)$ & (1\%) & $(0,8 \%)$ & $(0,2 \%)$ & $(28,6 \%)$ & $(0,7 \%)$ & $(2,3 \%)$ & $(0,8 \%)$ & $(1,7 \%)$ & $(0,7 \%)$ \\
\hline & cuve & $h a$ & 14682912 & $639.448,3$ & $96.793,8$ & 4.792 & 9.952 & $2.646,6$ & 775,5 & $567.878,1$ & $17.889,3$ & $65.902,4$ & $6.091,3$ & $43.764,9$ & 11.413 \\
\hline & & nd & $1.400 .291,2$ & $(43,6 \%)$ & $(6,6 \%)$ & $(0,3 \%)$ & $(0,7 \%)$ & $(0,2 \%)$ & $(0,05 \%)$ & $(38,7 \%)$ & $(1,2 \%)$ & $(4,5 \%)$ & $(0,4 \%)$ & $(3,0 \%)$ & $(0,8 \%)$ \\
\hline & & erencia FAP & -1.596 & -1.038 & -62 & -28 & -98 & +5 & -8 & 0 & -66 & -213 & -8 & -67 & -13 \\
\hline & & 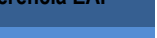 & $(-34,8 \%)$ & $(-39,8 \%)$ & $(-16,8 \%)$ & $(-77,8 \%)$ & $(-76,6 \%)$ & $(+26,3 \%)$ & $(-57,1 \%)$ & $(0 \%)$ & $(-76,7 \%)$ & $(-75,3 \%)$ & $(-25,0 \%)$ & $(-56,3 \%)$ & $(-37,1 \%)$ \\
\hline & & ferencia ha & $-235.086,8$ & $-316.414,3$ & $+2.827,1$ & -2.466 & $-15.343,2$ & $+1.074,4$ & $-11.835,5$ & $+186.859,2$ & $-18.391,2$ & $-40.300,4$ & $-3.683,2$ & $-17.915,8$ & $-441,8$ \\
\hline & & (2) & $(-13,8 \%)$ & $(-33,1 \%)$ & $(+3,0 \%)$ & $(-24,0 \%)$ & $(-60,7 \%)$ & $(+68,3 \%)$ & $(-93,8 \%)$ & $(+49,0 \%)$ & $(-50,7 \%)$ & $(-37,9 \%)$ & $(-37,7 \%)$ & $(-29,0 \%)$ & $(-3,7 \%)$ \\
\hline & & $\operatorname{EAP}(446,2$ & 1653 & 852 & 130 & 16 & 86 & - & - & 278 & 36 & 142 & - & 80 & 22 \\
\hline & 198 & prom) & & $(51,5 \%)$ & $(7,9 \%)$ & $(1,0 \%)$ & $(5,2 \%)$ & & & $(16,8 \%)$ & $(2,2 \%)$ & $(9,6 \%)$ & & $(4,8 \%)$ & $(1,3 \%)$ \\
\hline & inou & ha & 737.5762 & $359.257,6$ & 44.009 & 3.775 & $24.216,9$ & 42 & $20.938,5$ & $147.774,6$ & 11.745 & $71.105,9$ & - & $48.386,7$ & 6.325 \\
\hline & & & (10.0, & $(48,7 \%)$ & $(6,0 \%)$ & $(0,5 \%)$ & $(3,3 \%)$ & & $(2,8 \%)$ & $(20,0 \%)$ & $(1,6 \%)$ & $(9,6 \%)$ & & $(6,6 \%)$ & $(0,9 \%)$ \\
\hline & & FAP (776 nrom) & 962 & 446 & 81 & 3 & 49 & 6 & 4 & 164 & 4 & 124 & 12 & 49 & 20 \\
\hline Juárez & | & EAP (IIT promin) & 902 & $(46,4 \%)$ & $(8,5 \%)$ & $(0,3 \%)$ & $(5,1 \%)$ & $(0,6 \%)$ & $(0,4 \%)$ & $(17 \%)$ & $(0,4 \%)$ & $(12,9 \%)$ & $(1,2 \%)$ & $(5,1 \%)$ & $(2,1 \%)$ \\
\hline Celman & cuve & ha & 746.631 .5 & $285.196,4$ & $47.105,9$ & 563 & 24.932 & 160,5 & 645 & 104.338 & 2.757 & $230.685,2$ & $2.739,5$ & 37.745 & 9.764 \\
\hline & & na & 746.651,5 & $(38,2 \%)$ & $(6,3 \%)$ & $(0,1 \%)$ & $(3,3 \%)$ & & $(0,1 \%)$ & $(14,0 \%)$ & $(0,4 \%)$ & $(30,9 \%)$ & $(0,4 \%)$ & $(5,0 \%)$ & $(1,3 \%)$ \\
\hline & & erencia FAP & -691 & -406 & -49 & -13 & -37 & - & - & -114 & -32 & -18 & - & -31 & -2 \\
\hline & & 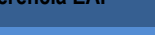 & $(-41,8 \%)$ & $(-47,7 \%)$ & $(-37,7 \%)$ & $(-81,2 \%)$ & $(-43,0 \%)$ & & & $(-59,0 \%)$ & $(-88,9 \%)$ & $(-12,7 \%)$ & & $(-38,7 \%)$ & $(-9,0 \%)$ \\
\hline & & feroncia ha & $+9.055,3$ & $-74.061,2$ & $+3.096,9$ & -3.212 & $+715,1$ & $+118,5$ & $-20.293,5$ & $-43.436,6$ & -8.988 & $+159.579,3$ & +2.739 .5 & $-10.641,7$ & +3.439 \\
\hline & & 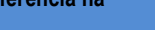 & $(+1,2 \%)$ & $(-20,6 \%)$ & $(+7,0 \%)$ & $(-85,1 \%)$ & $(+3,0 \%)$ & $(+282,1 \%)$ & $(-96,9 \%)$ & $(-29,4 \%)$ & $(-76,5 \%)$ & $(+224,4 \%)$ & - & $(-22,0 \%)$ & $(+54,4 \%)$ \\
\hline
\end{tabular}


Cuadro Nº 37 (Continuación)

\begin{tabular}{|c|c|c|c|c|c|c|c|c|c|c|c|c|c|c|c|}
\hline \multirow[b]{2}{*}{ Dpto. } & \multirow[b]{2}{*}{ CNA } & \multirow{2}{*}{$\begin{array}{l}\text { Cantidad } \\
\text { Superficie }\end{array}$} & \multirow[b]{2}{*}{ Total } & \multicolumn{6}{|c|}{ EAPs con toda su tierra en } & \multicolumn{5}{|c|}{ EAPs que combinan tierra en propiedad con } & \multirow{2}{*}{$\begin{array}{l}\text { Otras combinaciones } \\
\text { sin tierra en propiedad }\end{array}$} \\
\hline & & & & Propiedad & Arrendamiento & Aparcería & $\begin{array}{l}\text { Contrato } \\
\text { accidental }\end{array}$ & Ocupación & Otros & Arrendamiento & Aparcería & $\begin{array}{l}\text { Contrato } \\
\text { accidental }\end{array}$ & Ocupación & $\begin{array}{c}\text { Otras } \\
\text { combinaciones }\end{array}$ & \\
\hline \multirow{8}{*}{$\begin{array}{l}\text { Pte. Roque } \\
\text { Sáenz } \\
\text { Peña }\end{array}$} & \multirow{4}{*}{1988} & \multirow{2}{*}{ EAP } & \multirow{2}{*}{1.350} & 899 & 106 & 3 & - & 5 & 10 & 295 & 3 & 9 & - & 13 & - \\
\hline & & & & $(66,6 \%)$ & $(7,9 \%)$ & & & & $(0,7 \%)$ & $(21,9 \%)$ & & & & $(0,1 \%)$ & \\
\hline & & \multirow{2}{*}{ ha } & \multirow{2}{*}{$782.565,5$} & $535.118,3$ & $46.151,5$ & 140 & & 418 & 7.065 & $178.437,7$ & 1.105 & 4.447 & 721 & 8.089 & 573 \\
\hline & & & & $(68,4 \%)$ & $(5,9 \%)$ & & & & $(0,9 \%)$ & $(22,8 \%)$ & & $(0,6 \%)$ & & $(1,0 \%)$ & \\
\hline & \multirow{4}{*}{2002} & \multirow{2}{*}{ EAP } & \multirow{2}{*}{961} & 498 & 128 & 2 & 300 & 8 & 7 & 251 & - & 9 & 5 & 22 & 18 \\
\hline & & & & $(51,8 \%)$ & $(13,3 \%)$ & & & & & $(26,1 \%)$ & & & & $(2,3 \%)$ & $(1,9 \%)$ \\
\hline & & \multirow{2}{*}{ ha } & \multirow{2}{*}{$606.634,9$} & $304.788,4$ & $47.162,1$ & - & 13 & 1.394 & 565,5 & 191.810 & - & 15.897 & 1.740 & $23.717,2$ & 10,730 \\
\hline & & & & $(50,2 \%)$ & $(7,8 \%)$ & & $(1,4 \%)$ & $(0,2 \%)$ & & $(31,6 \%)$ & & $(2,6 \%)$ & $(0,3 \%)$ & $(3,9 \%)$ & $(1,8 \%)$ \\
\hline \multirow{16}{*}{$\begin{array}{c}\text { General } \\
\text { Roca }\end{array}$} & \multirow{2}{*}{\multicolumn{2}{|c|}{ Diferencia EAP }} & -389 & -401 & +22 & -1 & -13 & & -3 & -44 & -3 & 0 & +5 & +9 & +18 \\
\hline & & & $(-28,8 \%)$ & $(-44,6 \%)$ & $(+20,8 \%)$ & & & +3 & & $(-14,9 \%)$ & & & & & \\
\hline & \multirow{2}{*}{\multicolumn{2}{|c|}{ Diferencia ha }} & $-174.930,6$ & $-230.329,9$ & $+1.010,6$ & - & $+5.768,2$ & +976 & $-6.499,5$ & $+13.372,3$ & -1.105 & +11.450 & +1.019 & $+15.628,2$ & $+10.157,5$ \\
\hline & & & $(-22,5 \%)$ & $(-43,0 \%)$ & $(+2,2 \%)$ & & & & $(-92,0 \%)$ & $(+7,5 \%)$ & & $(257,5 \%)$ & & $(+193,2 \%)$ & \\
\hline & \multirow{4}{*}{1988} & \multirow{2}{*}{ EAP } & \multirow{2}{*}{1.556} & 984 & 142 & 22 & 3 & 12 & 5 & 312 & 35 & 16 & 6 & 15 & 4 \\
\hline & & & & $(63,2 \%)$ & $(9,1 \%)$ & $(1,4 \%)$ & & $(0,8 \%)$ & $(0,3 \%)$ & $(20,0 \%)$ & $(2,2 \%)$ & $(1,0 \%)$ & & $(1,0 \%)$ & \\
\hline & & \multirow{2}{*}{ ha } & \multirow{2}{*}{$1.188 .890,5$} & $737,497,4$ & $59.758,8$ & 19.486 & 582 & 1.038 & 12.962 & $279.685,2$ & 29.530 & 25.996 & 512 & 19.542 & 2.301 \\
\hline & & & & $(62,0 \%)$ & $(5,0 \%)$ & $(1,6 \%)$ & & & $(1,1 \%)$ & $(23,5 \%)$ & $(2,5 \%)$ & $(2,2 \%)$ & & $(1,6 \%)$ & $(0,2 \%)$ \\
\hline & \multirow{4}{*}{2002} & \multirow{2}{*}{ EAP } & 1188 & 603 & 203 & 2 & 19 & 5 & 2 & 301 & 2 & - & 15 & 16 & 15 \\
\hline & & & 1.188 & $(50,8 \%)$ & $(17,1 \%)$ & & $(1,6 \%)$ & & & $(25,3 \%)$ & & & $(1,3 \%)$ & $(1,3 \%)$ & $(1,3 \%)$ \\
\hline & & & & 556.425 & 132.157 & - & 6.533 & 339 & 404 & $279.163,5$ & - & $31.850,7$ & $4.579,5$ & 24.139 & 14.394 \\
\hline & & ha & 1.052.151,7 & $(52,9 \%)$ & $(12,6 \%)$ & & $(0,6 \%)$ & & & $(26,5 \%)$ & & $(3,0 \%)$ & $(0,4 \%)$ & $(2,3 \%)$ & $(1,4 \%)$ \\
\hline & & AIP FAP & -368 & -381 & +61 & -20 & +16 & -7 & -3 & -11 & -33 & -11 & +9 & +1 & +11 \\
\hline & & HCla EAT & $(-23,6 \%)$ & $(-38,7 \%)$ & $(+43,0 \%)$ & & & & & & & & & & \\
\hline & & ming & $-136.738,8)$ & $-181.072,4$ & $+72.398,2$ & - & +5.951 & -699 & -12.558 & $-521,7$ & - & +5.854 & $+4.067,5$ & +4.597 & +12.093 \\
\hline & & encia ha & $(-11,5 \%)$ & $(-24,6 \%)$ & $(+121,2 \%)$ & & & & & & & $(+22,5 \%)$ & & $(+23,5 \%)$ & \\
\hline
\end{tabular}

Fuente: Elaboración propia en base a la información aportada por los CNAs de 1988 y 2002. 
- El tercer lugar en los dos censos, en todos los departamentos -excepto en el Dpto. Juárez Celman-, al igual que a nivel provincial, en "cantidad" de establecimientos, corresponde a las "EAPs con toda su tierra en arrendamiento". En cambio, este posicionamiento, en relación con la "superficie" de las explotaciones, se torna errático. Es así como el tercer lugar en el censo de 1988, en los departamentos Río Cuarto y Juárez Celman, al igual que a nivel provincial, en "superficie" de los establecimientos, corresponde a las "EAPs con todas sus tierras en propiedad con contrato accidental” y en los departamentos Presidente Roque Sáenz Peña y General Roca, corresponde a las "EAPs con todas sus tierras en arrendamiento". El tercer lugar, en el censo de 2002, en todos los departamentos -excepto en el Dpto. Juárez Celman-, al igual que a nivel provincial, en "superficie" de los establecimientos, corresponde a las "EAPs con todas sus tierras en arrendamiento"; en cambio, en el Dpto. Juárez Celman, corresponde a las "EAPs que combinan tierras en propiedad con arrendamiento".

Por último, vienen otras instancias de régimen de tenencia de la tierra, con valores muy reducidos a mínimos.

En suma, se observa que en todos los casos - menos en el Dpto. Juárez Celman- después de las "EAPs con toda su tierra en propiedad", tanto en cantidad como en superficie de los establecimientos, le sigue con porcentajes mucho más reducidos pero con tendencia ascendente las "EAPs que combinan tierras en propiedad con arrendamiento". Esta realidad estaría indicando una concreta orientación a ampliar las superficies de las explotaciones mediante el arrendamiento de tierras, teniendo como anclaje campos en propiedad, lo que implica que aquellas explotaciones que se acrecientan cuentan con una base y capacidad económica para expandirse.

Observamos que el régimen de tenencia de la tierra que sigue tiene un desplazamiento errático. No obstante, en todos los casos -excepto en el Dpto. Juárez Celman-, en el censo de 2002, en tercer lugar se ubican las "EAPs con todas sus tierras en arrendamiento", lo que estaría señalando también una moderada tendencia a la adquisición de tierras arrendadas. Llama la atención también el decaimiento porcentual del "contrato accidental" en las dos variantes, de EAPs que no combinan y combinan tierras en propiedad, a excepción como ya puntualizamos del Dpto. Juárez Celman en el censo de 2002.

En síntesis, es interesante resaltar, reafirmando lo anteriormente expuesto, que la sumatoria de las EAPs con todas sus tierras en propiedad, arrendamiento, aparcería, etc., entre los dos censos, tanto en cantidad como en superficie de las explotaciones, tiende a decrecer y, 
a la inversa, la sumatoria de los EAPs que combinan tierras en propiedad tiende a incrementarse.

\subsubsection{Síntesis de la problemática fundiaria}

Dentro de las limitaciones analíticas de este tipo de trabajo, podemos expresar, a modo de síntesis final, los siguientes aspectos.

Se manifiesta en general, en nuestra área de estudio, una distribución de la tierra no estrictamente polarizada, pero al respecto corresponde hacer la siguiente observación: tradicionalmente en los departamentos Río Cuarto y Juárez Celman -de mayor peso poblacional- las tierras han estado más equitativamente repartidas; en cambio, en los departamentos Presidente Roque Sáenz Peña y General Roca, que se sitúan en el extremo sur provincial, históricamente la tierra ha estado más concentrada, debido a la presencia de grandes establecimientos. Por lo tanto, metodológicamente, hasta el censo de 1988, era conveniente diferenciar adecuadamente estos dos espacios. La alteración surge a partir del último censo de 2002, donde los guarismos respectivos demuestran que en el Dpto. Juárez Celman se va a producir una concentración de la tierra, tan aguda o más que en los departamentos del extremo sur provincial. Como en el Dpto. Río Cuarto también se manifiesta este fenómeno, pero en forma no tan acentuada, esto determinó que metodológicamente, salvando las correspondientes diferencias, hayamos tratado en conjunto los cuatro departamentos. Ahora, volviendo al punto, podemos resumir expresando que el número de explotaciones según el censo de 2002, en comparación con el censo anterior, ha disminuido acentuadamente en toda el área analizada, pero dentro de la cantidad de explotaciones que quedan, el grueso se ubica en forma esquemática dentro de la categoría de medianas explotaciones. En relación con la superficie que ocupan, es evidente que se manifiesta un incremento generalizado de las mismas, y dentro de esta tendencia, observamos que el mayor porcentaje de superficie del total que ocupan los establecimientos se ubica en la escala de más de 1.000,1 ha, superando en casi todos los casos holgadamente el $50 \%$ del total de la superficie involucrada.

En concreto, podemos decir que, a pesar de esta realidad, queda todavía una brecha -especialmente en el Dpto. Río Cuarto- de disponibilidad de superficie explotada por un número significativo de establecimientos, encuadrados como "pequeñas tendientes a medianas" y "medianas" explotaciones, que determina por un lado que no se manifieste una polarización areal aguda, y por otro, que dentro de las asimetrías existentes no se observe una atomización del parcelario en los extremos inferiores de la escala, ni un 
sobredimensionamiento del tamaño de las explotaciones en los extremos superiores de la misma, lo que no quiere significar que esta situación de distribución de la tierra no tan inequitativa se desestabilice totalmente en términos negativos más adelante.

En lo referente al tipo jurídico del productor, lo que sobresale es la intromisión paulatina y sostenida de las grandes sociedades formalmente constituidas, destacándose dentro de ellas las sociedades anónimas por el peso creciente que están asumiendo en la región de estudio.

Con respecto al régimen de tenencia de la tierra, se detecta un crecimiento importante en la demanda de tierras en alquiler, pero básicamente a partir de "EAPs que combinan tierras en propiedad con arrendamiento", lo que demuestra el peso que sigue teniendo en el área la propiedad jurídica de la tierra.

En suma, la conjunción de los resultados que se extraen de todas estas variables fundiarias, más otros indicadores que escapan a este análisis, nos indica una intromisión sostenida y de gran magnitud de pautas de un capitalismo avanzado en las prácticas agropecuarias en el área de estudio, en sintonía sin la menor duda con el resto del espacio pampeano. Lo que deja grandes dudas es si estos procedimientos netamente capitalistas en el agro van a beneficiar realmente en forma integral lo que queda del mundo rural en un futuro no lejano.

\subsection{Cambios productivos en el quehacer agropecuario (1988-2009/10)}

La finalidad, en esta instancia, pasa por analizar las transformaciones productivas que se vienen desarrollando en el quehacer agropecuario de la región sur de la provincia de Córdoba, en el lapso comprendido entre 1988 y 2009/10, con la inquietud de complementar esta indagación -a lo largo de esta tesis- con el análisis especialmente de los actores sociales que se desempeñan en dicho espacio, a fin de alcanzar un conocimiento más integral de las diversas y diferentes problemáticas que se entrelazan en el espacio aludido.

Nuestra área de trabajo -como ya se explicitó anteriormente-, al igual que todo el espacio pampeano y el campo argentino por extensión, está inmersa desde hace tiempo en profundas modificaciones estructurales, atinentes a sus actividades agropecuarias, con repercusiones acusadas en todas las facetas económicas, laborales, sociales y políticas que interactúan en la misma.

La intromisión de grandes capitales, de técnicas refinadas de última generación y de nuevos sectores sociales con un fuerte perfil productivista, va a alterar de raíz el tradicional 
marco en que se apoyaba la estructura agraria preexistente, donde el ingreso manifiesto de un capitalismo avanzado en las actividades agropecuarias trae como consecuencia -entre otrasuna fuerte concentración de mando de los principales factores económicos por parte de limitados pero calificados agentes sociales.

Dentro de este contexto, nuestra motivación central en esta instancia, pasa por indagar hasta qué extremo el fenómeno de la sojización afecta a los otros cultivos pampeanos y a las actividades ganaderas en general, que se desenvuelven en este medio.

A partir de esta preocupación, nos interesa analizar específicamente en nuestra región de estudio en primer lugar, hasta qué punto el proceso de agriculturización que conlleva a la implantación masiva de la soja, afecta la expansión areal y la producción en toneladas de los demás cultivos que tradicionalmente se vienen practicando en la zona -con especial referencia a los cereales-, como igualmente en la actividad ganadera, y en segundo lugar, las consiguientes repercusiones que desencadena este fenómeno en el ámbito económico y social en el sur cordobés, pero que se explicitan básicamente en otras partes de esta tesis.

Queda claro que a lo largo de este trabajo se pone el "ojo" en el comportamiento expansivo de la soja -fenómeno generador de beneficios inmediatos y de resultados posiblemente inciertos en un futuro no lejano-, ya sea en forma explícita e implícita.

En concreto, a lo arriba expresado lo podemos ampliar y especificar esquemáticamente en los siguientes objetivos:

- Analizar la evolución general de la producción agrícola y ganadera de los últimos veinte años en nuestra región.

- Diferenciar y comparar el incremento de las superficies sembradas y de los volúmenes en toneladas de producción obtenida de los cereales y oleaginosas en el área.

- Indagar hasta qué punto el proceso de agriculturización incide en la permanencia de las explotaciones mixtas (ganadería y agricultura) en la zona.

- Analizar hasta qué extremo la expansión de la soja le quita espacio y relevancia en la producción a los otros cultivos y a la ganadería.

- Contribuir, en base a los análisis arriba nombrados, a la mejor captación de las consecuencias que derivan del actual desarrollo rural de la región.

En lo que respecta a la metodología empleada, ésta -al igual que el tema central anterior- se basa principalmente en un trabajo de gabinete, con el apoyo de información directa de encuestas y de entrevistas a varios agentes productivos calificados, obtenida a través de los trabajos de campo anteriormente realizados sobre el mismo espacio asignado al 
actual estudio. Se vale especialmente de los datos provenientes de los Censos Nacionales Agropecuarios de 1988 y 2002 y de la información estadística correspondiente a las campañas agrícolas 1988/89-2009/10 provista por el Ministerio de Agricultura, Ganadería y Alimentos de la provincia de Córdoba, y de otras referencias - encuestas y relevamientos agropecuariosprovenientes de instituciones ligadas al agro.

En suma, la mecánica central de trabajo consiste en analizar las variables pertinentes a la estructura agraria productiva, a fin de detectar cómo ha evolucionado la producción agropecuaria de nuestra área de estudio, para luego indagar sobre el accionar de los principales agentes productivos en la estructura anteriormente nombrada y en la estructura agraria fundiaria, como así también en el desenvolvimiento socio-económico a nivel regional, entre otros aspectos a considerar. Asuntos todos que se seguirán profundizando y desarrollando en los capítulos siguientes.

En lo atinente a la caracterización agroproductiva del área de trabajo, los cuatro departamentos bajo estudio -hasta el Censo Nacional Agropecuario de 1988- conformaban una región heterogénea. Los mismos estaban afectados por diferentes sistemas productivos, dentro de una relativa macro homogeneidad de actividades mixtas ganadero-agrícolas en el extremo sur del área, virando a agrícola-ganadera hacia el extremo norte de la misma. A esta diversidad de sistemas la especifica muy bien Andrés Barsky (1997) -entre otros autores (Cascardo, Pizarro, Peretti y Gómez, 1991; Peretti, 2003)- en La puesta en valor y producción del territorio como generadores de nuevas geografías. Propuesta metodológica de zonificación agroproductiva de la Pampa Argentina a partir de los datos del CNA 1988, donde a partir de la información que brinda el Censo Nacional Agropecuario de 1988 toma como indicador central el "valor de la producción" de los recursos agrícolas que genera cada zona diseñada por él. Actualmente, con la nueva oleada sojera, y en menor término con la propagación areal de otros cultivos en la zona, ha cambiado sustancialmente la situación descripta precedentemente, homogeneizándose en gran parte las actividades productivas que se llevan a cabo en el espacio comprendido por los cuatro departamentos. Justamente el análisis de esta novedosa realidad productiva es lo que se describirá a continuación.

En suma, la regionalización que en este estudio establecemos tomando como recorte territorial a los cuatro departamentos mencionados (Mapa $\mathrm{N}^{\mathrm{o}} 12$ ), no se apoya ni en los factores naturales ni en los productivos, dado que los mismos se extienden a otros espacios; a lo sumo, éstos colaboran de forma muy genérica y acotada en la individualización de algunos rasgos geográficos de dicho espacio. En cambio, sí caracterizamos a este territorio -como ya lo afirmamos anteriormente- desde un criterio político-administrativo e histórico-social, 
apoyándonos a su vez, en cierta tradición que acostumbra involucrar a estos cuatro departamentos para definir la región sur de la provincia de Córdoba.

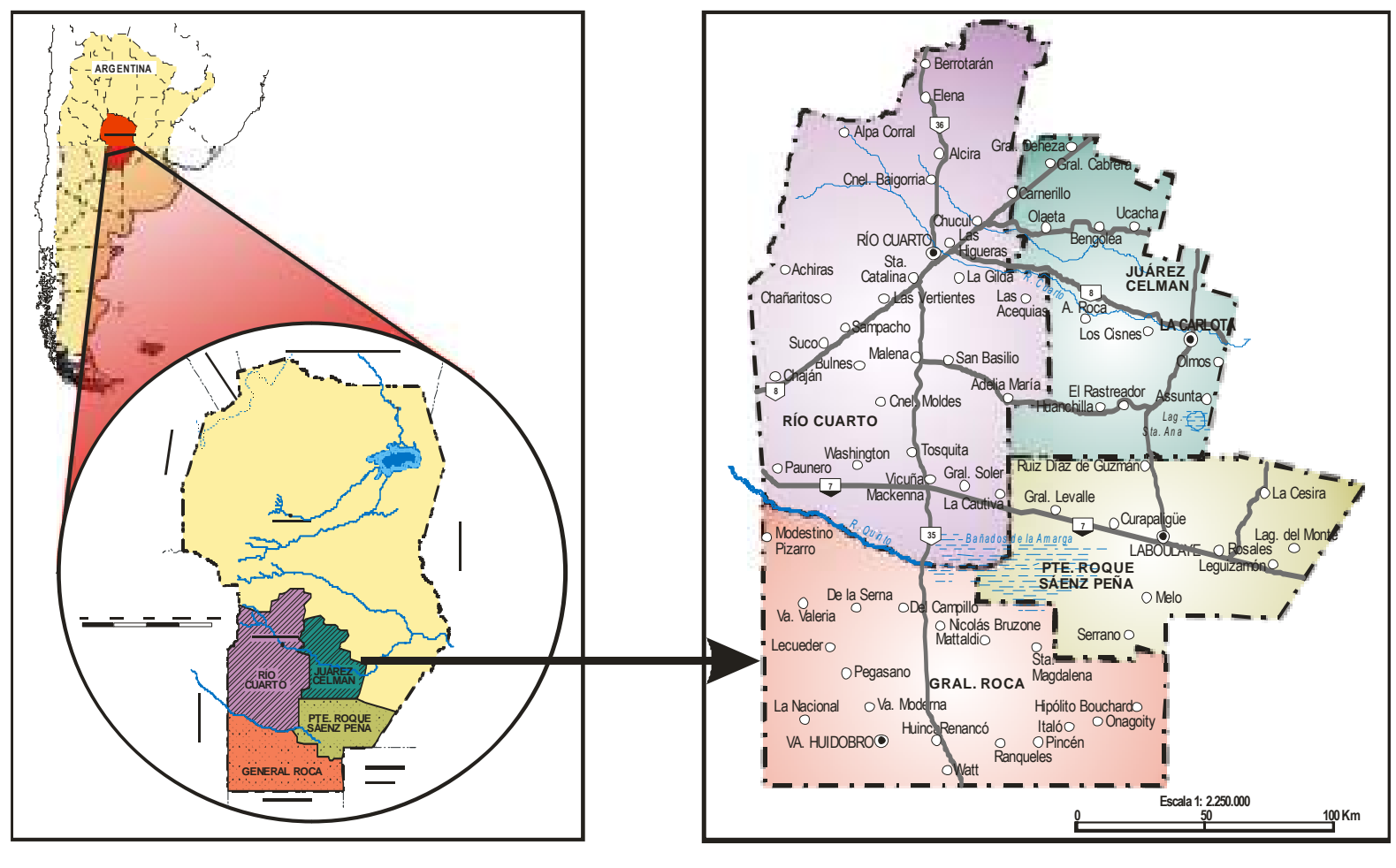

Escala nacional y provincial

Área de estudio

Mapa $\mathrm{N}^{\circ}$ 12. Localización detallada del área de estudio

En este sentido, cabe recordar que distinguimos a este espacio como el área que más tiempo tardó en incorporarse en términos socio-económicos al resto del territorio provincial de manera efectiva.

Por otra parte, dijimos que recién a partir de fines del siglo XIX y principios del XX, mediante el trazado progresivo de varias líneas ferroviarias que atraviesan el sur cordobés, principalmente en el sentido este-oeste, es cuando realmente se da comienzo al poblamiento, colonización -ésta de fuerte procedencia inmigratoria- y puesta en producción de este vasto espacio, acontecimientos que en este estudio circunscribimos, de forma un tanto arbitraria inevitablemente y con un propósito eminentemente práctico, a los cuatro departamentos arriba mencionados.

La cohesión espacial que luego se va a conformar en esta región, como pasa en muchas otras áreas del país, va a resultar incompleta, no del todo bien entrelazados los factores geográficos intervinientes; no obstante, la ciudad de Río Cuarto -históricamente un tanto desvinculada de la ciudad capital- funciona hasta cierto punto como centro aglutinador, 
disminuyendo progresivamente su influencia hacia los extremos sur y oriental del territorio en cuestión.

A continuación de esta descripción y de haberse planteado inicialmente el núcleo de la discusión principal que motiva este trabajo, pasamos al desarrollo concreto del mismo, empezando por analizar las variables de los cultivos de granos de la estructura agraria productiva, tanto a nivel provincial como de la región sur de la provincia de Córdoba, a fin de detectar comparativamente los cambios evolutivos registrados en el lapso intercensal 19882002 .

\subsubsection{Análisis comparativo de los Censos Nacionales Agropecuarios de 1988 y 2002, sobre el tipo de uso de la tierra de las EAPs* y de las superficies implantadas con cereales y oleaginosas, según departamentos involucrados}

Con respecto a la Superficie total de las EAPs, por tipo de uso de la tierra, observamos en el Cuadro $\mathrm{N}^{\mathrm{o}} 38$, a nivel provincial, que en la franja correspondiente a la superficie implantada figura un incremento intercensal en hectáreas considerable de los cultivos anuales $(56 \%)$ y una disminución acentuada de las forrajeras anuales (-46\%) y perennes (-25\%).

En la franja de la Superficie destinada a otros usos, la disminución en hectáreas se torna notoria en la columna de Pasturas naturales y en menor término en la de Bosques y/o montes naturales.

Es evidente que el incremento en superficie de los cultivos anuales se ha hecho a costa de ocupar en gran parte los espacios liberados por las forrajeras, pasturas y montes naturales arriba mencionados, lo que estaría indicando un avance notorio de estos cultivos sobre tierra destinada tradicionalmente a la ganadería.

Considerando ahora la sumatoria de los cuatro departamentos que constituyen el sur cordobés, vemos que -al igual que a nivel provincial- se destaca un importante incremento de la superficie de los cultivos anuales (57\%) y una disminución notoria de las forrajeras, como asimismo de las pasturas y montes naturales. Aquí también se hace evidente el avance de los cultivos anuales, a costa de los espacios dedicados a la ganadería. Por otra parte, es interesante observar, en la columna destinada a Bosques y/o montes implantados dentro de la superficie reducida que ocupa a nivel comparativo, un incremento notable de su expansión areal entre los dos censos. Esto se debe particularmente al avance de la forestación que se

* Explotaciones agropecuarias. 
Cuadro $\mathbf{N}^{\circ}$ 38. Superficie total de las EAPs, por tipo de uso de la tierra, según departamentos involucrados

\begin{tabular}{|c|c|c|c|c|c|c|c|c|c|c|c|c|c|c|c|}
\hline \multirow[b]{2}{*}{ Departamento } & \multirow[b]{2}{*}{$\begin{array}{c}\text { Superficie } \\
\text { total de las } \\
\text { EAPs }\end{array}$} & \multicolumn{7}{|c|}{ Superficie implantada en ha } & \multicolumn{7}{|c|}{ Superficie destinada a otros usos en ha } \\
\hline & & Total & $\begin{array}{l}\text { Cultivos } \\
\text { anuales }\end{array}$ & $\begin{array}{c}\text { Cultivos } \\
\text { perennes }\end{array}$ & $\begin{array}{c}\text { Forrajeras } \\
\text { anuales }\end{array}$ & $\begin{array}{l}\text { Forrajeras } \\
\text { perennes }\end{array}$ & $\begin{array}{l}\text { Bosques } \\
\text { y/o } \\
\text { montes }\end{array}$ & $\begin{array}{l}\text { Cultivos } \\
\text { sin } \\
\text { discriminar }\end{array}$ & Total & $\begin{array}{l}\text { Pasturas } \\
\text { naturales }\end{array}$ & $\begin{array}{c}\text { Bosques y/o } \\
\text { montes } \\
\text { naturales }\end{array}$ & $\begin{array}{c}\text { Superficie } \\
\text { apta no } \\
\text { utilizada }\end{array}$ & $\begin{array}{l}\text { Superficie } \\
\text { no apta o } \\
\text { de } \\
\text { desperdicio }\end{array}$ & $\begin{array}{l}\text { Caminos, } \\
\text { parques y } \\
\text { viviendas }\end{array}$ & $\begin{array}{c}\text { Sin } \\
\text { discriminar } \\
\text { uso }\end{array}$ \\
\hline $\begin{array}{l}\text { Provincia de } \\
\text { Córdoba } 1988\end{array}$ & $13.724 .885,5$ & $7.215 .042,3$ & $3.015 .594,5$ & $8.696,1$ & $2.021 .053,2$ & $2.102 .481,6$ & $36.685,3$ & $30.531,6$ & $6.509 .843,2$ & $3.119 .349,4$ & 2.195.251,2 & $280.581,7$ & $668.530,0$ & $246.130,9$ & \\
\hline $\begin{array}{l}\text { Provincia de } \\
\text { Córdoba } 2002\end{array}$ & $12.244 .257,8$ & $7.437 .338,2$ & $4.703 .861,8$ & $5.579,9$ & $1.096 .215,8$ & $1.580 .743,8$ & $29.648,8$ & $21.288,1$ & $4.806 .919,6$ & $2.105 .367,4$ & $1.923 .731,9$ & 222.214,6 & $410.997,5$ & 123.790 .3 & 7,9 \\
\hline Diferencia $\mathrm{N}^{\circ}$ & $-1.480 .627,7$ & $+222.295,9$ & $+1.688 .267,3$ & $-3.116,2$ & $-924.837,4$ & $-521.737,5$ & $-7.036,5$ & $-9.243,5$ & $-1.702 .923,6$ & $-1.013 .982,0$ & $-271.519,3$ & $-58.367,1$ & $-257.532,5$ & $-122.340,6$ & \\
\hline Diferencia \% & $-10,8 \%$ & $+3,1 \%$ & $+56 \%$ & $-35,8 \%$ & $-45,8 \%$ & $-24,8 \%$ & $-19,2 \%$ & $-30,3 \%$ & $-26,2 \%$ & $-32,5 \%$ & $-12,4 \%$ & $-20,8 \%$ & $-38,5 \%$ & $-49,7 \%$ & \\
\hline $\begin{array}{c}\text { General Roca } \\
1988 \\
\end{array}$ & $1.188 .890,5$ & $792.738,9$ & $194.705,3$ & 1,9 & $234.303,9$ & $363.241,3$ & 481,5 & 5 & $396.151,6$ & $194.988,6$ & 82.357 & $21.775,5$ & $73.462,4$ & $23.568,1$ & \\
\hline $\begin{array}{l}\text { General Roca } \\
2002\end{array}$ & $1.052 .151,7$ & $727.827,5$ & $329.866,5$ & - & $165.181,0$ & $231.782,0$ & 812,0 & 186,0 & $324.324,2$ & $107.805,8$ & $79.078,2$ & $57.353,0$ & $71.876,4$ & $8.210,8$ & \\
\hline Diferencia $\mathrm{N}^{0}$ & $-136.758,8$ & $-64.911,4$ & $+135.161,2$ & - & $-69.122,9$ & $-131.459,3$ & $+330,5$ & +181 & $-71.827,4$ & $-87.182,8$ & $-3.278,2$ & $+35.577,5$ & -1.586 & $-15.357,3$ & \\
\hline Diferencia \% & $-11,5 \%$ & $-8,2 \%$ & $+69,4 \%$ & - & $-29,5 \%$ & $-36,2 \%$ & $+68,8 \%$ & & $-18,1 \%$ & $-44,7 \%$ & $-4 \%$ & $+163,4 \%$ & $-2,2 \%$ & $-65,2 \%$ & \\
\hline $\begin{array}{l}\text { Pte. R. Sáenz } \\
\text { Peña } 1988\end{array}$ & $782.565,5$ & $429.026,9$ & $160.427,5$ & - & $92.311,5$ & $175.953,9$ & 84 & 250 & $353.538,6$ & $222.478,6$ & $5.804,5$ & 51.897 & $61.101,3$ & $12.257,2$ & \\
\hline $\begin{array}{l}\text { Pte. R. Sáenz } \\
\text { Peña } 2002\end{array}$ & $606.634,9$ & $309.159,3$ & $178.079,7$ & - & $31.884,1$ & $98.683,5$ & 508,5 & 3,5 & $297.475,6$ & $203.277,4$ & $1.573,5$ & $26.180,8$ & $60.763,1$ & $5.584,8$ & 96,0 \\
\hline Diferencia $\mathrm{N}^{\circ}$ & $-175.930,6$ & $-119.867,6$ & $+17.652,2$ & - & $-60.427,4$ & $-77.270,4$ & $+424,5$ & $-246,5$ & $-56.063,0$ & $-19.201,2$ & -4.231 & $-25.716,2$ & $-338,2$ & $-6.672,4$ & \\
\hline Diferencia \% & $-22,5 \%$ & $-27,9 \%$ & $+11 \%$ & - & $-65,5 \%$ & $-43,9 \%$ & $+505,4 \%$ & & $-15,9 \%$ & $-8.6 \%$ & $-72,9 \%$ & $-49,6 \%$ & $-0,6 \%$ & $-54,4 \%$ & \\
\hline $\begin{array}{c}\text { Juárez } \\
\text { Celman } 1988 \\
\end{array}$ & $737.576,2$ & $514.397,6$ & $252.745,8$ & 7,2 & $123.422,5$ & $137.723,1$ & 493,3 & 5,7 & 223.178,6 & $125.342,9$ & $2.857,8$ & 12.954 & $49.685,9$ & 32.338 & \\
\hline $\begin{array}{c}\text { Juárez } \\
\text { Celman } 2002\end{array}$ & $746.631,5$ & $598.336,8$ & $425.170,3$ & 0,1 & $60.669,5$ & $111.625,6$ & 432,2 & 439,1 & $148.294,7$ & $73.739,4$ & $2.587,8$ & $18.891,6$ & $44.601,6$ & $8.343,8$ & 130,5 \\
\hline Diferencia $\mathrm{N}^{\circ}$ & $+9.055,3$ & $+83.939,2$ & $+172.424,5$ & $-7,1$ & -62.753 & $-26.097,5$ & $-61,1$ & $+433,4$ & $-74.883,9$ & $-51.603,5$ & -270 & $+5.937,6$ & $-5.084,3$ & $-23.994,2$ & \\
\hline Diferencia \% & $+1,2 \%$ & $+16,3 \%$ & $+68,2 \%$ & & $-50,8 \%$ & $-19 \%$ & $-12,4 \%$ & & $-33,6 \%$ & $-41,2 \%$ & $-9,9 \%$ & $+45,8 \%$ & $-10,2 \%$ & $-74,2 \%$ & \\
\hline $\begin{array}{c}\text { Río Cuarto } \\
1988 \\
\end{array}$ & 1.703 .378 & 1.201.925,6 & $420.286,7$ & 41,9 & $443.852,3$ & 333.100 & $4.042,4$ & 602,3 & $501.452,4$ & $291.385,3$ & $41.956,7$ & $40.457,0$ & $92.394,0$ & $35.259,4$ & \\
\hline $\begin{array}{l}\text { Río Cuarto } \\
2002\end{array}$ & 1.468.291,2 & 1.131.833,1 & $679.318,6$ & 43,0 & $248.690,7$ & $195.458,5$ & $7.806,0$ & 516,3 & $336.458,1$ & $230.019,7$ & $26.714,0$ & $14.652,4$ & $48.410,9$ & $14.682,1$ & $1.979,0$ \\
\hline Diferencia $\mathrm{N}^{\circ}$ & $-235.086,8$ & $-70.092,5$ & $+259.031,9$ & $+1,1$ & $-195.161,6$ & $-137.641,5$ & +3.764 & -86 & $-164.994,3$ & $-61.365,6$ & $-15.242,7$ & $-25.804,6$ & $-43.983,1$ & $-20.577,3$ & \\
\hline Diferencia \% & $-13,8 \%$ & $-5,8 \%$ & $+61,6 \%$ & & $-44 \%$ & $-41,3 \%$ & $+93,1 \%$ & & $-32,9 \%$ & $-21,1 \%$ & $-36,3 \%$ & $-63,8 \%$ & $-47,6 \%$ & $-58,4 \%$ & \\
\hline ¿ 4 Dptos.1988 & $4.412 .410,2$ & 2.938 .089 & 1.028.165,3 & 51 & $893.890,2$ & $1.010 .018,3$ & $5.101,2$ & 863,0 & 1.474.321,2 & $834.195,4$ & $132.976,0$ & $127.083,5$ & $276.843,6$ & $103.422,7$ & $<$ \\
\hline ¿ 4 Dptos. 2002 & $3.873 .709,3$ & 2.767.156,7 & $1.612 .435,1$ & 43,1 & $506.425,3$ & $637.549,6$ & $9.558,7$ & $1.144,9$ & $1.106 .552,6$ & $614.842,3$ & $109.953,5$ & $117.077,8$ & $225,652,0$ & $36.821,5$ & $2.205,5$ \\
\hline Diferencia $\mathrm{N}^{\circ}$ & $-538.700,9$ & $-170.932,3$ & $+584.269,8$ & -7.9 & $-387.464,9$ & $-372.468,7$ & $+4.457,5$ & +281.9 & $-367.768,6$ & $-219.353,1$ & $-23.022,5$ & $-10.005,7$ & $50.991,6$ & $-66.601,2$ & $+2.205,5$ \\
\hline Diferencia \% & $-12,2 \%$ & $-5,8 \%$ & $+56,8 \%$ & $-15,5 \%$ & $-43,4 \%$ & $-36,9 \%$ & $+87,4 \%$ & $+32,7 \%$ & $-24,9 \%$ & $-26,3 \%$ & $-17,3 \%$ & $-7,9 \%$ & $-18,4 \%$ & $-64,4 \%$ & \\
\hline
\end{tabular}

Fuente: Elaboración propia en base a datos procedentes de los Censos Nacionales Agropecuarios de 1988 y 2002. 
llevó a cabo en dicho período intercensal, en las serranías y piedemonte que se recuestan al oeste del Dpto. Río Cuarto.

En concreto, tanto a nivel provincial como en el conjunto de los cuatro departamentos, no ha habido en el lapso analizado una variación areal sustancial en el total de la superficie implantada de las EAPs - al margen de un pequeño incremento en el total provincial (3\%) y de una suave disminución en el total de los departamentos involucrados (-6\%)-; en cambio, sí se ha producido en esta franja un reacomodamiento en el uso de la tierra.

En relación con la Superficie implantada de las EAPs, por grupo de cultivos (Cuadro $\mathrm{N}^{\mathrm{o}}$ 39), se observa a nivel provincial, considerando el desdoblamiento de los cultivos anuales en cereales para granos y oleaginosas, un importante aumento en hectáreas para el año 2002 de los primeros (42\%) y un incremento sustancial de las segundas (108\%), donde la incidencia de la soja en este caso desempeña un papel preponderante. En el caso de las forrajeras anuales y perennes, se detecta, al igual que en el cuadro anterior, una fuerte caída intercensal. En cambio, vemos, de acuerdo con la sumatoria de los cuatro departamentos, que la superficie destinada a los cereales para granos apenas ha sufrido un limitado incremento $(6,6 \%)$ en el período, a diferencia de las oleaginosas, cuyo incremento es más que importante (144\%), correspondiendo a las forrajeras un similar declive al que se registra en el nivel provincial.

En la desagregación por departamentos del sur cordobés, detectamos para el año 2002 en General Roca y Pte. Roque Sáenz Peña una verdadera irrupción de los sembradíos de oleaginosas, donde no tenía presencia destacada en años anteriores, y un leve declive en la superficie implantada con cereales, que indica a las claras el cambio de preferencias de los agricultores por el primer tipo de cultivos.

A su vez, se observa en los departamentos Juárez Celman y Río Cuarto, donde ya existía una tradición en los cultivos de oleaginosas, un incremento areal acusado de los mismos - especialmente en el Dpto. Río Cuarto (163\%)- para el censo del año 2002, con la relevancia de que en el Dpto. Juárez Celman se registra también un aumento significativo de la superficie implantada con cereales para granos, en concordancia con su marcada vocación agrícola.

En suma, de acuerdo con los guarismos registrados en el censo del año 2002, queda en evidencia el incremento sobresaliente en superficie de los cultivos de oleaginosas - de la mano de la soja, naturalmente-, tanto a nivel provincial como a nivel de nuestra región. Pero se debe considerar que los cultivos de los cereales para granos, aunque en menor escala, también acusan en el plano provincial un aumento destacado; en cambio no se da así en el sur cordobés, cuyo leve repunte intercensal, por otra parte, nos está indicando que no 
obligadamente el aumento de los cultivos de soja implica que tengan que disminuir los cultivos destinados a los cereales para granos.

Cuadro $N^{\circ}$ 39. Superficie implantada de las EAPs, por grupos de cultivo, según departamentos involucrados y período de ocupación, en ha

\begin{tabular}{|c|c|c|c|c|c|c|c|}
\hline Departamento & $\begin{array}{l}\text { Período de } \\
\text { ocupación } 1\end{array}$ & Total & $\begin{array}{c}\text { Cereales para } \\
\text { grano }\end{array}$ & Oleaginosas & $\begin{array}{c}\text { Forrajeras } \\
\text { anuales }\end{array}$ & $\begin{array}{c}\text { Forrajeras } \\
\text { perennes }\end{array}$ & $\begin{array}{l}\text { Otros } \\
\text { cultivos }\end{array}$ \\
\hline \multirow{3}{*}{$\begin{array}{l}\text { Provincia de } \\
\text { Córdoba } 1988\end{array}$} & Primera & $7.215 .042,3$ & $1.505 .072,7$ & $1.505 .174,2$ & $2.021 .053,2$ & $2.102 .481,6$ & $81.260,6$ \\
\hline & Segunda & $571.291,6$ & $66.826,9$ & $278.679,4$ & $195.055,1$ & $29.389,8$ & $1.340,4$ \\
\hline & Total & $7.786 .333,9$ & $1.571 .899,6$ & $1.783 .853,6$ & $2.216 .108,3$ & $2.131 .871,4$ & $82.601,0$ \\
\hline \multirow{3}{*}{$\begin{array}{l}\text { Provincia de } \\
\text { Córdoba } 2002\end{array}$} & Primera & $7.437 .338,2$ & $2.175 .001,6$ & $2.520 .667,0$ & $1.096 .215,8$ & $1.580 .743,8$ & $64.710,0$ \\
\hline & Segunda & $1.349 .155,9$ & $54.508,6$ & $1.189 .876,9$ & $98.218,1$ & - & $6.552,5$ \\
\hline & Total & $8.786 .494,1$ & $2.229 .510,2$ & $3.710 .543,9$ & $1.194 .433,9$ & $1.580 .743,8$ & $71.262,5$ \\
\hline \multicolumn{2}{|l|}{ Diferencia $\mathrm{N}^{0}$} & $+1.000 .160,2$ & $+657.610,6$ & $+1.926 .690,3$ & $-1.021 .674,4$ & $-551.127,6$ & $-11.338,5$ \\
\hline \multicolumn{2}{|l|}{ Diferencia \% } & $+12,8 \%$ & $+41,8 \%$ & $+108,0 \%$ & $-46,1 \%$ & $-25,9 \%$ & $-13,7 \%$ \\
\hline \multirow{3}{*}{$\begin{array}{c}\text { General Roca } \\
1988\end{array}$} & Primera & $792.738,9$ & $130.516,3$ & $64.189,0$ & $234.303,9$ & $363.241,3$ & 488,4 \\
\hline & Segunda & $64.598,3$ & $15.089,0$ & $9.309,0$ & $34.205,3$ & $5.995,0$ & - \\
\hline & Total & $857.337,2$ & $145.605,3$ & $70.498,0$ & $268.509,2$ & $369.236,3$ & 488,4 \\
\hline \multirow{3}{*}{$\begin{array}{c}\text { General Roca } \\
2002\end{array}$} & Primera & $727.827,5$ & $125.303,5$ & $204.433,0$ & $165.181,0$ & $231.782,0$ & $1.128,0$ \\
\hline & Segunda & $76.683,0$ & $12.368,0$ & $43.797,0$ & $20.518,0$ & - & - \\
\hline & Total & $804.510,5$ & $137.671,5$ & $248.230,0$ & $185.699,0$ & $231.782,0$ & $1.128,0$ \\
\hline \multicolumn{2}{|l|}{ Diferencia $\mathrm{N}^{0}$} & $-52.826,7$ & $-7.933,8$ & $+177.732,0$ & $-82.810,2$ & $-137.454,3$ & $+639,6$ \\
\hline \multicolumn{2}{|l|}{ Diferencia \% } & $-6,2 \%$ & $-5,5 \%$ & $+252,1 \%$ & $-30,8 \%$ & $-37,2 \%$ & $+130,9 \%$ \\
\hline \multirow{3}{*}{$\begin{array}{c}\text { Juárez Celman } \\
1988\end{array}$} & Primera & $514.397,6$ & $110.463,3$ & $142.279,5$ & $123.422,5$ & $137.723,1$ & 509,2 \\
\hline & Segunda & $30.246,6$ & $3.968,0$ & $13.622,2$ & $11.785,9$ & 870,0 & 0,5 \\
\hline & Total & $544.644,2$ & $114.431,3$ & $155.901,7$ & $135.208,4$ & $138.593,1$ & 509,7 \\
\hline \multirow{3}{*}{$\begin{array}{c}\text { Juárez Celman } \\
2002\end{array}$} & Primera & $598.336,8$ & $165.836,1$ & $259.324,2$ & $60.669,5$ & $111.625,6$ & $1.999,4$ \\
\hline & Segunda & $71.739,4$ & $1.699,0$ & $62.503,9$ & $6.418,5$ & - & - \\
\hline & Total & $670.076,2$ & $167.535,1$ & $321.828,1$ & $67.088,0$ & $111.628,6$ & $1.999,4$ \\
\hline \multicolumn{2}{|l|}{ Diferencia $\mathrm{N}^{0}$} & $+125.431,8$ & $+53.103,8$ & $+165.926,4$ & $-68.120,4$ & $-26.967,5$ & $+1.489,7$ \\
\hline \multicolumn{2}{|l|}{ Diferencia \% } & $+23,0 \%$ & $+46,4 \%$ & $+106,4 \%$ & $-50,4 \%$ & $-19,5 \%$ & $+292,3 \%$ \\
\hline \multirow{3}{*}{$\begin{array}{l}\text { Pte. R. Sáenz } \\
\text { Peña } 1988\end{array}$} & Primera & $429.026,9$ & $97.868,5$ & $62.559,0$ & $92.311,5$ & $175.953,9$ & 334,0 \\
\hline & Segunda & $27.879,5$ & $2.932,5$ & $12.711,0$ & $9.047,5$ & $3.188,5$ & - \\
\hline & Total & $456.906,4$ & $100.801,0$ & $75.270,0$ & $101.359,0$ & $179.142,4$ & 334,0 \\
\hline \multirow{3}{*}{$\begin{array}{l}\text { Pte. R. Sáenz } \\
\text { Peña } 2002\end{array}$} & Primera & $309.159,3$ & $85.148,2$ & $92.749,5$ & $31.884,1$ & $98.683,5$ & 694,0 \\
\hline & Segunda & $50.965,8$ & $1.636,0$ & $48.303,2$ & $1.026,6$ & - & - \\
\hline & Total & $360.125,1$ & $86.784,2$ & $141.052,7$ & $32.910,7$ & $98.683,5$ & 694,0 \\
\hline \multicolumn{2}{|l|}{ Diferencia $\mathrm{N}^{\circ}$} & $-96.781,3$ & $-14.016,8$ & $+65.782,7$ & $-68.448,3$ & $-80.458,9$ & $+360,0$ \\
\hline \multicolumn{2}{|l|}{ Diferencia \% } & $-21,2 \%$ & $-13,9 \%$ & $+87,4 \%$ & $-67,5 \%$ & $-44,9 \%$ & $+107,8 \%$ \\
\hline \multirow{3}{*}{ Río Cuarto 1988} & Primera & $1.201 .925,6$ & $253.536,1$ & $166.796,6$ & $443.852,3$ & $333.100,0$ & $4.640,6$ \\
\hline & Segunda & $92.381,7$ & $20.657,5$ & $10.076,5$ & $52.237,2$ & $9.401,5$ & 9,0 \\
\hline & Total & $1.294 .307,3$ & $274.193,6$ & $176.873,1$ & $496.089,5$ & $342.501,5$ & $4.649,6$ \\
\hline \multirow{3}{*}{ Río Cuarto 2002} & Primera & $1.131 .833,1$ & $274.129,9$ & $404.935,7$ & $248.690,7$ & $195.458,5$ & $8.618,3$ \\
\hline & Segunda & $83.562,1$ & $10.896,7$ & $60.624,4$ & $12.041,0$ & - & - \\
\hline & Total & $1.215 .395,2$ & $285.026,6$ & $465.560,1$ & $260.731,7$ & $195.458,5$ & $8.618,3$ \\
\hline \multicolumn{2}{|l|}{ Diferencia $\mathrm{N}^{0}$} & $-78.912,1$ & $+10.833,0$ & $+288.687,0$ & $-235.357,8$ & $-147.043,0$ & $+3.968,7$ \\
\hline \multicolumn{2}{|l|}{ Diferencia \% } & $-6,1 \%$ & $+3,9 \%$ & $+163,2 \%$ & $-47,4 \%$ & $-42,9 \%$ & $-85,4 \%$ \\
\hline \multicolumn{2}{|c|}{ Sumatoria 4 Dptos.1988 } & $3.153 .195,1$ & $635.031,2$ & $478.541,8$ & $1.001 .166,1$ & $1.029 .473,3$ & $5.981,7$ \\
\hline \multicolumn{2}{|c|}{ Sumatoria 4 Dptos.2002 } & $3.050 .107,0$ & $677.017,4$ & $1.176 .670,9$ & $546.429,4$ & $637.549,6$ & $12.439,7$ \\
\hline \multicolumn{2}{|l|}{ Diferencia $\mathrm{N}^{0}$} & $-103.088,1$ & $+41.986,2$ & $+690.128,9$ & $-454.736,7$ & $-391.923,7$ & $+6.458,0$ \\
\hline Diferencia \% & & $-3,3 \%$ & $+6,6 \%$ & $+145,9 \%$ & $-45,4 \%$ & $-38,1 \%$ & $+108,0 \%$ \\
\hline
\end{tabular}

1 "Primera" representa primera ocupación u ocupación permanente.

Fuente: Elaboración propia en base a datos procedentes de los Censos Nacionales Agropecuarios de 1988 y 2002. 
Cabe destacar, a modo de agregado, que los valores totales de las superficies implantadas de las EAPs en este cuadro y los subsiguientes van a ser un tanto superiores a los registrados en el Cuadro $\mathrm{N}^{\mathrm{o}} 38$, dado que en éstos se contabiliza la primera y segunda ocupación de cultivos que se practica sobre una misma superficie.

A continuación, pasamos a analizar la Superficie implantada con cereales para granos por cultivo, según el Cuadro $\mathrm{N}^{0}$ 40. A nivel provincial, observamos que en el censo de 1988 la mayor superficie implantada corresponde al maíz y en segundo término al trigo, invirtiéndose notoriamente esta disposición en el censo de 2002, lo que se traduce en un incremento sustancial de los cultivos de trigo (149\%) y en un incremento más bien regular de los cultivos de maíz (28\%). En lo que respecta a la superficie de avena y sorgo granífero, detectamos que sufren una caída abrupta entre 1988 y 2002. En cambio, cuando pasamos a considerar nuestra región de estudio en conjunto, vemos que en ambos censos el mayor cultivo implantado recae en el maíz y en segundo término en el trigo, manifestándose en el período intercensal un mayor incremento de este último con respecto al primero, pero con aumentos de las superficies implantadas en ambos cultivos de cereales más atenuadas que a nivel provincial. En nuestra región, también sufren una caída intercensal pronunciada los cultivos de avena y sorgo granífero.

Con respecto al análisis por departamento en el sur cordobés, vemos que en General Roca y Presidente Roque Sáenz Peña sobresalen los cultivos de trigo en ambos registros censales, dado que tradicionalmente por sus condiciones ambientales se han dedicado más a la implantación de este cereal, pero en ambos distritos en el período intercensal se ha producido, a su vez, un pequeño descenso en el total de los cultivos de cereales para grano. En estos resultados ha tenido mucho que ver la disminución pronunciada de los cultivos de avena y sorgo granífero.

En los departamentos Río Cuarto y Juárez Celman, en ambos censos, van a predominar los cultivos de maíz - por ser una zona más apropiada para este tipo de cultivo-, con un incremento intercensal destacado en el segundo distrito. También en los dos departamentos citados, entre 1988 y 2002, se va a manifestar un aumento importante de las superficies implantadas de trigo.

En síntesis, en la sumatoria de los valores departamentales del sur cordobés, los incrementos de los cultivos de trigo y, en menor medida, de los de maíz que acusa el censo del año 2002, no dejan de ser significativos, pero son contrarrestados en el total de la superficie implantada con cereales para grano por la pronunciada caída de los cultivos de avena y sorgo granífero que se manifiesta en el área. 
Cuadro $N^{\circ}$ 40. Superficie implantada con cereales para grano, por cultivo, según departamentos involucrados y período de ocupación, en ha

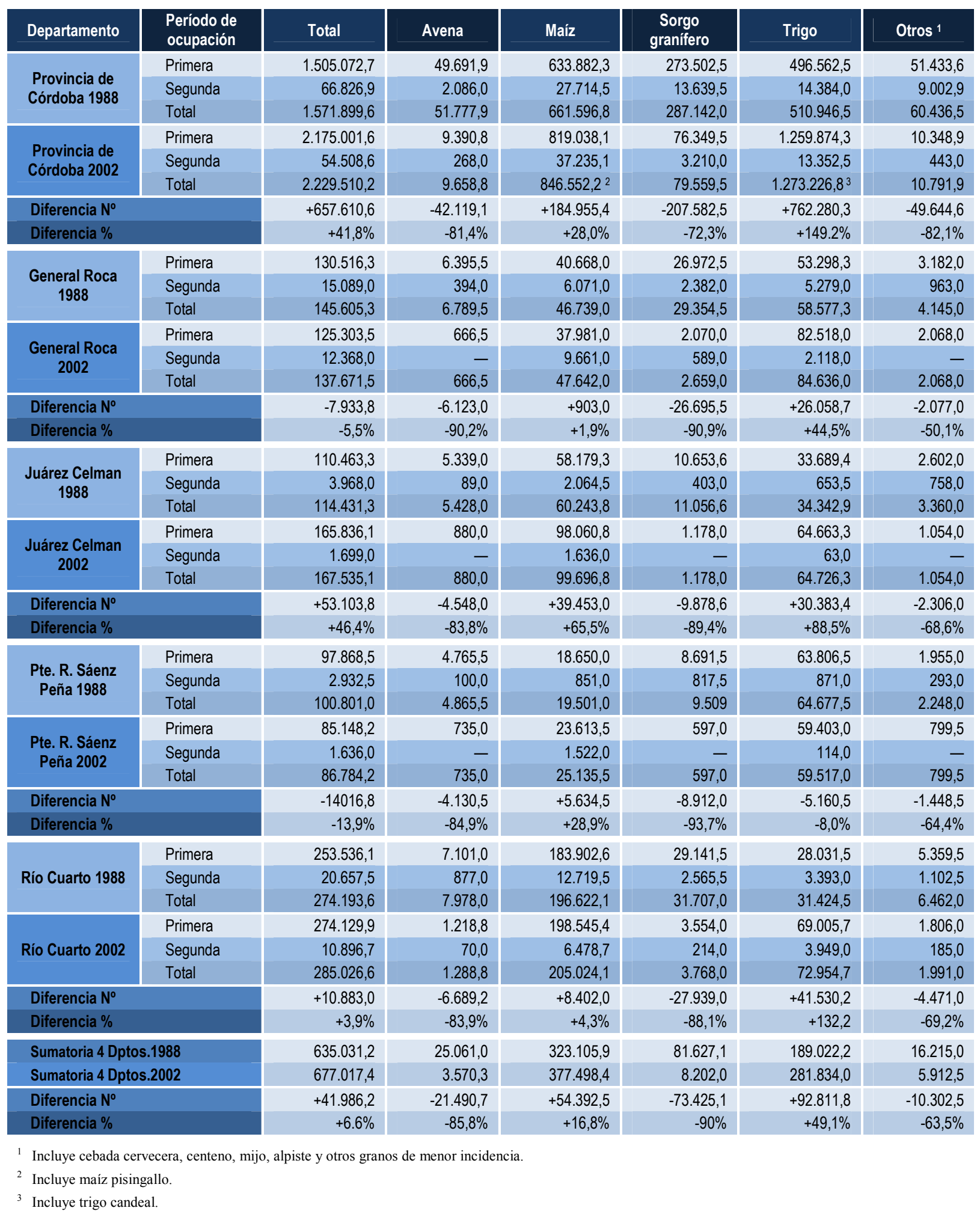

Fuente: Elaboración propia en base a datos procedentes de los Censos Nacionales Agropecuarios de 1988 y 2002

En relación con el análisis de la Superficie implantada con oleaginosas, por cultivo (Cuadro $\mathrm{N}^{\circ} 41$ ), observamos a nivel provincial que en ambos censos predominan abrumadoramente los cultivos de soja, el segundo lugar en el censo 1988 es ocupado por los 
Cuadro $\mathrm{N}^{\circ}$ 41. Superficie implantada con oleaginosas, por cultivo, según departamentos involucrados y período de ocupación, en ha

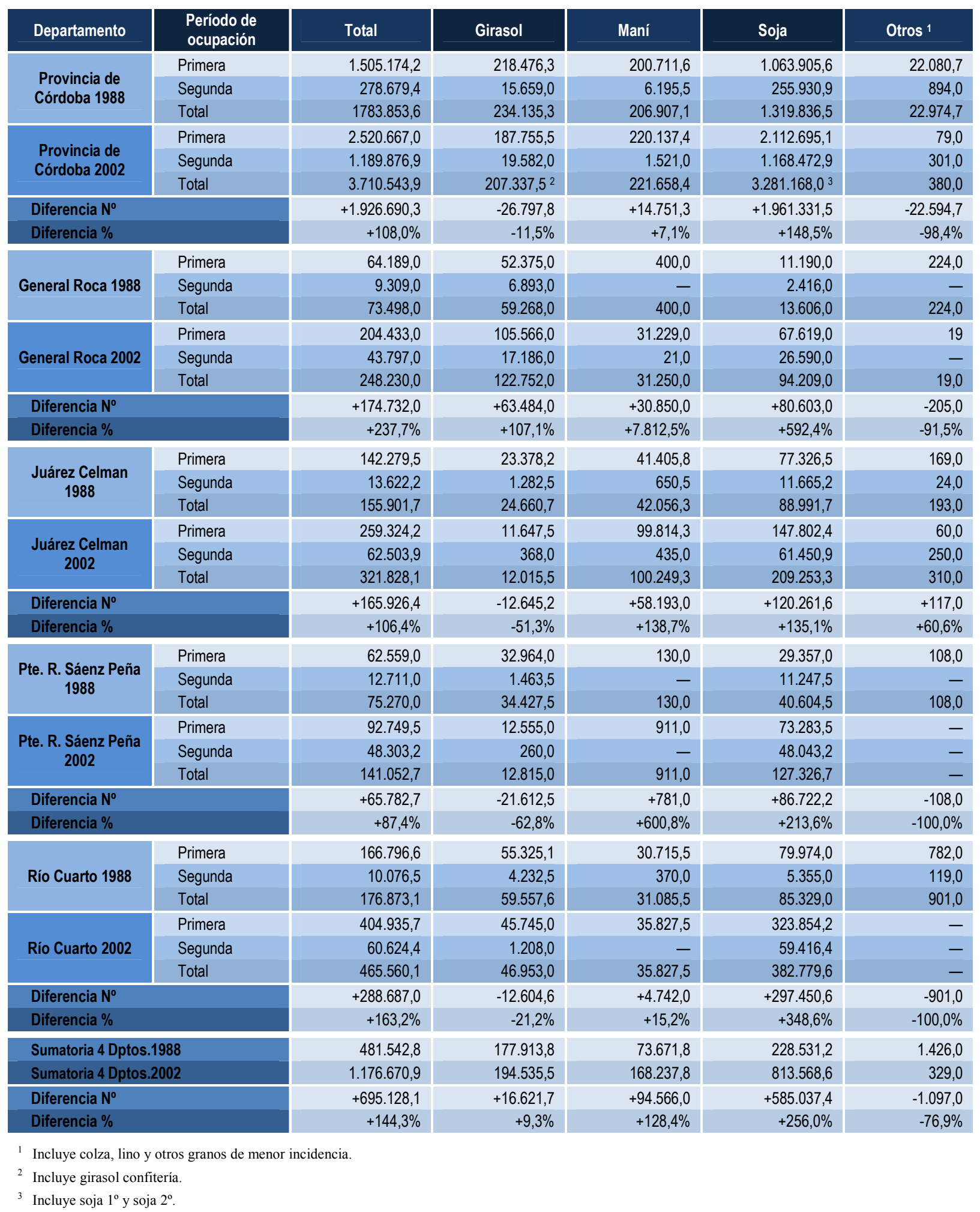

Fuente: Elaboración propia en base a datos procedentes de los Censos Nacionales Agropecuarios de 1988 y 2002.

sembradíos de girasol, pero éste en el 2002 va a ser desplazado por el de maní. En lo que respecta a la evolución intercensal, detectamos un incremento sobresaliente de la soja (148\%), pero no así en el caso del maní y del girasol. Dicha evolución se va a manifestar de manera 
similar en el conjunto departamental del sur cordobés, pero el incremento intercensal en los cultivos de la soja va a ser mucho más agudo (256\%) que a nivel provincial y se diferencia también en que en el censo de 2002 los sembradíos de girasol van a seguir ocupando el segundo lugar, pero con un incremento intercensal limitado. En cambio, no es así en el caso del maní, que a pesar de que todavía no está muy difundido en el extremo sur de la provincia, su cultivo va a acusar un aumento de importancia (128\%). Si desagregamos ahora el análisis a nivel departamental, observamos que en el Dpto. General Roca predomina en ambos censos el cultivo de girasol, con un incremento importante para el año 2002 (107\%), seguido por un sobresaliente repunte de los sembradíos de soja y la aparición prácticamente por primera vez del maní en este último año, con presencia de muchas hectáreas sembradas.

En el caso del Dpto. Roque Sáenz Peña, en ambos censos los cultivos de la soja van a ocupar el primer lugar, con un incremento también importante (214\%) para el año 2002, y con un descenso significativo en los sembradíos de girasol (-63\%).

Por último, en los departamentos Juárez Celman y Río Cuarto, los cultivos de soja van a ocupar en los dos censos el primer lugar, con un incremento intercensal particularmente sobresaliente en este último departamento (349\%). El segundo lugar en el Dpto. Juárez Celman está ocupado en ambos censos por su tradicional cultivo: el maní, con un incremento intercensal de importancia (138\%). Todavía hasta el año 2002 este cultivo se encuentra principalmente focalizado en el citado departamento. En años posteriores, se va a expandir notoriamente hacia todo el sur de la provincia. En cambio, en el Dpto. Río Cuarto, el segundo lugar de la superficie implantada con oleaginosas va a estar ocupado por el girasol, que, a pesar de sufrir una regular disminución intercensal (-21\%), sigue teniendo hasta el censo de 2002 una presencia nada desestimable.

A modo de síntesis, podemos concluir que, tanto a nivel provincial como en nuestra región, los cultivos de soja en el año 2002 acusan ya un repunte sobresaliente, seguido también por el maní, pero en mucho menor término; en cambio, en el caso de los sembradíos de girasol, éstos tienden a estancarse.

Hasta aquí llega el estudio comparado de los dos últimos Censos Nacionales Agropecuarios referidos a la evolución areal de los cultivos. Ahora, en el acápite siguiente, aparte de comparar también la evolución de los granos con otros registros estadísticos, nuestro propósito central pasa por introducir la variable producción en toneladas, obtenida por los cereales y oleaginosas, tanto a nivel provincial como en nuestra región de trabajo. 
5.2.2. Análisis de los resultados de las campañas agrícolas de los principales cereales y oleaginosas (1988/1989-2009/2010), según registros del Ministerio de Agricultura, Ganadería y Alimentos de la provincia de Córdoba ${ }^{4}$

A continuación, pasamos a describir y analizar los datos brindados por dicho organismo, correspondientes a las campañas agrícolas desde 1988/89 hasta 2009/10, que figuran -por razones operativas de tamaño- en el Cuadro $\mathrm{N}^{\mathrm{o}} 2^{5}$ del Anexo de este trabajo.

Si bien dicha información no se puede comparar estrictamente con los datos registrados en los dos censos anteriormente analizados, por obvias diferencias en el armado metodológico, hemos tratado, no obstante, de hacer coincidir el inicio de nuestra secuencia con el año 1988 -fecha correspondiente al primer censo estudiado- hasta los años 2009/2010, con la finalidad, además de efectuar comparaciones aproximativas con los resultados anteriormente descriptos, de introducir información desagregada de "superficies sembradas" y de "producciones obtenidas en toneladas", año por año, de los principales cereales y oleaginosas, a nivel provincial y a nivel de los cuatro departamentos que corresponden al área de estudio, como así también aportar datos lo más recientes posibles.

Entrando ahora en la descripción específica de los resultados que brinda dicho Ministerio, observamos a nivel provincial que la mayor superficie sembrada de granos a lo largo de toda la serie 1988/89-2009/10 corresponde a las oleaginosas (Gráfico No 5 y Cuadro $\mathrm{N}^{\mathrm{o}} 2$ del Anexo), en detrimento de los cereales, donde la soja, que ocupa un lugar preponderante, va a acusar un incremento sustantivo a partir de los años 1988/89 y 2009/10. El girasol y el maní, que si bien acompañan en la sumatoria del total de las oleaginosas, ocupan una superficie limitada. Las principales superficies sembradas de cereales corresponden al maíz y al trigo, y éstas ocupan un espacio mucho menor que la soja.

Con respecto a la mayor producción de granos, vemos en el Gráfico $\mathrm{N}^{\mathrm{o}} 6$ y Cuadro $\mathrm{N}^{\mathrm{o}} 2$ del Anexo que hasta el año 1999/00 fluctuó entre los cereales y las oleaginosas, lo que indica

\footnotetext{
4 Los datos de las mencionadas campañas han sido procesados y elaborados por la Dirección de Control de Gestión y Desarrollo, a través de la UPSIIA (Unidad Provincial de Sistema Integrado de Información Agropecuaria), con información suministrada por agentes zonales del Ministerio de Agricultura, Ganadería y Alimentos de la provincia de Córdoba.

5 Corresponde aclarar que en la secuencia de superficie sembrada y producción obtenida de granos que aquí se presenta, figuran solamente las principales oleaginosas y cereales para granos, que se practican tanto a nivel provincial como en el sur cordobés. En el caso de la soja, girasol y maní -aparte de la relevancia abrumadora de la soja-, prácticamente estos cultivos abarcan la casi totalidad de la producción de oleaginosas. En el caso de los cereales para grano, el terceto de maíz, sorgo y trigo, son claramente preponderantes, pero no excluyentes, quedando un pequeño margen productivo para otros cereales de aprovechamiento granario, que -desde hace muchos años- no lo registra el organismo arriba mencionado. En concreto, en este capítulo, cuando nos referimos en términos comparativos a los cereales para grano y oleaginosos, es como si prácticamente (a nivel cuantitativo) incluyéramos a toda la diversidad de esta clase de granos que se cultivan.
} 
que hasta esa fecha todavía la producción sojera no era preponderante a nivel provincial. Ésta recién se va a consolidar, y por ende arrastrar al conjunto de las oleaginosas, a partir de dicho año, con cifras de producción realmente importantes que llegan en los años 2009/10 a más de catorce millones y medio de toneladas, de las cuales a la soja le corresponde el 96,3\% del total de las oleaginosas obtenidas.

Gráfico $N^{0}$ 5. Superficie sembrada de los totales de cereales y oleaginosas que predomina en cada año agrícola de la serie 1988/89-2009/10. Provincia de Córdoba

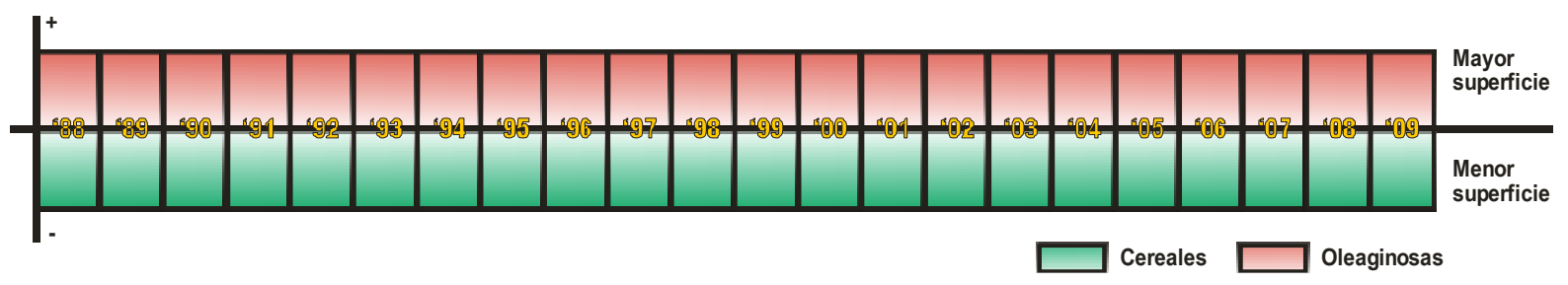

Fuente: Elaboración propia en base a datos procedentes del Ministerio de Agricultura, Ganadería y Alimentos de la provincia de Córdoba

Gráfico $N^{0}$ 6. Producción obtenida de los totales de cereales y oleaginosas que predomina en cada año agrícola de la serie 1988/89-2009/10. Provincia de Córdoba

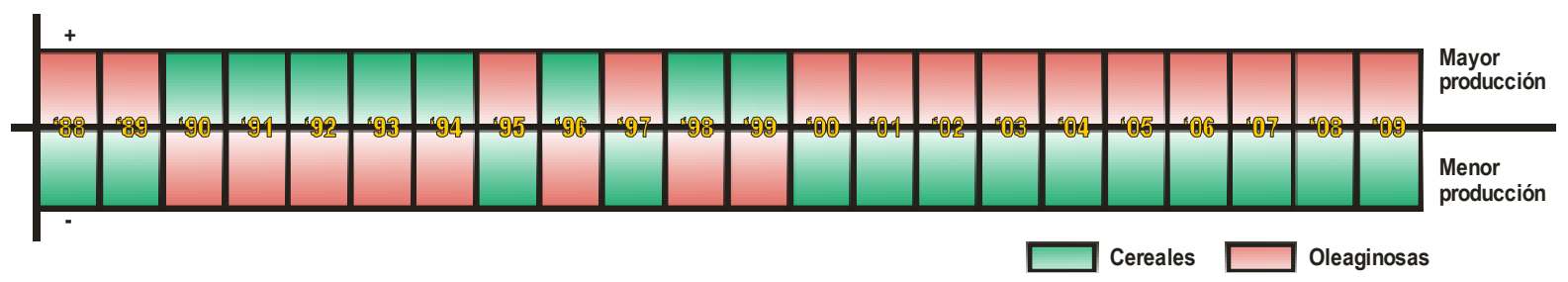

Fuente: Elaboración propia en base a datos procedentes del Ministerio de Agricultura, Ganadería y Alimentos de la provincia de Córdoba

Dentro de los cereales, el maíz y el trigo también acusan un incremento significativo, con las oscilaciones del caso, especialmente del trigo, que si sumamos la producción de los dos granos, o superaron en un momento a las oleaginosas, o no se despegan mucho de las mismas a lo largo de la serie analizada. La producción de sorgo, si bien no es desestimable, en general es de mucho menor volumen que la de los otros dos cereales.

En relación con la región sur de la provincia de Córdoba -donde se suman los valores correspondientes de los cuatro departamentos-, observamos que la mayor superficie sembrada hasta el año 1996 (Gráfico N 7 y Cuadro No 2 del Anexo) -exceptuando el año 1995corresponde a los cereales, donde el maíz y el trigo ocupan un lugar preponderante (Gráfico $\mathrm{N}^{\circ} 8$ ), para luego pasar a ocupar esta supremacía las oleaginosas hasta la última campaña 2009/10. En el caso específico de los sembradíos de soja, recién van a ocupar un lugar destacado en el área a partir del año 2000. El girasol, que solía abarcar espacios importantes hasta el año 2000, declina notoriamente en los años subsiguientes. En el caso del maní, cuyas superficies sembradas fueron siempre limitadas y localizadas especialmente en el Dpto. 
Juárez Celman -dentro de nuestra zona de estudio-, van a oscilar notablemente por un lado y deslocalizarse por otro, al cundir sus sembradíos hacia el extremo sur de la provincia.

\section{Gráfico $\mathrm{N}^{0}$ 7. Superficie sembrada de los totales de cereales y oleaginosas que predomina en cada año agrícola de la serie 1988/89-2009/10. Región Sur de la provincia de Córdoba}

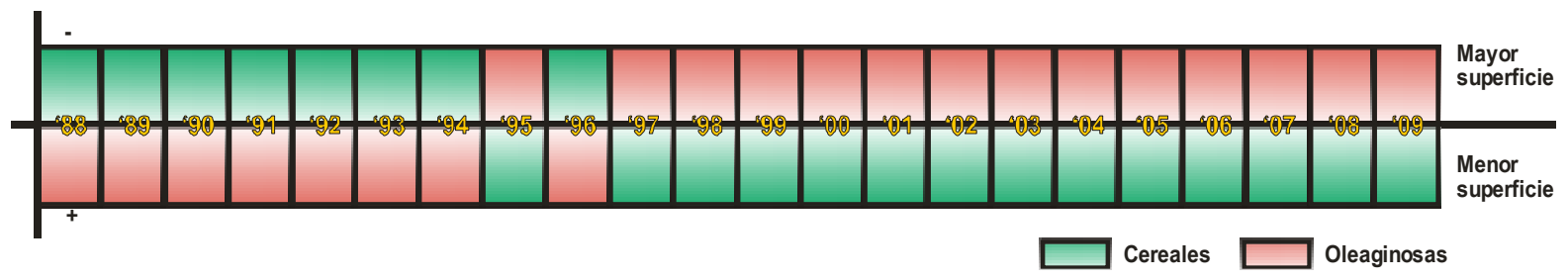

Fuente: Elaboración propia en base a datos procedentes del Ministerio de Agricultura, Ganadería y Alimentos de la provincia de Córdoba

Gráfico No 8. Curva de tendencia de la superficie de maíz, soja y trigo en el período 1988-2009 en la Región Sur de la provincia de Córdoba

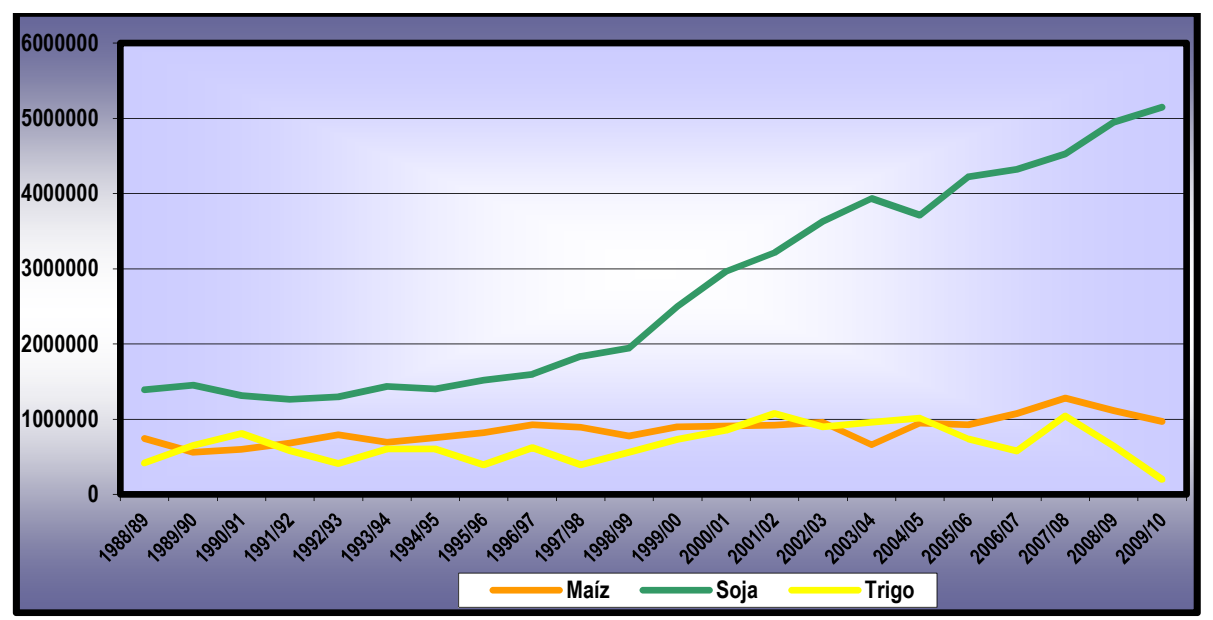

Fuente: Elaboración propia en base a datos procedentes del Ministerio de Agricultura, Ganadería y Alimentos de la provincia de Córdoba

En concreto, vemos que la evolución de las superficies sembradas de granos en nuestra región difiere un tanto de la señalada a nivel provincial, dado que la introducción masiva de la soja se inició más tarde que en otros sectores del campo cordobés.

A modo de síntesis, en este punto, a fin de darle continuidad a los datos estadísticos que se vienen manejando desde el censo de 1988, es interesante comparar de forma aproximativa el crecimiento en superficie sembrada de cereales y oleaginosas de nuestra región, entre los extremos 2002/03 y 2009/10 (Cuadro No 42-a y Cuadro No 2 del Anexo), según los datos provenientes del Ministerio de Agricultura de Córdoba, con el crecimiento de los mismos granos entre 1988 y 2002, según información proveniente de los censos respectivos. ${ }^{6} \mathrm{Se}$ observa, así, que el incremento de la superficie sembrada de oleaginosas entre 2002/03 y 2009/10

6 Es necesario especificar que los datos de superficies sembradas en hectáreas de los años 1988 y 2002 provenientes de los censos respectivos, no coinciden con los guarismos correspondientes a esos mismos años que brinda el Ministerio de Agricultura de Córdoba. 
Cuadro No 42-a. Evolución de las superficies sembradas de granos en el período 2002/03-2009/10 en la Región Sur de la provincia de Córdoba

\begin{tabular}{|c|c|c|c|c|c|c|c|}
\hline \multicolumn{4}{|c|}{ Cereales } & \multicolumn{4}{|c|}{ Oleaginosas } \\
\hline \multirow[b]{2}{*}{ Años } & \multirow{2}{*}{$\begin{array}{c}\text { Superficies } \\
\text { sembradas } \\
\text { (ha) }\end{array}$} & \multicolumn{2}{|c|}{ Variación \% } & \multirow[b]{2}{*}{ Años } & \multirow{2}{*}{$\begin{array}{c}\text { Superficies } \\
\text { sembradas } \\
\text { (ha) }\end{array}$} & \multicolumn{2}{|c|}{ Variación \% } \\
\hline & & $\begin{array}{l}2002-2007 \\
2007-2009\end{array}$ & 2002-2009 & & & $\begin{array}{l}2002-2007 \\
2007-2009\end{array}$ & 2002-2009 \\
\hline 2002 & 701.320 & & & 2002 & 995.000 & & \\
\hline 2007 & 766.700 & $+9.3 \%$ & & 2007 & 1.454 .000 & $+46,1 \%$ & \\
\hline 2009 & 568.600 & $-25,8 \%$ & $-18,9 \%$ & 2009 & 1.829 .100 & $+25,8 \%$ & $+83,8 \%$ \\
\hline
\end{tabular}

Fuente: Elaboración propia en base a datos procedentes del Ministerio de Agricultura, Ganadería y Alimentos de la Provincia de Córdoba.

-éstas ya están instaladas firmemente en la zona- corresponde a un destacado 83,8\%, pero que se diferencia del acentuado crecimiento del 144,3\% del período intercensal 1988-2002 (Cuadro $\mathrm{N}^{\mathrm{o}}$ 41) y, en el caso de los sembradíos de cereales, éstos acusan una caída del $-18,9 \%$, que difiere del incremento del $+6,6 \%$ del período intercensal 1988-2002 (Cuadro No 40). No obstante, cabe acotar, que si nos remitimos al lapso que se extiende entre 2002/03 y $2007 / 08,{ }^{7}$ vemos que media, por el contrario, un suave incremento de 9,3\% por parte de los cereales. Dicho de otro modo, lo importante de destacar en este caso, es que hasta la última fecha arriba aludida, los sembradíos de cereales en nuestra región no retroceden arealmente. Pero la disminución de las superficies sembradas, en cambio, se van a manifestar abruptamente luego, especialmente a partir de la última campaña 2009/10, totalizando en el subperíodo 2007/08-2009/10 una bajante del -25,8\%, a diferencia de las oleaginosas que en el mismo lapso tienen un incremento areal importante $-+25,8 \%-$ pero menor que del subperíodo anterior, que fue del $+46,1 \%$.

De todos modos, lo destacable de la evolución superficial de los cereales, no pasa tanto por la disminución en los últimos tiempos de sus sembradíos, ya que desde hace más de veinte años sus superficies sembradas en la región vienen fluctuando entre quinientas cincuenta mil y setecientas cincuenta mil hectáreas, sino el estancamiento dentro de esos márgenes areales.

Con respecto a la mayor "producción en toneladas" de granos (Gráfico No 9 y Cuadro No 2 del Anexo), observamos como caso significativo que la mayor producción en nuestra zona le va a corresponder a los cereales a lo largo de toda la serie -excepto las campañas de los años 2003/04 y 2005/06- hasta el 2007/08m para luego declinar en las dos campañas siguientes, especialmente en la primera -2008/09-, donde los rendimientos por hectárea y producción en toneladas del maíz y trigo disminuyeron notablemente. Pero, en general, el maíz, típico cultivo de la región centro-norte de la región -especialmente del Dpto. Río Cuarto- ha sido históricamente a nivel productivo la estrella de los granos. A pesar de

\footnotetext{
El corte que se efectúa a la altura de la campaña 2007/08, tiene como finalidad detectar a posteriori de dicho período, que coincide con el conflicto político que se desencadenó entre el campo y el actual gobierno, eventuales alteraciones o no, en el desarrollo general de los cultivos granarios.
} 
expandirse sobre una superficie relativamente limitada en términos comparativos, sus altos rendimientos por hectárea promedio así lo posicionaron. Esto se evidencia en que su producción en toneladas ha superado a la de al soja, generalmente con diferencias importantes a lo largo de casi toda la serie aludida, excepto los últimos años ya mencionados (Gráfico № 10).

Gráfico $\mathrm{N}^{\circ}$ 9. Producción obtenida de los totales de cereales y oleaginosas que predomina en cada año agrícola de la serie 1988/89-2009/10. Región Sur de la provincia de Córdoba

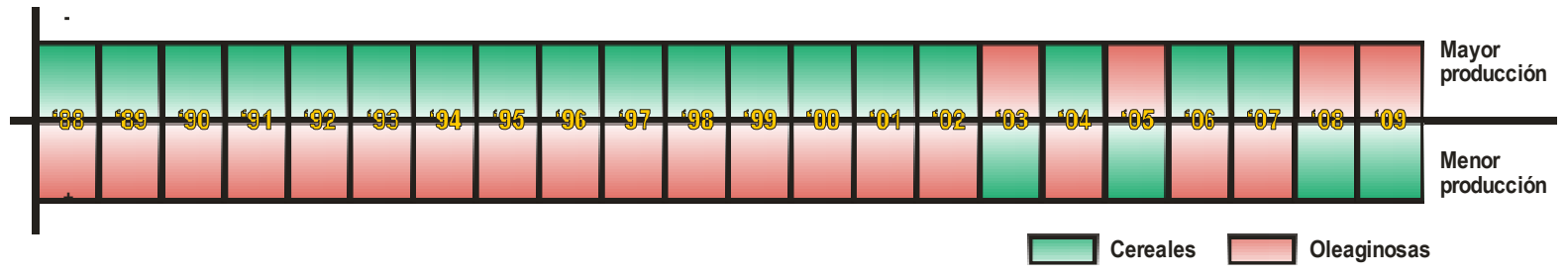

Fuente: Elaboración propia en base a datos procedentes del Ministerio de Agricultura, Ganadería y Alimentos de la provincia de Córdoba

Gráfico $N^{\circ} 10$. Curva de tendencia de la producción de maíz, soja y trigo en el período 1988-2009 en la Región Sur de la provincia de Córdoba

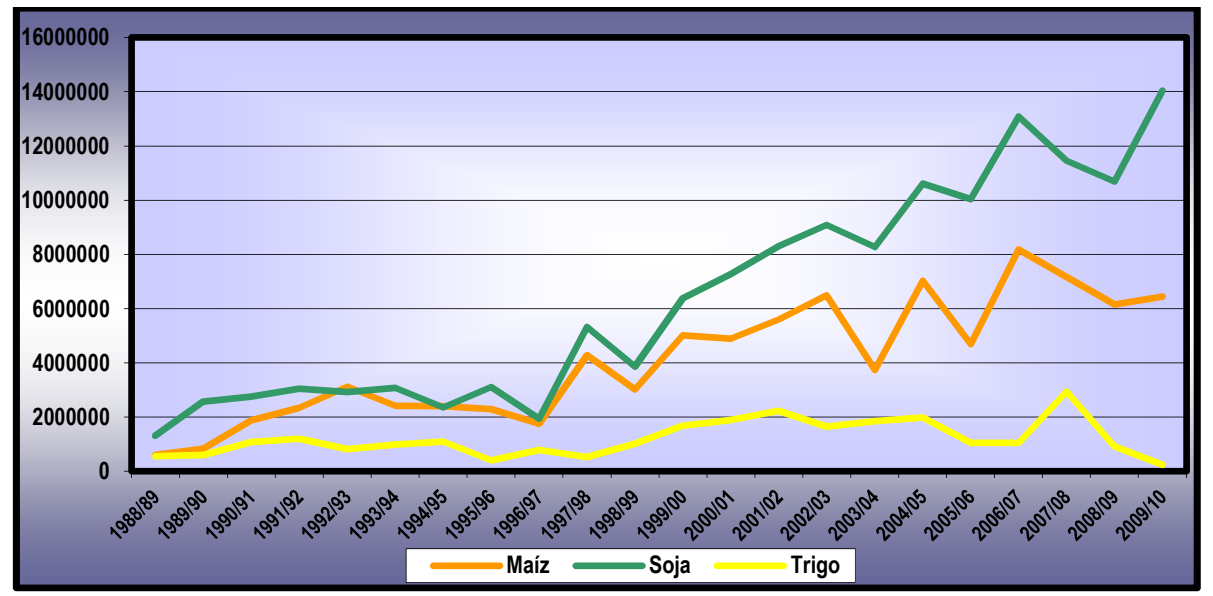

Fuente: Elaboración propia en base a datos procedentes del Ministerio de Agricultura, Ganadería y Alimentos de la provincia de Córdoba

En el caso de la producción triguera - cereal que tradicionalmente se ha cultivado más en los departamentos Presidente Roque Sáenz Peña y General Roca-, es de mucho menor volumen y de cosechas más erráticas que el maíz, especialmente en la última campaña 2009/10 en que su producción descendió a niveles inéditos -como igualmente a nivel provincial-. No cabe duda de que las restricciones gubernamentales a la exportación de este cereal ha desalentado su cultivo. No obstante, históricamente ha ayudado eficazmente al incremento productivo de los cereales de la región (Gráfico $\mathrm{N}^{\mathrm{o}} 10$ ). La producción de sorgo, al igual que a nivel provincial, no es para nada desestimable $\mathrm{y}$, a pesar de que en muchos años de la serie se acerca e inclusive supera los volúmenes obtenidos por el trigo, en general, está por debajo de éste. 
La producción de soja (Gráfico $\mathrm{N}^{\mathrm{o}} 10$ ) empieza a tomar vuelo en el sur cordobés a partir de 1997, en coincidencia obviamente con el incremento de sus superficies sembradas, que toma impulso ese mismo año. No obstante, no logra desplazar al maíz -excepto en los años 2003/04 y 2005/06- hasta la campaña 2007/08. Luego, a partir de ese momento en adelante, se vienen incrementando sustancialmente sus volúmenes. Por otra parte, la producción del girasol y el maní es muy limitada en relación con las de la soja, El girasol, en los últimos años, ha disminuido mucho sus volúmenes; en cambio, el maní ha incrementado su producción, aunque siempre dentro de valores acotados con respecto a los otros granos.

En relación con la evolución de la producción de granos a nivel provincial, es evidente que median diferencias de fondo con el sur cordobés, en el sentido de que en nuestra zona todavía se mantenía hasta el 2007/08 la supremacía productiva en toneladas de los cereales con respecto a las oleaginosas.

Cabe, por último, resaltar (Cuadro $\mathrm{N}^{\mathrm{o}}$ 42-b) -en base a los datos de las campañas agrícolas provistos por el Ministerio de Agricultura provincial- el incremento de la producción en toneladas de los cereales y oleaginosas de nuestra región en dos períodos: 1988-2002 y 2002-2009, procurando buscar un parangón aproximativo con los indicadores ya mencionados de la evolución de las superficies sembradas con granos.

Cuadro No 42-b. Evolución de las producciones obtenidas de granos en el período 2002/03-2009/10 en la Región Sur de la provincia de Córdoba

\begin{tabular}{|c|c|c|c|c|c|c|c|}
\hline \multicolumn{4}{|c|}{ Cereales } & \multicolumn{4}{|c|}{ Oleaginosas } \\
\hline \multirow[b]{2}{*}{ Años } & \multirow[b]{2}{*}{$\begin{array}{l}\text { Producción } \\
\text { (Tn) }\end{array}$} & \multicolumn{2}{|c|}{ Variación \% } & \multirow[b]{2}{*}{ Años } & \multirow[b]{2}{*}{$\begin{array}{l}\text { Producción } \\
\text { (Tn) }\end{array}$} & \multicolumn{2}{|c|}{ Variación \% } \\
\hline & & $\begin{array}{l}1988-2002 \\
2002-2007 \\
2007-2009\end{array}$ & 2002-2009 & & & $\begin{array}{l}1988-2002 \\
2002-2007 \\
2007-2009\end{array}$ & 2002-2009 \\
\hline 1988 & 781.140 & & & 1988 & 584.980 & & \\
\hline 2002 & 3.419 .442 & $+350,1 \%$ & & 2002 & 2.035 .833 & $+248,0 \%$ & \\
\hline 2007 & 3.724 .440 & $+5,8 \%$ & & 2007 & 3.536 .150 & $+73,7 \%$ & \\
\hline 2009 & 2.958 .840 & $-20,6 \%$ & $-15,9 \%$ & 2009 & 4.302 .350 & $+21,7 \%$ & $+111,4 \%$ \\
\hline
\end{tabular}

Fuente: Elaboración propia en base a datos procedentes del Ministerio de Agricultura, Ganadería y Alimentos de la Provincia de Córdoba

Vemos así cómo en el período 1988-2002, tanto las oleaginosas como los cereales del área acusan entre sus años extremos un incremente superlativo, más pronunciado en los cereales $(+350,1 \%)$ que en las oleaginosas $(+248 \%)$. Estos incrementos resultan muy elevados porque se debe recordar que se parte de un piso productivo muy bajo (1988) en el primer período, en relación con el segundo. Sin la menor duda, en estos saltos productivos intervienen durante la década del '90 -como lo afirman varios autores (Azcuy Ameghino, 2004; Barsky y Gelman, 2001)-, al igual que en toda la Región Pampeana, la expansión de los últimos avances tecnológicos en el quehacer agropecuario y una profunda modificación de la estructura agraria fundiaria, que va a dar como resultado una aguda concentración de las 
explotaciones, que deriva a su vez en un incremento de la producción -a pesar de ciertos altibajos- a gran escala en términos comparativos, con el año inicial de referencia (1988). Sin embargo, en los extremos del período 2002-2009/10, los cereales acusan un apreciable descenso en la producción (-15,9\%), demostrando que sus volúmenes productivos se empiezan a achicar progresivamente. En cambio, el incremento de la producción de las oleaginosas $(111,4 \%)$ es categórico, y demuestra a las claras cómo avanza y se impone con respecto a los cereales.

A su vez, corresponde especificar que desde 2002/03 hasta la campaña 2007/08, los cereales acusan entre sus extremos un leve incremento en la producción $(5,8 \%)$, lo que pone de manifiesto que hasta el 2007/08 los mismos siempre estuvieron expandiéndose, pero en el subperíodo 2007/2009 se observa una caída productiva de los cereales del 20,6\%, a diferencia de las oleaginosas, que tienen un incremento importante en toneladas del $21,7 \%$, pero menor que del subperíodo anterior, que fue del $73,7 \%$,

En concreto, no cabe duda de que todas estas alteraciones de los últimos años que es dable observar en los cultivos granarios -como venimos destacando en páginas anteriores-, tienen al fenómeno de la expansión sojera como responsable central. En este sentido, y a modo de cierre sobre la evolución estadística de los granos que venimos describiendo, volcamos a continuación en el Cuadro $N^{0} 43$, tanto a nivel provincial como así también a nivel del sur cordobés, y a lo largo de la secuencia 1988/89-2009/10, la incidencia exclusiva de la soja, con respecto al total de los otros granos que la acompañan, ya sea en relación con las superficies sembradas como con la producción en toneladas obtenida.

Contemplamos así, a nivel provincial:

a) que las "superficies sembradas" de la soja van a girar en torno al 40\% hasta 1999/00. Luego, a partir de 2000, se incrementa por arriba del 50\% y desde 2003/04 supera el $60 \%$, para llegar a ocupar en $2009 / 10$ el $75,6 \%$ de la superficie sembrada de granos a nivel provincial:

b) en relación con la "producción en toneladas" de la soja, la misma va a fluctuar entre u $30 \%$ y un $40 \%$ hasta $1999 / 00$, pero a partir de 2000/01 en adelante la producción sojera va a ascender por arriba del 40\% y, a partir de 2003/04, por arriba del 50\% -o muy cercana a este porcentaje-, para llegar a ocupar en la campaña provincial $2009 / 10$ el 62,5\% de la producción total de granos.

Con respecto al nivel del Sur Cordobés:

a) Aquí, en general, las “superficies ocupadas" por la soja son más modestas que a nivel provincial y, desde 1988/89 hasta 1999/00, su expansión areal va a fluctuar alrededor 
Cuadro $\mathrm{N}^{\circ}$ 43. Incidencia exclusiva de la soja. Superficie sembrada y producción, en relación con el total de los otros cultivos granarios, a nivel provincial y del Sur Cordobés. Serie 1988/89-2009/10

\begin{tabular}{|c|c|c|c|c|c|c|c|c|c|c|c|c|c|c|c|}
\hline \multirow[b]{2}{*}{ Departamento } & Años & \multicolumn{2}{|c|}{1988} & \multicolumn{2}{|c|}{1989} & \multicolumn{2}{|c|}{1990} & \multicolumn{2}{|c|}{1991} & \multicolumn{2}{|c|}{1992} & \multicolumn{2}{|c|}{1993} & \multicolumn{2}{|c|}{1994} \\
\hline & Granos & $\begin{array}{c}\text { Superficie } \\
\text { sembrada } \\
\text { (ha) }\end{array}$ & $\begin{array}{l}\text { Producción } \\
\text { (t) }\end{array}$ & $\begin{array}{l}\text { Superficie } \\
\text { sembrada } \\
\text { (ha) }\end{array}$ & $\begin{array}{c}\text { Producción } \\
\text { (t) }\end{array}$ & $\begin{array}{c}\text { Superficie } \\
\text { sembrada } \\
\text { (ha) }\end{array}$ & $\begin{array}{c}\text { Producción } \\
\text { (t) }\end{array}$ & $\begin{array}{l}\text { Superficie } \\
\text { sembrada } \\
\text { (ha) }\end{array}$ & $\begin{array}{l}\text { Producción } \\
\text { (t) }\end{array}$ & $\begin{array}{c}\text { Superficie } \\
\text { sembrada } \\
\text { (ha) }\end{array}$ & $\begin{array}{l}\text { Producción } \\
\text { (t) }\end{array}$ & $\begin{array}{c}\text { Superficie } \\
\text { sembrada } \\
\text { (ha) }\end{array}$ & $\begin{array}{l}\text { Producción } \\
\text { (t) }\end{array}$ & $\begin{array}{c}\text { Superficie } \\
\text { sembrada } \\
\text { (ha) }\end{array}$ & $\begin{array}{l}\text { Producción } \\
\text { (t) }\end{array}$ \\
\hline \multirow{3}{*}{$\begin{array}{l}\text { Provincia de } \\
\text { Córdoba }\end{array}$} & $\begin{array}{l}\text { Total de granos (oleaginosas } \\
\qquad+ \text { cereales) }\end{array}$ & 3.205 .526 & 3.333 .780 & 3.464 .720 & 5.130 .625 & 3.516 .250 & 7.686 .606 & 3.249 .060 & 8.001 .063 & 3.190 .050 & 8.485 .000 & 3.354 .600 & 8.034 .780 & 3.397 .050 & 7.094 .990 \\
\hline & Total de soja & 1.391 .840 & 1.306 .988 & 1.452 .800 & 2.577 .300 & 1.316 .300 & 2.751 .139 & 1.262 .900 & 3.041 .310 & 1.297 .000 & 2.928 .015 & 1.434 .800 & 3.083 .540 & 1.402 .500 & 2.357 .525 \\
\hline & $\begin{array}{l}\text { \% total de soja del total de } \\
\text { granos }\end{array}$ & $43,4 \%$ & $39,2 \%$ & $41.9 \%$ & $50,2 \%$ & $37,4 \%$ & $35,8 \%$ & $38,9 \%$ & $38 \%$ & $40,7 \%$ & $34.5 \%$ & $42,8 \%$ & $38,4 \%$ & $41,3 \%$ & $33,2 \%$ \\
\hline \multirow{3}{*}{$\begin{array}{c}\text { Sumatoria de } \\
\text { los } 4 \\
\text { departamentos }\end{array}$} & $\begin{array}{l}\text { Total de granos (oleaginosas } \\
\qquad+ \text { cereales) }\end{array}$ & 1.180 .500 & 1.366 .120 & 1.185 .500 & 1.212 .400 & 1.098 .000 & 2.043.539 & 1.054 .000 & 1.922 .905 & 1.029 .000 & 2.263 .555 & 1.041 .200 & 2.284.165 & 1.141 .000 & 2.795 .645 \\
\hline & Total de soja & 262.000 & 289.680 & 266.500 & 276.400 & 178.000 & 361.080 & 198.000 & 376.100 & 212.000 & 451.675 & 221.000 & 391.050 & 230.500 & 344.400 \\
\hline & $\begin{array}{l}\text { \% total de soja del total de } \\
\text { granos }\end{array}$ & $22,2 \%$ & $21,2 \%$ & $22,5 \%$ & $22,8 \%$ & $16,2 \%$ & $17,7 \%$ & $18,8 \%$ & $19,6 \%$ & $20,6 \%$ & $19,5 \%$ & $21,2 \%$ & $19,1 \%$ & $20,2 \%$ & $12,3 \%$ \\
\hline
\end{tabular}

Cuadro No 43 (Continuación)

\begin{tabular}{|c|c|c|c|c|c|c|c|c|c|c|c|c|c|c|c|}
\hline \multirow[b]{2}{*}{ Departamento } & Años & \multicolumn{2}{|c|}{1995} & \multicolumn{2}{|c|}{1996} & \multicolumn{2}{|c|}{1997} & \multicolumn{2}{|c|}{1998} & \multicolumn{2}{|c|}{1999} & \multicolumn{2}{|c|}{2000} & \multicolumn{2}{|c|}{2001} \\
\hline & Granos & $\begin{array}{l}\text { Superficie } \\
\text { sembrada } \\
\text { (ha) }\end{array}$ & $\begin{array}{c}\text { Producción } \\
(\mathrm{t})\end{array}$ & $\begin{array}{l}\text { Superficie } \\
\text { sembrada } \\
\text { (ha) }\end{array}$ & $\begin{array}{c}\text { Producción } \\
\text { (t) }\end{array}$ & $\begin{array}{c}\text { Superficie } \\
\text { sembrada } \\
\text { (ha) }\end{array}$ & $\begin{array}{c}\text { Producción } \\
\text { (t) }\end{array}$ & $\begin{array}{l}\text { Superficie } \\
\text { sembrada } \\
\text { (ha) }\end{array}$ & $\begin{array}{c}\text { Producción } \\
\text { (t) }\end{array}$ & $\begin{array}{l}\text { Superficie } \\
\text { sembrada } \\
\text { (ha) }\end{array}$ & $\begin{array}{c}\text { Producción } \\
\text { (t) }\end{array}$ & $\begin{array}{c}\text { Superficie } \\
\text { sembrada } \\
\text { (ha) }\end{array}$ & $\begin{array}{l}\text { Producción } \\
\text { (t) } \\
\end{array}$ & $\begin{array}{c}\text { Superficie } \\
\text { sembrada } \\
\text { (ha) }\end{array}$ & $\begin{array}{l}\text { Producción } \\
\text { (t) }\end{array}$ \\
\hline \multirow{3}{*}{$\begin{array}{l}\text { Provincia de } \\
\text { Córdoba }\end{array}$} & $\begin{array}{l}\text { Total de granos (oleaginosas } \\
+ \text { cereales) }\end{array}$ & 3.580 .600 & 7.726 .365 & 4.136 .420 & 6.020 .905 & 4.359 .700 & 13.178.497 & 4.475 .600 & 10.219 .460 & 5.157 .215 & 15.914 .112 & 5.540 .050 & 16.446 .409 & 5.884 .980 & 18.215.057 \\
\hline & Total de soja & 1.517 .100 & 3.112 .638 & 1.596 .700 & 1.937 .650 & 1.833 .650 & 5.316 .192 & 1.946 .950 & 3.862 .141 & 2.497 .065 & 6.382 .060 & 2.966 .000 & 7.274 .628 & 3.213 .350 & 8.311 .742 \\
\hline & $\begin{array}{l}\text { \% total de soja del total de } \\
\text { granos }\end{array}$ & $42,4 \%$ & $40,3 \%$ & $38,6 \%$ & $32,2 \%$ & $42,1 \%$ & $40,3 \%$ & $43,5 \%$ & $37,8 \%$ & $48,4 \%$ & $40,1 \%$ & $53,5 \%$ & $44,2 \%$ & $54,6 \%$ & $45.6 \%$ \\
\hline \multirow{3}{*}{$\begin{array}{c}\text { Sumatoria de } \\
\text { los } 4 \\
\text { departamentos }\end{array}$} & $\begin{array}{l}\text { Total de granos (oleaginosas } \\
+ \text { cereales) }\end{array}$ & 1.271 .000 & 2.376 .700 & 1.596 .500 & 1.617.133 & 1.598 .850 & 3.662 .849 & 1.509 .000 & 3.494.013 & 1.597 .500 & 4.738 .980 & 1.607 .650 & 4.463 .990 & 1.703 .300 & 5.386 .918 \\
\hline & Total de soja & 218.000 & 389.000 & 238.000 & 233.490 & 246.000 & 844.740 & 292.000 & 541.064 & 375.000 & 880.835 & 496.000 & 870.020 & 560.000 & 1.317 .058 \\
\hline & $\begin{array}{l}\text { \% total de soja del total de } \\
\text { granos }\end{array}$ & $17,2 \%$ & $16,4 \%$ & $14,9 \%$ & $14,4 \%$ & $15,4 \%$ & $23,1 \%$ & $19,3 \%$ & $15,5 \%$ & $23,5 \%$ & $18,6 \%$ & $30,8 \%$ & $19,5 \%$ & $32,9 \%$ & $24,4 \%$ \\
\hline
\end{tabular}


Cuadro No 43 (Continuación)

\begin{tabular}{|c|c|c|c|c|c|c|c|c|c|c|c|c|c|c|c|}
\hline \multirow[b]{2}{*}{ Departamento } & \multirow{2}{*}{$\begin{array}{l}\text { Años } \\
\text { Granos }\end{array}$} & \multicolumn{2}{|c|}{2002} & \multicolumn{2}{|c|}{2003} & \multicolumn{2}{|c|}{2004} & \multicolumn{2}{|c|}{2005} & \multicolumn{2}{|c|}{2006} & \multicolumn{2}{|c|}{2007} & \multicolumn{2}{|c|}{2008} \\
\hline & & $\begin{array}{l}\text { Superficie } \\
\text { sembrada } \\
\text { (ha) }\end{array}$ & $\begin{array}{l}\text { Producción } \\
\text { (t) }\end{array}$ & $\begin{array}{c}\text { Superficie } \\
\text { sembrada } \\
\text { (ha) }\end{array}$ & $\begin{array}{c}\text { Producción } \\
\text { (t) }\end{array}$ & $\begin{array}{l}\text { Superficie } \\
\text { sembrada } \\
\text { (ha) }\end{array}$ & $\begin{array}{c}\text { Producción } \\
(\mathrm{t})\end{array}$ & $\begin{array}{l}\text { Superficie } \\
\text { sembrada } \\
\text { (ha) }\end{array}$ & $\begin{array}{l}\text { Producción } \\
\text { (t) }\end{array}$ & $\begin{array}{l}\text { Superficie } \\
\text { sembrada } \\
\text { (ha) }\end{array}$ & $\begin{array}{l}\text { Producción } \\
(\mathrm{t})\end{array}$ & $\begin{array}{l}\text { Superficie } \\
\text { sembrada } \\
\text { (ha) }\end{array}$ & $\begin{array}{l}\text { Producción } \\
\text { (t) }\end{array}$ & $\begin{array}{c}\text { Superficie } \\
\text { sembrada } \\
\text { (ha) }\end{array}$ & $\begin{array}{l}\text { Producción } \\
\text { (t) }\end{array}$ \\
\hline \multirow{3}{*}{$\begin{array}{l}\text { Provincia de } \\
\text { Córdoba }\end{array}$} & $\begin{array}{l}\text { Total de granos (oleaginosas } \\
\qquad+ \text { cereales) }\end{array}$ & 6.075 .450 & 19.040.064 & 5.962 .430 & 14.983.638 & 6.148 .680 & 21.254 .087 & 6.337 .550 & 17.200 .537 & 6.542 .350 & 24.288.226 & 7.390 .700 & 23.230.624 & 7.208 .700 & 19.255 .010 \\
\hline & Total de soja & 3.633 .000 & 9.092 .363 & 3.933 .850 & 8.276 .196 & 3.714 .500 & 10.613 .013 & 4.221 .400 & 10.040 .395 & 4.323 .900 & 13.078 .365 & 4.527.200 & 11.462 .525 & 4.951 .900 & 10.690 .925 \\
\hline & $\begin{array}{l}\text { \% total de soja del total de } \\
\text { granos }\end{array}$ & $59,8 \%$ & $47,8 \%$ & $66 \%$ & $55,2 \%$ & $60,4 \%$ & $49,9 \%$ & $66,6 \%$ & $58,4 \%$ & $66,1 \%$ & $53,8 \%$ & $51,3 \%$ & $49,3 \%$ & $68,7 \%$ & $55,5 \%$ \\
\hline \multirow{3}{*}{$\begin{array}{l}\text { Sumatoria de } \\
\text { los } 4 \\
\text { departamentos }\end{array}$} & $\begin{array}{l}\text { Total de granos (oleaginosas } \\
++ \text { cereales) }\end{array}$ & 1.696 .520 & 5.555 .275 & 1.454 .900 & 3.438 .780 & 1.627 .750 & 6.377 .300 & 1.771 .500 & 4.239 .390 & 1.957 .500 & 2.596 .338 & 2.213 .500 & 7.260 .590 & 2.536 .800 & 6.482 .814 \\
\hline & Total de soja & 661.000 & 1.343 .913 & 864.900 & 1.905 .830 & 810.000 & 2.510 .000 & 1.063 .000 & 2.218 .800 & 1.142 .000 & 2.110 .250 & 1.211 .000 & 3.021 .050 & 1.569 .000 & 2.858 .350 \\
\hline & $\begin{array}{l}\% \text { total de soja del total de } \\
\text { granos }\end{array}$ & $38,9 \%$ & $24,2 \%$ & $59,4 \%$ & $55,4 \%$ & $49,8 \%$ & $39,4 \%$ & $60 \%$ & $52,3 \%$ & $58,3 \%$ & $37,7 \%$ & $54,7 \%$ & $41,6 \%$ & $61,8 \%$ & $44,1 \%$ \\
\hline
\end{tabular}

\section{Cuadro $N^{\circ} 43$ (Continuación)}

\begin{tabular}{|c|c|c|c|}
\hline \multirow[b]{2}{*}{ Departamento } & Años & \multicolumn{2}{|c|}{2009} \\
\hline & Granos & $\begin{array}{c}\text { Superficie } \\
\text { sembrada } \\
\text { (ha) }\end{array}$ & $\begin{array}{l}\text { Producción } \\
\text { (t) }\end{array}$ \\
\hline \multirow{3}{*}{$\begin{array}{l}\text { Provincia de } \\
\text { Córdoba }\end{array}$} & $\begin{array}{l}\text { Total de granos (oleaginosas } \\
++ \text { cereales) }\end{array}$ & 6.810 .800 & 22.955 .705 \\
\hline & Total de soja & 5.149 .550 & 14.036 .800 \\
\hline & $\begin{array}{l}\text { \% total de soja del total de } \\
\text { granos }\end{array}$ & $75,6 \%$ & $62,5 \%$ \\
\hline \multirow{3}{*}{$\begin{array}{l}\text { Sumatoria de } \\
\text { los } 4 \\
\text { departamentos }\end{array}$} & $\begin{array}{c}\text { Total de granos (oleaginosas } \\
++ \text { cereales) }\end{array}$ & 2.397 .700 & 7.262 .190 \\
\hline & Total de soja & 1.638 .000 & 3.878 .500 \\
\hline & $\begin{array}{l}\% \text { total de soja del total de } \\
\text { granos }\end{array}$ & $68,3 \%$ & $53,4 \%$ \\
\hline
\end{tabular}

Fuente: Elaboración propia en base a los resultados provistos por el Ministerio de Agricultura, Ganadería y Alimentos, Unidad Provincial del Sistema Integrado de Información Agropecuaria (UPSIIA) de la provincia de Córdoba. 
del $20 \%$-un poco por abajo o un poco por arriba de ese porcentaje-, para superar el $30 \%$ a partir de 2000 , e instalarse precipitadamente sus porcentajes por encima del $50 \%$ a partir de 2003/04, llegando al 68,3\% en la campaña 2009/10.

b) A su vez, la "producción" de soja va a ser también muy modesta a lo largo de toda la década del '90 y comienzos de la década siguiente hasta el año 2002, fluctuando entre un $15 \%$ y $25 \%$ escaso. Pero, a partir de 2003/04, el incremento va a ser vertiginoso, girando entre un $40 \%$ y un 50\% para llegar al 53,4\% en 2009/10,

Vemos, por lo tanto, a partir de esta descripción, la marcha ascendente de la soja -aparentemente imparable mientras los precios del mercado internacional sigan sobreelevados-, despegándose cada vez más de los otros cultivos, lo que no implica -como venimos observando- obligadamente la insoslayable disminución areal y productiva del resto de los principales granos, pero sí, sin la menor duda, representa un duro obstáculo en lo atinente a una posible expansión general de dichos granos en un futuro próximo.

Para finalizar este análisis, quisiéramos hacer la siguiente reflexión respecto de las vinculaciones existentes entre superficie sembrada y producción obtenida en toneladas de los cultivos.

En primer lugar, debemos recordar la variación profunda que media entre hectáreas sembradas y hectáreas cosechadas -que, en función de las contingencias del año agrícola, estas últimas suelen ser a veces sustancialmente menores que las primeras-, como así también con respecto al rendimiento por hectáreas obtenido de los cultivos a lo largo de las diferentes campañas agrícolas.

En segundo lugar, se debe relativizar o saber calibrar la expansión areal de ciertos cultivos -la soja, por ejemplo-, con respecto a otros, dado que se debe tomar en cuenta, además del incremento en superficie de los cultivos, los rendimientos promedios de los mismos, lo que determina como corolario la producción final obtenida por cada uno de ellos. En el caso del maíz, que con un rendimiento promedio por hectárea muy superior al de la soja y con una superficie destinada a su cultivo muy inferior al de ésta, en las campañas agrícolas de nuestra región -excepto las últimas- ha obtenido generalmente una producción en toneladas significativamente superior a la de la soja, al margen de que la tonelada de ésta se cotice mucho más en el mercado que la de maíz y que los costos de implantación y mantenimiento sean diferentes; pero esas variables económicas representan una cuestión diferente a lo que en esta instancia queremos destacar.

En suma, en este trabajo hemos hecho mucho hincapié en las oscilaciones de las superficies implantadas de los cultivos cuando hemos analizado los dos últimos censos, dado 
que éstos no disponen de datos sobre la producción, pero apoyándonos en la información proveniente del Ministerio de Agricultura de Córdoba, hemos querido también introducir la variable producción, por entender que en última instancia, cuando se calibra macroeconómicamente un cultivo -aparte de considerar su valor por unidad de peso-, se hace en base a la producción en toneladas obtenida por el mismo, por representar el fruto tangible de la capacidad productiva de un espacio agrícola dado.

A continuación, se analiza la incidencia de la actividad ganadera en el sur cordobés, en base a los datos de los censos ya mencionados y a la información proveniente del Ministerio de Agricultura de la provincia de Córdoba, a fin de poder arribar a una captación más integral de la evolución general de la economía rural del área, como así también a las consecuencias que provoca el fenómeno de la agriculturización sobre el quehacer ganadero.

\subsubsection{Análisis de la evolución de la ganadería bovina en nuestra región de estudio}

Respecto de la comparación censal de las explotaciones agropecuarias (EAPs) con ganado bovino y número de cabezas, por escala de tamaño del rodeo, se puede considerar lo siguiente (Cuadro $\left.\mathrm{N}^{\mathrm{o}} 44\right)$.

En primer lugar, observamos a nivel provincial:

- Una fuerte disminución de EAPs (41\%) y una apreciable merma de cabezas de ganado bovino (14\%) entre 1988 y 2002.

- El desplazamiento numérico de la mayor cantidad de cabezas que en 1988 se ubicaban en EAPs con rodeos entre 201-500 animales, a establecimientos con rodeos superiores a 2000 cabezas en el año 2002.

- Una disminución significativa de EAPs y de cabezas, respectivamente, en las escalas de menor tamaño del rodeo. En cambio, se observa un incremento intercensal de animales en aquellos establecimientos con rodeos superiores a las 501 cabezas, lo que indica a las claras una fuerte concentración de animales en las EAPs de mayor tamaño.

En segundo lugar, observamos a nivel de nuestra región que los departamentos involucrados en la misma siguen a grandes rasgos la tendencia evolutiva provincial; no obstante, cabe destacar ciertas características propias. Por ejemplo, en el Dpto. General Roca, poseedor de grandes establecimientos de fuerte tradición ganadera, en los dos censos, la mayor cantidad de cabezas se ubica en aquellas EAPs con rodeos superiores a 2.000 animales, e inclusive se manifiesta un incremento de cabezas en el 2002 con respecto a 1988 en las dos 
Cuadro $N^{\circ}$ 44. Cantidad de EAPs con ganado bovino y número de cabezas, por escala de tamaño del rodeo, según departamentos involucrados

\begin{tabular}{|c|c|c|c|c|c|c|c|c|c|}
\hline \multirow{2}{*}{ Departamento } & \multirow{2}{*}{$\begin{array}{l}\text { EAPs - } \\
\text { Cabezas }\end{array}$} & \multicolumn{8}{|c|}{ Escala de tamaño del rodeo (cabezas) } \\
\hline & & Total & Hasta 50 & $51-100$ & $101-200$ & $201-500$ & $501-1000$ & $1001-2000$ & Más de 2000 \\
\hline \multirow{2}{*}{$\begin{array}{c}\text { Provincia de Córdoba } \\
1988\end{array}$} & EAPs & 30.434 & 9.563 & 5.120 & 6.394 & 6.400 & 1.942 & 640 & 374 \\
\hline & Cabezas & 7.103 .074 & 224.232 & 386.969 & 946.237 & 1.999 .206 & 1.330 .534 & 883.798 & 1.332 .098 \\
\hline \multirow{2}{*}{$\begin{array}{c}\text { Provincia de Córdoba } \\
2002\end{array}$} & EAPs & 17.920 & 4.427 & 2.747 & 3.311 & 4.354 & 1.928 & 766 & 387 \\
\hline & Cabezas & 6.082 .263 & 112.995 & 205.032 & 487.371 & 1.418 .338 & 1.340 .422 & 1.039 .319 & 1.479 .041 \\
\hline \multicolumn{2}{|l|}{ Diferencia EAPs $\mathrm{N}^{\circ}$} & -12.514 & -5.136 & -2.373 & -3.083 & -2.046 & -14 & +126 & +13 \\
\hline \multicolumn{2}{|l|}{ Diferencia EAPs \% } & $-41,1 \%$ & $-53,7 \%$ & $-46,4 \%$ & $-48,2 \%$ & $-32,0 \%$ & $-0,7 \%$ & $+19,7 \%$ & $+3,5 \%$ \\
\hline \multicolumn{2}{|l|}{ Diferencia Cabezas $\mathrm{N}^{0}$} & -1.020 .811 & -111.237 & -181.937 & -458.866 & -580.868 & +9.888 & +155.521 & +146.943 \\
\hline \multicolumn{2}{|l|}{ Diferencia Cabezas \% } & $-14,4 \%$ & $-49,6 \%$ & $-47,7 \%$ & $-48,5 \%$ & $-29,1 \%$ & $+7,0 \%$ & $+17,6 \%$ & $+11,0 \%$ \\
\hline \multirow{2}{*}{ General Roca 1988} & EAPs & 1.453 & 171 & 153 & 276 & 423 & 206 & 123 & 101 \\
\hline & Cabezas & 908.751 & 3.919 & 11.930 & 41.490 & 137.412 & 145.249 & 171.694 & 397.057 \\
\hline \multirow{2}{*}{ General Roca 2002} & EAPs & 1.064 & 80 & 81 & 168 & 311 & 186 & 129 & 109 \\
\hline & Cabezas & 895.912 & 2.197 & 6.309 & 25.038 & 103.268 & 131.486 & 182.255 & 445.359 \\
\hline \multicolumn{2}{|l|}{ Diferencia EAPs $\mathrm{N}^{\circ}$} & -389 & -91 & -72 & -108 & -112 & -20 & +6 & +8 \\
\hline \multicolumn{2}{|l|}{ Diferencia EAPs \% } & $-26,8 \%$ & $-53,2 \%$ & $-47,1 \%$ & $-39,1 \%$ & $-26,5 \%$ & $-9,7 \%$ & $+4,9 \%$ & $+7,9 \%$ \\
\hline \multicolumn{2}{|l|}{ Diferencia Cabezas $N^{0}$} & -12.839 & -1.722 & -5.621 & -16.452 & -34.144 & -13.763 & +10.561 & +48.302 \\
\hline \multicolumn{2}{|l|}{ Diferencia Cabezas \% } & $-1,4 \%$ & $-43,4 \%$ & $-47,1 \%$ & $-39,7 \%$ & $-24,9 \%$ & $-9,5 \%$ & $+6,1 \%$ & $+12,2 \%$ \\
\hline \multirow{2}{*}{ Juárez Celman 1988} & EAPs & 1.349 & 196 & 237 & 337 & 345 & 142 & 45 & 47 \\
\hline & Cabezas & 503.840 & 5.510 & 18.423 & 50.504 & 110.922 & 97.716 & 63.491 & 157.274 \\
\hline \multirow{2}{*}{ Juárez Celman 2002} & EAPs & 742 & 69 & 74 & 162 & 246 & 116 & 38 & 37 \\
\hline & Cabezas & 413.565 & 2.068 & 5.493 & 23.980 & 80.578 & 80.049 & 52.933 & 168.464 \\
\hline \multicolumn{2}{|l|}{ Diferencia EAPs $\mathrm{N}^{\circ}$} & -607 & -127 & -163 & -175 & -99 & -26 & -7 & -10 \\
\hline \multicolumn{2}{|l|}{ Diferencia EAPs \% } & $-45,0 \%$ & $-64.8 \%$ & $-68,8 \%$ & $-51,9 \%$ & $-28,7 \%$ & $-18,3 \%$ & $-15,6 \%$ & $-21.3 \%$ \\
\hline Diferencia Cabezas № & & -90.275 & -3.442 & -12.930 & -26.524 & -30.344 & -17.667 & -10.558 & +11.190 \\
\hline Diferencia Cabezas \% & & $-17,9 \%$ & $-62,5 \%$ & $-70,2 \%$ & $-52,5 \%$ & $-27,4 \%$ & $-18,1 \%$ & $-16,6 \%$ & $+7.1 \%$ \\
\hline Pte. R. Sáenz Peña & EAPs & 1.266 & 111 & 175 & 326 & 403 & 144 & 61 & 46 \\
\hline 1988 & Cabezas & 548.124 & 3.316 & 13.705 & 48.713 & 129.256 & 99.424 & 86.139 & 167.571 \\
\hline Pte. R. Sáenz Peña & EAPs & 847 & 57 & 107 & 197 & 271 & 132 & 52 & 31 \\
\hline 2002 & Cabezas & 403.574 & 1.716 & 8.190 & 28.923 & 89.617 & 91.753 & 68.942 & 114.433 \\
\hline Diferencia EAPs $\mathrm{N}^{\circ}$ & & -419 & -54 & -68 & -129 & -132 & -12 & -9 & -15 \\
\hline Diferencia EAPs \% & & $-33,1 \%$ & $-48,7 \%$ & $-38,9 \%$ & $-39,6 \%$ & $-32,8 \%$ & $-8,3 \%$ & $-14,8 \%$ & $-32,6 \%$ \\
\hline Diferencia Cabezas № & & -144.550 & -1.600 & -5.515 & -19.790 & -39.639 & -7.671 & -17.197 & -53.138 \\
\hline Diferencia Cabezas \% & & $-26,4 \%$ & $-48,3 \%$ & $-40,2 \%$ & $-40,6 \%$ & $-30,7 \%$ & $-7,7 \%$ & $-20,0 \%$ & $-31,7 \%$ \\
\hline Ring & EAPs & 3.974 & 745 & 700 & 958 & 1.059 & 330 & 108 & 74 \\
\hline RIo Cua & Cabezas & 1.184 .899 & 20.318 & 53.408 & 142.998 & 336.570 & 231.210 & 149.049 & 251.346 \\
\hline Rinc $c$ & EAPs & 2.421 & 309 & 350 & 541 & 759 & 288 & 119 & 55 \\
\hline KIo cuarto 2002 & Cabezas & 921.604 & 9.414 & 26.832 & 79.862 & 246.393 & 195.089 & 159.116 & 204.898 \\
\hline Diferencia EAPs $\mathrm{N}^{\circ}$ & & -1.553 & -436 & -350 & -417 & -300 & -42 & +11 & -19 \\
\hline Diferencia EAPs \% & & $-39,1 \%$ & $-58,5 \%$ & $-50,0 \%$ & $-43,5 \%$ & $-28,3 \%$ & $-12,7 \%$ & $+10,2 \%$ & $-25,7 \%$ \\
\hline Diferencia Cabezas № & & -263.295 & -10.904 & -26.576 & -63.136 & -90.177 & -36.121 & +10.067 & -46.448 \\
\hline Diferencia Cabezas \% & & $-22,2 \%$ & $-53,7 \%$ & $-49,8 \%$ & $-44,2 \%$ & $-26,8 \%$ & $-15.6 \%$ & $+6,7 \%$ & $-18,5 \%$ \\
\hline Sumatoria 4 Dptos. EAF & 1988 & 8.042 & 1.223 & 1.265 & 1.897 & 2.230 & 822 & 337 & 268 \\
\hline Sumatoria 4 Dptos. Cak & :as 1988 & 3.145 .614 & 33.063 & 97.466 & 283.705 & 714.160 & 573.599 & 470.373 & 973.248 \\
\hline Sumatoria 4 Dptos. EAF & 2002 & 5.074 & 515 & 612 & 1.068 & 1.587 & 722 & 338 & 232 \\
\hline Sumatoria 4 Dptos. Cak & as 2002 & 2.634 .655 & 15.395 & 46.824 & 157.803 & 519.856 & 498.377 & 463.246 & 933.154 \\
\hline Diferencia EAPs $\mathrm{N}^{\circ}$ & & -2.968 & -708 & -653 & -829 & -643 & -100 & +1 & -36 \\
\hline Diferencia EAPs \% & & $-36,9 \%$ & $-57,9 \%$ & $-51,6 \%$ & $-43,7 \%$ & $-28,8 \%$ & $-12,2 \%$ & $+3,0 \%$ & $-13,4 \%$ \\
\hline Diferencia Cabezas $\mathrm{N}^{0}$ & & -510.959 & -17.668 & -50.642 & -125.902 & -194.304 & -75.222 & -7.127 & -40.094 \\
\hline Diferencia Cabezas \% & & $-16,2 \%$ & $-53,4 \%$ & $-52,0 \%$ & $-44,4 \%$ & $-27,2 \%$ & $-13,1 \%$ & $-1,5 \%$ & $-4,1 \%$ \\
\hline
\end{tabular}

Fuente: Elaboración propia en base a datos procedentes de los Censos Nacionales Agropecuarios de 1988 y 2002. 
últimas escalas del rodeo. En los departamentos Juárez Celman y Presidente Roque Sáenz Peña, el mayor peso del ganado en los dos censos se ubica en primer lugar en la escala de más de 2.000 cabezas, y en segundo lugar en la escala del rodeo de 201 a 1.000 vacunos. En estos departamentos, prácticamente en toda la escala por tamaño del rodeo, se observa una fuerte disminución intercensal de EAPs y de cabezas de vacunos.

En el caso del Dpto. Río Cuarto, es interesante destacar que la mayor cantidad de ganado en ambos censos se ubica, en primer término, en la escala del rodeo de 201 a 500 cabezas - coincidiendo con la mayor cantidad de EAPs-y, en segundo término, en la escala de más de 2.000 cabezas. Es de suponer que este orden refleje, por una parte, el peso que tiene en este departamento la significativa cantidad de EAPs de tamaño medio con ganado bovino, y por otra, la existencia de grandes establecimientos con una fuerte orientación hacia la actividad ganadera. Por último, cabe también resaltar que, al igual que los dos últimos departamentos mencionados, en todas las escalas por tamaño del rodeo, se observa una disminución intercensal tanto de EAPs como de ganado vacuno.

Considerando ahora los cuatro departamentos en su conjunto, la mayor cantidad de ganado se ubica en primer lugar en ambos censos en la escala del rodeo de más de 2.000 cabezas y, en segundo lugar, en la escala que va de 201 a 500 animales. En todas las escalas por tamaño del rodeo hay una pronunciada disminución intercensal de EAPs y de cabezas, exceptuando las escalas mayores, donde mucho tiene que ver -en lo que respecta a la última variable- la fuerte carga animal que detenta el Dpto. General Roca en sus escalas superiores de más de 1.001 animales.

En concreto, en nuestra región, además de concentrarse la mayor cantidad de animales en la escala del rodeo de más de 2.000 cabezas (o sea, en establecimientos ganaderos de grandes proporciones), cabe resaltar que en todos los departamentos involucrados y en ambos censos, la mayor cantidad de EAPs se ubican en la escala que va de 201 a 500 cabezas, lo que nos está indicando -al margen de no poseer estos establecimientos el mayor número de cabezas (excepto el Dpto. Río Cuarto)- que la mayor cantidad de EAPs que poseen ganado, responden presumiblemente a establecimientos de tamaño medio por el volumen de sus rodeos.

En relación con el total de cabezas de ganado bovino en el conjunto departamental del sur cordobés, vemos en el Cuadro $\mathrm{N}^{\circ} 45$ que, después de la fuerte caída intercensal de los rodeos en general $(16,2 \%)$, se observa en los registros subsiguientes un leve repunte de los mismos, con ciertas fluctuaciones, manteniéndose hasta el año 2007 en valores similares a los contabilizados en 2002. En concreto, no ha habido en nuestra área, hasta 2007, un 
vaciamiento de ganado, como tampoco un crecimiento sostenido del mismo, conservándose el rodeo relativamente estable. En cambio, a nivel provincial sí se va a observar un crecimiento de regular magnitud del rodeo entre 2002 y 2007.

Cuadro $N^{0}$ 45. Total de cabezas de ganado bovino, según departamentos involucrados

\begin{tabular}{|c|c|c|c|c|c|c|c|c|}
\hline \multirow{2}{*}{ Departamento } & \multicolumn{2}{|c|}{$\begin{array}{l}\text { Censos Nacionales } \\
\text { Agropecuarios }\end{array}$} & \multicolumn{6}{|c|}{$\begin{array}{l}\text { Información procedente del Ministerio de Agricultura, Ganadería y Alimentos de } \\
\text { la Provincia de Córdoba }\end{array}$} \\
\hline & 1988 & 2002 & 2005 & 2006 & 2007 & 2008 & 2009 & 2010 \\
\hline $\begin{array}{l}\text { Provincia de } \\
\text { Córdoba }\end{array}$ & 7.103.074 & 6.082 .263 & 6.593 .755 & 6.595 .615 & 6.418 .535 & 5.862 .316 & 5.386 .851 & 5.048 .964 \\
\hline General Roca & 908.751 & 895.912 & 998.071 & 958.985 & 908.300 & 808.011 & 688.917 & 618.221 \\
\hline Juárez Celman & 503.840 & 413.565 & 418.028 & 408.602 & 385.302 & 357.218 & 310.139 & 281.911 \\
\hline $\begin{array}{l}\text { Pte. R. Sáenz } \\
\text { Peña }\end{array}$ & 548.124 & 403.574 & 493.682 & 487.036 & 456.691 & 397.615 & 341.545 & 304.021 \\
\hline Río Cuarto & 1.184 .899 & 921.604 & 963.609 & 955.273 & 897.961 & 800.145 & 759.581 & 683.345 \\
\hline $\begin{array}{l}\text { Sumatoria } \\
\text { cabezas } 4 \\
\text { Dptos. }\end{array}$ & 3.145 .614 & 2.634 .655 & 2.873 .390 & 2.809 .896 & 2.648 .254 & 2.362 .989 & 2.100 .182 & 1.887 .498 \\
\hline \multirow{2}{*}{$\begin{array}{l}\% \text { del total de } \\
\text { los } 4 \text { Dptos. con } \\
\text { respecto al total } \\
\text { provincial }\end{array}$} & $44,3 \%$ & $43,3 \%$ & $43,6 \%$ & $42,6 \%$ & $41,3 \%$ & $40,3 \%$ & $39 \%$ & $37,4 \%$ \\
\hline & \multicolumn{2}{|c|}{$-16,2 \%$} & & & \multicolumn{4}{|c|}{$-28,7 \%$} \\
\hline
\end{tabular}

Fuente: Elaboración propia en base a los resultados de los Censos Nacionales Agropecuarios de 1988 y 2002, y de los datos procedentes del Ministerio de Agricultura, Ganadería y Alimentos de la Provincia de Córdoba

Pero, desde 2007 en adelante, hasta 2010, sí se va a observar en nuestra región una caída abrupta del rodeo, equivalente al 28,7\%. Esta disminución acentuada de vacunos también se va a manifestar a nivel provincial y del país, por el impulso evidente del avance de la agricultura sobre los campos ganaderos y por el cierre de las exportaciones de carne. Recién ahora -2011-2012- da la impresión -por informaciones de referentes claves-, dados los buenos precios vigentes, que se está estabilizando el stock ganadero, quedando las madres en los campos.

Por otra parte, corresponde destacar que la región sur de Córdoba ha contribuido -según los registros que figuran en el cuadro arriba mencionado- hasta 2008 , con más del $40 \%$ del total del rodeo provincial, para luego declinar hasta el 37,4\%. No obstante, no deja de marcar una tradición de fuerte vocación ganadera, combinada con la explotación agrícola en sus actividades rurales.

Al respecto, es interesante advertir en nuestra zona, de acuerdo con los datos censales (Cuadro $\mathrm{N}^{\circ} 46$ ), la acusada participación de EAPs con ganado bovino, en relación con el total de EAPs existentes. El porcentaje promedio de EAPs con ganado del total de EAPs existente en nuestra área, se ubica en ambos censos sobradamente por encima del $80 \%$-siendo un tanto menor a nivel provincial-, y si bien se percibe una disminución porcentual no muy 
pronunciada entre ambos censos en todos los departamentos involucrados -debido a una disminución intercensal más pronunciada de las EAPs con ganado que las que sufren el total de las EAPs-, este fenómeno no invalida la evidencia -por lo menos hasta 2002-, como decíamos más arriba, de una notoria vocación ganadera compartida con la agrícola en nuestra zona de estudio.

\section{Cuadro $N^{\circ}$ 46. Total de EAPs con ganado bovino, en relación al total de EAPs existentes, según} departamentos involucrados

\begin{tabular}{|c|c|c|c|c|}
\hline Departamento & Censos & Total de EAPs & $\begin{array}{c}\text { Total de EAPs con ganado } \\
\text { bovino }\end{array}$ & $\begin{array}{l}\% \text { de EAPs con ganado } \\
\text { bovino del total de EAPs }\end{array}$ \\
\hline \multirow{2}{*}{$\begin{array}{l}\text { Provincia de } \\
\text { Córdoba }\end{array}$} & 1988 & 40.061 & 30.434 & $76,0 \%$ \\
\hline & 2002 & 25.620 & 17.920 & $69,9 \%$ \\
\hline \multirow{2}{*}{ General Roca } & 1988 & 1.556 & 1.453 & $93,4 \%$ \\
\hline & 2002 & 1.188 & 1.064 & $89,6 \%$ \\
\hline \multirow{2}{*}{ Juárez Celman } & 1988 & 1.653 & 1.349 & $81,6 \%$ \\
\hline & 2002 & 962 & 742 & $77,1 \%$ \\
\hline \multirow{2}{*}{$\begin{array}{l}\text { Pte. R. Sáenz } \\
\text { Peña }\end{array}$} & 1988 & 1.350 & 1.266 & $93,8 \%$ \\
\hline & 2002 & 961 & 847 & $88,1 \%$ \\
\hline \multirow{2}{*}{ Río Cuarto } & 1988 & 4.580 & 3.974 & $86,8 \%$ \\
\hline & 2002 & 2.984 & 2.421 & $81,1 \%$ \\
\hline \multirow{2}{*}{$\begin{array}{l}\text { Sumatoria } 4 \\
\text { Dptos. }\end{array}$} & 1988 & 9.139 & 8.042 & $88,0 \%$ \\
\hline & 2002 & 6.095 & 5.114 & $83,9 \%$ \\
\hline
\end{tabular}

Fuente: Elaboración propia en base a datos procedentes de los Censos Nacionales Agropecuarios de 1988 y 2002

No obstante, está claro por los datos censales y la información registrada en los trabajos de campo, que hay una evidente disminución del rodeo en los establecimientos de menor tamaño, por el empuje evidente de la expansión agrícola, y un corrimiento cuantitativo de cabezas de ganado hacia las EAPs de grandes dimensiones. Todo ello, sin disminuir durante el período 2002-2007 el total del stock ganadero para luego decaer acentuadamente el mismo a partir de 2008, como lo expresamos más arriba.

A pesar de lo arriba expuesto, da la impresión -sin caer en la ingenuidad de incluir a todos los establecimientos con rodeos mínimos como EAPs mixtas- que debido al considerable porcentaje observable de EAPs que sigue reteniendo ganado bovino en relación con el total de establecimientos existentes, todavía no se ha desdibujado el tipo de "explotación mixta" predominante por tradición en el área, no obstante la fuerte presión agrícola impulsada por la expansión de los cultivos de soja. Esta realidad no quita que numerosas pequeñas explotaciones hayan sido cedidas en alquiler para el laboreo agrícola exclusivamente, y que todos los establecimientos en general hayan priorizado, amparados en la bonanza del momento, la actividad agrícola. Pero el punto está en dilucidar si el aluvión 
sojero de los últimos años, ha borrado o no la vocación por la actividad mixta en los establecimientos del área. Lo que nosotros sí detectamos a nivel de experiencia sobre el terreno es que, más allá de qué tipo de explotación predomina en la actualidad, todavía en la región, por un lado, no se observa una agriculturización aplastante -exceptuando ciertos sectores- y, por el otro, la estrategia de muchos productores, especialmente los medianos, de conservar ambas fuentes de actividad, como una forma de contar en primer lugar con ingresos frescos inmediatos vía venta de ganado y, en segundo lugar, estar cubiertos ante eventuales adversidades de orden natural y/o económico, que puedan llegar a afectar la actividad agrícola.

\subsubsection{Consecuencias de los cambios productivos}

Más allá de estudiar la evolución productiva agropecuaria de la región, paso inicial fundamental para arribar al conocimiento del estado de situación de la misma, el nudo central de nuestra inquietud ha consistido en desentrañar hasta qué punto la expansión de la soja afecta la producción de los otros cultivos y la actividad ganadera tradicional de la región.

Lo dicho anteriormente está ligado al proceso de agriculturización que, sin la menor duda, es motorizado por el crecimiento inusitado de los cultivos de soja y que desde hace años se viene manifestando en el campo argentino. Para nosotros, lo interesante de la cuestión ha pasado por dilucidar si la expansión areal de la soja: 1) le ha quitado espacio de superficie sembrada a los otros cultivos, principalmente a los cereales; 2) ha afectado negativamente la producción en toneladas de los mismos; y 3) hasta qué punto ha perjudicado a la actividad ganadera y, por carácter transitivo, al tipo de explotaciones mixtas.

Entrando ahora específicamente al desarrollo del tramo final de este análisis, vemos que el sur cordobés obviamente no está ajeno a este fenómeno de la agriculturización, teniendo también a la soja como abanderada. Es más, debemos tener presente que, dentro del incremento espectacular de esta oleaginosa a nivel país, que alcanzó hasta la campaña agrícola 2009/10 a cubrir 18.343.272 ha sembradas y obtener una producción estimativa de 52.676.620 toneladas (MAGyP de la Nación), la provincia de Córdoba ocupa el segundo lugar entre las provincias productoras, alcanzando el 26,6\% aproximadamente de la producción a nivel nacional, lo que significa que nuestra zona forma parte y contribuye a este importante desarrollo productivo provincial.

Por otra parte, el sur cordobés, al igual que la Región Pampeana en general, ha pasado y está pasando por todas las transformaciones productivas, con las derivaciones y consecuencias 
socio-económicas que son de imaginar, materializadas por la intromisión tangible de la soja en el circuito de la producción de granos, como hecho concreto, pero motivada por razones de complejo entramado económico. En este sentido, debe quedar claro para no demonizar arbitrariamente a la soja, que los reales e imaginarios perjuicios que esta oleaginosa provoca no se deben a su proliferación en sí misma, sino que en realidad es la consecuencia o el efecto explícito de un conjunto de fenómenos causales que produjeron como resultado la expansión de este cultivo. En forma sucinta y de manera esquemática, podemos decir que la conjunción del ingreso del gran capital -internacional y nacional- en las economías agrarias, de un paquete tecnológico de máxima eficiencia y de una demanda creciente a nivel mundial de forrajeras -especialmente de esta oleaginosa- que trajo aparejado como lógica consecuencia altos precios del producto, coadyuvó a la difusión extraordinaria de este grano. Proliferación que desde luego no se circunscribe solamente a nuestra nación, sino que incluye a los países vecinos, especialmente a Brasil, aparte de incidir en otras naciones del mundo.

Además de las causales generales arriba mencionadas, se debe agregar en el caso de nuestro país la ausencia de una política de Estado que pueda oficiar de reguladora de la producción agraria, en el sentido de establecer criterios distributivos equilibrados en beneficio de todos los sectores y ramas de la producción agropecuaria, con capacidad concreta para poder contrarrestar, por ejemplo, en esta circunstancia, la tendencia al monocultivo de la soja.

En suma, son los factores políticos - como manifestación de poder- los verdaderos vectores que digitan en el plano internacional y nacional las actividades agropecuarias, por encima del desenvolvimiento económico y tendencias de mercado reinantes, en cada etapa histórica y en cada espacio geográfico, lo que significa que sobre los factores económicos interactuantes en un lugar o no lugar específico, son las decisiones políticas hermanadas con los intereses económicos las que priman y mandan sobre los factores productivos.

A continuación, una vez expresadas esquemáticamente las causas generales -a nuestro juicio- del fenómeno de la agriculturización, vamos a pasar a desarrollar los efectos, es decir, el papel que juega este proceso en el sur cordobés.

Acortando camino, porque muchos de los aspectos y resultados que nos propusimos desentrañar ya fueron explicitados anteriormente, pasamos a expresar -refiriéndonos a nuestra región- las siguientes observaciones específicas.

Podemos resumir, así, a lo largo del recorrido de los cuadros y gráficos analizados, las siguientes tendencias:

1) Un incremento de las superficies de los cultivos anuales en desmedro de las forrajeras, pasturas y montes naturales, poniendo en evidencia el avance de los cultivos 
anuales a costa de ocupar en gran parte los espacios destinados a la ganadería, donde ya a partir de estos resultados se manifiesta la embestida de los cultivos sobre otros usos de la tierra.

2) Un incremento intercensal (1988-2002) pronunciadísimo de las superficies implantadas de oleaginosas (144\%) y un aumento leve de la superficie sembrada de cereales $(6,7 \%)$, progresión que se vuelve a manifestar en el período 2002/03-2007/08, ${ }^{8}$ con un incremento areal del $46 \%$ para las oleaginosas y un 9,3\% para los cereales. Pero, en el período que media entre 2007/08 y 2009/10, observamos, asimismo, una caída importante de los cereales del 25,8\% y un incremento del 25,8\% en las oleaginosas. En concreto, aparte del crecimiento vertiginoso de las superficies implantadas de oleaginosas donde, como ya dijimos, la soja es el motor de esta expansión, vemos que las superficies implantadas de cereales se han mantenido tenazmente hasta el 2007/08, para luego caer en las dos últimas campañas, como apuntamos más arriba. Por otra parte, se debe recordar que en los primeros años de la serie 1988/89-2009/10, las superficies sembradas de cereales predominaron sobre las oleaginosas, lo que demuestra una presencia no menor hasta 1996/97.

3) Un incremento pronunciado en el período 1988/89-2002/03 en la producción en toneladas de cereales (350\%), que decae notoriamente en el período 2002/03-2007/08, pero siempre con valores positivos (5,8\%). El incremento en la producción de oleaginosas $(248 \%)$ fue también muy alto en el primer período -aunque en menor medida que los cereales-, para luego disminuir su crecimiento entre 2002 y 2007, una vez instalados sus primeros picos productivos (74\%), lo que va a desembocar, no obstante, en una producción total para la campaña 2007/08 que le pisa los talones al de los cereales. Asimismo, se debe recordar que en nuestra región, a lo largo de toda la serie 1988-2007 -exceptuando los años 2003 y 2005-, los volúmenes de los cereales fueron superiores a los de las oleaginosas. Pero, como ya lo especificamos, en el último lapso 2007/08-2009/10, vemos que los valores productivos anteriores se revierten, marcando una tendencia negativa para los cereales. Es así como los mismos disminuyen en tonelaje un $-20,6 \%$ y las oleaginosas, a su vez, manifiestan un incremento del $21,7 \%$, con tendencia a seguir creciendo.

En síntesis, a pesar de que en muchos lugares la difusión de la soja ha arrasado con los cultivos granarios tradicionales, en el caso de nuestra región, vemos, en primer lugar, que las superficies sembradas de cereales, en la secuencia 1988/89-2009/10 no han variado dentro de

\footnotetext{
8 Recordar que se toma como punto de referencia la campaña 2007/08 y, por ende, el período 2002/032007/08, porque esta última campaña, aparte del conflicto agrario, es un momento de corte profundo, dado que hasta esa fecha los cereales mantuvieron su supremacía productiva, pero a partir de ahí en adelante, los mismos sufren una caída pronunciada.
} 
los promedios observables a lo largo de dicha serie, a pesar de la caída areal de los últimos años. En segundo lugar, observamos que la producción en toneladas de cereales no sólo ha crecido progresivamente -más allá de ciertos retrocesos en algunos años debido a diferentes contingencias-, sino que sus volúmenes en los últimos años también han sido superiores, en general, a los de las oleaginosas, exceptuando las dos últimas campañas, como ya lo especificamos, pero con el agravante de que en los próximos todas las señales indican que esta caída todavía se profundizará en relación con las oleaginosas. Por otra parte, nos interesa resaltar la variable producción en nuestra región por dos razones. La primera, para dejar en claro que si bien las superficies sembradas de cereales están limitadas y acotadas en relación con los sembradíos de soja, esta situación no ha impedido su crecimiento productivo a lo largo de gran parte de la serie analizada, aunque en los últimos dos años haya flaqueado su producción en términos comparativos a años anteriores. La segunda, en un plano más general, consiste en destacar que, aparte de la importancia económica de lo que representa la producción en términos volumétricos de los cereales, dicha relevancia también pasa por la connotación alimenticia indudable que tienen estos granos $\mathrm{y}$, muy en particular, en las actuales circunstancias de nuestro país.

Está claro que los cereales, hasta el momento, siguen teniendo presencia efectiva en nuestra zona, lo que no significa que más adelante puedan sufrir cambios sustanciales. Es evidente que hay signos claros de estancamiento $\mathrm{y}$, en cierto modo, de acorralamiento espacial de los mismos por parte obviamente de la soja, pero tampoco se perciben signos de retraso manifiesto, más allá de las circunstancias de los últimos malos años -lo que no quiere decir que, de mantenerse su producción histórica e inclusive de incrementarse manifiestamente, sus volúmenes no se sigan distanciando de las oleaginosas-, al suponer que, a la larga, seguirá mediando la demanda de trigo y maíz de algunas importantes industrias molineras instaladas en la región, además de cierta prevención en varios productores de mantener una diversificación en sus cultivos por razones agroecológicas y de tradición en el trabajo de los granos clásicos de la zona.

Resulta interesante, además, relacionar la situación por la que atraviesan los cereales en nuestra área, con la opinión de dos calificados investigadores (Barsky y Dávila, 2008) en una de sus últimas publicaciones, donde expresan, entre otras consideraciones, que no es del todo cierto como muchos creen, que la expansión de soja ha anulado el crecimiento de los otros cultivos pampeanos.

Sin entrar en las consideraciones que manifiestan estos autores vemos que, en nuestra región, a pesar de que las superficies sembradas y la producción volumétrica de los cereales 
están acosadas desde hace años por las oleaginosas, estas dos variables no han sufrido, a lo largo del tiempo aquí analizado, grandes retrocesos. ${ }^{9}$ El problema central reside más bien en su estancamiento productivo.

No obstante esta suerte de atrincheramiento de los cereales -con claros signos de debilidad progresiva- en nuestra zona, su futuro no deja de presentarse incierto si a este fenómeno de la sojización no se le pone límite, dado que obviamente, tiende a producir distorsiones distributivas en los otros cultivos granarios.

El otro punto ligado al proceso de agriculturización es la actividad ganadera, que sin la menor duda, de acuerdo con nuestra experiencia de campo, ha sufrido fuertes recortes espaciales. Pero, más allá de este achicamiento areal, que puede ser eventualmente compensado en parte con el sistema de feed-lot, lo cierto es que han entrado a jugar también otros factores que han limitado los rodeos, como por ejemplo las restricciones o cierre de las exportaciones de carnes.

En suma, a pesar de haberse mantenido la cantidad del rodeo de la región relativamente estable desde el año 2002 hasta el año 2007, luego, a partir de este año, donde sí se manifiesta una marcada inflexión negativa, lo real es que la cantidad de cabezas y, lo que es peor, la cantidad de EAPs con ganado bovino, tomando como punto de referencia el año 1988 al presente, ha disminuido notablemente.

No obstante, la importancia que sigue teniendo la ganadería del sur cordobés a nivel provincial, más la vocación ganadera de la zona expresada en la cantidad de establecimientos con rodeo en relación con el total de EAPs existentes para el mismo año de registro -si bien los datos son viejos (2002)-, más los relevamientos de campo nuestros, dan a entender que sigue vigente en gran parte el tipo de explotación mixta -aunque disminuida presumiblemente la parte que le corresponde a la actividad ganadera-, característica de la región.

En lo referente a las repercusiones del proceso de agriculturización en la estructura agraria fundiaria de la zona, si bien ya lo desarrollamos en la primera parte de este capítulo, aquí lo volvemos a reiterar en forma sintética, en los siguientes términos: al igual que en toda la Región Pampeana, en el sur cordobés se puede observar una disminución acentuada de EAPs entre 1988 y 2002, con signos de que continúa este declive, según información de procedencia empírica, con un incremento sostenido en el tamaño promedio de las explotaciones y un desplazamiento de las EAPs de dimensiones grandes hacia la escala de

Excepto el retraso coyuntural manifiesto en el caso del trigo que, por la confluencia de circunstancias políticas y naturales, tanto a nivel país, de provincia y de región, sus cultivos decayeron abruptamente en la última campaña 2009/10 registrada en este trabajo. 
extensión superior a las 1.000 ha, lo que nos indica una fuerte concentración de tierras en manos de los establecimientos de mayor tamaño.

Un incremento sustantivo de campos arrendados, especialmente por aquellas explotaciones que ya poseen tierra en propiedad, a fin de adecuarse a las nuevas escalas productivas y, por último, la proliferación del tipo jurídico del productor bajo la categoría de sociedades anónimas, que refleja la intromisión del gran capital en el quehacer agropecuario.

En síntesis, lo que manifiesta la actual estructura agraria fundiaria es la concentración del capital cada vez más en poder de pocas manos y la despersonalización progresiva de las actividades rurales.

Con respecto a la fuerza del trabajo rural -aspecto que está estrechamente ligado al fenómeno que venimos analizando-,lo trascendente de recordar es que las profundas modificaciones que viene sufriendo el campo se presentan acompañadas, también, con la aparición de nuevos actores laborales y con la adecuación a las nuevas circunstancias de aquellos agentes rurales que han podido o sabido sobrevivir a los cambios productivos imperantes.

Finalizando, cabe reafirmar, de acuerdo con todo lo antedicho, que el fenómeno de la sojización no se limita a generar solamente alteraciones estrictamente productivas, sino que viene acompañado también por alteraciones socio-económicas de todo tipo, que repercuten en forma directa o indirecta en la estructura social del país. Debe quedar en claro que el fenómeno aludido no es el origen de la causa de las alteraciones mencionadas, sino más bien el efecto tangible de un cúmulo de realidades y medidas político-económicas, interactuantes y dispuestas en diferentes planos jerárquicos de decisión. 


\section{Capítulo VI}

\section{Composición y articulación socio-económica, desde la perspectiva geográfica, de los}

principales actores sociales que componen la PEA Agropecuaria

La idea a desarrollar a continuación consiste en brindar especialmente los conocimientos y análisis respectivos, obtenidos de primera mano, sobre los principales actores sociales que conforman la fuerza laboral en nuestra región de estudio.

Para la recopilación de la información pertinente, nos hemos valido de las encuestas y entrevistas mencionadas en el capítulo 4 -que incluyen básicamente a productores y asalariados-, más los resultados de la realización de otras entrevistas orientadas a involucrar a otros agentes rurales. Por lo tanto, lo que aquí se expresa es el producto de una tarea eminentemente empírica, apuntalada, en menor término, por los aportes de información proveniente de otras fuentes complementarias. El propósito que se persigue, asimismo, aparte del análisis de los aspectos propios que atañen al desenvolvimiento de cada agente laboral, es precisar la correspondiente articulación y complementación que se establece entre los mismos.

En suma, en esta instancia, los principales agentes rurales que aquí se consideran van a ser, específicamente: los productores, asalariados, contratistas de servicios rurales y agroindustrias en su papel de productores primarios, y va a consistir básicamente en la caracterización de los perfiles socio-económicos de éstos, donde se vuelca con especial énfasis datos sobre la estructura familiar, nivel educativo, perfil laboral y perfil económico.

Se debe recordar que, en el capítulo 4, se brindó la información atinente al perfil locacional de los agentes rurales, proveniente también de las encuestas y entrevistas arriba mencionadas.

Por último, podemos decir que la explicitación temática que en este capítulo se desarrolla se puede considerar como la parte sustantiva del presente trabajo, en el sentido de que aquí se procura dar a conocer las indagaciones llevadas a cabo en forma directa sobre la actividad específica de los actores sociales que nos interesan, con sus respectivas implicancias territoriales, sujetos centrales de esta tesis. 


\subsection{Caracterización del perfil socio-económico de los productores agropecuarios}

Como expresáramos en otra parte de este trabajo, los productores agropecuarios, en un sentido conceptual amplio -en que se incluyen todas las escalas de tamaño de productores existentes-, representan, a nuestro juicio, la principal fuerza del trabajo rural, ya que son ellos los hacedores centrales de las actividades del campo, que arrastran y condicionan a los otros agentes rurales interactuantes. Su peso en todos los procesos productivos agrícolas y su intervención en las transformaciones laborales rurales es determinante. Pero, dentro del amplio espectro de escalas económicas que media en este tipo de agentes, resaltamos una vez más - de acuerdo con nuestro enfoque epistemológico sobre la temática general de esta tesis-, nuestro interés básico por el desempeño del pequeño productor y, como extensión, por el mediano productor también, en la medida que conserve identidad propia, no borrada por el anonimato empresarial. La realidad de la fuerza laboral de nuestra región de estudio es rica justamente en este tipo de productores, cuyas EAPs se caracterizan, a nuestro juicio “...como una forma de producción con predominio del trabajo familiar aplicado a la tierra, constituye una clase en transición, en activo proceso de diferenciación, entre las dos clases básicas del capitalismo rural, los empresarios y los asalariados" (Carballo González, 2007:65). Dentro de su predominancia numérica, que no prevalece en lo que respecta a la mayor posesión de tierra, vemos que muchos de ellos se destacan por su capacidad de capitalización en sus unidades productivas y por su rápida adecuación a las transformaciones tecnológicas, sin descartar que, en la zona, también coexisten EAPs familiares, cuya capacidad económica no cubre del todo o lo logra con mucha dificultad -si es que lo logra-, la reproducción ampliada de las unidades de producción. Aparte del interés por estos tipos de productores mencionados, obviamente también consideramos, para la comprensión integral de esta clase de agentes rurales, a los otros estratos sociales de la burguesía rural. En suma, en este acápite, trataremos de no hacer hincapié en la descripción de los aspectos generales del productor agropecuario, ya que, en lo atinente a las transformaciones que le afectan y a su papel dentro de la estructura fundiaria y productiva, entre otras problemáticas, ya nos hemos referido en diferentes partes de este escrito. En cambio, a renglón seguido, sí entraremos de lleno -a diferencia de una descripción genérica previa, que sí llevaremos a cabo con los otros agentes rurales, cuando tratemos sus características- a desarrollar los datos obtenidos de las encuestas ya mencionadas, sobre la caracterización socio-económica de los mismos.

A continuación, completaremos la descripción del relevamiento de datos que se llevó a cabo en los centros urbanos -correspondiente a los "pueblos testigo" ya mencionados más arriba-, en 1994. 


\subsubsection{Encuesta llevada a cabo a los productores en los centros urbanos. Año $1994^{1}$}

\section{ESTRUCTURA FAMILIAR}

El promedio general de miembros del N.F. de los productores que viven bajo un mismo techo $^{2}$ en los pueblos es de 4,6. Cifra similar pero un poco menor al del N.F. de los productores que residen en el campo. Lo que sí varía en relación con éstos es, en el caso de las familias residentes en los pueblos, en que el número de integrantes de sus familias ampliadas ${ }^{3}$ -que viven fuera del pueblo, o sea en las áreas rurales- es mucho mayor. Situación típica: los padres residen en el centro urbano y el hijo casado en la explotación. Concretamente, dicha extensión corresponde al $21 \%$ del total de miembros contabilizados en esta muestra.

De ciento cinco explotaciones relevadas, en el $25 \%$ de ellas, el N.F. está conformado por familias ampliadas.

Si bien en esta encuesta no se levantaron datos correspondientes a la edad de sus integrantes, tenemos presente que, en las entrevistas efectuadas a los productores jefes de familia, éstos respondían a edades que fluctuaban entre cuarenta y cinco y sesenta años, o sea, un promedio de edad más bien maduro. Es interesante destacar que, de ciento treinta y dos jefes de familia, que responde al 27,5\% del total de miembros del N.F., se desempeñan cinco mujeres (viudas) en calidad de productores jefes de familia. Las esposas, a su vez, representan el $26 \%$ del total de integrantes del N.F.

Los hijos (no están diferenciados por sexo) representan el 42,5\% del total de miembros del N.F., resultando este porcentaje un poco mayor que el correspondiente al de los hijos de los productores que residen en el campo, lo que da a entender que la familia de los productores que viven en los pueblos retienen en mayor medida a sus hijos bajo el mismo techo.

Aparte del grupo central (padres e hijos), que representa el 96\% del total de los N.F. entrevistados, lo poco que resta (4\%) corresponde a otros miembros de la familia.

Con respecto al estado civil de los productores, la amplia mayoría está casado (94\%), luego siguen los viudos-viudas (4,5\%) y por último los solteros $(1,5 \%)$.

El cuestionario completo de la encuesta llevada a cabo en 1994 figura en el Anexo de este trabajo.

2 Corresponde acotar que la presente encuesta, y la llevada a cabo en el año 2002, aparte de considerar solamente a los miembros del N.F. que viven bajo un mismo techo, también contabiliza a los hijos que viven fuera del hogar (ej.: estudiantes), pero que están a cargo del jefe de familia.

3 Como "familia ampliada" se entiende a aquellas unidades económicas-laborales familiares, que se extienden del pueblo hacia el campo, cuando la base principal de la localización está en el centro urbano, ej.: el padre vive en el pueblo y el hijo casado en el campo, y del campo hacia el pueblo, cuando la base principal de la localización está en el campo, ej.: el jefe -generalmente el padre- vive en la EAP y el hijo -u otro miembroen el pueblo. 


\section{PERFIL ECONÓMICO}

\section{Régimen de tenencia y extensión de las explotaciones}

De las ciento cinco explotaciones encuestadas, casi todos los productores son propietarios $(95 \%)$. Con respecto al tamaño original de las explotaciones $-\mathrm{o}$ sea, en la condición de propiedad del productor- le corresponden a las P.E. el 59\%, a la M.E. el 24\% y a las G.E. el $18 \%{ }^{4}$

Si bien se sabe que la condición del tamaño no debe ser determinante para diferenciar la capacidad productiva de las explotaciones -como bien se explicitó en el capítulo anterior- ya que se deben contemplar otras variables, como recursos tecnológicos, manejo de las mismas, disponibilidad de capital, las que inciden juntamente con el tamaño en los niveles de producción; en general, en la región estudiada, todas las variables mencionadas evidencian un sentido de proporcionalidad en relación con las dimensiones de las explotaciones. Por lo tanto, se puede adoptar como válido en nuestra área de trabajo la diferencia de tamaño de los predios para distinguir los distintos niveles productivos de las explotaciones.

Los establecimientos que a su vez arriendan campos de otros con la finalidad de ampliar sus explotaciones, corresponden a un $47 \%$ del total de los mismos. Si a los que arriendan campos los desagregamos por tamaño, vemos que a los que ampliaron sus dimensiones del total de su categoría les corresponde a las P.E. el 43,5\%, a las M.E. el 44\% y las G.E. el 61\%.

El resultado de este incremento de tierra arriba mencionado es el siguiente: las P.E. originales, del 59\% del total, se van a reducir a un 41\%; las M.E. originales, del $24 \%$ del total, se van a incrementar a un $32 \%$, y las G.E. originales, del $18 \%$ del total, se van a acrecentar a un $27 \%$. En suma, el $39 \%$ de los establecimientos que arrendaron campos ascendieron de categoría de explotación por tamaño.

En cambio, son muy pocos los establecimientos (el 6\%) que alquilan alguna parcela de su campo. Cabe recordar que este último guarismo -como los anteriores- responde a la encuesta que se realizó en 1994; por lo tanto, es de suponer que, en la actualidad, más que la modalidad de arrendar parcelas de las explotaciones, la tendencia pase posiblemente por

\footnotetext{
Aquí median dos aclaraciones:

1. En esta instancia, dentro de las grandes EAPs - de acuerdo con la clasificación por tamaño de las EAPs establecidas en el capítulo anterior-, quedan incluidas las "medianas grandes", de 500 a 1.000 ha, y "grandes" propiamente dichas, de más de 1.000 ha., como una forma de sintetizar la descripción de los diferentes estratos de los establecimientos. Cabe recordar, a su vez, que promediando las diferencias zonales, consideramos como P.E. a aquellas que se extienden hasta las 200 ó 300 ha. y M.E. hasta las 500 ó 600 ha.

2. Los diferentes porcentajes por tamaño de las EAPs obtenidas en la presente encuesta, si bien no reflejan con precisión, sino aproximadamente la distribución fundiaria por extensión de los predios, sirven más bien para apreciar cómo se agranda la base original por tamaño de las EAPs, al incrementar su dimensión mediante el arriendo.
} 
arrendar directamente toda la EAP, en el caso de aquellos pequeños establecimientos descapitalizados.

\section{Tipo de explotación que se lleva a cabo}

Los establecimientos del total que se dedican "exclusivamente a la agricultura" se limitan al 8\%, sobresaliendo la zona rural de General Deheza, y "exclusivamente a la ganadería” también el 8\%. Aquí no sobresale ninguna zona rural específica.

Dentro de la "actividad mixta" que se lleva a cabo "por partes iguales", le corresponde a esta franja el 36\% de los establecimientos, destacándose las áreas rurales de Alcira (Gigena), Adelia María y General Cabrera. A la "actividad mixta" donde "predomina la agricultura", le corresponde el 13\% y donde predomina la ganadería los valores ascienden al 35\%, sobresaliendo las zonas de Sampacho, Vicuña Mackenna, Coronel Moldes y Ucacha, las dos últimas con fuerte incidencia tambera. En los casos de Alejandro Roca y Berrotarán, si bien no hay predominancia definida hacia alguno de los dos tipos de explotación practicados, la tendencia se inclina más hacia la agricultura.

Es importante resaltar la fuerte presencia de establecimientos tamberos en Ucacha y Coronel Moldes y, en menor medida, en Adelia María.

En suma, predominan las actividades mixtas, que involucran al $84 \%$ de los establecimientos, con una clara supremacía hacia la ganadería. De acuerdo con el tamaño de los establecimientos, solamente sobresalen netamente dentro de los diferentes tipo de explotaciones que se llevan a cabo, las G.E. en la franja de actividad mixta con predominancia de la ganadería.

\section{Tipo jurídico de los productores}

De las ciento cinco explotaciones relevadas, sólo el 37\% de sus productores se constituyen en sociedad, porcentaje menor que el de los productores que viven en el campo, no diferenciándose en esta encuesta si la sociedad conformada es de hecho o legal. A su vez, predomina ampliamente la vinculación societal entre familiares (95\%).

\section{Extensión de actividad económica fuera de la explotación}

\section{- Actividad económica urbana}

Un 14\% de los productores desarrollan, a su vez, una actividad económica urbana. Es indudable que el hecho de vivir en el pueblo facilita eventualmente vincularse con un quehacer urbano. 


\section{- Otro tipo de actividad económica rural fuera de la explotación}

En esta encuesta, se detectó que el 9,5\% de los productores se dedican a otra actividad económica rural fuera de la que desarrollan en sus respectivas explotaciones. Por carecer de la información específica, se presume, dado que un porcentaje similar de encuestados disponen -dentro de su parque de maquinaria- también de cosechadoras, que se desempeñan básicamente como contratistas rurales, aparte de sus tareas específicas en las EAPs.

En síntesis, considerando a todos los productores que desarrollan otra actividad fuera de la explotación (24\%), vemos que constituyen una porción importante del total de ellos.

\section{Asociación a cooperativas}

Un poco más de la mitad de los responsables de las EAPs encuestadas (51\%), revisten en calidad de socios de cooperativas agropecuarias, pero este porcentaje se reduce a un $29 \%$, si descontamos a los establecimientos tamberos que, en la zona, para poder funcionar, tienen que depender casi todos ellos de una cooperativa láctea. En concreto, este tipo de asociativismo está poco desarrollado en general en la región de estudio, exceptuando tres localidades -en las que intervienen dos cooperativas- de las diez encuestadas, donde sí se manifiesta una participación societaria destacable.

\section{Maquinaria disponible}

A criterio de los productores, el 14\% está básicamente equipado de maquinarias, el 74\% bien equipado y el $12 \%$ muy bien equipado. Por lo tanto, los productores disponen de buena maquinaria. En todos los tamaños de explotaciones, predominan los establecimientos que están bien equipados.

Cabe acotar que, en esta encuesta de 1994, el estar "bien equipado" de maquinaria, no implica disponer obligadamente de cosechadora, cuando la actividad de cosechar la llevaban a cabo generalmente los contratistas de servicios, y menos de sembradora directa cuando, para esa fecha, esta innovación tecnológica recién se estaba introduciendo en la región. Ahora, el disponer de estas últimas herramientas, sí daba lugar al ingreso del nivel de los "muy bien equipados". 


\section{PERFIL LABORAL DE LOS PRODUCTORES Y DEL PERSONAL DEPENDIENTE}

\section{Características laborales de los productores}

\section{- Fuerza laboral y familia dependiente}

El total de la PEA Agropecuaria representa el 33\% del total del N.F., porcentaje mucho más bajo que el de los productores que residen en las explotaciones, lo que está expresando que, aparte de los jefes de familia -que representan el 85,5\% del total de la PEA Agropecuaria-, la participación en el trabajo de los otros miembros de la familia es muy baja.

Cuadro $\mathrm{N}^{\circ}$ 47. Distribución de la fuerza laboral y familia dependiente. 1994

\begin{tabular}{|c|c|c|c|}
\hline \multirow{2}{*}{ Total del NF } & Potal & Familia dependiente \\
\cline { 2 - 4 } & $160(33 \%$ del total del NF) & Jefes $132\left(\begin{array}{c}(82,5 \% \text { del total de la PEA } \\
\text { Agropecuaria })\end{array}\right.$ & $320(67 \%$ del total del NF $)$ \\
\hline Fuente: & Elaboración propia en base a los datos recogidos de la encuesta de 1994.
\end{tabular}

Cabe recordar que figuran ciento treinta y dos jefes de familia en ciento cinco explotaciones; por lo tanto, hay establecimientos que cuentan con más de un jefe de familia o productor a cargo de las mismas, y que en esta encuesta estos casos corresponden a la familia ampliada. Un jefe vive en el pueblo (por ejemplo, el productor padre) y el otro en la explotación (por ejemplo, el productor hijo).

\section{- Atención de las explotaciones}

Del total de los productores que viven en los pueblos, atienden sus establecimientos de manera personalizada el 30,5\%, a través de un familiar y/o empleado el 11,5\% (corresponde a la atención indirecta), y los que combinan ambas formas (o sea, atención directa e indirecta) el $58 \%$. Este último porcentaje refleja bien la realidad laboral de los productores que residen en los centros urbanos, dejando en claro que, en general, no existe de parte de éstos una atención rigurosa de sus explotaciones.

\section{- Perspectivas futuras con respecto a la atención de las explotaciones}

En este ítem, a diferencia de la encuesta realizada a los productores que viven en la explotación -donde lo que se evalúa cuando nos referimos a perspectivas futuras, está en relación con la capacidad productiva que pueden generar las diversas formas de trabajar la explotación-; lo que se procura básicamente medir en esta instancia es la intencionalidad a futuro que media por parte de los responsables con respecto a la atención individual de sus campos. 
En este sentido, comprobamos que prioritariamente media la voluntad de seguir como hasta ahora con el 75,20\%, seguido por la intención de atenderlo en forma más personalizada con el 19,8\% y luego en porcentajes muy reducidos vienen las variantes: está pensando en volver al campo $(2 \%)$, pasar a vivir nuevamente al campo personalmente con su familia $(2 \%)$ $\mathrm{y}$, por último, pasar a vivir nuevamente al campo a través de un miembro de su familia (1\%).

En suma, se observa una modesta preocupación y tendencia de parte de los productores por procurar brindar una mayor atención a las explotaciones, como una forma de incrementar su capacidad productiva y de sobrevivencia, en última instancia. Recordemos que en el año en que se llevó a cabo esta encuesta, la situación económica agropecuaria no atravesaba por los mejores momentos, motivo por el cual, para esa época, se instaló nuevamente en el imaginario de los productores, como una salida utópica de superación de las dificultades económicas y falta de apoyo estatal, el "regreso al campo", entendiéndose tal proceder como una suerte de sobrevivencia protectora, para poder atravesar el mal trance del momento. Obviamente, esta inquietud no tuvo eco y rápidamente perdió vigencia.

\section{- Características laborales de los trabajadores dependientes de que disponen los productores}

En este ítem, se ha contabilizado tanto los empleados fijos como temporarios.

Los productores que residen en los pueblos cuentan con más empleados fijos (63\%) que temporarios (37\%). Dentro de los trabajadores fijos, el 19\% vive en los pueblos y el $81 \%$ en las explotaciones. El último porcentaje responde lógicamente a la necesidad que requieren los campos de un cuidado permanente $y$, a la inversa, el 7,5\% de los temporarios residen en la explotación y el 92,5\% en los pueblos.

Del total de la PEA de los productores y PEA de los asalariados que interviene en esta encuesta, el 58\% corresponde a la PEA de los asalariados y el $42 \%$ a la PEA de los productores. En cambio, en la encuesta de los productores que residen en las explotaciones, predomina netamente la PEA de estos últimos.

En síntesis, y por razones obvias, la cantidad de empleados de que disponen los productores que residen en los pueblos es mucho mayor que la que disponen los que viven en las explotaciones.

Del total de las ciento cinco explotaciones, el 69\% cuenta con empleado y, en muchos casos, con más de uno de ellos. Porcentaje muy superior al de la otra encuesta referida, guarismo que guarda relación con la necesidad de cuidado que requieren las explotaciones cuyos dueños no viven en ellas. 


\subsubsection{Encuesta llevada a cabo a los productores en las zonas rurales. Año $2002^{5}$ PERFIL SOCIAL}

\section{ESTRUCTURA FAMILIAR}

El promedio de integrantes que componen el N.F. que viven bajo un mismo techo varía entre cuatro y cinco miembros. El promedio exacto es de 4,76\% integrantes por familia. Si bien hay ciertos ejemplos de familias conformadas por muchos miembros, la realidad indica que no son numerosas, como sí lo fueron -según testimonios del medio- las correspondientes a una o dos generaciones anteriores a las actuales. En lo que respecta a las familias ampliadas de los hogares rurales, vemos que el porcentaje de integrantes que por extensión residen en los centros urbanos, es de apenas el 6,3\% del total de miembros contabilizados, lo que indica que la prolongación del N.F. de los hogares rurales en los pueblos es muy reducida.

Es pertinente precisar que muchas familias rurales cuentan con más hijos que los contabilizados, pero éstos ya no viven en el hogar paterno ni dependen económicamente de los padres. Por lo tanto, a pesar de que el número original de los miembros de las familias rurales es un poco mayor que lo establecido por nosotros, esta circunstancia no altera que la cantidad de integrantes de las mismas sea más bien limitada, con valores estándar similares a las familias de los centros urbanos.

La edad de los productores jefes de familia fluctúa entre los cuarenta y siete y cincuenta y ocho años, siendo el promedio general de 52,5 años, lo que representa una dirección y fuerza laboral de las explotaciones más que madura.

El promedio general de edad de las esposas de los jefes de familia es de cuarenta y ocho años, cuya diferencia de años con respecto a sus esposos se puede considerar como normal, de acuerdo con los cánones clásicos de diferencia de edad que media entre el hombre y la mujer cuando se constituyen en matrimonio en la sociedad argentina.

El N.F. cuenta con más hijos que hijas (casi el doble), debido a que éstas, entre los veinte y veinticinco años, al formar pareja, dejan el hogar paterno. Fenómeno que resulta ser más acusado en las mujeres que en los varones. La edad promedio de los hijos es de 18,5 años, lo que indica, en general, que están en condiciones de ayudar al padre. Muchos de ellos están casados y conviven con los padres en la misma casa o en una vivienda adyacente dentro de la misma explotación. Esta última se considera como una prolongación del hogar rural. La edad promedio de las hijas es menor, situándose en los 16,7 años.

\footnotetext{
Encuestamos aquí a los productores que viven a campo traviesa, o sea, aquellos que forman parte de la población rural dispersa. El cuestionario de esta encuesta, llevada a cabo en 2002, se encuentra en el Anexo de este trabajo.
} 
Fuera del grupo central (padres e hijos), que representa el $81 \%$ del total del N.F. encuestado, participan también del mismo otros miembros, como padres a cargo, con edad promedio muy elevada (setenta y ocho años), hermanas y hermanos (en escasísima proporción), yernos y nueras, nietos y otros, ${ }^{6}$ especialmente observable en las familias numerosas.

Con respecto al estado civil de los productores, predominan ampliamente los casados (89\%), luego siguen los solteros $(7,1 \%)$, viudos $(2,6 \%)$ y divorciados $(1,3 \%)$. El alto porcentaje de productores casados estaría indicando una fuerte predominancia de hogares constituidos de forma clásica.

\section{Nivel de instrucción de los jefes de familia}

De un total de ciento cincuenta y cinco productores jefes de familia considerados, el grado de instrucción alcanzado por los mismos es el siguiente:

- Enseñanza primaria: el 85\%, de los cuales han completado el ciclo el $69 \%$.

- Enseñanza media: el 14\%, de los cuales han completado el ciclo el $48 \%$.

- Enseñanza superior: el 1\%, de los cuales todos han completado el ciclo.

Como se puede observar, la amplia mayoría de los productores solamente cuentan con el grado de instrucción primaria (nivel que en general poseen muchos otros miembros mayores del grupo familiar), con el agravante de que un $31 \%$ no ha terminado el mencionado ciclo. Es interesante destacar que dentro de esta realidad están involucrados todos los niveles socio-económicos de los productores, o sea, tanto los pequeños y medianos como grandes productores, lo que no altera esta situación es que el grueso de la pequeña franja de los que han accedido a la enseñanza media corresponde a los medianos y grandes productores.

En suma, a pesar del bajo nivel de instrucción en general de los productores, corresponde precisar que el bagaje de conocimientos y educación no formal de muchos de ellos es apreciablemente alto. Es indudable que las características de su trabajo, en un medio productivo cada vez más complejo -incentivado, a su vez, por la proliferación de los medios de comunicación- y el propio afán de superación, han incidido positivamente en este incremento educativo a nivel individual. A modo de ejemplo, no cabe duda de que la participación en exposiciones, reuniones de asesoramiento de parte de organismos oficiales, actuación gremial e intercambio profesional entre colegas y vecinos ayuda a incrementar la formación cultural de estos agentes.

6 "Otros": en esta categoría se incluye a familiares con otros grados de consanguineidad y a personal que no posee vínculos de consanguineidad, pero que están incorporados al N.F. del productor. 


\section{PERFIL ECONÓMICO}

\section{Régimen de tenencia y extensión de las explotaciones}

Casi todos los productores de ciento treinta y dos explotaciones encuestados son propietarios (el 97\%), quedando en evidencia que la figura del arrendatario tradicional (el que alquila el campo por varios años) prácticamente ha desaparecido de la región bajo estudio, lo que indicaría una consolidación progresiva de la propiedad de la tierra por parte de los productores. Esta característica no implica que no se esté alquilando cada vez más campos bajo el sistema de arrendamiento accidental, que consiste en un arrendamiento por un lapso menor de dos años. Cabe aclarar que, en nuestra encuesta, nos hemos abocado a entrevistar a los productores con varios años de permanencia en la explotación.

Con respecto al tamaño de las explotaciones encuestadas, en relación con su tamaño original $-\mathrm{o}$ sea, en la condición de propiedad del productor-, le corresponde a las P.E. el $61,4 \%$, a las M.E. el $24,2 \%$ y a las G.E. el $14,4 \%$ del total.

Los predios que a su vez arriendan campos con la finalidad de ampliar sus explotaciones corresponden a un 54,5\% del total relevado de los mismos. Si las desagregamos por tamaño, vemos que las que ampliaron sus dimensiones del total de su estrato, les corresponde a las P.E. el $48 \%$, a las M.E. el $62,5 \%$ y a las G.E. el $68 \%$, porcentuales que coinciden con sus respectivas capacidades económicas.

El resultado de esta incorporación de tierras es que se va a producir una transformación del tamaño original de las explotaciones. Es así como las P.E. originales, del 61,4\% del total relevado se van a reducir definitivamente a un 47\%; las M.E. originales, del 24,2\% del total se van a incrementar a un 27,3\%, y las G.E. originales, del 14,4\% se van a acrecentar a un $25,7 \%$. En concreto, se produce una transferencia de pequeñas a medianas y de éstas a grandes explotaciones, siendo estas últimas las que más se incrementan numéricamente. Modificaciones más que elocuentes, que estarían señalando el propósito de consolidarse económicamente de parte de los pocos productores que todavía quedan en las áreas rurales.

En cambio, al igual que en la otra encuesta de 1994, son muy pocos los productores (un 9,8\%) que dan en alquiler alguna parcela de su campo. Generalmente, las arriendan a los sojeros y maniceros bajo la figura del arrendamiento accidental, ya que éstos pagan muy buenos precios por el alquiler de los campos.

Es importante aclarar que los bajos porcentajes de desprendimiento de parcelas por parte de los productores que mencionamos más arriba, responde a lo relevado hasta 2002. Pero tenemos referencias concretas de que, en el tiempo transcurrido hasta la actualidad, se ha incrementado sobremanera esta práctica de alquiler, pero más que porciones de los campos, el 
arriendo -como lo dijimos en el acápite anterior- involucra toda la EAP, ya sea para hacer soja o maní, particularmente a contratistas capitalistas, pools de siembra o a grandes empresas agroindustriales.

\section{Tipo de explotación que se lleva a cabo}

Los establecimientos del total que se dedican exclusivamente a la agricultura se limitan al 6,8\% y exclusivamente a la ganadería el 12,1\%. Aquí sobresale la actividad tambera.

De las diez zonas rurales de los pueblos testigos analizados, se destaca como zona agrícola el área rural de General Deheza, y como zona ganadera pero especializada en la actividad tambera, la de Ucacha.

Dentro de la actividad mixta que se lleva a cabo por "partes iguales", le corresponde a este ítem el 23,5\% de los establecimientos y donde predomina la agricultura el 18,2\%. Las zonas rurales de actividad mixta con predominancia de agricultura van a ser General Cabrera, Berrotarán y Alcira (Gigena). A la actividad mixta donde predomina ganadería le corresponde el 39,4\% de los establecimientos y representa el tipo de explotación preponderante de todos los descriptos. Las zonas rurales donde predomina la ganadería son Sampacho, Coronel Moldes, Vicuña Mackenna, Adelia María y Alejandro Roca, pero se observa una fuerte recaída de la actividad tambera en Coronel Moldes y Adelia María.

En síntesis, lo que debe quedar claro es que, en general, en el área de estudio -al igual que en la encuesta de 1994- predominan las actividades mixtas con supremacía ganadera, totalizando dentro de este ítem el $81 \%$ de los establecimientos. Por último, corresponde precisar que no se observa una preponderancia neta por tamaño de establecimiento en los diferentes tipos de explotaciones que se llevan a cabo, salvo en el rubro exclusivamente ganadería, donde prevalecen las P.E., básicamente representadas por la actividad tambera.

\section{Producción de las explotaciones}

\section{- Ganadería bovina}

De las ciento veintitrés explotaciones que realizan actividad ganadera, predominan -con un $35 \%$ - los que practican ciclo completo, seguidos con igual porcentaje por los que practican cría $(10,5 \%$ y recría $(10,5 \%)$; luego vienen los que hacen tambo (9\%); a continuación, los que practican el sistema de capitalización (5\%) y, por último, un resto escaso del $2 \%$ representado por las actividades de granja, cabaña y ganadería ovina.

Todas las prácticas específicas arriba nombradas representan el $72 \%$ del total de explotaciones encuestadas, correspondiendo el $28 \%$ de establecimientos restantes a diferentes 
“combinaciones" de las diversas prácticas ganaderas nombradas. De estos últimos, sobresalen las explotaciones que combinan la actividad de cría y recría.

Si a los establecimientos que realizan ciclo completo les sumamos aquellos que, en la combinación que practican, también hacen en parte ciclo completo, el porcentaje de esta última práctica asciende al 48\%. Queda claro que, en los productores encuestados, hay una firme tendencia a procurar -en la medida de lo posible- lograr la terminación de los animales, con el objeto de obtener mayores ganancias.

\section{- Agricultura}

Considerando a todas las zonas involucradas, en la presente encuesta se destaca, en primer lugar, el cultivo de soja, seguido por el de maíz. Luego viene el de maní, seguido por el trigo como cultivo de invierno y, por último, de manera muy parcializada, el de girasol. Obviamente, de los datos del año 2002 aquí vertidos a la actualidad, la producción sojera se incrementó sustancialmente, como bien lo expresan los guarismos volcados al respecto en el capítulo anterior.

\section{Condiciones de las explotaciones}

\section{- Problemas naturales y de origen antrópico en los campos}

El 46\% de las explotaciones tienen algún tipo de problemas de origen natural, antrópico o combinado, que afectan alguna porción de la superficie de los campos. Cabe observar que los establecimientos afectados representan un porcentaje muy elevado. Los tipos de problemas más frecuentes son enlagunamientos, cárcavas y ascenso de la capa freática; en menor término, socavamiento producido por cursos hídricos, agotamiento de suelos, erosión hídrica y eólica, médanos y merodeo de pumas.

\section{Movimiento financiero y comercial}

\section{- Utilización de créditos}

Del total de establecimientos, solamente el $40 \%$ acude a la utilización de créditos. Este bajo porcentaje, en gran parte, se debe a que, en años anteriores, especialmente a fines de la década del '70, el sector bancario general aplicó mecanismos indexatorios leoninos, que convirtieron a muchos de los préstamos otorgados en impagables, razón por la cual varios productores perdieron sus campos.

Del total de las P.E., acuden al crédito el 27\%, las M.E. el 44\% y las G.E. el 59\%, porcentajes que guardan relación con la capacidad económica de los establecimientos. La principal institución que otorga créditos es el Banco Nación, con una participación del 58\%. El 
otorgamiento de préstamos por parte de las cooperativas y empresas privadas es muy escaso. El destino de los créditos está orientado básicamente a la producción, con un 83\%; luego, en muy pequeña escala, está orientado a la compra de tierra, amortización de deudas, etc.

\section{- Comercialización de la cosecha}

Del total de explotaciones encuestadas (ciento treinta $y$ dos explotaciones), comercializan la cosecha el $86 \%$ de los establecimientos, ya que el resto se dedica exclusivamente a la ganadería.

Los principales compradores son los acopiadores, con el 55\% de la comercialización, seguidos por las cooperativas con un $24 \%$, y luego vienen las combinaciones de firmas con un 14\%. Queda un porcentaje sobrante, que se reparte entre agroindustria, particulares y exportadores. Hay poca participación de las cooperativas en la comercialización de granos, debido a que funcionan muy pocos - como ya lo manifestamos- en la región de estudio, salvo algunas focalizadas en sectores determinados del área aludida.

\section{- Comercialización del ganado y productos lácteos}

Del total de las explotaciones, el 93\% comercializa ganado y productos lácteos, ya que el resto se dedica exclusivamente a la agricultura. Los principales compradores resultan ser las firmas combinadas, con un 38\% (esta categoría responde a la situación en que el productor le vende a más de un comprador), seguida por las ferias, con un $29 \%$ y luego vienen los particulares, con un $22 \%$. Finalmente, queda un resto de compradores que se distribuye entre frigoríficos, cooperativas, empresas lácteas, etc. Cabe aclarar que la venta de animales a las ferias ha disminuido notablemente en los últimos tiempos.

De la actividad tambera llevada a cabo en veintiún establecimientos -once exclusivamente dedicados al tambo y diez que combinan con otras actividades agropecuarias-, venden su producción básicamente a SanCor (52\%), desgranándose el resto de la venta en numerosas firmas lácteas.

\section{Tipo jurídico de los productores}

En el $45 \%$ de las ciento treinta y dos explotaciones, los productores que participan en las mismas se constituyen en sociedad de hecho siendo, por lo tanto, muy pocos los que legalizan esta situación. Predomina ampliamente la vinculación entre familiares con un 92\% $\mathrm{y}$, entre éstos, prevalece primero el vínculo entre hermanos (56\%), seguido por el vínculo entre hijos y padres $(31 \%)$. 


\section{Disponibilidad y manejo tecnológico}

\section{- Maquinaria disponible}

A juicio de los productores, el $31 \%$ de las explotaciones están básicamente equipadas con maquinarias, el $49 \%$ bien equipado y el $20 \%$ muy bien equipado (dos explotaciones no cuentan con maquinaria). Por lo tanto, en general, se dispone de buena maquinaria. Dentro de las P.E., predominan las que están bien equipadas (48\%), igual que las M.E. (50\%) y, dentro de las G.E., prevalecen también las que están bien equipadas (50\%), seguidas muy de cerca por las muy bien equipadas (41\%).

\section{Tipos de empleo tecnológico}

\section{- Tipo de siembra}

Los productores que practican "siembra directa", representan el 11\%, "siembra tradicional" (arado de disco, de reja) el 20\% y "siembra moderna" (más actualizada, labranza mínima, cincel, doble acción, etc.), el 21\%, lo que totaliza entre los tres tipos mencionado el $52 \%$. El 48\% restante de los productores practican diferentes "combinaciones" de siembra. Corresponde destacar que, entre los productores que practican exclusivamente siembra directa, más los que en su práctica de combinar también hacen siembra directa, el porcentaje asciende al 49\% de las explotaciones que están incursionando en esta nueva forma de sembrar, lo que indica todo un proceso de actualización en este sentido. Cabe aclarar que, en muchas explotaciones, la tarea de este tipo de siembra la llevan a cabo los contratistas rurales.

Corresponde precisar que no se ha detectado una predominancia de un determinado tipo de práctica de siembra en relación con los diferentes tamaños de las explotaciones.

Las explotaciones que utilizan semilla mejorada representan el 91\%; plaguicidas, el 93\%, y fertilizantes, el 45\%. Este último insumo no acusa todavía valores altos en la región. De los establecimientos que hacen ganadería, la aplicación de inseminación artificial (19\%) acusa porcentajes bajos; en cambio, en las explotaciones que practican el mejoramiento por cruza $(72 \%)$, es más bien elevado.

\section{- Asesoramiento tecnológico}

E1 88\% de las explotaciones reciben algún tipo de asesoramiento tecnológico, dentro de los cuales el $86 \%$ proviene del sistema privado, el $10 \%$ del oficial y el $4 \%$ de forma combinada, o sea, oficial y privado.

Los agentes que prestan servicios de asesoramiento dentro del sistema privado, en porcentajes, son: particulares (veterinarios e ingenieros agrónomos) el 65\%, cooperativas el 
16\%, familiares el 11\% (esta franja corresponde a los familiares profesionales de que dispone el productor, ej.: hijos veterinarios o ingenieros agrónomos), y otros el 8\% (empresas agroindustriales, etc.).

Los agentes que prestan servicios dentro del sistema oficial, en porcentajes, son: INTA, 25\%, y Cambio Rural, el 75\%. Los agentes que prestan servicios dentro de la forma combinada, en porcentajes, son: agentes privados con el INTA, el 40\%, y agentes privados con Cambio Rural, el 60\%. En suma, resulta muy alto el porcentaje de asesoramiento que reciben las explotaciones.

PERFIL LABORAL DE LOS PRODUCTORES Y DEL PERSONAL DEPENDIENTE

\section{Características laborales de los productores}

- Fuerza laboral y familia dependiente

Cuadro $N^{0}$ 48. Distribución de la fuerza laboral y familia dependiente. 2002

\begin{tabular}{|c|c|c|c|c|c|c|c|}
\hline \multirow{2}{*}{ Total del NF } & \multirow{2}{*}{ Total de la PEA } & \multicolumn{4}{|c|}{ PEA Agropecuaria } & \multirow{2}{*}{$\begin{array}{c}\text { PEA no } \\
\text { Agropecuaria } \\
\text { total }\end{array}$} & \multirow{2}{*}{$\begin{array}{c}\text { Familia } \\
\text { dependiente }\end{array}$} \\
\hline & & Total & & iénes & & & \\
\hline 636 & $\begin{array}{c}331 \\
(52 \% \text { del total de } \\
\text { la PEA) }\end{array}$ & $\begin{array}{c}320 \\
\text { (97\% del total } \\
\text { de la PEA) }\end{array}$ & $\begin{array}{l}\text { Jefes } \\
\text { Esposas } \\
\text { Hijos } \\
\text { Hijas } \\
\text { Otros }\end{array}$ & $\begin{array}{r}(155): \\
(48): \\
(81): \\
(8): \\
(30): \\
(320)\end{array}$ & $\begin{array}{r}48,5 \% \\
14,5 \% \\
25,0 \% \\
2,5 \% \\
9,5 \%\end{array}$ & $\begin{array}{c}11 \\
\text { (3\% del total de la } \\
\text { PEA) }\end{array}$ & $\begin{array}{c}335 \\
\text { (48\% del total } \\
\text { del NF) }\end{array}$ \\
\hline
\end{tabular}

El total de la PEA relevada en esta muestra representa el $52 \%$ del total de la N.F., porcentaje relativamente elevado en relación con la familia dependiente, lo que indica una participación importante en el trabajo de parte de todo el grupo familiar. A su vez, el total de la PEA se desagrega en una PEA Agropecuaria, representada por el 97\%, y una PEA No Agropecuaria (los que realizan trabajos no agropecuarios), representada escasamente por el 3\%. En esta última categoría, participan los hijos y básicamente las esposas de los productores, principalmente en la docencia y en tareas urbanas.

Dentro de la PEA Agropecuaria, la fuerza laboral se desagrega en jefes de familia -los productores-, que representan el 48,5\%, o sea casi la mitad; las esposas, el 14,5\%, los hijos (varones), el 25\%, que es un porcentaje destacable; las hijas (mujeres), el 2,5\%, que es un valor muy bajo, y por último, la categoría otros (incluye hermanos, yernos y nueras, nietos, etc. del productor), el 9,5\%.

Cabe aclarar que figuran ciento cincuenta y cinco jefes de familia en ciento treinta y dos explotaciones; por lo tanto, hay explotaciones que cuentan con más de un jefe de familia o 
productor a cargo de la misma (por ej.: dos hermanos o padre e hijo, que detentan el mismo nivel de responsabilidad y representatividad del establecimiento, a juicio de los implicados).

Otra valoración interesante es que del total de hijos varones que forman parte del N.F., participan de la PEA Agropecuaria el 54\%; del total de esposas, el 33\%; del total de hijas mujeres, el 10\%, y del total de la categoría otros, el 25\%. O sea, los porcentajes son mucho más elevados cuando se mide la participación dentro de la misma categoría, lo que se acerca más a la realidad con respecto a la colaboración laboral que brinda cada grupo familiar.

\section{- Perspectivas futuras respecto de la forma de trabajar las explotaciones}

Ante todo, corresponde precisar qué interpretación le asignamos a cada uno de los ítems en que se desgrana la sección que pasamos a describir:

- Seguir trabajando en el campo como hasta ahora: implica no realizar ninguna modificación del trabajo y de la capacidad productiva.

- Ampliar la producción: implica básicamente incrementar la producción, a través, por ejemplo, de la compra y/o alquiler de tierras, incrementando la ganadería, ampliando el tambo, cultivando más hectáreas, mejorando las pasturas, incrementando el ganado a corral, etc.

- Modificar el esquema productivo: implica infligir un cambio de las actividades productivas, generalmente en el propósito también de incrementar la producción, como desarrollar una actividad o una modificación que hasta ahora no se ha llevado a cabo. Ej.: poner criadero de cerdos, adoptar régimen de inseminación, sembrar menos y acrecentar la ganadería o a la inversa, hacer actividad mixta, agricultura igual a ganadería, poner feed-lots, dedicarse exclusivamente a la ganadería, etc.

- Reducir la capacidad productiva: implica disminuir la capacidad productiva directa por parte del productor, a través, por ejemplo, del arrendamiento o venta de una parcela de su campo.

Del total de productores entrevistados, el $42 \%$ en el futuro piensa seguir trabajando el campo como hasta ahora; el 37\%, ampliar la producción; el 11\%, modificar el esquema productivo; el 1\%, reducir la capacidad productiva, y el 9\%, combinar algunas de las formas antes descriptas. Si sumamos las intenciones de ampliar y modificar el trabajo productivo, vemos que predomina, con el $48 \%$, la voluntad de cambio por modificar o incrementar la producción. Es más, si sumamos algunas de las formas combinadas que contemplan en su mixtura variantes que implican crecimiento productivo, el porcentaje último se incrementa hasta el 53\%. 
Del total de las P.E., éstas predominan, con el 48\%, en la franja seguir trabajando como hasta ahora; del total de las M.E., éstas también predominan en la misma franja, con el 39\%, y le sigue muy de cerca la franja ampliar la producción, con el 36\%. Del total de las G.E., éstas predominan en la penúltima franja nombrada, con el 44\%. Esta última ubicación hacia el incremento productivo se correlaciona con la mayor capacidad económica de las G.E.

\section{- Características laborales de los trabajadores dependientes de que disponen los productores}

En esta sección, se contabiliza exclusivamente a los "empleados fijos" que trabajan en las explotaciones en las que viven los productores. La amplia mayoría de los empleados viven en las explotaciones (94\%) y, dentro de éstas, casi todos (el 93\%) en viviendas aparte de la casa del dueño. La PEA de los empleados constituye el 37\% del total de su N.F., porcentaje mucho más reducido que la PEA de los productores. E1 61\% del total de su N.F. reside en la explotación y el 39\% en los pueblos aledaños. La situación de este último caso generalmente consiste en que el esposo vive en la explotación y su familia en el pueblo.

Del total de la PEA familiar del productor, la PEA del asalariado representa el 27\%, o sea, se establece una relación aproximada de un empleado cada cuatro miembros trabajadores del grupo familiar del productor.

Del total de las explotaciones, el 32\% cuentan con empleados y, en muchos casos, con más de uno de ellos. Porcentaje nada despreciable si se tiene en cuenta que estamos considerando establecimientos cuyos dueños viven permanentemente en las mismas.

El ingreso de los empleados consiste, en general, en una mensualidad, cuyo monto se circunscribe al básico asignado al peón rural, más un porcentaje o premio por tareas realizadas. Son muy pocos los casos en que se paga por día. En el caso de los tamberos, éstos van a porcentaje; por lo tanto, la relación laboral funciona como una suerte de mediería, en la que se establece un contrato de trabajo, pero los aportes los pagan los tamberos.

Al 64\% de los empleados, los productores les efectúan los aportes jubilatorios y de la obra social y solamente al 50\% de ellos se le efectúa un contrato de trabajo. Valores que están muy por debajo de la obligación de cubrir la seguridad y estabilidad laboral de los asalariados.

\subsubsection{Análisis de las encuestas descriptas}

Ante todo, lo que dejan traslucir varios indicadores de las encuestas mencionadas, es que las mismas se llevaron a cabo dentro del período de las grandes transformaciones productivas, que viene sufriendo el agro, y que empiezan a insinuarse entre las décadas del 
'70 y del '80, toman impulso en la del '90 del siglo pasado y se manifiestan plenamente a lo largo de la primera década del presente siglo.

Si bien los cambios observados entre el relevamiento efectuado en 1994 y el de 2002 no alcanzan a registrar todas las profundas reconversiones de los últimos diez años, deja percibir, no obstante, el dinámico avance progresivo de transformación agropecuaria por el que atraviesa la región. Justamente, algunas de estas modificaciones es lo que explicitaremos a continuación. En este sentido, vemos, por ejemplo, el afán de los productores, tanto en el relevamiento de 1994 como en el de 2002, por acrecentar la superficie de sus explotaciones, mediante el arriendo de campos de otros colegas. Queda claro que el esfuerzo por incrementar el tamaño de las EAPs depende, más que de la ambición de aumentar la ganancia personal, de la necesidad concreta de adaptarse a las nuevas exigencias de contar con una mayor escala productiva, a fin de no quedar fuera del sistema. En concreto, el resultado de incorporar nuevas tierras, produce como consecuencia una transformación del tamaño original de las EAPs, mediante una transferencia de pequeñas a medianas y de éstas a grandes EAPs. En conclusión, de los totales originales, va a haber una disminución de P.E. y un incremento de las medianas y grandes explotaciones, en coincidencia aproximada con lo observado en el Censo Nacional Agropecuario de 2002. A su vez, el fenómeno de acrecentamiento de tamaño de los establecimientos - como es de esperar-se manifiesta más en la última encuesta que en la primera.

En lo que respecta al "tipo de explotación" que caracteriza al área, vemos que la actividad mixta con sesgo ganadero figura como predominante en los dos censos, sin insinuarse todavía claramente el avance de la agriculturización en el último relevamiento, a pesar de que en el rubro "producción agrícola" de la encuesta ya se destaca en primer lugar el cultivo de la soja. Lo que sí es observable nítidamente, entre las dos encuestas, es la caída abrupta de tambos en la región, síntoma que, en cierto modo, preludia el próximo avance de la sojización. Fenómeno que se despliega en toda su magnitud en estos últimos años, sin perder la región, por ello, como práctica productiva tradicional, el tinte de zona de explotación mixta. Es interesante acotar que no se observa una predominancia neta por tamaño de establecimiento, en lo que respecta a los diferentes "tipos de explotación" que se llevan a cabo en el área, salvo el caso de las G.E., caracterizadas como estancias, las cuales sí caen dentro de la franja de "actividad mixta con predominancia ganadera". En síntesis, lo que se quiere decir es que, para las fechas de las encuestas aludidas, le actividad mixta va a predominar en todos los tamaños de EAPs. Realidad que sufrió en los últimos años fuertes alteraciones, al incrementarse la actividad agrícola especializada en las P.E., sin perder por ello, 
aparentemente, las características de sostener una actividad mixta, aunque volcada en forma muy asimétrica hacia la agricultura.

En lo atinente al tipo de empleo tecnológico que registra la encuesta de 2002, vemos cómo, dentro de los tipos de siembra que se llevan a cabo en el área, la "siembra directa", sin desarrollar todavía un papel preponderante, empieza a ocupar un lugar importante. Para esa época, los productores estaban aún "tanteando" esta nueva forma de preparar la tierra y, como es sabido, al poco tiempo cundió su práctica en forma abrumadora en toda la región. Inclusive un número apreciable de productores bien posicionados económicamente cuentan en la actualidad con sembradora directa.

Otro tema a discutir y todavía no saldado, que se desprende del análisis de las encuestas aquí realizadas, de los censos nacionales agropecuarios y de otras fuentes estadísticas en general, es la posibilidad de poder comparar el día de mañana las diversas escalas de importancia económica de las EAPs con las diversas escalas de importancia económica de los productores que, como bien se sabe, son dos categorías de análisis bien diferenciadas en los estudios de estructura agraria social y económica. La realidad indica, a modo de ejemplo, que la dirección de una EAP puede estar en manos de más de una persona, es decir, el tipo jurídico, puede asumir un manejo individual o de relación societal, que el productor en relación a la tenencia puede ser propietario o arrendatario, y que el nivel de importancia de la EAP puede basarse en el criterio tradicional del tamaño de las mismas, como así también bajo otros puntos de vista, como pueden ser la valoración de técnicas empleadas, capital disponible, tipo de manejo, etc. Todos estos factores, sin la menor duda, contribuyen a complejizar la pretendida comparación planteada por nosotros. Por cierto que esta inquietud no pretende ir más allá de esbozar estas breves líneas, porque entendemos que para arribar a una suerte de equivalencia entre los diferentes niveles económicos de productores y EAPs debe mediar un estudio y debate profundo de conjunto entre varias especialidades científicas que traten estas variables.

A pesar de ello, simplemente, en esta instancia, queremos preanunciar el camino, diciendo que quizás una forma de entrar en el tema consista en partir del presupuesto de considerar a las diferentes categorías económicas de EAPs en función del criterio clásico, basado en el tamaño de las mismas - de acuerdo con el criterio explicitado en el Capítulo V, apartado 5.1-, de modo tal que, a fin de establecer los diferentes niveles económicos existentes de productores, se crucen, por ejemplo, los siguientes indicadores, entre otros posibles: las "dimensiones" de las EAPs que manejan, la "tenencia" de las mismas y el "tipo jurídico" de los productores, para saber cuántos de ellos usufructúan el establecimiento. En 
suma, lo arriba expresado queda planteado como una inquietud que debe asumirse colectivamente y que todavía está pendiente de resolución.

Por último, es pertinente tener presente que, aparte de mediar ocho años de diferencia entre una encuesta y la otra -con los cambios lógicos que es de suponer-, las mismas se llevaron a cabo en ámbitos diferentes; el primer relevamiento incluyó a los productores que vivían en los pueblos y el segundo a los que vivían en el campo. En este último aspecto, cabe puntualizar que, a pesar de las diferencias de localización, tanto los productores que viven en uno como en otro medio, aplican para sus predios las mismas prácticas y tipos de explotación. Pero donde sí se manifiesta una diferencia entre una localización y otra es en la atención medida en tiempo que le dispensa cada productor a su EAP, según donde viva, y en la disponibilidad de mano de obra. En este último caso, vemos que los que residen en los pueblos cuentan con mayor cantidad de empleados fijos, y los que viven en el campo con mayor cantidad de mano de obra familiar.

En suma, lo que reflejan las encuestas es un preludio de los fuertes cambios que actualmente se están generando, perceptibles por la información que vuelcan en lo que respecta a movimiento financiero y comercial, disponibilidad y manejo tecnológico, incremento areal de las EAPs, entre otros indicadores, pero lo concreto es que la reconversión productiva se va a acentuar y multiplicar notoriamente a partir de 2002 -última encuesta- en adelante.

\subsubsection{Reflexiones generales sobre los productores}

A modo de cierre en el tratamiento específico de los productores como agentes sociales centrales del quehacer agropecuario, es de nuestro interés, en esta instancia, volcar unas breves reflexiones en lo que atañe a su evolución social y económica, en base a informaciones propias, estadísticas y académicas, puestas de manifiesto en los últimos tiempos.

En primer lugar, sobresale la agudización de las asimetrías económicas existentes entre los miembros del mismo sector. Es indudable que el accionar del capitalismo avanzado en el área de estudio -que se puede hacer extensivo a toda la Región Pampeana- no produce una situación de equilibrio entre sociedad y naturaleza, sino que, al contrario, en su afán eficientista y especulativo de generar mayor renta, agudiza las desigualdades socioeconómicas existentes desde siempre, observable en la concentración de la producción y que se traduce en establecimientos de mayor tamaño, reducción numérica de los mismos y menor cantidad de productores participantes en la explotación agropecuaria. Vemos así que las reconversiones productivas que genera la nueva marcha del capital concentrado van a 
repercutir sobre los eslabones más débiles del engranaje productivo, dificultando y expulsando del sistema a los agricultores de menores capacidades económicas. Rofman lo expresa así: "Los pequeños productores y muchos agricultores medianos fueron quedando, en su mayoría, al margen de tales transformaciones, dada la elevada exigencia de recursos financieros $y$ de capital que estaban condenados a afrontar si seguian las pautas de comportamiento de los 'ganadores' del proceso" (Rofman et al., 2008:425).

Cabe recordar que, en la década del '90, se agudizó la situación social y económica de muchos productores, requiriéndose para lograr la reproducción y crecimiento de las EAPs una escala de mayor tamaño de las mismas. La rentabilidad alcanzada estaba muy por debajo de la necesaria para absorber los costos, inclusive “...en los casos en los que la EAP se realizaba con la mejor tecnología y métodos de gestión" (Lattuada et al., 2005:34).

En concreto, el fenómeno en cuestión es que se incrementó el costo de vida en forma notable, en comparación con los precios de los productos agropecuarios en general, lo que va a exigir a las unidades económicas, para mantener los mismos niveles productivos, el incremento de la superficie de la tierra trabajada. Otro ejemplo, que sirve también de punto de referencia de cómo ha evolucionado el mayor requerimiento de tierras, a fin de mantener los mismos niveles de ingresos, lo expresa Coscia, citado por Barsky, en estos términos: "Hacia 1950 Coscia señala que las unidades familiares - en que la totalidad de las tareas, excepto las cosechas, eran efectuadas por el productor y su familia-tenían extensiones entre 50 a $80 \mathrm{ha}$, en la región maicera tradicional y de 80 a 150 en el resto de la región agrícola pampeana" (Barsky, 1992:29).

La realidad indica que, en general, el agricultor familiar que ha logrado mantenerse dentro del actual sistema agropecuario lo ha hecho gracias a que ha podido capitalizarse a través del esquema productivo vigente. Para ello, ha tenido que disponer de “....una estructura productiva exclusivamente para el mercado con inversiones importantes de capital y menores requerimientos laborales. Ello hace que desde los '60 el agricultor familiar haya variado rápidamente su relación con la tierra" (Carballo González, 2007:69).

Dentro de estas variaciones, cabe destacar la desaparición prácticamente de la producción con fines de consumo doméstico, en la que participaba toda la familia. Está claro que hay una ruptura en el aprovechamiento integral y sustentable de las EAPs.

Cabe acotar, también, como corolario macroeconómico de todas estas transformaciones vigentes, que "Hay coincidencia en señalar el peso dominante de la producción generada en las unidades de mayor tamaño, situación que contrasta con el dominio productivo agrícola de las unidades familiares hace pocas décadas" (Barsky, 1992:34). 
Por otra parte, en nuestra región -a diferencia de otras áreas de la Región Pampeana-, las P.E. familiares no manifiestan todavía, en general, una ruptura tajante entre actividades agrícolas y ganaderas, conservando aunque en forma desequilibrada un tipo de actividad mixta -quizás a modo de reaseguro económico-, como acusan las encuestas a las que ya hicimos referencia.

Por último, se debe tener presente que los requerimientos del sector productivo son muy exigentes, y si los implicados no están o se acercan a la punta de la ola tecnológica y de disponibilidad financiera, las posibilidades de salir del sistema son muy grandes. Situación que ahora -como dijimos en otra parte de este trabajo- está disimulada por la bonanza que proyecta la fiebre de la soja.

\subsection{Caracterización del perfil socio-económico de los trabajadores rurales dependientes}

La inquietud es explicitar aquí el estado de situación y las transformaciones laborales que vienen sufriendo los asalariados rurales como resultado de los nuevos procesos productivos observables en nuestra zona de estudio y en la Región Pampeana en general.

Se parte de la concepción de que los trabajadores rurales dependientes, por ser el eslabón más débil de la cadena del trabajo rural, son los que sufren las mayores consecuencias de las fluctuaciones económicas y de los cambios en el desempeño laboral, casi nunca favorables a su condición como tales, a diferencia del grueso de los otros sectores, que en los últimos años muchos de ellos se han visto muy beneficiados económicamente.

La notoria polarización de ingresos - de ahora y siempre- que media entre los trabajadores y sus empleadores, sobre todo en este período de bonanza por el que atraviesa el campo, resulta una clara muestra de lo antedicho. A lo expresado, se suma una histórica subordinación de los asalariados a sus patrones, que recién desde no hace muchas décadas fueron alcanzando, a través de paulatinas conquistas sociales, un progresivo respeto laboral a sus personas. No obstante, a pesar de ciertos progresos económico-sociales -de muy relativa incidencia en el caso de los asalariados temporarios, como veremos más adelante-, estos agentes rurales siguen ocupando un lugar muy subalterno dentro del conjunto de las fuerzas agropecuarias.

Nuestra preocupación pasa, entonces, en esta instancia, por conocer de este sector de trabajo su papel en la ocupación del territorio y su compleja y sufrida realidad laboral. Se procura comprender, también, cómo esta franja se ensambla y articula con el sector empleador. 
En lo que respecta al análisis específico de este sector, se deben diferenciar dos tipos de agentes, dependiendo de su continuidad en las tareas rurales. Por un lado, los trabajadores permanentes que residen tanto en el campo como en los centros urbanos $\mathrm{y}$, por el otro, a los trabajadores temporarios o jornaleros -los más precarizados de todos-, que casi en su totalidad viven en los pueblos.

Por otra parte, en lo referente al tipo de trabajo que desempeñan, podemos diferenciar a los trabajadores calificados -relacionados generalmente con el manejo de maquinarias agrícolas- y a los trabajadores no calificados.

A continuación, desde una perspectiva eminentemente empírica, de contacto directo con los agentes implicados, y con una orientación analítica de tipo cualitativo-cuantitativo, pasamos a volcar los resultados, en primer lugar, de un stock de entrevistas sistematizadas ${ }^{7}$ en número de cincuenta y dos- realizadas a los trabajadores rurales propiamente dichos $\mathrm{y}$, en segundo lugar -después de una sucinta descripción del sindicato que los representa-, los resultados de las entrevistas efectuadas a los delegados responsables de cinco filiales regionales del gremio que los nuclea. Luego, cerrando la información mencionada, exponemos unas breves reflexiones sobre el desenvolvimiento actual y el futuro laboral de los trabajadores rurales.

Cabe especificar que las entrevistas arriba mencionadas se llevaron a cabo durante los años 2007 y 2008, dentro de nuestra zona de estudio, en las localidades de Alcira (Gigena), Coronel Moldes, Ucacha, Sampacho y Del Campillo, así como en sus respectivas áreas rurales de influencia. Dichas localidades fueron privilegiadas como casos de estudio, debido a que cuentan con las respectivas delegaciones gremiales.

A renglón seguido, pasamos a desarrollar las variables de análisis que dan luz sobre las características de la realidad socio-económica por la que atraviesa el sector, empezando por la descripción de la entrevista sistematizada llevadas a cabo a los trabajadores rurales en general.

\subsubsection{Resultado de las entrevistas a los trabajadores rurales en general}

\subsubsection{CARACTERIZACIÓN SOCIAL}

\section{Estructura familiar}

El promedio de su N.F. es más bien reducido, conformado por alrededor de cuatro miembros, siendo un poco menos numerosos los N.F. que residen en los centros urbanos que

7 El cuestionario de las entrevistas sistematizadas figura en el Anexo de este trabajo. 
los que viven en el campo. Lo cierto es que la realidad dista mucho de la idea generalizada de que las familias de los trabajadores dependientes -siempre refiriéndonos a los que viven bajo un mismo techo- están constituidas por numerosos integrantes.

Con respecto a la edad promedio de los jefes de familia, podemos considerar que gira alrededor de los cuarenta y cinco a cincuenta años, lo que nos indica que estamos en presencia de una franja laboral más bien madura. Esto adquiere características más notables en la franja de los trabajadores temporarios, que registran un pico mínimo de edad más alto que los permanentes. El estado civil de la amplia mayoría de los asalariados reviste en calidad de casados, pero este estado quizás no sea tal en varios casos correspondientes a los trabajadores temporarios. En esta categoría, es dable observar una menor formalidad en la constitución de las parejas y del tiempo de convivencia de las mismas. Asimismo, no se nota una diferencia sustantiva entre la cantidad de hijos y de hijas que viven bajo un mismo techo.

Por último, es notorio el incremento aparente de edad, que acusan especialmente los trabajadores temporarios con respecto a la edad real que detentan.

\section{Nivel de instrucción de los jefes de familia}

La entrevista sistematizada nos indica que la mayoría de los asalariados permanentes han completado el ciclo de enseñanza primaria, no manifestándose así en el caso de los temporarios, donde es dable observar que el grueso de ellos no ha completado dicho nivel.

A su vez, algunos trabajadores permanentes han iniciado el nivel secundario -especialmente en escuelas agropecuarias- y muy pocos lo han terminado.

En general, predomina un bajo nivel de instrucción, sobre todo en el caso de los temporarios. Si bien no se observan analfabetos, tampoco se registran trabajadores dependientes que hayan accedido a la enseñanza superior, con excepción de los encargados de algunos establecimientos relevados, que sí cuentan con estudios terciarios y/o universitarios.

\section{Otros aspectos sociales a considerar}

Con respecto a las aspiraciones educativas de los padres hacia los hijos de los trabajadores en general, vemos que muchos de los jóvenes se benefician del acceso a la instrucción de nivel medio, generalmente relacionada con la especialidad agro-técnica, en colegios de la zona.

En lo referente a las condiciones de vida a nivel familiar, como si están satisfechas las necesidades de vivienda, alimenticias, de vestimenta, de salud, entre otras, la respuesta es siempre afirmativa, donde no cabe la menor duda de la subjetividad apreciativa de cada 
respuesta, dado que seguramente cada implicado considera de acuerdo con sus posibilidades que modestamente cubre las necesidades arriba mencionadas. En este aspecto, podemos decir que, a nuestro juicio, se percibe en muchos casos una pobreza estructural acentuada en los asalariados temporarios, no así, en cambio, en el caso de los trabajadores permanentes. Se observa, también, de parte de los asalariados en general, unas aceptables vinculaciones y participación social en su medio, puestos de manifiesto tanto con sus parientes como con sus vecinos. Vemos que hacen uso asiduo de los medios de comunicación masivos y frecuentan a menudo los clubes de la zona en sus tiempos libres. Asimismo, la respuesta es notoriamente negativa cuando se les pregunta a los asalariados si participan en política en general.

\subsubsection{Perfil laboral}

Las entrevistas realizadas expresan que, tanto en el caso de los asalariados permanentes como temporarios, de toda la fuerza laboral familiar, el jefe de familia -generalmente- es el único que se desempeña específicamente en las tareas agropecuarias. Pero, en la categoría de los trabajadores temporarios -se debe recordar que la amplia mayoría vive en los pueblos-, muchos de ellos, en la temporada baja de trabajo, también desarrollan tareas de índole urbana, generalmente de escasa calificación laboral, a fin de poder sobrevivir.

Asimismo, es dable observar en la situación de los asalariados permanentes que residen en los pueblos, como así también especialmente en el caso de los temporarios, un apoyo laboral de índole urbana nada desestimable de parte de sus familiares, pero particularmente de sus esposas, generalmente en el desempeño de empleadas domésticas. Corresponde aclarar que, en el caso de las esposas de los asalariados permanentes que viven conjuntamente con ellos en el campo, generalmente sus obligaciones laborales se limitan a las tareas hogareñas, o sea, no acompañan al esposo en las labores rurales -salvo el caso de las esposas de empleados de tambo-.

De los asalariados entrevistados, el grueso del trabajo calificado recae en los asalariados permanentes $\mathrm{y}$, en menor término, también en los temporarios, que se desempeñan como conductores de maquinaria agrícola.

Con respecto a las horas trabajadas por día, fluctúan entre las ocho y doce horas promedios, en el caso de los permanentes, dependiendo de las exigencias laborales de la época del año. En cambio, en el caso de los temporarios, quizás lo más adecuado -por el tipo de trabajo a destajo que realizan- consista en contabilizar sus tareas a nivel de días trabajados por 
semana y meses trabajados por año. En este sentido, en el período fuerte de "bolseo"8 de la cosecha, se trabaja todos los días de manera intensa, por un lapso de tres meses promedio -abril, mayo y junio-, que puede extenderse eventualmente de cuatro a siete meses. En época de descanso del campo - segunda mitad del año-, el trabajo de "changa" se circunscribe a uno o dos días de trabajo por semana, con las consecuencias de estrecheces económicas que es de imaginar de parte de los implicados. Por cierto que el trabajo no calificado recae básicamente en la franja de los temporarios que llevan a cabo tareas de bolseo y de changas rurales en general. Cabe acotar que la mayoría tiene conciencia de sus limitaciones laborales, debido a la diversidad de tareas que realizan, como así también al corto tiempo de perdurabilidad de las mismas, lo que no quita que varios de ellos logren adaptarse a los nuevos avances tecnológicos.

En concreto, en el caso de los trabajadores temporarios no calificados, dentro de las estrategias de sobrevivencia adoptadas, se observa una tendencia a la multiocupación agropecuaria y no agropecuaria. En el área estudiada, se pudo constatar que gran parte de los jornaleros no calificados se dedican a la albañilería como una manera de complementar sus magros ingresos económicos en aquellos meses en los que no pueden desarrollar tareas agropecuarias.

En relación con la readecuación laboral desarrollada por los asalariados permanentes y temporarios calificados, vemos -en base a la información proveniente de las entrevistas- una destacable flexibilidad adaptativa y de adecuación laboral, ante las nuevas técnicas (especialmente en maquinaria altamente sofisticada) y ante las nuevas orientaciones de manejo productivo que se están aplicando en el agro pampeano, lo que representa en estos casos, para los implicados, ingresos salariales más altos que el grueso del sector.

Esta situación se ve favorecida, algunas veces, por la posibilidad de capacitación brindada por diversas fuentes, por lo general, proveniente de entidades privadas y del gremio de trabajadores rurales (UATRE). Este último, dentro del programa de sus actividades, tiene establecido ofrecer asesoramiento técnico referente no sólo al manejo de la tecnología, sino también al manejo de medidas de seguridad e higiene. Lamentablemente, de acuerdo con nuestras comprobaciones, estos servicios de asesoramiento se han brindado muy poco en las delegaciones con que cuenta la UATRE en nuestra región de estudio.

En lo referente a la periodicidad en el desplazamiento al lugar de trabajo de parte de los asalariados permanentes que viven en los pueblos, se dan diferentes frecuencias. En muchos

\footnotetext{
8 El término "bolseo" hace referencia específica a la acción de cargar y descargar bolsas de granos o productos similares, generalmente en los centros de acopio de granos.

9 El término "changa" se refiere a trabajos rurales de muy diverso tipo y discontinuos en el tiempo.
} 
casos, se trasladan a la explotación todos los días - generalmente con el patrón- y, en otros, regresan al pueblo, donde residen sus familias solamente los fines de semana.

Con respecto a la orientación de los varones menores de edad, si tienden o no a desempeñarse en el futuro como asalariados, al igual que sus padres, vemos que media una fuerte voluntad de parte de los mismos de que los hijos sigan estudiando. No obstante, en algunos pocos casos, es dable observar a menores de dieciocho años en el rol de asalariados, al igual que sus padres, lo que no quiere decir que no haya, en muchos casos, hijos de asalariados mayores de edad que sí se desempeñan, al igual que los padres, como trabajadores rurales, pero generalmente éstos ya no viven bajo el mismo techo de sus progenitores.

Asimismo, casi todos los trabajadores permanentes entrevistados manifiestan que trabajan cómodos en el lugar donde se desempeñan, como igualmente les gusta la tarea que desarrollan.

Por otra parte, es dable constatar que no todos los trabajadores permanentes están asociados gremialmente -entiéndase en la UATRE-, pero en cambio sí es así en el caso de los temporarios, donde la afiliación es total. En general, los asociados se sienten representados pero, por el contrario, la participación de los mismos en las entidades gremiales es prácticamente nula en los permanentes y mínima en los temporarios.

Por último, es pertinente resaltar que no se detectó en la región de estudio el doble desempeño laboral de agricultor y asalariado temporario. Nos estamos refiriendo obviamente a aquellos agentes que parte del año se desempeñan como agricultores, trabajando un campo por su cuenta, y otra parte del año como asalariados en diversas tareas rurales. Más allá de que puedan coexistir en nuestra región unos pocos casos en esas condiciones, que se escapan a nuestra mirada, lo cierto es que la fuerte polarización de rolos bien definidos entre productores versus asalariados nos está indicando la profundidad de la dinámica capitalista imperante en nuestra zona.

\subsubsection{PERFIL ECONÓMICO}

El nivel económico de los trabajadores rurales en general es muy limitado, alcanzando en muchos casos a satisfacer escasamente las necesidades básicas. Cabe destacar que la remuneración mínima, vital y móvil del peón rural corresponde al salario oficial más bajo vigente a escala nacional. ${ }^{10}$

10 De acuerdo con la Resolución 75/010 de la Comisión Nacional de Trabajo Agrario, del 20/09/2010, el salario mínimo del "peón general" a nivel "sueldo" se estipuló en \$2.210,07 en bruto y, a nivel "jornal", en \$97,24. A su vez, el salario máximo correspondiente a la categoría "encargado" se estipuló en $\$ 2.835,58$ en bruto. Para el año 2011, de acuerdo con la Resolución 71/011 del 01/07/2011, el salario mínimo del "peón rural" a nivel "sueldo" se estipuló en $\$ 2.763,00$ en bruto y, a nivel "jornal", en $\$ 121,55$. A su vez, el salario máximo correspondiente a la categoría "encargado" se estipuló en \$3.544,48 en bruto. 
Esta realidad, por cierto, no se manifiesta de manera diferente en los asalariados de nuestras entrevistas. Ellos obviamente también sufren de estrecheces económicas.

Entrando en detalle, de acuerdo con las consultas realizadas, vemos, por ejemplo, que en el caso de los trabajadores permanentes que gozan de una relativa estabilidad laboral, reciben en una alta proporción, aparte del sueldo básico, algún tipo de incentivo que puede ser en premios o mediante una participación en la producción, el cual es percibido al finalizar la cosecha o bien a fin de año. En cambio, los trabajadores temporarios sufren una situación de gran precariedad económica, dado que desempeñan tareas a destajo -con discontinuidades agudas de días laborales-, que apenas logran cubrir sus necesidades esenciales. Aparte del jornal estipulado por día como forma de pago, también cuando los temporarios realizan tareas de estiba, se les paga por movimiento de bulto, pero las retribuciones en general son muy bajas.

En lo atinente a la situación previsional, la mayoría de los encuestados, tanto permanentes como temporarios, declaró que sus empleadores les efectúan los descuentos correspondientes para el aporte jubilatorio, como así también para la obra social de manera regular.

Con relación a la situación contractual, es otro elemento a tener en cuenta al referirnos a la estabilidad laboral. Se observó que un mínimo de los entrevistados trabaja bajo las condiciones impuestas por algún contrato laboral, ya que en la mayoría de los casos median acuerdos de palabra, por lo que realizan sus actividades sin ningún marco contractual formal, ya sea porque los asalariados se encuentran trabajando en condiciones estables de mutua confianza desde hace un largo tiempo, o porque la situación de temporalidad y/o precariedad laboral así lo determina. ${ }^{11}$

Por otra parte, además, como manifestáramos más arriba, media en muchos casos un apoyo económico de parte de las esposas y, en algunas circunstancias, también de parte de otros miembros de la familia, pero esta colaboración se da casi exclusivamente en el caso de los trabajadores temporarios. ${ }^{12}$ Asimismo, esta misma categoría laboral manifiesta que recibe poca ayuda económica de origen gubernamental o de organizaciones no oficiales. Eso sí, todos los trabajadores dependientes, de ambas categorías consultadas, cuentan con mutual

11 Cabe aclarar que esta información sobre aportes y contratos coincide con los datos sobre los "asalariados permanentes que trabajan con los productores", expuestos en la encuesta correspondiente a estos últimos agentes, desarrollada en páginas anteriores.

12 Esta realidad se amplía para el caso de los "empleados tamberos", donde sí media una fuerte colaboración en el trabajo por parte de la mujer, en tanto se considera a estos tamberos como empleados y no como contratistas de aparcería -figura laboral que estaría fuera de la categoría "asalariados", dado que no implica estrictamente relación de dependencia-. 
(OSPRERA, en este caso), que les brinda cobertura de salud. Comprobamos también que en muy pocos casos acuden al crédito formal para cubrir sus necesidades hogareñas.

Como un bien económico propio, es pertinente destacar que la mayoría de los trabajadores permanentes -sobre todo si viven en las explotaciones-cuentan en la actualidad con vehículo automotor para su movilidad personal y la gente joven, en muchos casos, dispone de motos para sus desplazamientos.

En lo que respecta a la situación económica de los antepasados de los asalariados entrevistados, alrededor de la mitad de los trabajadores permanentes manifestó que sus padres o abuelos trabajaron tierras por su cuenta. El motivo por el cual los agentes consultados no siguieron trabajando en dichos campos corresponde en general al fenómeno de subdivisión familiar de la propiedad, que deviene como consecuencia del traspaso de la tierra de una generación a otra y que, al haber muchos herederos, obliga al grueso de los miembros de la familia implicados a tener que buscar trabajo fuera de la explotación familiar. Corresponde aclarar que esta suerte de diáspora familiar se debe, en gran parte, a que los padres y/o abuelos eran productores de pequeñas explotaciones, con tenencia precaria en muchos casos; por lo tanto, con poca capacidad de contención laboral para los herederos. En suma, resulta preocupante el declive económico que se pone en evidencia al cambiar generacionalmente el rol de productor por el de trabajador dependiente, evidenciando el drástico cambio que significa trabajar para terceros, habiendo gozado las generaciones anteriores de independencia laboral.

Se les preguntó también a los trabajadores permanentes, a fin de captar sus intencionalidades, lo siguiente: si el gobierno eventualmente les otorgara tierras a crédito, con el compromiso de trabajarlas $-\mathrm{y}$ obviamente tener que cumplir periódicamente con el préstamo otorgado-, desearían ser beneficiados. La respuesta expresada de manera cauta, en general, fue que podría ser, en la medida en que las condiciones fueran buenas, lo que está indicando un reparo a ciertos beneficios, que pueden no resultar, a la larga, una verdadera ayuda.

Por último, en lo atinente a las perspectivas futuras que albergan nuestros asalariados consultados, en relación con sus actividades económico-laborales, hubo de parte de ellos respuestas muy variadas. La mayoría considera que seguirán trabajando como hasta ahora, en la tarea que desempeñan actualmente. No obstante, algunos tienen la pretensión de pasar a trabajar con las máquinas, otros -unos pocos, como caso curioso- trabajar más adelante los campos - de no muy grandes dimensiones- que actualmente son de los padres y que por el momento los explotan ellos y, en el caso de los temporarios, la inquietud de algunos de ellos 
pasa por pretender desempeñarse como asalariados permanentes. También una minoría de asalariados permanentes pretende cambiar de trabajo por uno urbano. Por ejemplo, desempeñarse como camionero, mecánico, instalar un kiosco, etc., donde la motivación central consiste en tener algo propio. En síntesis, se percibe, de parte de los trabajadores dependientes consultados, unas pretensiones, aunque no mayoritarias, hacia una moderada movilidad socio-económica.

Cabe agregar, como aclaración complementaria, que los datos provenientes del título “Características laborales de los trabajadores dependientes de que disponen los productores", que figuran en el tema anterior, referido a la caracterización de los productores, dentro de los puntos 6.1.1. y 6.1.2., coinciden y se complementan con la información de las entrevistas arriba desarrolladas.

\subsubsection{VINCULACIÓN GREMIAL}

En Argentina, el grueso de los trabajadores rurales dependientes se encuentran nucleados en el sindicato denominado Unión Argentina de Trabajadores Rurales y Estibadores, conocido por sus siglas como UATRE.

Su historia se remonta a 1947, año en que se forma la FATRE (Federación Argentina de Trabajadores Rurales y Estibadores), como el sindicato más representativo del sector rural. Dos años más tarde, el sindicato fortalece su presencia, cuando se gesta por primera vez un instrumento legal que ampara al trabajador rural: el Estatuto del Peón Rural, constituyendo un reconocimiento de sus derechos básicos, tales como horas de descanso y vestimenta adecuada.

Finalmente, la FATRE adquiere, por una resolución del Ministerio de Trabajo de la Nación, la condición de Unión, o sea, su estructura se modifica, pasando de una asociación de segundo grado a conformar una asociación de primer grado a nivel nacional, recibiendo el nombre definitivo de UATRE en 1988.

El trabajador rural, aparte de contar con el gremio que lo representa, dispone también de una obra social, cuya mutual se denomina OSPRERA, cuyo servicio abarca a todos los asalariados, estén o no agremiados. Asimismo, mediante la reglamentación de la Ley Nacional 25.181, del año 2001, se crea la Libreta del Trabajador Rural, “destinada a regir los distintos aspectos de la contratación de los trabajadores rurales de todo el país, tanto permanentes como transitorios y de cosecha" (Brondo et al., 2001:227) y pone en funcionamiento a dicho efecto el Registro Nacional de Trabajadores Rurales y Empleadores (RENATRE), que "es un ente autárquico de derecho público no estatal" (Brondo et al., 2001:235). 
Además de estos apoyos de derechos laborales, donde el gremio ayudó al logro de estas conquistas, recién en 2004 los trabajadores del campo acceden a las primeras prestaciones por desempleo, beneficio del cual estaban excluidos desde 1991.

A continuación, volcamos los datos extraídos de las entrevistas efectuadas a los delegados de las filiales regionales, visitados en nuestra región de estudio.

\section{Resultados de las entrevistas efectuadas a los delegados de las filiales regionales de la UATRE, afincadas en la zona de estudio}

Al respecto, se pudo extraer la siguiente información:

La cantidad de afiliados a las cinco regionales visitadas fluctúa entre ciento veinte y trescientos cincuenta asociados, con un promedio de doscientos por filial. Incluye tanto a asalariados temporarios como permanentes, en cantidades muy similares, pero con una leve predominancia numérica de estos últimos. El nivel de participación de los asociados es mínimo, limitándose a la simple concurrencia a las asambleas regionales anuales.

El aporte realizado al gremio corresponde al 2\% del total de las remuneraciones percibidas por los asalariados, con excepción de los afiliados a la asociación sindical, que quedan exentos del pago de dicho porcentaje.

Los beneficios que el gremio brinda a sus afiliados consiste en la provisión de material escolar, concurrencia a centros vocacionales propios, participación en el Programa de Alfabetización Rural (PAR) y en eventuales cursos de capacitación laboral.

El sistema por el cual se canaliza el trabajo del asalariado temporario es el que se conoce como Bolsa de Trabajo. La misma consiste básicamente en un registro diario de trabajadores disponibles. Se maneja con una lista de los asalariados del día. La tarea consiste en paleo, traslado de bolsas, manejo de fertilizantes, entre otros. El trabajo es remunerado en función de los movimientos que realizan. El pago del jornal de trabajo tiene como monto base el estipulado por ley y la duración del mismo es de ocho horas. El control de la tarea realizada se registra en la "libreta de trabajo".

Los beneficios que brinda la "libreta de trabajo" como aporte de fondo es que permite el control de trabajo realizado, o sea, ayuda al blanqueo del trabajador. Específicamente, sirve como aporte para la jubilación, la mutual y el seguro de vida. A juicio de los delegados entrevistados, este instrumento está funcionando bien.

Los afiliados, que tienden a incrementarse, corresponden a los permanentes. En cambio, en el caso de los changarines temporarios, éstos tienden a disminuir; por lo tanto, la bolsa de 
trabajo como institución, a la larga, se inclina a desaparecer. En concreto, los asalariados transitorios buscan trabajos más estables y mejor remunerados.

En algunos casos, las delegaciones regionales están bien consolidadas, con una antigüedad que ronda los sesenta años de existencia y, en otros, la situación es crítica, dada la escasa oferta de trabajo que reina en el medio que obviamente perjudica a los temporarios.

El promedio de hijos con que cuentan las familias de los asalariados ronda los tres hijos y la edad promedio del asalariado jefe gira en torno a los cuarenta años y no menos, debido a la dificultad de encontrar gente joven para llevar al campo, según manifiestan los delegados entrevistados.

Los hijos menores de edad, en general, están escolarizados y persiste un fuerte interés en que no abandonen la escuela.

La procedencia de localización de los trabajadores y de sus antecesores proviene naturalmente de las áreas rurales, pero particularmente, en el caso de los asalariados temporarios -recordar que el grueso de los mismos reside en los centros urbanos- esa procedencia rural corresponde especialmente a la generación de sus abuelos, o sea, es más bien lejana.

El origen de procedencia de los trabajadores rurales, en su amplia mayoría, es criolla, claramente expresado en los apellidos que detentan.

Las condiciones de las viviendas propias de los trabajadores que residen en los pueblos son variadas, en el sentido de que en algunos centros urbanos las mismas fluctúan entre precarias y aceptables, y en otros pueblos los entrevistados consideran que las viviendas que predominan son modestas pero dignas. Una situación interesante también de tener en cuenta es que, de los empleados permanentes que residen en el campo, una mayoría apreciable cuenta con vivienda propia en el pueblo.

Por último, los delegados consultados manifestaron que la tendencia con respecto a la continuidad o no de permanencia en el lugar de residencia por parte de los asalariados corresponde, para aquellos que viven en los pueblos, la de seguir residiendo en los mismos y, para aquellos que viven en el campo, la de trasladarse a los pueblos.

\subsubsection{Comentarios sobre las entrevistas realizadas}

En síntesis, considerando lo vertido en ambas entrevistas realizadas a los asalariados y a los delegados gremiales, vemos que, salvo ciertas diferencias apreciativas, lo expresado sobre la realidad del trabajador dependientes es muy similar en general. 
Resumiendo vemos que la edad promedio del asalariado jefe se puede considerar como madura, pero no tan elevada como la de los productores. Su instrucción escolar es muy limitada pero, a pesar de ello, media un fuerte interés en que los hijos "sigan estudiando", con la pretensión de abrirle un mejor camino laboral y no precisamente el que ejercen sus padres.

En lo referente a las condiciones de vida en general, en el caso de los trabajadores temporarios clásicos -changarines-, se manifiesta una pobreza estructural indisimulable, pero más decorosa que la que se evidencia entre los pobres de las zonas urbanas.

Asimismo, el asalariado despliega una aceptable vinculación social con su medio, pero con muy limitada participación en actividades políticas y en prácticas religiosas.

En el caso de los temporarios, media un fuerte apoyo laboral de parte de sus respetivas esposas, generalmente a través de tareas domésticas. Con respecto al trabajo calificado, vemos que recae tanto en los asalariados permanentes como temporarios, que se desempeñan en el manejo de maquinaria agrícola, como en el despliegue de otras habilidades laborales. Aquí cabe hacer una breve aclaración sobre el concepto de trabajo calificado, en el sentido de que a esta jerarquía laboral se la asocia casi exclusivamente con el manejo de maquinaria agrícola -aunque sí es la habilidad más valorada-, sin considerar que hay una serie de especialidades laborales camperas, especialmente en el plano ganadero, como inseminadores, ordeñadores, domadores, prácticas de vacunación y yerra, entre otras, como asimismo en el plano de prácticas agrícolas diversas que, sin la menor duda, también se debe considerar como trabajo calificado.

Por cierto que este criterio amplio está contemplado en la Ley 22.248 del Régimen Nacional de Trabajo Agrario, donde sí se diferencia en la escala de remuneraciones el trabajo no calificado del calificado. Es interesante acotar que, entre la base y el vértice de la pirámide, media solamente una diferencia del $17 \%$ en la escala de remuneraciones salariales. En la realidad, este estrecho margen se despega hacia la cúspide de la pirámide -tractoristas, maquinistas de máquinas agrícolas-, mediante el pago de retribuciones extras por trabajos realizados que reciben este tipo de operarios. Por otra parte, en relación con el manejo de maquinarias agrícolas sofisticadas, es dable observar la gran capacidad de adaptación y de prontitud en el aprendizaje de dicho manejo, de parte especialmente de la gente joven.

En lo que respecta al trabajo no calificado, recae, como es sabido, en la franja de los asalariados temporarios tradicionales, ${ }^{13}$ que llevan a cabo, en general, tareas de changarín de

13 Corresponde diferenciar el trabajador "temporario tradicional", que sería al que hacemos referencia, del "temporario calificado", que se caracteriza por un amplio conocimiento en el manejo de maquinarias agrícolas de última generación. 
paleo y de carga y descarga de bultos. La estrategia de subsistencia de esta clase de trabajador pasa justamente por la tendencia a la multiocupación agropecuaria y no agropecuaria, como una forma de paliar su crónico déficit de ingresos.

Corresponde resaltar la carencia, en nuestra zona de estudio -que se observa en general en toda la Región Pampeana-, de la doble actividad laboral: agricultor-asalariado, lo que indica una fuerte polarización entre las figuras del productor y el asalariado, como producto del pleno funcionamiento de un modelo agropecuario capitalista muy avanzado.

Con respecto específicamente al nivel económico en general que detentan los asalariados, vemos que es muy limitado e históricamente insuficiente para la cobertura de sus necesidades reales.

En el caso de los asalariados temporarios, como ya lo expresamos, vemos que están afectados por una gran precariedad económica, motivado en gran parte por las tareas a destajo que realizan, con grandes discontinuidades en sus actividades laborales, donde el tiempo efectivo de máximo provecho de trabajo que se les ofrece ronda entre tres y cinco meses al año. En cambio, el sueldo básico de los permanentes -siempre escaso como ya lo resaltamosestá reforzado generalmente por premios e incentivos que sumados, en algunos casos -no en todos-, a la obtención de ciertos productos de granja en el caso de aquellos que viven en la explotación, les permite detentar una posición más desahogada.

Es importante comprobar que la mayoría de los asalariados, especialmente los permanentes, cuentan con el aporte previsional y de obra social. Lamentablemente, en algunos casos, nos informaban que hay patrones abusadores que suelen contar todavía con asalariados -particularmente temporarios- trabajando en negro. No está generalizada, hasta el momento, la vigencia formal de contratos de trabajo escritos entre las partes implicadas.

Asimismo, llama la atención, aunque se puede considerar como un fenómeno previsible, el hecho de que varios de los antepasados -padres y/o abuelos- de los asalariados trabajaban predios por su cuenta. Aquí se evidencia el peso de la sucesión familiar en la atomización parcelaria y en la salida de la explotación de los miembros familiares que no pueden ser contenidos dentro de la misma.

Comprobamos, a su vez, que las perspectivas futuras de vida que albergan los asalariados en general parten de unas pretensiones muy moderadas por mejorar su situación económica, reconociendo implícitamente sus limitaciones en lo que respecta a posibilidades efectivas de ascenso social. 
En el plano gremial, vemos que las filiales de la UATRE en nuestra región tienen una presencia discreta y que, si bien no contienen a todos los trabajadores rurales del área, el número de sus afiliados representa una cantidad aceptable. No obstante, da la impresión -se debe recordar que los locales de estas filiales funcionan básicamente como bolsas de trabajo- que en un plazo no muy lejano, posiblemente, tiendan a desaparecer si no se les encuentra otra finalidad concreta, en la medida en que vaya mermando la cantidad de trabajadores temporarios por el avance de la propia dinámica tecnológica excluyente, que rechaza toda mano de obra no especializada.

Por otra parte, los trabajadores afiliados al sindicato en nuestra región de trabajo tienen una participación gremial real muy pobre, demostrando poco interés en intervenir en las problemáticas cotidianas de la asociación.

Por último, es de destacar la fuerte ascendencia criolla del trabajador rural de nuestro medio, con poca incidencia de procedencia inmigratoria en sus antecesores familiares.

Como observación complementaria sobre los aspectos arriba sintetizados del trabajador rural de nuestra zona, corresponde destacar que el mismo no se diferencia mayormente en sus características genéricas del resto de los otros trabajadores de la Región Pampeana.

\subsubsection{Reflexiones generales sobre el trabajador rural}

De acuerdo con los acontecimientos y transformaciones socio-económicos agropecuarios que venimos describiendo, queda claro que las reconversiones productivas de los últimos tiempos en el mundo rural han generado sustanciales modificaciones en la caracterización y proceder del trabajador rural.

Esta realidad ha repercutido no solamente -como ya especificamos en la introducción de esta tesis- en una disminución generalizada del asalariado rural, sino también en la aparición de un trabajador calificado, idóneo en el manejo de maquinaria agrícola de alta complejidad, tanto dentro de los trabajadores permanentes como de los temporarios. Por lo tanto, como producto de las nuevas formas de organización del trabajo, se genera un profundo abismo -en habilidades y remuneraciones- en la "condición laboral" entre trabajo calificado y no calificado. Concretamente, se manifiesta dentro de la misma clase de los asalariados, acentuadas “...tendencias a la diferenciación social interna ... y una complejización en las estrategias e identidades ocupacionales" (Aparicio et al., 1992:134). En resumidas cuentas, se 
registran menos asalariados en términos estadísticos, pero notoriamente más diferenciados internamente.

A su vez, se hace evidente un progresivo desapego del campo como lugar habitual de residencia por parte de los trabajadores permanentes, en consonancia - pero en forma más aletargada- con el desplazamiento ya clásico de los productores del campo hacia los pueblos. Justamente resaltando el incremento de la urbanización de los trabajadores rurales, Lattuada y Neiman se expresan diciendo: "La Región Pampeana presenta los valores más elevados de urbanización de la mano de obra con un tercio de los trabajadores agropecuarios residiendo en localidades urbanas" (Lattuada y Neiman, 2005:49). Está claro, por otra parte, que la mezcla de trabajo agrícola y urbano que practican muchos de los asalariados temporarios desdibuja los vínculos de clase y las diferencias entre los espacios urbanos y rurales (Aparicio et al., 1992:139). Asimismo, se debe tener presente que el incremento de trabajadores especializados, receptores de salarios altos, no modifica la cruda realidad de que todavía el grueso de los asalariados rurales, en general, siguen recibiendo remuneraciones muy bajas, inclusive más bajas que las que reciben los trabajadores urbanos. En suma, debe resaltarse que la precariedad de los ingresos, de la estabilidad y condiciones de trabajo (Aparicio y Benencia, 1999) sigue teniendo, en muchas circunstancias, plena vigencia.

Por otro lado, es una realidad que las transformaciones productivas, a través de la excepcional mecanización e introducción de prácticas agrícolas, han tenido una fuerte incidencia -como es de imaginar-en la disminución de la mano de obra asalariada en general. Es así como, por ejemplo, la incorporación de la "siembra directa" incidió, por un lado, en “...la reducción en la demanda de mano de obra... y, por otro, la emergencia de nuevos actores especializados encargados de dirigir y orientar el proceso de producción" (Blanco, 2001:136).

En concreto, como producto de los fuertes procesos de cambio en el ámbito agropecuario, aparece y se consolida un nuevo tipo de trabajador - en reducido número todavía-, altamente especializado, en muchos casos con preparación técnico-profesional que, sin abandonar su condición de asalariado, se diferencia grandemente en ingresos, capacidad y conocimientos sistematizados del resto de los trabajadores del sector.

Con respecto a la incidencia del trabajador rural en las modificaciones socio-territoriales del paisaje agrario, su participación es más bien pasiva, limitándose su contribución al despoblamiento del campo, como consecuencia de la disminución numérica del trabajador permanente que reside en el mismo, como así también por el cambio de localización ruralurbana de esta fuerza de trabajo. Debe quedar claro que los asalariados rurales no son los que 
deciden sobre las transformaciones territoriales, pero sí ofician, en cambio, de instrumentos de dichas transformaciones.

En suma, la tendencia concreta que es dable inferir con respecto al futuro evolutivo del trabajador rural es que se manifiesta, por un lado, en una disminución progresiva de los trabajadores no calificados y, por el otro, como contrapartida, en un incremento de la mano de obra calificada y, por ende, entre otros aspectos, en una mejora en términos relativos de los salarios vigentes.

Como aporte final sobre estas reflexiones, cabe resaltar sucintamente el grado de pobreza y desempleo que afecta especialmente al sector de los asalariados temporarios tradicionales de nuestra área, y creemos que esa situación se reproduce, en mayor o en menor medida, en casi toda la llanura pampeana.

Cuesta imaginar que, dentro del espacio agropecuario más rico del país, pueda convivir una fuerza laboral altamente precarizada, de escasísimos ingresos y, en general, de muy bajo nivel de vida, con productores rurales cuya capacidad económica y condiciones de vida son notoriamente superiores. Esta situación paradojal es digna de considerar en todos los sentidos posibles.

Como ya lo mencionamos en párrafos anteriores, llama la atención lo reducido de los ingresos de estos agentes y los pocos días laborables que suman al mes, exceptuando el período de cosechas. En aquellos pueblos donde existe una filial del gremio que los nuclea $-\mathrm{y}$ de acuerdo con nuestras observaciones que van más allá de lo recogido en las entrevistas efectuadas a los delegados de dichas seccionales-, este grupo de trabajadores, desde muy temprano, se ubican en la sede a la espera de que algún "patrón" requiera de sus servicios. Es así como pueden estar todo un día o varios días acantonados en el sindicato, sin conseguir conchabo alguno. Además, deben soportar, en muchos casos, las "reglas de juego" que establece cada delegado en su jurisdicción, en lo referente a la distribución del trabajo, las que muchas veces están acompañadas por una fuerte carga de arbitrariedad y verticalismo.

Sus estrategias de sobrevivencia se apoyan obviamente en la sumatoria del trabajo familiar, donde la mujer cumple un rol fundamental, debido a que por largos períodos su labor representa el único ingreso del hogar. También, aunque parezca insólito y a contramano de los tiempos que se viven, en los momentos de fuerte receso laboral, varios de los integrantes de este sector han debido acudir a la caza de animales silvestres para completar su sustento alimenticio. En suma, llevan una vida que se aproxima a la miseria y su situación de pobres estructurales queda en cierto modo oculta, porque el número de sus integrantes en las comunidades donde residen no resulta significativo. 
Este clásico "bolsero" o "changarín", signado por una inestabilidad permanente en el trabajo, conforma posiblemente el escalón más bajo de los agentes rurales y el estrato poblacional más pobre y marginado de los pueblos de esta región.

Sus defensas como grupo social son muy escasas. El sector gremial que los agrupa no está presente en todos los núcleos urbanos, donde el grueso de esta fuerza laboral se concentra $\mathrm{y}$, además, por su concepción organizativa, el apoyo que les brinda -a pesar de ciertos avances laborales logrados en los últimos tiempos- es limitado. Su marcada subordinación al dirigente gremial y al empresariado agrícola del cual depende, la falta de apoyo de los organismos no gubernamentales y la falta de reconocimiento suficiente de parte de las autoridades públicas, constituyen factores que van en desmedro de este sector, generándole un cuadro social de extrema debilidad estructural.

Indudablemente, la falta de especialidad laboral repercute también en la dificultad para consolidar una identidad colectiva que los afirme como grupo y dignifique como trabajadores.

En última instancia, más allá de los bajos ingresos y condiciones de extrema pobreza, el problema central de esta franja pasa por su situación de "exclusión" dentro del sector productivo en el que se desempeña, donde la dinámica propia del desarrollo agropecuario va a determinar que el sistema productivo los rechace cada vez en forma más concluyente.

Parece -como expresáramos en párrafos anteriores- que representa una fuerza laboral en extinción, cuya reproducción social está seriamente comprometida, situación que, si evolucionase -como salida inmediata- en el sentido, por ejemplo, de la propuesta formulada más adelante de dar curso a la exploración de posibles implementaciones de microemprendimientos cooperativizados, sería dar un paso más que positivo.

De más está decir que el incremento en la tecnificación agraria, en combinación con los ajustes cíclicos que sufre el productor rural, son uno de los principales desencadentantes que impulsan esta exclusión. No obstante, esta fuerza laboral sigue por ahora teniendo vigencia y constituye una parte concreta de la PEA Agropecuaria. Por lo tanto, se la debe considerar si se pretende una comprensión integral de la misma.

En suma, cabe observar lo engañoso que resulta a veces la descripción sin mediaciones de la pobreza rural a nivel espacial, cuando, en muchos casos en forma agazapada, ésta también convive con gran crudeza en las áreas consideradas ricas del territorio nacional. 


\subsection{Caracterización del perfil socio-económico de los contratistas rurales}

\subsubsection{Introducción}

En esta instancia, pasamos a analizar, desde una perspectiva geográfica, a los “contratistas rurales" en su desempeño específico, como así también su participación en la transformación de la estructura agraria de la región.

Desde hace varios años - como venimos afirmando en otros puntos de este trabajo-, se manifiesta, especialmente en el área pampeana, una acentuada concentración de la producción (capital), que se refleja en un incremento sustancial de la superficie media de las explotaciones, acompañado, al mismo tiempo, por una disminución numérica pronunciada de las mismas. Está claro que esta profunda modificación en la estructura fundiaria -que los resultados del Censo Nacional Agropecuario de 2002 pusieron en evidencia-, sin el desempeño del contratismo rural como instrumento de trabajo a gran escala y de expansión de las tierras trabajadas, no hubiese sido posible de llevarse a cabo, lo que demuestra la importancia que reviste este agente en el contexto de las actividades productivas agropecuarias pampeanas, donde la concentración económica aludida viene acompañada, a su vez, de notorios cambios tecnológicos y organizacionales de punta y por una pronunciada demanda de la tierra bajo el sistema de arrendamiento y contrato accidental.

Con respecto a la caracterización de dicha figura laboral, la misma se identifica por poseer como factor productivo de capital equipos de maquinarias agrícolas y conforma, a su vez, dos tipos de agentes productivos diferentes: "los contratistas de servicios", que prestan servicios de laboreo y cosecha a terceros, y los "contratistas de producción", llamados también "contratistas tanteros" o "contratistas capitalistas", que arriendan campos casi siempre por un lapso no mayor a un año -arrendamiento accidental- y lo trabajan por su cuenta. Este último agente, en sí, es un arrendatario transitorio que arrienda campos por un tiempo limitado y le paga en general un porcentaje de la producción al dueño del predio. Pero, a su vez, los dos agentes productivos mencionados pueden ser dueños de explotaciones y por lo tanto investir también la figura de "productores agropecuarios". Es más, pueden reunir ambas figuras de contratistas rurales, o sea, desempeñarse como "contratistas de servicios" y "contratistas de producción", e incluso reunir las tres figuras: de "productor agropecuario", de “contratista de servicios" y de "contratista de producción” en una sola persona. En síntesis, en la tipología general de los contratistas rurales, expresada en el Cuadro 47, distinguimos dos variantes principales, según el agente desarrolle una sola actividad agrícola productiva o más de una. El primer caso incluye a los dos tipos centrales de contratistas y, en el segundo caso, 
se incluyen las cuatro posibilidades de combinación de actividades que pueden desarrollar los mismos.

\section{Cuadro $\mathrm{N}^{\circ}$ 49. Tipología general de los contratistas rurales}

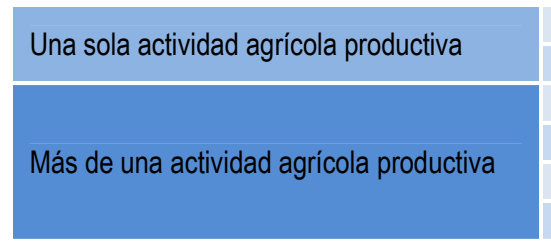

Fuente: Elaboración propia.
Contratista de servicios

Contratista de producción

Contratista de servicios y productor agropecuario

Contratista de servicios y contratista de producción

Contratista de servicios, contratista de producción y productor agropecuario

Contratista de producción y productor agropecuario

Aparte de la riqueza de combinaciones en actividades laborales que puede desempeñar el contratista rural, lo que está indicando una fuerte fluidez de trabajo hacia la búsqueda de optimizar su capital, también corresponde destacar la dinámica de sus actividades al pasar eventualmente de un desempeño laboral a otro, a medida que se le van presentando mejores oportunidades de utilización plena de su equipo de maquinaria y de incrementar sus ganancias en general, lo que implica que a veces resulta muy difícil tabicar a estos agentes, cuando cumplen a su vez un doble o triple rol dentro de las actividades agropecuarias.

En este sentido, resulta interesante referirnos a cómo generalmente han evolucionado secuencial y económicamente aquellos contratistas rurales que combinan más de una actividad.

Por ejemplo, en la dupla "contratista de servicios - productor agropecuario", generalmente nuestro agente de referencia reviste primero el rol de productor agropecuario -entendiéndolo como propietario de la tierra-, luego pasa también a desempeñarse como contratista de servicios. Esta secuencia evolutiva es clásica en toda la Región Pampeana (Forni y Tort, 1991).

Tradicionalmente, esta transformación se da a partir de una sobremecanización del productor de referencia, que lo lleva a ampliar sus tareas, utilizando asimismo sus máquinas en campos vecinos y de allí en más puede proyectar su trabajo a otras zonas de la llanura pampeana.

En el terceto "contratista de servicios - contratista de producción - productor agropecuario", el camino es similar pero más largo. Primero se inicia como productor agropecuario, luego pasa a ser también contratista de servicios $\mathrm{y}$, por último, pasa a desempeñarse como contratista de producción.

También existe la dupla "contratista de servicios - contratista de producción”, que es posiblemente, de todas las combinaciones, la más importante. Esta secuencia es un clásico del contratismo rural, dado que son cada vez más numerosos los casos de contratistas de servicios 
que, a fin de ampliar sus ingresos mediante la utilización plena de su maquinaria de punta, arriendan campos por un tiempo limitado y pasan también a desarrollar el rol de contratistas de producción. En muchas situaciones, luego rompen la dupla laboral y se convierten exclusivamente en contratistas de producción.

Con respecto a la historia de la conformación de esta fuerza laboral en la Región Pampeana, la mayoría de los autores que han estudiado estos agentes productivos (Burmeister, 1980; Tort, 1983; Llovet, 1991; Pucciarelli, 1993; Forni y Tort, 1991; Barsky y Gelman, 2001, entre otros que también han tratado el tema) coinciden en que la emergencia de los mismos es el resultado de la conjunción de una serie de factores económicos, sociales, políticos y territoriales que se dieron en diferentes períodos históricos.

Si bien estos prestadores de servicios están presentes desde los inicios de la explotación agropecuaria extensiva (Bialet Massé, 1986), ${ }^{14}$ empiezan progresivamente a sobresalir de manera relevante a partir de finales de la década del '50 y principios de la década del '60 (Llovet, 1991), que es cuando van a interactuar de manera conjunta políticas crediticias favorables a la mecanización, intervención del Estado en el mercado de arrendamiento (esta intervención se inicia en la década del '40) que va a incidir en la disminución abrupta del arrendamiento tradicional, ${ }^{15}$ el inicio de profundos cambios tecnológicos y el incremento paulatino y sostenido de la producción agrícola. Todas estas instancias concurrentes van a favorecer el incremento y la consolidación de los prestadores de servicios, que por cierto tienen una procedencia de lugar netamente rural.

Es así como para varios de aquellos pequeños productores que habían logrado mecanizarse, pero que contaban con una reducida explotación o se habían quedado sin ella, dedicarse a las tareas de servicios agrarios representó como estrategia laboral -central o complementaria- la posibilidad de permanecer dentro del sistema productivo agropecuario (Tort, 1983).

Luego del afianzamiento del contratismo de servicios, a partir de la década del '70 empieza a tomar forma la figura del "contratista de producción” (Llovet, 1991), alcanzando más adelante una gran difusión -siendo muchos de ellos, como explicitamos más arriba, contratistas de servicios que ampliaron sus actividades empresariales mediante el alquiler de campos a porcentaje de la cosecha a los dueños de los mismos-, que va a reemplazar hasta

14 Es interesante observar cómo Bialet-Massé, en su clásico Informe sobre el estado de la clase obrera, de principios del siglo XX, ya describe y analiza con ojo crítico el uso de maquinaria agrícola, concretamente el funcionamiento de las trilladoras en la provincia de Santa Fe.

15 La intervención del Estado en el mercado de arrendamientos, si bien por un lado permitió la conversión de muchos arrendatarios tradicionales en pequeños propietarios familiares, por el otro, produjo como resultado efectos desfavorables en perjuicio de los arrendatarios, quedando muchos de ellos fuera de las explotaciones. 
cierto punto la función de los clásicos arrendatarios y aparceros tradicionales (Llovet, 1991). Todo ello, en consonancia con la nueva dinámica general de ampliar y multiplicar el capital en el menor tiempo posible, lo que da lugar a una serie de nuevas situaciones y readaptaciones por parte de los contratistas rurales, a fin de responder a las nuevas exigencias que reclama el medio. En este sentido, se va a incrementar acusadamente el número de estos agentes y, en general, va a mejorar notablemente su parque de maquinaria, capacidad de trabajo y sus conocimientos técnicos en las labores que desempeñan (Lódola y Fossati, 2004).

Por lo tanto, en la actualidad, con la intromisión profunda del capitalismo avanzado en la economía agropecuaria, se han convertido en el motor imprescindible que impulsa y permite el espectacular ritmo productivo pampeano y también extrapampeano.

En síntesis, se parte de la idea de que, si bien es difícil conjeturar sobre la evolución a futuro de estos agentes rurales, es de suponer, por su alto grado de especialización en las labores agropecuarias, la sostenida capitalización y la proliferación cada vez más acentuada del "contratismo de producción", que seguirán colaborando eficazmente a que la estructura agraria actual continúe sufriendo profundos cambios fundiarios y socio-económicos.

A continuación de este esbozo general, pasamos concretamente a desarrollar la investigación

que se llevó a cabo sobre estos agentes. La misma contempla cuatro instancias: el desenvolvimiento de los contratistas de servicios, la opinión de los productores con respecto a los servicios que reciben de parte de los contratistas, el desempeño de los contratistas de producción y la actuación del gremio que aglutina a esta fuerza laboral. Todo ello centrado, desde una perspectiva geográfica, sobre las consecuencias modificatorias que el contratismo contribuye a desencadenar a nivel socio-territorial, en un área relativamente pequeña, dentro de la región sur de la provincia de Córdoba. Ésta se ubica en el sector noroeste de la Región

Pampeana, al norte del Departamento Río Cuarto, zona correspondiente a la pampa subhúmeda en contacto con las sierras de Comechingones (Mapa No 13). Comprende básicamente las localidades de Alcira (Gigena) y Berrotarán y sus respectivas zonas rurales de influencia, donde se llevaron a cabo las entrevistas correspondientes y el trabajo de campo en general. El área cuenta con una población de regulares dimensiones, fuertemente concentrada en los centros urbanos, ${ }^{16}$ y con una población rural sumamente escasa, que ha disminuido progresiva y notoriamente en los últimos años. El tipo de explotación que se lleva a cabo en esta zona se puede caracterizar como de actividad mixta,

16 De acuerdo con el Censo Nacional de Población y Vivienda de 2001, tienen Alcira Gigena 5.486 habitantes y Berrotarán 6.441 habitantes. 


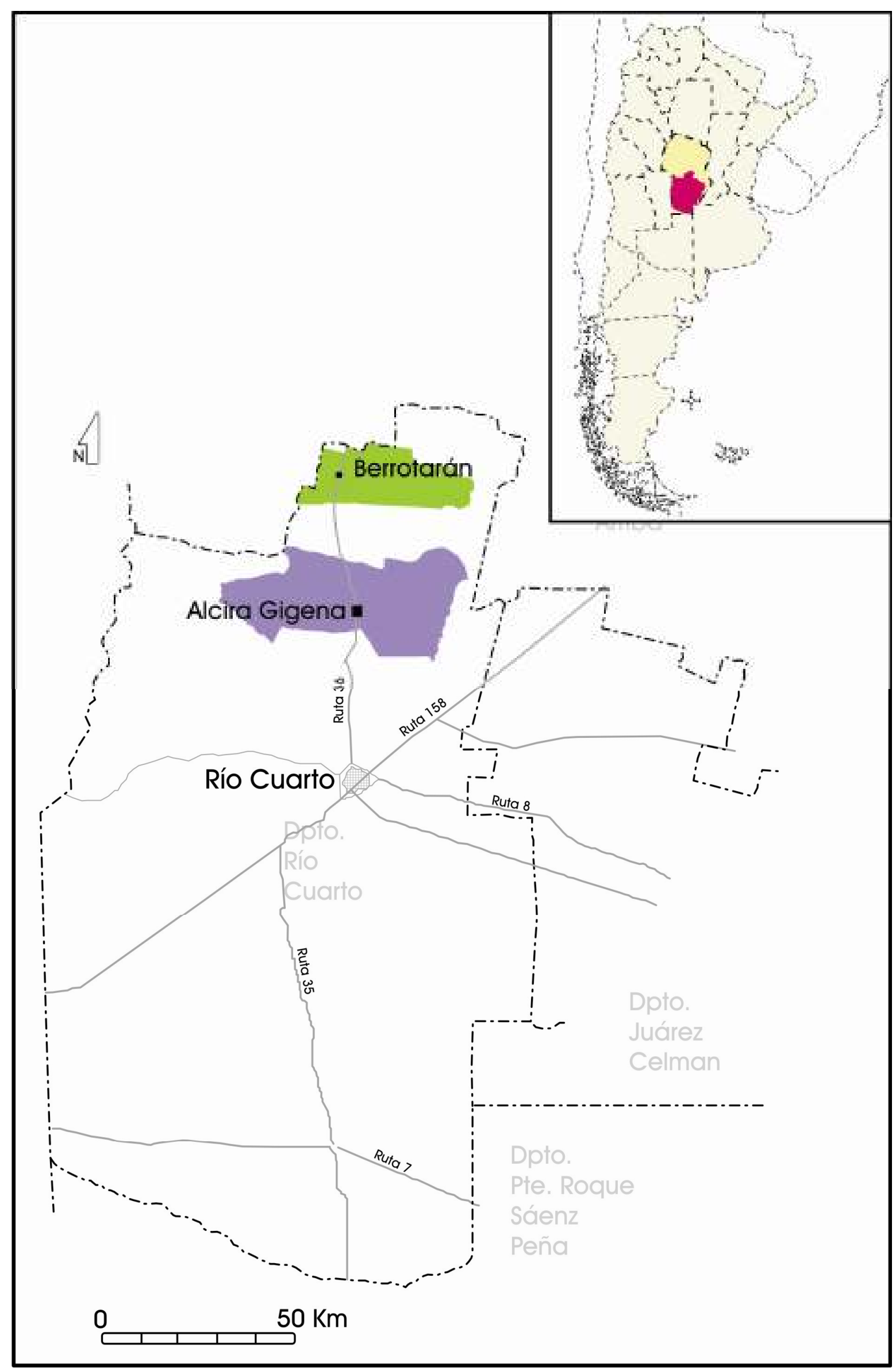

Mapa N ${ }^{\circ} 13$. Zonas rurales de influencia de las localidades de Berrotarán y Alcira (Gigena). 
con predominancia de la agricultura, pero con valores productivos intermedios, en concordancia con su ubicación periférica dentro de la llanura pampeana.

Desde no hace muchos años, al igual que gran parte del resto de la planicie mencionada, se viene manifestando un fuerte proceso de agriculturización, con la presencia destacada del cultivo de la soja. Tradicionalmente, el grueso de su parcelario se ha caracterizado por pequeñas y medianas explotaciones, producto de la fragmentación sucesiva de la tierra, originalmente en poder de grandes estancias establecidas de antiguo en la zona. No obstante, en los últimos tiempos, se observa en el área aludida -al igual que en el resto de la llanura pampeana- un incremento acentuado en el tamaño promedio de las explotaciones $\mathrm{y}$, al mismo tiempo, una disminución pronunciada en la cantidad de explotaciones.

Por último, cabe destacar que, en esta zona, el fenómeno de aparición y posterior transformación del contratismo rural ha sido similar, pero más tardío, y la presencia y capacidad económica menos acusada que en otras áreas de la Región Pampeana. En concreto, la potencialidad económica de nuestra zona de análisis tiene sus limitaciones y éstas se reflejan en la capacidad empresarial de los contratistas que residen en la misma.

En lo que respecta al desempeño específico del contratista rural, la investigación procura indagar sobre las actividades que desarrollan, sobre su estructura económico-laboral y social y en qué forma y magnitud este prestador incide a nivel socio-territorial.

Los problemas que esta investigación se propuso resolver consistieron en los siguientes aspectos: estudiar el perfil socio-laboral del contratista en general, sus familiares y de los trabajadores que dependen del mismo, o sea, sobre la organización social del trabajo al interior de la empresa; captar las características locacionales y las zonas de desempeño laboral; establecer la magnitud de su perfil económico en lo atinente a la dotación de recursos, manejo tecnológico, actividades que desarrolla y nivel de ingreso; conocer sus relaciones sociales en sus múltiples formas de vincularse y expresarse; detectar el origen de su actividad laboral, contemplando las diversas razones que motivaron este tipo de emprendimiento, su posterior evolución y orientación futura en su actividad económica; captar el rol que cumple en la articulación entre la propiedad de la tierra, el capital y el trabajo, conocer la opinión de los productores agropecuarios sobre la calidad de los servicios que brindan los contratistas, indagar sobre las funciones y dimensionamiento de la entidad gremial que nuclea a estos agentes productivos y, por último, indagar sobre la contribución del contratismo rural en las transformaciones socio-territoriales, con especial preferencia en lo atinente a las modificaciones acaecidas en los últimos tiempos en la estructura agraria. 
La metodología empleada en este estudio -al igual que los análisis de los otros agentes descriptos- consiste en una tarea eminentemente empírica, y que se complementa con aportes de trabajos teóricos y de información general. La idea se sustenta en obtener información de primera mano. Para ello, se optó por elegir una acotada y no muy grande "unidad territorial", donde resulte factible medir en detalle las variables que nos interesan. Las instancias desarrolladas fueron las siguientes: recopilación de datos generales y cualitativos, a través de entrevistas a referentes claves, a fin de obtener información básica y los conocimientos necesarios que nos ayudaran a orientarnos en los pasos subsiguientes; luego se procedió a la obtención de una "encuesta por muestreo" no aleatoria, ${ }^{17}$ realizada a los contratistas rurales, y se acudió también a la indagación de diversas fuentes, como el gremio que los nuclea, información de procedencia académica y periodística, entre otras.

A continuación, pasamos a desarrollar los resultados del accionar de los contratistas de servicios del área de estudio mencionada.

\subsubsection{Análisis del desempeño de los contratistas de servicios}

Las entrevistas de la encuesta efectuadas a este tipo de contratistas se llevaron a cabo en el primer semestre del año 2006 y se aproximan al 30\% del total del universo de contratistas de servicios que residen en el área estudiada -quince entrevistados de una lista de cincuenta y un nombres-. Corresponde especificar, también, que el análisis de algunos resultados de la encuesta está reforzado por información proveniente de entrevistas efectuadas a referentes claves.

\subsubsection{La organización social del trabajo al interior de la empresa}

El "tipo de fuerza laboral" que predomina en las empresas de contratistas de servicios es la familiar (51\%), aunque por escaso margen con respecto a la de los trabajadores dependientes del contratista (49\%). Dentro de la fuerza de trabajo familiar, se observa que el peso laboral de los jefes de familia es pronunciado (57,7\%). Participan de las tareas en primer lugar los hijos varones y, en segundo lugar, los hermanos de los jefes. Cabe aclarar que en muchos casos el trabajo del contratista jefe representa la única fuerza laboral a nivel familiar.

Del total de familiares que trabajan con el contratista, el 10\% se desempeña como capataz o encargado, el $60 \%$ como operadores especializados en maquinarias: tractoristas y maquinistas, y

17 Cabe especificar que para el relevamiento de los contratistas rurales, la encuesta que se implementó se apoyó y construyó en base a cuatro ejes centrales: estructura social, características locacionales, perfil laboral y perfil económico. El cuestionario de esta encuesta, llevada a cabo en 2006, se encuentra en el Anexo de este trabajo. 
el 30\% realiza todo tipo de tareas. En concreto, más allá de esta diferenciación ocupacional, todo el grupo familiar sabe manejar la maquinaria y la maneja, ya sea de manera continua o alternada, dado que este tipo de habilidad laboral es central para el desarrollo de la actividad del contratista.

En relación con los "ingresos" que perciben los familiares que trabajan con el contratista, todos reciben una suerte de ingreso equivalente a un porcentaje del trabajo total, que se realiza. A los hermanos -subordinados laboralmente al jefe de familia- e hijos, les corresponde entre un 7\% y $8 \%$ promedio de la actividad que se lleva a cabo en cada período de trabajo. Ese porcentaje asignado funciona como una caja de ahorro en manos del contratista jefe y éste le entrega dinero al familiar de acuerdo con sus necesidades, o todo el porcentaje estipulado, si el mismo desea realizar algún tipo de inversión. En general, el hijo, por ejemplo, cobra como los empleados, por una cuestión de disciplina ético-laboral y de aprendizaje de administración doméstica. ${ }^{18}$

En el caso de los hermanos que trabajan como socios, o sea que están en un pie de igualdad, la ganancia se reparte por partes iguales.

En esta encuesta no se han registrado casos de familiares que trabajen con el contratista que perciban ingresos fijos en dinero.

Con respecto al "tiempo de trabajo" que al contratista le demandan sus tareas, vemos que dicho tiempo varía de acuerdo con los distintos tipos de cultivos según la época del año. En el Cuadro 50, se diferencian los diversos tiempos de trabajo que requieren los cultivos de invierno y de verano, según corresponda a la tarea de siembra o de cosecha.

\section{Cuadro $\mathbf{N}^{\circ}$ 50. Tiempos de trabajos de los cultivos de invierno y de verano}

\begin{tabular}{l|l} 
Cosecha: los contratistas prestan el servicio de cosecha de granos de invierno durante los meses de \\
noviembre a diciembre. Se hace notar que del total de contratistas rurales encuestados el $20 \%$ no trabaja \\
(solamente cosecha) \\
con cultivos de invierno. Dentro del $80 \%$ restante el $54 \%$ de los contratistas, el tiempo de trabajo alcanza \\
a un mes, mientras que el $26 \%$ de los contratistas prolongan su labor por dos meses. \\
Los principales cultivos recolectados por los contratistas son: el trigo, con el $84 \%$ del total cosechado, y la \\
avena, con el $16 \%$.
\end{tabular}

Fuente: Elaborado por Andrea Rivarola y Rita Maldonado (2006:12) "El accionar de los contratistas de servicios agropecuarios en un sector de la Pampa cordobesa", ponencia presentada en el Congreso Internacional de la Asociación Geográfica von Humboldt, en Colón, Entre Ríos, 2006.

18 En relación con los hermanos que trabajan como socios, en nuestra encuesta hemos detectado algunos casos, y esto se expresa en los siguientes términos: en el 73,3\% de las empresas entrevistadas, los contratistas que participan en las mismas son personas físicas, es decir que hay un solo dueño en la empresa. El 26,7\% restante se constituye en "sociedad de hecho" con familiares. En este último caso, los vínculos societales se establecen con los hermanos. 
Por lo arriba expuesto, queda claro que en nuestra área el fuerte es el cultivo de verano y el receso laboral coincide básicamente con el invierno.

En concreto, el tiempo de trabajo durante el año de los contratistas entrevistados fluctúa entre tres y nueve meses, y el promedio general se establece entre los cuatro meses y medio y cinco meses. Durante los siete meses promedio que no se desempeñan como maquinistas, en general y especialmente los contratistas puros, se dedican al mantenimiento de la maquinaria. En muchos casos, a las cosechadoras las desarman completamente y las vuelven a armar. En el caso de los contratistas que a su vez realizan tareas agropecuarias, aparte de reparar las maquinarias, se dedican también a la atención de sus campos.

En relación con las "horas trabajadas por día", para los cultivos de invierno le dedican a la cosecha un promedio de catorce horas por día. Esta carga horaria coincide con el verano que es cuando los días son más largos. Al trabajar con cultivos de verano, le dedican a la cosecha un promedio de nueve horas y media por día, en correspondencia con el otoño y mitad de invierno que es cuando los días son más cortos.

Sobre los "trabajadores dependientes" del contratista, en nuestro caso observamos que el $60 \%$ se desempeña como trabajadores permanentes y el $40 \%$ como transitorios. Cada contratista tiene un promedio de dos empleados y la residencia urbana de los mismos coincide con la del empleador.

El grueso de los trabajadores permanentes y transitorios se desempeñan como operadores especializados -el $85 \%$ y el $80 \%$, respectivamente- en el manejo de tractores y máquinas cosechadoras. El promedio de tiempo de contratación en el caso de los transitorios es de cinco meses al año; generalmente los trabajadores transitorios son siempre los mismos.

En el período de la campaña agrícola, tanto a los empleados permanentes como a los transitorios se les paga un porcentaje del trabajo total realizado, el cual varía según las actividades que desempeñen. Por ejemplo, a los maquinistas les corresponde un $8 \%$ y a los tractoristas entre un $6 \%$ y un 7\%. Pero cuando las hectáreas a trabajar suman grandes extensiones, el porcentaje que se le paga a los trabajadores es un poco menor. En el caso de los empleados permanentes, en el período que no se trabaja con la maquinaria, pasan a cobrar en general el sueldo correspondiente por ley a los trabajadores rurales.

A todos los empleados permanentes los contratistas les efectúan los aportes jubilatorios y de la obra social durante todo el año, al igual que a los transitorios, pero a éstos solamente durante el período que desarrollan su trabajo. A su vez, tanto los permanentes como los transitorios en ningún caso cuentan con un contrato laboral formal. 
Por último, a modo de síntesis de este apartado, corresponde resaltar el rol eminentemente familiar del contratismo de servicio en nuestra área, característica que se reitera en otros lugares del país. Vemos que la empresa gira alrededor de la dirección e impulso del jefe de familia con el apoyo central de su descendencia masculina. El capital que posee, que puede ser muy importante, se concentra en el núcleo hogareño y generalmente no se reparte entre otras personas ajenas al mismo. Por otra parte, la participación de la mujer en nuestro caso es nula, aunque en otros ámbitos empieza progresivamente a asumir un débil protagonismo (Bertello, 2006).

El empleado, a su vez, representa un apoyo fundamental en las tareas de la empresa. Su aporte laboral es imprescindible para el funcionamiento de la misma. Otra característica que se da en nuestro medio es que la fuerza laboral de conjunto - la de la familia más la de los empleados- que trabaja en cada unidad es más bien limitada, fluctuando entre tres y cuatro miembros por empresa.

\subsubsection{Características locacionales}

En nuestra encuesta, prácticamente todos los contratistas entrevistados -menos un casoresiden en las localidades ya citadas junto a sus grupos familiares, lo que refleja la tendencia locacional de los mismos. En nuestra área de estudio es escaso el número de contratistas que residen en las zonas rurales y obviamente corresponden a aquellos agentes de servicios que, a su vez, son productores agropecuarios, o sea, viven en sus explotaciones.

Con respecto a los que residen en los pueblos, la gran mayoría proviene del entorno rural cercano a los mismos, y unos pocos siempre vivieron en los centros urbanos.

En cuanto a las causas que provocaron originalmente el cambio de lugar de residencia desde las zonas rurales hacia los pueblos, por cierto han sido varias, pero en nuestro trabajo figura, en primer lugar, "por dificultades económicas" - de las cuales se deriva en muchos casos el nuevo emprendimiento laboral como contratistas-; en segundo lugar, "por razones educativas", y en tercer lugar, "por problemas de salud o por búsqueda de comodidades urbanas". Cabe especificar que los entrevistados que argumentaron que la razón del cambio de localización se debió a dificultades económicas, en general, éstas tuvieron relacionadas con problemas de la tierra, ya sea porque el campo familiar quedó chico, se vendió, o por limitaciones económicas para hacerlo producir.

Vemos que la mayoría de los contratistas son propietarios de sus viviendas (87\%) y la calidad de las mismas se puede considerar como buena. En relación con las dimensiones de las viviendas, predominan las de tamaño mediano (67\%), con un promedio de dos a tres 
habitaciones en cada una de ellas, seguidas por las de gran tamaño, con cuatro o más habitaciones.

En lo que se refiere a su hábitat, vemos que los contratistas se manifiestan como sólidos propietarios de casas en buenas condiciones y con un aceptable confort en sus viviendas. ${ }^{19}$ Lo notable es que, a pesar de los buenos o muy bueno ingresos que obtienen muchos de estos agentes productivos, se observa una falta de ostentación en sus moradas.

De todo lo expuesto queda claro, por una parte, el origen eminentemente rural de los contratistas, y por otra, la predominante localización urbana de los mismos, fenómeno que -por lo que se sabe- se reitera con todos los agentes de servicios que residen en otros puntos del país (Barsky, 2001). No cabe duda de que los centros urbanos -siempre y cuando no sean de grandes dimensiones- para los contratistas son el lugar más apropiado como base operativa de sus tareas. Todo lo anteriormente mencionado está obviamente relacionado con la localización "fija" de estos agentes de servicios, pero queda pendiente la explicitación de la otra forma de localización que podríamos llamar "difusa", que particularmente ejerce este tipo de actor social, recordando que un poco más o un poco menos de medio año reside fuera de su localidad. Practica por lo tanto una suerte de nomadismo, trasladándose permanentemente durante el período de trabajo de un punto a otro dentro de las zonas rurales del país, con su casilla rodante a cuestas (Cicaré, 2004). Durante el período que está fuera de su casa, alterna dentro de un mundo eminentemente masculino, aunque últimamente debido a las nuevas comodidades que brindan las viviendas móviles, algunos contratistas suelen convivir con sus respectivas mujeres.

En lo referente a nuestros encuestados, todos poseen viviendas móviles, de las cuales el 60\% de las mismas están "medianamente" equipadas, luego a las "bien" y "muy bien" equipadas les corresponde un $20 \%$ a cada una. Pero más allá de esta diferenciación de categoría, todos disponen de suficientes comodidades para cubrir satisfactoriamente las necesidades de sus ocupantes.

En cuanto a las "zonas de trabajo" donde desarrollan sus actividades, el $40 \%$ de los contratistas se desempeñan exclusivamente dentro del área donde viven -lo que no quiere decir que, por esta circunstancia, duerman en su casa del pueblo-; el 13\% trabaja dentro de la misma área y fuera de la misma, y el $47 \%$ trabaja fuera del área, en otros parajes de la provincia de Córdoba, La Pampa y Salta. Por último, cabe acotar que el mayor porcentaje de agentes que trabajan en otras zonas corresponde a los contratistas de servicios puros, dado que

19 En esta instancia, se entiende por "confort" cuando la vivienda dispone de la suficiente disponibilidad de espacio y de los accesorios necesarios que brindan comodidad a sus habitantes. 
éstos disponen de un mayor grado de especialización y de una mayor libertad de movilidad laboral.

\subsubsection{La dotación de recursos en equipamiento y manejo tecnológico}

A juicio de los contratistas entrevistados, el 40\% considera que posee un nivel de equipamiento de regular a aceptable, el 53,3\% que posee un buen nivel de equipamiento y un solo entrevistado $(6,7 \%)$ considera que dispone de un equipamiento muy bueno.

En relación con la maquinaria básica, observamos que la mayoría de los agentes de servicios cuentan con dos o tres tractores por empresa. El promedio de potencia es de $100 \mathrm{Hp}$. Con respecto a la antigüedad de los mismos -se debe recordar que la encuesta data de 2006-, observamos que el 74\% corresponde a las décadas del '70 y ' 80 , el 19\% a la década del '90 y el 3\% a la primera década de 2000. En síntesis, se puede decir que los tractores son de potencia media y con una antigüedad elevada; sólo unos pocos contratistas han modernizado sus tractores.

En lo referente a las "sembradoras", solamente el $27 \%$ de los agentes poseen sembradoras directas de grano grueso.

La totalidad de los encuestados disponen de "máquinas cosechadoras de granos", en general una unidad por empresa, con una potencia promedio de $185 \mathrm{Hp}$, que se puede considerar de valores intermedios. La antigüedad de las cosechadoras varía, correspondiendo el $34 \%$ a la década del ' 80 , el $40 \%$ a la década del ' 90 y el $26 \%$ a la primera década de 2000 . Vemos que este parque de maquinaria no es tan antiguo como el de tractores. Por otra parte, observamos que las cosechadoras más nuevas las poseen, en general, los contratistas de servicios puros, que serían los que están más profesionalizados en las tareas de laboreo y cosecha.

Con respecto a las perspectivas futuras de adquisición de maquinaria, el $73 \%$ de nuestros contratistas piensa comprar implementos. De este porcentaje, el 60\% piensa cambiar las herramientas y sólo el 13\% acrecentar las mismas. En ambos casos, los implementos a comprar serían usados, dando prioridad a las cosechadoras y luego a las sembradoras y tractores. La amplia mayoría lo haría a través de las facilidades otorgadas por concesionarios y vendedores. Queda claro que la tendencia pasa por renovar los equipos a fin de poder competir adecuadamente.

En lo que respecta a instalaciones disponibles, el $87 \%$ de los contratistas consideran que cuentan con edificios básicos y el 13\% con instalaciones buenas, con un promedio de $162 \mathrm{~m}^{2}$ techados. Son por lo tanto galpones de tamaño mediano a grande. El 53\% de los agentes piensan acrecentar las instalaciones ampliando las ya existentes o edificando nuevos galpones. 
Es significativa la cantidad (60\%) de contratistas que realizan por sus propios medios la reparación compleja de su maquinaria, mientras que el resto refacciona lo simple; generalmente las reparaciones se realizan en las localidades de origen de los contratistas. Un gran número de ellos $(80 \%)$ posee taller fijo y muchos cuentan también con el taller móvil, desplazándolo según sus necesidades y el lugar de trabajo.

El 73\% de los contratistas encuestados se desplazan con la maquinaria por sus propios medios hasta el sitio de trabajo, cuando éste no está muy alejado, ya que el costo de traslado en vehículos transportadores, llamados también carretones, es muy elevado. Pero cuando las distancias a recorrer superan los $300 \mathrm{~km}$, los contratistas acuden a este tipo de vehículos.

Por otra parte, todos los contratistas de servicio reciben algún tipo de "asesoramiento tecnológico", dentro de los cuales el 67\% proviene del sistema privado, y el resto (33\%) "de otra forma". Llama la atención que en ningún caso el asesoramiento proviene del sistema oficial. Dentro del sistema privado, los agentes que prestan servicios son, fundamentalmente, los concesionarios y en menor término las cooperativas. Los agentes que prestan servicios dentro de otras formas son, principalmente, los colegas, seguido por la información recogida en las exposiciones rurales.

Queda en evidencia la inquietud por parte de los contratistas de servicios por actualizarse en todo lo atinente a los nuevos avances tecnológicos que se vinculan con su actividad.

En relación con el "nivel de acceso económico al mejoramiento tecnológico", según opinión de los propios contratistas, el 46,7\% considera que su acceso económico al mismo es limitado, mientras que un igual porcentaje (46,7\%) considera que su acceso es aceptable; en un solo caso piensa que posee un buen nivel de acceso económico a la modernización tecnológica.

En síntesis, por la dotación de recursos en equipamiento y manejo tecnológico de que disponen los contratistas bajo estudio, se puede decir que están en similar sintonía con el resto de los colegas del país.

\subsubsection{Las actividades que desarrollan}

Para explicitar adecuadamente las actividades que desarrollan los agentes de servicio en nuestra área, consideramos que es necesario como paso previo, diferenciar los tipos de contratista de servicios encuestados en nuestro trabajo.

En este sentido, encontramos que el 53,3\% corresponde a los contratistas de servicios puros, que son los que se dedican exclusivamente a sus tareas específicas, mientras que el $46,7 \%$ son contratistas de servicios que a su vez desarrollan otra actividad económica agropecuaria. 
De este último porcentaje se desprende un 13,3\% que corresponde a los contratistas de servicios que se desempeñan a su vez como productores agropecuarios -son propietarios de sus explotaciones- y un $33,7 \%$ que corresponde a contratistas de servicios que se desempeñan también como productores agropecuarios y contratistas de producción. ${ }^{20}$

Con respecto a los servicios que puede realizar un contratista, los mismos son muy variados, entre ellos se encuentra la roturación, siembra, mantenimiento de los cultivos, cosecha de granos, preparación de reserva forrajera, entre otros.

En esta investigación se ha prestado atención a dos de ellos, la siembra y la cosecha de granos. En el primer caso, el 33,3\% de los contratistas prestan servicios de siembra directa de grano grueso (soja y maíz). En el segundo caso, la totalidad de los encuestados realizan cosecha de granos, ya sea grano fino o grueso. En la cosecha de grano fino, se destacan los cultivos de trigo, avena, trébol y cebada, y la realizan el 73,3\% de los contratistas. La cosecha de grano grueso la realizan todos los contratistas, o sea el $100 \%$, en la cual predominan la soja, el maíz y el girasol.

La cantidad de hectáreas anuales trabajadas de todos los agentes involucrados -exclusivamente en función de prestación de servicios- promedia las 1690 ha., cifra que se puede considerar como de un valor regular a intermedio dentro del quehacer del contratismo de servicios. Pero corresponde aclarar que el promedio de las hectáreas trabajadas por los contratistas de servicios puros es muy superior al valor arriba dado.

Si se desagrega por ciclo de cultivo, hallamos que el cultivo de invierno ocupa un promedio trabajado de 516 ha y el cultivo de verano promedia las 1289 ha, cifra muy superior que reafirma la preponderancia de la cosecha gruesa en la llanura occidental cordobesa. Cabe recordar que la intromisión del doble cultivo trigo-soja, que se puso en práctica a partir de la siembra directa, ha incrementado notablemente en general la demanda del contratismo de servicios.

Por otra parte, la mayoría de los contratistas de servicios trabajan principalmente para "personas físicas" y en segundo lugar para "sociedades formalmente constituidas". Esta preponderancia laboral con los primeros determina que a la larga se establezcan fuertes vinculaciones entre las partes. Estas relaciones, a su vez, permiten captar nuevos clientes a través de los contactos que brindan los productores conocidos. Por lo tanto, la mayoría de los

20 En relación con al desempeño como "productor agropecuario" y "contratista de producción" de aquellos contratistas de servicios que desarrollan más de una actividad, podemos decir que como "productores agropecuarios" son propietarios de las explotaciones, pero en lo referente al tamaño de las mismas, predominan los pequeños predios, y como "contratistas de producción", los campos que se arriendan son de grandes dimensiones, con un tamaño promedio cercano a las 1.000 ha., con un mínimo de 500 y un máximo de 1.500 ha. Por lo tanto, son contratistas con un alto poder económico, por el nivel de inversión que deben realizar para arrendar grandes cantidades de hectáreas. La totalidad de los predios arrendados son dedicados a la agricultura, con un fuerte predominio de los granos: primero, soja, y segundo, cereales. 
contratistas recurren a las redes sociales ya establecidas con productores amigos, que son los que sirven de nexo en muchos casos para expandir sus actividades.

En cuanto al tratamiento ambiental, especialmente del suelo, y protección de las instalaciones de las explotaciones, los contratistas manifiestan tener el cuidado suficiente. Dicen cuidar mucho estos aspectos, a fin de conservar al cliente para la próxima temporada de trabajo. Cabe resaltar que ésta es la respuesta de los contratistas, queda pendiente la respuesta sobre la misma consulta de parte de los productores agropecuarios, que se explicita más adelante.

\subsubsection{Nivel de ingresos y movimiento financiero}

La "forma de pago" al contratista por el servicio de "cosecha" 21 es la siguiente: el 60\% de los agentes encuestados cobra un monto fijo por hectárea trabajada, en este caso, quintales fijos por hectárea, y el 40\% restante cobra por porcentaje de la producción. Para ambos casos, los valores varían según el cultivo y el rendimiento por hectárea. A continuación se especifican los valores por cultivo (Cuadro $\mathrm{N}^{\mathrm{o}} 51$ )

Cuadro $\mathrm{N}^{\circ}$ 51. Forma de pago por cultivo realizado

\begin{tabular}{|c|c|c|c|}
\hline Cultivo & \% de la producción & Qa. Fijos por ha. & Rendimiento por ha. \\
\hline Soja & 9 & 2 & \\
\hline Maíz & 7 & 7 & Hasta los 20 Qa/Ha de rinde se mantienen los valores. Luego el \\
\hline Girasol & 9.5 & 2 & \\
\hline Trigo & & 2,5 & \\
\hline Avena varía según el aumento del rendimiento por hectárea.
\end{tabular}

Fuente: Elaborado por Andrea Rivarola y Rita Maldonado (2006:9) "El accionar de los contratistas de servicios agropecuarios en un sector de la Pampa cordobesa”, ponencia presentada en el Congreso Internacional de la Asociación Geográfica von Humboldt, en Colón, Entre Ríos, 2006.

21 A modo de ejemplo, se detalla a continuación el precio orientativo de la cosecha fina con su correspondiente desglose, de la campaña 2009-10, calculado por el Ing. Agr. Ricardo Garbers, jefe del Departamento Técnico Económico de FACMA (Garbers, 2009:s/n).

Desglose precio cosecha fina 2009-10

\begin{tabular}{|c|c|c|}
\hline & Cultivo: Trigo & \multirow{4}{*}{$\begin{array}{l}\text { Categoría B } 235 \text { HP } \\
2400 \mathrm{~kg} / \mathrm{ha} \\
4,67 \mathrm{ha} / \mathrm{h}\end{array}$} \\
\hline Cosechadora & & \\
\hline Rendimiento de cálculo & & \\
\hline Capacidad operativa & & \\
\hline
\end{tabular}

Desglose del precio a $24 \mathrm{QQ} / \mathrm{ha}$

\begin{tabular}{|c|c|c|}
\hline Gasto operativo & $\$ /$ ha & $\%$ \\
\hline Conservación y reparación & 28,4 & $16 \%$ \\
\hline Combustible y lubricantes & 45,5 & $26 \%$ \\
\hline Personal / Aportes & 33,3 & $19 \%$ \\
\hline Administración + Seguros, Tasas & 7,6 & $4 \%$ \\
\hline Subtotal gasto operativo & 114,8 & $65 \%$ \\
\hline Costo propiedad & 32,7 & $18 \%$ \\
\hline Total costo operativo & 147,5 & $83 \%$ \\
\hline Utilidad $20 \%$ s/costo operativo & 29,4 & $17 \%$ \\
\hline Precio orientativo & 177,21 & $100 \%$ \\
\hline
\end{tabular}

(Cálculo basado en un equipo compuesto por dos cosechadoras y 2 tractores-tolva) 
Para el caso de la "siembra directa", los contratistas cobran un monto fijo en pesos por hectárea. Este precio puede variar si se fertiliza el cultivo al sembrarlo. Los principales cultivos realizados bajo siembra directa son soja, maíz y trigo.

Con respecto al "costo operativo en porcentaje por trabajo realizado" que tiene el contratista, según la opinión de los encuestados, por ejemplo en la "cosecha", el costo del trabajo asciende al 45\% o 50\% de los ingresos brutos, mientras que para la "siembra" el costo es un poco menor (40\%), sin considerar el "costo de propiedad" que abarca los ítems de amortización e intereses de la maquinaria (Garbers, 2009:5). El costo incluye el gasto en combustible, mantenimiento de maquinaria, empleados, gastos domésticos, desplazamiento, administración, seguros, entre otros.

En relación con los "impuestos" que deben pagar los contratistas, éstos son: impuesto a las ganancias (aportan el 10\%), el impuesto a ingresos brutos (aportan el 3,5\%) y el impuesto al valor agregado (10,5\%). Obviamente, aunque no lo expliciten, es de suponer que no obligadamente - por lo menos en todos los casos- facturan todo lo que hacen.

Con respecto a los "seguros que contratan", podemos diferenciar por un lado los "seguros de equipo": en este caso el 53,3\% de los contratistas posee un seguro contra todo riesgo, mientras que el $40 \%$ opta por el seguro contra terceros únicamente; y por otro está el "Seguro de Riesgo de Trabajo": aquí el 60\% de los agentes de servicios contrata seguro de riesgo de trabajo para sus empleados. Este seguro en el caso de los empleados temporarios solamente se realiza por el tiempo de contrato del trabajador. Sobre este punto, vemos que los contratistas en general toman de manera relativamente aceptable ciertas precauciones relacionadas con el desenvolvimiento de su trabajo.

Del total de contratistas, un poco más de la mitad, sus "transacciones de dinero" -cobranza, pago, depósitos- las realizan con el Banco Provincia de Córdoba y el resto prácticamente con el Banco Nación Argentina. Solamente el 20\% acude al "crédito bancario", con el objetivo principal de comprar maquinaria. Es evidente el peso de los bancos oficiales en el movimiento financiero de los contratistas.

La totalidad de los encuestados posee un "contador" que asesora y administra la contabilidad de la empresa, lo que demuestra la complejidad creciente que va asumiendo la misma.

Por último, el 40\% de los contratistas se encuentra asociado a una cooperativa agrícola establecida en Berrotarán, dado que ese $40 \%$ vive específicamente en esa localidad.

De lo anteriormente expuesto en este apartado, corresponde destacar que a pesar de los onerosos costos de producción que tienen los contratistas, los ingresos netos son 
considerables. Por cierto que depende de la cantidad de hectáreas trabajadas, pero en general representan cifras más que importantes.

\subsubsection{Las relaciones sociales}

Las vinculaciones sociales de los contratistas son diversas, por la variedad de interlocutores con los que debe tratar, y a su vez particularmente dispersas espacialmente debido a la actividad ambulatoria de los mismos.

Dentro de esta amplia gama de relaciones, empezamos este análisis con su "estructura familiar", donde observamos que su Núcleo Familiar (NF) constituido por los miembros que viven bajo un mismo techo está conformado por un promedio de cuatro integrantes por familia. Los hogares con familias numerosas son muy raros.

La edad promedio de los contratistas jefes de familia es de 49 años, su rango oscila entre $\operatorname{los} 36$ y 70 años y su media va de $\operatorname{los} 45$ a 50 años. Estos valores indican que la jefatura de la fuerza laboral de los hogares encuestados es bien madura, característica que también se observa en los productores agropecuarios de la misma zona.

El NF está integrado por más hijos varones que mujeres, debido a que éstas -como ya dijimos en otros apartados-, entre los 20 y 25 años, al formar pareja dejan el hogar paterno. Todos los hijos que forman parte del NF están solteros y dependen económicamente de las actividades que realiza el padre.

Cada familia tiene un promedio de dos hijos, con una edad promedio de 17 años para los varones y 12 años para las mujeres.

Cabe acotar que en relación a la cantidad de hijos por hogar, la reproducción de la fuerza laboral a futuro se puede presentar como limitada.

En cuanto al estado civil de los contratistas de servicios, en un 100\% están casados, es decir son todos hogares formalmente constituidos.

Dentro del "nivel de instrucción" alcanzado por los jefes de familia, observamos lo siguiente:

Enseñanza primaria: el 69,5\%, de los cuales han completado el ciclo el 54,2\%.

Enseñanza secundaria: el 30,5\%, de los cuales han completado el ciclo el 7,5\%.

En síntesis, vemos que el grado de instrucción alcanzado por los contratistas jefes es más bien limitado.

Con respecto al nexo social que mantienen los contratistas con sus "empleados", éste es muy particular y se diferencia notablemente de los vínculos que se establecen en otras actividades laborales entre patrón y empleado. En este ámbito el compañerismo es muy 
acentuado, debido a la estrecha convivencia que se ven obligados a practicar. Se debe recordar que comparten la casilla, la comida diaria y los momentos de descanso entre otras instancias. Además, en muchos casos, la falta de diferenciación en las tareas -todos hacen de todo- ayuda a este acercamiento.

En concreto, el trato que le dispensan los contratistas a sus trabajadores, suele ser de compañeros y en algunos casos de amigo.

En lo atinente al nivel de vinculación que existe entre colegas, de acuerdo con lo detectado por nosotros, esta relación es un tanto errática. Algunos comparten ciertos momentos como viajar juntos o información, por ejemplo sobre lugares de trabajo y precios, y otros manifiestan tener poca relación o ninguna con sus colegas. En general, todos los encuestados declaran no tener mucho contacto entre ellos. No cabe la menor duda de que en este aspecto está mediando la potencial competencia que se puede establecer entre pares. Por otra parte, los entrevistados manifiestan no estar afiliados al gremio que los aglutina.

Por último, los vínculos que establecen los contratistas con sus clientes suelen ser sólidos en muchos casos, especialmente con aquellos con quienes trabajan regularmente todos los años. Es frecuente que la relación que se establece entre las partes sea de mutua confianza. El productor agropecuario en general respeta al contratista por su profesionalidad y conocimiento de los quehaceres agropecuarios.

En síntesis, las relaciones sociales que establece el contratista con los actores sociales con que trata suelen ser fluidas, respetuosas y de un espectro muy amplio.

\subsubsection{El origen de la actividad y perspectivas futuras}

Son diversas las causas que motivaron a los contratistas a emprender su profesión, cuyas razones de fondo y posterior evolución en parte se explicitaron en la introducción de este escrito. Lo interesante es ver que ciertas tendencias y características que dieron lugar a este fenómeno del contratismo -descripto más arriba- se reproducen en los resultados obtenidos en las encuestas realizadas.

Vemos así, por ejemplo, que con un 33,3\% predominan aquellos agentes cuya iniciación en esta actividad se debe al hecho de ser "hijos de contratistas" o "antiguos empleados" del patrón, que cuando éste se retiró les vendió las máquinas. Generalmente los hijos varones de los contratistas tienden a continuar con la profesión del padre. Luego, el 26,7\% corresponde a “ex-productores" que en la actualidad no poseen campo pero su oficio de origen es el de agricultor. Aquí la derivación hacia el contratismo se debe generalmente a la venta del campo original por sucesión familiar. 
Siguen también, con el 26,7\% aquellos contratistas de servicios que revisten a su vez la categoría de "productores" y/o "contratistas de producción", cuya motivación central de desempeñarse a su vez como contratistas de servicios y/o arrendatarios accidentales, ha consistido en ampliar sus ingresos económicos.

Por último, el 13,3\% recae en aquellos "productores" que se han dedicado también al contratismo, como estrategia de sobrevivencia por posesión de explotaciones pequeñas.

En concreto, en nuestro caso la mayor parte de los contratistas tiene su raíz en la actividad agraria, por haber sido o ser también agricultor, o indirectamente, por provenir de familias de agricultores.

Con respecto a la obtención del capital para la compra original del equipo, el grueso de los contratistas obtuvo el capital base ya sea a través de la ganancia obtenida como productor, del crédito bancario o de la venta del campo, o mediante la combinación de algunas de estas variantes. El resto de los contratistas obtuvo el capital ya sea mediante la asociación económica con familiares, herencia, venta de camión, etc.

Vemos así que han sido sumamente variadas las fuentes para obtener el capital destinado a la compra de maquinaria.

Con relación a cómo evolucionó a posteriori el equipamiento de los contratistas entrevistados, observamos que el 33,3\% continúa con el mismo nivel de equipamiento, en cambio el $73,3 \%$ lo acrecentó.

Desagregando este último porcentaje, encontramos que el 50\% lo acrecentó mediante la intensificación del trabajo, el 33\% por medio de préstamos de instituciones financieras y el $17 \%$ restante mediante la asociación con otros empresarios, herencia, etc. En concreto, se observa una gran heterogeneidad de estrategias a fin de disponer del capital necesario para acrecentar el equipamiento.

Por último, en lo que respecta a la "orientación futura de la actividad empresarial" de los contratistas encuestados, vemos que solamente el 20\% de los mismos piensa seguir manteniendo el mismo nivel de aprovechamiento económico que lleva a cabo en la actualidad. En cambio, el 80\% piensa obtener un mayor aprovechamiento económico de sus tareas. Este porcentaje se desagrega en un 66,7\%, que corresponde a aquellos agentes que piensan incrementar sus ganancias sin modificar su esquema de trabajo, a través de la intensificación de sus tareas en la misma zona, o ampliando la misma, concretamente trabajando más hectáreas. En cambio, el 13,3\% restante pretende incrementar sus actividades modificando su esquema de trabajo, por medio del arrendamiento accidental -o sea, pasarían 
a cumplir el rol de contratistas de producción- o mediante la especialización en un servicio, o incorporando a sus actividades un nuevo servicio.

En suma, se evidencia en general una clara intencionalidad de parte de los contratistas de ampliar sus ingresos empresariales mediante la práctica de diferentes estrategias laborales.

\subsubsection{Síntesis de la encuesta realizada}

De acuerdo con la encuesta arriba analizada, podemos comprobar, en líneas generales, que las características intrínsecas, funciones y desarrollo de los contratistas de servicios de nuestra área de estudio no se diferencian en lo sustancial con respecto a sus colegas de otras zonas del país.

También corroboramos que su origen y posterior evolución laboral se asemeja a lo observado empíricamente y planteado en términos teóricos por diversos autores -algunos de ellos ya citados en este texto- que han estudiado el tema del contratismo.

En nuestra área se han manifestado y se manifiestan varias de las causales que han dado lugar al surgimiento y subsiguiente desenvolvimiento de estos agentes, como transformación de productores a contratistas por pérdida de sus explotaciones o debido al achicamiento de las mismas, sobremecanización de los pequeños productores, y tendencia a la prolongación o conversión de contratistas de servicios a contratistas de producción, con el propósito de ampliar la capacidad de ingresos.

Por otra parte, queda en claro que los contratistas de nuestra área, que responden a una concreta realidad físico-territorial, no detentan el nivel de empresas de punta, como sí lo tienen muchas de las unidades establecidas en la Pampa Húmeda.

A modo de ejemplo, si bien el rango de hectárea trabajada por nuestros encuestados va de 600 a 3.700 ha., lo que indica que hay contratistas con una gran capacidad de trabajo -en nuestro caso solamente dos agentes-, el promedio general al ser de 1.700 ha. nos indica una capacidad laboral intermedia en nuestro medio.

Con respecto a los resultados expuestos en los apartados precedentes, destacamos a modo de resumen las características más sobresalientes de nuestros agentes productivos, en los siguientes aspectos:

- Una definida organización del trabajo en términos de empresa familiar, con un fuerte aporte laboral del contratista jefe, y una reducida dotación de trabajadores que lo acompañan. 
- Una localización eminentemente urbana y un radio de acción laboral compartido, tanto en la misma zona donde residen como en otros parajes del país.

- Un nivel de equipamiento que fluctúa entre medianamente bueno a bueno, un manejo tecnológico aceptable y un interés acusado por estar permanentemente actualizados.

- Una oferta de servicios básicamente orientada a la siembra y cosecha, y realizada con eficacia y profesionalismo.

- Un nivel de utilidades que, a pesar de los altos costos operativos de la empresa, se pueda considerar -en proporción a las diferentes dimensiones de las mismas- como muy rentable.

- Una buena capacidad de establecer vínculos sociales diversos y fluidos.

- Y por último, la observancia de una gran variedad de causas que dieron lugar al origen de este tipo de emprendimiento laboral.

En suma, podemos decir, en general, que los contratistas encuestados conforman unidades bien constituidas -aunque la mayoría no de grandes dimensiones--, con experiencia laboral y con éxito económico en el trabajo que realizan.

\subsubsection{Opinión de los productores agropecuarios con respecto a la calidad de los servicios que les brindan los contratistas de servicios}

Nos pareció importante que, una vez efectuada la encuesta pertinente a los contratistas de servicios, realizáramos una pequeña cantidad de entrevistas a los productores agropecuarios que hacen uso de estos agentes, a fin de conocer la opinión que tienen con respecto a la calidad de los servicios que reciben. Además, para conocer otras especificidades de tipo laboral y económico que se establecen entre estos dos agentes productivos. A tal fin, se elaboró un cuestionario que contempla los interrogantes que interesa dilucidar, empezando por los servicios que solicita a los contratistas, los gastos que le demanda, control de trabajo que realiza y evaluación general del trabajo, entre otros varios aspectos que también se consideran.

Los resultados se pueden resumir en los siguientes términos. Con respecto a los servicio que solicitan a los contratistas, un tercio de los productores requiere asistencia en la "siembra directa" de grano grueso; en cambio, el 100\% recibe asistencia en la "cosecha" de grano grueso. Una mayoría requiere servicio en la "preparación de reservas forrajeras" y en "mantenimiento de cultivos". A juicio de los productores entrevistados, el tamaño de las 
cosechadoras de los contratistas empleados, fluctúa entre medianas y grandes, y el estado de las máquinas es bueno.

El laboreo que los productores realizan por su cuenta es el de "roturación" (el 50\% de los entrevistados), mediante el empleo de labranza vertical (cincel) para forrajes, de "siembra directa" (los dos tercios restantes que no acuden a los contratistas) y la mayoría realiza "mantenimiento de cultivos" en lo referente a fumigación y fertilización. El estado de las maquinarias de los productores varía de buena a muy buena.

Todos los productores entrevistados pagan la cosecha por cantidad fija por hectárea, y dicho pago se efectiviza a la terminación del trabajo. La mayoría de los productores pagan al contratista combinando ahorro personal con la venta de la cosecha. Con respecto a la pregunta "si considera razonable el monto que le pagan al contratista", los dos tercios respondieron que más o menos, y el tercio restante respondió que no. Queda claro que es difícil conformar en este aspecto a los productores.

Solamente la mitad de los productores trabaja con contratistas de servicios puros. Por otro lado, dos tercios de los agricultores acuden al servicio de más de un contratista para todas las labores que deben realizar. Asimismo, dos tercios trabajan con el mismo contratista que levanta la cosecha. El total de los productores considera que la vinculación laboral que mantienen con los contratistas es buena a muy buena.

Con respecto al control del trabajo que realiza el contratista, la mayoría de los productores lleva a cabo un control permanente y la minoría un control más bien moderado. Todos, al iniciar el trabajo del contratista, le dan indicaciones de algún tipo, especialmente referidas al cuidado del suelo y a evitar pérdida de cantidad de granos cosechados.

En relación con los diferentes aspectos a considerar referidos al cuidado de las explotaciones por parte de los contratistas, a juicio de los productores, son muy pocos los que cuidan bien el suelo. En cambio, consideran que la mayoría de los contratistas respetan las curvas de nivel, todos tienen el cuidado de evacuar los desechos en tambores. En lo referente al cuidado de los caminos adyacentes a las explotaciones, la mayoría de los productores entienden que los contratistas los preservan, como asimismo a las instalaciones de los establecimientos.

En suma, el $50 \%$ de los productores considera que los contratistas les cuidan bien las explotaciones y el resto considera que el cuidado que llevan de los establecimientos fluctúa entre deficiente y regular. 
Por último, con respecto a la pregunta clave al productor sobre "cómo evalúa en general el trabajo del contratista", las dos terceras partes de los entrevistados "están conformes", y en algunos casos plenamente, y el tercio restante está "medianamente conforme".

En conclusión, en base a todas las respuestas de los productores, se entiende que la opinión de los mismos sobre los servicios que reciben de los contratistas, en general, es favorable, más allá de ciertas deficiencias que puedan tener en su trabajo.

\subsubsection{Análisis del desempeño de los contratistas de producción}

Como especificamos en el apartado introductorio, el "contratista de producción" o "contratista capitalista" es aquel agente que básicamente se desempeña como un productor arrendatario transitorio, que posee generalmente un potente equipo de herramientas agrícolas y que puede prestar, a su vez, servicios de máquinas a terceros. En esta instancia, para este trabajo, a lo largo del año 2007, se llevaron a cabo diez entrevistas a contratistas de producción, en el área ya mencionada y adyacencias de la misma.

\section{Perfil económico}

Del grupo de agentes entrevistados, se puede hacer la siguiente clasificación, según su tipología: contratista de producción exclusivo, 30\%; contratista de producción, productor agropecuario y contratista de servicios, 10\%; contratista de producción y productor agropecuario, $60 \%$. Como se observa, predomina entre los contratistas esta última categoría.

El promedio de la tierra en propiedad en manos de estos agentes es más bien limitado (278,5 ha.), aspecto que no es de extrañar, dado que una de las características centrales de los contratistas capitalistas no pasa justamente por acrecentar su capital en propiedades, sino más bien en que su dinámica productiva la orientan hacia el incremento del arrendamiento de tierras, ya que priorizan contar con una mayor flexibilidad evolutiva del capital. En este sentido, prevalece el arrendamiento accidental, que reúne las siguientes características: los acuerdos se establecen a través de contratos escritos avalados por un juez de paz o escribano público, renovables anualmente, el valor actualmente se estipula en quintales fijos por hectárea de soja $\mathrm{a}^{22}$ y el tamaño promedio de los campos en arrendamiento ronda las 1.600 ha.

En concordancia con la función esencial de agricultores de estos agentes, las explotaciones que trabajan van a estar dedicadas exclusivamente a la actividad agrícola y que,

22 En el año 2007, el valor oscilaba entre los 13 a 15 qq/ha, según la calidad de los suelos de los predios; pero, en el año 2008, los alquileres disminuyeron notablemente a valores entre 7 a 8 qq/ha. 
según los promedios obtenidos, se expresan en este orden de importancia: soja (927 ha), maní (725 ha), trigo (660 ha), maíz (524 ha), forrajeras (250 ha). Es evidente que la predominancia de la soja a nivel nacional se reproduce en este sector del borde de la llanura pampeana, beneficiado por los buenos precios y el margen de rentabilidad que brinda.

Es interesante observar que los predios arrendados por los contratistas se distribuyen, básicamente, de manera discontinua, en un promedio de siete parcelas por agente, en un radio de 50 a $100 \mathrm{~km}$ de distancia de los lugares donde residen, alquilados éstos a propietarios diferentes. Queda en evidencia, así, la avidez de estos agentes por sumar tierras a sus labores agrícolas.

En este relevamiento, las tierras arrendadas provinieron de treinta y ocho propietarios, en algunos casos mediante el alquiler completo de sus campos y, en otros, arrendando solamente alguna parcela. Vemos así cómo, por ejemplo, diez empresas contratistas de producción pueden modificar activamente la estructura agraria fundiaria del lugar y desplazar, a su vez, a varios propietarios rurales - no obligadamente en este caso a los treinta y ocho dueños- a la categoría pasiva de rentistas.

Jurídicamente, los entrevistados conforman mayoritariamente sociedad con familiares y no familiares y, en menor término, revisten la forma jurídica de persona física. El capital para iniciarse en esta actividad ha provenido de tres fuentes principales: de los beneficios generados por la producción agropecuaria, por la venta del campo familiar y, por último, por las ganancias obtenidas de la actividad comercial.

Detentan un nivel de equipamiento, a su juicio, de bueno a muy bueno, en muchos casos de última generación y con alta tecnología, lo que les permite operatividad en el manejo del tiempo, disminución de costos e incremento en la productividad por hectárea alquilada.

Poseen un capital en maquinaria muy importante, que acrecientan con el apoyo financiero de concesionarios y de la banca oficial y privada, lo que les permite incrementar paulatina pero sólidamente su capacidad económica. Muchos de estos agentes también contratan seguros de riesgo climático, principalmente sobre granizo, para todos los cultivos, como una estrategia de protección y cobertura de los costos iniciales de producción.

Respecto de los criterios adoptados para la consolidación de la maquinaria, vemos que el $60 \%$ de estos contratistas tiene pensado acrecentar su parque de maquinaria, a través de la compra de equipos usados (cosechadoras y fumigadoras autopropulsadas), y el resto renovar su equipamiento, manteniendo la última tecnología, sin aumentar el parque de maquinaria, utilizando facilidades crediticias de las concesionarias regionales. 
En cuanto al costo operativo de producción, en calidad de productores (incluyendo pago de alquileres, empleados, compra de insumos agrícolas, entre otros), éste oscila entre el 50\% y el $65 \%$ del total de los ingresos brutos, sin incluir los gastos de amortización e intereses del equipo. Generalmente, un promedio del 30\% del producido se destina al pago de arrendamientos.

Los contratistas entrevistados declararon que pagan ingresos brutos, IVA, impuesto a las ganancias y retenciones por venta de cereales.

En relación con proyección económica a futuro, los contratistas de producción consultados, en el papel de arrendatarios transitorios a gran escala, el 80\% piensa acrecentar su escala productiva, incorporando mayor superficie de trabajo, en la medida que continúe la bonanza de buenos precios de la producción granaría a nivel nacional e internacional.

\section{Componente social}

Todos los contratistas capitalistas entrevistados provienen de familias de origen agropecuario. Los jefes de familia se caracterizan por ser adultos relativamente jóvenes, con un promedio de cuarenta y dos años, muy por debajo del promedio de edad de los contratistas de servicios responsables de familia.

El nivel de instrucción de los jefes se aproxima, en general, al nivel de enseñanza media completa y, sólo en dos casos, los responsables de familia son profesionales universitarios. En concreto, el nivel de instrucción de estos agentes laborales se puede decir que es bastante aceptable.

Por otra parte, vemos que el $85 \%$ de estos contratistas se encuentra participando de algún organismo cooperativo o consorcista. Asimismo, manifiestan mantener una escasa vinculación entre ellos, salvo aquella que provee información sobre la disponibilidad de campos en alquiler en el mercado de tierras de la zona.

\section{Perfil laboral}

La fuerza laboral de los contratistas de producción está conformada únicamente por el jefe de familia y hay una diferenciación en la organización del trabajo, bien explícita en estas unidades productivas. Los dueños de la empresa se dedican a su organización y administración, pero no participan activamente en la realización de las tareas físicas, empleando para ellas, obviamente, a asalariados permanentes y transitorios.

Los contratistas entrevistados tienen un promedio de cinco trabajadores permanentes y dos transitorios por empresa. En el primer caso, se les paga un sueldo fijo mensual, más un porcentaje de lo producido; en el segundo caso, se les paga también un sueldo fijo mensual, 
pero se los contrata por un período de cinco a seis meses por año. En general, tanto los trabajadores permanentes como los temporarios realizan todo tipo de tareas, especialmente en lo referente al manejo de diversas maquinarias.

\section{Breve síntesis}

Es indudable que el perfil de los contratistas de producción está muy a tono con los nuevos requerimientos productivos que impone el actual modelo económico nacional que, a nuestro juicio, no es otro que el que viene imperando desde hace mucho tiempo, con su carga eficientista pero, al mismo tiempo, excluyente para aquellos ruralistas que no disponen de un capital consolidado. En nuestro caso, se reproducen las características generales que los distinguen, por ejemplo, en la práctica de una lógica productiva flexible, en el sentido de ampliar su escala económica, apoyándose en el sobredimensionamiento del capital operativo y una limitada posesión del capital fijo (posesión de tierras).

En general, disponen de un aceptable a buen manejo tecnológico y un acusado interés por estar permanentemente actualizados, como una forma ineludible de poder mantener el ritmo productivo que exige el funcionamiento de sus empresas. El nivel de ingresos de éstas, a pesar de los altos costos operativos, se puede considerar como muy rentable.

En lo atinente a cómo los contratistas capitalistas de nuestra área se iniciaron en esta actividad, comprobamos que predominan aquellos que se relacionan con una actividad agraria original.

En suma, aquí, como en otras zonas de la llanura pampeana, ha habido una evolución progresiva de productores agropecuarios y/o contratistas de servicios al paso siguiente de contratistas de producción, en el afán de búsqueda de una mayor rentabilidad de sus equipos -no inmovilizando el capital en compras de tierras-, mediante la proyección de sus labores hacia el arrendamiento accidental, como una estrategia de consolidación y enriquecimiento económico.

\subsubsection{El gremio que nuclea a los contratistas rurales}

A nivel institucional, la Federación Argentina de Contratistas de Máquinas Agrícolas (FACMA) representa, en el plano nacional, a los contratistas rurales. Esta agrupación, si bien incluye básicamente a los contratistas de servicios, también contempla dentro de sus asociados a aquellos que detentan el doble rol de productores agropecuarios - contratistas de servicios. La misma fue creada en 1996, con sede en Casilda (Santa Fe), y tiene como antecedente el Gremio de Trabajadores de Máquinas Rurales, fundado en 1948, en la misma 
ciudad. Dicha entidad está integrada por siete asociaciones de contratistas de diferentes provincias del país.

Los beneficios y servicios que presta la federación, entre otros, son:

- "Gestión de permisos de tránsito para maquinaria agrícola.

- Envío de circulares informativas relacionadas con la actividad y las gestiones oficiales realizadas, su seguimiento y sus resultados.

- Convenios de seguros.

- Recepción de inquietudes y requerimientos de orden local, provincial o nacional.

- Acceso al detalle de cálculos de costos de cosechas y laboreos que se realizan antes de cada campaña fina y gruesa.

- Invitaciones especiales a seminarios y programas de capacitación para contratistas rurales y su personal, organizados y/o auspiciados por la federación" (Anuario FACMA, 2008:6)

La entidad cuenta con 3.300 asociados, sobre un total estimado de 17.000 contratistas que existen en todo el país, motivo por el cual se está trabajando firmemente para incrementar el número de afiliados. En este sentido, las dificultades son varias, pero hay dos escollos que sobresalen para lograr tal fin: el fuerte individualismo del contratista y los lugares de trabajo siempre dispersos de los mismos. Por otra parte, si bien es cierto que la gama de servicios que realizan los contratistas es muy amplia, debiéndose considerar también a aquellos que realizan trabajos en cultivos no pampeanos, la federación, debido a razones de capacidad operativa, se preocupa, por ahora, en aglutinar principalmente a los maquinistas de agricultura extensiva, que se calculan en 8.000 contratistas de cosecha y siembra.

Según los directivos de la federación, algunos de los problemas que afectan al sector son los siguientes: la aparición de nuevos contratistas advenedizos que, aprovechándose de la actual bonanza del campo, han invertido parte de sus ganancias en la compra de maquinaria para realizar trabajos a terceros, con un criterio netamente especulativo y cortoplacista y sin tener los conocimientos suficientes para el desempeño de este oficio. Conclusión: trabajan mal, perjudican al empleador y desacreditan a los contratistas profesionalizados. Otra de las dificultades que procura solucionar el gremio está en relación con la normativa de tránsito en las rutas, que se encuentran desactualizadas con respecto a las exigencias de circulación que demandan las nuevas maquinarias del sector. La federación, a su vez, está trabajando en la mejora del acceso al crédito para renovar o cambiar la maquinaria, como así también se encuentra abocada a la solución del déficit periódico de abastecimiento de combustible y a problemas de tipo impositivo.

Por último, cabe destacar que la dirigencia de FACMA, más allá de los vaivenes de coyuntura que sufre periódicamente la producción agropecuaria, considera que el futuro del contratista es promisorio y que su rol se va a consolidar cada vez mejor. Interpreta que, de 
acuerdo con el actual esquema productivo en vigencia, su desempeño en las labores es insustituible y su participación en las mismas resulta cuasi hegemónica. En este sentido, cabe resaltar que los contratistas son un brazo multiplicador de la producción y tecnología de la agricultura argentina, responsables de más del 60\% del componente "Labores de la producción granaría" en trigo, maíz, soja, girasol y demás cultivos (ver Cuadro № 52).

Cuadro $N^{\circ}$ 52. Aporte contratista. Aporte de labores de los contratistas agrícolas a la producción granaría argentina

\begin{tabular}{|l|c|c|c|}
\hline SIEMBRA CONVENCIONAL & \multicolumn{3}{|c|}{} \\
\hline Labor & $\$ /$ ha & Participación $\%$ & Subtotal \\
\hline Labranza & 100 & $30 \%$ & 30 \\
\hline Siembra & 50 & $30 \%$ & 15 \\
\hline Protección de cultivos & 20 & $30 \%$ & 6 \\
\hline Cosecha & 125 & $80 \%$ & 100 \\
\hline Total & 295 & & 151 \\
\hline Participación contratista & & & $51 \%$ \\
\hline
\end{tabular}

\begin{tabular}{|l|c|c|c|}
\hline SIEMBRA DIRECTA & \multicolumn{3}{|l|}{} \\
\hline Labor & $\mathbf{\$} / \mathbf{h a}$ & Participación $\%$ & Subtotal \\
\hline Labranza & - & - & - \\
\hline Siembra & 70 & $50 \%$ & 35 \\
\hline Protección de cultivos & 60 & $50 \%$ & 30 \\
\hline Cosecha & 125 & $80 \%$ & 100 \\
\hline Total & 255 & & 165 \\
\hline Participación contratista & & & $65 \%$ \\
\hline
\end{tabular}

\begin{tabular}{|l|c|c|c|}
\hline TOTAL & & & \\
\hline Sistema de cultivo & $\%$ Total & Contratista $\%$ & Total \\
\hline Siembra convencional & $20 \%$ & $51 \%$ & $10 \%$ \\
\hline Siembra directa & $80 \%$ & $65 \%$ & $52 \%$ \\
\hline Participación contratista & & & $62 \%$ \\
\hline
\end{tabular}

Fuente: Elaboración propia en base a datos aportados por FACMA.

Si valorizamos en pesos por hectárea la participación del contratista de acuerdo con el precio por hectárea de las labores y el porcentaje que realiza el contratista sobre el total trabajado en el país, vemos que, en siembra convencional, el contratista participa del $50 \%$ del valor de las labores realizadas y, en el caso de la siembra directa, del $65 \%$.

Si ponderamos ambas cifras por sus respectivas participaciones en el contexto argentino de la producción granaría $(20 \%+80 \%)$, vemos que la participación promedio de los contratistas en la valuación económica de las labores de maquinaria agrícola ascienda al $62 \%$ del total (Garbers, , en Anuario Facma, 2008:23-24).

\subsubsection{Reflexiones generales sobre los contratistas rurales}

Una vez analizados y descriptos estos agentes productivos en sus características intrínsecas y de desempeño general, cabe ahora referirnos al papel que cumplen en las 
transformaciones socio-territoriales en el área de estudio que, por la información que poseemos, pareciese que resultan muy similares a las alteraciones que se manifiestan en otros espacios rurales del país.

En este sentido, y en un plano de aproximación general, corresponde destacar el papel del contratista rural en:

a) Su contribución -en algunos casos, indirecta, no responsable, únicamente en el caso de los contratistas de servicios- al despoblamiento del campo, al reemplazar eficazmente, mediante la acción de su maquinaria, a gran parte de la fuerza laboral que residía en el mismo, y facilitando el traslado de esta población rural hacia las localidades pequeñas e intermedias más cercanas de su ámbito original.

b) Su contribución a la modificación de las estructuras agrarias en los siguientes aspectos:

- en el aporte -en algunos casos- al mantenimiento e incremento de hectáreas trabajadas por parte de los productores agropecuarios (Lódola y Fossati, 2004) (aquí interviene solamente el contratista de servicios);

- en poner un límite a la concentración de la propiedad, al evitar en muchos casos que los pequeños productores salgan de la escena productiva, al convertir en rentables sus reducidas explotaciones (aquí interviene solamente el contratista de servicios);

- en la disminución acentuada de explotaciones y, por ende, de productores -observable entre los dos últimos censos agropecuarios (1988 y 2002)-, la cual sin el aporte del trabajo del contratista de servicios y de producción no hubiese sido posible. Este fenómeno no implica obligadamente un incremento de la concentración de la propiedad, pero sí en cambio un incremento de la concentración en la producción (capital) (Barsky, 2003);

- en un incremento de los pequeños propietarios rentistas como consecuencia de lo anteriormente descripto, al dejar en manos de los empresarios capitalistas la explotación de sus campos;

- en un aumento de los arrendamientos a corto plazo, bajo la figura de contratos accidentales, donde el contratista de producción se convierte en el personaje central, por ser uno de los principales demandantes de este tipo de contratos;

- en el incremento en el promedio del tamaño medio de las explotaciones, como consecuencia de la reducción numérica de las mismas. 
En suma, todos los cambios arriba expuestos tienen implicancias geográficas, a veces observables claramente en el paisaje rural, y en otros de manera no tan detectable pero, sin embargo, poseedores de una fuerte connotación socio-territorial.

Corresponde reconocer que no cabe la menor duda de que los contratistas rurales, en general, contribuyen eficazmente a las modificaciones territoriales, o sea de la estructura agraria anteriormente descripta, pero a fin de delimitar $-\mathrm{y}$ evitar posibles confusiones- los diferentes niveles de participación y responsabilidad, según se trate de contratistas de servicios o de producción, se debe recordar que, centralmente el punto de contacto entre los dos tipos de agentes mencionados, consiste en que, para ambos, la base de su capital operativo se apoya en la posesión de equipos integrados de maquinaria agrícola de alto valor económico y también en lo que respecta a la evolución como agentes productivos, dado que generalmente el contratista de producción se inicia como contratista de servicios, para luego derivar a su actual rol.

Pero, a su vez, se debe distinguir que la participación del contratista de producción en lo referente a las modificaciones territoriales y productivas que genera, las lleva a cabo en su rol de arrendatario transitorio como "agente activo responsable" de las mismas, en cambio los contratistas de servicios ofician -en tanto presten exclusivamente servicio a terceros- como “instrumentos" o "agentes pasivos" de los verdaderos sujetos que producen las alteraciones en el quehacer productivo y territorial.

Por otra parte, la fuerte incidencia del contratismo rural en las tareas agropecuarias, que en forma notoria las disminuye y simplifica, convirtiéndolas en eficientes y altamente productivas, no soluciona otro tipo de problemas estructurales, como los medioambientales ${ }^{23}$ y el de aquellos productores a quienes el mismo sistema de funcionalidad agropecuaria de alta exigencia tecnológica y de disponibilidad financiera los retira de la escena productiva (Barsky y Gelman, 2001), convirtiéndolos ya sea en pequeños propietarios rentistas o directamente expulsándolos del sistema agropecuario.

En síntesis, no cabe la menor duda que, de acuerdo con el actual sistema económico vigente, los contratistas rurales van a seguir cumpliendo un rol clave en el proceso productivo agropecuario. Lamentablemente este éxito y papel relevante que desarrollan estos agentes, no se refleja en otros actores laborales agrarios, como en ciertos pequeños productores,

23 Sobre la incidencia del contratismo con respecto a los problemas ambientales, en un análisis en profundidad habría que distinguir el accionar del contratista de servicio por un lado, del contratista de producción, por el otro. En este sentido, pareciera que el contratista de servicios tiende a preservar el recurso tierra, ya que de este cuidado depende la demanda recurrente de sus servicios por parte del productor. En cambio, en el caso del contratista de producción, la preservación del suelo por parte de éste se torna relativa, ya que su objetivo es obtener el mayor provecho de los campos arrendados a corto plazo. 
campesinos y asalariados rurales, dado que la actual política agraria en marcha, no los incluye plenamente en su esquema productivo de corte eficientista.

\subsection{Caracterización económica de las agroindustrias y empresas agrocomerciales en relación con su injerencia en la explotación primaria agrícola}

\subsubsection{Introducción}

El tema que aquí se presenta consiste en una aproximación indagatoria sobre la injerencia y forma de trabajo de la agroindustria y empresas agrocomerciales en general, sobre la actividad primaria agrícola, mediante la explotación directa de tierras en propiedad y arrendadas, bajo un acuerdo de partes y en relación societal, conformando para ello vinculaciones de diversa índole entre los diferentes actores del mundo rural, a través de un complejo entramado de relaciones socio-económicas.

El área de estudio tiene como pivote la ciudad de Río Cuarto, pero su análisis, en esta oportunidad, abarca toda la región sur de la provincia de Córdoba, o sea, comprende los cuatro departamentos clásicos especificados al principio de esta tesis (Mapa $\mathrm{N}^{\mathrm{o}} 1$ ).

Es pertinente recordar que, por similitudes geográficas, las relaciones que a continuación se explicitan y que se manifiestan en nuestra área de trabajo, se reproducen en mayor o en menor medida en varios sectores de la llanura pampeana.

En lo que respecta a la intromisión de los complejos agroindustriales y agrocomerciales, en la explotación primaria agrícola en nuestro medio geográfico, no es un fenómeno nuevo, sino que viene manifestándose desde hace varias décadas. Por otra parte, no caben dudas de que, al igual que en el resto del país, estos complejos, con sus tendencias hegemónicas, han ayudado a subordinar y desdibujar los roles de muchos de los agentes rurales tradicionales de nuestra área, repercutiendo en la estructura agraria y desencadenando fuertes modificaciones socio-territoriales.

En concreto, sobre la incidencia de las agroindustrias en la producción agraria directa, son varios los autores y numerosos los trabajos que han analizado este fenómeno (Teubal y Pastore, 1995; Gutman y Gatto, 1990; Teubal y Rodríguez, 2003), sin que por ello se termine de estudiar esta problemática. Motivo por el cual nos hemos animado a investigar, por un lado, el accionar de estos complejos -a título de estudio de caso- en nuestra región, y por el otro, por considerar que es en cierto modo una "novedad" interesante de profundizar que: 1) el nexo en la "integración asociativa" se establece actualmente entre empresa-productor individual (variante vertical), y no a través de pools de siembra (variante horizontal) -como se 
daba especialmente en la década anterior- donde intervienen varios agentes, muchos de ellos ajenos al métier agropecuario y donde se prioriza sobre todo el volumen del aporte financiero, y 2) que dicha integración entre los actores mencionados en el punto 1 básicamente se manifiesta principalmente a partir de la crisis económica 2001-2002.

En síntesis, consideramos que la injerencia -utilizando diferentes estrategias- de los complejos agroindustriales y empresas conexas en la producción "primaria" contribuye a incrementar las asimetrías socio-territoriales (de claras consecuencias negativas), que cada vez en forma más nítida se ponen de manifiesto en el campo argentino.

Recordemos que los objetivos que se propusieron en esta investigación consistieron en detectar el accionar y el peso económico de las agroindustrias y empresas de comercialización de granos sobre la estructura agraria, y desentrañar a su vez el modo en que las mismas extienden su dominio hacia la actividad agrícola mediante diferentes modalidades de integración vertical.

Asimismo, se procuró captar los diversos roles y estrategias de adaptación desarrollados por los productores vinculados con los complejos agroalimentarios.

Por último, se analizaron las progresivas modificaciones socio-territoriales resultantes.

Para la consecución de estos objetivos, en esta oportunidad, nos basamos en el análisis de material bibliográfico pertinente, a fin de diseñar un marco teórico conceptual y principalmente en el trabajo de campo, con el propósito de obtener información de primera mano. Para ello, se realizaron entrevistas sistematizadas ${ }^{24}$ a personas ligadas a los complejos de empresas arriba aludidos mediante la confección de diversas guías de entrevistas, que se adecuaron según las características específicas de los interlocutores. Asimismo, para el relevamiento de campo se elaboraron guías estandarizadas, a fin de volcar en éstas de manera ordenada la información oral recogida, datos provenientes de material cartográfico e impresiones de lo observado directamente, con el propósito de cualificar variables centrales que ayuden a construir el marco estructural del trabajo, de modo de arribar a la comprensión de la situación actual y detección de posibles tendencias a futuro.

A continuación se describen las diferentes formas y características de integración vertical "hacia atrás" (o sea, sobre la producción agropecuaria), que emplean las agroindustrias y empresas agrocomerciales relacionadas con la actividad granaria de acuerdo con la clasificación ideada por nosotros en base a la observación en el área de estudio (Gráfico No 11).

\footnotetext{
24 El cuestionario de entrevistas sistematizadas llevadas a cabo en 2006 figura en el Anexo de este trabajo.
} 
Gráfico No 11. Clasificación de las diferentes formas y características de integración vertical "hacia atrás" (es decir, sobre la producción agropecuaria propiamente dicha), que emplean las agroindustrias y empresas agrocomerciales

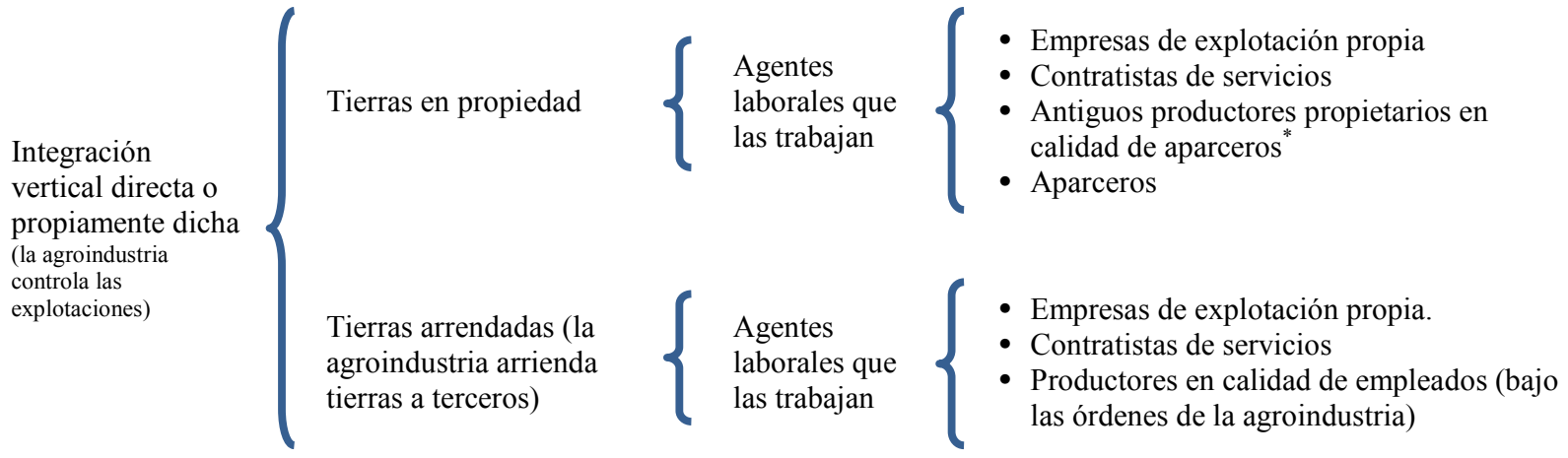

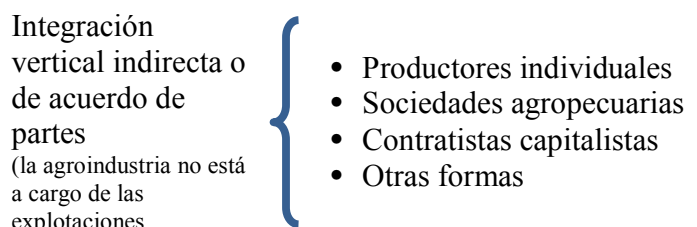

6.4.2. Formas de integración vertical hacia la actividad primaria de las agroindustrias y empresas agrocomerciales que se desempeñan en nuestro medio

\subsubsection{Integración vertical directa (o propiamente dicha)}

Corresponde cuando la empresa controla en forma directa la producción primaria, o sea, explota los campos por cuenta propia bajo su responsabilidad y riesgo.

Para llevar a cabo este tipo de integración vertical "hacia atrás", dispone de tierras en propiedad y/o de tierras arrendadas. Los agentes laborales que trabajan este campo pueden ser:

- empresas de explotación propia, que dependen del departamento de campo de la firma;

- contratistas de servicios;

- antiguos productores, propietarios en calidad de aparceros;

- aparceros;

- otras formas. 
Corresponde aclarar, a título general, que todas las empresas que se integran a la producción agropecuaria cuentan con un Departamento de Campo encargado de dirigir la actividad productiva, que en algunos casos constituyen firmas independientes ligadas obviamente a las empresas, pero legalmente autónomas, por razones operativas y económicas. En general, asesoran y dirigen las explotaciones, pero no cuentan con maquinaria propia; no obstante, en algunos pocos casos, sí cuentan con equipo de laboreo propio.

En concreto, tanto en las tierras en propiedad como en las arrendadas a terceros, la dirección, administración y control están a cargo de la empresa y, por consiguiente, no comparte los beneficios ni los riesgos con otros agentes productivos.

Esta modalidad de integración permite aplicar técnicas evolucionadas de laboreo y contar asimismo con calidad y previsibilidad en los volúmenes productivos requeridos.

\subsubsection{Integración vertical indirecta (o de acuerdo de partes)}

En este tipo de investigación, la empresa no dirige las explotaciones sino que las mismas pertenecen a los productores, que son quienes las dirigen y trabajan. Éstos se desempeñan laboralmente de manera independiente, o sea, trabajan por cuenta propia. Lo que sí se establece entre las partes es una suerte de acuerdo por medio del cual la empresa en general adelanta los insumos (semillas y agroquímicos) y el productor, que pone la tierra y el trabajo, devuelve el préstamo en granos. Este tipo de operatoria se suele denominar "contrato de entrega de granos". La empresa no participa de los riesgos sino que éstos corren por cuenta del productor que se desempeña en forma autónoma. Lo que se establece es un "canje" que en algunos casos puede consistir en una especie de ayuda económica al productor, comprometiéndose éste a hacer entrega del producto cosechado.

El adelanto de insumos de parte de la empresa va acompañado, en general, por exigencias al productor en lo que atañe a la calidad y fecha estimativa de entrega del producto.

En nuestra área de estudio, normalmente estos acuerdos son de palabra, sin mediar contratos por escrito. Ésta es una característica que posiblemente marca la diferencia de la aparente integración similar (o equivalente) a la que Teubal denomina "integración vertical contractual o agricultura de contrato", en su clasificación sobre formas de integración vertical en algunos complejos agroindustriales (Teubal y Pastore, 1995).

En síntesis, entendemos que la incidencia de las empresas en este tipo de integración es indirecta, el responsable y el que arriesga es indudablemente el productor; no obstante, gran parte de la orientación y resultados productivos -en forma mediatizada- son canalizados a través de las empresas, con las ventajas para las mismas de poder contar en una fecha 
aproximada con un stock de mercadería determinada y calidad prevista. A su vez, la ventaja para el productor -que puede ser relativa y de consecuencias imprevisibles si el grado de dependencia económica es agudo- consiste en poder contar con una especie de crédito para iniciar la campaña agrícola, asesoramiento técnico en muchos casos y eventualmente precios previsibles y garantía de la venta de la producción.

\subsubsection{Integración vertical asociativa}

En esta relación, la empresa por una parte y un agente productivo por otra conforman una "sociedad" de explotación de la tierra. Las dos partes intervienen en el control de la explotación, comparten los riesgos y reparten la producción proporcionalmente, de acuerdo con lo que aporta cada uno en el vínculo societal.

El productor generalmente aporta con la tierra y las labores, y la empresa con los insumos, el asesoramiento técnico y eventualmente con el transporte. El reparto de los beneficios se hace proporcionalmente, según lo que cada uno haya contribuido a la producción. Se trabaja normalmente con el "contrato de aparcería". Cabe aclarar que lo que se reparte son los frutos y no las ganancias, o sea, al momento de repartir los beneficios, lo que se reparte es la producción.

En este tipo de integración, las empresas intervinientes trabajan en la mayoría de los casos con los productores individuales y no con otras empresas. Solamente en unas pocas circunstancias o en situaciones coyunturales, por ejemplo de tener que cumplir con un pedido de compra de mercadería de grandes proporciones, se lleva a cabo una relación societal de tipo interempresarial.

Esta nueva estrategia de las agroindustrias -que parece reemplazar a los clásicos pools de siembra- consiste en entablar sociedades con un sinnúmero de productores, dando la impresión de ser la modalidad predominante y más novedosa de integración vertical hacia atrás que se da en nuestro medio geográfico (sur de la provincia de Córdoba), donde todos salen ganando, pero las empresas en mayor proporción, utilizando diversas variantes de contratos según las posibilidades de los productores.

Corresponde especificar que por lo general los aportes que realizan las empresas en esta vinculación societal son mayores que los que disponen los productores, por lo tanto obviamente son mayores los beneficios, aparte de otras ventajas que obtienen a partir de la sumatoria de asociaciones que establecen.

Por otra parte, los productores deben reunir ciertas condiciones de solvencia a juicio de las empresas, como ser preferentemente propietarios de explotaciones de regular a gran 
tamaño; disponer de maquinaria o parte de la misma adecuada a la siembra directa, y manejar en general las modernas técnicas agropecuarias.

Existe una gran variedad de formas de asociación que se adecuan a la situación económica de cada propietario, pero aparte de la clásica vinculación arriba descripta entre el productor y la empresa, donde el primero aporta la tierra y las labores, en muchos casos es la misma empresa la que contribuye con tierras, mediante el arrendamiento de campos -o parte de ellos-, ya sea a los mismos productores asociados -en esta circunstancia éstos van a percibir una cantidad menor de beneficios- o a terceros. También puede darse el caso de que la empresa y el productor, en forma conjunta, arrienden tierras a terceros.

En estas situaciones, donde media el alquiler de tierras, los contratos de arrendamientos que se establecen son todos por escrito; en cambio, los aportes que realizan en la vinculación societal cada una de las partes se acuerdan de palabra.

Por último, cabe aclarar también que la diferencia de este tipo de integración societal descripta con respecto a la que denomina casi del mismo modo Teubal (integración vertical asociativa y cooperativizada) en su clasificación sobre la integración de los complejos agroindustriales ya mencionada, es que él se refiere básicamente a un tipo de asociación entre varias unidades de producción del sector primario que "se articulan horizontalmente para participar en otra etapa e integrar verticalmente sus respectivas producciones y/o procesos productivos" (Teubal y Pastore, 1995:120); en cambio, en nuestro caso, la vinculación es entre dos agentes productivos, el productor y la agroindustria que integra a éste. En suma, en general es éste el tipo de vinculación societal de por sí asimétrica el que se manifiesta en nuestro medio y no aquel al que hace referencia Teubal, lamentablemente.

El nivel de asociaciones de productores y de vínculos cooperativizados en defensa de la producción granaria está muy poco desarrollado en nuestra zona de estudio.

\subsubsection{Características generales y desempeño en el proceso de integración vertical hacia atrás de algunas de las agroindustrias y agrocomercios más representativos de nuestro medio dedicados a la industrialización y comercialización de granos}

Seguidamente, pasamos a describir, a modo de ejemplo, en forma sucinta, las características y desempeño direccionados hacia la actividad agrícola de algunas de las mayores empresas agroindustriales y agrocomerciales más representativas de nuestro medio, que forman parte, a su vez, del complejo cerealero y aceitero argentino. 
Es pertinente aclarar que las empresas a las cuales hemos analizado, en general están integradas por un conjunto de firmas autónomas, pero subsidiarias de una empresa madre y que en conjunto desempeñan dentro del sector agropecuario múltiples funciones económicas, en el rubro industrial, primario, comercial, de servicios y financiero, constituyendo en última instancia verdaderos grupos empresariales.

No obstante la diversidad de actividades económicas que detentan las empresas arriba mencionadas, en este acápite las diferenciamos por la actividad económica por la que se la distingue en nuestro medio, englobándolas en conjunto por similitud de desempeño productivo, tanto las correspondientes a la actividad agroindustrial como agrocomercial.

\subsubsection{Empresas agroindustriales de oleaginosas y cereales}

Con respecto a la actividad agroindustiral granaria en nuestra zona, se destaca la aceitera y molinera. Dentro de la primera sobresale una firma que está catalogada como una de las empresas más importantes del país, que si bien la empresa madre se ubica en nuestra área de estudio, sus plantas industriales y de acopio se distribuyen en numerosas provincias de la nación.

El complejo agroindustrial aceitero que se centra en nuestro medio cubre todo el circuito productivo desde la actividad industrial, pasando por la primaria hasta la comercialización de la producción aceitera y de diversos productos derivados de semillas oleaginosas y cerealeras. El proceso integrador a partir del núcleo agroindustrial, tanto hacia atrás como hacia adelante, está sumamente desarrollado y consolidado.

En lo atinente a la agroindustria molinera, la misma está bastante extendida en nuestra zona y una de las materias primas básicas que utiliza es el trigo. Una de las principales firmas está representada por un grupo agroindustrial de extensas ramificaciones que se prolonga también en diversas provincias del país. Cuenta con molinos harineros, campos propios, plantas de acopio, fábricas de productos alimenticios, empresas prestadoras de servicios agropecuarios, etc., pero en nuestro medio se destaca como agroindustria molinera. Representa a un grupo empresarial sumamente diversificado, dueño de distintas firmas que se integran entre sí, pero cada una actúa de manera autónoma.

Cabe aclarar que dentro de la cadena productiva de las agroindustrias mencionadas, la injerencia operativa en la actividad agrícola en la industria aceitera está a cargo de un Departamento de Campo, encargado de la parte técnica, pero no cuenta con maquinaria propia; por lo tanto, las labores están tercerizadas. En cambio, en el caso de la industria molinera, la dirección del manejo de la empresa está a cargo de una firma subsidiaria de la 
empresa madre, que sí cuenta con maquinaria propia y ella misma lleva a cabo en gran parte las labores agropecuarias.

Con respecto a las diferentes formas de integración vertical que aplican las mencionadas agroindustrias, tanto una como la otra practican la integración vertical directa. La agroindustria aceitera, para ello, dispone de tierras en propiedad como arrendadas que ocupan extensiones más que importantes, y las mismas son trabajadas por contratistas de servicios o productores que cumplen un rol similar al de los contratistas.

La agroindustria molinera, en cambio, trabaja casi exclusivamente tierras en propiedad, que también ocupan grandes extensiones, y las labores de las mismas se llevan a cabo mediante explotación propia a través de la empresa subsidiaria destinada a tal fin. La integración vertical indirecta la aplica solamente la agroindustria aceitera, donde media en muchos casos un contrato de entrega de granos y donde este intercambio de integración opera como un canje entre las partes.

La integración vertical asociativa actúa en los dos tipos de agroindustria, pero en la aceitera solamente opera -a gran escala- con los productores, bajo la figura en general del contrato modelo de aparcería; en cambio, en la molinera, los vínculos asociativos se establecen entre empresas, o sea, a nivel de empresas de grandes dimensiones económicas.

La ubicación geográfica de las tierras trabajadas por ambas agroindustrias tiene en general una gran dispersión por todo el sur cordobés, pero especialmente la aceitera se ha extendido sobremanera hacia el sur, hasta traspasar el límite establecido entre las provincias de Córdoba y La Pampa.

Los cultivos que practica la agroindustria molinera están muy diversificados y tanto los de invierno como los de verano son relevantes, pero lo que produce en mayor proporción, como es de esperar, es la soja (60\%), seguida por el maíz, el maní, el girasol, el trigo, etc.

En el caso de la agroindustria aceitera, los granos que cultiva son: soja, que ocupa un lugar relevante, girasol, maní (que oficia como materia prima tradicional de esta industria), trigo y maíz.

En ambas agroindustrias la producción granaria que las alimentan proviene de campos laborados con siembra directa y las semillas que se utilizan, en gran parte producidas por la misma empresa, son las genéticamente modificadas. Los campos con los cuales trabajan reciben asesoramiento tecnológico y controles de calidad.

La política de la agroindustria molinera en relación con la producción primaria se basa, por un lado, en no arrendar campos a terceros, o sea, la idea es trabajar con campos propios de la firma; por otro, diversificar en todo lo posible la producción para disminuir los riesgos. 
Por otra parte, la política de la agroindustria aceitera propicia los siguientes criterios: que cada planta de acopio de su propiedad se maneje en su zona con total autonomía de decisión, a través del gerente de planta; no comprar tierras pero sí arrendar más. No obstante, las políticas a largo plazo no apuntan a salir a buscar tierras para arrendar, sino que los productores se acerquen a la agroindustria con el objetivo de asociarse.

\subsubsection{Empresas agrocomerciales de acopio y comercialización de granos}

En nuestra zona de estudio son varias las organizaciones que se dedican al acopio y a su vez tienen injerencia en la producción primaria, pero en este trabajo tomamos como ejemplo una empresa acopiadora de importancia zonal que cuenta con numerosas sucursales en la región, y que además funciona como distribuidora de insumos y de combustible. Asimismo, incluimos en el análisis a una cooperativa muy consolidada en nuestro medio, que cuenta también con varias sucursales, pero con un área de influencia relativamente restringida, que no cubre toda la región. Por último, también incluimos en este análisis la descripción, a modo de ejemplo, de una planta de acopio modelo, ubicada en nuestra zona, dependiente de una agroindustria aceitera líder en la que, al poder desempeñarse con total autonomía de decisión en lo que respecta a las relaciones con los productores, el gerente de planta puede entablar diferentes vinculaciones de integración con los agentes productivos.

El sector responsable de la dirección de la producción primaria en la empresa acopiadora está a cargo de una firma subsidiaria de la misma, y en el caso de la cooperativa y de la planta de acopio modelo, la responsabilidad recae en los respectivos Departamentos de Campo habilitados a tal fin. Ninguna de estas tres instancias organizativas cuenta con maquinaria propia, por lo tanto las labores también se tercerizan.

En relación con los tipos de integración vertical que se implementan, en las dos primeras organizaciones nombradas se aplica la integración vertical directa, no así en cambio en la planta de acopio modelo. En la empresa acopiadora se realiza a través del empleo de tierras en propiedad y arrendadas, y son trabajadas por contratistas de servicios; en cambio en la cooperativa se lleva a cabo solamente en tierras arrendadas (donde se siembra exclusivamente maní) y son trabajadas por contratistas de servicios. En los dos casos mencionados, las tierras laboradas bajo esta forma de integración no abarcan extensiones de grandes dimensiones.

La integración vertical indirecta no se aplica en la cooperativa, pero sí en la empresa acopiadora, donde media en muchos casos una suerte de contrato de siembra, y también en la 
planta de acopio modelo, cuya aplicación aquí sobre todo cumple la función de ayuda económica al productor, quien debe devolver con la producción.

Por último, la integración vertical asociativa se manifiesta en las tres organizaciones nombradas, y es la que tiene mayor difusión dentro de las diferentes formas de integración. A su vez, las tres organizaciones económicas trabajan exclusivamente con productores, donde el vínculo que se establece de hecho es por demás asimétrico. En lo que respecta a la cooperativa, da la impresión de que la misma se desempeña más como empresa comercial, que como asociación de productores que se unen para alcanzar ventajas y beneficios económicos equitativamente compartidos.

La localización geográfica de las empresas agrocomerciales citadas se esparcen también por todo el sector centro-sur de la provincia de Córdoba, pero especialmente próximas a las sucursales respectivas.

La empresa acopiadora, en los campos arrendados, cultiva en general un $70 \%$ de soja, $20 \%$ de maíz y $10 \%$ de girasol. En los campos propios se trata de hacer a siguiente rotación: $33 \%$ de soja de primera, 33\% de maíz y 33\% de trigo-soja de segunda. Queda claro que en las tierras propias, no así en las ajenas, media un criterio conservacionista, con el objetivo de no agotar el suelo y mejorar su productividad.

En el caso de la cooperativa, ocupa un lugar importante el cultivo de maní, debido a que cuenta con una planta industrial seleccionadora de este grano a la que debe abastecer. También ocupa un lugar relevante el acopio de soja, seguido por otros granos como el maíz y el girasol.

En la planta acopiadora modelo, el principal cultivo corresponde a la soja, seguido por el maíz, el girasol y el maní.

En la producción granaria que alimenta a todas las empresas vinculadas al acopio se aplica la siembra directa, se utilizan semillas mejoradas y se lleva a cabo el correspondiente control de calidad.

En relación con la política a futuro de la empresa acopiadora, ésta consiste en especializarse más en la parte comercial que en la productiva, es decir, tender más a una integración hacia adelante. Por otra parte, no piensa comprar más tierras, sino arrendar campos con contratos por períodos más prolongados, para tener así una mayor continuidad sobre las tierras. Actualmente tiene establecidos contratos por una sola campaña y la idea es aumentar el período a tres años, para el bien de todos.

En lo que respecta a la política que sustenta la cooperativa, considera que, si bien tiene que sembrar maní por cuenta propia, a fin de garantizar una cantidad fija de materia prima 
para abastecer a su planta seleccionadora, entiende que la tarea de sembrar en general no es su función, sino que esa actividad le corresponde al productor.

\subsubsection{Conclusiones sobre el desempeño de las empresas descriptas}

En la integración que se establece entre el agro y la industria en nuestro medio, queda claro que los beneficios y ventajas que obtienen las agroindustrias y agrocomercios granarios -donde éstos últimos están estrechamente ligados a las primeras- pasa, en primer lugar, por garantizar la cuota de materia prima que requiere el procesamiento industrial, y no dejar librado a los vaivenes del libre mercado, el aprovisionamiento de los insumos necesarios y, en segundo lugar, por obtener un mejor precio de las materias primas requeridas, al evitar o disminuir la intermediación, al tener acceso directo a la producción primaria.

Con respecto a la otra cara de la vinculación, o sea la de los productores agropecuarios, conviene recordar que la asociación con las empresas en nuestra zona surge o se acrecienta fundamentalmente a partir de la crisis y devaluación de 2001-2002, cuando a un número considerable de productores, por endeudamiento y/o por falta de capital, se les dificultó seguir trabajando de manera independiente. Surgió entonces la posibilidad de establecer nuevas estrategias, tales como asociaciones de diversa índole con empresas del medio. En cierto modo, las agroindustrias -durante ese período de crisis- se ocuparon de suplir la falta de crédito por parte de diversos organismos.

Ahora bien, no todos los agricultores estuvieron o están en situación de poder cubrir las condiciones técnico-financieras que el ritmo económico digitado desde la cúspide de la cadena agroindustrial exige actualmente a la producción del campo, donde se debe en forma pareja reunir calidad y precios competitivos de las materias primas, rendimiento apreciable por unidad de superficie y fechas de entrega de la producción en tiempos estimativos, entre otras exigencias más, lo que determina obviamente que los productores más desvalidos no puedan competir.

Por otra parte, más allá de los requerimientos que actualmente solicitan las empresas a los productores que sí pueden reunir las condiciones de exigencia nombradas, entran ahora también en el juego de las relaciones asociativas contratistas capitalistas, de claro perfil empresarial, de gran capacidad económica, que en muchos casos no figuran como productores clásicos ni como dueños de explotaciones.

En concreto, el rol en general que van a desempeñar los productores de características tradicionales vinculadas a las agroindustrias es básicamente el de socios menores y 
dependientes de las mismas. El asociarse implica, por un lado, una forma de subsistir, y por otro, poder permanecer dentro del sistema productivo, compitiendo gracias al auxilio del “hermano mayor”. Por cierto, ganan todos, pero el productor en menor proporción.

Además, es pertinente destacar que dentro de las formas de integración vertical -según nuestra clasificación- que se manifiestan en nuestro medio, predomina la integración vertical asociativa que, por sus características, determina que los vínculos que se establecen entre las partes implican para el productor una fuerte dependencia general y una marcada asimetría relacional.

De acuerdo con lo expuesto, se plantea un fenómeno dialéctico, en el sentido de que, por un lado, las agroindustrias cumplen -o cumplieron, por lo menos, al inicio de la crisis 2001-2002- la función de salvataje o ayuda para mantener en actividad a ciertos estratos de productores, y por otro, su injerencia en la producción primaria agudiza la asimetría y la concentración de capital en el campo, lo que a la larga repercute negativamente en el grueso de los productores agropecuarios y, por carácter transitivo, en los asalariados rurales, al imponer criterios hegemónicos y competitivos que condicionan las potencialidades económicas a futuro y coartan la independencia productiva de las explotaciones.

Todas estas contradicciones están dentro y forman parte de un contexto más amplio, que tiende a incrementar el aposentamiento y consolidación de un sistema capitalista avanzado de control del capital sobre la tierra, donde los individuos y las relaciones socio-económicas tradicionales son arrasadas, imponiendo la despersonalización y la obtención de la mayor tasa de ganancia posible a costa de forzar técnicas y naturaleza.

Volviendo a nuestra región de estudio, observamos que este fenómeno de relación asimétrica entre las partes, empresas-productores, de seguir así, puede llegar a producir en un sentido amplio una disminución numérica más pronunciada de los pequeños y medianos productores familiares, dado que las agroindustrias, al optimizar la producción del campo convirtiéndola en altamente competitiva, por una parte, y preferir en la relación societal a los productores acomodados o capitalistas, por otra, determinan que los mismos queden acorraladas entre dos fuegos. Esto lleva a su vez a un incremento de la disponibilidad de tierras en arrendamiento de parte de aquellos propietarios, que no disponen de los medios suficientes para encarar de manera independiente o asociativa la explotación de sus campos; en cambio, de este modo sí pueden obtener una buena renta. Cabe recordar que en esta circunstancia, el agricultor deja de ser productor para convertirse en rentista.

En relación con las consecuencias socio-territoriales que produce la injerencia en las actividades primarias de las agroindustrias en nuestra zona, podemos decir que son múltiples. 
Las modificaciones sociales y espaciales que desencadenan son evidentes, no obstante corresponde precisar que el fenómeno de las alteraciones socio-territoriales no se debe exclusivamente al accionar de las agroindustrias, ya que en este sentido entran en juego un cúmulo de otros factores, pero sí es indudable que estos agentes económicos las incrementan.

En concreto, en nuestro medio las alteraciones mencionadas se manifiestan, en un plano general, en profundas modificaciones de la estructura agraria, de los actores sociales intervinientes y en el deterioro del medio ambiente, entre otras realidades.

Con respecto a los cambios específicos -que las agroindustrias van a tender a acentuar-, podemos puntualizar los siguientes aspectos:

- Una sobrevaluación del precio de la tierra, con la consecuente limitación de la venta de la misma, lo que conlleva un incremento de la disponibilidad de la tierra en arrendamiento.

- A pesar de la mayor disponibilidad de tierras para arrendar, la competencia por las mismas también se acrecienta, generando -nuevamente- desigualdades en su acceso. De esta manera, las grandes empresas pueden contratar (y pagar el alquiler) por adelantado, consiguiendo así precios más bajos en un contexto en el que los valores de arrendamiento continúan incrementándose notablemente.

- Un incremento del tamaño de las explotaciones y disminución numérica de las mismas -no así obligadamente de las tierras en propiedad-, como así también de los productores. Estos aspectos nombrados se van a reflejar en fuertes alteraciones de la estructura agraria fundiaria.

- Sobreintensificación -acompañada de cuasi monocultivo- en el uso de la tierra y expansión de las explotaciones agrícolas en sectores periféricos, con el previsible deterioro del medio ambiente.

- Aparición y consolidación de sectores sociales no tradicionales -que si bien no son agentes productivos estrictamente nuevos, se incrementaron sobremanera en los últimos tiempos-. Éstos van a estar representados por productores capitalistas de origen urbano, contratistas de producción y obviamente las mismas agroindustrias.

- Intensificación del proceso de despoblamiento del campo, ya iniciado desde hace muchos años.

- Achicamiento de la PEA Agropecuaria en general, con particular incidencia en los productores residentes en el campo y en los asalariados permanentes y transitorios no especializados. 
- Alteraciones de ciertos rasgos materiales típicos del paisaje agrario, como las ya mencionadas en otros acápites de este trabajo.

Como reflexión final, podemos decir que la tendencia a futuro de la incidencia directa de las agroindustrias en la producción agropecuaria, a nuestro parecer, no son halagüeñas, en el sentido de que cada vez se van a acentuar más las asimetrías ya descriptas, acelerando la concentración del capital y alejando la posibilidad de una distribución social más equitativa de los beneficios que pueda llegar a brindar la tierra.

Asimismo, entendemos que las alternativas que se pueden presentar en la búsqueda más equitativa en provecho de los pequeños y medianos productores agropecuarios, si bien son difusas y están muy lejos de alcanzarse, quizás pase -como bien puntualizaba un productor entrevistado- por enfrentar al actual sistema societario agroindustrias-productores "impuesto" por las primeras, mediante la implementación de "asociaciones auténticamente horizontales de productores" que busquen, todos a la vez, la defensa de su trabajo y producción en base a la potenciación proveniente de la sumatoria de sus capitales y de la unión grupal. Pero por ahora, de acuerdo con las orientaciones económicas predominantes que rigen el quehacer agropecuario del campo argentino, se está seguramente muy lejos de alcanzar esta suerte de utopía.

\subsection{Breves observaciones sobre los agentes rurales analizados en este capítulo}

Es pertinente enfatizar que, en este capítulo -como dice el título que precede al mismo-, se ha procurado resaltar a los principales actores sociales rurales intervinientes en el área, con los cuales tuvimos contacto directo a través de las encuestas y entrevistas ya descriptas. Si bien nuestro esquema de trabajo consistió en analizar los agentes rurales que representan, a nuestro juicio, los pilares centrales que intervienen en la producción primaria agropecuaria, no por ello desconocemos la participación de otros agentes rurales de estructura más compleja, como las sociedades anónimas agropecuarias, los pools de siembra, los fondos o grupos de inversión, entre otros. En concreto, además de los actores sociales rurales que analizamos, desde la profundización del régimen capitalista en el campo, aparecen en escena nuevos agentes ingresantes, como así también se manifiesta una readecuación al sistema de varios de los agentes rurales preexistentes, con el propósito obviamente de permanecer dentro del mismo.

Muchas de estas modificaciones las explicitamos en el primer capítulo, como fenómeno generalizado que afectaba a las fuerzas laborales de casi toda la llanura pampeana, según 
opinión de numerosos autores (Barsky y Gelman, 2001; Azcuy Ameghino, 2004; Aparicio, Giarraca y Teubal, 1992). Fenómeno que, de acuerdo con nuestras observaciones, esta irrupción de nuevos agentes rurales y adaptación de varios de los preexistentes, también se manifestó plenamente en la región sur de la provincia de Córdoba.

Aclarado este punto, es nuestro propósito, a continuación, tratar sucintamente, a modo de una primera observación, el tipo de articulación que se establece, a nuestro entender, entre los sectores rurales centrales que intervienen en el quehacer agropecuario. Con la idea a priori de que "no existe la igualdad social ni la proporcionalidad de ingresos económicos justos" entre los agentes intervinientes en el ámbito rural, como en ningún otro donde el engranaje capitalista se manifiesta en toda su potencialidad.

Sin la menor duda, para que el sistema funcione, tienen que mediar vinculaciones y articulaciones de dominación y subordinación entre los diferentes actores intervinientes, y esta realidad está en relación directa con el acceso de cada agente a los medios de producción.

De este modo, resultan insoslayables los intereses específicos y las contradicciones existentes que median entre los diferentes sectores del trabajo rural. Por otra parte, cabe acotar que consideramos como un movimiento ideológico de "diversión”, el estudiar exclusivamente de manera aislada a cada agente rural, aplanando a los mismos como si todos ellos fueran iguales en sus respectivos roles de trabajadores rurales, y que los vínculos que se establecen entre ellos fueran meras externalidades entre las partes.

Con respecto a nuestra área de estudio, el sur de Córdoba, y al igual que en otras zonas donde prima un capitalismo agropecuario maduro, el corte básico de los actores sociales analizados desde la perspectiva laboral, o sea, en relación con el acceso a los medios de producción, se sintetiza de manera esquemática y predominante en una burguesía y en un proletariado rural, respectivamente. En relación con la primera categoría, se debe diferenciar una pequeña y mediana burguesía, que en general coincide con la categoría de los que denominamos pequeños y medianos productores, estando todos ellos representados, en términos genéricos, dentro de la clase media ${ }^{25}$ que, como bien puntualizamos cuando, en el Capítulo V, tratamos la estructura agraria fundiaria, vemos que, a nivel numérico, esta pequeña y mediana burguesía tiene una especial relevancia -particularmente en los departamentos Río Cuarto y Juárez Celman, pero no así en lo atinente a la predominancia en superficie ocupada dentro del área.

25 El tema de las clases sociales intervinientes en nuestro medio es tratado in extenso en el capítulo siguiente. 
Este estrato vive, como especificábamos en capítulos anteriores- especialmente en los pueblos y, en menor término, en las explotaciones donde trabaja. Concretamente, forma parte y se siente involucrado dentro de la sociedad que habita la región. Su incidencia y peso socioeconómico en el área es, desde luego, significativa y participa plenamente en la cadena productiva que se estructura dentro de la zona.

Representa una burguesía rural medianamente joven -pero no tan joven, obviamente, como la que describía de Imaz en su momento de su pueblo natal, Ucacha (de Imaz, 1962)que paulatinamente se va consolidando.

En su proceso de conformación, quedan claros los rastros de una amplia camada original de colonos, muchos de ellos especialmente -como destacábamos en otro acápite- de procedencia italiana que, a través de dos, tres y cuatro generaciones, transitaron mediante condiciones de extrema laboriosidad, un rápido ascenso de estrato socio-económico, que coincide con la gran movilidad social observable desde fines del siglo XIX hasta mediados del XX, en el resto de la llanura pampeana.

Dentro de este estrato -donde prevalecen cuantitativamente los pequeños productoreshay especialmente una fracción que podríamos catalogar entre medianos y medianos grandes productores, a quienes ya nos referimos en forma genérica en otra parte -con campos que se extienden hasta las 1.000 ha aproximadamente-, que se desempeñan como auténticos empresarios modernos, con un acusado dinamismo y versatilidad en el manejo de sus explotaciones. Representan a una mediana burguesía de fuerte sesgo capitalista, y es la primera que se adapta a los cambios tecnológicos y a sus consecuentes prácticas agropecuarias. Funciona, en síntesis, como un potente motor de empuje dentro del área.

Queda, finalmente, una reducida porción de grandes propietarios, que sería la punta de la pirámide, correspondiente a la gran burguesía terrateniente, representada por los grandes productores rurales, en muchos casos bajo la figura clásica del estanciero tradicional y, en otros, bajo el papel de grandes empresarios agropecuarios, bajo diferentes formas de investidura operacional y jurídica, en el que sus socios o participantes, no obligadamente desde el punto de vista del status social, forman parte de la gran burguesía. Muchos de los integrantes de esta clase alta social no viven en el área; por lo tanto, se desempeñan como propietarios ausentistas y su participación en el lugar es efímera, la posesión de tierras de esta gran burguesía se manifiesta especialmente en los departamentos del extremo sur provincial, o sea, General Roca y Pte. Roque Sáenz Peña.

Cabe recordar que, cuando hacemos referencia a los agentes que actúan en la cúspide de la pirámide, se debe agregar también, dentro de este extremo apical, a muchas agroindustrias 
y acopiadores que, si bien sabemos tienen básicamente sus pies puestos en la actividad industrial y comercial respectivamente, extienden algunos de sus brazos productivos a la actividad primaria agropecuaria, como estrategia empresarial.

En suma, dentro del amplio abanico de la burguesía rural, donde median obviamente diferentes niveles de posesión de los medios de producción, determinan a su vez diferentes niveles de acumulación, donde los ritmos productivos los marca el grupo económico más poderoso. Esta realidad determina fuertes tensiones y una seguidilla de escalones de dependencia y subordinación económica de una punta a la otra del espinel de la burguesía rural. Los intereses específicos y las contradicciones existentes entre los diversos estamentos de la burguesía rural están bien presentes.

En lo que respecta al otro extremo de la escala de la fuerza laboral, o sea el sector del proletariado rural, ya especificamos -en otro acápite- que el que reside en nuestra área no se diferencia mayoritariamente del que vive en otros sectores de la llanura pampeana. En relación con su capacidad económica, cabe recordar que hay un grupo de asalariados calificados que marcan una fuerte diferencia de ingresos con respecto a los no calificados. $\mathrm{Su}$ dependencia del empleador es muy marcada y sus ingresos, en general, sideralmente inferiores. Los avances tecnológicos en el agro le juegan en contra por ahora. Las contradicciones de clase con el empleador, o sea con el productor, son obvias. Media, como decíamos, una fuerte subordinación al patrón, y las tensiones sociales que sufre este proletariado, que por cierto existen, están fuertemente contenidas, sin desbordar por el momento, y el gremio que los nuclea-UATRE- aparentemente juega un rol contemporizador entre las partes en cuestión.

A continuación de estos dos polos sociales clásicos, como parte de los actores centrales intervinientes en las relaciones de producción de mutua interdependencia, se debe considerar, asimismo, a los trabajadores independientes del agro, o sea, los que nosotros hemos denominado en este trabajo como "agentes ligados", de los cuales, como se recuerda, los más significativos de todos son los contratistas de servicios. Aquí nos encontramos con un empresario dueño de medios de producción, como son las máquinas agrícolas, que a diferencia de otros agentes ligados que prácticamente cuentan con sus brazos y conocimientos solamente, disponen de un capital y capacidad laboral muy variable, pero nunca intrascendente. Mantienen su autonomía laboral en relación con los que los contratan, pero dentro de sus empresas, en la medida de que dispongan de empleados -y casi siempre los tienen-, establecen la misma relación histórica de dependencia de patrón-obrero. Justamente, cabe acotar que, en el mundo del contratismo, se desempeña una no despreciable cantidad de 
empleados de maquinaria que, por su actividad, se encuentran bastante ocultos a los ojos de los que participan en las problemáticas rurales (Villulla, 2010).

En síntesis, en nuestro ámbito laboral de la producción primaria de base agropecuaria, vemos que, si bien como decíamos está cargado de tensiones de intereses contrapuestos de clase y bloqueadores de lograr alcanzar mejores ventajas económicas, media desde hace tiempo una fluida y dinámica articulación entre las partes intervinientes, que se expresa en la actualidad como de relativa convivencia pacífica, donde la participación de las corporaciones que representan a los diferentes agentes laborales tiene mucho que ver en el control y apaciguamiento de los intereses encontrados.

Otra observación de la que aquí queremos dejar constancia se refiere a las condiciones de "reproducción de la fuerza del trabajo familiar", ${ }^{26}$ a nivel especialmente de las pequeñas empresas, en relación con la continuidad generacional que media de padres a hijos en la explotación de los establecimientos.

Por lo que nosotros pudimos detectar a través de las encuestas llevadas a cabo a los productores en nuestra área, en muchos casos se vislumbra un abrupto corte en la permanencia a futuro de la unidad productiva, debido a que los hijos se inclinan más a desarrollar otra actividad económica diferente a la agropecuaria; aparte, puede resultar más tentador en el futuro inmediato direccionar a los pequeños predios hacia el arrendamiento accidental. La atracción de los centros urbanos y la orientación profesional ajena a las tareas agropecuarias de varios de los hijos de los pequeños productores que han podido estudiar tiene mucho que ver en el vacío de continuidad al que hacemos referencia. Situación que, en la actualidad, puede haberse morigerado en parte, ante la eventual coyuntura económica favorable por la que atraviesa el campo, pero que no por ello deja de tener vigencia la realidad descripta. No obstante, a pesar de las incertidumbres y limitaciones que presenta a futuro, en muchos casos, este tipo de reproducción familiar, vemos como ejemplo positivo que un numeroso grupo de productores de nuestro medio cuentan con los hijos estudiando en la Facultad de Agronomía y Veterinaria de la universidad local. En este sentido, queda claro que el apoyo técnico y la influencia de la UNRC como creadora de recursos humanos para el servicio del campo es de vital y estratégica importancia para la zona. A su vez, se debe agregar el sólido aporte que brindan, asimismo, en la formación de futuros técnicos

26 Cabe aclarar que no estamos haciendo referencia estrictamente a la reproducción social de la fuerza del trabajo, en el sentido específico de "...la reproducción de los bienes materiales o del producto social global" (Borisov et al., 1977:206), sino simplemente a la continuidad generacional de padre a hijo de seguir trabajando o no el mismo predio. 
agropecuarios las numerosas y prestigiosas escuelas agronómicas provinciales, ubicadas también en nuestra región. 


\section{Capítulo VII}

\section{Aspectos laborales y socio-culturales específicos de los agentes rurales bajo estudio}

Nos interesa, a continuación, plantear algunos aspectos específicos en torno al desempeño laboral de un particular agente rural y abrir, a su vez, un ángulo de análisis sobre ciertas realidades socio-culturales, con claras connotaciones territoriales en el ámbito rural.

De acuerdo con lo antedicho, tratamos, en primer lugar, el rol de la mujer en el agro, en torno básicamente al papel que desempeña como agente productivo y político en defensa de las EAPs familiares.

Luego, en segundo lugar, pasamos a desarrollar la incidencia de las clases sociales agropecuarias en relación con su vinculación socio-ocupacional, con especial énfasis en el análisis de la estratificación social de los productores del sur cordobés.

Por último, nos interesa analizar la dimensión cultural en el paisaje agrario de nuestra área de trabajo, destacando las diferentes lógicas que se manifiestan en la configuración de dicho espacio humanizado.

En concreto, a renglón seguido, pasamos a desarrollar los tres aspectos arriba mencionados, con el propósito de contribuir a enriquecer y profundizar el horizonte de análisis del presente trabajo.

\subsection{El rol de la mujer en el ámbito rural}

El propósito de este trabajo consiste en analizar el rol de la mujer-específicamente de aquella relacionada con el productor agropecuario- en el ámbito rural del sur de la provincia de Córdoba. La información que se vierte en este estudio proviene en gran parte de datos desagregados de investigaciones precedentes referidas a diferentes aspectos sobre el comportamiento de la Población Económicamente Activa Agropecuaria en el área mencionada.

La metodología empleada, al igual que las indagaciones arriba aludidas, se apoya básicamente en una labor empírica con un fuerte sesgo en el trabajo de campo.

En esta instancia nos interesa privilegiar el papel de la mujer que se desenvuelve o está relacionada con este medio, donde tradicionalmente el varón ha ocupado y todavía ocupa en gran parte un rol protagónico en todo lo atinente a las actividades rurales, con el fin de 
penetrar más cabalmente -desde una perspectiva geográfica- a través de la desagregación analítica del género, en la comprensión de algunos de los tantos factores que inciden a nivel de célula familiar, en la construcción de los espacios humanizados.

Resulta interesante destacar, en el área de nuestro estudio, del mismo modo que en otros territorios rurales de nuestro país y del mundo, un avance progresivo del protagonismo de la mujer en todas las manifestaciones del quehacer humano, al igual que en el ámbito urbano, pero por cierto, de forma más lentificada.

No obstante estos progresos, priman todavía fuertes resabios de índole cultural que encasillan a la mujer en un plano de subordinación con respecto al hombre, en todo lo referente al trabajo productivo y a los contactos públicos y decisiones económicas que se generan fuera del seno hogareño. Esta tendencia atraviesa todas las clases sociales y diferentes espacios geográficos. Ésta es tan así, que hasta en organizaciones como el Movimiento de Trabajadores Rurales sin Tierra (MST) del Brasil, que involucra a los sectores sociales más desposeídos del ámbito rural, la diferenciación de género en detrimento de la mujer está presente y resulta difícil de erradicar (García y Thomas, 2002).

En los países latinoamericanos en general, como en otras áreas del mundo, especialmente el subdesarrollado, esta desvalorización hacia el sector femenino, particularmente en el medio rural, está fuertemente arraigada.

En nuestra órbita geográfica este imperialismo cultural que expresa la asimetría en las relaciones de género, viene a ser un producto de la racionalidad occidental y de otras procedencias, que a través de la reelaboración de conductas humanas precedentes, las sintetiza en gran parte de manera aparentemente neutra, pero que en los hechos privilegia el accionar del hombre sobre el de la mujer.

Esta diferenciación se manifiesta explícitamente en el tipo de trabajo que la tradición cultural le asigna a cada una de las partes, donde el trabajo oculto de la mujer queda subsumido al trabajo productivo que genera el hombre, sin considerar acabadamente que las funciones reproductivas que realiza el sector femenino, aunque no tengan una traducción estrictamente remunerativa, al articularse con las tareas globales que lleva a cabo el resto del núcleo familiar, pasan a poseer también un valor económico.

A diferencia de los centros urbanos, donde el trabajo se realiza en espacios separados del lugar donde se habita, en el cual tradicionalmente “...el hombre queda asociado al mundo de la producción donde predominan las relaciones profesionales y públicas, y la mujer permanece en el ámbito doméstico donde predominan las relaciones personales" (Escamilla Herrera y Santos Cerquera, 2003:64), en el ámbito rural, históricamente esta partición espacial 
entre hogar y lugar de trabajo para los agricultores que viven específicamente en el campo nunca existió. Por lo tanto, en este medio las tareas de la mujer siempre resultaron ser más difusas, y por ende difíciles de encasillar, ya que según el sector socio-económico al que pertenece, al momento histórico vivido y del lugar que se trate, además de las labores inherentes al hogar, suele realizar tareas complementarias como la producción de alimentos para el autoconsumo familiar $\mathrm{y}$, según las circunstancias, también se suma al trabajo estrictamente productivo.

El rasgo positivo, en este sentido, consiste en que desde hace tiempo la mujer vinculada al mundo rural viene bregando por abrir nuevas brechas participativas, tanto en el aspecto de las actividades productivas como de las actividades públicas, con el propósito de revalorizar de igual a igual su condición, además de cómo madre y esposa, fundamentalmente como persona.

Este transitar se manifiesta en forma lenta pero progresiva, donde es dable observar $-\mathrm{y}$ las estadísticas así lo demuestran- cada vez más la presencia activa de la mujer en el medio rural.

Por último, queremos precisar desde nuestra perspectiva de estudio, nuestro interés por analizar particularmente las diferencias sociales que median entre hombres y mujeres, en relación con el territorio, tanto en el plano económico como público. En otras palabras, lo que pretendemos saber es cómo se desempeñan las relaciones de género a nivel espacial. A continuación pasamos a tratar la referida problemática.

\subsubsection{El papel de la mujer en las explotaciones agropecuarias y su evolución a través del tiempo}

Aquí se presentan varias instancias a tener en cuenta: el momento histórico, la localización, la actividad predominante de la explotación y el nivel socio-económico del grupo familiar considerado.

Es pertinente recordar que, recién a partir de la expansión de la agricultura a fines del siglo XIX, que coincide con el arribo de la inmigración europea, es cuando se empieza a poblar sustancialmente la llanura pampeana.

En esta circunstancia los colonos europeos se van a tener que adecuar progresivamente a un tipo de explotación extensiva, mecanizada y de orientación predominantemente comercial, que va a requerir sobre todo la presencia del trabajo masculino. A esta realidad se suma que, si bien eran diferentes los trabajos culturales que realizaban los colonos europeos de estirpe campesina en sus lugares de origen, donde la mujer en muchos casos tenía un 
importante protagonismo laboral, se acordaba que su función básica estaba centrada en las tareas del hogar. Todo ello da como resultado que el rol de la mujer en el espacio pampeano se va a circunscribir fundamentalmente al cuidado del hogar y de los hijos, y como extensión de tareas, el cuidado de la huerta, cuyos productos van a estar destinados al consumo familiar.

Cabe acotar que, en los primeros tiempos de la colonización, hay muchos testimonios que relatan que la mujer solía trabajar codo a codo con el hombre para levantar la vivienda y labrar los primeros surcos, como así también no se debe desestimar a los chacareros empobrecidos, cuya compañera y el resto de la familia, seguramente trabajaban a la par de él. Pero, en el grueso de las explotaciones, una vez lograda cierta estabilidad económica, es el hombre -se entiende por ello al padre y a los hijos varones- el que desempeña la responsabilidad de la actividad productiva; no obstante ello, sigue habiendo un porcentaje minoritario de mujeres que realizan también labores rurales remunerativas.

En concreto, el papel de subordinación asignado a la mujer se va a prolongar en los tiempos hasta hace pocas décadas atrás y, sin que esta sumisión haya desaparecido, es dable detectar en la actualidad un impulso naciente del sector femenino por ganar espacios en el plano productivo y público -por ejemplo, en la defensa del patrimonio familiar-, con el propósito de acercarse al hombre en su dignificación laboral.

Todo lo dicho sobre el desempeño de la mujer en la Región Pampeana es válido también para nuestra área específica de estudio, y es pertinente a su vez constatar cómo la tradición de dejar en manos de la mujer la tarea de "hacer la huerta" (donde va incluida la cría de pequeños animales) es observable asimismo en nuestro sector de trabajo. De acuerdo con el Cuadro $N^{o} 53$, que refleja parte de los resultados de la encuesta del año 2002, llevada a cabo en los establecimientos donde residen las familias de forma permanente, observamos que casi las dos terceras partes cuentan con huertas, decreciendo los porcentajes, como es de esperar, a medida que nos desplazamos de las pequeñas explotaciones hacia las grandes, con una tendencia, según nos informaban, a disminuir cada vez más estas huertas a medida que avanza la sojización, a pesar de un aparente repunte de esta actividad complementaria, como más adelante explicitaremos. De todos modos, la presencia de la quinta aledaña a la vivienda nos está indicando toda una tradición de una práctica cultural, que se expresa en la prolongación del trabajo de la mujer en una actividad complementaria. 
Cuadro $N^{\circ}$ 53. Explotaciones que cuentan con huerta. Año 2002

\begin{tabular}{|c|c|c|c|c|}
\hline & & & \\
\hline & & & Sí & No \\
\hline \multirow{2}{*}{$\frac{\mathscr{g}}{\frac{\mathscr{J}}{\mathrm{J}}}$} & \multicolumn{2}{|c|}{ Valores absolutos } & 84 & 48 \\
\hline & \multicolumn{2}{|c|}{$\%$} & 63,6 & 36,4 \\
\hline \multirow{6}{*}{ 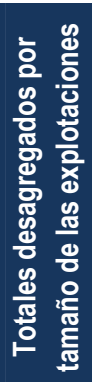 } & \multirow{2}{*}{$\begin{array}{c}\text { Pequeñas } \\
\text { Explotaciones }\end{array}$} & $\begin{array}{l}\text { Valor } \\
\text { absoluto }\end{array}$ & 45 & 17 \\
\hline & & $100 \%$ & $73 \%$ & $27 \%$ \\
\hline & \multirow{2}{*}{$\begin{array}{c}\text { Medianas } \\
\text { Explotaciones }\end{array}$} & $\begin{array}{l}\text { Valor } \\
\text { absoluto }\end{array}$ & 23 & 13 \\
\hline & & $100 \%$ & $64 \%$ & $36 \%$ \\
\hline & \multirow{2}{*}{$\begin{array}{c}\text { Grandes } \\
\text { Explotaciones }\end{array}$} & $\begin{array}{l}\text { Valor } \\
\text { absoluto }\end{array}$ & 16 & 18 \\
\hline & & $100 \%$ & $47 \%$ & $53 \%$ \\
\hline
\end{tabular}

Fuente: Elaboración propia en base a la encuesta del año 2002.

Otro aspecto a tener en cuenta en relación con el rol de la mujer en las explotaciones es cuando un alto porcentaje de productores se trasladaron con sus familias a vivir en los pueblos. Obviamente, la mujer dejó de hacer huerta y se desligó en general de las tareas relacionadas con el campo. Recién ahora, dentro de la tónica general de que la mujer está dispuesta a asumir un mayor protagonismo, se observa una paulatina participación en las labores de índole rural por parte del sector femenino localizado en los pueblos -fundamentalmente las esposas-, pero en mucha menor escala, naturalmente, con respecto a la mujer que sigue residiendo en las explotaciones. Es importante también precisar que dentro de nuestro ámbito de estudio, en las zonas dedicadas al tambo -al igual que en todos los lugares donde se desarrolla esta actividad-, la mujer trabaja a la par del hombre, pero con la característica de que este trabajo, en general, no lo efectúan los dueños sino los medieros con sus respectivas esposas e hijos.

Con respecto a la participación de la mujer en el trabajo productivo y su relación con el nivel socio-económico al cual pertenece, es sabido que, a medida que se ascendía en la escala social, disminuía su participación. No obstante, con los nuevos aires de cambio ya descriptos, esta tendencia se está modificando, ya que es notable la injerencia de la mujer perteneciente a los niveles medio y superior de la escala socio-económica en las tareas productivas del campo.

En lo hasta aquí explicitado, si bien se hace hincapié en el rol de la mujer de las pequeñas y medianas explotaciones -que son las que predominan numéricamente en nuestro espacio de estudio-, los comportamientos descriptos atraviesan en general todos los estratos sociales. 


\subsubsection{Estado de situación de la mujer}

En este acápite pasamos a describir y analizar la incidencia de la mujer en la estructura familiar y el nivel educativo alcanzado por la misma, como así también por el varón, con la finalidad de realizar comparaciones. Todos los datos que se exponen provienen de la encuesta ya mencionada, efectuada en los establecimientos rurales donde residen las familias de forma permanente.

\section{ESTRUCTURA FAMILIAR}

- Como se puede observar en el Cuadro $\mathrm{N}^{\mathrm{o}} 54$, el total de mujeres que están involucradas en las explotaciones arriba aludidas representan el 45,1\% del total del Núcleo Familiar (NF). El índice resultante de femineidad es del 82,2\%, o sea 82,2 mujeres cada 100 varones. Estos guarismos, que expresan un menor porcentaje de mujeres, coinciden con otros datos de procedencia censal, que indican una prevalencia masculina en el campo. Esto se debe, obviamente, a que hay un mayor requerimiento de la fuerza laboral masculina en las áreas rurales. Las mujeres jóvenes tendrían una mayor tendencia a dejar de residir en el campo que los varones.

Cuadro N$^{\circ}$ 54. Estructura Familiar del Total del Núcleo Familiar. Año 2002

\begin{tabular}{|c|c|c|c|c|c|c|c|c|c|}
\hline \multicolumn{10}{|c|}{ Mujeres } \\
\hline $\begin{array}{c}\text { Total del } \\
\text { NF }\end{array}$ & $\begin{array}{l}\text { Total de } \\
\text { Mujeres }\end{array}$ & $\begin{array}{l}\text { Jefa de } \\
\text { Explot. }\end{array}$ & $\begin{array}{l}\text { Esposas de } \\
\text { Jefe de } \\
\text { Explot. }\end{array}$ & Hijas & Hermanas & Abuelas & Nueras & Nietas & Otras \\
\hline 636 & 287 & 1 & 138 & 77 & 3 & 18 & 23 & 18 & 9 \\
\hline \multirow[t]{3}{*}{$100 \%$} & $45,1 \%$ & & & & & & & & \\
\hline & $100 \%$ & $0,3 \%$ & $48,1 \%$ & $26,8 \%$ & $1 \%$ & $6,3 \%$ & $8 \%$ & $6,3 \%$ & $3,2 \%$ \\
\hline & & $\begin{array}{l}\text { P.E.: } 52 \\
\text { años }\end{array}$ & $\begin{array}{l}\text { P.E.: } 47,8 \\
\text { años }\end{array}$ & $\begin{array}{c}\text { P.E.: 16,7 } \\
\text { años }\end{array}$ & $\begin{array}{l}\text { P.E.: } 57 \\
\text { años }\end{array}$ & $\begin{array}{c}\text { P.E.: } 74,8 \\
\text { años }\end{array}$ & $\begin{array}{l}\text { P.E.: } 26 \\
\text { años }\end{array}$ & $\begin{array}{c}\text { P.E.: 6,8 } \\
\text { años }\end{array}$ & $\begin{array}{c}\text { P.E.: } 41,7 \\
\text { años }\end{array}$ \\
\hline \multicolumn{10}{|c|}{ Varones } \\
\hline $\begin{array}{c}\text { Total del } \\
\text { NF }\end{array}$ & $\begin{array}{l}\text { Total de } \\
\text { Varones }\end{array}$ & $\begin{array}{l}\text { Jefe de } \\
\text { Explot. }\end{array}$ & & Hijos & Hermanos & Abuelos & Yernos & Nietos & Otros \\
\hline 636 & 349 & 154 & & 151 & 6 & 8 & 3 & 18 & 9 \\
\hline \multirow[t]{3}{*}{$100 \%$} & $54,9 \%$ & & & & & & & & \\
\hline & $100 \%$ & $44,1 \%$ & & $43,3 \%$ & $1,7 \%$ & $2,3 \%$ & $0,8 \%$ & $5,2 \%$ & $2,6 \%$ \\
\hline & & $\begin{array}{c}\text { P.E.: } 52,5 \\
\text { años }\end{array}$ & & $\begin{array}{l}\text { P.E.: 18,5 } \\
\text { años }\end{array}$ & $\begin{array}{c}\text { P.E.: 52,7 } \\
\text { años }\end{array}$ & $\begin{array}{c}\text { P.E.: 80,5 } \\
\text { años }\end{array}$ & $\begin{array}{c}\text { P.E.: } 36,7 \\
\text { años }\end{array}$ & $\begin{array}{c}\text { P.E.: 6,5 } \\
\text { años }\end{array}$ & \\
\hline \multirow{2}{*}{$\begin{array}{c}\text { Total del } \\
\text { NF }\end{array}$} & 636 & 155 & 138 & 228 & 9 & 26 & 26 & 36 & 18 \\
\hline & $100 \%$ & $24,4 \%$ & $21,7 \%$ & $35,8 \%$ & $1,4 \%$ & $4,1 \%$ & $4,1 \%$ & $5,7 \%$ & $2,8 \%$ \\
\hline
\end{tabular}

Fuente: Elaboración propia en base a la encuesta del año 2002.

- Dentro de la franja de las mujeres que viven en el campo, predominan las esposas de los jefes de explotación, con un 48\%, seguidas por las hijas con casi un $27 \%$, las nueras con un $8 \%$ y las abuelas y nietas igualmente con un $6,3 \%$. Los otros miembros restantes ocupan 
un porcentaje muy reducido. Por otra parte en nuestra encuesta pudimos detectar una sola jefa de explotación.

La edad promedio de las esposas es de casi 48 años; la de las hijas de 16,7 años. Este promedio tan bajo se debe - como ya se explicitó en otro acápite- al vacío en cantidad que dejan al casarse muy jóvenes y pasar a vivir fuera del hogar paterno, quedando obviamente las de menor edad. La edad promedio de las nueras -26 años- indica también la existencia de matrimonios muy jóvenes.

- Al comparar la estructura femenina con la masculina, comprobamos que hay casi el doble de hijos que hijas, en gran parte por las razones arriba expuestas y, por otra parte, porque presumiblemente las mujeres tienden a trasladarse a la ciudad en mayor proporción que los varones para realizar tareas de tipo urbano o continuar estudios superiores.

También se observan más hermanos que hermanas; en cambio, es mucho mayor el porcentaje de abuelas que de abuelos, en concordancia con la mayor esperanza de vida de las mujeres. A su vez, es mucho menor la cantidad de yernos que de nueras, lo que se explica porque el hijo varón, al casarse, tiende a quedarse a vivir en la explotación de los padres, en mayor proporción que la mujer. El total de nietos y nietas está repartido por partes iguales.

- El porcentaje del grupo central (padres e hijos/as), que representa el 82\% del total del $\mathrm{NF}$, es muy elevado. Esto se debe principalmente a la reducida cantidad de matrimonios $-11,4 \%-$, entre los hijos -varones y mujeres- de los productores que viven en el campo, que se traduce en un bajo porcentaje de hijos políticos (nueras y yernos) y de nietos en general.

- Con respecto al Estado Civil de las mujeres (Cuadro $N^{\circ}$ 55), en situación de casadas predominan desde luego las esposas de los productores, seguido por las nueras; entre las viudas sobresalen las abuelas.

Cuadro No 55. Estado Civil de la Mujer. Año 2002

\begin{tabular}{|l|c|c|c|c|}
\hline Estructura femenina & Casada & Viuda & Soltera & $\begin{array}{c}\text { Totales } \\
\text { parciales }\end{array}$ \\
\hline Jefa de Explotación & - & 1 & - & 1 \\
\hline Esposas & 138 & - & - & 138 \\
\hline Hijas & 3 & - & 74 & 77 \\
\hline Hermanas del Jefe & - & - & 3 & 3 \\
\hline Abuelas & 8 & 10 & - & 18 \\
\hline Nueras & 23 & - & - & 23 \\
\hline Nietas & - & - & 18 & 18 \\
\hline Otras & 4 & 3 & 2 & 9 \\
\hline Totales & 176 & 14 & 97 & 287 \\
\hline $100 \%$ & $61,3 \%$ & $4,9 \%$ & $33,8 \%$ & $100 \%$ \\
\hline
\end{tabular}

Fuente: Elaboración propia en base a la encuesta del año 2002. 
En síntesis, dentro de la estructura familiar correspondiente a los productores que residen específicamente en el campo, van a predominar los varones sobre las mujeres. Hay notoriamente más hijos que hijas y, consecuentemente, más nueras que yernos. Hay pocos matrimonios entre la gente joven y baja edad promedio de los hijos (especialmente de las mujeres), nueras y nietos. Esta última característica, sumada al promedio de edad madura de los productores -y en menor medida de las esposas-, determina una baja representatividad de la generación intermedia en las áreas rurales estudiadas.

\section{NIVEL EDUCATIVO ALCANZADO POR MUJERES Y VARONES}

Ante todo, corresponde aclarar que las personas aludidas en este ítem ya no participan como alumnos en ningún nivel educativo formal.

- Del total de mujeres encuestadas (Cuadro No 56), el mayor nivel educativo alcanzado por la mayoría corresponde a la primaria completa $(42,7 \%)$, seguido por la primaria incompleta $(21,3 \%)$ y el secundario completo $(19,4 \%)$. Este mismo nivel de gradiente se reproduce en el caso de los varones.

La diferencia educativa por sexo reside en que es mayor el porcentaje de varones que alcanzaron solamente el nivel primario completo y el secundario incompleto. En cambio, en el caso de las mujeres, es notoriamente mayor el porcentaje que alcanzó el secundario completo y el terciario/universitario, lo que nos indica a las claras que las mujeres del área rural analizada alcanzaron niveles educativos más altos que los varones.

- En la desagregación por edad, observamos que en la franja etaria de 18 a 29 años, el mayor porcentaje del nivel educativo alcanzado por mujeres y varones, corresponde al secundario completo, seguido por el secundario incompleto, en el caso de las mujeres, y por el primario completo, en el caso de los varones. Es notable el mayor porcentaje $(54,8 \%)$ del secundario completo alcanzado por las mujeres, que el logrado por los varones $(36,4 \%)$.

En la franja de 30 a 49 años, el mayor porcentaje de nivel educativo alcanzado por mujeres y varones corresponde al primario completo, seguido por el secundario completo. En la franja de 50 a 64 años, el mayor porcentaje de nivel educativo alcanzado por ambos sexos corresponde al primario completo, seguido por el primario incompleto.

Por último, en la franja de 65 y más años, el mayor porcentaje de nivel educativo alcanzado por las mujeres, al igual que los varones, corresponde al primario incompleto, seguido por el primario completo.

Es evidente el gradiente decreciente de la instrucción en ambos sexos, a medida que se avanza en edad. Como también queda en evidencia un mayor grado de instrucción por parte 
de la mujer en las tres primeras franjas de edad. En cambio, en la última franja, los varones poseen un mayor grado de instrucción que las mujeres.

- Lo anteriormente explicitado queda demostrado en la Brecha de Género, donde desde el primario incompleto hasta el secundario incompleto, el mayor porcentaje alcanzado en dichos niveles le corresponde a los varones. En cambio, desde el secundario completo hasta el terciario/universitario completo, el mayor porcentaje alcanzado en dichos niveles le corresponde a las mujeres.

En suma, en el área rural de nuestro estudio, el nivel de instrucción alcanzado por las mujeres en general, es superior al de los varones.

Cuadro N$^{\circ}$ 56. Máximo nivel de educación alcanzado. Año 2002

\begin{tabular}{|c|c|c|c|c|c|c|c|c|c|c|c|}
\hline & \multicolumn{5}{|c|}{ Mujeres } & \multicolumn{5}{|c|}{ Varones } & \multirow[b]{2}{*}{$\begin{array}{l}\text { Brecha } \\
\text { de } \\
\text { Género' }\end{array}$} \\
\hline & Total & $18-29$ & $30-49$ & $50-64$ & $\begin{array}{l}650 \\
\text { más } \\
\text { años }\end{array}$ & Total & $18-29$ & $30-49$ & $50-64$ & $\begin{array}{l}650 \\
\text { más } \\
\text { años }\end{array}$ & \\
\hline Nunca asistió & $\begin{array}{c}1 \\
0,5 \%\end{array}$ & - & - & - & $\begin{array}{c}1 \\
3,1 \%\end{array}$ & $\begin{array}{c}2 \\
0,8 \%\end{array}$ & - & - & - & $\begin{array}{c}2 \\
4,1 \%\end{array}$ & 0,63 \\
\hline $\begin{array}{l}\text { Primario } \\
\text { incomp. }\end{array}$ & $\begin{array}{c}45 \\
21,3 \% \\
\end{array}$ & - & $\begin{array}{c}7 \\
7,8 \% \\
\end{array}$ & $\begin{array}{c}13 \\
22,4 \% \\
\end{array}$ & $\begin{array}{c}25 \\
78,1 \% \\
\end{array}$ & $\begin{array}{c}55 \\
22,4 \% \\
\end{array}$ & $\begin{array}{c}1 \\
2,3 \% \\
\end{array}$ & $\begin{array}{c}8 \\
9,1 \%\end{array}$ & $\begin{array}{c}20 \\
30,8 \% \\
\end{array}$ & $\begin{array}{c}26 \\
53,1 \% \\
\end{array}$ & 0,95 \\
\hline $\begin{array}{l}\text { Primario } \\
\text { completo }\end{array}$ & $\begin{array}{c}90 \\
42,7 \% \\
\end{array}$ & $\begin{array}{c}3 \\
9,7 \%\end{array}$ & $\begin{array}{c}40 \\
44,4 \%\end{array}$ & $\begin{array}{c}41 \\
70,7 \%\end{array}$ & $\begin{array}{c}6 \\
18,8 \%\end{array}$ & $\begin{array}{c}121 \\
49,2 \%\end{array}$ & $\begin{array}{c}12 \\
27,3 \%\end{array}$ & $\begin{array}{c}49 \\
55,7 \%\end{array}$ & $\begin{array}{c}43 \\
66,2 \%\end{array}$ & $\begin{array}{c}17 \\
34,7 \%\end{array}$ & 0,87 \\
\hline $\begin{array}{l}\text { Secundario } \\
\text { incomp. }\end{array}$ & $\begin{array}{c}12 \\
5,7 \%\end{array}$ & $\begin{array}{c}5 \\
16,1 \%\end{array}$ & $\begin{array}{c}5 \\
5,6 \%\end{array}$ & $\begin{array}{c}2 \\
3,5 \%\end{array}$ & - & $\begin{array}{c}24 \\
9,8 \%\end{array}$ & $\begin{array}{c}10 \\
22,7 \%\end{array}$ & $\begin{array}{c}12 \\
13,6 \%\end{array}$ & $\begin{array}{c}1 \\
1,5 \%\end{array}$ & $\begin{array}{c}1 \\
2,0 \% \\
\end{array}$ & 0,58 \\
\hline $\begin{array}{l}\text { Secundario } \\
\text { completo }\end{array}$ & $\begin{array}{c}41 \\
19,4 \%\end{array}$ & $\begin{array}{c}17 \\
54,8 \%\end{array}$ & $\begin{array}{c}23 \\
25,6 \%\end{array}$ & $\begin{array}{c}1 \\
1,7 \%\end{array}$ & - & $\begin{array}{c}37 \\
15,0 \%\end{array}$ & $\begin{array}{c}16 \\
36,4 \%\end{array}$ & $\begin{array}{c}18 \\
20,5 \%\end{array}$ & $\begin{array}{c}1 \\
1,5 \%\end{array}$ & $\begin{array}{c}2 \\
4,1 \%\end{array}$ & 1,29 \\
\hline $\begin{array}{l}\text { Terc../univ. } \\
\text { incomp. }\end{array}$ & $\begin{array}{c}7 \\
3,3 \%\end{array}$ & $\begin{array}{c}4 \\
12,9 \%\end{array}$ & $\begin{array}{c}3 \\
3,3 \%\end{array}$ & - & - & $\begin{array}{c}4 \\
1,6 \%\end{array}$ & $\begin{array}{c}3 \\
6,8 \%\end{array}$ & $\begin{array}{c}1 \\
1,1 \%\end{array}$ & - & - & 2,06 \\
\hline $\begin{array}{l}\text { Terc./univ. } \\
\text { completo }\end{array}$ & $\begin{array}{c}15 \\
7,1 \%\end{array}$ & $\begin{array}{c}2 \\
6,5 \%\end{array}$ & $\begin{array}{c}12 \\
13,3 \%\end{array}$ & $\begin{array}{c}1 \\
1,7 \%\end{array}$ & - & $\begin{array}{c}3 \\
1,2 \%\end{array}$ & $\begin{array}{c}2 \\
4,5 \% \\
\end{array}$ & - & - & $\begin{array}{c}1 \\
2,0 \% \\
\end{array}$ & 5,92 \\
\hline Total & 211 & 31 & 90 & 58 & 32 & 246 & 44 & 88 & 65 & 49 & \\
\hline
\end{tabular}

Fuente: Elaboración propia en base a la encuesta del año 2002.

\subsubsection{La influencia de la mujer en los cambios de localización y en el confort hogareño}

Como se recordará, en nuestra zona de trabajo, los cambios de localización de los productores con sus respectivas familias del campo hacia los pueblos, desde fines de la década del '50 y principios del ' 60 -cuyo porcentaje fue muy alto-, tuvo como uno de los motivos centrales el facilitar el acceso de los hijos a la enseñanza secundaria.

El período citado coincide con la proliferación de inauguraciones de escuelas secundarias en los pueblos. A su vez, para esas fechas, los medios de comunicación (teléfono

1 Es el cociente entre el porcentaje de mujeres que alcanzaron cada nivel educativo y el porcentaje correspondiente de varones. 
y transporte) no estaban suficientemente desarrollados, y los caminos en un estado mucho más precario que en la actualidad. Por lo tanto, el traslado del campo a los centros urbanos resultaba mucho más dificultoso y el aislamiento, en síntesis, era más notorio que en el presente. Esta realidad de nuestra área de estudio se reproducía, en general, en toda la Región Pampeana.

Dentro de este contexto y de acuerdo con la información recogida en nuestras investigaciones, en la decisión de cambiar de lugar de asentamiento, a fin de privilegiar la enseñanza de sus hijos, tuvo mucho que ver la influencia de las madres por lograr este cometido.

En la decisión de trasladarse ha influido también en las mujeres, al igual que en los hombres - pero en éstos en menor medida-, la atracción de mayores comodidades, la cercanía a los servicios de salud y el mayor acceso a la vinculación social, que brindaban en términos comparativos los pueblos. En concreto, como es de ver, la mujer ha tenido incidencia en los cambios de distribución espacial de la población rural.

De modo complementario, es importante resaltar que la situación de aislamiento arriba descripta no se ha superado del todo. Razón por la cual una informante calificada nos instaba a que bregásemos por concientizar sobre la necesidad de crear escuelas de enseñanza media en las áreas rurales. El motivo que aduce es el siguiente: si bien considera que la población del campo se ha estabilizado relativamente y por consiguiente los desplazamientos definitivos rural-urbanos no son tan frecuentes, los hijos en edad de asistir a las escuelas medias van a vivir a los pueblos solos o en casa de familiares, lo que provoca un desmembramiento familiar y profundas conductas de desarraigo en las nuevas generaciones. Esta situación trae aparejada la dificultad de revertir a posteriori esta movilidad juvenil nuevamente hacia el campo, con las lógicas implicancias laborales. Como se ve, ésta es una problemática a considerar en profundidad.

Por otra parte, en las numerosas visitas (fueron 132) que hicimos a los establecimientos rurales con el objeto de levantar la encuesta citada, comprobamos personalmente -como ya lo describimos en otro lugar- el apreciable confort de la vivienda del campo. En general, se puede decir que las comodidades de que actualmente disponen las familias que residen en las áreas rurales se asemejan mucho a las que poseen las familias de los sectores medios, e inclusive altos, que viven en los centros urbanos. Especialmente llama la atención, entre otras comodidades, el confort en las cocinas-comedor de que disponen muchas casas del campo, inclusive en aquellas de construcción mediocre. Naturalmente, la influencia de la mujer en todos estos avances es incuestionable. 
En una palabra, en la actualidad, las mejoras generales mencionadas ayudan a contrarrestar, en parte o mucho, la afluencia poblacional del campo a la ciudad. Y, por lo tanto, aunque de manera más sutil, el disponer de mayor confort también influye en la localización espacial.

\subsubsection{El trabajo productivo de la mujer en las explotaciones}

Como expresamos en párrafos precedentes, la mujer ha ido en ganando terreno paulatinamente en los últimos años, tanto en el trabajo productivo como así también en las organizaciones corporativas.

Es de suponer que en el incremento de su rol participativo en las tareas del campo ha influido un conjunto de factores, tanto intrínsecos -relacionados, por ejemplo, con las variaciones de precios de los productos agropecuarios, el costo de la mano de obra y el manejo productivo de las explotaciones-, como externos, referidos al protagonismo creciente del sector femenino a escala mundial, con progresivas filtraciones hacia el medio rural.

Es así como en la Argentina, según el Censo Nacional Agropecuario (CNA) de 1988, las mujeres ocupadas en las tareas agropecuarias representaban el 17,5\% del total de la PEA Agropecuaria y el $35 \%$ si sólo se considera la categoría trabajadores familiares del productor (Giarraca y Teubal, 1997).

En el caso de nuestra área de estudio (Cuadro $\mathrm{N}^{\circ}$ 57), según los guarismos que se desprenden de la encuesta del año 2002 ya mencionada, la fuerza laboral de la mujer que vive en el campo representa el $21 \%$ del total de la PEA Agropecuaria. No es una cifra elevada, pero tampoco intrascendente, y nos está indicando que la mujer tiene cierta presencia en el trabajo productivo de nuestra zona.

En la desagregación de los miembros femeninos participantes, las esposas de los productores contribuyen en el esfuerzo laboral con el 14,4\%, y las nueras y las hijas con el 2,5\% cada una. En este último caso, se debe tener en cuenta la baja edad promedio de las mismas.

Si consideramos a las mujeres que trabajan del total de las esposas, éstas representan el $33,3 \%$, las hijas el $10 \%$ y las nueras el $31 \%$. Porcentajes que nos permiten apreciar la participación interna de cada grupo laboral femenino interviniente.

En suma, en nuestra encuesta, es la mujer del productor la que más colabora en el trabajo productivo. 
Asimismo, corresponde observar que el 21\% -según nuestra encuesta- de mujeres que trabajan en las explotaciones del total de la PEA Agropecuaria, es bastante inferior al 35\% equivalente de la categoría trabajadores familiares del productor del CNA de 1988, que citamos en párrafos anteriores. Este último porcentaje más elevado se debe presumiblemente a la mayor participación laboral de la mujer en las regiones deprimidas del país -lo que incrementa el porcentaje general-, en términos comparativos con la Región Pampeana.

Lamentablemente, en la encuesta que hicimos en 1994, a los productores agropecuarios que residen en los centros urbanos, no pudimos extraer con precisión los datos de todas las mujeres que trabajan en las explotaciones, pero por la propia dificultad que implica el traslado a los establecimientos desde una localidad urbana y por el bajo porcentaje de la PEA Agropecuaria del total del NF (33\%) que reside en los pueblos, estamos seguros de que la fuerza laboral femenina correspondiente es sustancialmente menor que aquella que vive en el campo.

Cuadro $N^{\circ}$ 57. Fuerza laboral de las mujeres que viven en el campo. Año 2002

\begin{tabular}{|l|c|c|c|c|}
\hline $\begin{array}{c}\text { Estructura } \\
\text { laboral } \\
\text { femenina }\end{array}$ & $\begin{array}{c}\mathbf{N}^{0} \text { absoluto del } \\
\text { total de la PEA } \\
\text { Agropecuaria }\end{array}$ & $\begin{array}{c}\% \text { del total de la } \\
\text { PEA } \\
\text { Agropecuaria }\end{array}$ & $\begin{array}{c}\mathbf{N}^{0} \text { total de } \\
\text { esposas, hijas, } \\
\text { nueras y otras } \\
\text { del NF }\end{array}$ & $\begin{array}{c}\% \text { de mujeres } \\
\text { que trabajan del } \\
\text { total de las } \\
\text { mismas }\end{array}$ \\
\hline Esposas & 46 & $14,4 \%$ & 138 & $33,3 \%$ \\
\hline Hijas & 8 & $2,5 \%$ & 77 & $10,4 \%$ \\
\hline Nueras & 8 & $2,5 \%$ & 26 & $31,0 \%$ \\
\hline Otras & 1 & $1,3 \%$ & 9 & $44,4 \%$ \\
\hline Jefa de \\
explotación
\end{tabular}

Con respecto al tipo de trabajo productivo que realizan las mujeres en el área de estudio, aparte de la colaboración manual en las tareas agrícolas tradicionales, como así también la labor que desarrollan a la par del hombre en los tambos, hemos comprobado que hay una clara tendencia por participar en el trabajo de comercialización y administración de los establecimientos rurales. Esta última actividad, especialmente, la llevan a cabo aquellas que viven en los pueblos.

Es interesante resaltar lo vertido por una informante clave, en este caso, de la localidad de Coronel Moldes. Nos comentaba en 2004 que en algunas unidades de producción las mujeres desarrollaban "actividades específicas", como por ejemplo: cría de terneros, cultivos alternativos, etc. 
Destacaba la importancia de la mujer en la formación de "huertas", en la cual la informante mencionada desempeñaba tareas de capacitación a través del INTA de Río Cuarto, en el Programa Rural Sustentable (PRADERUS), vinculado con el Programa Prohuerta. El objetivo es producir excedentes, más allá de la simple obtención de alimentos.

Estas acciones han permitido el desarrollo de las denominadas "ferias francas" en Río Cuarto, con el apoyo del INTA de dicha ciudad, que ha logrado convocar a unos treinta municipios de la zona.

Dicho Programa está orientado a generar ingresos alternativos, y en él participa especial y activamente tanto la mujer que reside en las localidades como en el campo. Para ello se han organizado talleres de capacitación y gestión.

Comentaba que percibía un cambio en el rol de las mujeres, con una dinámica diferente a la del hombre. Destacaba que la mujer se acercaba con mayor facilidad a consultar a los encargados del Programa, y la que aspiraba a armar una producción distinta, como plantas aromáticas, producción de dulces y conservas, etc.

Tareas que se habían dejado de realizar, como la "granja" o "huerta", vuelven a llevarse a cabo, no sólo con la finalidad de generar alimentos para la familia, sino también para maximizar ingresos, principalmente en la franja de los pequeños productores.

En síntesis, las labores de huerta con orientación excedentaria se han convertido en los últimos tiempos en una tarea más donde la mujer desempeña un rol preponderante.

En relación con las mujeres jefas de explotación, si bien en nuestra área de trabajo pudimos detectar a través de nuestras encuestas solamente una jefa entre aquellos productores que residen en el campo en forma permanente, y cinco jefas entre aquellos productores que viven en los pueblos, a nivel de todo el país, en 2004, había 39.000 mujeres que manejaban establecimientos agropecuarios, sobre un número de 330.000 productores, o sea el 11,8\% del total de los mismos (La Nación, 2004:126).

Porcentaje muy similar es el del CNA de 1988, que acusó el 11\% de las explotaciones encabezadas por mujeres (Giarraca, 2001). Esto indica que la mujer es más que una excepción en las tareas de dirección de las explotaciones, tradicionalmente a cargo de los varones.

Por ahora, no tenemos en claro si los guarismos señalados corresponden exclusivamente a jefaturas no compartidas, o si en cambio incluye a jefaturas compartidas (con esposos, hijos, etc.). A pesar de esta duda y de la escasa presencia -aparentemente- del sector femenino a cargo de explotaciones en nuestra área, el rol de la mujer como jefa de explotación en el contexto general no deja de tener su importancia. 
Con respecto a su participación, en nuestra zona, en cooperativas y asociaciones gremiales tradicionales - no simplemente como socias, sino cumpliendo un papel activo-, podemos decir que es escasa, no siendo así en otras áreas de la Región Pampeana.

\subsubsection{El accionar político-gremial en defensa de las explotaciones familiares}

Son conocidas las medidas que emprendieron un grupo de mujeres trabajadoras del agro que, a partir de 1995, salieron en defensa de sus explotaciones familiares, al correr éstas el peligro de ser rematadas. Este accionar, que se inició en la localidad de Winifreda (provincia de La Pampa), y que cundió rápidamente por varias provincias del país, especialmente de la Región Pampeana, pasó a denominarse Movimiento de Mujeres Agropecuarias en Lucha (MML).

El problema de estas explotaciones, cuyo estrato social representativo no correspondía a los sectores más pobres de la población rural y que podríamos definir como "explotaciones agrarias familiares capitalizadas" (Giarraca, 2001:10), comienza cuando, bajo el slogan de la "revolución productiva" de la década del '90, se induce - mediante un discurso amañado- a la tecnificación del agro mediante el ofrecimiento de créditos expeditivos que brindaban las instituciones bancarias, motivo por el cual se incrementó sustancialmente el endeudamiento agropecuario.

La política global de ese momento, basada en la "convertibilidad" que equipara el peso al dólar, las "privatizaciones", "desregulaciones" - especialmente en el sector laboral- y "apertura al exterior", van a repercutir de manera heterogénea en el quehacer agropecuario, pero en forma negativa para los pequeños y medianos productores.

Efectivamente, la eliminación de organismos estatales reguladores, “...precios internacionales relativamente bajos agravados por la sobrevaluación del peso, costos internos en alza básicamente por el aumento de las tarifas de los servicios y una presión impositiva creciente a pesar de la rebaja de las retenciones a las exportaciones, incidieron significativamente sobre la rentabilidad del sector agropecuario" (Giarraca y Teubal, 1997:103).

Esta realidad se completa con la situación financiera, donde las tasas de interés bancario muy elevadas, otros costos que incluye el crédito bancario, más los intereses exorbitantes provenientes de gastos de endeudamiento, van a tornar a los créditos pendientes -tomados particularmente por los pequeños productores-, en muchos casos en impagables por usurarios, pero sí desde luego, a costa de la pérdida de los bienes patrimoniales. Ésta resultó ser la 
situación de aquellos productores que, para "modernizarse", optaron por endeudarse (Giarraca, 2001).

En el contexto de esta etapa económica crítica, es cuando entra en escena la mujer, ya sea en calidad de esposa del productor, de trabajadora familiar o de jefa de explotación. Los resortes que impulsan al género femenino a salir de manera decidida y pública en defensa de su patrimonio familiar son difíciles de comprender en su totalidad, debido a su complejidad. No obstante, da la impresión de que la causa primaria es de índole cultural, de acuerdo con los roles asignados tradicionalmente a cada sexo sobre la forma de actuar y desempeñarse en el medio rural. En este sentido, pareciera que al varón, por una actitud vergonzante, le resulta muy difícil oponer resistencia a la ejecución de una deuda; en cambio, la mujer, ante una deuda confiscatoria y por ende injusta, es capaz de oponerse abiertamente a la ejecución de la misma, debido a que está más dispuesta a defender por sobre todas las cosas el patrimonio de su familia.

Este cuadro de situación descripto se va a reproducir en nuestro espacio de estudio, especialmente en la localidad de Coronel Moldes y su zona rural de influencia. Aquí también se va a gestar un movimiento impulsado por la mujer en defensa de sus establecimientos.

Nuevamente recurrimos a la persona anteriormente citada, dado que formó parte de ese movimiento.

Comentaba que, a raíz del gran endeudamiento contraído por varios de los pequeños productores de la zona -muy difícil de amortizar-, alrededor de 1997 se reunieron de manera espontánea un grupo de diez a quince mujeres en defensa de sus intereses familiares y crearon la Asociación de Mujeres de Coronel Moldes (AMCOM), en conexión con el grupo original de Winifreda (La Pampa) que inició estas demandas, y que a esa fecha ya se había convertido en un movimiento a nivel nacional.

Si bien la asociación citada -a la cual también se acercaron mujeres de Huinca Renancó y Laboulaye- no se plasmó formalmente, sirvió de centro de reunión para analizar las deudas pendientes y solicitar a la sucursal del Banco Nación (principal acreedor) la explicación pormenorizada de las mismas, donde saltaba a la vista que el monto sobredimensionado de lo adeudado estaba teñido de numerosas irregularidades contables.

En la zona realizaron una serie de acciones, como la toma del Banco Nación, asambleas y paradas frente a los campos por rematarse, donde estorbaban el procedimiento, logrando evitar en varias oportunidades la ejecución de los mismos. 
Al principio la población en general de la localidad miraba con indiferencia y a veces con animadversión estas movilizaciones, pero paulatinamente fueron aceptando a estas mujeres y sus actuaciones públicas.

Hubo también una participación del grupo de Coronel Moldes a nivel nacional, en coordinación con los movimientos surgidos en otras provincias, con la finalidad de solicitar la refinanciación de las deudas contraídas (en la Cámara de Diputados, en la sede central del Banco Nación, etc.).

El movimiento en el plano nacional, aparte de gestar una propuesta de lucha específica de características defensivas, también presentó proclamas contra la política agropecuaria del momento, por considerar que favorecía la concentración de la tierra, y contra la privatización del Banco Nación.

Actualmente, el grupo de Coronel Moldes está disuelto y se desarmó cuando, aparentemente, se entrecruzaron diferentes visiones políticas. No obstante, se mantienen las conexiones originales.

La referente citada agregaba, a modo de conclusión, que dentro de la profundización de la política neoliberal de la década del '90, de clara tendencia hacia la concentración económica, todo indicaba que subyacía en este subespacio, como en otros de la Región Pampeana, la intencionalidad y la posibilidad de acaparar grandes extensiones de tierra por parte de grandes grupos económicos nacionales e internacionales, y que para lograr estos fines se atacó a los eslabones más débiles de la cadena, que venían a ser los pequeños productores endeudados, con la connivencia de gerentes de bancos, jueces y abogados.

Actualmente varios productores todavía están enfrentando juicios pendientes.

Por último, en esta zona -relataba otra referente consultada-, el sector de los tamberos resultó especialmente perjudicado, ya que después de participar -crédito bancario mediantede la tecnificación general a la que accedió gran parte de los pequeños productores, se endeudaron nuevamente al comprar "equipos de frío", inducidos por SanCor, con la finalidad de evitar la rápida descomposición de la leche. Como no hubo una política clara de financiación de estos sistemas de enfriado, varios de ellos para pagar la deuda contraída -más las otras obligaciones que también tenían pendientes- tuvieron que vender campos y perdieron sus casas, que quedaron en poder del Banco.

En síntesis, éstos fueron los avatares que atravesaron varios de los pequeños y medianos productores de la zona aludida, que dieron lugar a la conformación del movimiento de mujeres mencionado. 


\subsubsection{Consideraciones finales}

A lo largo de estas páginas, hemos tratado de desarrollar los avances progresivos sobre el protagonismo de la mujer, específicamente de aquella que está relacionada con el productor agropecuario, en todos los ámbitos donde se desenvuelve dentro del medio rural. Ahora queremos volcar algunas reflexiones y opiniones, incluyendo algunas consideraciones que involucran también al género femenino en general.

Entendemos que es fundamental valorar en la mujer sus aptitudes y capacidades y a su vez valorarse ella misma, respetando sus propios ritmos en el sentido de considerar que además de sus obligaciones tradicionales inherentes a su condición de madre y organizadora del hogar, puede desempeñar tareas y funciones sumamente beneficiosas, acorde con sus habilidades y disponibilidad de tiempo.

Asimismo, debe mediar una inquietud propia por parte de la mujer, con el objeto de incrementar su educación, como instrumento central, a fin de ganar espacios protagónicos en el núcleo familiar y en la comunidad en general.

En este sentido, también debe esmerarse por seguir ganando espacios públicos, a través de actuaciones político-gremiales. Es evidente que el mayor desafío para la mujer en la actualidad, aparte de sostener sus reivindicaciones y luchas, pasa por imaginar y diseñar nuevos escenarios alternativos, que la posicionen favorablemente ante las futuras problemáticas y realidades sociales.

Con respecto al mundo rural propiamente dicho, y en el caso de los productores agropecuarios que requieren especialmente mano de obra, es recomendable que pongan énfasis en tender una mirada despojada de prejuicios hacia la mujer, aprovechando de ella sus potencialidades para el trabajo productivo, con el cuidado de no convertirla en un ser “explotado" más.

A su vez, es de vital importancia revertir la desestimación de la mujer en las políticas destinadas al sector agropecuario, aunque existen algunos amagues por enmendar esta falencia. Está muy claro que quedan al margen de los beneficios -cuando éstos existen- que ofrecen las políticas agropecuarias, ya que hay una marcada preferencia por el productor masculino en los distintos servicios que presta el Estado al sector. Es imprescindible que las políticas agropecuarias consideren a la mujer, tanto en lo legal y económico, como en el acceso al crédito, a la asistencia técnica, productiva, comercial y a la capacitación. Justamente sobre este último aspecto se debe hacer especial hincapié. Si bien algo se viene realizando al respecto, es de suma importancia incrementar la capacitación de la mujer en el manejo de las actividades agropecuarias, a través de talleres especializados en este sentido. Tiene que 
mediar un asesoramiento permanente que favorezca la inserción y crecimiento laboral del género femenino en el medio rural. En síntesis, se la debe ayudar a capacitarse y, a su vez, ella misma debe requerir esa capacitación.

En relación con las posibles políticas que se instrumenten para beneficio de la mujer, aparte de las consideraciones globales donde se involucre a todas ellas, se deben contemplar con cuidado las diferencias socio-económicas del mundo femenino rural, lo que va a requerir políticas específicas orientadas a los intereses y posibilidades de cada estrato social donde éstas estén insertas.

Por otra parte, el sector laboral femenino merece y requiere un aliento y espacio más amplio por parte de la conducción de las organizaciones corporativas, tales como cooperativas y asociaciones gremiales.

En concreto, la importancia de la valoración de la mujer debe cubrir varias facetas: en el cuidado del hogar, en el trabajo productivo y en la actuación política.

Es trascendente, a su vez, sembrar conciencia a diferentes escalas: en ellas mismas, en el seno del hogar, en la comunidad donde están insertas y en el plano institucional privado y estatal.

En suma, es de suponer que la ampliación del proceso reivindicativo de la mujer debe seguir avanzando desde el propio núcleo activo que promueve estos avances, y el resto de la sociedad -conformada por hombres y mujeres no intervinientes en este proceso- disponer de buena voluntad para comprender este fenómeno y ayudar a tal fin.

En última instancia y desde la visión geográfica, todo el conjunto de actuaciones y reivindicaciones que explicitamos, tienen una proyección socio-espacial, porque en todos los sucesos y modificaciones territoriales que se están llevando a cabo, la mujer como sujeto social emergente, a la par del varón, es la que produce hechos y cambios espaciales voluntaria o involuntariamente. Dicho de otro modo, si bien es muy difícil captar su marca particular en el territorio, si consideramos que es una de las dos caras que conforman el género humano, testigo y actor indiscutible de los fenómenos y modificaciones geográficas; por lo tanto, su valoración como parte del todo asume otra dimensión.

\subsection{Las clases sociales del sector agropecuario, en relación con su inserción socio-laboral}

La presente descripción, de base esencialmente cualitativa, es una aproximación analítica a la estructura social particularmente de los productores agropecuarios que se desempeñan en nuestra área de estudio. 
Una vez concluida, en páginas anteriores, la caracterización de los actores sociales rurales intervinientes en el sur cordobés, la idea parte del propósito de ordenar a los mismos en una escala de jerarquías socio-ocupacionales dentro de la estructura social correspondiente. Para ello, es pertinente precisar, en primer lugar, lo que entendemos por clases sociales.

Partimos del concepto de considerar a las clases sociales como una de las formas, no la única, de comprender y tratar a la estructura social. En lo específico, interpretamos a la estructura de clases como las relaciones que establecen los diferentes agentes sociales con los medios de producción, sin desestimar otros aspectos concomitantes, como vínculos de jerarquía, tipo de existencia, nivel económico, autoidentificación y otros. Pero lo que le da sentido al concepto de clase es su conexión con el proceso productivo que genera la sociedad. En este sentido, Torrado se expresa diciendo: “...definimos, teóricamente, a las clases sociales como subconjuntos de agentes que ocupan una posición social análoga en el proceso de producción económica” (Torrado, 1992:35). A su vez, Germani dice: “...se acepta comúnmente que las clases sociales están constiuidas por determinadas ocupaciones o grupos de ocupaciones" (Germani, 1987:140).

En suma, el vínculo conceptual de las clases sociales con la estructura ocupacional es estrecho.

Asimismo, se debe tener en cuenta que la estratificación de las clases sociales no es una mera disposición de estratos superpuestos, sino que responde más bien a las permanentes contradicciones internas que se manifiestan en el sistema social. Por tanto, "las estratificaciones están basadas en las relaciones entre las clases y tienden a reflejarlas" (Stavenhagen, 1971:38). En concreto, la estructura de clases que pretendemos determinar, en esta oportunidad, va a estar representada por la PEA Agropecuaria del área de estudio.

Es pertinente precisar que, ante la insuficiencia de datos estadísticos departamentales sobre los diferentes grupos de agentes rurales que componen la PEA Agropecuaria del sur cordobés, en esta instancia, nos limitaremos a describir, en primer lugar, de manera teórica, la composición cualitativa de la estratificación social que conforma toda la PEA Agropecuaria de la zona $\mathrm{y}$, en segundo lugar, mediante la cuantificación en términos indirectos, la estratificación referida exclusivamente de los productores rurales del sector.

Antes de entrar en los aspectos específicos que acabamos de mencionar, cabe recordar que son muchos los cambios que se vienen produciendo, desde hace varias décadas, en la estructura agraria y social del área pampeana y, por ende, de nuestra región. En este sentido, se debe tener presente que las clases no son inamovibles en el tiempo y que sus perfiles responden al momento histórico en que se desenvuelve cada sociedad. Es así como algunas 
situaciones o estereotipos de realidades sociales, encasilladas tradicionalmente en ciertos niveles de análisis, merecen ser consideradas a la luz de los fenómenos que se perciben en la actualidad. Por ejemplo, siempre se han diferenciado las estratificaciones que corresponden al sector urbano de las del sector rural. No obstante, si bien persisten básicamente diferencias, ahora, como consecuencia del proceso de globalización en expansión, especialmente en los sectores agrícolas más dinámicos, muchas de las mismas se han diluido bajo un marco regulatorio de tipo burgués. En concreto, la estructura de clases entre el medio urbano y rural no discrepa tanto en la actualidad, como sí se manifestaba hasta hace unas décadas atrás. Lo dicho vale sobre todo en los ámbitos rurales más evolucionados, donde las relaciones de producción corresponden a una relación totalmente salarial.

Ayuda, indudablemente, a este acercamiento de uniformidad entre los dos grupos de clases sociales de ámbitos diferentes, el derrame de numerosas pautas urbanas en el medio rural y la separación tajante en éste de la economía doméstica de la producción comercial. No obstante, se debe tener presente que todavía median, en última instancia, diferencias intrínsecas entre estos dos medios de producción mencionados.

Por otra parte, dentro de las últimas modificaciones observables en la estructura de las clases rurales, cabe resaltar la repercusión que ha tenido el extraordinario valor adquirido por la tierra en los últimos tiempos, como consecuencia del proceso de sojización y de la demanda general de otros granos, especialmente en el área pampeana. Este fenómeno se traduce en el incremento notable del capital constante en los propietarios rurales en general y asume especial importancia en los "pequeños productores propietarios", al disponer éstos de un capital en tierra que los ubica muy distantes de la figura empobrecida, que Germani atribuye a Giberti, cuando dice que éste estimaba, alrededor de 1950, "que los ingresos y el nivel de vida del campesino en una chacra media podrá considerarse muy inferior al que gozaban los obreros en un centro urbano" (Germani, 1987:167). Está claro que ese pequeño productor rural poseedor -a modo de ejemplo- de 100 a 200 ha en la llanura pampeana, en la actualidad, está lejos de ser un modesto chacarero propietario.

Además, no debemos olvidar que, desde principios de la década del '70 en adelante, debido a la conjunción de una serie de factores -ya expresados en detalle en otras partes de este trabajohubo un proceso de surgimiento de "contratistas capitalistas" y de "productores familiares capitalizados" -farmerización para algunos estudiosos- que “...dio origen a una estructura agraria con importante peso de los sectores medios, y a sistemas productivos de gran flexibilidad" (Aparicio et al., 1992:135). Pero se debe tener presente que, concomitantemente, hubo un descabezamiento de numerosos pequeños productores que salieron de la escena 
productiva, al no poder adecuarse a las nuevas pautas económicas imperantes en el agro. Es así como, en los últimos tiempos, a raíz de la concentración del capital en la estructura agraria fundiaria, inclusive muchos de los farmers arriba citados también desaparecieron de la escena productiva.

En suma, todos estos factores de cambio concurrieron a modificar, en parte, la estratificación social del agro pampeano.

\subsubsection{Esquema cualitativo de la estratificación social de la PEA Agropecuaria del sur cordobés}

A continuación, volcamos en el Cuadro $\mathrm{N}^{0} 58$, de forma esquemática, las diferentes clases y estratos sociales que, a nuestro juicio, conforman todas las fuerzas del trabajo rural en nuestra área de estudio. En el mismo, no figuran los totales de cada grupo socio-ocupacional, por carecer -como ya dijimos- de los datos estadísticos respectivos. De todos modos, nos pareció interesante proponer un orden tentativo de las fuerzas laborales concurrentes, como una forma de alcanzar una imagen jerárquica integral del conjunto laboral que nos interesa.

Cuadro $N^{\circ}$ 58. PEA del sector agropecuario según clases y estratos sociales, observable en el sur cordobés ${ }^{2}$

\begin{tabular}{|l|l|l|}
\hline \multicolumn{1}{|c|}{ Nivel social } & \multicolumn{1}{c|}{ Grupos laborales que lo integran } \\
\hline \multicolumn{1}{|c|}{ Clase alta (alta burguesía) } & Nivel superior & Grandes productores, entre 1.000 y 2.500 ha \\
\hline (burguesía media) & Nivel medio & Medianos y medianos grandes productores, entre 200 y 1.000 ha \\
\hline $\begin{array}{l}\text { Clase media autónoma } \\
\text { (pequeña burguesía } \\
\text { aautónoma) }\end{array}$ & Nivel inferior & $\begin{array}{l}\text { Pequeños productores hasta } 200 \text { ha y minifundistas } \\
\text { agropecuarias, fumigadores-aviadores, etc. }\end{array}$ \\
\hline $\begin{array}{l}\text { Clase media } \\
\text { dependiente } \\
\text { (pequeña burguesía } \\
\text { dependiente) }\end{array}$ & Nivel inferior & $\begin{array}{l}\text { Emplesionales de las ciencias } \\
\text { establecimientos) }\end{array}$ \\
\hline \begin{tabular}{l} 
Clase obrera autónoma subalternos (administración de establecimientos rurales) \\
\hline Clase obrera asalariada
\end{tabular} & Trabajadores por cuenta propia: alambradores, molineros, etc. \\
\hline
\end{tabular}

Fuente: Elaboración propia en base a los análisis sobre estructuras sociales de la fuerza del trabajo llevados a cabo por Gino Germani (1987) y Susana Torrado (1992)

2 Corresponde especificar que, para la diferenciación de categorías de productores por escala de extensión de sus EAPs, y, por ende, de clases y estratos, nos hemos basado en los criterios adoptados al respecto por Germani (1987) y por de Imaz (1965), pero adecuados a nuestra actual realidad analítica. 
Para tal fin, nos hemos apoyado básicamente en las estructuras sociales de la fuerza del trabajo elaboradas por Gino Germani, en su libro Estructura social de la Argentina, y en el libro Estructura social de la Argentina (1945-1985), de Susana Torrado.

Con respecto a la caracterización de nuestro cuadro, conviene aclarar que, para las diferenciaciones de jerarquías socio-ocupacionales en el caso de los productores rurales, nos hemos valido centralmente de las dimensiones por escala de extensión de las explotaciones. Si bien somos conscientes de las limitaciones de estos indicadores sobre tamaños de los predios, ${ }^{3}$ lamentablemente carecemos de otros elementos valorativos económicos concretos atinentes al capital total y a la capacidad productiva que detenta cada explotación pero, a falta de mayores precisiones estadísticas, consideramos que, como aproximación a la caracterización de los diferentes niveles sociales, "la clasificación de las explotaciones por superficie no deja de representar un reflejo [...] del control económico de la tierra" (Germani, 1987:159-160).

Por otra parte, en este tipo de estratificación que hemos construido, entendemos que no es necesario resaltar la variable referida a la tenencia de la tierra, en su doble manifestación de propietarios y arrendatarios tradicionales, con la connotación para esta última categoría de ocupar -a iguales dimensiones de explotaciones- un peldaño socioeconómico por debajo del de sus vecinos propietarios, dado que la variante de arrendatarios clásicos no tiene peso demográfico en la actualidad. En cambio, desde hace tiempo, se entremezclan profusamente propietarios que combinan tierra en propiedad con tierra en arrendamiento, arrendatarios accidentales, grandes arrendatarios capitalistas y contratistas de producción -que básicamente arriendan tierra bajo el sistema de contrato accidental-, donde las supuestas diferencias económicas por tenencia se diluyen sobremanera, motivo por el cual la figura del patrono, que es la que realmente nos interesa, la pasamos a denominar con el apelativo de productores, en nuestro esquema de estructura de clases. Dentro de esta denominación, quedan incluidas las diferentes sociedades comerciales rurales existentes.

Entrando en la descripción cualitativa concreta de las estratificaciones sociales de la fuerza laboral que reside en nuestro espacio geográfico, diferenciamos, en primer lugar, una clase alta, correspondiente a la alta burguesía, cuyos agentes están representados por los muy grandes productores, con explotaciones cuyas dimensiones están por encima de las 2.500 ha. En algunos casos, superan las 10.000 ha. Este grupo está constituido, en parte, por los terratenientes tradicionales, la oligarquía, según Germani, con residencia en Buenos Aires de

Como por ejemplo sobre la posesión por parte de un propietario de varias explotaciones y de la diversidad de cotizaciones que puede tener la tierra, según la calidad de la misma. 
varios de sus miembros ${ }^{4}, \mathrm{y}$ también por grandes empresarios agropecuarios con residencia en el área de estudio.

Luego viene la clase media autónoma, en cuyo nivel superior se ubican los grandes productores, con extensiones de tierra de entre 1.000 y 2.500 ha. A continuación, dentro de la misma clase, se desarrolla un nivel medio, con fuerte protagonismo socioeconómico en la región, donde se ubican los medianos y medianos grandes productores, con explotaciones entre 200 y 1.000 ha, y que en la actualidad -al igual que lo destacado por Germani en 1947se caracterizan porque en general emplean mano de obra fija. Cabe recordar que a estos productores medianos con residencia en el Dpto. Río Cuarto, José Luis de Imaz los denominó burguesía rural de base local (de Imaz, 1965:73).

Tanto el nivel medio como el superior antes nombrados corresponden a la burguesía media, que a fuerza de trabajo y de acumular capital, mediado dicho proceso por dos o tres generaciones, pudieron escalar en el área la actual posición de clase.

Finalmente, dentro de la clase media autónoma, se ubica el nivel inferior, correspondiente a la pequeña burguesía. Este estrato es compartido por los pequeños productores, con EAPs de hasta 200 ha y minifundistas, ${ }^{5}$ por un lado, y por agentes de servicios, por otro, bajo la figura de contratistas de servicios, profesionales de las ciencias agropecuarias, fumigadores-aviadores, etc. Todos estos agentes trabajan por su cuenta y poseen diversas dimensiones de capital propio motivo por el cual, eventualmente, pueden ubicarse en niveles sociales superiores al nivel inferior- y/o educación superior. En lo que respecta a los pequeños productores, en general, no utilizan mano de obra fija -aunque una gran cantidad de ellos se valen de los contratistas de servicios- y se diferencian claramente de la figura del minifundista, agente que, como tal -más allá de las numerosas pequeñas explotaciones que acusan los censos agropecuarios-, no prolifera en nuestra área. Cabe agregar que el minifundista de nuestra región, en calidad de pequeño productor con tierras insuficientes, o sea, por debajo de la unidad económica estándar del lugar, raramente se limitan sus ingresos al producido de su reducida EAP, sino que generalmente acrecientan sus ganancias con otras actividades económicas complementarias que le permitan sostenerse, a nivel de clase, dentro de la pequeña burguesía.

Las explotaciones de estos terratenientes se encuentran especialmente en el extremo sur de la provincia.

Se entiende, en esta instancia, por "minifundistas" a los poseedores de pequeñas EAPs, cuyas extensiones en hectáreas están por debajo de la "unidad económica estándar" del lugar. Se entiende por "unidad económica estándar" del lugar a la superficie mínima requerida por una pequeña explotación, dentro de las actividades agropecuarias clásicas o comunes que se practican en un lugar o región determinada, para que la misma sea rentable a nivel familiar. 
A continuación, cerrando el grupo de las capas medias -y siguiendo el criterio de Germani-, viene la clase media dependiente, con escaso peso demográfico, correspondiente a la pequeña burguesía dependiente, con un nivel superior representado por los administradores, mayordomos, profesionales que brindan dirección y apoyo técnico a los establecimientos, y un nivel inferior representado por los empleados subalternos de administración de establecimientos rurales.

Por último -siguiendo ahora a Torrado en las denominaciones de clases (Torrado, 1992:132)-, en la base de la pirámide se ubica la clase obrera autónoma, representada por los trabajadores manuales por cuenta propia, como alambradores, molineros, etc., y la clase obrera asalariada, en sendas vertientes de trabajadores calificados y no calificados, con la inclusión, en las dos instancias, de los asalariados fijos y temporarios.

\subsubsection{Estratificación social de los productores rurales del sur cordobés}

En este punto, el objetivo que se persigue consiste en valernos de los datos disponibles sobre cantidad y superficie de las explotaciones por escala de extensión de los departamentos del sur de Córdoba, que figuran en el Cuadro $\mathrm{N}^{\mathrm{o}} 34$ del Capítulo V del presente escrito, y adecuarlo con el fin de establecer una estratificación social exclusivamente de los productores rurales, de manera aproximada e indirecta, mediante la cuantificación -en porcentaje- de la cantidad de explotaciones que representa y la superficie en hectáreas que controla cada nivel de clase social de los agentes referidos (ver Cuadro $\mathrm{N}^{0} 59$ ).

Concretamente, se procura brindar otra mirada, con los mismos datos del primer cuadro mencionado, pero esta vez correlacionando las cifras del caso con cada nivel de clase social.

Por otra parte, si bien sabemos que los censos agropecuarios contabilizan explotaciones y no productores, y que estas dos categorías no son equivalentes -por razones ya explicadas anteriormente-, entendemos que puede considerarse, también de manera groseramente aproximada, la cantidad de explotaciones registradas como igual a la cantidad de productores.

A continuación, pasamos a la descripción evolutiva de las estratificaciones sociales de los departamentos que corresponden al sur cordobés, de acuerdo con los guarismos de los censos nacionales agropecuarios de 1969, 1988 y 2002.

En el caso del Departamento Río Cuarto, se observa:

- La mayor cantidad de explotaciones está representada, a lo largo de los tres censos, pero de manera decreciente, en el nivel inferior de los productores de la clase media. 
Cuadro $\mathrm{N}^{\circ}$ 59. Estratificación social en base a la cantidad y superficie de las EAPs de los productores rurales del sur cordobés, de acuerdo con los Censos Nacionales Agropecuarios de 1969, 1988 y 2002

\begin{tabular}{|c|c|c|c|c|c|c|c|c|c|c|c|}
\hline \multirow{3}{*}{ Dpto. } & \multirow{3}{*}{\multicolumn{2}{|c|}{ Nivel social }} & \multirow{3}{*}{$\begin{array}{l}\text { Grupos laborales } \\
\text { que lo integran }\end{array}$} & \multicolumn{8}{|c|}{ Censos Nacionales Agropecuarios } \\
\hline & & & & \multicolumn{2}{|c|}{1969} & \multicolumn{4}{|c|}{1988} & \multicolumn{2}{|c|}{2002} \\
\hline & & & & $\begin{array}{l}\text { Cant. de expl. } \\
\text { que representan }\end{array}$ & $\begin{array}{l}\text { Sup. en ha que } \\
\text { controlan }\end{array}$ & $\begin{array}{l}\text { Car } \\
\text { que }\end{array}$ & $\begin{array}{l}\text { de expl. } \\
\text { resentan }\end{array}$ & $\begin{array}{l}\text { Sup. } \\
\text { CC }\end{array}$ & $\begin{array}{l}\text { h ha que } \\
\text { trolan }\end{array}$ & $\begin{array}{l}\text { Cant. de expl. } \\
\text { que } \\
\text { representan }\end{array}$ & $\begin{array}{l}\text { Sup. en ha que } \\
\text { controlan }\end{array}$ \\
\hline \multirow{4}{*}{ Río Cuarto } & \multicolumn{2}{|c|}{ Clase alta (alta burguesía) } & $\begin{array}{l}\text { Muy grandes } \\
\text { productores con más } \\
\text { de } 2.500 \text { ha }\end{array}$ & $1,44 \%$ & $25,25 \%$ & \multicolumn{2}{|c|}{$1,79 \%$} & \multicolumn{2}{|c|}{$21,61 \%$} & $3,02 \%$ & $27,68 \%$ \\
\hline & \multirow{3}{*}{$\begin{array}{l}\text { Clase media } \\
\text { autónoma }\end{array}$} & $\begin{array}{l}\text { Nivel superior } \\
\text { (burguesía media) }\end{array}$ & $\begin{array}{l}\text { Grandes productores } \\
\text { entre } 1.000 \text { y } 2.500 \text { ha }\end{array}$ & $3,18 \%$ & $15,56 \%$ & \multicolumn{2}{|c|}{$4.65 \%$} & \multicolumn{2}{|c|}{$18,79 \%$} & $7,84 \%$ & $24,12 \%$ \\
\hline & & $\begin{array}{l}\text { Nivel medio (burguesía } \\
\text { media) }\end{array}$ & $\begin{array}{l}\text { Medianos y medianos } \\
\text { grandes productores } \\
\text { entre } 200 \text { y } 1.000 \text { ha }\end{array}$ & $31,41 \%$ & $39,90 \%$ & \multicolumn{2}{|c|}{$41,53 \%$} & \multicolumn{2}{|c|}{$45,70 \%$} & $44,50 \%$ & $39,03 \%$ \\
\hline & & $\begin{array}{l}\text { Nivel inferior (pequeña } \\
\text { burguesía) }\end{array}$ & $\begin{array}{l}\text { Pequeños } \\
\text { productores y } \\
\text { minifundistas menos } \\
\text { de } 200 \text { ha, }\end{array}$ & $63,97 \%$ & $19,29 \%$ & \multicolumn{2}{|c|}{$52,03 \%$} & \multicolumn{2}{|c|}{$13,90 \%$} & $44,64 \%$ & $9,17 \%$ \\
\hline \multirow{4}{*}{$\begin{array}{l}\text { Juárez } \\
\text { Celman }\end{array}$} & \multicolumn{2}{|c|}{ Clase alta (alta burguesía) } & $\begin{array}{l}\text { Muy grandes } \\
\text { productores con más } \\
\text { de } 2.500 \text { ha }\end{array}$ & $2,38 \%$ & $36,08 \%$ & \multirow{2}{*}{ 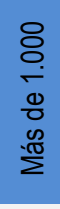 } & \multirow{2}{*}{$9,44 \%$} & \multirow{2}{*}{ 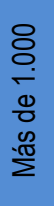 } & \multirow{2}{*}{$47,53 \%$} & $4,68 \%$ & $43,88 \%$ \\
\hline & \multirow{3}{*}{$\begin{array}{l}\text { Clase media } \\
\text { autónoma }\end{array}$} & $\begin{array}{l}\text { Nivel superior } \\
\text { (burguesía media) }\end{array}$ & $\begin{array}{l}\text { Grandes productores } \\
\text { entre } 1.000 \text { y } 2.500 \text { ha }\end{array}$ & $3,35 \%$ & $13,70 \%$ & & & & & $12,89 \%$ & $24,78 \%$ \\
\hline & & $\begin{array}{l}\text { Nivel medio (burguesía } \\
\text { media) }\end{array}$ & $\begin{array}{l}\text { Medianos y medianos } \\
\text { grandes productores } \\
\text { entre } 200 \text { y } 1.000 \text { ha }\end{array}$ & $33,54 \%$ & $34,51 \%$ & & $35 \%$ & & $11 \%$ & $44,39 \%$ & $26,33 \%$ \\
\hline & & $\begin{array}{l}\text { Nivel inferior (pequeña } \\
\text { burguesía) }\end{array}$ & $\begin{array}{l}\text { Pequeños } \\
\text { productores y } \\
\text { minifundistas menos } \\
\text { de } 200 \text { ha, }\end{array}$ & $60,73 \%$ & $15,71 \%$ & & $21 \%$ & & $36 \%$ & $38,04 \%$ & $5,01 \%$ \\
\hline
\end{tabular}


Cuadro N $^{\circ} 59$ (Continuación)

\begin{tabular}{|c|c|c|c|c|c|c|c|c|c|c|c|}
\hline \multirow{3}{*}{ Dpto. } & \multirow{3}{*}{\multicolumn{2}{|c|}{ Nivel social }} & \multirow{3}{*}{$\begin{array}{l}\text { Grupos laborales } \\
\text { que lo integran }\end{array}$} & \multicolumn{8}{|c|}{ Censos Nacionales Agropecuarios } \\
\hline & & & & \multicolumn{2}{|c|}{1969} & \multicolumn{4}{|c|}{1988} & \multicolumn{2}{|c|}{2002} \\
\hline & & & & $\begin{array}{l}\text { Cant. de expl. } \\
\text { que representan }\end{array}$ & $\begin{array}{l}\text { Sup. en ha que } \\
\text { controlan }\end{array}$ & & $\begin{array}{l}\text { it. de expl. } \\
\text { representan }\end{array}$ & & $\begin{array}{l}\text { en ha que } \\
\text { ontrolan }\end{array}$ & $\begin{array}{l}\text { Cant. de expl. } \\
\text { que }\end{array}$ & $\begin{array}{l}\text { Sup. en ha que } \\
\text { controlan }\end{array}$ \\
\hline \multirow{4}{*}{$\begin{array}{l}\text { Pte. Roque } \\
\text { Sáenz Peña }\end{array}$} & \multicolumn{2}{|c|}{ Clase alta (alta burguesía) } & $\begin{array}{l}\text { Muy grandes } \\
\text { productores con más }\end{array}$ & $3,39 \%$ & $37,38 \%$ & \multirow{2}{*}{$\begin{array}{l}8 \\
\\
\\
0 \\
0 \\
.0 \\
.00\end{array}$} & \multirow{2}{*}{$12,68 \%$} & \multirow{2}{*}{ 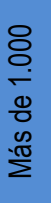 } & \multirow{2}{*}{$55,71 \%$} & $3,85 \%$ & $31,84 \%$ \\
\hline & \multirow{3}{*}{$\begin{array}{l}\text { Clase media } \\
\text { autónoma }\end{array}$} & $\begin{array}{l}\text { Nivel superior } \\
\text { (burguesía media) }\end{array}$ & $\begin{array}{l}\text { Grandes productores } \\
\text { entre } 1.000 \text { y } 2.500 \text { ha }\end{array}$ & $5,32 \%$ & $16,76 \%$ & & & & & $11,34 \%$ & $27,61 \%$ \\
\hline & & $\begin{array}{l}\text { Nivel medio (burguesía } \\
\text { media) }\end{array}$ & $\begin{array}{l}\text { Medianos y medianos } \\
\text { grandes productores } \\
\text { entre } 200 \text { y } 1.000 \text { ha }\end{array}$ & $42,23 \%$ & $35,32 \%$ & & $48,88 \%$ & & $36,38 \%$ & $47,36 \%$ & $33,64 \%$ \\
\hline & & $\begin{array}{l}\text { Nivel inferior (pequeña } \\
\text { burguesía) }\end{array}$ & $\begin{array}{l}\text { Pequeños } \\
\text { productores y } \\
\text { minifundistas menos } \\
\text { de } 200 \text { ha, }\end{array}$ & $49,06 \%$ & $10,54 \%$ & & $38,44 \%$ & & $7,91 \%$ & $37,46 \%$ & $6,91 \%$ \\
\hline \multirow{4}{*}{ General Roca } & \multicolumn{2}{|c|}{ Clase alta (alta burguesía) } & $\begin{array}{l}\text { Muy grandes } \\
\text { productores con más } \\
\text { de } 2.500 \text { ha }\end{array}$ & $5,18 \%$ & $44,57 \%$ & & $6,69 \%$ & & $45,08 \%$ & $8,16 \%$ & $47,25 \%$ \\
\hline & \multirow{3}{*}{$\begin{array}{l}\text { Clase media } \\
\text { autónoma }\end{array}$} & $\begin{array}{l}\text { Nivel superior } \\
\text { (burguesía media) }\end{array}$ & $\begin{array}{l}\text { Grandes productores } \\
\text { entre } 1.000 \text { y } 2.500 \text { ha }\end{array}$ & $9,01 \%$ & $21,86 \%$ & & $11,18 \%$ & & $22,95 \%$ & $13,64 \%$ & $24,22 \%$ \\
\hline & & $\begin{array}{l}\text { Nivel medio (burguesía } \\
\text { media) }\end{array}$ & $\begin{array}{l}\text { Medianos y medianos } \\
\text { grandes productores } \\
\text { entre } 200 \text { y } 1.000 \text { ha }\end{array}$ & $42,63 \%$ & $27,89 \%$ & & $45,82 \%$ & & $27,29 \%$ & $48,40 \%$ & $25,10 \%$ \\
\hline & & $\begin{array}{l}\text { Nivel inferior (pequeña } \\
\text { burguesía) }\end{array}$ & $\begin{array}{l}\text { Pequeños } \\
\text { productores y } \\
\text { minifundistas menos } \\
\text { de } 200 \text { ha, }\end{array}$ & $43,18 \%$ & $5,68 \%$ & & $36,31 \%$ & & $4,68 \%$ & $29,80 \%$ & $3,43 \%$ \\
\hline
\end{tabular}

Fuente: Elaboración propia 
- El mayor control en superficie de las explotaciones corresponde al nivel medio de la clase media, en los tres censos, con un control en ascenso en 1988, para descender bruscamente en 2002 .

- En suma, se puede inferir indirectamente que, en todos los censos, la mayor cantidad de productores corresponde al nivel inferior y los que acaparan mayor cantidad de superficie se ubican en el nivel medio. Cabe aclarar que, si contabilizamos conjuntamente los productores del nivel superior de la clase media y de la clase alta, o sea todos aquellos agentes que poseen predios por encima de las 1.000 ha, vemos que éstos pasan a disponer de mayor cantidad de superficie, tanto en el censo de 1969 como en el de 2002.

En el caso del Departamento Juárez Celman, se observa:

- La mayor cantidad de explotaciones está representada en el nivel inferior de la clase media en los censos de 1969 y 1988, y asciende al nivel medio en el censo de 2002.

- El mayor control de superficie de las explotaciones corresponde a la clase alta, en los censos de 1969 -supuestamente también en el censo de 1988, pero se carece del dato específico- y de 2002, con una acentuada concentración en superficie en este último censo.

- En síntesis, indirectamente, se puede inferir que la mayor cantidad de productores se ubica en el nivel inferior en los censos de 1969 y 1988 y, en el nivel medio en el de 2002. Por su parte, en todos los censos, los productores que ocupan la mayor cantidad de superficie de las explotaciones se ubican en la clase alta.

En el caso del Departamento Roque Sáenz Peña, se observa:

- La mayor cantidad de explotaciones está representada en el nivel inferior de la clase media en el censo de 1969, para desplazarse categóricamente al nivel medio en los dos censos siguientes.

- El mayor control en superficie de las explotaciones corresponde a la clase alta en el censo de 1969 -posiblemente, también en el de 1988-, y en el nivel medio en el censo de 2002.

- En suma, indirectamente, se puede inferir que la mayor cantidad de productores, del censo de 1969 en adelante, se ubica en el nivel medio de la clase media, y los productores que acaparan la mayor cantidad de superficie de las explotaciones se ubican, en 1969, dentro de la alta burguesía, y posiblemente también en 1988, para trasladarse al nivel medio de la clase media en el censo de 2002. Con la aclaración de que, si contabilizamos conjuntamente, en este último censo, a los productores del 
nivel superior de la clase media y a los de la clase alta, o sea, todos aquellos agentes que poseen campos por encima de las 1.000 ha, vemos que, rotundamente, son éstos los que pasan a disponer del mayor control de la superficie de las explotaciones.

En el caso del Departamento General Roca, se observa:

- La mayor cantidad de explotaciones está representada en el nivel inferior de la clase media en el censo de 1969, para desplazarse notoriamente al nivel medio, en los dos censos siguientes.

- El mayor control en superficie de las explotaciones corresponde netamente a la alta burguesía en los tres censos respectivos.

- En síntesis, se puede inferir, indirectamente, que la mayor cantidad de productores se sitúa, a partir de 1988, claramente en el nivel medio de la clase media, y los productores que poseen la mayor cantidad de superficie de las explotaciones se ubican, en los tres censos, netamente en el sector de la clase alta, con porcentajes muy relevantes.

En suma, de manera aproximada, podemos decir que, en el sur de Córdoba, a lo largo de los tres censos mencionados, la mayor cantidad de productores, en general, ha ido desplazando su ubicación del Nivel Inferior al Nivel Medio de la Clase Media Autónoma Rural, o sea productores que contaban con explotaciones de menos de 200 ha han pasado a ocupar establecimientos de entre 200 y 1.000 ha. Si bien, en el Dpto. Río Cuarto, estrictamente, este desplazamiento no se efectúa pero sí se insinúa, en los restantes departamentos -especialmente Presidente Roque Sáenz Peña y General Roca- se hace evidente, lo que determina toda una tónica de estilo de vida y sistema de actitudes, correspondiente a una pequeña burguesía y burguesía media, en paulatino proceso de consolidación y maduración.

En lo que respecta a los productores que poseen la mayor cantidad de superficie de las explotaciones, vemos que, a lo largo de los tres censos, solamente en el Dpto. Río Cuarto se ubican en el nivel medio de la clase media; en cambio, en los otros departamentos, se sitúan casi sin excepción, en el nivel social de la alta burguesía, con porcentajes relevantes. Aquí la clase alta -en relación con el tamaño de las explotaciones- está bastante alejada de los niveles medio o inferior de la clase media rural.

Queda, por último, la necesidad de reafirmar que, para un encuadre analítico integral de clase social, las valoraciones cuantitativas anteriormente detalladas, en función del nexo socio-ocupacional que ocupan los agentes implicados, obviamente resultan insuficientes, al no incluir en el análisis las otras variables sociales ya nombradas más arriba en este acápite, que 
permitirían ajustar sólidamente el perfil social de estructura de clase de los diferentes grupos humanos que nos interesan. Al carecer de información cuantitativa sobre estas variables, nos hemos abocado, en esta instancia, con las pocas herramientas disponibles, a realizar simplemente un encuadre de estratificación social limitado.

\subsection{La dimensión cultural en el paisaje agrario}

El interés que nos anima en este punto consiste en describir el espacio humanizado inmediato que cobija a los actores sociales anteriormente analizados, correspondiendo dicho espacio al paisaje agrario en nuestro caso. Para ello, partimos del concepto de "paisaje" como esa "expresión del territorio que percibimos a través de los sentidos" (Chiozza, 2006:88), en el que desarrolla su trajinar la sociedad del lugar y en el que deja sus huellas mediante sucesivas transformaciones del mismo.

Aquí podemos decir que entramos al revés en el tema, en el sentido de que parte de los fenómenos y razones que dieron lugar al paisaje de nuestro interés ya fueron explicados y/o analizados en el transcurso de este trabajo, a diferencia de los estudios clásicos de la geografía cultural, que inician su procesamiento analítico de lo acaecido en el paisaje a partir de los elementos observados en el mismo.

Esto quiere decir que, en esta instancia, básicamente nos limitamos a describir en lo "cercano" las huellas de la sociedad en general y de los agentes rurales de nuestro ámbito en particular, que modelaron el área de nuestro estudio, desde una dimensión cultural.

En concreto, la idea es tomar al paisaje agrario como "punto de referencia", como amarre de los vínculos que establece la sociedad rural con su medio de vida, la tierra, en el sentido más amplio del término; ver cómo dicha población se expresa en el paisaje, en ese espacio cercano, cómo lo vive y qué representan los lugares para ella.

Por lo tanto, nuestro propósito a desarrollar sobre esta temática consiste en brindar una descripción sucinta y esquemática del paisaje agrario donde se asienta el sur cordobés, ${ }^{6}$ a modo de marco referencial desde donde poder constatar, a modo de ejemplo, que pueden mediar diferentes miradas del paisaje en cuestión, como: a) una mirada objetiva en el plano de la funcionalidad útil que brindan las materialidades del paisaje; b) una mirada en el plano de las representaciones que los individuos vuelcan en el paisaje; c) una mirada arqueológica en el

\footnotetext{
${ }^{6}$ Cabe agregar que, durante y dentro de los diferentes proyectos de investigación a nuestro cargo, llevados a cabo en el área, incorporamos en su oportunidad a varios becarios para que realizaran el relevamiento del "paisaje agrario" en detalle de diversos sectores del mismo, motivo por el cual incorporamos en el Anexo, como un aporte metodológico, una serie de cuadros indicativos para el relevamiento respectivo.
} 
plano de las diferentes temporalidades que cargan las formas visibles en su transitar histórico, y d) una mirada de los individuos desde adentro del paisaje, o sea, cómo éstos se sienten involucrados dentro del mismo. Todas estas formas de ver, a su vez, se concatenan con las diferentes lógicas factibles de explicar en la estructuración de nuestro espacio humanizado, a fin de captar lo mejor posible la dimensión cultural que se observa en el mismo. En tal sentido, resulta relevante destacar la existencia de una lógica funcional, en el plano de los aprovechamientos económicos, del confort de vida y convivencia social que deja traslucir el paisaje; una lógica simbólica, en lo referente al significado de la vida que poseen los grupos humanos y cuyos ideales, sentimientos y anhelos, a modo de representaciones, se expresan espacialmente; una lógica temporal, en el sentido de distinguir el significado de los diferentes estratos temporales, de las formas visibles que atraviesan diferentes períodos históricos y que perduran y se superponen en el paisaje, y una lógica existencial, en el sentido de cómo los individuos implicados sienten su ser a partir de estar involucrados en el paisaje y formar parte del mismo (Besse, 2010).

Antes de entrar en el desarrollo de lo arriba expresado, nos parece pertinente explayarnos conceptual y brevemente sobre el significado de lo que entendemos por paisaje geográfico, a fin de engarzar epistemológicamente, de la mejor manera, con la descripción de nuestro paisaje agrario.

Debemos tener presente que el estudio de los paisajes corresponde -entre otras disciplinas- a una temática clásica de la geografía cultural, pero no es el único tópico que trata la misma, ya que son muchos los procesos culturales que se desarrollan en el espacio geográfico y no por ello se manifiestan en el paisaje. Es más, en diversos casos, el accionar de las culturas no se limita al paisaje, sino que va mucho más allá; puede llegar a incidir en la conformación de la existencia, o no, de un territorio determinado. Por ejemplo, “...sin el cristianismo, no existiría el estado etíope" (Claval, 1999:270).

No obstante, a pesar de que la dimensión de los fenómenos culturales sobrepasa la visibilidad de lo que deja trasuntar un paisaje, la descripción de éste como una primera aproximación a la captación de las diversas improntas que deja la sociedad en el espacio no deja de tener su real importancia.

En este sentido, es interesante destacar que "los paisajes llevan la huella de la cultura y la influencian al mismo tiempo" (Claval, 1999:270); a su vez, la cultura oficia, o puede oficiar -entre otras funciones y finalidades-, como marco referencial de la territorialidad. Asimismo, entre sus diferentes formas de manifestación perceptiva, el paisaje refleja, entre otros aspectos, "la organización social del trabajo" (Galfioni, 2010:11), así como las costumbres, 
tradiciones, creencias, actitudes, aspiraciones que los grupos humanos elaboran en sus representaciones también tienen su expresión espacial. De igual modo, los paisajes, más allá de sus funcionalidades prácticas y económicas, albergan una serie de significaciones, donde "el pasado coexiste con el presente" (Claval, 1999:213) como testimonio de su complejidad estructural.

Con respecto a las diferentes formas en que puede expresarse un paisaje, nos interesa destacar, por ejemplo, las limitaciones que conlleva la asociación clásica de relaciones hombre/medio, donde se comprueba, en muchos casos, que los fenómenos culturales logran disociarse de los factores naturales y alcanzan autonomía propia. Estas realidades las detectó muy bien Pierre Gouru (1973), demostrando que la vigencia de ciertas prácticas culturales puede provenir de otros lugares de origen como arrastre de costumbres y, por lo tanto, están despegados de la relación hombre/medio. Un ejemplo paradigmático de lo anteriormente dicho, en nuestra área de estudio, representó el cultivo de trigo como grano principal, llevado a cabo por inmigrantes ítalo-austríacos en los inicios de la colonia de Sampacho -ubicada 50 kilómetros al sudoeste de Río Cuarto- donde, a pesar de ser una zona más apropiada para los cultivos de verano, se impuso el peso cultural de sembrar el grano que más se conocía y apreciaba, perduración de costumbres que no deja de representar-océano de por medio- una manifestación simbólica.

Nos preocupa también resaltar que hay un paisaje cultural ideologizado por las superestructuras del poder que ocultan, "mediante una serie de artificios imaginarios, la realidad de los conflictos sociales y políticos" (Besse, 2010:3), o sea, las causas de las desigualdades socio-territoriales.

Esta situación la explica magistralmente Raymond Williams (2001), cuando destaca cómo la burguesía terrateniente del siglo XIX, en Inglaterra, en franca expansión durante la revolución industrial, disfraza la explotación abusiva del campesinado y el vaciamiento productivo de la campiña británica, mediante un enmascaramiento literario de representación idílica y bucólica de los paisajes agrarios, acompañado de fuerte encantamiento de paz y armonía reinando en los mismos, lo que implica que, para conjurar todos estos ocultamientos, debe mediar una perspectiva deconstructivista de posicionamiento crítico, que permita desactivar las desfiguraciones de la realidad social del espacio humanizado "y a buscar detrás de las representaciones paisajísticas los procesos históricos que les dieron origen" (Besse, 2010:3).

Una vez vertidas estas conceptualizaciones básicas, pasamos a continuación a describir de manera esquemática el paisaje agrario de nuestra área de estudio como expresión cultural, 
para proseguir luego con la caracterización de las diferentes lógicas que se manifiestan en su configuración.

\subsubsection{Breve descripción, a modo de marco referencial, de nuestro paisaje agrario}

Dentro de nuestra porción de llanura pampeana, tenemos un sustrato natural muy variado, en consonancia con la diversidad de ambientes naturales de la región. Dicho sustrato, a su vez, está muy modificado por las transformaciones antrópicas acaecidas en el área, pero no por ello deja de actuar de tanto en tanto, generando importantes alteraciones ambientales, muchas de ellas activadas por el accionar del hombre.

Se observa, en el paisaje, un "parcelario" de diferentes tamaños, cuyas dimensiones suelen guardar cierta proporcionalidad con la magnitud real de las explotaciones. Muchas de las parcelas -equivalentes a potreros, en algunos casos-, con características de abandono -que fueron descriptas en más de una oportunidad en capítulos anteriores- acompañadas con viviendas desocupadas, alambrados caídos y tranqueras clausuradas, da a entender indirectamente la ampliación en tamaño que vienen registrando numerosos establecimientos, ya sea por compra o arrendamiento de campos, vecinos o no.

La forma que asume el parcelario es de tipo geométrico, en cuadrados o rectángulos -a fin de facilitar el trabajo y la mensura- conformando una suerte de enrejado como dibujo final en el terreno. El cercado perimetral de las EAPs dispone en general de un alambrado en buenas condiciones, disminuyendo dicha calidad en el cercado de los potreros. Es visible que hay un orden y un criterio distributivo interno de la tierra dentro de los establecimientos.

De acuerdo con la producción que dejan traslucir los campos, vemos, en primer lugar, una preponderancia marcada de la agricultura sobre la ganadería -observable en algunos casos por la falta de alambrado interno dentro de las propiedades-; en segundo lugar, una supremacía de los cultivos de verano sobre los de invierno y, en tercer lugar, la prevalencia de la actividad mixta en las EAPs, con algunos establecimientos tamberos ubicados en ciertos sectores de la región de trabajo.

Es dable también observar una infraestructura productiva dispersa en nuestro paisaje, como: aguadas artificiales embalsadas con paredones de tierra, bebederos con y sin tanque australiano, los clásicos molinos de todos los tamaños y edades, algunos silos fijos de chapa, generalmente en predios de EAPs grandes, y una gran proliferación de "silos bolsa" esparcidos por todos los campos. También en nuestra área se observan algunas cremerías 
abandonadas -en zonas de cuencas lecheras venidas a menos-, unas pocas acopiadoras, fábricas lácteas y frigoríficos, en sectores disociados de los centros urbanos pueblerinos.

En este inmenso cuadriculado de parcelas que se abre a la vista del pasante, vemos de tanto en tanto que alternan formaciones forestales exóticas, distribuidas de manera puntual. En muchos casos corresponden a plantaciones añosas que ocupan varias hectáreas de la planicie. Sin duda, estas formaciones arbóreas ayudan a romper la monotonía del relieve y le imprimen belleza a la llanura.

En lo que respecta a las obras de ingeniería presentes en el área, se puede decir que es sumamente variada. Sobresale una red eléctrica sostenida por postes de tipo estándar, que se extiende por todos los campos. Es explotada por cooperativas eléctricas ubicadas en ciertos pueblos, que proveen de energía a la mayoría de los establecimientos rurales de la región. A su vez, atraviesa el área una red eléctrica provincial, sostenida por grandes torres de primer orden, para servicios generales.

Se detecta también en el área algunas antenas retransmisoras de diferentes dimensiones. Cuenta, asimismo, este espacio, con el trazado de canales de drenaje -revestidos algunos y otros no- que en varias oportunidades, en las grandes avenidas, no alcanzaron a contener el derrame de las aguas.

A nivel de estructuras edilicias no vinculadas a las actividades agropecuarias, se observan algunas pocas escuelas rurales -en general en buen estado de conservacióndispersas por el área y algún almacén situado sobre la vera de los caminos principales.

Dentro del amplio espacio que nos atañe, el mismo está atravesado por importantes rutas nacionales, tanto en el sentido este-oeste, como sur-norte, encontrándose asfaltadas y en diferentes estados de mantenimiento. Asimismo, se debe contabilizar un cierto número de rutas provinciales, asfaltadas y de tierra compactada, de buenas a regulares condiciones, acompañadas por una intrincada red de caminos rurales troncales y vecinales, administrados por diversos consorcios camineros de la zona, cuyo estado de mantenimiento, especialmente los caminos vecinales, en general, suele ser deficientes.

Queda, por último, mencionar el trazado ferroviario que, como se recordará, formaba una relativamente densa red de vías paralelas, que surcaban especialmente en el sentido esteoeste todo el centro y sur provincial. Como se sabe, la mayoría de estas vías, al no circular los trenes actualmente, están fuera de servicio e inclusive en algunos tramos los rieles están desclavados del terreno.

Con respecto a la distribución del "hábitat rural" (vivienda más entorno complementario), ésta se manifiesta claramente dispersa -en concordancia con la distribución 
general de la población rural-, sin desestimar que median también algunos pocos caseríos, con una relación bastante estrecha entre la calidad de las viviendas y las dimensiones de los establecimientos donde éstas se encuentran. En este sentido, podemos observar, en general, que las viviendas que corresponden a las pequeñas y medianas EAPs son de estructura sencilla, sin estilo arquitectónico, salvo en algunos casos de viviendas construidas en las últimas décadas, que asumen el aspecto de chalets tipo californiano, cuyas líneas de diseño representan buen gusto. En general, son casas sólidas, de paredes de ladrillo, muchas de ellas con varios años de antigüedad, con techos altos de chapa o tejas, y si la vivienda es más nueva, aparece coronando la misma la losa. En pocos casos, cuentan con galería, poseen formato sencillo, dos a cuatro dormitorios, con la característica de que casi siempre la cocina y el comedor están fusionados. Los ambientes, en general, son amplios y, en varios casos, se evidencia que la vivienda fue construida en distintas etapas. Corresponde recordar que el confort interno fluctúa entre aceptable a muy bueno.

En relación con el entorno que rodea a la casa, es válido destacar que, en la mayoría de los casos, la misma está rodeada por una cortina de árboles diferentes. En conjunto, viendo estas formaciones arbóreas desde lejos, se asemejan a agradables islas plantadas en el medio de la llanura circundante, con algún techo sobresaliendo por algún rincón.

Pasando ahora a las dependencias contiguas a la vivienda, muchas de ellas cuentan con un pequeño jardín inmediato, distribuyéndose a su alrededor, eventualmente, alguna vivienda secundaria de menor jerarquía, posible gallinero y porqueriza, y también estanque con molino asociado, con o sin tanque australiano contiguo. Rodean a la casa, asimismo, corrales y galpones y, si la EAP practica la agricultura, es probable que cuente con taller mecánico y con silos fijos.

En lo atinente a las viviendas de las grandes EAPs, obviamente presentan una edificación muy superior. Aquí aparecen, en el área de trabajo, muchos cascos de estancia de gran jerarquía arquitectónica y de dimensiones edilicias considerables, con un confort general de primer nivel, rodeados en algunos casos por verdaderos parques artificiales. Todas las dependencias que rodean a estas propiedades guardan proporcionalidad de calidad y tamaño en relación con los cascos. Por cierto que hay también grandes establecimientos que cuentan con viviendas menos lujosas y más sencillas, pero casi siempre de importante presencia edilicia. En concreto, media un pronunciado desnivel de magnitud y calidad del hábitat entre los pequeños y grandes establecimientos.

Cabe, por último, referirnos a la disposición y características morfológicas de los pequeños centros urbanos ubicados dentro del paisaje agrario, dado que en general guardan 
una correspondencia estrecha. Con respecto a su descripción, es conveniente marcar dos instancias, una referida a su evolución clásica, con sus características tradicionales, y la otra, referida a los cambios por los que vienen atravesando muchos pueblos en la actualidad. En relación con la primera instancia, cabe recordar que los pueblos de nuestra área, a semejanza de la mayoría de los que se esparcen por la llanura pampeana, tienen un origen similar, ya sea a partir de una estación ferroviaria, de un paraje preexistente, de un antiguo casco de estancia o de un previo loteo para una colonia agrícola a implementar. En general, surgieron -como ya lo puntualizamos en otro capítulo- a partir de fines del siglo XIX y principios del XX. Su morfología clásica consta de una estructura en damero, pero a diferencia de los pueblos de origen colonial del país, sus calles y veredas son anchas, sus plazas generalmente son de grandes dimensiones en relación con el tamaño de la localidad, con alguna que otra diagonal $\mathrm{y}$, a veces, también aparece un boulevard, con pretensiones de embellecer el entramado. A su vez, su planimetría -en varios casos- es segregacionista, dado que "del otro lado de la estación ferroviaria" opuesto al casco principal se ubica el barrio pobre de la localidad.

La mayoría de las viviendas suelen ser amplias y de una sola planta, de fachada sencilla $\mathrm{y}$, en su aspecto grueso, muy parecidas unas a otras. En relación con la cantidad de habitantes de la localidad, la planta urbana en general está muy extendida $\mathrm{y}$, por sus bordes, penetra el campo, ubicándose en dicho perímetro instalaciones relacionadas con las actividades agropecuarias, como silos, agroindustrias, predios de ferias y de asociaciones rurales, frigoríficos, galpones de almacenaje de productos agrícolas, comercios de maquinarias agrícolas, etc. En suma, en todas las localidades donde predomina una perspectiva de vida estática, se reproduce y despliega una "monotonía" en su formato y un ritmo bucólico muy evidente en su dinámica doméstica.

En relación con la segunda instancia, lo que queremos destacar es cómo, en las localidades más desarrolladas de nuestro espacio especialmente, la "ruralidad" como expresión perceptiva y real se va desdibujando y va adquiriendo una imagen urbana cada vez más progresiva.

Edificios de propiedad horizontal, supermercados con aires de shopping y multiplicidad de nuevos comercios y servicios, son algunas de las tantas pruebas materiales que demuestran este avance de la forma de vida urbana sobre los pueblos más avanzados de la región. Da la impresión de que la población relacionada directa o indirectamente con el campo se atrinchera en estas localidades, buscando o pretendiendo alcanzar el mismo nivel de confort de las ciudades propiamente dichas. En suma, las poblaciones a las que hacemos referencia, sin perder sus condiciones de pivote de las áreas rurales a las que representan, están muchas de 
ellas en franco proceso de "aggiornamiento" y cambio de ritmo, de apariencia y de funcionalidad cada vez más urbana.

\subsubsection{Las diferentes lógicas que se manifiestan en la configuración de nuestro paisaje agrario}

Proseguimos ahora con la caracterización de las mencionadas lógicas, que interactúan en nuestro paisaje agrario, mediante algunos casos significativos de aplicación de las mismas, que distan de ser exhaustivos, pero que consideramos válidos como ejemplos de la realidad que queremos tratar.

Para la captación -a través de las lógicas- de la dimensión cultural en los espacios humanizados, resulta fundamental tener presente que en ellos se superponen lógicas múltiples, o sea que la incidencia de una no excluye a las otras (Claval, 1999).

Es importante agregar que, por ejemplo, la "funcionalidad" como lógica de un paisaje responde a "condicionantes maestros", como puede ser la incidencia de los factores naturales sobre un territorio y el accionar de posicionamientos ideológicos traducidos en políticas económicas que, actuando en diferentes momentos históricos, levantan las columnas directrices sobre las que se edificará un paisaje humanizado.

Como dijimos al principio del acápite, en esta instancia no remontamos el camino de la búsqueda de las causales a partir de lo que reflejan los espacios humanizados, sino que más bien nos limitamos a observar lo que los paisajes dejan entrever.

Aclarando estos puntos, pasamos al análisis específico prometido. Por ejemplo, la geometrización sistemática de los campos de nuestra área, las inmensas dimensiones de metódicos cultivos, las modernas instalaciones que se esparcen por la llanura, todo ello, obviamente, indica un criterio de aprovechamiento "funcional" del espacio, con clara orientación utilitaria, económica y vincular, a lo que se debe sumar una adecuación al medio -a veces no del todo lograda- en lo que respecta a las prácticas culturales agrícolas vigentes, a los ritmos de trabajo, al tipo de vivienda, a la convivencia y a los vínculos sociales establecidos entre sus habitantes, materializados en escuelas, clubes, centros de reunión, etc., teniendo presente que, generalmente, las pautas culturales vigentes resultan ser un producto -aunque no invariablemente- de la relación hombre/medio.

Además de esta funcionalidad que dejan trasuntar las áreas rurales de nuestro entorno, las mismas, con sus predios prolijos y ordenados, transmiten signos de bienestar y progreso en 
paralelo con los avances de la modernidad -entendida esta modernidad como la última en tiempo presente-.

Hay un orgullo implícito y legítimo en el orden y prolijidad que "marca" el trabajo en el espacio rural proyectando, por ende, una "lógica simbólica" de prosperidad.

Cabe observar, a su vez, que la lógica funcional que opera en las áreas rurales no es neutra. Por ejemplo, en varios sectores de nuestra región, se puede constatar una serie de "tramos" de caminos carreteros -inclusive rutas nacionales- y de vías férreas, cuyo trazado, en su momento, se adecuó de manera que el recorrido de los mismos se acercara lo más posible o entrara en contacto directo con los predios de algunas de las EAPs más relevantes del área pertenecientes, por cierto, a la alta burguesía terrateniente del país. Aquí, obviamente operó una "lógica funcional asimétrica".

Por otra parte, las vías férreas de un gran número de ramales abandonados en nuestra zona ofician de mudos testimonios de otra época, de cómo en ese momento se conectaba la economía de la región. En estas circunstancias, al comparar estas vías con las actuales carreteras, se puede observar una estratificación de realidades funcionales que responden a diferentes períodos históricos. Por lo tanto, vemos manifestarse, en esta instancia, una "lógica temporal".

Es interesante, también, constatar cómo cerca de las actuales viviendas de algunas EAPs se suele conservar en pie una "vieja casa" de gruesas paredes y altos techos, de un formato rectangular simple, con habitaciones alineadas una al lado de la otra -que se utiliza en muchos casos como galpón-, que en el presente oficia de testimonio de la primera vivienda que levantaron muchas décadas atrás los ascendientes -generalmente abuelos o bisabuelos- de los actuales propietarios del establecimiento. No cabe duda de que, para los descendientes, estos viejos edificios guardan un "simbolismo" y les marcan una "temporalidad".

Con respecto a las características morfológicas de los pueblos del área, en principio, podemos acotar que el trazado de amplias calles, veredas y espacios públicos y la pulcritud que prima en muchas viviendas y localidades en general, estarían indicando claros signos de búsqueda de bienestar y convivencia vecinal. A su vez, se observa en ellos un formato lavado de ornamentos, que estaría indicando una vida comunitaria de costumbres sencillas, de asentamientos humanos nuevos, en los cuales todavía no se ha conformado una tradición añeja del lugar. Sobre esta realidad, por lo tanto, se manifiestan tanto criterios funcionales cuanto interpretaciones simbólicas.

En páginas anteriores hicimos referencia a una segregación espacial que persiste en ciertos pueblos, debido a la partición territorial del entramado urbano que provocan las vías 
del tren, lo que deriva en un acuerdo tácito de "jerarquización zonal simbólica" por parte de los habitantes de la localidad, al quedar definidos claramente dos niveles de calidad de hábitat, en función del lugar de asentamiento de los mismos, correspondiendo al más pobre "el otro lado de la vía" y el mejor posicionado al lado del casco principal.

Por último, cabe referirnos a la estandarización en el armado y apariencia de nuestros pueblos, que se relacionan, desde luego, con cierta forma de vida y que se asemejan en muchos aspectos al resto de los que se ubican en la llanura pampeana. La homogeneidad y monotonía edilicia y chatura tradicional en su traza -aspectos que tienden a revertirse en las localidades más pujantes, como ya lo explicitamos-, conforman un modelo urbano que podríamos acotar de clásico formato pampeano, tan duramente criticado por Ezequiel Martínez Estrada en su libro Radiografía de la pampa, cuando, refiriéndose al monótono parecido que estas poblaciones guardan entre sí, dice: "Tras mucho andar, el pueblo que primero se encuentra parece el último, como si después de ése no hubiera otro más. Nos invade un sentimiento de pena, y la alegría de la llegada se defrauda en un abatimiento de aldea chata, incolora, hecha a imagen y semejanza del campo" (Martínez Estrada, 1946, I:135). ${ }^{7}$ Esta razón motiva a muchos referentes de estas comunidades a imprimirle cierta singularidad a la apariencia material de sus pueblos, a fin de diferenciarlos de otros similares. Esta suerte de marca simbólica se puede plasmar en la construcción de un edificio público distintivo, municipalidad por ejemplo, con el trazado de nuevas avenidas arboladas, de parques de recreación, etc. En pocas palabras, el emprendimiento pasa por darle una tónica diferente a la localidad, que la individualice del resto de sus vecinas.

En síntesis, hasta aquí nos hemos referido a cómo se manifiestan aquellas lógicas que, a partir de las materialidades que se observan en un paisaje, pueden mediar en el mismo, tanto desde una mirada objetiva práctica, de representación, como arqueológica. Por lo tanto, de acuerdo con estas miradas, entran en juego -y se superponen en su aplicabilidad- las lógicas funcional, simbólica y temporal ${ }^{8}$ que, a través de unos pocos casos, ejemplificamos más arriba. Estas formas de ver e interpretar el paisaje son "desde afuera", o sea, las diferentes maneras de cómo percibimos y procesamos las formas visibles que nos brinda el espacio humanizado. Queda pendiente otra forma de considerar el paisaje -a la que ya nos referimos en páginas anteriores-, y es la que responde a la mirada que llevan a cabo los individuos

Posiblemente, esta visión tan negativa, vertida por Martínez Estrada, apunte a una fuerte crítica sobre la mediocridad de la sociedad en general, que primaba en ese momento - década del '30-, a su juicio, en el país, comparando dicha mediocridad, de modo simbólico, con la presumible chatura que destila la pampa.

8 Queda pendiente, entre otras posibles interpretaciones paisajísticas, la lógica de la dimensión estética, de gran valor formativo y empleada desde antiguo. 
desde adentro del paisaje; cómo las personas sienten y se identifican con el lugar donde viven; cómo, en su imaginario, se consideran formando parte del paisaje y cómo sus aspiraciones de vida se insertan en un posible marco espacial deseado. Esta visión, se entiende, se apoya en una "lógica existencial", donde el individuo, de acuerdo con el sentir de su ser, proyecta sus vivencias desde adentro del todo que lo rodea.

Desde la perspectiva de esta lógica, podemos aportar unos pocos ejemplos, recogidos en las entrevistas semiestructuradas efectuadas en su oportunidad a los "asalariados rurales" de nuestro medio, referidos a la vivencia e identificación cultural que cargan los mismos, en relación con el lugar donde viven. A los ejemplos mencionados los podemos resumir así: En el primer ítem donde se les preguntó "si sienten cariño -se identifican- con el lugar donde viven", hubo un sí rotundo en todos los entrevistados. Se constató, por lo tanto, una fuerte identificación de los asalariados con "el lugar" donde viven.

Luego, en el segundo ítem, referido a "si se identifican con las tradiciones camperas", o sea aquellas asociadas al paisaje, la amplia mayoría respondió que sí, pero en el tercer ítem, donde se les preguntó "si esta identificación la transmiten a sus hijos", la respuesta en general fue que sí, pero aquí quedó la impresión de que la receptividad por parte de los hijos de lo transmitido se relativiza, debido a que también hay otros intereses que los motivan.

Por último, a los asalariados se les preguntó "si les transmiten a sus hijos -como práctica cultural-sus conocimientos rurales" y la respuesta fue "más o menos", ya que en este estrato social, en la actualidad, el interés principal pasa por "que los hijos sigan estudiando", a fin de que puedan aspirar a una condición de vida mejor que la de sus padres.

En suma, como pequeño aporte empírico de nuestra área de análisis, podemos decir que los asalariados entrevistados, en general, se sienten consustanciados y formando parte de su entorno.

Finalizando, cabe una reflexión atinente a cómo se manifiestan las tradiciones desde adentro en nuestra área de referencia. Hay una tradición gauchesca, relacionada obviamente con las entidades del quehacer ganadero, perpetuada en domas, festivales folklóricos, desfiles y fogones criollos, que se mantiene y cultiva en el área -al igual que en el resto de la Región Pampeana- y que se ha insertado con particular fuerza en la mayoría de la población rural descendiente de antiguos colonos extranjeros, conformando con la población criolla -cuya mayoría se desempeña como asalariados- una sólida afinidad por la conservación de las tradiciones y costumbres camperas. Debe quedar claro que esas tradiciones a las que nos referimos han sido gestadas en otro momento histórico y en otra sociedad, diferente de la proveniente de la colonización inmigratoria -que tanto incidió en nuestra zona-, pero 
adoptada con gran estima por los descendientes de estos colonos, que vendría a representar el grueso de la actual población de nuestro territorio de estudio. Esto no quita, como posibilidad cierta, dado que las prácticas culturales son dinámicas, que se estén gestando progresivamente en nuestra área "nuevas pautas" de costumbres y tradiciones, pero esta verificación corresponde a otro tipo de investigación, diferente a la presente.

Volviendo a nuestra realidad, cabe destacar la persistencia, en diferentes escalas, que ofrecen las comunidades rurales de nuestro medio en conservar sus identidades y preservar sus tradiciones de trabajadores de la tierra. En este sentido, es claramente observable el agrupamiento de personas enlazadas por afinidades sociales y un mismo propósito de vida. En base al esfuerzo del trabajo procuran defenderse del anonimato y de no desaparecer bajo el accionar de prácticas agrarias exclusivamente especulativas.

En suma, a partir de todo lo expuesto, vemos que son profundos los procesos modificatorios de nuestro paisaje agrario, todavía no del todo visibles, dado que los cambios físicos sobre el terreno que emanan de las actuales alteraciones, de la estructura agraria en general y de la fundiaria en particular, tardan en redibujarse en el paisaje. Lo concreto es que, desde una mirada política, nuestro campo figura cada vez con menos presencia humana, pero tampoco nos debemos dejar engañar por las apariencias, dado que ese "aspecto" no tiene por qué considerarse obligadamente negativo, en la medida en que las áreas rurales cumplan como proveedoras genuinas de alimentos y se detenga, a su vez, el achicamiento numérico de los agentes rurales en general. Pero para ello tiene que mediar, entre otros factores socioeconómicos equilibrantes, una política de desactivación de la producción especulativa de mercado, medida política que aparentemente está lejos de aplicarse. 


\section{Capítulo VIII}

\section{Conclusiones generales}

\subsection{Validación de objetivos e hipótesis}

Como cierre del trabajo emprendido, a modo de balance general, cabe constatar el haber logrado cumplimentar con el "objetivo central", consistente en conformar un cuadro de situación integrador que contemple las vinculaciones que se establecen entre la PEA Agropecuaria y el territorio de nuestro estudio.

Asimismo, se pudieron satisfacer los "objetivos específicos" propuestos, tales como la indagación sobre la evolución geo-histórica del poblamiento regional, el desarrollo de la dinámica demográfica y de la magnitud y problemáticas de localización de la PEA Agropecuaria, las alteraciones espaciales motivadas por las transformaciones socioterritoriales que se están llevando a cabo, el estudio de los perfiles socio-económicos de los principales sectores sociales rurales con su correspondiente caracterización de clase que se desempeñan en nuestra región. Cabe acotar que este último punto, cuya temática es el nudo de esta tesis, resultó el que ofreció mayores dificultades y el que demandó mayor tiempo de trabajo.

También se cubrieron los objetivos referidos al estudio de las estrategias de sobrevivencia que desarrollan los sectores más vulnerables del agro y se indagó sobre las nuevas estrategias técnico-laborales que exige la actual dinámica productiva. Se analizaron, asimismo, con mucha atención, las condiciones de reproducción generacional de la fuerza de trabajo en nuestra zona de estudio.

Se trató, por otra parte, la incidencia de las pautas culturales que desarrollan los agentes rurales en las actividades productivas.

Con respecto al planteo de la "hipótesis central" de esta tesis, que considera que la profundización de los cambios estructurales que se vienen manifestando en las actividades agropecuarias seguirán generando notables modificaciones socio-económico-políticas en el ámbito rural, sin alterar la estructura de poder $\mathrm{y}$, por ende, sin producir transformaciones de fondo que impliquen una mayor equidad entre los agentes productivos implicados, parece que sigue persistiendo hasta ahora y presumiblemente seguirá así por largo tiempo. Está claro que en el vigente mundo rural media una firme tendencia de reafirmación de la hipótesis planteada. No cabe duda de que, para su reversión, o sea, para conseguir la apertura de un 
verdadero desarrollo social integral del agro, la única manera de lograrlo, dado que sectorialmente es imposible de alcanzar, solamente se producirá cuando se imponga, mediante la conjunción de todas las fuerzas populares, un cambio del sistema político excluyente imperante.

Es evidente que las profundas modificaciones que se vienen manifestando en el ámbito agrario, sin alterar las inequidades del mismo, forman parte de un "todo" más amplio que involucra a todas las actividades económicas que se desarrollan en una sociedad, lo que implica que, para el tratamiento específico de las problemáticas rurales, se debe procurar armonizarlas y ensamblarlas dentro del contexto global de las complejidades sociales.

En lo concerniente a las "hipótesis derivadas" planteadas para nuestro sur cordobés -con prolongaciones muchas de ellas hacia otros sectores de la llanura pampeana-, su tratamiento y validación, a modo de sucintos alcances, los pasamos a resumir a continuación, a través de las siguientes conclusiones:

- Una perceptible quietud demográfica o a lo sumo una débil disminución de la población rural en nuestra área de estudio, por entender que la misma está cerca del mínimo requerido para que el campo funcione operativamente.

- Un moderado incremento del tiempo de dedicación en la atención de las EAPs por parte de los productores que residen en los pueblos, y un inmovilismo locacional por parte de los muy pocos productores que siguen residiendo en el campo, como una forma, por parte de los dos tipos de productores, según su lugar de residencia, de atender mejor sus establecimientos, ante las fuertes presiones de cantidad y calidad que actualmente se le exige a la producción agropecuaria.

- Un incremento y una adecuación en combinar trabajo rural-urbano en dos niveles: uno, correspondiente a un sector de fuerte base económica, que combina, a modo de ejemplo, una actividad comercial de jerarquía con una explotación agropecuaria del mismo tenor; y otro, a escala económica más exigua, preferentemente familiar, que involucra a pequeños productores y muy especialmente a los asalariados rurales temporarios, cuyo trabajo en ambos medios responde a una estrategia concreta de sobrevivencia.

- La percepción real de que la única forma válida de permanencia en la escena productiva por parte de los pequeños productores -más allá de la coyuntura económica favorable del momento-, sólo podrá ser factible si media básicamente una política pública de apoyo económico y tecnológico adecuado, expresamente orientado a favor de este sector. 
- Una continuación en la disminución numérica de las EAPs más vulnerables y, por ende, en general, de los pequeños productores, de manera definitiva o transitoria, por presión económica del sistema y la constatación, en otros casos, de la pérdida de independencia -subordinación económica- en el manejo de las EAPs.

- La comprobación de la consolidación económica de numerosos medianos y medianograndes productores, que pudieron capitalizarse en el actual sistema productivo, como así también de ciertos pequeños productores que lograron alcanzar tasas de rentabilidad apreciables en el manejo de sus EAPs (farmerización).

- La continuación de una pronunciada expansión de las grandes empresas agropecuarias y una acusada tendencia de varias de ellas de fusionarse con el gran capital de origen urbano, transfiriendo el poder de decisión empresarial y las ganancias respectivas al capital extra-sectorial de los grandes núcleos poblacionales.

- La consolidación cada vez más acentuada del "contratista de servicios" -agente rural no explicitado en las hipótesis derivadas, pero sí implícitamente considerado- por su rol técnico laboral imprescindible en la producción agropecuaria pampeana, especialmente en la de escala.

- La comprobación de la interdigitación cada vez más notoria de las actividades primarias con las secundarias, impulsada por la injerencia englobante de las agroindustrias, pero siempre con ventajas económicas a favor de estas últimas.

- Una mayor especialización técnica y laboral por parte de los agricultores en el manejo de las EAPs, como una de las condiciones imprescindibles para poder subsistir y permanecer dentro del actual ritmo de la producción agropecuaria.

A continuación, dentro del listado de las conclusiones obtenidas en consonancia con las hipótesis derivadas, cabe resaltar algunas de ellas a nivel de "problemáticas destacadas" por su importancia intrínseca y necesidad de profundizar su estudio en búsqueda de soluciones efectivas.

\subsection{Problemáticas pendientes de profundizar provenientes del tratamiento de las hipótesis}

Entre ellas, mencionamos:

- La creciente dificultad para lograr la continuidad de la "reproducción generacional" de la fuerza del trabajo, especialmente en muchas EAPs de los pequeños y medianos productores familiares -tema ya mencionado en el Capítulo VI-. Específicamente, nos estamos refiriendo al vacío presencial por parte de los descendientes de los 
productores para continuar con la conducción de los establecimientos. Esta ausencia es muy visible al constatar la actual edad madura de los productores jefes y la predominancia cuantitativa de los mismos en relación con el resto de la PEA familiar.

Es evidente, por lo menos en nuestra área de estudio, la falta de presencia de una "generación intermedia" en la jefatura de los productores familiares. No cabe duda de que entre las dificultades en la continuidad para asumir las responsabilidades de las EAPs, además de razones económicas en los casos de establecimientos de pobre capacidad productiva, median también por parte de los hijos de los productores otras expectativas de vida, donde -como decíamos en otra instancia- el ritmo urbano y la atracción social citadina ejercen una gran influencia.

Éste, obviamente, no es un tema menor pero no por estar alejado de otras problemáticas rurales acuciantes se torna menos preocupante, dado que sus efectos potenciales pueden resultar muy nocivos. En suma, de acuerdo con nuestro criterio, amerita su consideración y el diseño de factibles soluciones al respecto a nivel de políticas públicas.

- La presencia de una "fuerte tensión cultural" -disimulada en parte por el ritmo especulativo del quehacer agropecuario general- como consecuencia de la dinámica económica imperante, entre una forma de vida tradicional de mayor afinidad con la tierra y otra donde el campo se mimetiza con los estilos de vida urbana, acompañada por un criterio de aprovechamiento económico exclusivamente circunscripto a la obtención de rápidas ganancias, despegado de toda convivencia real con el mundo rural.

En síntesis, ese transitar de "no vivir el campo" por parte de muchos nuevos agentes rurales, conlleva el peligro de pérdida de afecto a la tierra. Problemática no muy visible, pero de importancia capital si se quiere afianzar el respeto por las diferentes formas -según los lugares- de culturas del trabajo y por el medio ambiente en un sentido integral.

- La desprotección y vulnerabilidad del sector asalariado rural, expresado en los tres aspectos siguientes:

- La acentuada desconexión física y asociativa observable entre sus miembros, por lo menos en nuestra área de trabajo. A la natural dispersión territorial existente entre pares, como consecuencia de las características intrínsecas de su trabajo, se 
debe sumar un insuficiente enlace aglutinador gremial entre ellos. En suma, están muy aislados en todo sentido como fuerza laboral.

- La disminución numérica pronunciada de los asalariados permanentes y de los temporarios - changarines, salvo los temporarios calificados que han incrementado su número, lo que implica -para los dos primeros casos- una imperiosa necesidad de sostenerlos y/o recuperarlos dentro del ámbito laboral rural, pero encuadrados dentro de un nivel de vida decoroso.

- La comprobación del profundo abismo económico que media entre el mundo de los asalariados rurales y el de los productores en general. Resulta una verdadera paradoja que, en un territorio como la llanura pampeana, con las condiciones agroecológicas superlativas que posee, convivan en fuerte contraste socioeconómico estas dos clases de agentes rurales. Está claro que el supuesto permeo de la riqueza hacia los sectores vulnerables por parte de aquellos que la generan abundantemente no se manifiesta de ningún modo en nuestro ámbito. Es más, es durísimo constatar, especialmente en esta etapa de bonanza agropecuaria donde fluye el dinero generosamente, cómo los asalariados temporarios - changarines siguen percibiendo ingresos auténticamente de hambre.

Resulta increíble, aunque todo el mundo rural conoce esta situación de inequidad social extrema, que nada se diga abiertamente cuando se tratan recurrentemente los problemas del ámbito agropecuario. Es de esperar que, cuando llegue el momento de sentarse a formular una verdadera y esperada política pública agropecuaria, esta "postergación social" sea la primera a la que haya que brindarle justicia económica y social.

- La necesidad de arbitrar en el diseño de políticas públicas agropecuarias todos los mecanismos posibles de “incorporación efectiva de la mujer" en el mundo productivo rural, abriéndoles espacios de inserción en los ámbitos asociativos y económicos laborales. Es de suponer que deben prestar especial colaboración al respecto las asociaciones gremiales, cooperativas y organismos pertinentes del Estado como promotores de dicha inclusión, sin desconocer que median desde hace tiempo programas gubernamentales de promoción a la producción a cargo de la mujer. En suma, es un tema que merece ser reforzado mediante su estudio en profundidad y que requiere, a su vez, de la implementación de múltiples estrategias para arribar al logro de dicho fin. 
- Por último y como punto recurrente que atañe básicamente al nudo de esta investigación, se observa la persistente disminución de la cantidad de agentes rurales en general, pero particularmente de los productores familiares en la categoría, sobre todo, de pequeños y medianos agricultores, que detentan el rol de sostén y motor de la dinámica del mundo social rural. Resulta obvio que esta realidad, a nuestro entender, por su envergadura y por sus connotaciones socio-económicas, debe ser tratada para su reversión en los más altos niveles gubernamentales y que el cumplimiento de las posibles propuestas progresivas de solución que surjan deben ser consideradas como "política de Estado".

\subsection{Propuestas específicas a considerar}

A continuación, como corolario de las conclusiones arriba planteadas, pasamos a formular unas escuetas propuestas, no con la idea de brindar soluciones integrales sino de ofrecer y colaborar para posibles alternativas a explorar tendientes a ese fin. El criterio que se persigue es que estas sugerencias simples y parciales que se presentan no queden prisioneras de la coyuntura y sí, en cambio, se puedan insertar dentro de un contexto de propuestas de fondo.

Por otra parte, si bien es cierto, en un sentido amplio, que estas sugerencias están orientadas para ser eventualmente tenidas en cuenta en el diseño de políticas públicas agropecuarias, albergan también el propósito de poder ser consideradas de manera mucho más concreta y simple por diferentes tipos de instituciones, tanto privadas como oficiales, que tengan relación directa o aproximada con la temática propositiva que se pone a consideración. ${ }^{1}$

Tales propuestas pueden resumirse en las siguientes posibles acciones:

- Impulsar la creación y/o perfeccionamiento de un "sistema educativo rural integral", como una de las armas más eficaces para evitar el desgranamiento poblacional del campo y brindar más educación en sí misma, mediante las siguientes instancias:

$\left.1^{\circ}\right)$ Revitalizar la red de escuelas rurales", desechando aquellos criterios economicistas de medición costo-beneficio, que repercutirían favorablemente, en primera instancia, en la retención de la familia del asalariado rural en el lugar;

\footnotetext{
Motivo por el cual al final de cada "propuesta" se mencionan las instituciones a las que, por su naturaleza, les correspondería tratarla y de aquellas otras que, por sus características propias, pueden colaborar en la concreción de la misma.
} 
$2^{\circ}$ ) Considerar la posibilidad de "creación de puntuales escuelas secundarias" -en lo posible, con internado- en áreas rurales específicas o en pequeños poblados, donde pueden converger un número significativo de potenciales estudiantes de diferentes campos vecinos;

$3^{\circ}$ ) Propiciar "becas de sostén individual" para que puedan vivir solos en las localidades cercanas aquellos adolescentes de procedencia rural que están en condiciones de cursar la escuela secundaria;

$\left.4^{\circ}\right)$ Prever, donde pueda aplicarse, la implementación de una "red de transportes escolares de alumnos secundarios", para el traslado de los mismos a las poblaciones cercanas.

Posibles organismos habilitados para su tratamiento: Ministerio de Educación Provincial, Ministerio de Economía, municipalidades asociadas al lugar, cooperativas, ligas solidarias de vecinos.

- Promover la creación de "ligas solidarias de mutuo apoyo de vecinos rurales" a nivel zonal, con el objeto de incentivar entre los mismos la ayuda generalizada -que de hecho ya existe en muchos lugares-, pero bajo un criterio formal y ordenado, y especialmente direccionado a brindar apoyo comunitario vecinal en salud, educación, seguridad y conservación de modos de vida, entre otros.

Posibles organismos habilitados para su tratamiento: municipalidades del lugar, cooperativas, clubes de campo, consorcios camineros.

- Apoyar las "fuentes de trabajo" y fomentar el "arraigo", particularmente de aquellos trabajadores dependientes que viven o pueden llegar a vivir en el campo, mediante la concreción de algún mecanismo compensatorio a favor de los potenciales productores empleadores -que puede ser una desgravación impositiva o un subsidio de efecto equivalente o la simplificación de la cuestión burocrática-laboral que evite la necesidad de acudir a los servicios de contadores o abogados para la toma de personal-, con el objetivo de morigerar el costo salarial que demanda el contratar personal dependiente.

Posibles organismos habilitados para su tratamiento: Ministerio de Trabajo, Ministerio de Economía, Ministerio de Agricultura, UATRE.

- Fomentar e incentivar los "sistemas de actualización tecnológica y capacitación laboral" al servicio de los trabajadores dependientes, con centro de reunión en algunas localidades específicas a designar como centros aglutinadores de potenciales educandos obreros rurales, a fin de favorecer el empleo y mejorar el ingreso salarial 
de los mismos. Tarea que, en parte, lleva a cabo la UATRE, pero que, por la dispersión territorial de sus afiliados y por la magnitud demográfica de los asalariados rurales en general, no puede cubrir plenamente. Es obvio, por lo tanto, que tienen que intervenir también otros tipos de apoyo, especialmente de los ministerios de Educación y de Agricultura, entre otros organismos posibles, para poder desarrollar plenamente un servicio como el que aquí se sugiere.

Posibles organismos habilitados para su tratamiento: UATRE, Ministerio de Agricultura, Ministerio de Educación.

- Impulsar proyectos de "microemprendimientos colectivos" a favor de los trabajadores temporarios no calificados -changarines-, bajo la forma, por ejemplo, de "microcooperativas" relacionadas con la actividad agropecuaria o con la urbana, como puede ser mediante la explotación grupal de una parcela destinada al cultivo hortícola intensivo, cría de aves de corral, fabricación de ladrillos block, elaboración de alimentos balanceados, etc.

La razón de esta inquietud proviene de la situación crítica de agravamiento de subsistencia futura de los asalariados rurales temporarios no calificados, ante la virtual desaparición de muchos de ellos como producto de la dinámica técnico laboral imperante, que excluye el trabajo no especializado. Cabe aclarar que específicamente este proyecto fue presentado -en su momento- por delegados obreros regionales de nuestra área ante la sede central de la UATRE en Buenos Aires, y si bien medió buena voluntad de las autoridades del gremio para la ejecución del proyecto, finalmente el mismo no prosperó por diferentes motivos.

Por lo tanto, lo que ahora se pretende es rescatar la idea original y tratar, mediante diferentes estrategias políticas -impulsadas ya sea por el gremio o a través de programas implementados por el Ministerio de Agricultura-, de que una amplia mayoría de este sector de mano de obra no calificada pueda incorporarse, a través de este tipo de emprendimientos colectivos, al proceso productivo -en gran parte- en calidad de trabajadores autónomos. ${ }^{2}$

\footnotetext{
En relación con esta propuesta genérica, cabe acotar que se puede entrecruzar con una problemática no menor, pero factible de solución y que consiste en lo siguiente: si bien la figura laboral que asumirían los integrantes de los microemprendimientos pierden, por definición -o sea, por la nueva relación que se establece con los medios de producción-, su condición de trabajadores dependientes al convertirse en trabajadores por cuenta propia, es de suponer que seguirán perteneciendo al gremio y gozando de los beneficios que brinda el mismo, dado que es de suponer que, para incrementar sus ingresos, continuarán con el trabajo de changas a destajo, ya que en mayor o en menor medida dicha práctica siempre se va a requerir en el ámbito rural.
} 
- Explorar la posibilidad de conformar una suerte de "ligas zonales de acuerdos económicos horizontales de productores", de acuerdo con las identificaciones mutuas e intereses compartidos en defensa del trabajo y la producción, en el sentido de poder defender los "precios de sus producciones", ofreciendo una verdadera resistencia -por los potenciales volúmenes que manejarían en conjunto- a las imposiciones económicas provenientes de las grandes corporaciones agropecuarias, especialmente de las agroindustrias y empresas agrocomerciales. Las presiones emanadas de este tipo de concentraciones agropecuarias se manifiestan muy claramente en nuestra área -tema tratado en la cuarta parte del Capítulo VI-, pero lamentablemente no median por parte de los productores mecanismos defensivos de conformación de asociaciones auténticamente horizontales, unidas de manera permanente o ad hoc, que puedan contrarrestar esta sumisión económica al gran empresariado agroindustrial.

Dificultan en nuestra zona la posibilidad de lograr este tipo de "unidad" la insuficiencia de cooperativas, especialmente las de primer grado, o sea, con fuerte participación de sus afiliados (Lattuada y Renold, 2004) y el marcado y tradicional individualismo del productor en su forma de vida en general.

En suma, entendemos que se puede probar gestionar esta forma de "unidad de defensa económica", ya sea a través de eventuales cooperativas que se avengan a promocionar este tipo de vínculo o mediante acuerdos ad hoc que establezcan los propios productores interesados de una zona determinada.

Posibles organismos habilitados para su tratamiento: cooperativas zonales, Ministerio de Agricultura, asociaciones gremiales de productores.

- Promover, desde un plano académico, la creación de un "taller de discusión", con la participación de docentes universitarios abocados a los estudios agropecuarios, técnicos del INTA, especialistas del INDEC (sección censos agropecuarios) y técnicos de los ministerios de agricultura de la nación y provinciales, para la búsqueda de un "patrón de equivalencia" entre el tamaño y capacidad productiva de las EAPs con la cantidad de productores jefes que usufructúan las mismas. Concretamente, nos estamos refiriendo a aquellos casos donde la "jefatura real" de una EAP es compartida, por ejemplo, entre padre e hijo, o entre dos o más hermanos, como puede ser también entre dos o más socios; por lo tanto, como no es igual la cantidad de establecimientos y la cantidad de productores, nos parece de suma importancia poder diferenciar y acordar mediante acuerdos consensuados hasta 
dónde se debe considerar pequeños, medianos y grandes productores en relación con la magnitud económica de las EAPs que usufructúan, cuando dos o más de ellos comparten por partes iguales una misma EAP.

Consideramos que la presente inquietud tiene su relevancia, al entender que a través de los ajustes propuestos se podría regular mejor la clasificación de jerarquías de aquellos productores que participan de las EAPs compartidas. A su vez, el día de mañana, al poder comparar la cantidad de EAPs con la cantidad real de productores que se benefician de las mismas, se podrá tener una idea más cabal de la magnitud de los diferentes estratos socio-económicos que participan del producido agropecuario.

Por último, sobre estas sugerencias, corresponde especificar los siguientes aspectos que se han tenido en cuenta al respecto:

- Las propuestas se circunscriben, en primer lugar, a nuestra área de trabajo, sin perjuicio de que su aplicabilidad se pueda extender a un marco más amplio, como puede ser la misma Región Pampeana.

- En el tratamiento de las mismas, se parte de la idea de poder contar especialmente con la ayuda de los organismos institucionales oficiales y privados provinciales, por lo menos en primer término.

- Muchas de las propuestas que aquí se presentan o ideas similares que se aproximan a las mismas, han surgido de los propios agentes rurales entrevistados, como pensamientos decantados por ellos a partir de las experiencias recogidas de los ambientes donde viven y que nosotros reproducimos a través del filtro de nuestro criterio, pero respetando la procedencia intelectual de los mismos.

\subsection{Reflexiones finales y sugerencia de fondo}

En el plano de las consideraciones finales, cabe tratar un aspecto pendiente de análisis y es el que se refiere a si se han detectado "tensiones de clase" entre los agentes rurales de nuestra área de estudio. Al respecto, podemos decir que durante el período de años que comprendió nuestro trabajo, no se evidenciaron dichas tensiones, por lo menos en forma explícita. Por lo tanto, puede dar la impresión de que cada grupo socio-ocupacional se circunscribe a su ámbito de trabajo sin que medien choques de intereses entre las partes concurrentes en el funcionamiento del complejo laboral agropecuario. Pero bien sabemos que no existe tal neutralidad entre los diversos miembros del engranaje laboral que mueve la economía del campo. 
Lo real, a nuestro juicio, es que la pugna entre los diferentes intereses de clase no se exterioriza en los últimos tiempos de manera evidente en nuestra área, lo que no quiere decir que nuestro espacio de investigación como parte del territorio que Ferrero (1999) denomina "Pampa Gringa Cordobesa" -juntamente con las áreas cerealeras de las provincias de Santa Fe, Buenos Aires y Entre Ríos- no haya atravesado por serios conflictos laborales. Éstos se produjeron entre los obreros rurales, por una parte, y los productores -tanto terratenientes como chacareros-, las empresas cerealistas y los contratistas, por otra, durante la década de 1910 y en algunos años específicos de las décadas de 1920 y 1930. Cabe recordar que durante esos años efectivamente se verificaron serios encontronazos entre estos sectores en pugna (Ansaldi, 1993; Santarelli, 1993). El reclamo reiterado de los obreros rurales consistió básicamente en exigir incremento salarial, jornadas de ocho horas y reconocimiento gremial. Estas protestas del proletariado rural tenían la particularidad de manifestarse a través de huelgas locales en forma puntual y no al unísono, en diferentes pueblos de la llanura pampeana. Por lo tanto, estos conflictos tuvieron la característica de no cubrir de manera homogénea ni estallar al mismo tiempo en el territorio pampeano. Son estallidos diacrónicos cuya onda de propagación es local -el pueblo y su zona rural aledaña-, pero reproduciéndose constantemente en numerosas poblaciones de la campaña y en ciertos momentos específicos de las décadas mencionadas, en coincidencia casi siempre con períodos de alza de la lucha obrera general a nivel país. En concreto, estos movimientos obreros rurales, dentro de sus peculiaridades expresivas, representaron protestas conmocionantes en su momento, que a la larga implicó, juntamente con los movimientos obreros urbanos, un avance real en la conquista de los derechos de la clase.

En las décadas siguientes -siempre refiriéndonos al área pampeana-, la confrontación abierta entre los diferentes agentes rurales convivientes casi desapareció de escena, no así en cambio contra las estructuras externas representadas por el Estado en sus diversos niveles, tanto nacional como provinciales. De este tipo de conflictos, como es sabido, hubo varios en casi todos los tiempos y siempre están latentes potenciales desacuerdos que eclosionan con el aparato estatal.

Volviendo a lo arriba expresado sobre la casi ausencia desde hace mucho tiempo de confrontaciones abiertas entre los diferentes agentes rurales de nuestro estudio, esto no implica que no hayan mediado ni medien una serie de tensiones socio-económicas entre los mismos, ya sea entre los asalariados y sus patrones, entre los contratistas de servicios y sus empleados (Villulla, 2010), entre los pequeños productores y los grandes empresarios agropecuarios, o entre los pequeños y medianos agricultores y ciertas agroindustrias, todas 
ellas como fenómenos lógicos que responden, entre otras causales, a la relación insoslayable que media entre cada clase de agente rural y los medios de producción.

Muchas de estas pujas distributivas las hemos mencionado en su momento directa e indirectamente a lo largo de este trabajo y, si bien no las hemos ampliado en profundidad por no ocupar el centro de nuestra temática, queremos dejar constancia de que dichas tensiones de intereses contrapuestos siguen teniendo plena vigencia en nuestra región.

Por último, cabe observar que, en las organizaciones gremiales rurales que representan a los diferentes sectores laborales, en varias circunstancias, mediante acuerdos de convivencia que se establecen entre ellas a nivel superestructural, vemos que este proceder ayuda en gran parte a distender y apaciguar los intereses latentes de clase y de estratos de clase que se manifiestan en el ámbito agropecuario.

Otro aspecto que debemos contemplar, como producto de estas reflexiones finales y que al comienzo de este trabajo destacamos como una condición ineludible de todo estudio sobre las problemáticas agrarias, es el de sostener como consigna la reivindicación de la tierra como bien social, y recordar que el destino central obligado de la misma es el de producir los suficientes alimentos que demanda la sociedad en su integralidad.

Más allá de posicionamientos idealizados y de buenas intenciones, lo que aquí queremos enfatizar es que, dentro del complejo y amplio abanico de problemáticas rurales que cada estudioso está dispuesto a desentrañar, lo importante consiste en aportar elementos que ayuden a la convergencia progresiva de esfuerzos tendientes a revertir el actual uso especulativo de la tierra para darle el destino central de proveedora de bienestar social y de reaseguro ambiental. Por otra parte, entendemos que la pretendida conjunción colectiva a la que hacemos referencia no se debe limitar solamente a sumar conocimientos con el destino último arriba mencionado, sino que a nuestro juicio se debe batallar también contra los argumentos académicos que de diferentes formas, explícitas o encubiertas, apoyan y justifican los privilegios que emanan de los intereses particulares desmedidos en el uso general de la tierra. Por cierto que aquí ya entramos en el campo de los posicionamientos políticos ideológicos, cuando esbozamos este tipo de enfoque, pero acaso ¿existe un ingreso al conocimiento que esté exento de estas directrices del pensamiento?

Por último, entrando al tramo definitivo de este trabajo, cabe rescatar la siguiente idea genérica pero central, a nuestro juicio. La misma no es otra que la de reivindicar y reinstalar la necesidad impostergable de implementar en nuestra llanura pampeana, como primer territorio de prueba, una "reforma agraria" en el más amplio sentido del concepto. Para esta amplia propuesta, partimos de la realidad socio-económica que, a través de nuestro análisis, trasluce 
nuestra área de trabajo y que entendemos que viene a ser un reflejo de los mismos fenómenos -pero con ciertas peculiaridades- que se reproducen en general, en otras zonas de la llanura aludida.

Si bien nuestra investigación en el sur cordobés no se orientó hacia el estudio de una economía agraria general, pudimos constatar, no obstante -como ya lo desgranamos en diferentes partes de este escrito-, dos realidades simples pero lógicas: a) un tamaño promedio de las EAPs exageradamente grande, donde el grueso de las tierras involucradas corresponden a los grandes establecimientos, en consonancia con la participación de una fuerza laboral muy poco numerosa $\mathrm{y}$, como corolario de lo expresado, una cantidad y densidad poblacional reducida en el espacio mencionado, y b) un potencial de fuerza laboral rural residente en la zona insuficientemente aprovechada, desposeída la mayoría de ella de tierra alguna que le permita generar un aceptable bienestar familiar. A partir de estos dos puntos mencionados a modo de ejemplo, queda claro que en el ámbito rural media una situación de fuerte desequilibrio socio territorial, que da pie a pensar sobre la validez de un cambio de estructuras en profundidad, que vaya mucho más allá de modificaciones estrictamente fundiarias. Dentro de esta inquietud, cabe especificar que, en esta instancia, no estamos haciendo ninguna proposición cierta sobre qué tipo de reforma agraria se debe implementar; simplemente entendemos que si la misma implica "modificaciones estructurales de fondo de un complejo territorial agropecuario dado", la inquietud central pasa por volver a pensar sobre las posibilidades de una construcción colectiva que permita desarrollarla y concretarla.

También es válido preguntarnos si volver a plantear esta idea no sería considerarla como fuera de lugar por genérica y trillada. No obstante, interpretamos que, si bien sus alcances podrán discutirse de acuerdo con los diferentes puntos de vista en juego, su validez es indiscutible, dado que su finalidad inicial y básica sería la de reconsiderar la anacrónica distribución de la tierra que, por más centenaria que sea su asimetría fundiaria, no deja de ser injusta e irracional. En este sentido, no cabe duda de que en nuestra área de análisis -siempre a modo de ejemplo y extensible a otros espacios de la llanura pampeana- hay lugar para disponer de tierra y trabajo para sus sectores sociales más postergados y poder receptar y generar bienestar a mucha más población que la que actualmente reside en la misma.

Sabemos, por otra parte, que en la Argentina no es nuevo el tema de la posibilidad de implementar una reforma agraria. Vemos, por ejemplo, que en el lejano año 1946 el presidente de la FAA, Irineo Barrios, ya decía en ese tiempo: "No por debatido este problema, en todos los tiempos y en todas las latitudes, podemos decir nosotros que es tema agotado o fuera de época" (Barrios, 1946:13). Efectivamente, ya por esa época, debido a las 
importantes modificaciones jurídicas que se habían realizado o se estaban procurando realizar -Estatuto del Peón Rural, Ley de Arrendamientos y Aparcerías, Ley de Promoción a la Colonización, Estatuto del Tambero Mediero- (Bustamante, 2011), el tema estaba en plena efervescencia, tanto en boca de las fuerzas progresistas como del gobierno de turno -primera presidencia de Perón-, aunque el discurso gubernamental se mantuvo solamente “...hasta 1952, momento en el cual la prédica por la Reforma Agraria en marcha, [...] se irá sustituyendo lentamente por un nuevo objetivo estratégico, el aumento de la producción" (Martínez Dougnac, 2009:71). En los años siguientes, esta idea fuerza se fue diluyendo en nuestro país, donde democracias débiles alternando con gobiernos dictatoriales conspiraron para mantener en pie este proyecto. A ello se debe sumar que, en las últimas décadas -como sabemos-, el avance de la transnacionalización de la economía al compás de políticas neoliberales a escala mundial y nacional, más la consigna -en el caso de nuestro ámbito agropecuario- de hacer prevalecer el eficientismo sobre otras variables socio-económicas posibles, determinó que toda idea de abrir el abanico para favorecer con los nuevos adelantos técnico-productivos a la mayor cantidad posible de potenciales beneficiarios rurales desapareció de la agenda, tanto a nivel institucional como de las grandes fuerzas políticas.

Por lo tanto, el hecho de volver la mirada, especialmente en el plano académico, hacia una posible nueva implementación de reforma agraria, no parte a priori de ninguna definición concreta sobre el significado y alcance de la misma, ya que entendemos que ese análisis debe formar parte del debate que implícitamente sugerimos. Los aspectos a considerar, como es sabido, son por demás múltiples y complejos y, para arribar a la diagramación de un "plan" posible, se requiere de una participación multidisciplinaria de especialistas, en lo posible numerosa y comprometida.

Cabe remarcar que nuestra inquietud surge dentro de las limitaciones de nuestro estudio de observar, en el sur cordobés y a modo de ejemplo de otras áreas de similares características, lo ya dado a entender más arriba: "la abundancia de tierra para distribuir entre mucha más gente", así de simple, pero sin desconocer que el avance de la justicia social en el agro tiene que estar acompañado de la eficacia económica. En concreto, contemplar mejorar la "distribución", "producción” y "sustentabilidad" de la tierra implica una trilogía de procederes, inseparable de toda acción reformadora razonable.

A nuestro juicio, la vigencia de rescatar esta propuesta obviamente no se apoya, como hace setenta años atrás, en la crítica a la proliferación del latifundio rentístico e insuficientemente explotado. Ahora esa situación no se da -o se da en forma muy parcial-; la mayor parte de las grandes propiedades se desempeñan como empresas agropecuarias 
exitosas, lo que no exime que sus "dimensiones superlativas" le resten oportunidades de afincamiento a potenciales usufructuarios del agro, carentes en la actualidad de tierras. Es pertinente recordar que el aumento inusitado de tierras arrendadas en la actualidad ya no proviene, o proviene en forma residual, del sector de los terratenientes tradicionales; ahora, en cambio, son varios los actores que intervienen en esta operatoria, desapareciendo de la escena productiva agropecuaria en muchos casos los agricultores que ceden tierras.

En concreto, la propuesta es volver a pensar colectivamente un "plan" que no solamente frene el proceso de achicamiento de la fuerza laboral agropecuaria, sino que permita también incrementar sustancialmente la participación de la mayor cantidad de agricultores con acceso directo a la posesión de la tierra. Empezando primero por el otorgamiento de tierras a escala individual o de colonias cooperativizadas de producción, con gente del lugar: trabajadores dependientes, ex obreros rurales, arrendatarios familiares, ex productores desposeídos, minifundistas propiamente dichos, etc., para continuar con potenciales interesados procedentes de otros espacios geográficos del país, lo que implicaría proveer al campo de estructuras económicas remozadas y socialmente más justas.

Todas estas medidas, de clara pertinencia del Estado nacional, como poder político real y único capaz de llevarlas a cabo en gran escala, pueden considerarse para ser ejecutadas también por las provincias en un nivel más modesto y no por ello de menor trascendencia efectiva y política. Esta posible vía de intervención provincial en la readecuación social del uso económico de la tierra se puede tornar a futuro como un inicio válido para entrar en el tratamiento de la problemática. Puede inclusive haber proyectos que, aunque reducidos, sean altamente significativos en la medida que formen parte de un horizonte de propuestas más amplias interrelacionadas de manera integral.

En suma, sin abrigar la inquietud de impulsar ni la expulsión de los grandes propietarios -aunque sí el recorte de sus fundos- ni la aplicación de políticas conducentes a prácticas minifundistas, la idea genérica que aquí proponemos de reflotar viejos anhelos reformistas es mostrar una posible brecha en la cual seguir trabajando en conjunto sobre las potencialidades socio-económicas que se pueden llegar a desplegar en el ámbito agropecuario, buscando siempre un equilibrio de equidad social. La intención, en síntesis, es volver a instalar en la agenda la discusión sobre la posibilidad de construir colectivamente un proyecto de reforma agraria, básica, amplia e inclusiva, que tienda a un aprovechamiento más equitativo de la riqueza que puede llegar a ofrecer la tierra.

Por último, cabe expresar que todo lo vertido a lo largo de esta tesis corresponde al análisis de una realidad determinada, en un territorio específico y en un momento histórico 
dado. Pero la historia continúa; por lo tanto, la pretensión de lo expuesto es simplemente que sirva como un escalón más a futuras indagaciones vinculadas a la temática de este trabajo, con la esperanza de que se corrijan los errores cometidos y se mejore y profundice el análisis de las problemáticas rurales aquí planteadas. 


\section{BIBLIOGRAFÍA}

\section{Bibliografía general}

- AgüERo, R. 1998. "La coexistencia de una franja laboral marginada con un espacio rural próspero". En: Boletín del Centro de Estudios Alexander von Humboldt, Año 2, No 3. Buenos Aires.

- AgÜEro, R. et al. 1997. "Estudio de la PEA rural que reside en los centros urbanos. Los cambios de localización y sus implicancias territoriales". En: Cronía, Año 1, Vol. I, № 2. Revista de Investigaciones de la Facultad de Ciencias Humanas, UNRC. Río Cuarto.

- AgüEro, R. et al. 2000. "Magnitud y factores de localización de la PEA Agropecuaria que reside específicamente en las áreas rurales". En: Actas del Segundo Encuentro Internacional Humboldt. CD-ROM. Centro de Estudios von Humboldt. Mar del Plata.

- Agüero, R. et al. 2003/2004. “Diagnosis, problemáticas y perspectivas de la localización de la PEA Agropecuaria. La región pampeana que rodea a la ciudad de Río Cuarto". En: Reflexiones Geográficas, $\mathrm{N}^{\mathrm{o}}$ 11. ISSN 0328-0004. Agrupación de Docentes Interuniversitarios de Geografía. Río Cuarto.

- AgüEro, R. et al. 2005. "Análisis de las características socio-económicas laborales que interactúan en la PEA Agropecuaria. El área pampeana aledaña a la ciudad de Río Cuarto". En: Geograficando, Año 1, No 1. Facultad de Humanidades y Ciencias de la Educación, UNLP. La Plata.

- AgÜERo, R. et al. 2005/2006. "Evolución de la estructura agraria fundiaria en el sur de la provincia de Córdoba. Período 1969-2002”. En: Reflexiones Geográficas, N 12. ISSN 0328-0004. Agrupación de Docentes Interuniversitarios de Geografía. Río Cuarto.

- AgÜERO, R. et al. 2008/2009. "Cambios productivos en las actividades agropecuarias de la región sur de la provincia de Córdoba (1988-2007)". En: Reflexiones Geográficas, № 13. ISSN 0328-0004. Agrupación de Docentes Interuniversitarios de Geografía. Río Cuarto.

- AgüERo, R. y J. GonZÁLez. 1998. "Estado de situación y complejidades en el análisis de la PEA Agropecuaria que se localiza específicamente en las áreas rurales". En: Cronía, Año 2, Vol. 2, $\mathrm{N}^{\mathrm{o}}$ 2. Revista de Investigaciones de la Facultad de Ciencias Humanas, UNRC. Río Cuarto.

- Agüero, R. y J. GonZÁlez. 2002. "Socio-economic evolution and labor forcé development in the Pampas Region of the Argentina Republic". En: SAIKIA, A. (comp.) 
Population, Environment and the Challenge of Development. Gauhati University, Dep. of Geography, India.

- Agüero, R., A. Rivarola y R. Maldonado. 2007. “Caracterización del contratismo de servicios en un sector de la pampa cordobesa: las localidades de Alcira Gigena y Berrotarán. Presentación de resultados preliminares de investigación”. En: Mundo Agrario. Revista electrónica. Vol. 7, No $14,1^{\circ}$ semestre. Facultad de Humanidades y Ciencias de la Educación, UNLP. La Plata.

- Agüero, R., J. GonzÁlez y E. Puigdomenech. 1999. "Factores y cambios de localización de la PEA Agropecuaria en un espacio de estructura capitalista prevaleciente". En: Actas del $7^{\circ}$ Encuentro de Geógrafos de América Latina. CD-ROM. Departamento de Geografía, Universidad de Puerto Rico. San Juan de Puerto Rico.

- Alvarado Ledesma, M. 2003. La Argentina agrícola. Temas Grupo Editorial. Buenos Aires.

- ANSALDI, W. (comp.). 1993. Conflictos obrero-rurales pampeanos/1 (1900-1937). CEAL. Buenos Aires.

- Ansaldi, W. y M. VeCI. 1993. "El fantasma del maximalismo. La conflictividad obrera rural en Córdoba, 1919-1921”. En: ANSALDI, W. (comp.) Conflictos obrero-rurales pampeanos/2 (1900-1937). CEAL. Buenos Aires.

- Aparicio, S. y P. Benencia. 1999. Empleo rural en tiempos de flexibilidad. La Colmena. Buenos Aires.

- Aparicio, S. y R. Benencia. 2001. Antiguos y nuevos asalariados en el agro argentino. La Colmena. Buenos Aires.

- Aparicio, S., N. Giarraca y M. Teubal. 1992. "Las transformaciones en la agricultura. El impacto sobre los sectores sociales”. En: Jorral, J. y R. SAUTU (comp.). Después de Germani. Exploraciones sobre estructura social de la Argentina. Paidós. Buenos Aires.

- Azcuy Ameghino, E. 2004. "De cultivo marginal a motor de la agriculturización: hipótesis y problemas en torno a la sojización”. En: Docuemtnos del CIEA, No 2 .

- Azcuy Ameghino, E. 2004. Trincheras en la historia. Imago Mundi. Buenos Aires.

- Azcuy Ameghino, E. 2007. "Pruebe a nombrar de memoria cinco empresas que estén explotando campos... Propiedad y renta de la tierra en Argentina a comienzos del siglo XXI”. En: Revista Interdisciplinaria de Estudios Agrarios, № 26 y 27, $1^{\circ}$ y $2^{\circ}$ semestre. Facultad de Ciencias Económicas, UBA.

- Azcuy Ameghino, E. 2009. “¿Es eterno? ¿Nació de un repollo? ¿No chorreaba restos e impregnaciones de un pasado diferente? Reflexiones sobre el desarrollo del capitalismo en 
el agro pampeano". Documentos del CIEA, № 4. Facultad de Ciencias Económicas, UBA. Buenos Aires.

- Azcuy Ameghino, E. 2011. Una historia casi agraria. Hipótesis y problemas para una agenda de investigación sobre los orígenes y desarrollo del capitalismo en Argentina. Ediciones del PIEA. Buenos Aires.

- BARSKY, A. 1997. "La puesta en valor y producción del territorio como generadores de nuevas geografías. Propuesta metodológica de zonificación agroproductiva de la Pampa argentina a partir de los datos del CNA 1988”. En: BARSKY, O. y A. PUCCIARELLI. El agro pampeano. Fin de un período. FLACSO-UBA. Buenos Aires.

- BARSKY, A. 1999. “La organización espacial pampeana (1914-1988): algunas reflexiones a partir del trabajo metodológico de zonificación agroproductiva en los censos nacionales agropecuarios". En: Anuario de la División Geográfica 1999. Dpto. de Geografía, Universidad Nacional de Luján.

- BARSKY, O. (ed.). 1991. El desarrollo agropecuario pampeano. Grupo Editor Latinoamericano. Buenos Aires.

- Barsky, O. 1992. "Explotaciones familiares en el agro pampeano: procesos, interpretaciones y políticas". En: BARSKY, O. et al. Explotaciones familiares en el agro pampeano/1. CEAL. Buenos Aires.

- BARSKY, O. 1997. "La información estadística y las visiones sobre la estructura agraria pampeana”. En: BARSKY, O. y A. PUCCIARELli. El agro pampeano. El fin de un período. FLACSO-UBA. Buenos Aires.

- Barsky, O. 2003. "Censo del campo: una foto nítida”. En: Clarín, 9 de abril. Buenos Aires.

- BARSKY, O. et al. 1988. La agricultura pampeana. FCE. Buenos Aires.

- Barsky, O. y A. PuCciarelli. 1997. El agro pampeano: el fin de un período. FLACSOUBA. Buenos Aires.

- BARSky, O. y J. DJenderedjIAn. 2003. Historia del capitalismo agrario pampeano. Tomo 1. Siglo XXI. Buenos Aires.

- Barsky, O. y J. Gelman. 2001. Historia del agro argentino. Grijalbo-Mondadori. Buenos Aires.

- Barsky, O. y M. DÁvila. 2008. La rebelión del campo. Historia del conflicto agrario argentino. Sudamericana. Buenos Aires.

- BARSKy, O. y M. MuRMis. 1986. Elementos para el análisis de las transformaciones de la Región Pampeana. CISEA. Buenos Aires. 
- Bastide, R. y otros. 1968. Sentidos y usos del término estructura en las ciencias del hombre. Paidós. Buenos Aires.

- Basualdo, E. 1995. "El nuevo poder terrateniente; una respuesta". En: Realidad Económica, № 132 . Buenos Aires.

- Basualdo, E. y M. Khavisse. 1993. El nuevo poder terrateniente. Planeta. Buenos Aires.

- Basualdo, E. y M. Khavisse. 1994. "La gran propiedad rural en la provincia de Buenos Aires". En: Desarrollo Económico, No 134. IDES. Buenos Aires.

- BAUMEISTER, E. 1980. Estructura agraria ocupacional y cambio tecnológico en la región maicera. La figura del contratista de máquinas. Documento de trabajo $\mathrm{N}^{\mathrm{o}}$ 10. CEIL. Buenos Aires.

- Bendini, M. et al. (comp.). 2003. El campo en la sociología actual. La Colmena. Buenos Aires.

- Benencia, R. 1992. "El mercado de trabajo rural: posibles cambios en un futuro próximo". En: Realidad Económica, № 109. IDES. Buenos Aires.

- Benencia, R. 1997. "Transformaciones laborales en el agro argentino”. En: ViLlanueva, E. (comp.). Empleo y globalización. La nueva gestión social en la Argentina. Universidad Nacional de Quilmes. Bernal.

- Benencia, R. y F. Forni. 1991. "Condiciones de trabajo y condiciones de vida de familias campesinas y asalariados". En: FORNI, F. et al. Empleos, estrategias de vida y reproducción. Hogares rurales en Santiago del Estero. CEAL. Buenos Aires.

- Benítez, M. 1998. La Argentina que desaparece. Desintegración de comunidades rurales y poblados en vías de desaparición. Tesis de doctorado. Universidad de Belgrano. Buenos Aires.

- Bernier, X. y J. Giacottino. 1997. Les Mutations des Espaces ruraux dans les Pays en Voie de Développement. Ed. Económica. París.

- Bertello, F. 2006. "Mujeres al frente”. En: La Nación. Suplemento Campo. 21 de octubre. Buenos Aires.

- Bertrand, G. y C. Bertrand. 2007. Uma geografia transversal. O meio ambiente a través dos territórios e das temporalidades. Massonis. Maringá, Paraná, Brasil.

- BESSE, J. 2010. "El espacio del paisaje”. Conferencia impresa, dictada en las III Jornadas del Doctorado en Geografía, organizado por la Facultad de Humanidades y Ciencias de la Educación, UNLP. La Plata.

- Bialet Massé, J. 1986. Informe sobre el estado de la clase obrera. Tomo 1 y 2. Hyspamérica. Buenos Aires. 
- Blanco, M. 2001. "La agricultura conservacionista y sus efectos sobre la mano de obra rural. La aplicación de siembra directa en el cultivo de cereales y oleaginosas". En: NeIman, E. (comp.) Trabajo de campo. Ciccus. Buenos Aires.

- Borisov, O. et al. 1977. Diccionario de economía política marxista. Ediciones Armadillo. Bogotá.

- Brondo, A. y C. Luparia. 2001. "La libreta de trabajo para el trabajador rural”. En: Neiman, E. (comp.) Trabajo de campo. Ciccus. Buenos Aires.

- Bustamante, M. 2011. "Viraje en las políticas públicas de tierras. Continuidades y discontinuidades a partir de la segunda mitad del siglo XX, Región Pampeana. Argentina”, En: terra nueva etapa, Vol. XXVII, No 41, enero-junio 2011. Facultad de Humanidades y Educación, Universidad Central de Venezuela.

- Bustamante, M. y D. Zalazar. 2001. "Estudio de la PEA Rural concentrada en base al análisis de un centro poblacional de menos de 2.000 habitantes. El caso de La Cautiva". Informe de Beca de Ayudantía de la SeCyT, UNRC, realizada a través del Dpto. de Geografía, Facultad de Ciencias Humanas. Director: R. Agüero.

- CANTÓn, A.H. 2008. El regalo del rey. Editorial de la UNRC. Río Cuarto.

- CarabañA, J. y A. DE Francisco (comp.). 1995. Teorías contemporáneas de las clases sociales. Editorial Pablo Iglesias. Madrid.

- Carballo GonzÁlez, C. 2007. “Cincuenta años de agricultura familiar y desarrollo rural en el INTA”. En: Revista Interdisciplinaria de Estudios Agrarios, $\mathrm{N}^{\circ} 26$ y 27, $1^{\circ}$ y $2^{\circ}$ semestre. Facultad de Ciencias Económicas, UBA. Buenos Aires.

- Carballo, C. 2002. Extensión y transferencia de tecnología en el sector agrario argentino. Editorial Facultad Agronomía. Buenos Aires.

- CÁRCANO, M.A. 1972. Evolución histórica del régimen de la tierra pública. 1810-1916. EUDEBA. Buenos Aires.

- Cascardo, A, J. Pizarro, M. Peretti y P. Gómez. 1991. "Sistemas de producción predominante". En: BARSKY, O. (ed.). El desarrollo agropecuario pampeano. Grupo Editor Latinoamericano. Buenos Aires.

- Chañi-lao (Bustamante, J.). 1962. Nace un imperio. Namuncurá. Río Cuarto.

- Chayanov, A. 1974. La organización de la unidad económica campesina. Nueva Visión. Buenos Aires.

- Chiozza, E. y C. CARBALlo. 2006. Introducción a la Geografia. Universidad Nacional de Quilmes. Bernal.

- CiCARÉ, S. 2004. “Los nómades de la cadena agrícola”. En: La Capital. 4 de marzo. 
- Cimminelli, N. 1999/2000. "Evolución socio-democrática de la región pampeana argentina. El poblamiento del sur de la provincia de Córdoba (1813-1914)." En: Reflexiones Geográficas, No 9. ISSN 0328-0004. Agrupación de Docentes Interuniversitarios de Geografía. Río Cuarto.

- Claval, P. 1999. La geografía cultural. EUDEBA. Buenos Aires.

- CócCAro, J.M. 2003/2004. "El agua como idea de ciencia. Una lectura situada desde la Geografía marítima que interpela responsabilidades". Reflexiones Geográficas, № 11. ISSN 0328-0004. Agrupación de Docentes Interuniversitarios de Geografía. Río Cuarto.

- Cóccaro, J.M. y G. Maldonado. 2008/2009. "Reflexiones críticas para repensar el territorio hoy. El pretexto de la soja en la Argentina. Vulnerabilidad social y ambiental". En: Reflexiones Geográficas, N ${ }^{o}$ 13. ISSN 0328-0004. Agrupación de Docentes Interuniversitarios de Geografía. Río Cuarto.

- CucCorese, H.J. 1969. Historia de los ferrocarriles en la Argentina. Macchi. Buenos Aires.

- DE Francisco, A. 1995. "Problemas del análisis de clases: a modo de introducción”. En: CARABAÑA, J. y A. DE FrAncisco (comp.). Teorías contemporáneas de las clases sociales. Editorial Pablo Iglesias. Madrid.

- DE IMAZ, J. 1962. "Estratificación social del sector primario en Ucacha”. En: Desarrollo Económico, № 4, Vol. 1, enero-marzo.

- DE IMAZ, J. 1965. Estructura social de una ciudad pampeana. Cuaderno de Sociología 1-2. Facultad de Humanidades y Ciencias de la Educación, UNLP. La Plata.

- DE Jong, G. 2009. Geografía, método regional y planificación. Catálogos. Buenos Aires.

- De Prada, J. y J. Penna (ed.). 2008. Percepción económica y visión de los productores agropecuarios de los problemas ambientales del sur de Córdoba, Argentina. Ediciones INTA. Buenos Aires.

- DenIS, P. 1987. La valorización del país. La República Argentina. 1920. Solar. Buenos Aires.

- Derruau, M. 1964. Tratado de geografia humana. Vicens Vives. Barcelona.

- Devoto, R. 1989. Contratistas de servicio y contratistas de producción en la visión de los años '80. Temas de Investigación $\mathrm{N}^{\mathrm{o}} 38$. INTA-EEA. Pergamino.

- DomíngueZ, N. y G. ORSINI. 2009. Impactos en la estructura agraria por la ampliación de la frontera agrícola en base a la expansión del cultivo de soja en la Región Pampeana: la historia reciente de Entre Ríos. Ediciones Cooperativas. Buenos Aires. 
- Escamilla Herrera, I. y C. Santos Cerquera. 2003. "El mercado laboral en México desde la perspectiva de Geografía del Género". En: Pegada. Vol. 4, № 1. UNESP. Campus de Presidente Prudente, Brasil.

- Exboir, J., R. Fiorentino y L. LunARdelli. 1990. "La ocupación de la mano de obra rural argentina". En: Desarrollo Económico, N 119. IDES. Buenos Aires.

- Federación Argentina de Contratistas de Maquinaria. 2008. Anuario Facma. Casilda (Santa Fe).

- Ferrer, A. 2005. Campo e industria. CI Capital Intelectual. Buenos Aires.

- Ferrero, R. 1978. La colonización agraria de Córdoba. Junta Provincial de Historia. Córdoba.

- Ferrero, R. 1999. La pampa gringa cordobesa. Ediciones del Corredor Austral. Córdoba.

- Flichman, G. 1982. La renta del suelo y el desarrollo agrario argentino. Siglo XXI. Buenos Aires.

- Formento, L. 2007. "El sur cordobés: un antes y un durante en el proceso de sojización". En $V$ Jornadas Interdisciplinarias de Estudios Agrarios y Agroindustriales. CD-ROM. FCE, UBA. Buenos Aires.

- Forni, F. y M. TORT. 1980. “La tecnología y el empleo en un nuevo enfoque del desarrollo agropecuario. El caso argentino”. En: Desarrollo Económico, 76, Vol. 19.

- Forni, F. y M. TORT. 1991. De chacareros a farmers contratistas. Documento de Trabajo No 25. CEIA. Buenos Aires.

- FORNI, F. y M. TORT. 1992. "Las transformaciones de la explotación familiar en la producción de cereales de la Región Pampeana”. En: JORRAL, J.R. y R. SAUTU (comp.) Después de Germani. Exploraciones sobre estructura social de la Argentina. Paidós. Buenos Aires.

- Franco, L. 1967. Los grandes caciques de la pampa. Ediciones del Candil. Buenos Aires.

- Gaignard, R. 1989. La Pampa argentina. Solar. Buenos Aires.

- Galfioni, M. 2010. Análisis del paisaje agrario y del nexo entre agentes públicos y privados de los centros urbanos y sus áreas rurales de influencia en el contexto neoliberal. Los casos de Berrotarán y Alcira Gigena. Tesis de Licenciatura en Geografía. Dpto. de Geografía, Facultad de Ciencias Humanas, UNRC. Río Cuarto.

- Gallo Mendoza, G. 2002. De regreso al campo. Narvaja Editor. Córdoba.

- Gallo, E. 2004. La Pampa Gringa. La colonización agrícola en Santa Fe (1870-1895). Edhasa. Buenos Aires. 
- Garbers, R. 2009. Informe del Dpto. Técnico Ecónomico de la FACMA. Federación Argentina de Contratistas de Maquinaria Agrícola. Casilda (Santa Fe).

- García RAmón, M.D. 1981. Métodos y conceptos en geografía rural. Oikos-tau. Barcelona.

- GarcíA, M. y A. ThOmAs. 2002. "Trabalhadoras rurais e luta pela terra no Brasil: interlocução entre género, trabalho e territorio". En: Terra Livre, Ano 18, Vol. 2, No 19. Geografía, movimientos sociáis e teoría. Associação de Geógrafos Brasileiros. São Paulo.

- George, P. 1966. Geografía activa. Ariel. Barcelona.

- Germani, G. s/f. "Manual del encuestador". Publicación interna No 22 del Dpto. de Sociología de la Facultad de Filosofía y Letras de la UBA. En: Apuntes. Ciencias de la Información de Córdoba, Escuela de Ciencias de la Información, Universidad Nacional de Córdoba.

- Germani, G. 1987. Estructura social de la Argentina. Solar. Buenos Aires.

- Geymonat, A.M. y M. WehBe. 1997. "El sector agropecuario del sur de la provincia de Córdoba. Reflexiones sobre su desenvolvimiento". En: Fundamentos, $\mathrm{N}^{\mathrm{o}}$ 6. Revista de la Facultad de Ciencias Económicas, UNRC. Río Cuarto.

- Giarraca, N. (comp.). 2001. ¿Una nueva ruralidad en América Latina? CLACSO. Buenos Aires.

- GiarraCA, N. 2001. "El movimiento de mujeres agropecuarias en lucha: protesta agraria y género durante el último lustro en Argentina”. En: GIARRACA, N. (comp.). ¿Una nueva ruralidad en América Latina? CLACSO. Buenos Aires.

- GiarracA, N. y B. LeVy. 2004. Ruralidades latinoamericanas. CLACSO Libros. Buenos Aires.

- Giarraca, N. y M. Teubal. 1995. "El día en que la Plaza de Mayo se vistió de campo". En: Teubal, M. Globalización y expansión agroindustrial. Corregidor. Buenos Aires.

- Giarraca, N. y M. Teubal. 1997. "El movimiento de Mujeres Agropecuarias en Lucha. Las mujeres en la protesta rural en la Argentina". En: Realidad Económica, № 150. Buenos Aires.

- Giarraca, N. y S. Cloquell (comp.). 1998. Los agricultores del Mercosur. La Colmena. Buenos Aires.

- Giberti, H. 2009. "Evolución y problemas del agro argentino". En: Revista Interdisciplinaria de Estudios Agrarios, $\mathrm{N}^{\mathrm{o}} 30,1^{\mathrm{o}}$ semestre. Facultad de Ciencias Económicas, UBA. Buenos Aires. 
- Girbal de Blacha, N. 1998. Ayer y hoy de la Argentina rural. La Página (edición de Página 12). Buenos Aires.

- Gómez MendozA, J. et al. 1982. El pensamiento geográfico. Alianza. Madrid.

- GORI, G. 1971. Inmigración y colonización en la Argentina. EUDEBA. Buenos Aires.

- Gouru, P. 1981. Geografía humana. Alianza. Buenos Aires.

- Grammont, H. (comp.). 2006. La construcción de la democracia en el campo latinoamericano. CLACSO Libros. Buenos Aires.

- GutiÉrRez, S. 1996. "Distribución y uso de la tierra en el Departamento Río Cuarto entre 1870 y 1914”. Ponencia presentada en Jornadas de Historia de Córdoba. JPHC. Córdoba.

- Gutman, G. 2008. “Agricultura de contrato de pequeños productores agropecuarios con agroindustrias y/o agrocomercios en la Argentina". En: ScheJTMAn, A. y O. BARSKY. Desarrollo rural en la Argentina. Siglo XXI. Buenos Aires.

- Gutman, G. y F. Gatto (comp.). 1990. Agroindustrias en la Argentina. Cambios organizativos y productivos (1970-1990). CEAL. Buenos Aires.

- HARVEY, D. 1998. La condición de la posmodernidad. Investigación sobre los orígenes del cambio cultural. Amorrortu. Buenos Aires.

- HarVey, D. 2004. El nuevo imperialismo. Akal. Madrid.

- HorA, R. 2002. Los terratenientes de la pampa argentina. Una historia social y política. 1860-1945. Siglo XXI. Buenos Aires.

- INDEC. 2000. Situación de las mujeres en la Argentina I. Seria Análisis Social. Buenos Aires.

- Jofre CABello, A (coord.). 2000. La teoría de las redes sociales y las migraciones de españoles a la Argentina (1860-1960). Ediciones Al Margen. La Plata.

- Kausky, K. 1970. La cuestión agraria. Ruedo Ibérico. París.

- KleIN, E. 1993. “El mundo del trabajo”. En: Nueva Sociedad, N 120. Caracas.

- Kulacs, P. 1971. Los terratenientes. CEAL. Buenos Aires.

- La Nación. 2004. Anuario del campo argentino 2004/05. Año I, $N^{o} 1$. Buenos Aires.

- La Voz Del Interior (ed.). 1998. Atlas político de la provincia de Córdoba. Córdoba.

- LAtTes, A. 1979. La dinámica de la población rural en la Argentina entre 1870 y 1970. CENEP. Buenos Aires.

- LAtTuAdA, M. 1995. "Una lectura sobre el nuevo poder terrateniente y su significado en la Argentina actual". En: Realidad Económica, N 132. Buenos Aires.

- Lattuada, M. y G. Neiman. 2005. El campo argentino. CI Capital Intelectual. Buenos Aires. 
- Lattuada, M. y J.M. Renold. 2004. El cooperativismo agrario ante la globalización. Siglo Veintiuno. Buenos Aires.

- LÁzzaro, S. y G. Galafassi (comp.). 2005. Sujetos, política y representaciones del mundo rural. Argentina 1930-1945. Siglo XXI. Buenos Aires.

- Lenin, V. 1960. Primer esbozo de las tesis sobre el problema agrario. Obras Completas. T. XXXI; pp. 145 y ss. Cartago.

- Lenin, V. 1975. La cuestión agraria: el programa agrario de la socialdemocracia en la primera revolución rusa. Ayuso. Madrid.

- LeNIN, V. 1979. Notas críticas sobre el problema nacional. Ed. Progreso. Moscú.

- Llovet, I. 1988. Expansión agrícola y cambio social: los nuevos contratistas de la Región Pampeana. CISEA. Buenos Aires.

- Llovet, I. 1991. “Contratismo y agricultura”. En: BARSKY, O. (ed.). El desarrollo agropecuario pampeano. Grupo Editor Latinoamericano. Buenos Aires.

- LódolA, A. y R. FosSATI. 2004. Servicios agropecuarios y contratistas en la provincia de Buenos Aires. Documento de Trabajo No 115. Área Estudio Agrarios, Universidad de Belgrano. Buenos Aires.

- LóPez, V. 1978. Métodos y técnicas de encuesta. Serie E, № 25. Centro Latinoamericano de Demografía. Santiago de Chile.

- LuCero Moriconi, R. 1999. La inmigración italiana en el sur de Córdoba 1870-1920. Quarto Río. Río Cuarto.

- LuKaCs, G. 1969. Historia y conciencia de clase Estudios de dialéctica marxista. Grijalbo. México.

- ManZAnAl, M. 1993. Estrategias de sobrevivencia de los pobres rurales. CEAL. Buenos Aires.

- Manzanal, M. 2006. "Regiones, territorios e institucionalidad del desarrollo rural”. En: ManZanal, M., G. Neiman y M. LAtTUADA. Desarrollo rural, organizaciones, instituciones y territorios. Ciccus. Buenos Aires.

- Manzanal, M. y S. SChneIDER. 2011. “Agricultura familiar y política de desarrollo rural en Argentina y Brasil (análisis comparativo, 1990-2010)”. En: Revista Interdisciplinaria de Estudios Agrarios, № 34. Facultad de Ciencias Económicas, UBA. Buenos Aires.

- ManZano Fernández, B. 1996. MST formação e territorialização. Hucitec. São Paulo.

- Marincioni, V. 1999. "Estudio de la PEA Rural concentrada en base al análisis de un centro poblacional de menos de 2.000 habitantes. El caso de Chaján”. Informe de Beca de 
Ayudantía de la SeCyT, UNRC, realizada a través del Dpto. de Geografía, Facultad de Ciencias Humanas. Director: R. Agüero.

- Martínez Estrada, E. 1946. Radiografía de la Pampa. 2 tomos. Losada. Buenos Aires.

- Martínez Sarasola, C. 1992. Nuestros paisanos los indios. Emecé. Buenos Aires.

- MuÑoz, R. 2005. La patria contratista: escenarios agrícolas 2005/2006. Jefatura de Economía. INTA. Pergamino.

- Murmis, M. 1998. "El agro argentino: algunos problemas para su análisis". En: GiarracA, N. y S. Cloquell (comp.) Los agrigultores del Mercosur. El papel de los actores sociales. La Colmena. Buenos Aires.

- Neiman, G. (comp.). 2001. Trabajo de campo. Producción, tecnología y empleo en el medio rural. Ciccus. Buenos Aires.

- Neiman, G. et al. 2006. Los asalariados del campo en la Argentina. SeAGPyA. Buenos Aires.

- Ortega Cantero, N. 1988. Geografía y cultura. Alianza Universidad. Madrid.

- ORTEGA, L.E. s/f. "Sobre el pequeño productor y el impacto diferencial de las retenciones a las exportaciones agrarias, 2002-2008”. En: Villulla, J.M. y D. FernÁNDEZ (comp.). Sobre la tierra. Centro Interdisciplinario de Estudios Agrarios. Facultad de Ciencias Económicas, UBA. Buenos Aires.

- Peñalva, S. y A. Rofman (comp.) 1996. Desempleo estructural, pobreza y precariedad. Nueva Visión. Buenos Aires.

- Peretti, M. (coord.). 2003. Monitoreo económico de los sistemas productivos predominantes del sector agropecuario de Córdoba. Resultados campaña 2002/03 y proyección campaña 2003/04. INTA, UNRC. Secretaría de Agricultura y Ganadería de la Provincia de Córdoba. Río Cuarto.

- Preda, G. 2000. “¿Productores accidentales o empresarios flexibles?”. En: Realidad Económica, № 172 . Buenos Aires.

- PRIETO, O. 1995. "Estructura agraria y población en el sur de Córdoba", presentado en Terceras Jornadas Argentinas de Estudio de la Población. Universidad Nacional de La Pampa.

- Pucciarelli, A. 1986. El capitalismo agrario pampeano 1880-1930. Hyspamérica. Buenos Aires.

- Pucciarelli, A. 1993. “Cambios en la estructura agraria de la pampa bonaerense”. En: Ciclos, $\mathrm{N}^{\mathrm{o}} 5$. 
- Quinteros, G. 1996. "Los roles sociales femeninos en el mundo rural rioplatense durante la primera mitad del siglo XIX”. En: Estudios de Historia Rural IV, No 27. Facultad de Humanidades y Ciencias de la Educación, UNLP. La Plata.

- ReCA, L. y G. PARElladA. 2001. El sector agropecuario argentino. Editorial Facultad Agronomía, UBA. Buenos Aires.

- Reclus, E. 1975. El hombre y la tierra. 1/Los antepasados. Doncel. Madrid.

- ReNOLD, J.M. 1995. Estructura y organización cooperativa en el campo argentino. Editorial Magisterio. Rosario.

- Revista Interdisciplinaria de Estudios Agrarios, $\mathrm{N}^{\circ} 31,2^{\circ}$ semestre de 2009. Facultad de Ciencias Económicas, UBA. Buenos Aires.

- Ríos, M. y L. Achával. 1905. Geografía de la provincia de Córdoba. Vol. I y II. Compañía Sud-Americana de Billetes de Banco. Buenos Aires.

- Rivarola, A. 1999. "Estudio de la PEA Rural concentrada en base al análisis de un centro poblacional de menos de 2.000 habitantes. El caso de Suco". Informe de Beca de Ayudantía de la SeCyT, UNRC, realizada a través del Dpto. de Geografía, Facultad de Ciencias Humanas. Director: R. Agüero.

- Rivarola, A. y R. Maldonado. 2006. "El accionar de los contratistas de servicios agropecuarios en un sector de la Pampa cordobesa", ponencia presentada en el Congreso Internacional Humboldt. Colón (Entre Ríos).

- Rofman, A. y J.L. Romero. 1996. Sistema socio-económico y estructura regional argentina. Amorrortu. Buenos Aires.

- Rofman, A. y M. Foti. 2008. "Temas fundamentales en financiamiento operativo y de inversiones de micro, pequeñas y medianas empresas por una estrategia de desarrollo rural”. En: SCHEJTMAN, A. y O. BARSKY. El desarrollo rural en la Argentina. Siglo XXI. Buenos Aires.

- RuBio, B. 2010. "El péndulo del conocimiento rural, ¿gira de nuevo hacia la izquierda?". En: Revista Interdisciplinaria de Estudios Agrarios, $\mathrm{N}^{\mathrm{o}} 32,1^{\mathrm{o}}$ semestre. Centro Interdisciplinario de Estudios Agrarios, Facultad de Ciencias Económicas, UBA. Buenos Aires.

- SÁbAto, J. 1988. La clase dominante en la Argentina moderna. Formación y características. CISEA-Grupo Editor Latinoamericano.

- Salvatore, S. 1997. La renta diferencial internacional. Una teoría inconsistente. Cuadernos del PIEA 2. Facultad de Ciencias Económicas, UBA. 
- Samaja, J. 1993. Epistemología y metodología. Elementos para una teoría de la investigación científica. EUDEBA. Buenos Aires.

- Santarelli, E. 1993. "Rehacer todo lo destruido. Los conflictos obrero-rurales en la década 1927-1937”. En: ANSALDI, W. (comp.). Conflictos obrero-rurales pampeanos/3 (1900-1937). CEAL. Buenos Aires.

- SANTARELli, E. 1993. “Sindicatos obrero-rurales en la región pampeana, 1900-1922”. En: Ansaldi, W. (comp.). Conflictos obrero-rurales pampeanos/3 (1900-1937). CEAL. Buenos Aires.

- Santos, M. 2000. La naturaleza del espacio. Ariel. Barcelona.

- Scalabrini Ortiz, R. 2006. Historia de los ferrocarriles argentinos. Lancelot. Buenos Aires.

- Schejtman, A. y O. Barsky. 2008. El desarrollo rural en la Argentina. Siglo XXI. Buenos Aires.

- ScobIE, J. 1968. Revolución en las Pampas. Historia social del trigo argentino. 18601910. Solar. Buenos Aires.

- SlutzKY, D. 1968. “Aspectos sociales del desarrollo rural en la pampa húmeda argentina”. En: Desarrollo Económico, Vol. 8, № 29. IDES. Buenos Aires.

- Stavenhagen, R. 1971. Las clases sociales en las sociedades agrarias. Siglo XXI. México.

- TAdeO, N. (coord.). 2002. Procesos de cambio en las áreas rurales argentinas. Nidia S. Tadeo Editora. La Plata.

- Terzaga, A. 1963. Geografía de Córdoba. Assandri. Córdoba.

- Terzaga, A. 1996. Claves de la historia de Córdoba. UNRC. Río Cuarto.

- Teubal, M. 1995. Globalización y expansión agroindustrial. Corregidor. Buenos Aires.

- Teubal, M. 2001. “Globalización y nueva ruralidad en América Latina”. En: GiarraCA, N. (comp.) ¿Una nueva ruralidad en América Latina? CLACSO. Buenos Aires.

- Teubal, M. y J. RodríGuez. 2003. Agro y alimentos en la globalización: una perspectiva crítica. La Colmena. Buenos Aires.

- Teubal, M. y R. Pastore. 1995. "El agro y los complejos agroindustriales: el caso argentino". En: TEUBAL, M. Globalización y expansión agroindustrial. Corregidor. Buenos Aires.

- Torrado, S. 1992. Estructura social de la Argentina: 1945-1985. Ediciones de la Flor. Buenos Aires. 
- TORT, M. 1983. Los contratistas de maquinaria agrícola: una modalidad de organización económica del trabajo agrícola en la pampa húmeda. Documento de Trabajo No 11 . CEIL. Buenos Aires.

- Trigo, E. et al. 2002. Transgénicos en la agricultura. Libros del Zorzal. Buenos Aires.

- Vedoya, J. 1975. “La mujer en las Pampas”. En: Todo es Historia, № 95. Buenos Aires.

- VillanueVA, E. (coord.) 1997. Empleo y globalización. Universidad Nacional de Quilmes. Bernal.

- Villulla, J. 2010. “Las cosechas récord y sus trabajadores 'invisibles': los asalariados agrícolas y el contratismo de servicios en la pampa húmeda". En: Revista Interdisciplinaria de Estudios Agrarios, $\mathrm{N}^{\mathrm{o}} 33,2^{\circ}$ semestre. Facultad de Ciencias Económicas, UBA. Buenos Aires.

- Vitulo, A. 1947. Historia de Río Cuarto. Imprenta Sabino. Río Cuarto.

- WeBer, M. 1996. La ética protestante y el espíritu del capitalismo. Ediciones Coyoacán. México.

- Williams, R. 2001. El campo y la ciudad. Paidós. Buenos Aires.

- Wright, E. 1995. "Reflexionando una vez más sobre el concepto de estructura de clases". En: CarabañA, J. y A. DE Francisco (comp.). Teorías contemporáneas de las clases sociales. Editorial Pablo Iglesias. Madrid.

- Zalazar, D. y M. Bustamante. 2001. "Estudio de la PEA Rural concentrada en base al análisis de un centro poblacional de menos de 2.000 habitantes. El caso de Monte de los Gauchos”. Informe de Beca de Ayudantía de la SeCyT, UNRC, realizada a través del Dpto. de Geografía, Facultad de Ciencias Humanas. Director: R. Agüero.

- Zalazar, D. y M. Bustamante. 2001. "Estudio de la PEA Rural concentrada en base al análisis de un centro poblacional de menos de 2.000 habitantes. El caso de Washington y Tosquita”. Informe de Beca de Ayudantía de la SeCyT, UNRC, realizada a través del Dpto. de Geografía, Facultad de Ciencias Humanas. Director: R. Agüero.

- Zemborain, S.M. 1973. La verdad sobre la propiedad de la tierra en la Argentina. Instituto de Estudios Económicos de la Sociedad Rural Argentina. PROPAL SAS. Buenos Aires. 


\section{Fuentes documentales}

- Caracterización del sector agropecuario de la provincia de Córdoba. Proyecto PNUD Argentino 85/019. Ministerio de Agricultura de la Provincia de Córdoba. 1993.

- Censo Nacional de Población, Hogares y Viviendas 2001.

- Censos Nacionales de Población y Vivienda 1980 y 1991.

- Estimaciones de las campañas agrícolas 1988-2010 de la provincia de Córdoba según departamento. Secretaría de Agricultura, Ganadería y Alimentos de la Provincia de Córdoba, Subsecretaría de Agricultura, Unidad de Estimaciones Agrícolas. 2011.

- INDEC. 1991. Censo Nacional Agropecuario 1988. Provincia de Córdoba. Presidencia de la Nación, Secretaría de Planificación. Buenos Aires.

- INDEC. 2003. Censo Nacional Agropecuario 2002. Provincia de Córdoba. Presidencia de la Nación, Secretaría de Planificación. Buenos Aires.

- INDEC. Censo Nacional Agropecuario 1969, datos del relevamiento agrícola. Ministerio de Economía, Secretaría de Estado de Programación y Coordinación Económica. Buenos Aires.

- Información aportada por la Gerencia de Estadísticas y Censos del Gobierno de la Provincia de Córdoba (2004).

- Secretaría de Agricultura y Ganadería de Córdoba. Caracterización del sector agropecuario provincial por departamento. 2001. Ministerio de Producción y Trabajo. Córdoba.

- Secretaría de Agricultura y Ganadería de CóRdoba. Relevamiento agropecuario 1999 de la provincia de Córdoba. Ministerio de Producción y Trabajo. Córdoba. 


\section{Anexos}


Anexo 1

\section{Cuestionarios}




\section{Cuestionario de la Encuesta a los Productores Agropecuarios Que residen en LOS CENTROS URBANOS}

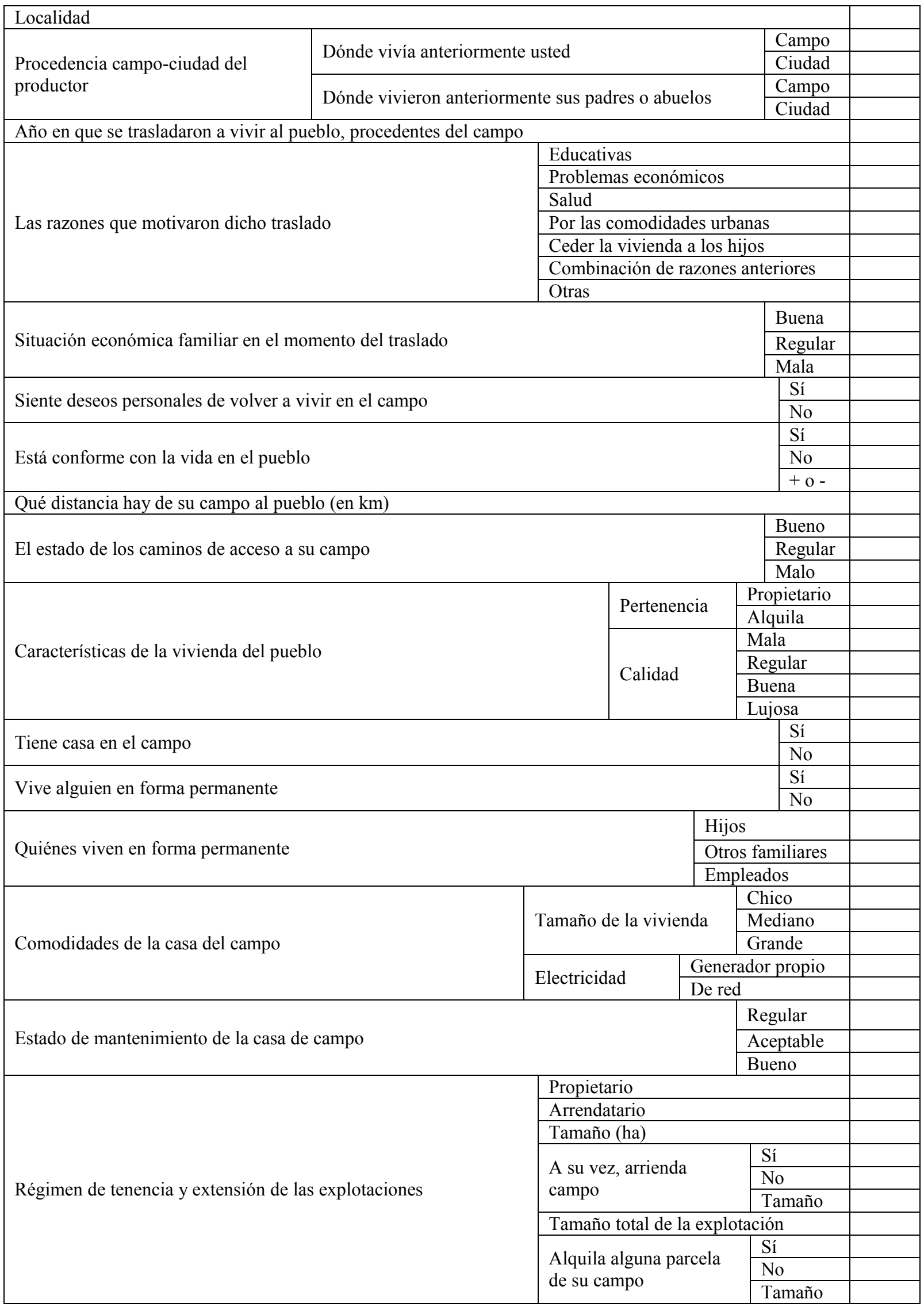




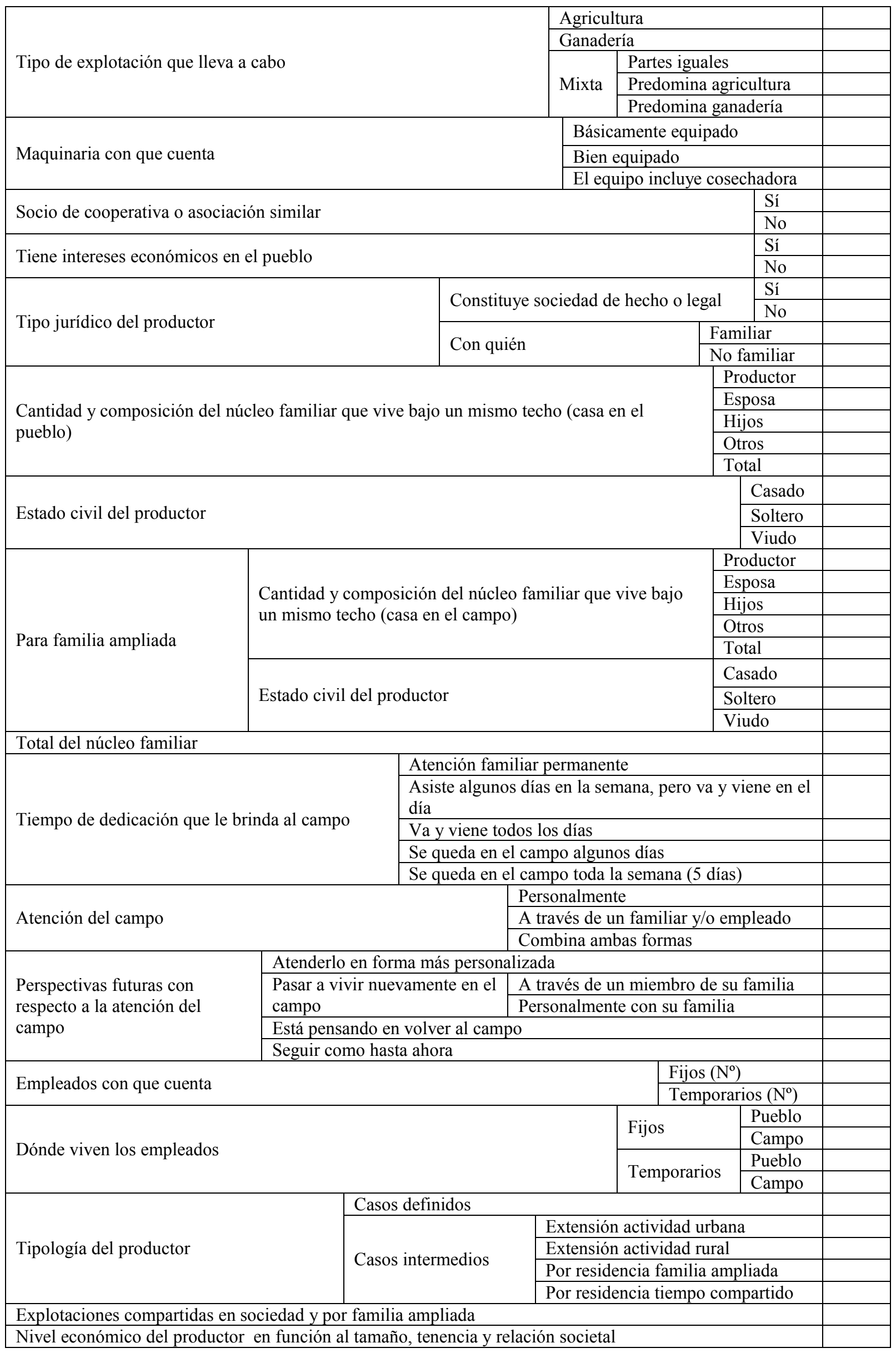




\section{Cuestionario de la ENTREVista a los ASAlariados RuRALES QUE RESIDEN EN LOS CENTROS URBANOS}

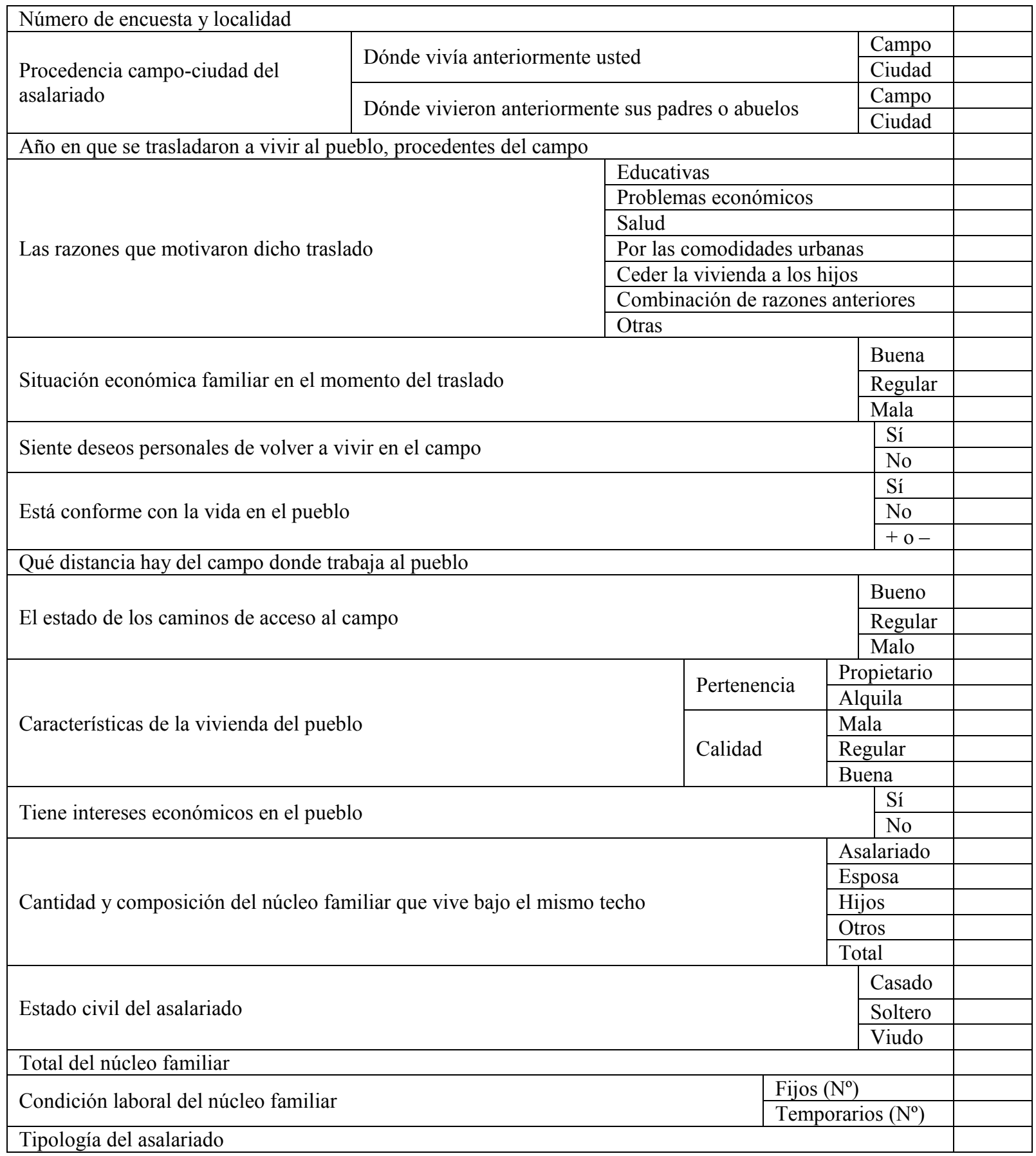




\section{Cuestionario de EnTReVista a los Agentes Ligados QUe ReSiden EN LOS CENTROS URBANOS}

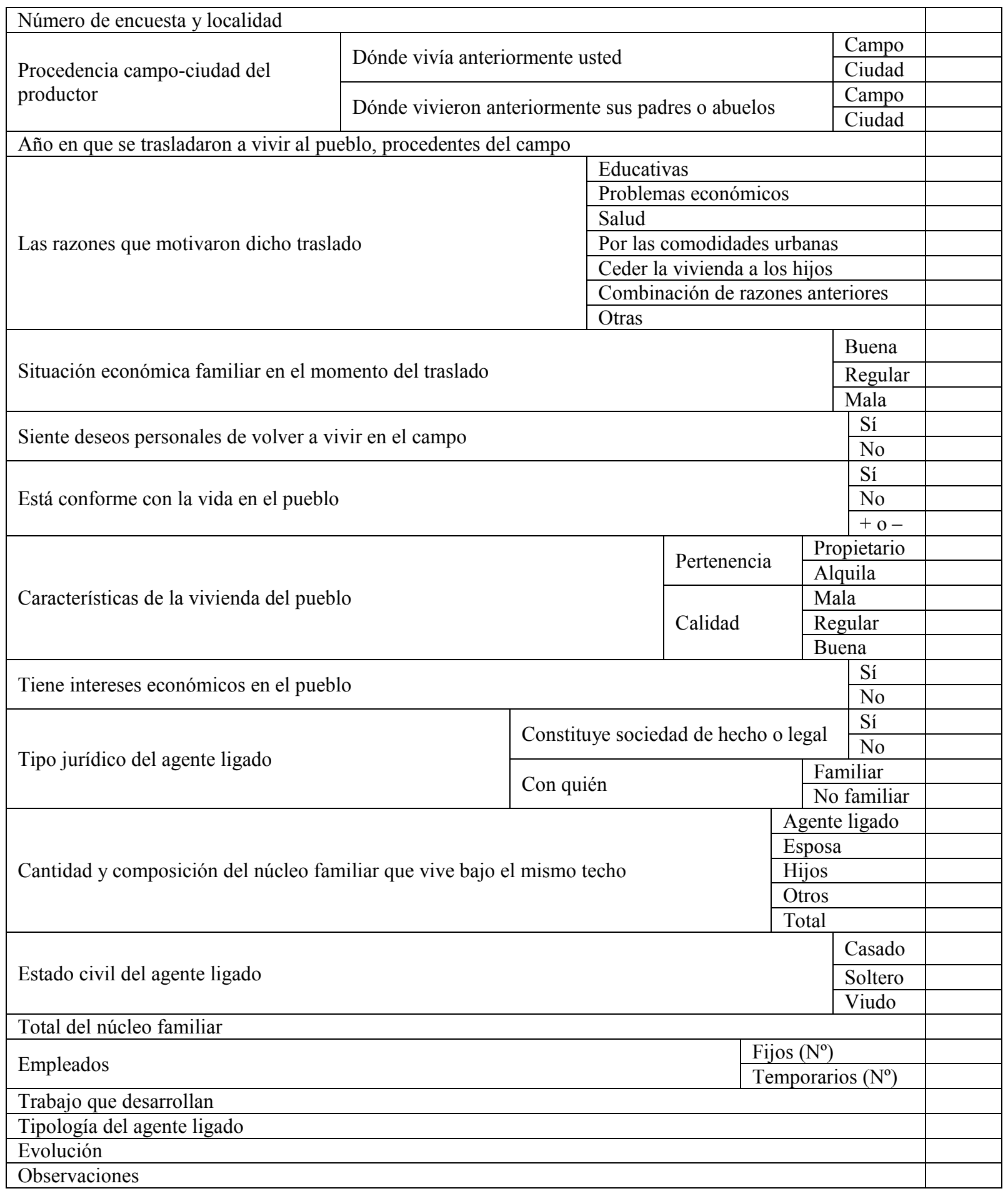




\section{Cuestionario de la Encuesta a los Productores Agropecuarios Que residen ESPECÍFICAMENTE EN LAS ZONAS RURALES}

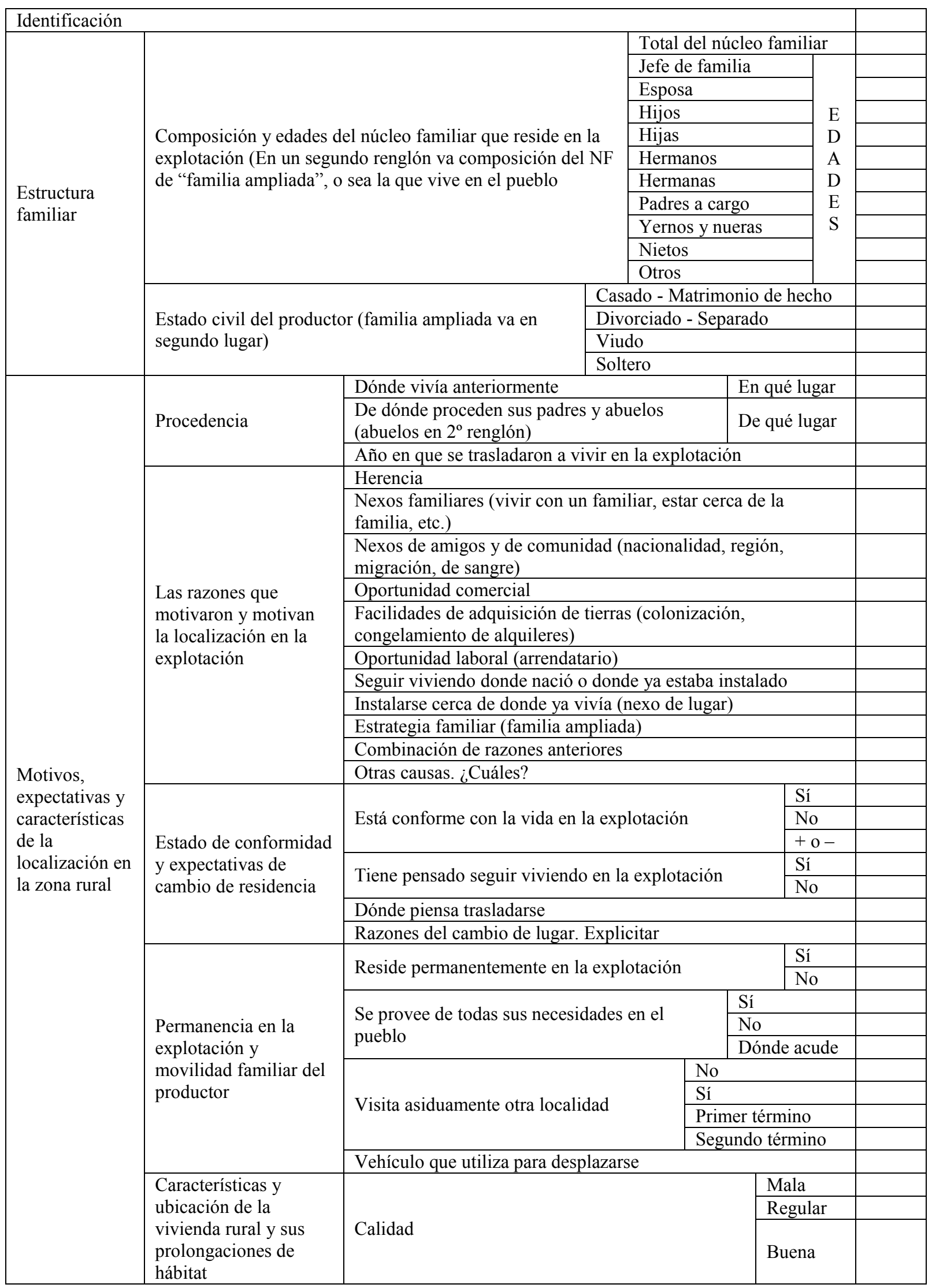




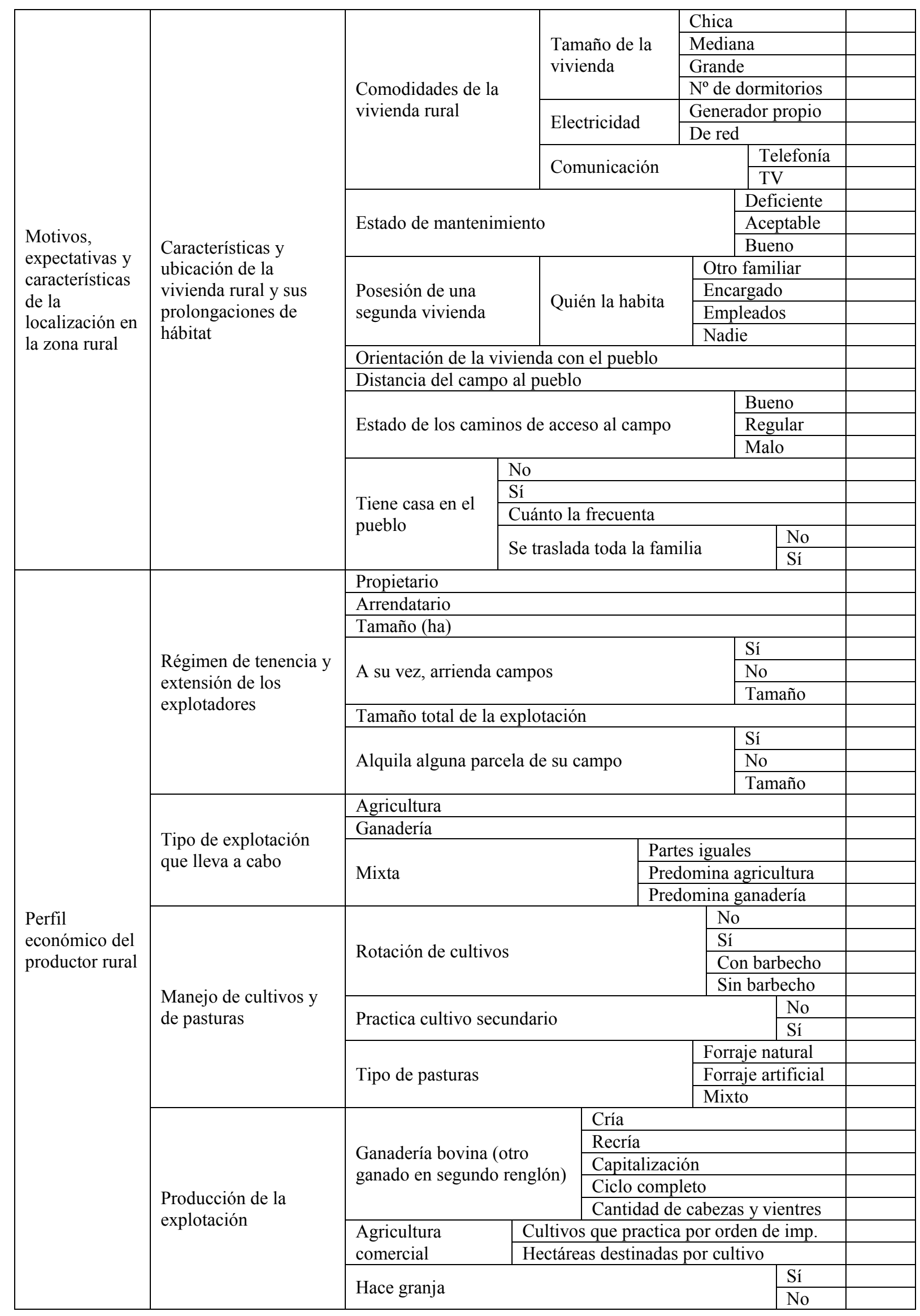




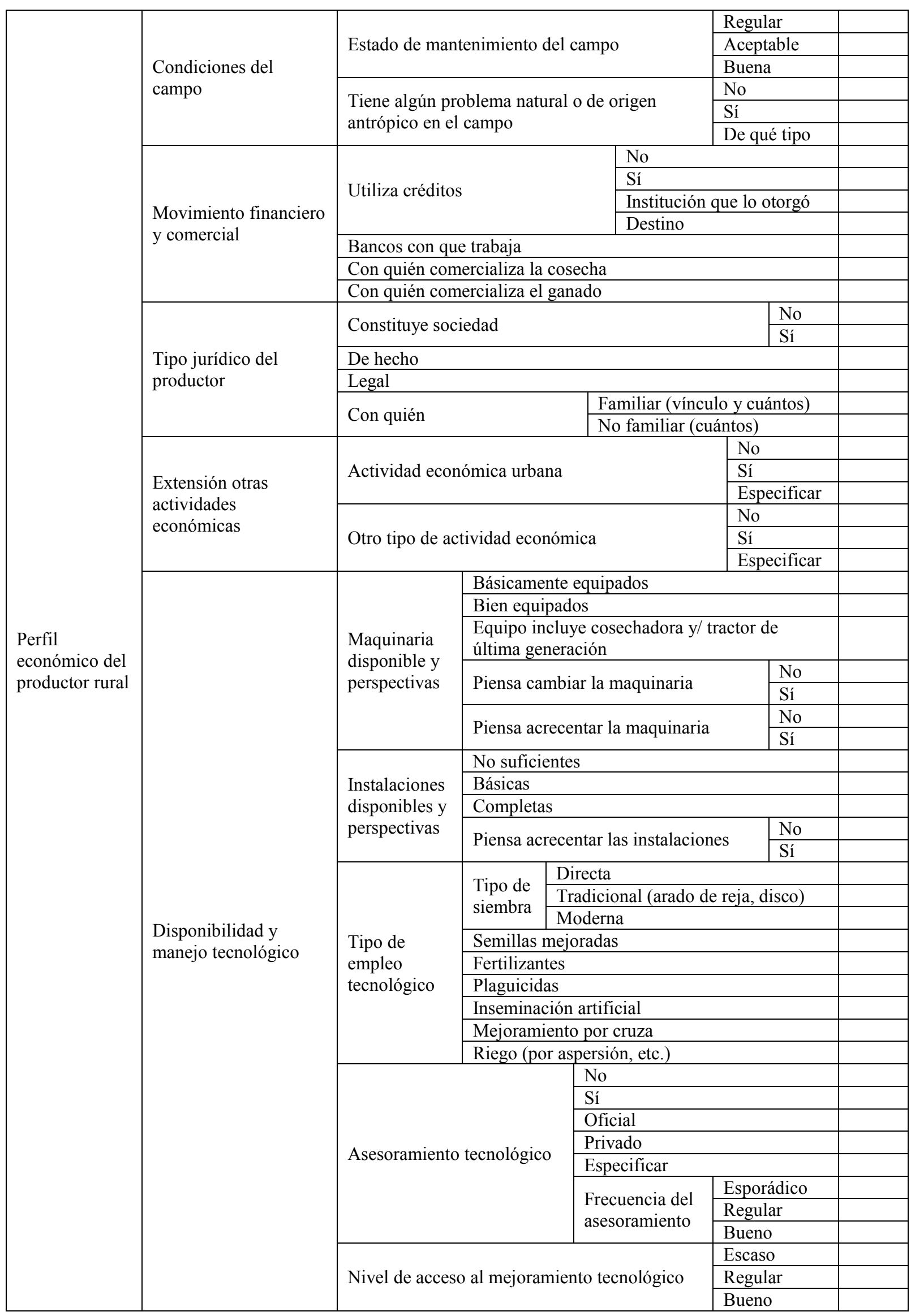




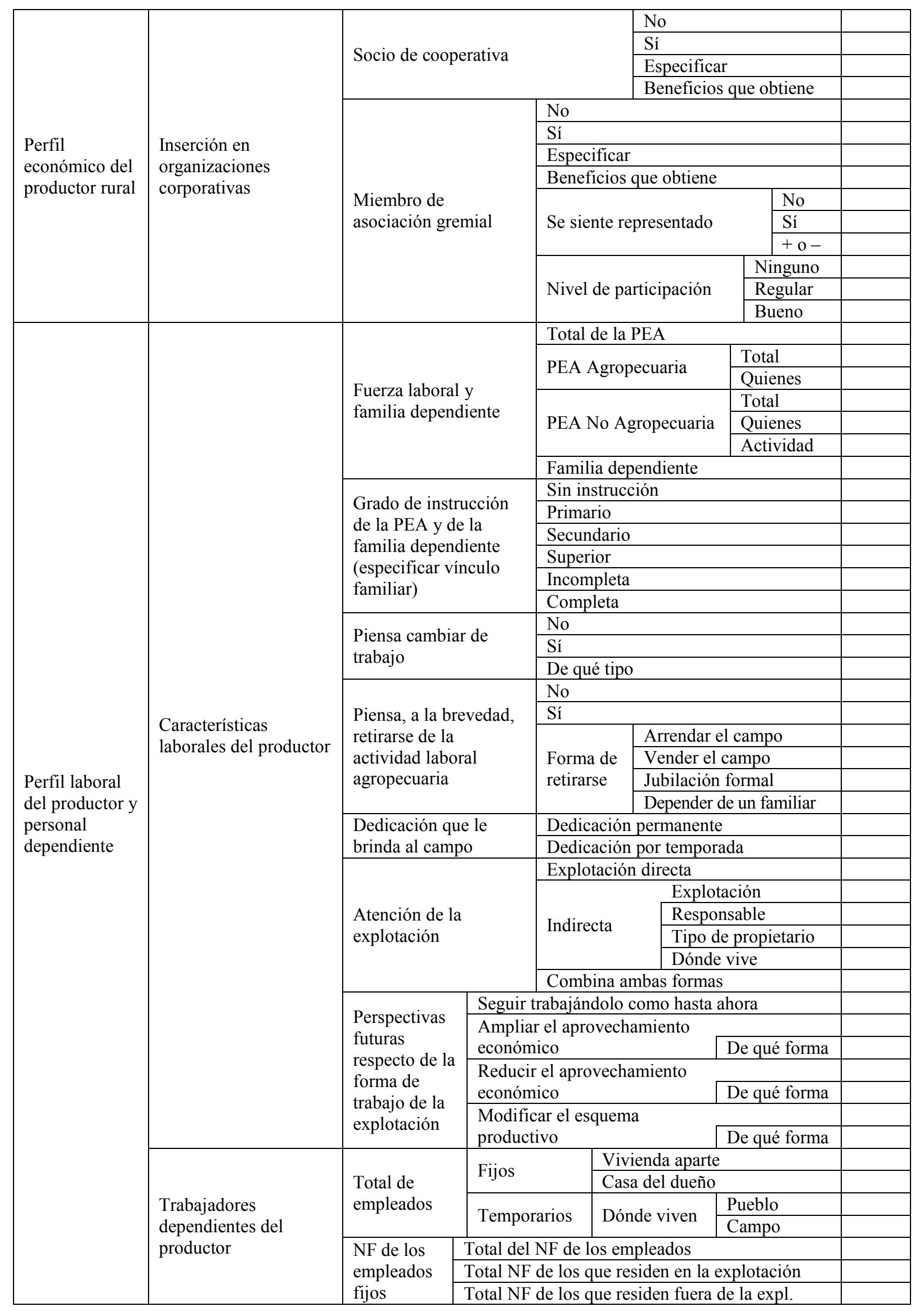




\begin{tabular}{|c|c|c|c|c|c|}
\hline \multirow{8}{*}{$\begin{array}{l}\text { Perfil laboral } \\
\text { del productor y } \\
\text { personal } \\
\text { dependiente }\end{array}$} & \multirow{8}{*}{$\begin{array}{l}\text { Trabajadores } \\
\text { dependientes del } \\
\text { productor }\end{array}$} & \multirow{2}{*}{\multicolumn{2}{|c|}{ Ingresos de los empleados fijos }} & \multirow{2}{*}{\multicolumn{2}{|c|}{$\begin{array}{l}\text { Formas de pago } \\
\text { Monto del pago }\end{array}$}} \\
\hline & & & & & \\
\hline & & \multirow{6}{*}{$\begin{array}{l}\text { Aportes y } \\
\text { contratos a } \\
\text { empleados fijos }\end{array}$} & \multirow{2}{*}{\multicolumn{2}{|c|}{ Le efectúa aportes jubilatorios }} & No \\
\hline & & & & & Sí \\
\hline & & & \multirow{2}{*}{\multicolumn{2}{|c|}{ Le efectúa aportes de obra social }} & No \\
\hline & & & & & Sí \\
\hline & & & \multirow{2}{*}{\multicolumn{2}{|c|}{ Media contrato de trabajo }} & $\begin{array}{ll}\text { No } \\
\text { Sí }\end{array}$ \\
\hline & & & & & Sí \\
\hline
\end{tabular}




\section{CUestionario de ENTREVista A LOS ASAlariados RuRales (GENERAL)}

\begin{tabular}{|c|c|c|c|c|c|c|c|c|c|}
\hline \multicolumn{9}{|c|}{ Identificación del asalariado y fecha } & \\
\hline \multirow{11}{*}{$\begin{array}{l}\text { Estructura familiar } \\
\text { del asalariado }\end{array}$} & \multirow{10}{*}{$\begin{array}{l}\text { Composición y } \\
\text { edades del NF que } \\
\text { vive bajo un } \\
\text { mismo techo }\end{array}$} & \multicolumn{7}{|c|}{ Total del Núcleo Familiar } & \\
\hline & & \multicolumn{7}{|c|}{ Jefe de familia } & \\
\hline & & \multicolumn{7}{|l|}{ Esposa } & \\
\hline & & \multicolumn{7}{|l|}{ Hijos } & \\
\hline & & \multicolumn{7}{|l|}{ Hijas } & \\
\hline & & \multicolumn{7}{|c|}{ Hermanos (diferenciar sexo) } & \\
\hline & & \multicolumn{7}{|c|}{ Padres a cargo (diferenciar sexo) } & \\
\hline & & \multicolumn{7}{|c|}{ Yernos y nueras } & \\
\hline & & \multicolumn{7}{|c|}{ Nietos (diferenciar sexo) } & \\
\hline & & \multicolumn{7}{|c|}{ Otros (diferenciar sexo) } & \\
\hline & & Estado civil del asalariado (casado, divorciado, viudo, soltero) \\
\hline & \multirow{17}{*}{$\begin{array}{l}\text { Localización } \\
\text { urbana }\end{array}$} & \multirow{5}{*}{ Procedencia } & \multirow{2}{*}{\multicolumn{5}{|c|}{ Dónde vivía anteriormente }} & Campo & \\
\hline & & & & & & & & Ciudad & \\
\hline & & & \multirow{2}{*}{\multicolumn{5}{|c|}{$\begin{array}{l}\text { De dónde proceden sus padres y } \\
\text { abuelos (abuelos en } 2^{\circ} \text { renglón) } \\
\text { Nacionalidad }\end{array}$}} & Campo & \\
\hline & & & & & & & & Ciudad & \\
\hline & & & \multicolumn{6}{|c|}{ Año en que se trasladaron a vivir al pueblo } & \\
\hline & & \multicolumn{7}{|c|}{$\begin{array}{l}\text { Las razones que motivaron dicho traslado (para los que } \\
\text { proceden del campo o de otra ciudad) Ej. educativas, problemas } \\
\text { económicos, salud, comodidades urbanas, otras) }\end{array}$} & \\
\hline & & & & & & & & Sí & \\
\hline & & & & $\begin{array}{l}\text { Esta cor } \\
\text { nueblo }\end{array}$ & orme & $\operatorname{con} \mathrm{v}$ & vir en el & No & \\
\hline & & conformidad y & & & & & & $+0-$ & \\
\hline & & expectativas de & & Tiene $\mathrm{p}$ & isado & segui & viviendo & Sí & \\
\hline & & cambio de & & en el pu & & & & No & \\
\hline & & & & Dónde 1 & ensa t & raslac & arse & & \\
\hline & & & & Razones & e can & nbio d & lugar (ex & splicitar) & \\
\hline & & & & Pertene1 & ia (pr & opiet & rio o inqu & ilino) & \\
\hline & & Características & & Calidad & precal & ria, re & sular, buen & & \\
\hline & & la vivienda & & Tamaño & la la & Chi & a, median & a, grande & \\
\hline & & & & viviend & & $\mathrm{N}^{\mathrm{o}} \mathrm{C}$ & e habitacic & ones & \\
\hline Características de & & & & $\begin{array}{l}\text { nde vivía } \\
\text { teriormen }\end{array}$ & & & En qué lu & ugar & \\
\hline & & $\begin{array}{l}\text { Procedencia y } \\
\text { ubicación del }\end{array}$ & & $\begin{array}{l}\text { dónde pi } \\
\text { dres y abu } \\
\text { uelos en }\end{array}$ & $\begin{array}{l}\text { ceden } \\
\text { los } \\
\text { o reng }\end{array}$ & sus & $\begin{array}{l}\text { De qué ll } \\
\text { (naciona }\end{array}$ & $\begin{array}{l}\text { ugar } \\
\text { lidad) }\end{array}$ & \\
\hline & & $\begin{array}{l}\text { lugar de } \\
\text { residencia }\end{array}$ & & $\begin{array}{l}\text { sde cuán } \\
\text { lugar) }\end{array}$ & resic & de en & a explotac & ión (o en & \\
\hline & & & & icación d & 1 luga & & $\begin{array}{l}\text { Orientaci } \\
\text { respecto }\end{array}$ & $\begin{array}{l}\text { ión con } \\
\text { al pueblo }\end{array}$ & \\
\hline & & & & & & & Distancia & al pueblo & \\
\hline & & & & & Suel & Ido ad & ecuado y $\mathrm{p}$ & premios & \\
\hline & Localización rural & & & & Vivi & ienda & aceptable & & \\
\hline & & Las razones po & & $\begin{array}{l}\text { uales } \\
\text { idir en la }\end{array}$ & Bue & $\mathrm{n}$ trat & & & \\
\hline & & decidio trabaja & y r & idir en la & $\mathrm{Hab}$ & er nac & ido en el 1 & ugar & \\
\hline & & brindarle trabaj & & parte de & $\begin{array}{l}\text { No t } \\
\text { obli }\end{array}$ & $\begin{array}{l}\text { tener } \\
\text { gacio }\end{array}$ & $\begin{array}{l}\text { iijos con } \\
\text { les escolar }\end{array}$ & & \\
\hline & & & & & Otra & & & & \\
\hline & & & & Está cor & orme & con la & vida en la & Sí & \\
\hline & & Estado de & & explotac & & & & No & \\
\hline & & conformidad y & & Tiene $\mathrm{p}$ & isado & segui & viviendo & Sí & \\
\hline & & expectativas de & & en la ex & otacic & & & No & \\
\hline & & residencia & & Dónde $\mathrm{p}$ & ensa t & raslac & arse & & \\
\hline & & & & Razones & del ca & mbio & de lugar $(\mathrm{e}$ & explicitar) & \\
\hline
\end{tabular}




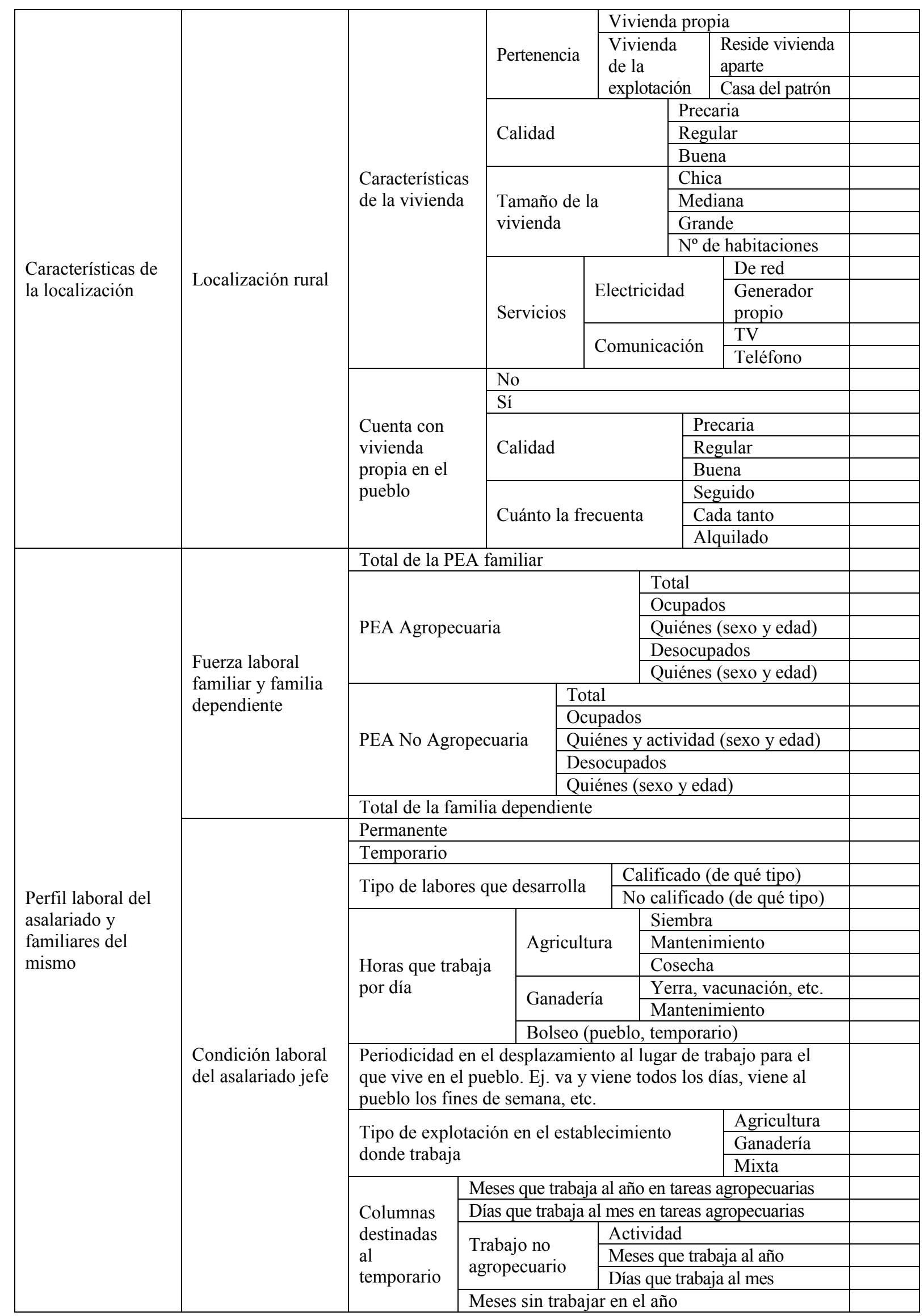




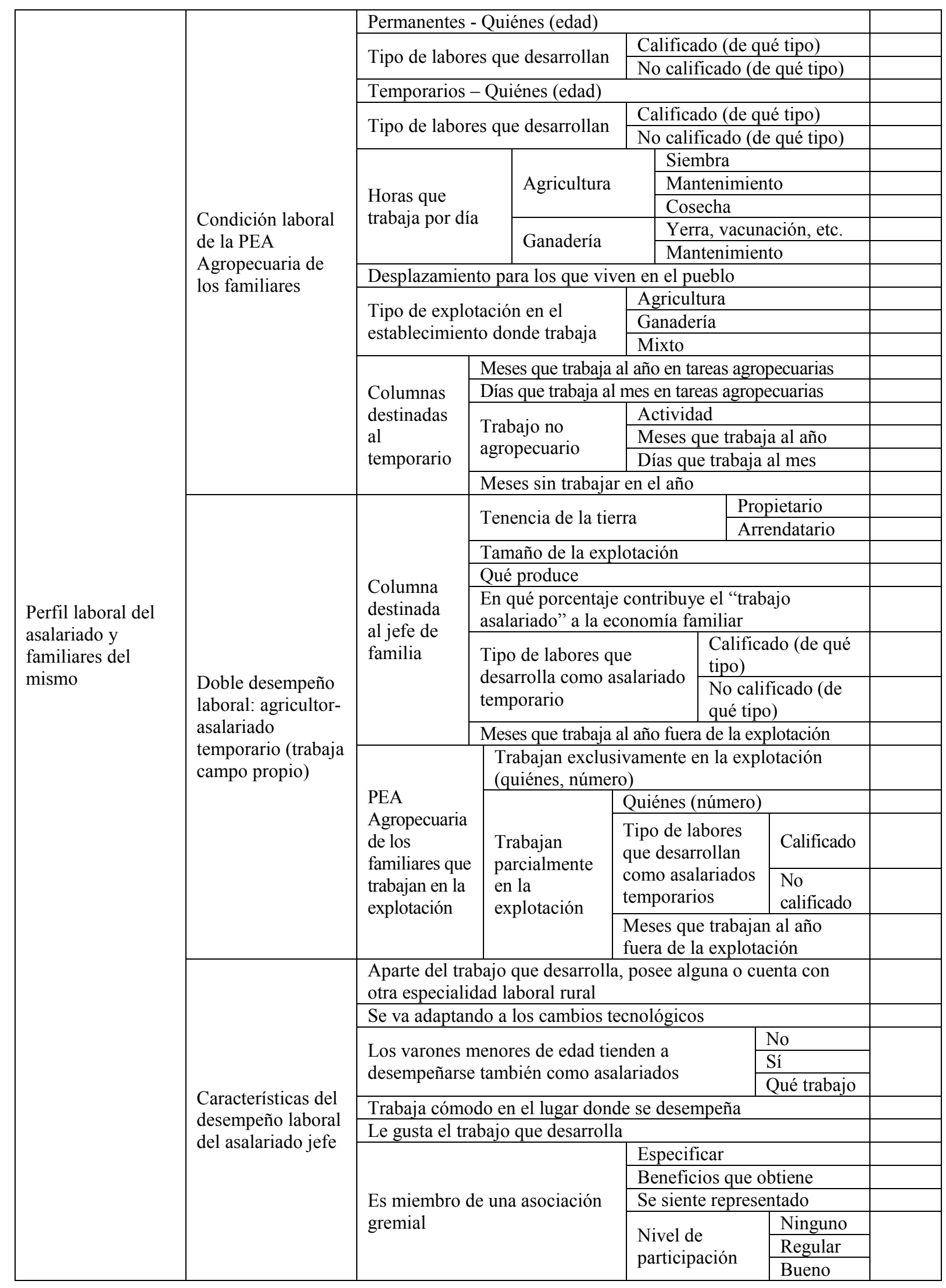




\begin{tabular}{|c|c|c|c|c|c|}
\hline & \multirow{4}{*}{$\begin{array}{l}\text { Ingresos del } \\
\text { asalariado } \\
\text { permanente jefe }\end{array}$} & \multicolumn{3}{|c|}{ Monto de la mensualidad (en \$) } & \\
\hline & & \multirow{2}{*}{$\begin{array}{l}\text { Otros ingresos que } \\
\text { complementan la } \\
\text { mensualidad }\end{array}$} & \multicolumn{2}{|c|}{ Premios (en \$) } & \\
\hline & & & \multicolumn{2}{|c|}{$\begin{array}{l}\text { Participación en la producción (en } \\
\% \text { o en monto fijo) }\end{array}$} & \\
\hline & & \multicolumn{3}{|c|}{ Total del ingreso mensual } & \\
\hline & \multirow{8}{*}{$\begin{array}{l}\text { Aportes y } \\
\text { contratos al } \\
\text { asalariado } \\
\text { permanente jefe }\end{array}$} & \multirow{2}{*}{\multicolumn{2}{|c|}{ Se le efectuaron aportes jubilatorios }} & Sí & \\
\hline & & & & No & \\
\hline & & \multicolumn{3}{|c|}{ Realizan aportes jubilatorios por su cuenta } & \\
\hline & & \multirow{2}{*}{\multicolumn{2}{|c|}{ Se le efectuaron aportes de obra social }} & Sí & \\
\hline & & & & No & \\
\hline & & \multicolumn{3}{|c|}{ Realiza aportes de obra social por su cuenta } & \\
\hline & & \multirow{2}{*}{\multicolumn{2}{|c|}{ Media contrato de trabajo }} & Sí & \\
\hline & & & & No & \\
\hline & \multirow{14}{*}{$\begin{array}{l}\text { Aportes y } \\
\text { contratos al } \\
\text { asalariado } \\
\text { temporario jefe }\end{array}$} & \multirow{2}{*}{$\begin{array}{l}\text { Formas de pago } \\
\text { en tareas } \\
\text { agropecuarias }\end{array}$} & \multicolumn{2}{|c|}{$\begin{array}{l}\text { Por cantidad de trabajo: has, hs. trabajadas, } \\
\text { por bolas, etc. (monto en } \$ \text { ) }\end{array}$} & \\
\hline & & & \multicolumn{2}{|c|}{$\begin{array}{l}\text { Por jornal, semana, quincena, mes (monto } \\
\text { en \$) }\end{array}$} & \\
\hline & & \multirow{2}{*}{$\begin{array}{l}\text { Forma de pago } \\
\text { en tareas no } \\
\text { agropecuarias }\end{array}$} & \multicolumn{2}{|c|}{$\begin{array}{l}\text { Por cantidad de trabajo : hs. trabajadas, } \\
\text { tareas realizadas, etc. (monto en } \$ \text { ) }\end{array}$} & \\
\hline & & & \multicolumn{2}{|c|}{$\begin{array}{l}\text { Por jornal, semana, quincena, mes (monto } \\
\text { en \$) }\end{array}$} & \\
\hline & & \multicolumn{3}{|c|}{ Ingreso mensual en época de tareas agropecuarias } & \\
\hline & & \multicolumn{3}{|c|}{ Ingreso mensual en época de inactividad agropecuaria } & \\
\hline & & \multirow{2}{*}{\multicolumn{2}{|c|}{ Se le efectuaron aportes jubilatorios }} & Sí & \\
\hline & & & & No & \\
\hline \multirow{19}{*}{$\begin{array}{l}\text { Perfil económico } \\
\text { del asalariado }\end{array}$} & & \multicolumn{3}{|c|}{ Realiza aportes jubilatorios por su cuenta } & \\
\hline & & \multirow{2}{*}{\multicolumn{2}{|c|}{ Se le efectuaron aportes de obra social }} & Sí & \\
\hline & & & & No & \\
\hline & & \multicolumn{3}{|c|}{ Realiza aportes de obra social por su cuenta } & \\
\hline & & \multirow{2}{*}{\multicolumn{2}{|c|}{ Media contrato de trabajo }} & Sí & \\
\hline & & & & No & \\
\hline & $\begin{array}{l}\text { Apoyo económico } \\
\text { de la esposa y }\end{array}$ & Cuánto contribu. & en \$ mensualmente & & \\
\hline & $\begin{array}{l}\text { otros miembros en } \\
\text { tareas no } \\
\text { agropecuarias }\end{array}$ & $\begin{array}{l}\text { Cuánto contribuy } \\
\text { familiares }\end{array}$ & mensualmente en & & \\
\hline & Algún tipo de & Plan Trabajar $(\mathrm{q}$ & n o quiénes, tareas & & \\
\hline & ayuda económica & Ayuda alimentar & escolar, remedios, & & \\
\hline & que recibe & Qué institución 1 & otorga esos benefic & & \\
\hline & Cuenta con mutual & De qué tipo & & & \\
\hline & Socio de & Especificar & & & \\
\hline & cooperativa & Beneficios que 0 & iene & & \\
\hline & $\begin{array}{l}\text { Accede al crédito } \\
\text { normalmente }\end{array}$ & De qué tipo & & & \\
\hline & $\begin{array}{l}\text { Los padres o } \\
\text { abuelos han } \\
\text { trabajado un }\end{array}$ & En calidad de pr & ietarios o arrendatar & & \\
\hline & $\begin{array}{l}\text { campo por su } \\
\text { cuenta }\end{array}$ & Cuál fue el moti & de no seguir trabaja & & \\
\hline & $\begin{array}{l}\text { Potencial } \\
\text { otorgamiento de } \\
\text { tierras }\end{array}$ & $\begin{array}{l}\text { Si el gobierno ot } \\
\text { trabajarlas, desec }\end{array}$ & $\begin{array}{l}\text { gase tierras a crédit } \\
\text { a ser beneficiado }\end{array}$ & & \\
\hline & $\begin{array}{l}\text { Medio de } \\
\text { locomoción propio }\end{array}$ & De qué tipo & & & \\
\hline
\end{tabular}




\begin{tabular}{|c|c|c|c|c|c|c|}
\hline \multirow{10}{*}{$\begin{array}{l}\text { Perfil económico } \\
\text { del asalariado }\end{array}$} & \multirow{10}{*}{$\begin{array}{l}\text { Perspectivas } \\
\text { futuras en su } \\
\text { actividad } \\
\text { económica laboral }\end{array}$} & \multicolumn{4}{|c|}{ Seguir trabajando como hasta ahora } & \\
\hline & & \multirow{4}{*}{$\begin{array}{l}\text { Cambiar de } \\
\text { trabajo en la } \\
\text { actividad } \\
\text { agropecuaria }\end{array}$} & \multicolumn{3}{|c|}{ De temporario a permanente o viceversa } & \\
\hline & & & \multicolumn{3}{|c|}{ Trabajar con las máquinas } & \\
\hline & & & \multicolumn{3}{|c|}{$\begin{array}{l}\text { Trabajar un campo propio como arrendatario o } \\
\text { propietario }\end{array}$} & \\
\hline & & & \multicolumn{3}{|l|}{ Otra forma } & \\
\hline & & \multicolumn{2}{|c|}{$\begin{array}{l}\text { Cambiar de trabajo en la actividad } \\
\text { no agropecuaria }\end{array}$} & \multicolumn{2}{|c|}{ Por qué tipo de trabajo } & \\
\hline & & \multirow{3}{*}{\multicolumn{3}{|c|}{ Cambiar el trabajo rural por uno urbano }} & De qué tipo & \\
\hline & & & & & Dónde & \\
\hline & & & & & Motivaciones & \\
\hline & & \multicolumn{3}{|c|}{ La "mujer" desea cambiar de trabajo } & De qué tipo & \\
\hline \multirow{34}{*}{$\begin{array}{l}\text { Caracterización } \\
\text { social del grupo } \\
\text { familiar del } \\
\text { asalariado }\end{array}$} & \multirow{9}{*}{$\begin{array}{l}\text { Nivel de } \\
\text { instrucción del } \\
\text { total del NF del } \\
\text { asalariado } \\
\text { (especificar } \\
\text { vínculo familiar }\end{array}$} & & \\
\hline & & \multirow{2}{*}{$\begin{array}{l}\text { No lee / No escribe } \\
\text { Primario }\end{array}$} & Completo & & & \\
\hline & & & Incompleto & & & \\
\hline & & \multirow{3}{*}{ Secundario } & \multirow{2}{*}{\multicolumn{2}{|c|}{ Completo }} & Del sector & \\
\hline & & & & & Otro & \\
\hline & & & \multicolumn{3}{|l|}{ Incompleto } & \\
\hline & & \multirow{3}{*}{$\begin{array}{l}\text { Terciario / } \\
\text { Universitario }\end{array}$} & \multirow{2}{*}{\multicolumn{2}{|c|}{ Completo }} & Del sector & \\
\hline & & & & & Otro & \\
\hline & & & \multicolumn{3}{|l|}{ Incompleto } & \\
\hline & \multirow{5}{*}{$\begin{array}{l}\text { Disponibilidad y } \\
\text { aspiraciones } \\
\text { educativas }\end{array}$} & \multicolumn{4}{|c|}{$\begin{array}{l}\text { Disponibilidad y calidad de escuelas rurales (para los que viven } \\
\text { en el campo) }\end{array}$} & \\
\hline & & $\begin{array}{l}\text { Nivel de acce } \\
\text { en el campo) }\end{array}$ & a las escuelas secun & & ara los que viven & \\
\hline & & Mujer: preten & ones con respeto a la & duc & ón de los niños & \\
\hline & & Tiene pretens & nes de realizar algún & ipo & estudio (mujer) & \\
\hline & & $\begin{array}{l}\text { De implemen } \\
\text { participaría d }\end{array}$ & $\begin{array}{l}\text { rse un "plan de perfe } \\
\text { mismo }\end{array}$ & & iento laboral”, & \\
\hline & & La vivienda $\mathrm{s}$ & isface las necesidade & fan & Ires & \\
\hline & Condiciones & Tiene cubiert & las necesidades bási & d & confort" hogareño & \\
\hline & socioeconómicas & Cubre las nec & idades alimenticias & & & \\
\hline & de vida a nivel & Cubre las nec & idades de vestimenta & & & \\
\hline & familiar (entrevista & Cubre las nec & idades de la salud fa & ilia & & \\
\hline & a la “mujer”) & Se siente cóm & da en el lugar donde & & & \\
\hline & & Los ancianos & n contenidos en el ho & gar & iiliar & \\
\hline & & Vinculación & $\mathrm{n}$ los parientes (limita & la, & table, intensa) & \\
\hline & & $\begin{array}{l}\text { Vinculacione } \\
\text { clubes) }\end{array}$ & con el entorno (vecin & & dades vecinales, & \\
\hline & Vinculaciones y & $\begin{array}{l}\text { Vinculacione } \\
\text { provincias) }\end{array}$ & con el entorno más le & & dades, otras & \\
\hline & $\begin{array}{l}\text { participacion } \\
\text { social }\end{array}$ & $\begin{array}{l}\text { Medios de co } \\
\text { radio, compu }\end{array}$ & $\begin{array}{l}\text { unicación que frecue } \\
\text { lora) }\end{array}$ & & ono, celular, TV, & \\
\hline & & $\begin{array}{l}\text { Empleo del ti } \\
\text { lectura) }\end{array}$ & npo libre (deportes, $v$ & & seos, caza, & \\
\hline & & Participación & política y opinión d & 1 & & \\
\hline & & Cuál es su vi & ncia del país & & & \\
\hline & & Creencia y pr & tica religiosa & & & \\
\hline & & Siente cariño & e identifica) con el lu & $\operatorname{ar}$ & de vive & \\
\hline & $\begin{array}{l}\text { Vivencia y } \\
\text { formación cultural }\end{array}$ & $\begin{array}{l}\text { Se identifica } \\
\text { tradicionales) }\end{array}$ & n las tradiciones cam & 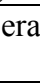 & ogones, centros & \\
\hline & & Esta identific & ión la transmite a sus & n1jo & & \\
\hline & & Le transmite & us hijos sus conocim & ent & rales & \\
\hline & & Cuáles son su & aspiraciones de vida & & & \\
\hline
\end{tabular}




\section{Cuestionario de la EnCuesta a los Contratistas de Servicios}

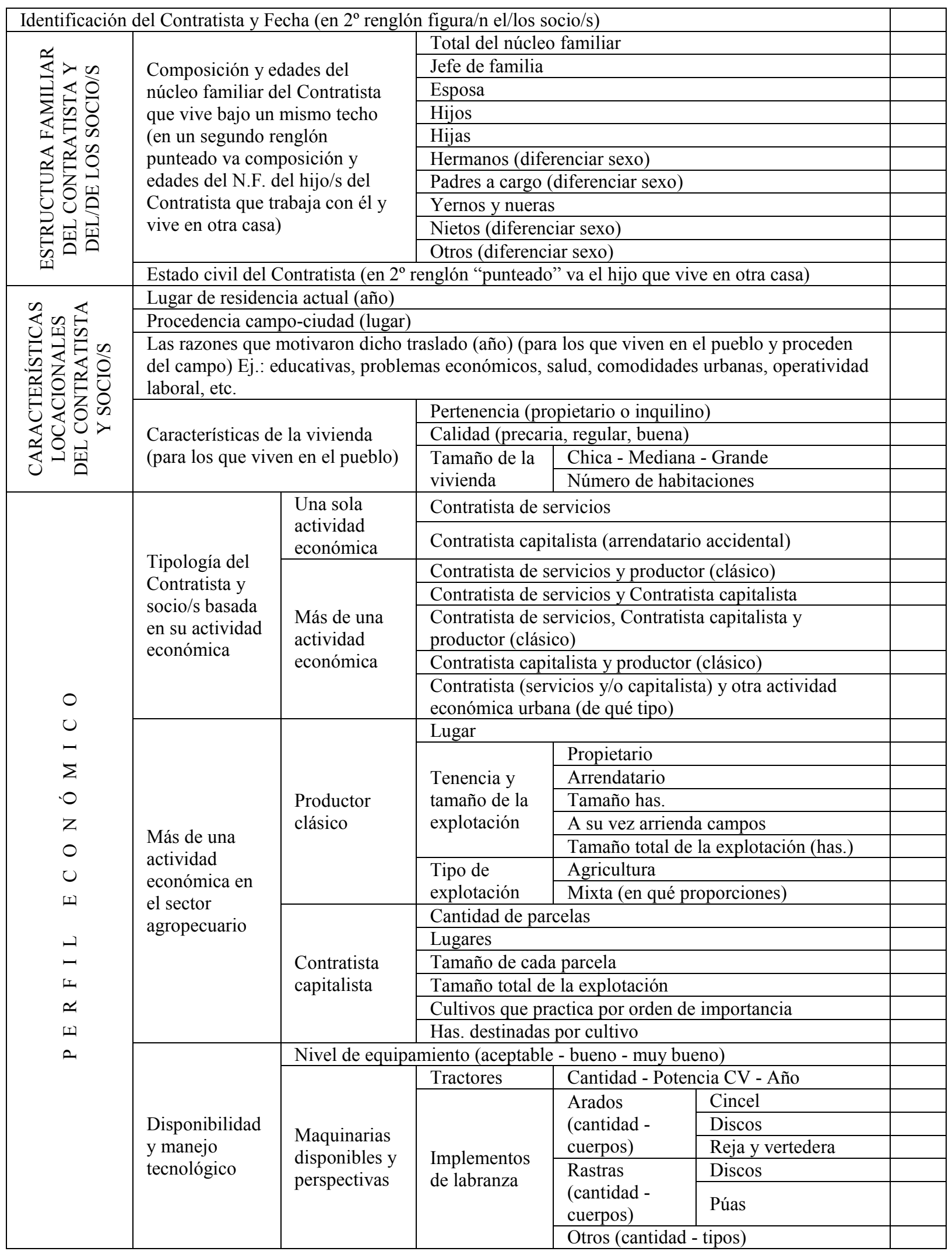




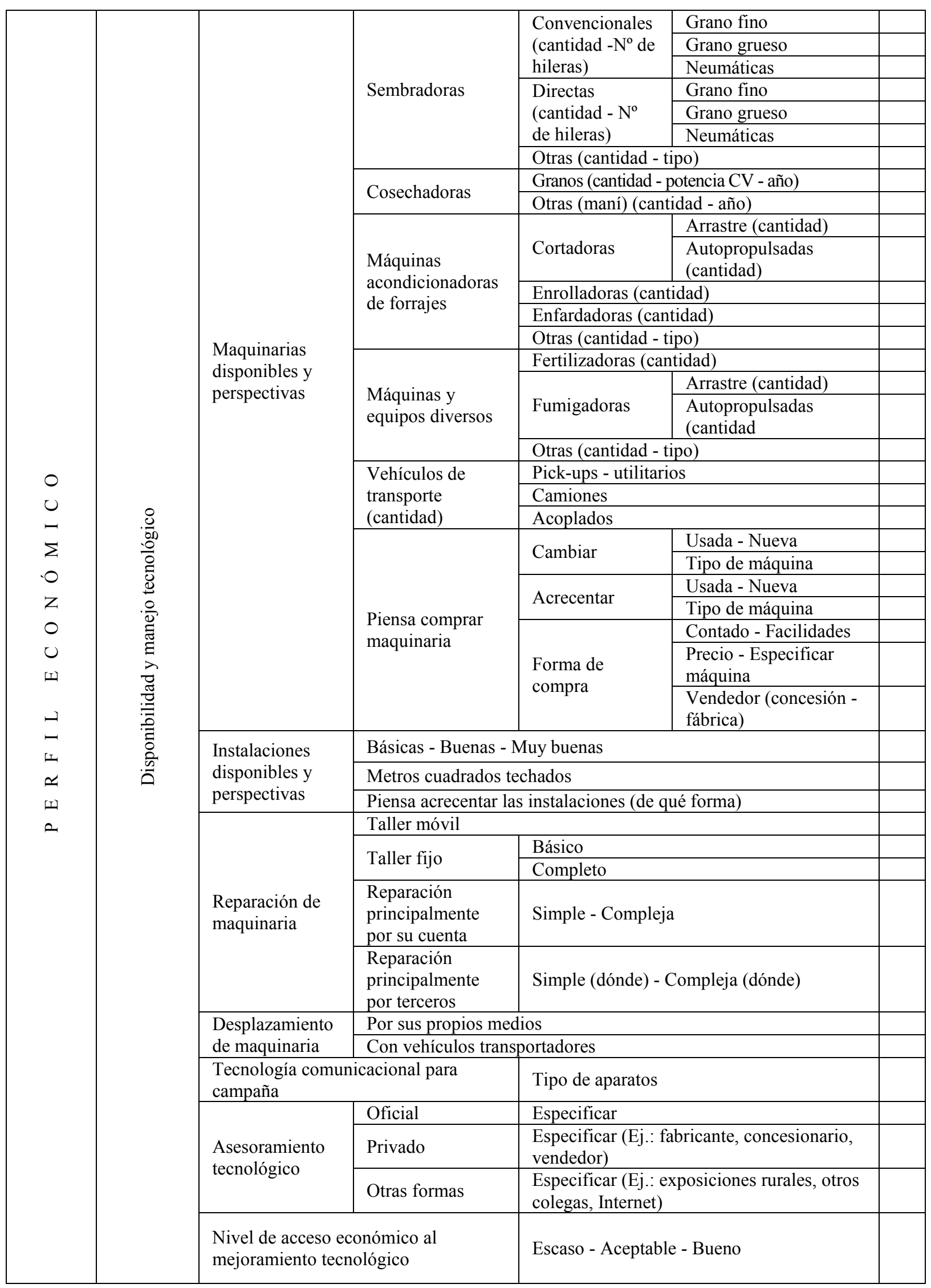




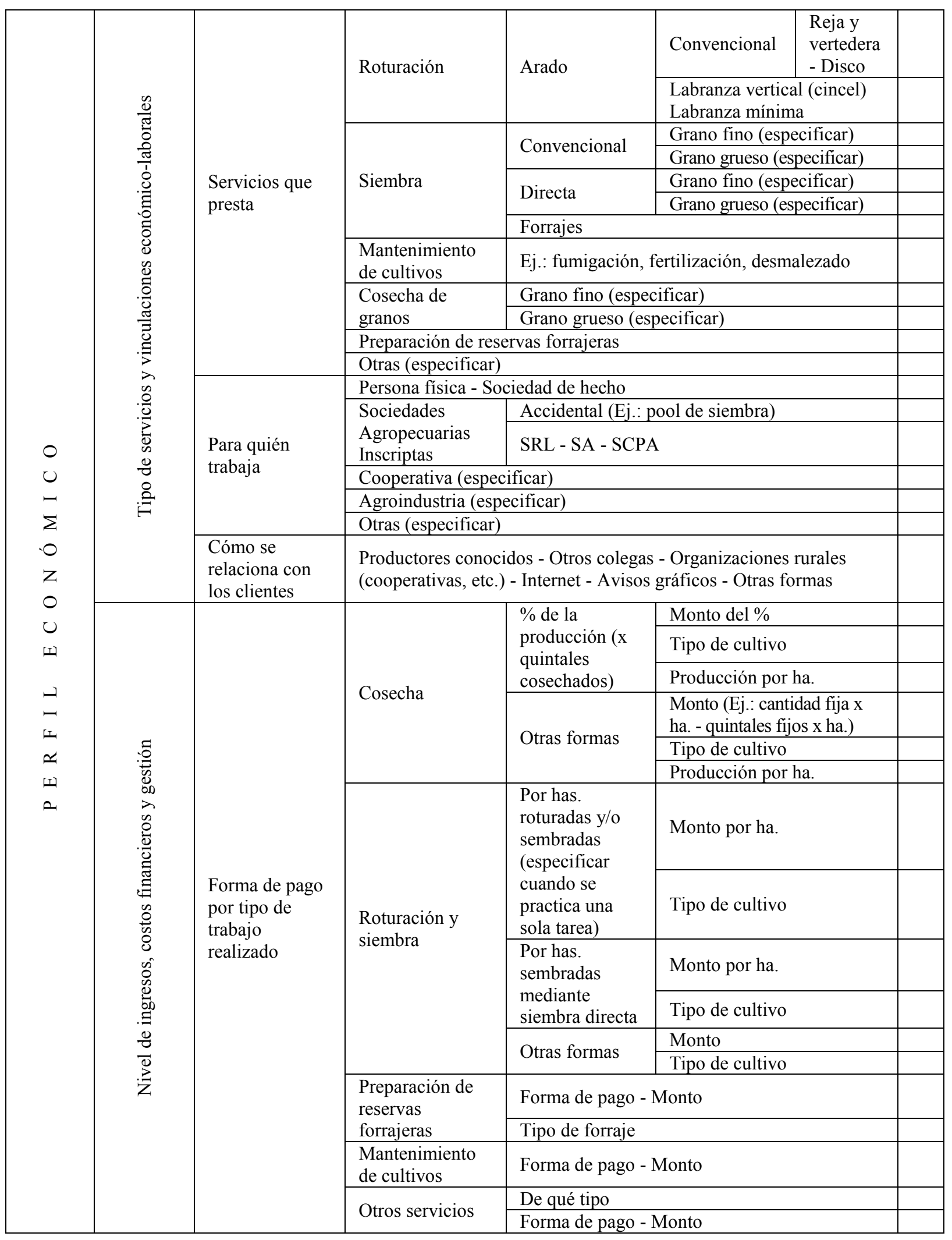




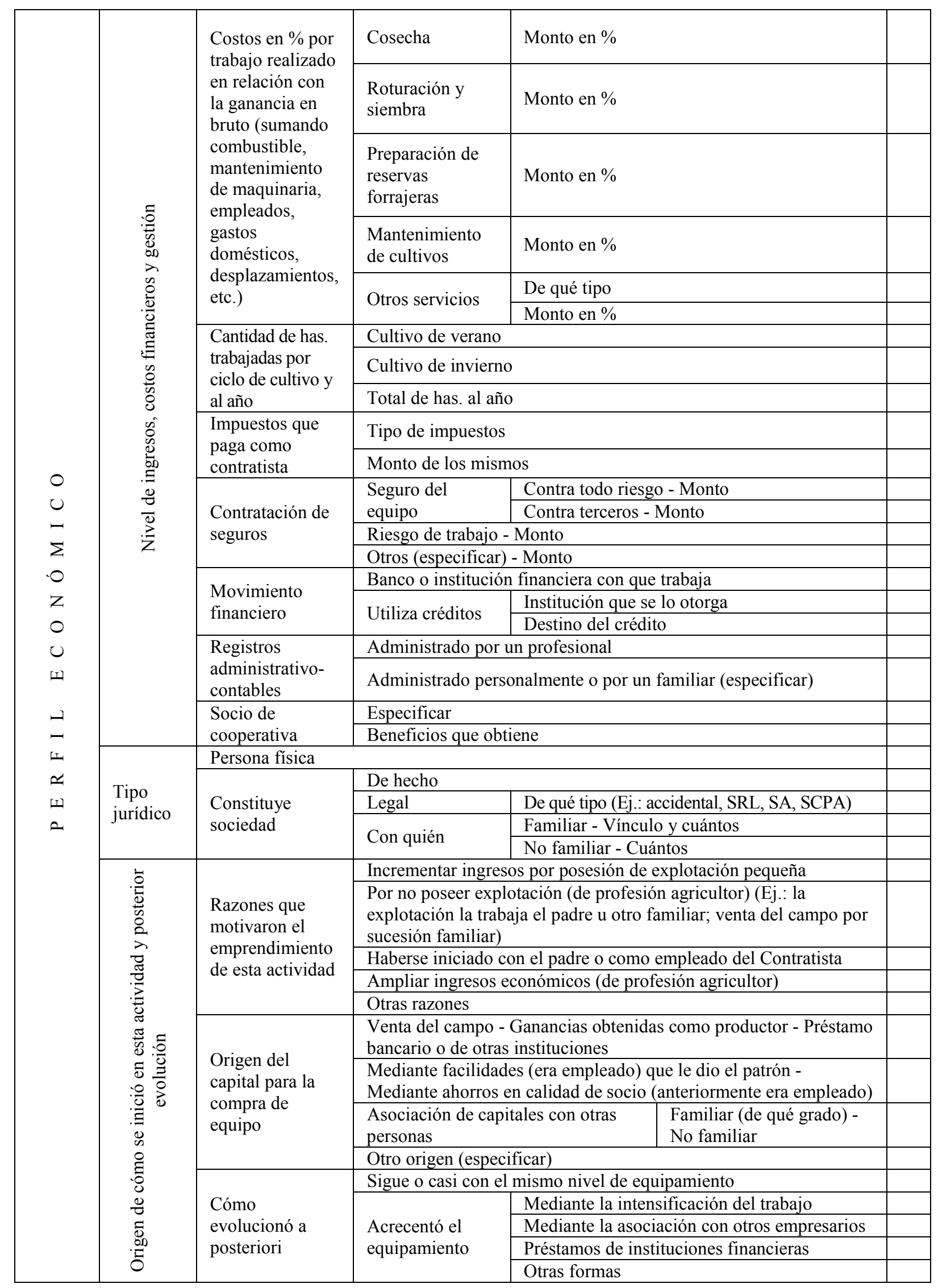




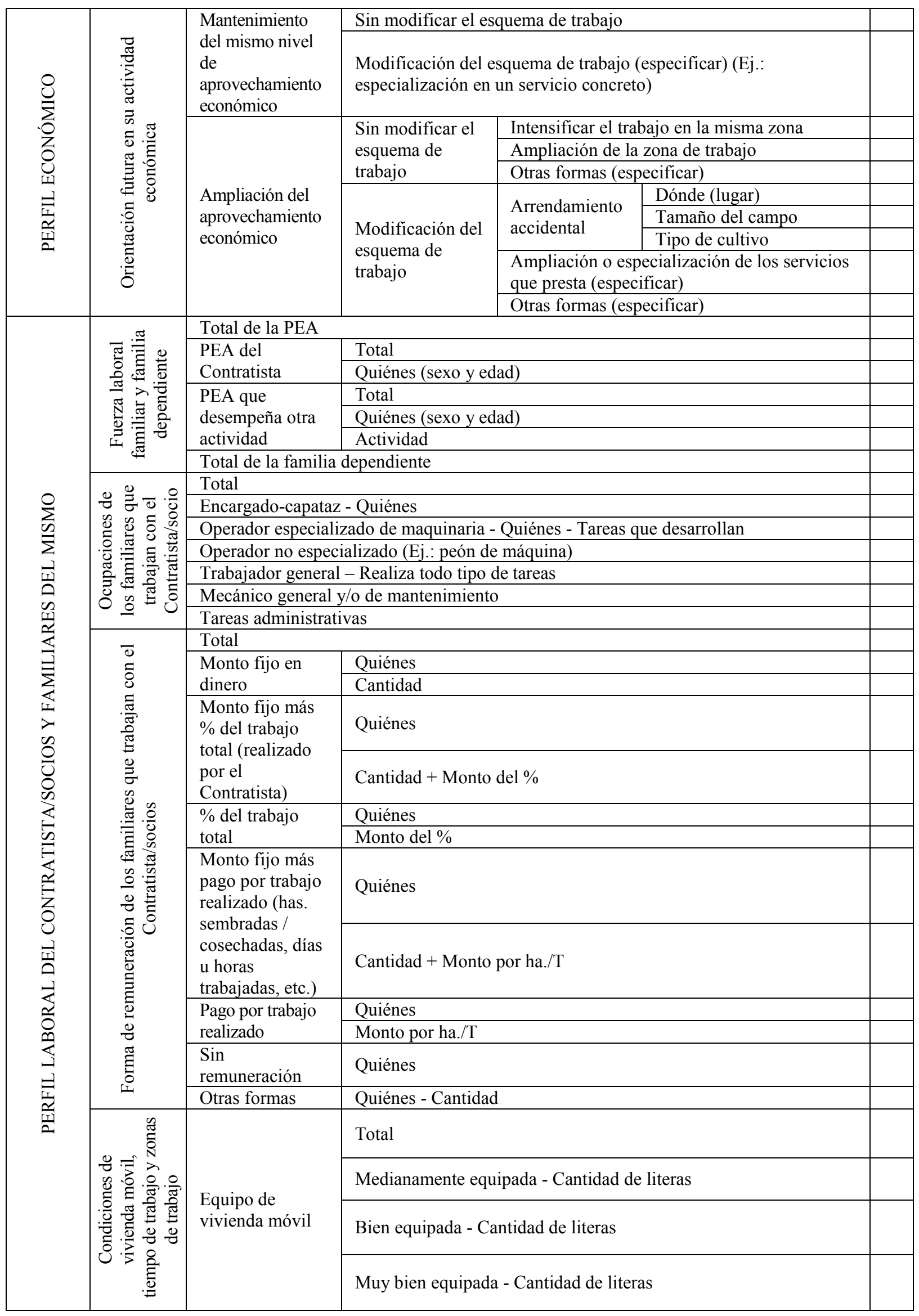




\begin{tabular}{|c|c|c|c|c|c|}
\hline & & & & Roturación y & Meses del año - Fechas \\
\hline & & & & siembra & Cultivo \\
\hline & & & Cultivos de & Cosecha & Meses del año - Fechas \\
\hline & $\vec{\pi}$ & & verano & cosecha & Cultivo \\
\hline & & & & Mantenimiento & Meses del año - Fechas \\
\hline & & & & Mantenimiento & Cultivo \\
\hline$\underline{\Omega}$ & $\bar{\Xi}$ & & & Roturación y & Meses del año - Fechas \\
\hline $\bar{\Sigma}$ & $=. ㅇ$ & & & siembra & Cultivo \\
\hline $\overrightarrow{\mid r}$ & $\overline{3}$ & Tiempo de & Cultivos de & & Meses del año - Fechas \\
\hline$\overline{0}$ & 凅 & trabajo & invierno & Cosecha & Cultivo \\
\hline I & $\frac{\pi}{2}$ & & & Mantenimiento & Meses del año - Fechas \\
\hline 索 & ฮี & & & vantenimiento & Cultivo \\
\hline$\exists$ & $\Rightarrow N$ & & Total de meses d & rabajo en el año & \\
\hline$\sum$ & $\frac{0}{0}$ & & & Cultivo de & Siembra \\
\hline 厌 & $\mathscr{\infty}$ & & Horario de & verano & Cosecha \\
\hline 7 & 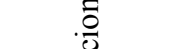 & & trabajo en el día & Cultivo de & Siembra \\
\hline 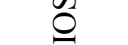 & :- & & & invierno & Cosecha \\
\hline$\overline{0}$ & อี & & Tiempo fuera de & casa (meses) & \\
\hline 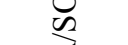 & & Zonas de trahaio & En la zona donde & ive (especificar) & \\
\hline$\overleftrightarrow{\leftrightarrows}$ & & Zonas de tradajo & Fuera de la zona & onde vive (espec & \\
\hline 导 & 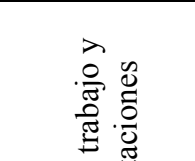 & $\begin{array}{l}\text { Nivel de } \\
\text { vinculación con } \\
\text { otros } \\
\text { Contratistas } \\
\end{array}$ & $\begin{array}{l}\text { Intercambio de ir } \\
\text { Intercambio de } \mathrm{n}\end{array}$ & $\begin{array}{l}\text { ormación - Ayud } \\
\text { quinaria - Trabaj }\end{array}$ & $\begin{array}{l}\text { necánica - Viajan juntos - } \\
\text { n conjunto - Otras formas }\end{array}$ \\
\hline 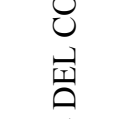 & $\begin{array}{l}\overline{0} \\
0 \\
0 \\
0 \\
0 \\
0 \\
0 \\
0 \\
0\end{array}$ & $\begin{array}{l}\text { Control del } \\
\text { trabajo por parte } \\
\text { del Productor }\end{array}$ & $\begin{array}{l}\text { Control bajo (dej } \\
\text { (control permane }\end{array}$ & $\begin{array}{l}\text { hacer) - Control } \\
\text { e) }\end{array}$ & diano - Control alto \\
\hline 光 & $8 \div$ & & Tratamiento del s & elo (en relación & la erosión) \\
\hline 능 & $\underbrace{0}_{0}$ & Tratamiento & En el laboreo sig & las curvas de ni & \\
\hline 便 & 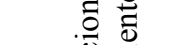 & ambiental de la & Cómo evacúa los & esechos de las $\mathrm{m}$ & uinas \\
\hline 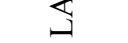 & $\underset{\Xi}{\mathbb{E}} \cdot \Xi$ & explotación por & Cómo trata los ca & inos de acceso a & explotación \\
\hline 龸 & $\stackrel{\bar{E}}{\leftrightarrows}$ & $\begin{array}{l}\text { parte del } \\
\text { Contratista }\end{array}$ & $\begin{array}{l}\text { Cómo trata las in } \\
\text { cañerías) }\end{array}$ & alaciones de la e & otación (alambrados, \\
\hline$\frac{\pi}{2}$ & & & Otros cuidados & & \\
\hline & & Especificar & & & \\
\hline & Afrllacion a & Se siente represen & do - Sí/No & & \\
\hline & $\begin{array}{l}\text { una } \\
\text { institución }\end{array}$ & & Ninguna & & \\
\hline & $\begin{array}{l}\text { institucion } \\
\text { gremial }\end{array}$ & $\begin{array}{l}\text { Nivel de } \\
\text { narticinación }\end{array}$ & Regular & & \\
\hline & & & Buena & & \\
\hline & No lee / No e & & & & \\
\hline & Primario & Completo & & & \\
\hline ช. & Primario & Incompleto & & & \\
\hline 50 & & Completo & Del sector & & \\
\hline 芯苛 & Secundario & Compreto & Otro & & \\
\hline O & & Incompleto & & & \\
\hline 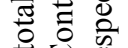 & & Comnleto & Del sector & & \\
\hline & $\begin{array}{l}\text { Ierciario / } \\
\text { Universitario }\end{array}$ & Completo & Otro & & \\
\hline & & Incompleto & & & \\
\hline$\infty \stackrel{0}{=}$ & & & Total & & \\
\hline 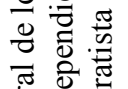 & Total de & Permanentes & Residencia fija - & dgar & \\
\hline 疍 & $\begin{array}{l}\text { trabajadores } \\
\text { dependientes }\end{array}$ & & Total & & \\
\hline 可 & & Transitorios & Residencia fija - & ugar & \\
\hline (0 & & Total general & & & \\
\hline
\end{tabular}




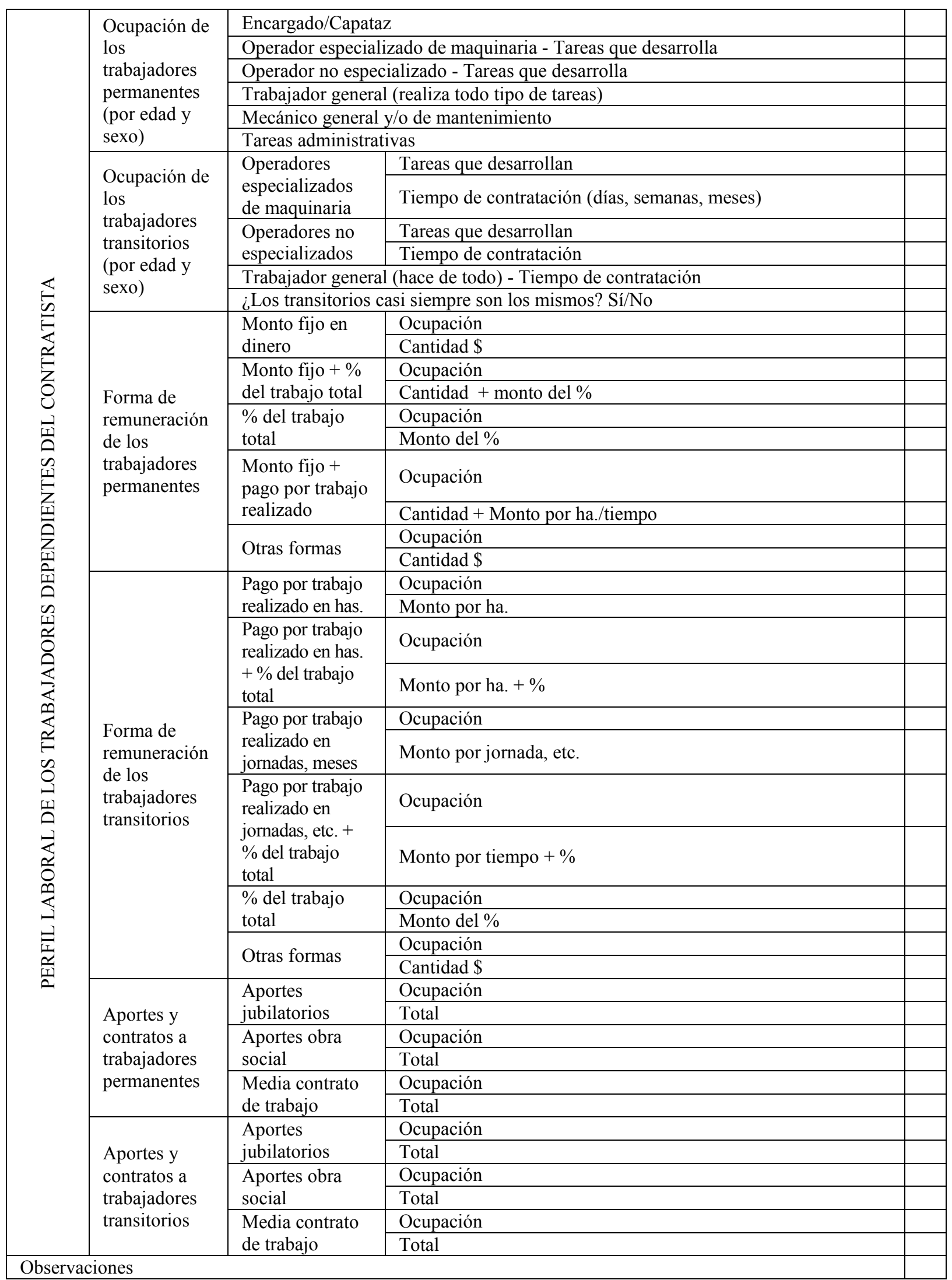




\section{Cuestionario de Entrevista a Productores Agropecuarios Que hacen uso del SERVICIO DE CONTRATISTAS}

\begin{tabular}{|c|c|c|c|c|c|}
\hline \multicolumn{5}{|c|}{ Identificación del productor y fecha } & \\
\hline \multicolumn{5}{|c|}{ Ubicación del campo } & \\
\hline \multirow{2}{*}{$\begin{array}{l}\text { Actividad del } \\
\text { establecimiento }\end{array}$} & & \multicolumn{3}{|c|}{ Agricultura } & \\
\hline & & \multicolumn{3}{|c|}{ Mixta } & \\
\hline \multirow{5}{*}{$\begin{array}{l}\text { Totales de has. } \\
\text { destinadas al } \\
\text { cultivo (granos } \\
\text { y forrajes) }\end{array}$} & \multicolumn{4}{|l|}{ Tipos de cultivos } & \\
\hline & \multicolumn{4}{|l|}{ Cantidad de has. } & \\
\hline & \multicolumn{4}{|l|}{ Cultivo único } & \\
\hline & & \multicolumn{3}{|l|}{ De $1^{\circ}$} & \\
\hline & & \multicolumn{3}{|l|}{$\operatorname{De} 2^{\circ}$} & \\
\hline \multirow{43}{*}{ 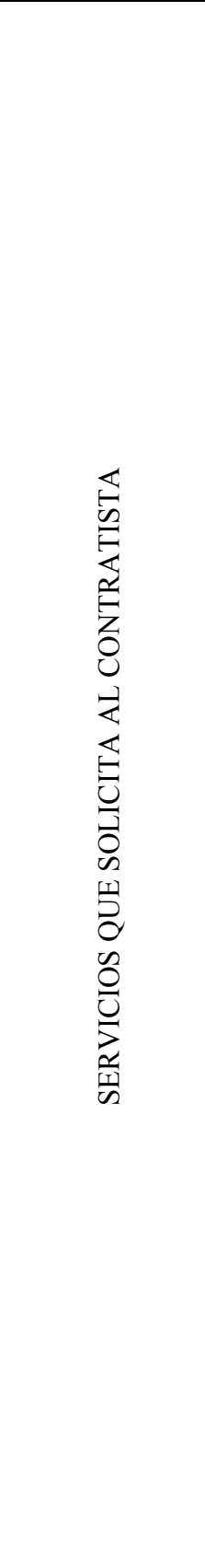 } & En el mismo lote & \multirow{2}{*}{$\begin{array}{l}\text { Convencional (reja y } \\
\text { vertedera, disco) }\end{array}$} & \multicolumn{2}{|c|}{ Especificar cultivo } & \\
\hline & \multirow{5}{*}{ ROTURACIÓN } & & Cantidad de $\mathrm{h}$ & & \\
\hline & & \multirow{2}{*}{$\begin{array}{l}\text { Labranza vertical } \\
\text { (cincel) }\end{array}$} & \multicolumn{2}{|c|}{ Especificar cultivo } & \\
\hline & & & Cantidad de $\mathrm{h}$ & & \\
\hline & & & Especificar cu & & \\
\hline & & Labranza minıma & Cantidad de $\mathrm{h}$ & & \\
\hline & & & & Especificar cultivo & \\
\hline & & & Grano tino & Cantidad de has. & \\
\hline & & Convencional & & Especificar cultivo & \\
\hline & & Convencional & Grano grueso & Cantidad de has. & \\
\hline & & & & Especificar forraje & \\
\hline & & & Forrajes & Cantidad de has. & \\
\hline & SIEMBRA & & & Especificar cultivo & \\
\hline & & & Grano tino & Cantidad de has. & \\
\hline & & Directa & Grano orueso & Especificar cultivo & \\
\hline & & Dilecta & Urano grueso & Cantidad de has. & \\
\hline & & & Forraies & Especificar forraje & \\
\hline & & & Forrajes & Cantidad de has. & \\
\hline & & & & Especificar cultivo & \\
\hline & & Cosecha de oranos & Grano tino & Cantidad de has. & \\
\hline & COSECHA & Cosecha de granos & Grano orueso & Especificar cultivo & \\
\hline & COSECHA & & Grano grueso & Cantidad de has. & \\
\hline & & Otras cosechas (man & & Especificar cultivo & \\
\hline & & Utras cosecnas (man! & & Cantidad de has. & \\
\hline & & & & Especificar forraje & \\
\hline & & & Cortado & Cantidad & \\
\hline & & & & Especificar forraje & \\
\hline & $\begin{array}{l}\text { PREPARACION DE } \\
\text { RFSERYAS }\end{array}$ & Tino de nrenaración & Enrollado & Cantidad & \\
\hline & $\begin{array}{l}\text { RESERVAS } \\
\text { FORRAJERAS }\end{array}$ & 1юро de preparacion & Enfardado & Especificar forraje & \\
\hline & & & Enfardado & Cantidad & \\
\hline & & & Otros & Especificar forraje & \\
\hline & & & Otros & Cantidad & \\
\hline & & & Tipo de fumis & & \\
\hline & & Fumigación & Especificar cu & & \\
\hline & & & Cantidad de $\mathrm{h}$ & & \\
\hline & & & Tipo de fertili & & \\
\hline & MANTENIMIENTO & Fertilización & Especificar cu & & \\
\hline & DE CULTIVOS & & Cantidad de $\mathrm{h}$ & & \\
\hline & & & En qué tipo d & ltivo & \\
\hline & & Desmalezado & Cantidad de $\mathrm{h}$ & & \\
\hline & & Otros & De qué tipo & & \\
\hline & & mantenimientos & Cantidad de $\mathrm{h}$ & & \\
\hline & OTROS SERVICIOS & & Especificar & & \\
\hline Tamaño del equi & del contratista & & Dimensiones & encia & \\
\hline Estado de la ma & naria del contratista & & $\begin{array}{l}\text { Condiciones } \\
\text { Antigüedad }\end{array}$ & Incionamiento - & \\
\hline
\end{tabular}




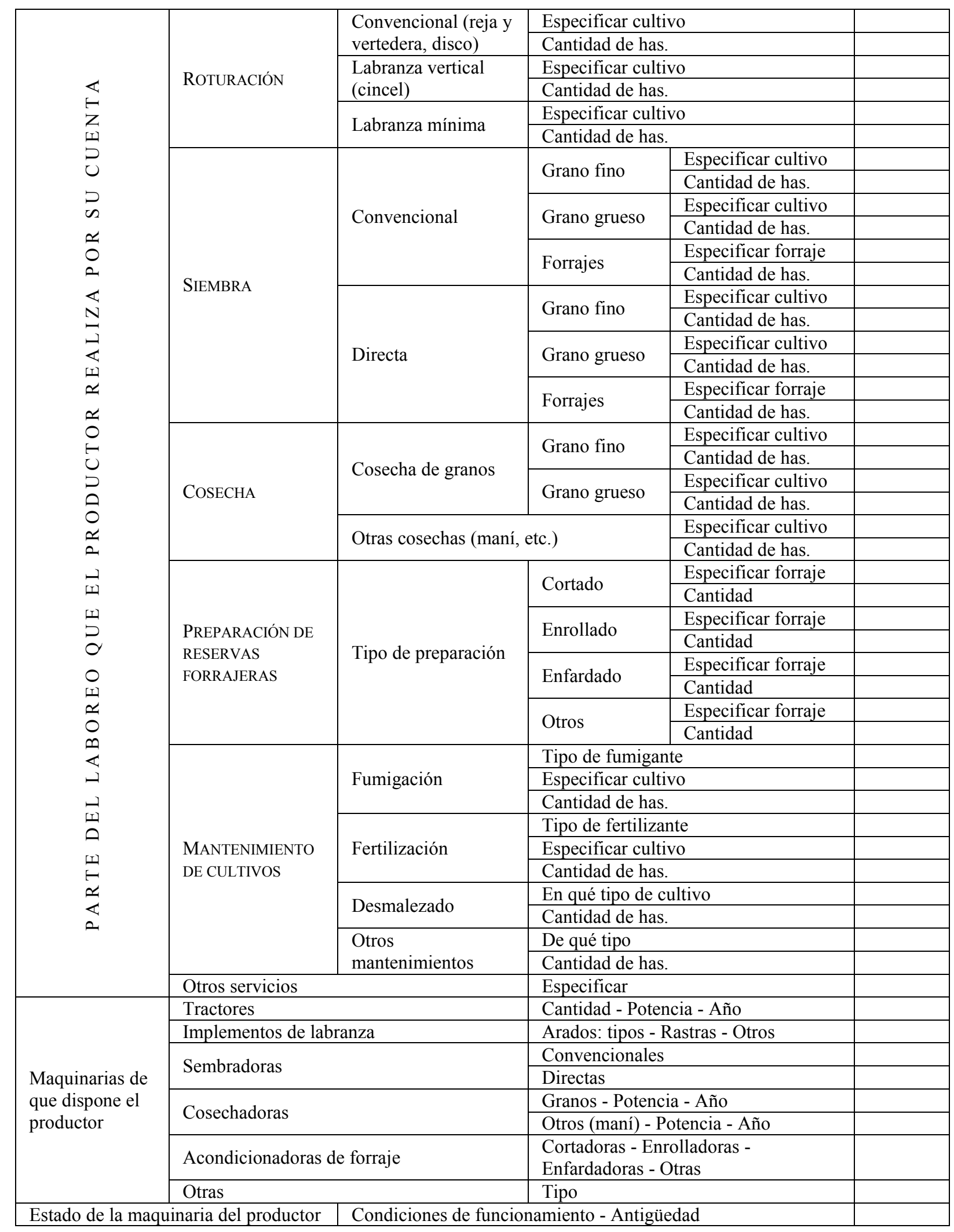




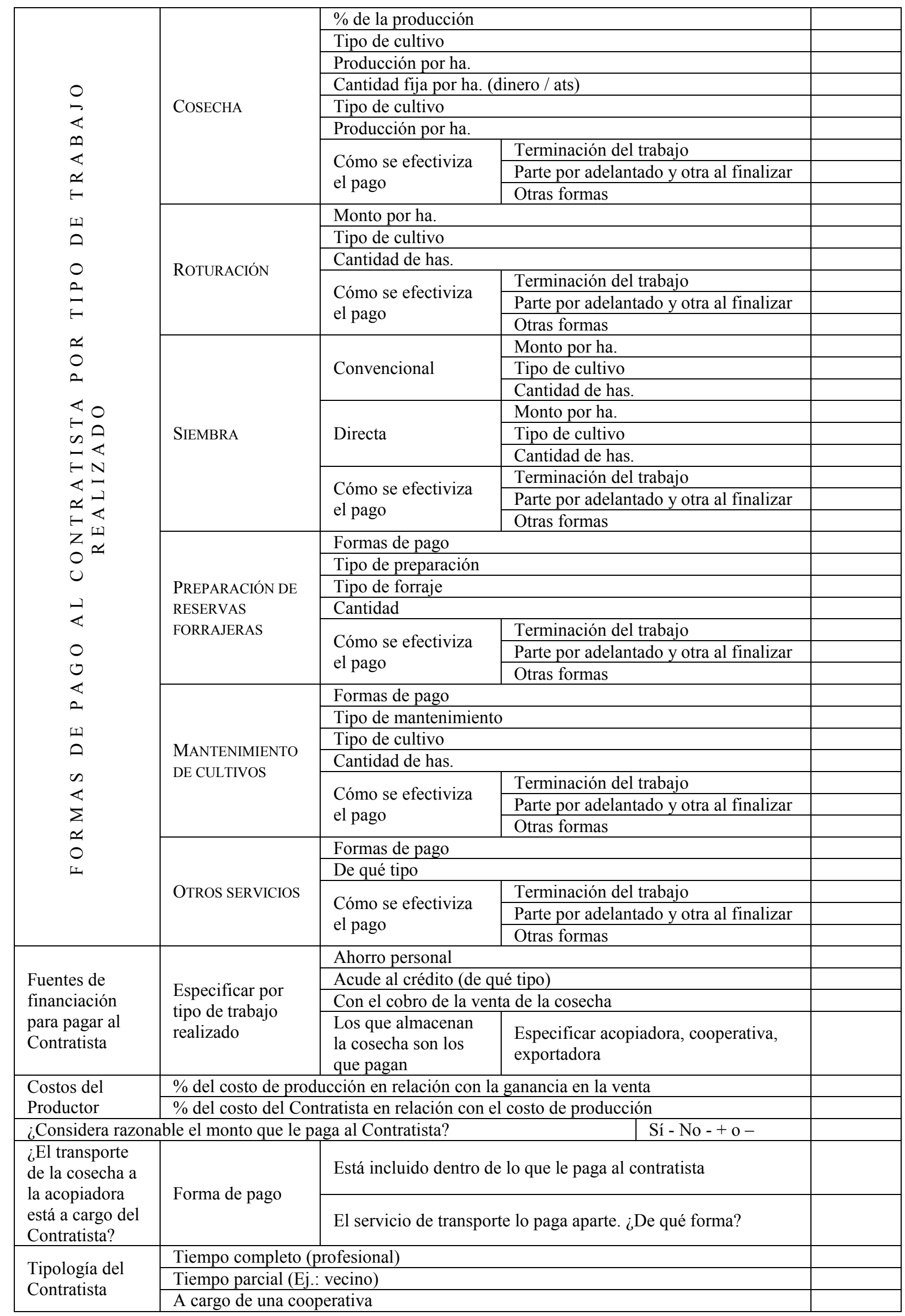




\begin{tabular}{|c|c|c|}
\hline $\begin{array}{l}\text { Trabaja con más } \\
\text { de un } \\
\text { Contratista }\end{array}$ & \multicolumn{2}{|c|}{ ¿Qué tareas realiza cada uno? } \\
\hline \multirow{2}{*}{$\begin{array}{l}\text { Relación } \\
\text { temporal con el } \\
\text { Contratista }\end{array}$} & \multicolumn{2}{|c|}{ Trabaja siempre con el mismo Contratista } \\
\hline & \multicolumn{2}{|c|}{ Cambia de Contratista en cada campaña } \\
\hline \multirow{5}{*}{$\begin{array}{l}\text { Vinculación } \\
\text { laboral con el } \\
\text { Contratista }\end{array}$} & \multicolumn{2}{|c|}{ Neutra - Buena - Muy buena } \\
\hline & \multicolumn{2}{|c|}{ ¿Se establece una vinculación personal? } \\
\hline & \multicolumn{2}{|c|}{ ¿El Productor le brinda alguna ayuda doméstica? ¿De qué tipo? } \\
\hline & \multirow{2}{*}{$\begin{array}{l}\text { Al iniciar el } \\
\text { trabajo el } \\
\text { Contratista }\end{array}$} & Le deja hacer su tarea libremente \\
\hline & & Le da indicaciones de algún tipo. ¿Qué indicaciones? \\
\hline \multirow{5}{*}{$\begin{array}{l}\text { Características } \\
\text { generales del } \\
\text { Contratista }\end{array}$} & \multicolumn{2}{|c|}{ Procedencia del Contratista: De la zona - De otro lugar } \\
\hline & \multicolumn{2}{|c|}{ Cantidad de personas que trabajan con el Contratista } \\
\hline & \multirow{3}{*}{$\begin{array}{l}\text { Dónde viven los } \\
\text { Contratistas } \\
\text { mientras trabajan } \\
\text { en la explotación }\end{array}$} & Instalan casilla en la explotación \\
\hline & & Se ubican en las viviendas de la explotación \\
\hline & & No se instalan en la explotación \\
\hline \multirow{6}{*}{$\begin{array}{l}\text { Tiempo que le } \\
\text { demanda el } \\
\text { trabajo al } \\
\text { Contratista por } \\
\text { servicio }\end{array}$} & \multicolumn{2}{|c|}{ Roturación (grano fino o grueso) } \\
\hline & \multicolumn{2}{|c|}{ Siembra (grano fino o grueso) } \\
\hline & \multicolumn{2}{|c|}{ Cosecha (grano fino o grueso) } \\
\hline & \multicolumn{2}{|c|}{ Preparación de reservas forrajeras (de qué tipo) } \\
\hline & \multicolumn{2}{|c|}{ Mantenimiento (cuál) } \\
\hline & \multicolumn{2}{|l|}{ Otros } \\
\hline \multirow{3}{*}{$\begin{array}{l}\text { Control de } \\
\text { trabajo que } \\
\text { realiza el } \\
\text { Contratista }\end{array}$} & \multicolumn{2}{|c|}{ Control bajo (deja hacer) } \\
\hline & \multicolumn{2}{|l|}{ Control mediano } \\
\hline & \multicolumn{2}{|c|}{ Control alto (permanente) } \\
\hline \multirow{6}{*}{$\begin{array}{l}\text { Cuidado de la } \\
\text { explotación por } \\
\text { parte del } \\
\text { Contratista }\end{array}$} & \multicolumn{2}{|c|}{ Tratamiento del suelo (en relación con la erosión) } \\
\hline & \multicolumn{2}{|c|}{ En el laboreo sigue las curvas de nivel } \\
\hline & \multicolumn{2}{|c|}{ Cómo evacúa los desechos de las máquinas } \\
\hline & Cómo trata los cam & nos de acceso a la explotación \\
\hline & Cómo trata las inst & aciones (alambrados, cañerías) \\
\hline & Otros aspectos que & e deben considerar \\
\hline A su juicio, el & Deficientemente & \\
\hline $\begin{array}{l}\text { Contratista } \\
\text { cuida su }\end{array}$ & Regularmente & \\
\hline explotación & Bien - Muy bien & \\
\hline Cómo evalúa en & neral el trabajo del & Está conforme (plenamente) \\
\hline $\begin{array}{l}\text { Contratista (consi } \\
\text { de la explotación }\end{array}$ & $\begin{array}{l}\text { erando el cuidado } \\
\text { el trabajo que }\end{array}$ & Medianamente conforme \\
\hline realiza propiamen & e dicho) & No está conforme \\
\hline & Piensa seguir traba & ndo con Contratistas \\
\hline piensa seguir & Iniciar un laboreo $\mathrm{p}$ & r su cuenta (de qué tipo) \\
\hline manejando el & Incrementar un lab & ceo por su cuenta (de qué tipo) \\
\hline laboreo agrícola & Disminuir el labore & por su cuenta \\
\hline
\end{tabular}




\section{CUESTIONARIO DE ENTREVISTA A LOS DIRECTIVOS DEL GREMIO DE CONTRATISTAS denominado Federación Argentina de Contratistas de Máquinas Agrícolas (FACMA)}

1. ¿Por qué el transporte por carretones a veces es más peligroso?

2. ¿Cómo se transmite la "capacitación” del operador de maquinaria? ¿Se ha pensado en una suerte de centro o escuela a tal fin?

3. La legislación laboral para los empleados, ¿sigue siendo el código del peón rural? ¿Hay un nuevo proyecto al respecto?

Características de las "fábricas de carretones": cantidad, ubicación, marcas, costo de traslado, conveniencias.

4. ¿Cuál es la dificultad para cobrar el trabajo, que determina que muchas veces la única forma de cobrar es llevarse el grano?

5. ¿Cómo es el acuerdo con la AFIP para el cobro en cereal de los servicios que prestan a los productores? ¿Rige actualmente una metodología concreta?

6. ¿Son muy significativos los productores que prestan servicios a terceros y que se convierten en un problema?

7. Cantidad de afiliados del total de contratistas rurales.

8. Dificultades para incrementar la afiliación.

9. ¿Cuál es la participación de la gente joven (es significativa su participación)?

10. ¿Hay avances concretos con respecto a la legislación de tránsito?

11. La "legislación impositiva", ¿qué escollos presenta?

12. Nivel de facilidades en la compra de maquinaria.

13. Disponibilidad de mano de obra y nivel de eficiencia de la misma.

14. Nivel de relación social con el personal dependiente.

15. En general, ¿hay mayor demanda de trabajo? ¿En qué porcentaje en los últimos años se ha incrementado?

16. Estrategias diseñadas para incrementar la afiliación.

17. ¿Se constituyó el "foro de discusión" con la SAGByA?

18. ¿Como se le paga a los trabajadores familiares?

¿Quiénes predominan más, los permanentes o los transitorios?

19. ¿Cómo se les paga a los trabajadores dependientes?

20. ¿En qué porcentaje provienen del entorno rural? 
21. ¿Cómo es el nivel de control por parte de los productores del trabajo que realizan los contratistas?

22. ¿Cómo es el nivel de cuidado ambiental del suelo y de las instalaciones por parte de los contratistas?

23. El costo, en porcentaje, por trabajo realizado, en relación con los ingresos brutos (por ejemplo: cosecha, siembra).

24. Impuestos a las ganancias $(10 \%)$

Impuestos sobre ingresos brutos $(3,5 \%)$

Impuesto al valor agregado $(10,5 \%)$

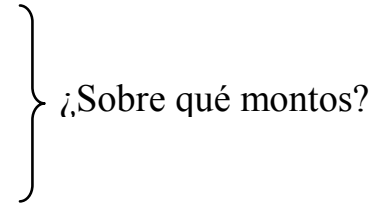

25. El origen de la actividad, diferentes variantes.

26. La orientación futura de la actividad empresarial.

27. ¿Sigue teniendo o prevaleciendo una orientación de empresa familiar?

28. ¿Están asociados también los "contratistas de producción puros".

29. ¿Qué magnitud calculan de "contratistas de servicios" que se desempeñan también como “contratistas de producción"?

30. El "contratista de producción”, ¿preserva el medio ambiente al mismo nivel que el "contratista de servicios"?

31. ¿Son muchos los contratistas de servicios que se transforman en contratistas de producción exclusivamente? 


\section{Cuestionario de entrevista a las Agroindustrias y ACOPiadoras en la EXPLOTACIÓN PRIMARIA AGRÍCOLA ${ }^{1}$}

1. La empresa interviene de manera directa en la producción primaria, es decir, controla las explotaciones

(Integración vertical propiamente dicha)

\begin{tabular}{|c|c|c|c|}
\hline \multirow{10}{*}{$\begin{array}{l}\text { 1.1. Es propietaria de } \\
\text { las tierras que trabaja }\end{array}$} & \multirow{10}{*}{$\begin{array}{l}\text { 1.1.1. ¿Quiénes la } \\
\text { trabajan? }\end{array}$} & \multirow{2}{*}{ Empresas de explotación propia } & Sí \\
\hline & & & No \\
\hline & & \multirow{2}{*}{ Contratistas de servicios } & Sí \\
\hline & & & No \\
\hline & & \multirow{2}{*}{$\begin{array}{l}\text { Antiguos propietarios en calidad de } \\
\text { aparceros }\end{array}$} & Sí \\
\hline & & & No \\
\hline & & \multirow{2}{*}{ Aparceros propiamente dichos } & Sí \\
\hline & & & No \\
\hline & & \multirow{2}{*}{ Otras formas } & Sí \\
\hline & & & No \\
\hline \multirow{8}{*}{$\begin{array}{l}\text { 1.2. La empresa } \\
\text { arrienda tierras a } \\
\text { terceros }\end{array}$} & \multirow{8}{*}{$\begin{array}{l}\text { 1.2.1. ¿Quiénes la } \\
\text { trabajan? }\end{array}$} & \multirow{2}{*}{ Empresas de explotación propia } & Sí \\
\hline & & & No \\
\hline & & \multirow{2}{*}{ Contratistas de servicios } & Sí \\
\hline & & & No \\
\hline & & \multirow{2}{*}{$\begin{array}{l}\text { Productores en calidad de aparceros o } \\
\text { empleados de la agroindustria o acopiadora }\end{array}$} & Sí \\
\hline & & & No \\
\hline & & \multirow{2}{*}{ Otras formas } & Sí \\
\hline & & & No \\
\hline
\end{tabular}

2. La empresa no tiene un control directo sobre la producción primaria (no es propietaria ni arrienda tierras)

(Integración vertical contractual)

\begin{tabular}{|c|c|c|}
\hline \multirow{8}{*}{ 2.1. ¿Con quién trabaja? } & \multirow{2}{*}{ Productores individuales } & Sí \\
\hline & & No \\
\hline & \multirow{2}{*}{ Sociedades agropecuarias } & Sí \\
\hline & & No \\
\hline & \multirow{2}{*}{ Contratistas capitalistas } & Sí \\
\hline & & No \\
\hline & \multirow{2}{*}{ Otras formas } & Sí \\
\hline & & No \\
\hline \multirow{6}{*}{ 2.2. Los contratos consisten en } & \multirow{2}{*}{ Compromiso de venta de la producción } & Sí \\
\hline & & No \\
\hline & \multirow{2}{*}{$\begin{array}{l}\text { Provisión de insumos y/o semillas por } \\
\text { parte de la agroindustria o acopiadora }\end{array}$} & Sí \\
\hline & & No \\
\hline & \multirow{2}{*}{ Otros } & Sí \\
\hline & & No \\
\hline
\end{tabular}

3. La empresa junto con otro agente productivo conforma una sociedad de producción primaria. Las dos partes intervienen en el control de la producción

(Integración vertical combinada)

\begin{tabular}{|l|l|l|l|}
\hline \multirow{4}{*}{$3.1 . ¿$ ¿Cómo se lleva a cabo esta sociedad? } & $\begin{array}{l}\text { El agente productivo pone la tierra y la maquinaria y } \\
\text { la empresa los insumos, semillas y otras erogaciones }\end{array}$ & No & \\
\cline { 2 - 5 } & El agente productivo y la empresa en forma conjunta & Sí & \\
\cline { 3 - 5 } & son dueños de la tierra o arriendan la misma & No & \\
\hline
\end{tabular}

1 Planilla adaptada por la Lic. Marina Bustamante y Diego Zalazar. 
4. Origen de los insumos que procesa la agroindustria

4.1. Localización geográfica de los predios propios o arrendados.

4.2. Localización geográfica de los predios sobre los que no se tiene un control directo

4.3. Localización geográfica de los predios trabajados en sociedad

4.4. Procedencia geográfica de los insumos que se obtienen del mercado libre

\section{Estructura agraria}

5.1. Tamaño de los predios propios de la empresa (en ha)

5.2. Tamaño de los predios arrendados por la empresa (en ha)

5.2.1. Tipo de arrendamiento

5.2.2. ¿A quiénes se arrienda?

Pequeños productores (menos de $200 \mathrm{ha}$ )

Medianos productores (200 a $500 \mathrm{ha})$

Grandes productores (más de $500 \mathrm{ha}$ )

Sociedades agropecuarias

5.3. Tamaño de los predios sobre los cuales no se tiene control directo (en ha)

5.4. Tamaño de los predios trabajados en sociedad (en ha)

6. Producción de las explotaciones

\begin{tabular}{|c|c|c|}
\hline \multirow{18}{*}{$\begin{array}{l}\text { 6.1. Producción de las } \\
\text { explotaciones propias y } \\
\text { arrendadas }\end{array}$} & \multirow{18}{*}{$\begin{array}{l}\text { 6.1.1. Cultivos por orden de } \\
\text { importancia }\end{array}$} & Hectáreas \\
\hline & & Toneladas \\
\hline & & $\%$ en el total de granos \\
\hline & & Hectáreas \\
\hline & & Toneladas \\
\hline & & $\%$ en el total de granos \\
\hline & & Hectáreas \\
\hline & & Toneladas \\
\hline & & $\%$ en el total de granos \\
\hline & & Hectáreas \\
\hline & & Toneladas \\
\hline & & $\%$ en el total de granos \\
\hline & & Hectáreas \\
\hline & & Toneladas \\
\hline & & $\%$ en el total de granos \\
\hline & & Hectáreas \\
\hline & & Toneladas \\
\hline & & $\%$ en el total de granos \\
\hline \multirow{18}{*}{$\begin{array}{l}\text { 6.2. Producción de las } \\
\text { explotaciones sobre las que } \\
\text { no se tiene un control } \\
\text { directo }\end{array}$} & \multirow{18}{*}{$\begin{array}{l}\text { 6.2.1. Cultivos por orden de } \\
\text { importancia }\end{array}$} & Hectáreas \\
\hline & & Toneladas \\
\hline & & $\%$ en el total de granos \\
\hline & & Hectáreas \\
\hline & & Toneladas \\
\hline & & $\%$ en el total de granos \\
\hline & & Hectáreas \\
\hline & & Toneladas \\
\hline & & $\%$ en el total de granos \\
\hline & & Hectáreas \\
\hline & & Toneladas \\
\hline & & $\%$ en el total de granos \\
\hline & & Hectáreas \\
\hline & & Toneladas \\
\hline & & $\%$ en el total de granos \\
\hline & & Hectáreas \\
\hline & & Toneladas \\
\hline & & $\%$ en el total de granos \\
\hline
\end{tabular}




\begin{tabular}{|c|c|c|c|}
\hline \multirow{18}{*}{$\begin{array}{l}\text { 6.3. Producción de las } \\
\text { explotaciones trabajadas en } \\
\text { sociedad }\end{array}$} & \multirow{18}{*}{$\begin{array}{l}\text { 6.3.1. Cultivos por orden de } \\
\text { importancia }\end{array}$} & Hectáreas & \\
\hline & & Toneladas & \\
\hline & & $\%$ en el total de granos & \\
\hline & & Hectáreas & \\
\hline & & Toneladas & \\
\hline & & $\%$ en el total de granos & \\
\hline & & Hectáreas & \\
\hline & & Toneladas & \\
\hline & & $\%$ en el total de granos & \\
\hline & & Hectáreas & \\
\hline & & Toneladas & \\
\hline & & $\%$ en el total de granos & \\
\hline & & Hectáreas & \\
\hline & & Toneladas & \\
\hline & & $\%$ en el total de granos & \\
\hline & & Hectáreas & \\
\hline & & Toneladas & \\
\hline & & $\%$ en el total de granos & \\
\hline \multirow{12}{*}{$\begin{array}{l}\text { 6.4. Productos primarios } \\
\text { obtenidos del mercado libre }\end{array}$} & \multirow{12}{*}{$\begin{array}{l}\text { 6.4.1. Cultivos por orden de } \\
\text { importancia }\end{array}$} & Toneladas & \\
\hline & & $\%$ en el total de granos & \\
\hline & & Toneladas & \\
\hline & & $\%$ en el total de granos & \\
\hline & & Toneladas & \\
\hline & & $\%$ en el total de granos & \\
\hline & & Toneladas & \\
\hline & & $\%$ en el total de granos & \\
\hline & & Toneladas & \\
\hline & & $\%$ en el total de granos & \\
\hline & & Toneladas & \\
\hline & & $\%$ en el total de granos & \\
\hline \multirow{12}{*}{\multicolumn{2}{|c|}{ 6.5. Granos procesados por la agroindustria }} & Toneladas & \\
\hline & & $\%$ en el total de granos & \\
\hline & & Toneladas & \\
\hline & & $\%$ en el total de granos & \\
\hline & & Toneladas & \\
\hline & & $\%$ en el total de granos & \\
\hline & & Toneladas & \\
\hline & & $\%$ en el total de granos & \\
\hline & & Toneladas & \\
\hline & & $\%$ en el total de granos & \\
\hline & & Toneladas & \\
\hline & & $\%$ en el total de granos & \\
\hline \multirow{12}{*}{\multicolumn{2}{|c|}{ 6.6. Granos destinados al mercado (sin procesar) }} & Toneladas & \\
\hline & & $\%$ en el total de granos & \\
\hline & & Toneladas & \\
\hline & & $\%$ en el total de granos & \\
\hline & & Toneladas & \\
\hline & & $\%$ en el total de granos & \\
\hline & & Toneladas & \\
\hline & & $\%$ en el total de granos & \\
\hline & & Toneladas & \\
\hline & & $\%$ en el total de granos & \\
\hline & & Toneladas & \\
\hline & & $\%$ en el total de granos & \\
\hline
\end{tabular}


7. ¿Cómo se provee la empresa en el mercado libre?

\begin{tabular}{|l|l|l|}
\hline 7.1. Compra directa a los productores & Compra directa & \\
\cline { 2 - 4 } 7.2. Acopiadores particulares & Formas de pago & \\
\hline \multirow{2}{*}{ 7.3. Cooperativas } & Compra directa & \\
\cline { 2 - 4 } & Formas de pago & \\
\cline { 2 - 4 } & Compra directa & \\
\hline
\end{tabular}

\section{Perfil laboral de la empresa}

8.1. ¿La empresa posee un Departamento de Campo? Especificar la estructura y el funcionamiento del mismo.

8.2. ¿Con qué cantidad de empleados cuenta este departamento?

8.3. ¿Cuántos de ellos corresponden a la planta permanente y cuántos a la planta transitoria?

8.4. Cantidad de productores que trabajan en forma "directa" con la empresa (en propiedad o arrendadas)

8.5. Cantidad de productores que trabajan en forma indirecta con la empresa

8.6. Cantidad de productores que trabajan en sociedad con la empresa

\section{Disponibilidad y manejo tecnológico del Departamento de Campo}

9.1. Especificar las maquinarias disponibles por el Departamento de Campo

9.2. Especificar las instalaciones con que cuenta el Departamento de Campo

9.3. Ubicación y cantidad de plantas acopiadoras

9.4. Disponibilidad de asesoramiento tecnológico

9.4.1. Equipos de asesoramiento propio

9.4.2. Asesoramiento externo (tipo y origen)

9.4.3. Tipo de servicios que brinda y a quiénes

9.5. Tipo de siembra (directa y/o convencional)

9.6. Tipo de semillas

9.7. Tipo de agroquímicos (fertilizantes, herbicidas, etc.)

9.8. Riego artificial y de qué tipo

9.9. Incorporación de nuevas tecnologías

10. Origen de los insumos que procesa la agroindustria

\begin{tabular}{|l|l|}
\hline 10.1 . Enfatizar en la compra de tierras (¿dónde?) & \\
\hline 10.2 . Enfatizar en el arrendamiento (¿dónde?) & \\
\hline 10.3. Enfatizar en la integración indirecta & \\
\hline 10.4. Enfatizar en la integración societal & \\
\hline 10.5. Comprar más granos en el mercado libre & \\
\hline
\end{tabular}


Anexo 2

Cuadros 
Cuadro $N^{\circ}$ 1. Cantidad y superficie de las EAPs Agropecuarias por escala de extensión, en cifras y en porcentajes de los departamentos que constituyen la región sur de la provincia de Córdoba. Censos Nacionales Agropecuarios de 1969, 1988 y 2002 (versión completa)

\begin{tabular}{|c|c|c|c|c|c|c|c|c|c|c|c|c|c|c|c|}
\hline \multirow[b]{2}{*}{ Departamento } & \multirow[b]{2}{*}{ CNA } & \multicolumn{2}{|c|}{ Total } & \multicolumn{4}{|c|}{ Hasta 5 ha } & \multicolumn{4}{|c|}{ Desde 5,1 hasta 25 ha } & \multicolumn{4}{|c|}{ Desde 25,1 hasta 100 ha } \\
\hline & & $\begin{array}{l}\text { Cantidad } \\
\text { explotaciones }\end{array}$ & $\begin{array}{l}\text { Superficie } \\
\text { hectáreas }\end{array}$ & $\begin{array}{l}\text { Cantidad } \\
\text { explotaciones }\end{array}$ & $\begin{array}{c}\% \text { del } \\
\text { total }\end{array}$ & $\begin{array}{l}\text { Superficie } \\
\text { hectáreas }\end{array}$ & $\begin{array}{l}\% \text { del } \\
\text { total }\end{array}$ & $\begin{array}{l}\text { Cantidad } \\
\text { explotaciones }\end{array}$ & $\begin{array}{l}\% \text { del } \\
\text { total }\end{array}$ & $\begin{array}{l}\text { Superficie } \\
\text { hectáreas }\end{array}$ & $\begin{array}{l}\% \text { del } \\
\text { total }\end{array}$ & $\begin{array}{l}\text { Cantidad } \\
\text { explotaciones }\end{array}$ & $\begin{array}{l}\% \text { del } \\
\text { total }\end{array}$ & $\begin{array}{l}\text { Superficie } \\
\text { hectáreas }\end{array}$ & $\begin{array}{c}\% \text { del } \\
\text { total }\end{array}$ \\
\hline \multirow{3}{*}{$\begin{array}{c}\text { Provincia de } \\
\text { Córdoba }\end{array}$} & 1969 & 57.826 & 14.207 .230 & 4.952 & 8,56 & 12.159 & 0,085 & 7.765 & 13,43 & 108.192 & 0,76 & 15.461 & 26,74 & 980.760 & 6,90 \\
\hline & 1988 & 40.061 & 13.724 .885 & 1.386 & 3,46 & 3.999 & 0,029 & 3.763 & 9,39 & 54.945 & 0,40 & 9.390 & 23,44 & 601.842 & 4,38 \\
\hline & 2002 & 25.620 & 12.244 .257 & 809 & 3,16 & 2.174 & 0,02 & 1.891 & 7,38 & 27.091 & 0,22 & 5.000 & 19,52 & 326.798 & 2,67 \\
\hline \multirow{3}{*}{ Río Cuarto } & 1969 & 6.040 & 1.819 .171 & 292 & 4,83 & 910 & 0,05 & 610 & 10,1 & 8.296 & 0,46 & 1.338 & 22,15 & 90.060 & 4,95 \\
\hline & 1988 & 4.580 & 1.703 .378 & 61 & 1,33 & 198 & 0,01 & 273 & 5,96 & 3.867 & 0,23 & 918 & 20,04 & 60.651 & 3,56 \\
\hline & 2002 & 2.984 & 1.468 .291 & 30 & 1,01 & 107 & 0,01 & 149 & 4,99 & 2.165 & 0,14 & 510 & 17,09 & 34.610 & 2,36 \\
\hline \multirow{3}{*}{ Juárez Celman } & 1969 & 2.060 & 787.375 & 58 & 2,81 & 172 & 0,02 & 132 & 6,41 & 1.889 & 0,24 & 464 & 22,52 & 31.587 & 4,01 \\
\hline & 1988 & 1.653 & 737.576 & 10 & 0,60 & 39 & 0,005 & 56 & 3,39 & 849 & 0,11 & 332 & 20,08 & 22.555 & 3,06 \\
\hline & 2002 & 962 & 746.631 & 5 & 0,52 & 21,3 & & 36 & 3.74 & 52,5 & 0,07 & 144 & 14,97 & 9.531 & 1,28 \\
\hline \multirow{3}{*}{$\begin{array}{c}\text { Presidente } \\
\text { Roque Sáenz } \\
\text { Peña }\end{array}$} & 1969 & 1.653 & 808.482 & 42 & 2,54 & 130 & 0,02 & 77 & 4,66 & 1.033 & 0,12 & 270 & 16,33 & 18.996 & 2,35 \\
\hline & 1988 & 1.350 & 782.565 & 5 & 0,37 & 17 & 0,002 & 31 & 2,30 & 443 & 0,05 & 155 & 11,48 & 10.992 & 1,40 \\
\hline & 2002 & 961 & 606.634 & 5 & 0,52 & 8,8 & & 19 & 1,98 & 268,5 & 0,04 & 123 & 12,80 & 8.602 & 1,42 \\
\hline \multirow{3}{*}{ General Roca } & 1969 & 1.797 & 1.211 .829 & 90 & 5,00 & 281 & 0,02 & 133 & 7,40 & 1.751 & 0,14 & 216 & 12,02 & 14.005 & 1,15 \\
\hline & 1988 & 1.556 & 1.188 .890 & 38 & 2,44 & 145 & 0,01 & 68 & 4,37 & 964 & 0,08 & 174 & 11,18 & 11.039 & 0,93 \\
\hline & 2002 & 1.188 & 1.052 .151 & 9 & 0,76 & 32 & & 41 & 3,45 & 533 & 0,05 & 136 & 11,45 & 9.121 & 0,87 \\
\hline
\end{tabular}




\section{Cuadro No 1 (continuación)}

\begin{tabular}{|c|c|c|c|c|c|c|c|c|c|c|c|c|c|c|c|c|c|}
\hline \multirow{2}{*}{ Departamento } & \multirow{2}{*}{ CNA } & \multicolumn{4}{|c|}{ Desde 100,1 hasta 200 ha } & \multicolumn{4}{|c|}{$\begin{array}{c}\text { Desde } 200,1 \text { hasta } 400 \text { ha } \\
\text { (Censo 1969) }\end{array}$} & \multicolumn{4}{|c|}{$\begin{array}{l}\text { Desde } 200,1 \text { hasta } 500 \text { ha } \\
\text { (Censos } 1988 \text { y 2002) }\end{array}$} & \multicolumn{4}{|c|}{$\begin{array}{c}\text { Desde } 400,1 \text { hasta } 1.000 \text { ha } \\
\text { (Censo 1969) }\end{array}$} \\
\hline & & $\begin{array}{l}\text { Cantidad } \\
\text { explotaciones }\end{array}$ & $\begin{array}{l}\% \text { del } \\
\text { total }\end{array}$ & $\begin{array}{l}\text { Superficie } \\
\text { hectáreas }\end{array}$ & $\begin{array}{c}\% \text { del } \\
\text { total }\end{array}$ & $\begin{array}{c}\text { Cantidad } \\
\text { explotaciones }\end{array}$ & $\begin{array}{c}\% \text { del } \\
\text { total }\end{array}$ & $\begin{array}{l}\text { Superficie } \\
\text { hectáreas }\end{array}$ & $\begin{array}{c}\% \text { del } \\
\text { total }\end{array}$ & $\begin{array}{c}\text { Cantidad } \\
\text { explotaciones }\end{array}$ & $\begin{array}{c}\% \text { del } \\
\text { total }\end{array}$ & $\begin{array}{l}\text { Superficie } \\
\text { hectáreas }\end{array}$ & $\begin{array}{c}\% \text { del } \\
\text { total }\end{array}$ & $\begin{array}{l}\text { Cantidad } \\
\text { explotaciones }\end{array}$ & $\begin{array}{c}\% \text { del } \\
\text { total }\end{array}$ & $\begin{array}{l}\text { Superficie } \\
\text { hectáreas }\end{array}$ & $\begin{array}{l}\% \text { del } \\
\text { total }\end{array}$ \\
\hline \multirow{3}{*}{$\begin{array}{l}\text { Provincia de } \\
\text { Córdoba }\end{array}$} & 1969 & 13.240 & 22,9 & 1.999 .746 & 14,07 & 9.633 & 16,66 & 2.719 .536 & 19,14 & & & & & 4.726 & 8,17 & 2.834 .610 & 19,95 \\
\hline & 1988 & 9.072 & 22,64 & 1.366 .534 & 9,96 & & & & & 10.423 & 26,02 & 3.302 .001 & 24,06 & & & & \\
\hline & 2002 & 5.013 & 19,7 & 765.840 & 6,25 & & & & & 6.964 & 27,18 & 2.273 .460 & 18,57 & & & & \\
\hline \multirow{3}{*}{ Río Cuarto } & 1969 & 1.624 & 26,9 & 251.694 & 13,83 & 1.296 & 21,46 & 363.609 & 19,98 & & & & & 601 & 9,95 & 362.161 & 19,90 \\
\hline & 1988 & 1.131 & 24,69 & 172.004 & 10,10 & & & & & 1.415 & 30,90 & 444.930 & 26,12 & & & & \\
\hline & 2002 & 643 & 21,5 & 97.794 & 6,66 & & & & & 947 & 31,70 & 308.815 & 21,00 & & & & \\
\hline \multirow{3}{*}{ Juárez Celman } & 1969 & 597 & 29,98 & 90.058 & 11,44 & 457 & 22,18 & 128.956 & 16,38 & & & & & 234 & 11,36 & 142.806 & 18,40 \\
\hline & 1988 & 399 & 24,14 & 60.372 & 8,18 & & & & & 486 & 29,40 & 154.679 & 20,97 & & & & \\
\hline & 2002 & 181 & 18,8 & 27.292 & 3,65 & & & & & 277 & 28,80 & 89.747 & 12,00 & & & & \\
\hline \multirow{3}{*}{$\begin{array}{l}\text { Presidente } \\
\text { Roque Sáenz } \\
\text { Peña }\end{array}$} & 1969 & 422 & 25,53 & 65.022 & 8,04 & 437 & 26,44 & 128.119 & 15,85 & & & & & 261 & 15,79 & 157.465 & 19,47 \\
\hline & 1988 & 328 & 24,30 & 50.437 & 6,44 & & & & & 460 & 34,07 & 146.384 & 18,70 & & & & \\
\hline & 2002 & 213 & 22,16 & 33.044 & 5,44 & & & & & 304 & 31,63 & 97.979 & 16,15 & & & & \\
\hline \multirow{3}{*}{ General Roca } & 1969 & 337 & 18,75 & 52.776 & 4,35 & 431 & 23,98 & 127.294 & 10,50 & & & & & 335 & 18,64 & 210.685 & 17,38 \\
\hline & 1988 & 285 & 18,32 & 43.500 & 3,66 & & & & & 462 & 29,69 & 148.452 & 12,49 & & & & \\
\hline & 2002 & 168 & 14,14 & 26.356 & 2,50 & & & & & 371 & 31,20 & 120.504 & 11,45 & & & & \\
\hline
\end{tabular}


Cuadro $N^{\circ} 1$ (continuación)

\begin{tabular}{|c|c|c|c|c|c|c|c|c|c|c|c|c|c|c|c|c|c|}
\hline \multirow{2}{*}{ Departamento } & \multirow{2}{*}{ CNA } & \multicolumn{4}{|c|}{$\begin{array}{l}\text { De } 500,1 \text { hasta } 1.000 \text { ha } \\
\text { (Censos } 1988 \text { y 2002) }\end{array}$} & \multicolumn{4}{|c|}{ Desde $1.000,1$ hasta 2.500 ha } & \multicolumn{4}{|c|}{ Desde $2.500,1$ hasta 5.000 ha } & \multicolumn{4}{|c|}{ Desde $5.000,1$ hasta 10.000 ha } \\
\hline & & $\begin{array}{l}\text { Cantidad } \\
\text { explotaciones }\end{array}$ & $\begin{array}{l}\% \text { del } \\
\text { total }\end{array}$ & $\begin{array}{l}\text { Superficie } \\
\text { hectáreas }\end{array}$ & $\begin{array}{l}\% \text { del } \\
\text { total }\end{array}$ & $\begin{array}{c}\text { Cantidad } \\
\text { explotaciones }\end{array}$ & $\begin{array}{l}\% \text { del } \\
\text { total }\end{array}$ & $\begin{array}{l}\text { Superficie } \\
\text { hectáreas }\end{array}$ & $\begin{array}{l}\% \text { del } \\
\text { total }\end{array}$ & $\begin{array}{c}\text { Cantidad } \\
\text { explotaciones }\end{array}$ & $\begin{array}{l}\% \text { del } \\
\text { total }\end{array}$ & $\begin{array}{l}\text { Superficie } \\
\text { hectáreas }\end{array}$ & $\begin{array}{c}\% \text { del } \\
\text { total }\end{array}$ & $\begin{array}{l}\text { Cantidad } \\
\text { explotaciones }\end{array}$ & $\begin{array}{l}\% \text { del } \\
\text { total }\end{array}$ & $\begin{array}{l}\text { Superficie } \\
\text { hectáreas }\end{array}$ & $\begin{array}{l}\% \text { del } \\
\text { total }\end{array}$ \\
\hline \multirow{3}{*}{$\begin{array}{l}\text { Provincia de } \\
\text { Córdoba }\end{array}$} & 1969 & & & & & 1.407 & 2,44 & 2.159 .390 & 15,20 & 416 & 0,72 & 1.447 .702 & 10,19 & 169 & 0,29 & 1.146 .886 & 8,07 \\
\hline & 1988 & 3.652 & 9,12 & 2.541 .102 & 18,51 & 1.737 & 4,33 & 2.628 .913 & 19,16 & 437 & 1,09 & 1.498 .705 & 10,92 & 164 & 0,41 & 1.113 .682 & 8,11 \\
\hline & 2002 & 3.334 & 13,01 & 2.353 .869 & 19,21 & 1.872 & 7,31 & 2.825 .344 & 23,08 & 490 & 1,91 & 1.706 .678 & 13,94 & 172 & 0,67 & 1.158 .876 & 9,46 \\
\hline \multirow{3}{*}{ Río Cuarto } & 1969 & & & & & 192 & 3,18 & 283.102 & 15,56 & 62 & 1,03 & 209.978 & 11,54 & 15 & 0,25 & 93.223 & 5,12 \\
\hline & 1988 & 487 & 10,63 & 333.572 & 19,58 & 213 & 4,65 & 320.054 & 18,79 & 60 & 1,31 & 201.022 & 11,80 & 19 & 0,41 & 121.495 & 7,13 \\
\hline & 2002 & 381 & 12,76 & 264.323 & 18,00 & 234 & 7,84 & 354.109 & 24,12 & 62 & 2,08 & 207.229 & 14,11 & 25 & 0,84 & 161.046 & 10,97 \\
\hline \multirow{3}{*}{ Juárez Celman } & 1969 & & & & & 69 & 3,35 & 107.789 & 13,69 & 24 & 1,16 & 84.696 & 10,76 & 20 & 0,97 & 135.527 & 17,21 \\
\hline & 1988 & 214 & 12,95 & 148.529 & 20,14 & 116 & 7,02 & 174.947 & 23,72 & 31 & 1,87 & 106.416 & 14,43 & - & - & - & - \\
\hline & 2002 & 150 & 15,60 & 106.856 & 14,3 & 124 & 12,89 & 185.052 & 24,79 & 30 & 3,12 & 104.771 & 14,03 & 11 & 1,14 & 70.969 & 9,50 \\
\hline \multirow{3}{*}{$\begin{array}{l}\text { Presidente } \\
\text { Roque Sáenz } \\
\text { Peña }\end{array}$} & 1969 & & & & & 88 & 5,32 & 135.541 & 16,76 & 36 & 1,21 & 120.577 & 14,91 & 14 & 0,85 & 94.488 & 11,68 \\
\hline & 1988 & 200 & 14,81 & 138.252 & 17,66 & 121 & 8,96 & 184.545 & 23,58 & 31 & 2,30 & 101.915 & 13,02 & - & - & - & - \\
\hline & 2002 & 151 & 15,71 & 106.086 & 17,48 & 109 & 11,34 & 167.505 & 27,61 & 23 & 2,39 & 85.196 & 14,04 & 11 & 1,14 & 73.483 & 12,11 \\
\hline \multirow{3}{*}{ General Roca } & 1969 & & & & & 162 & 9,02 & 264.969 & 21,87 & 52 & 2,89 & 191.446 & 15,8 & 32 & 1,78 & 223.579 & 18,45 \\
\hline & 1988 & 251 & 16,13 & 175.954 & 14,80 & 174 & 11,18 & 272.876 & 22,95 & 68 & 4,37 & 242.759 & 20,42 & 30 & 1,93 & 205.694 & 17,30 \\
\hline & 2002 & 204 & 17,17 & 143.572 & 13,64 & 162 & 13,64 & 254.865 & 24,22 & 63 & 5,30 & 227.975 & 21,67 & 27 & 2,27 & 171.912 & 16,34 \\
\hline
\end{tabular}


Cuadro No 1 (continuación)

\begin{tabular}{|c|c|c|c|c|c|}
\hline \multirow{2}{*}{ Departamento } & \multirow[b]{2}{*}{ CNA } & \multicolumn{4}{|c|}{ Más de 10.000 ha } \\
\hline & & $\begin{array}{c}\text { Cantidad } \\
\text { explotaciones }\end{array}$ & $\begin{array}{l}\% \text { del } \\
\text { total }\end{array}$ & $\begin{array}{l}\text { Superficie } \\
\text { hectáreas }\end{array}$ & $\begin{array}{l}\% \text { del } \\
\text { total }\end{array}$ \\
\hline \multirow{3}{*}{$\begin{array}{l}\text { Provincia de } \\
\text { Córdoba }\end{array}$} & 1969 & 51 & 0,08 & 798.265 & 5,62 \\
\hline & 1988 & 37 & 0,09 & 613.159 & 4,47 \\
\hline & 2002 & 45 & 0,18 & 804.122 & 6,57 \\
\hline & 1969 & 10 & 0,17 & 156.135 & 8,58 \\
\hline \multirow[t]{2}{*}{ Río Cuarto } & 1988 & 3 & 0,06 & 45.582 & 2,67 \\
\hline & 2002 & 3 & 0,10 & 38.090 & 2,60 \\
\hline \multirow{3}{*}{ Juárez Celman } & 1969 & 5 & 0,24 & 63.893 & 8,11 \\
\hline & 1988 & - & - & - & - \\
\hline & 2002 & 4 & 0,42 & 151.864 & 20,34 \\
\hline \multirow{3}{*}{$\begin{array}{l}\text { Presidente } \\
\text { Roque Sáenz } \\
\text { Peña }\end{array}$} & 1969 & 6 & 0,36 & 87.107 & 10,77 \\
\hline & 1988 & - & - & - & - \\
\hline & 2002 & 3 & 0,31 & 34.460 & 5,68 \\
\hline & 1969 & 9 & 0,50 & 125.040 & 10,32 \\
\hline \multirow[t]{2}{*}{ General Roca } & 1988 & 6 & 0,38 & 87.505 & 7,36 \\
\hline & 2002 & 7 & 0,59 & 97.280 & 9,25 \\
\hline
\end{tabular}

Fuente: Elaboración propia en base a la información aportada por los CNAs de 1969, 1988 y 2002. 
Cuadro $\mathrm{N}^{\circ}$ 2. Resultados de las campañas agrícolas 1988/89-2009/10 de cereales y oleaginosas a nivel de provincia de Córdoba y del Sur Cordobés

\begin{tabular}{|c|c|c|c|c|c|c|c|c|c|c|c|c|c|c|c|c|c|c|}
\hline \multirow[b]{2}{*}{ Departamento } & \multirow{2}{*}{\multicolumn{2}{|c|}{$\begin{array}{l}\text { Años } \\
\text { Granos }\end{array}$}} & \multicolumn{2}{|c|}{ 1988/89 } & \multicolumn{2}{|c|}{ 1989/90 } & \multicolumn{2}{|c|}{$1990 / 91$} & \multicolumn{2}{|c|}{ 1991/92 } & \multicolumn{2}{|c|}{ 1992/93 } & \multicolumn{2}{|c|}{ 1993/94 } & \multicolumn{2}{|c|}{$1994 / 95$} & \multicolumn{2}{|c|}{ 1995/96 } \\
\hline & & & $\begin{array}{c}\text { Superficie } \\
\text { sembrada } \\
\text { (ha) }\end{array}$ & $\begin{array}{l}\text { Producción } \\
\text { (t) }\end{array}$ & $\begin{array}{c}\text { Superficie } \\
\text { sembrada } \\
\text { (ha) }\end{array}$ & $\begin{array}{c}\text { Producción } \\
\text { (t) }\end{array}$ & $\begin{array}{l}\text { Superficie } \\
\text { sembrada } \\
\text { (ha) }\end{array}$ & $\begin{array}{c}\text { Producción } \\
\text { (t) }\end{array}$ & $\begin{array}{c}\text { Superficie } \\
\text { sembrada } \\
\text { (ha) }\end{array}$ & $\begin{array}{l}\text { Producción } \\
\text { (t) }\end{array}$ & $\begin{array}{c}\text { Superficie } \\
\text { sembrada } \\
\text { (ha) }\end{array}$ & $\begin{array}{l}\text { Producción } \\
\text { (t) }\end{array}$ & $\begin{array}{l}\text { Superficie } \\
\text { sembrada } \\
\text { (ha) }\end{array}$ & $\begin{array}{l}\text { Producción } \\
\text { (t) }\end{array}$ & $\begin{array}{c}\text { Superficie } \\
\text { sembrada } \\
\text { (ha) }\end{array}$ & $\begin{array}{l}\text { Producción } \\
\text { (t) }\end{array}$ & $\begin{array}{c}\text { Superficie } \\
\text { sembrada } \\
\text { (ha) }\end{array}$ & $\begin{array}{l}\text { Producción } \\
\text { (t) }\end{array}$ \\
\hline \multirow{8}{*}{$\begin{array}{l}\text { Provincia de } \\
\text { Córdoba }\end{array}$} & \multirow{4}{*}{ 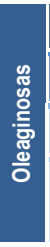 } & Soja & 1.391 .840 & 1.306 .988 & 1.452 .800 & 2.577 .300 & 1.316 .300 & 2.751 .139 & 1.262 .900 & 3.041 .310 & 1.297 .000 & 2.928 .015 & 1.434 .800 & 3.083 .540 & 1.402 .500 & 2.357 .525 & 1.517 .100 & 3.112 .638 \\
\hline & & Girasol & 265.720 & 297.868 & 362.300 & 372.160 & 298.400 & 490.610 & 322.800 & 337.490 & 320.300 & 288.920 & 251.200 & 428.730 & 304.700 & 565.490 & 370.500 & 560.420 \\
\hline & & Maní & 158.116 & 134.758 & 181.200 & 193.390 & 227.100 & 464.795 & 152.400 & 247.400 & 94.200 & 150.310 & 132.200 & 218.235 & 135.500 & 183.400 & 220.700 & 409.956 \\
\hline & & Total & $\begin{array}{c}1.815 .676 \\
+\end{array}$ & $\begin{array}{c}1.739 .614 \\
+\end{array}$ & $\begin{array}{c}1.996 .300 \\
+\end{array}$ & $\begin{array}{l}3.142 .850 \\
+\end{array}$ & $\begin{array}{c}1.841 .800 \\
+\end{array}$ & $\begin{array}{c}3.706 .544 \\
\cdot-\end{array}$ & $\begin{array}{c}1.738 .100 \\
+\end{array}$ & $\begin{array}{c}3.626 .200 \\
\cdot\end{array}$ & $\begin{array}{c}1.711 .500 \\
+\end{array}$ & $\begin{array}{c}3.307 .245 \\
\cdot\end{array}$ & $\begin{array}{c}1.818 .200 \\
+\end{array}$ & $\begin{array}{c}3.730 .505 \\
\cdot\end{array}$ & $\begin{array}{c}1.843 .700 \\
+\end{array}$ & $\begin{array}{c}3.106 .415 \\
\cdot\end{array}$ & $\begin{array}{l}2.108 .300 \\
+\end{array}$ & $\begin{array}{l}4.083 .014 \\
+\end{array}$ \\
\hline & \multirow{4}{*}{ 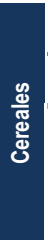 } & Maiz & 743.310 & 607.081 & 561.650 & 842.535 & 596.850 & 1.882 .272 & 682.300 & 2.337 .288 & 792.100 & 3.118 .200 & 694.000 & 2.422 .765 & 752.350 & 2.396 .660 & 820.100 & 2.289 .810 \\
\hline & & Sorgo & 230.740 & 431.110 & 257.350 & 541.380 & 267.700 & 1.013 .855 & 246.900 & 839.950 & 276.800 & 1.182 .310 & 329.250 & 895.890 & 194.000 & 493.045 & 258.500 & 953.471 \\
\hline & & Trigo & 415.800 & 555.975 & 649.420 & 603.860 & 809.900 & 1.083 .935 & 581.760 & 1.197 .625 & 409.650 & 827.295 & 603.150 & 985.620 & 607.000 & 1.098 .870 & 393.700 & 400.070 \\
\hline & & Total & $\begin{array}{c}1.389 .850 \\
.\end{array}$ & $\begin{array}{c}1.594 .166 \\
-\end{array}$ & $\begin{array}{c}1.468 .420 \\
.\end{array}$ & $\begin{array}{c}1.987 .775 \\
.\end{array}$ & $\begin{array}{c}1.674 .450 \\
.\end{array}$ & $\begin{array}{c}3.980 .062 \\
+\end{array}$ & $\begin{array}{c}1.510 .960 \\
-\end{array}$ & $\begin{array}{l}4.374 .863 \\
+\end{array}$ & $\begin{array}{c}1.478 .550 \\
.\end{array}$ & $\begin{array}{l}5.127 .805 \\
+\end{array}$ & $\begin{array}{c}1.536 .400 \\
.\end{array}$ & $\begin{array}{c}4.304 .275 \\
+\end{array}$ & $\begin{array}{c}1.553 .350 \\
.\end{array}$ & $\begin{array}{c}3.988 .575 \\
+\end{array}$ & $\begin{array}{c}1.472 .300 \\
.\end{array}$ & $\begin{array}{c}3.643 .351 \\
-\end{array}$ \\
\hline \multirow{8}{*}{ General Roca } & \multirow{4}{*}{ 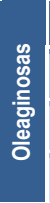 } & Soja & 12.000 & 18.000 & 9.000 & 10.800 & 9.000 & 9.180 & 6.000 & 9.300 & 6.000 & 13.500 & 9.000 & 18.000 & 15.000 & 28.500 & 2.000 & 3.300 \\
\hline & & Girasol & 60.000 & 90.000 & 70.000 & 84.000 & 60.000 & 103.800 & 70.000 & 105.000 & 60.000 & 75.400 & 70.000 & 105.000 & 100.000 & 160.000 & 65.000 & 72.500 \\
\hline & & Mani & - & - & - & - & - & - & - & - & - & - & - & - & - & - & - & - \\
\hline & & Total & 72.000 & 108.000 & 79.000 & 94.800 & 69.000 & 112.980 & 76.000 & 114.300 & 66.000 & 88.900 & 79.000 & 123.000 & 115.000 & 188.500 & 67.000 & 75.800 \\
\hline & \multirow{4}{*}{ 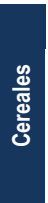 } & Maiz & 35.000 & 45.000 & 25.000 & 62.500 & 16.000 & 36.000 & 25.000 & 67.500 & 35.000 & 72.000 & 35.000 & 105.000 & 30.000 & 90.000 & 25.000 & 39.000 \\
\hline & & Sorgo & 35.000 & 140.000 & 25.000 & 75.000 & 18.000 & 40.320 & 12.000 & 36.000 & 16.000 & 45.000 & 18.000 & 71.100 & 15.000 & 52.500 & 16.000 & 48.000 \\
\hline & & Trigo & 33.500 & 33.600 & 55.000 & 60.000 & 55.000 & 86.400 & 35.000 & 52.500 & 25.000 & 21.600 & 25.000 & 50.000 & 35.000 & 70.000 & 28.000 & 16.800 \\
\hline & & Total & 103.500 & 218.600 & 105.000 & 199.500 & 89.000 & 162.720 & 72.000 & 156.000 & 76.000 & 138.600 & 78.000 & 226.100 & 80.000 & 212.500 & 69.000 & 103.800 \\
\hline \multirow[t]{8}{*}{ Juárez Celman } & \multirow{4}{*}{ 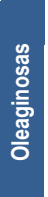 } & Soja & 92.000 & 77.280 & 82.500 & 70.000 & 60.000 & 136.800 & 70.000 & 139.650 & 75.000 & 135.375 & 70.000 & 110.250 & 65.000 & 84.000 & 80.000 & 144.000 \\
\hline & & Girasol & 32.000 & 8.000 & 35.000 & 20.000 & 20.000 & 36.000 & 26.000 & 16.380 & 21.000 & 22.680 & 16.000 & 32.000 & 20.000 & 36.000 & 60.000 & 65.000 \\
\hline & & Mani & 40.000 & 40.800 & 43.000 & 39.000 & 60.000 & 132.000 & 60.000 & 102.600 & 45.000 & 87.750 & 58.000 & 96.425 & 70.000 & 102.000 & 95.000 & 172.900 \\
\hline & & Total & 164.000 & 126.080 & 160.500 & 129.000 & 140.000 & 304.800 & 156.000 & 258.630 & 141.000 & 245.805 & 144.000 & 238.675 & 155.000 & 222.000 & 235.000 & 381.900 \\
\hline & \multirow{4}{*}{ 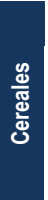 } & Maiz & 55.000 & 32.000 & 35.000 & 32.400 & 40.000 & 179.360 & 50.000 & 140.000 & 60.000 & 229.500 & 85.000 & 326.700 & 90.000 & 399.500 & 100.000 & 180.000 \\
\hline & & Sorgo & 15.000 & 18.000 & 20.000 & 14.400 & 20.000 & 75.600 & 15.000 & 43.200 & 15.000 & 52.725 & 12.000 & 46.740 & 10.000 & 34.200 & 20.000 & 70.000 \\
\hline & & Trigo & 31.000 & 54.000 & 70.000 & 74.250 & 75.000 & 40.500 & 50.000 & 88.000 & 35.000 & 66.500 & 30.000 & 72.000 & 35.000 & 66.500 & 40.000 & 30.800 \\
\hline & & Total & 101.000 & 104.000 & 125.000 & 121.050 & 135.000 & 295.460 & 115.000 & 271.200 & 110.000 & 348.725 & 127.000 & 445.440 & 135.000 & 500.200 & 160.000 & 280.800 \\
\hline
\end{tabular}


Cuadro 2. Resultados (continuación)

\begin{tabular}{|c|c|c|c|c|c|c|c|c|c|c|c|c|c|c|c|c|c|c|}
\hline \multirow[b]{2}{*}{ Departamento } & \multirow{2}{*}{\multicolumn{2}{|c|}{$\begin{array}{l}\text { Años } \\
\text { Granos }\end{array}$}} & \multicolumn{2}{|c|}{ 1988/89 } & \multicolumn{2}{|c|}{ 1989/90 } & \multicolumn{2}{|c|}{ 1990/91 } & \multicolumn{2}{|c|}{ 1991/92 } & \multicolumn{2}{|c|}{ 1992/93 } & \multicolumn{2}{|c|}{ 1993/94 } & \multicolumn{2}{|c|}{$1994 / 95$} & \multicolumn{2}{|c|}{$1995 / 96$} \\
\hline & & & $\begin{array}{c}\text { Superficie } \\
\text { sembrada } \\
\text { (ha) }\end{array}$ & $\begin{array}{l}\text { Producción } \\
\text { (t) }\end{array}$ & $\begin{array}{c}\text { Superficie } \\
\text { sembrada } \\
\text { (ha) }\end{array}$ & $\begin{array}{c}\text { Producción } \\
\text { (t) }\end{array}$ & $\begin{array}{c}\text { Superficie } \\
\text { sembrada } \\
\text { (ha) }\end{array}$ & $\begin{array}{c}\text { Producción } \\
\text { (t) }\end{array}$ & $\begin{array}{c}\text { Superficie } \\
\text { sembrada } \\
\text { (ha) }\end{array}$ & $\begin{array}{l}\text { Producción } \\
\text { (t) }\end{array}$ & $\begin{array}{c}\text { Superficie } \\
\text { sembrada } \\
\text { (ha) }\end{array}$ & $\begin{array}{l}\text { Producción } \\
\text { (t) }\end{array}$ & $\begin{array}{l}\text { Superficie } \\
\text { sembrada } \\
\text { (ha) }\end{array}$ & $\begin{array}{c}\text { Producción } \\
\text { (t) }\end{array}$ & $\begin{array}{c}\text { Superficie } \\
\text { sembrada } \\
\text { (ha) }\end{array}$ & $\begin{array}{l}\text { Producción } \\
\text { (t) }\end{array}$ & $\begin{array}{c}\text { Superficie } \\
\text { sembrada } \\
\text { (ha) }\end{array}$ & $\begin{array}{l}\text { Producción } \\
\text { (t) }\end{array}$ \\
\hline \multirow{8}{*}{$\begin{array}{l}\text { Presidente } \\
\text { Roque Sáenz } \\
\text { Peña }\end{array}$} & \multirow{4}{*}{ 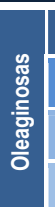 } & Soja & 28.000 & 29.400 & 25.000 & 28.800 & 14.000 & 27.000 & 24.000 & 26.400 & 28.000 & 70.000 & 34.000 & 52.800 & 30.500 & 49.500 & 31.000 & 52.700 \\
\hline & & Girasol & 28.000 & 35.100 & 30.000 & 25.200 & 26.000 & 45.000 & 35.000 & 30.000 & 37.000 & 39.600 & 37.000 & 81.400 & 52.000 & 109.200 & 76.000 & 134.100 \\
\hline & & Maní & - & - & - & - & - & - & - & - & - & - & - & - & - & - & - & - \\
\hline & & Total & 56.000 & 64.500 & 55.000 & 54.000 & 40.000 & 72.000 & 59.000 & 56.400 & 65.000 & 109.600 & 71.000 & 134.200 & 82.500 & 158.700 & 107.000 & 186.800 \\
\hline & \multirow{4}{*}{ 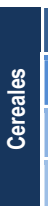 } & Maiz & 20.000 & 10.000 & 14.000 & 21.600 & 16.000 & 39.000 & 24.000 & 70.000 & 20.000 & 42.000 & 13.200 & 42.000 & 12.000 & 45.600 & 15.000 & 30.600 \\
\hline & & Sorgo & 8.000 & 13.440 & 7.000 & 12.350 & 8.000 & 26.400 & 12.000 & 22.400 & 4.000 & 12.000 & 6.000 & 21.600 & 3.500 & 13.300 & 3.000 & 9.450 \\
\hline & & Trigo & 45.000 & 50.400 & 58.000 & 67.200 & 75.000 & 131.400 & 50.000 & 80.000 & 45.000 & 76.500 & 45.000 & 74.400 & 52.000 & 135.000 & 54.000 & 85.000 \\
\hline & & Total & 73.000 & 73.840 & 79.000 & 101.150 & 99.000 & 196.800 & 86.000 & 172.400 & 69.000 & 130.500 & 64.200 & 138.000 & 67.500 & 193.900 & 72.000 & 125.050 \\
\hline \multirow{8}{*}{ Río Cuarto } & \multirow{4}{*}{ 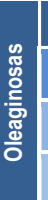 } & Soja & 130.000 & 165.000 & 150.000 & 166.800 & 95.000 & 188.100 & 98.000 & 200.750 & 103.000 & 232.800 & 108.000 & 210.000 & 120.000 & 182.400 & 105.000 & 189.000 \\
\hline & & Girasol & 85.000 & 106.400 & 95.000 & 102.300 & 85.000 & 129.210 & 85.000 & 75.000 & 105.000 & 87.750 & 71.000 & 112.200 & 70.000 & 151.800 & 88.000 & 155.700 \\
\hline & & Mani & 15.000 & 15.000 & 20.000 & 17.100 & 28.000 & 44.352 & 19.000 & 20.900 & 8.000 & 9.600 & 21.000 & 22.050 & 20.000 & 22.000 & 60.000 & 96.600 \\
\hline & & Total & 230.000 & 286.400 & 265.000 & 286.200 & 208.000 & 361.662 & 202.000 & 296.650 & 216.000 & 330.150 & 200.000 & 344.250 & 210.000 & 356.200 & 253.000 & 441.300 \\
\hline & \multirow{4}{*}{$\frac{\mathscr{s}}{\mathbf{E}}$} & Maíz & 305.000 & 261.000 & 240.000 & 128.000 & 230.000 & 576.000 & 232.000 & 534.600 & 252.000 & 792.000 & 232.000 & 539.000 & 250.000 & 855.000 & 265.000 & 728.750 \\
\hline & & Sorgo & 45.000 & 83.200 & 30.000 & 50.000 & 15.000 & 43.065 & 15.000 & 38.475 & 18.000 & 61.050 & 18.000 & 28.500 & 12.000 & 24.000 & 15.000 & 36.900 \\
\hline & & Trigo & 31.000 & 40.500 & 47.000 & 50.700 & 73.000 & 94.250 & 41.000 & 87.250 & 16.000 & 18.225 & 28.000 & 67.200 & 34.000 & 84.645 & 28.000 & 15.600 \\
\hline & & Total & 381.000 & 384.700 & 317.000 & 228.700 & 318.000 & 713.315 & 288.000 & 660.325 & 286.000 & 871.275 & 278.000 & 634.700 & 296.000 & 963.645 & 308.000 & 781.250 \\
\hline \multirow{8}{*}{$\begin{array}{l}\text { Sumatoria de los } \\
\text { cuatro } \\
\text { departamentos }\end{array}$} & \multirow{4}{*}{ 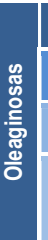 } & Soja & 262.000 & 289.680 & 266.500 & 276.400 & 178.000 & 361.080 & 198.000 & 376.100 & 212.000 & 451.675 & 221.000 & 391.050 & 230.500 & 344.400 & 218.000 & 389.000 \\
\hline & & Girasol & 205.000 & 239.500 & 230.000 & 231.500 & 191.000 & 314.010 & 216.000 & 226.380 & 223.000 & 225.430 & 194.000 & 330.400 & 242.000 & 457.000 & 289.000 & 427.300 \\
\hline & & Maní & 55.000 & 55.800 & 63.000 & 56.100 & 88.000 & 176.352 & 79.000 & 123.500 & 53.000 & 97.350 & 79.000 & 118.475 & 90.000 & 124.000 & 155.000 & 269.500 \\
\hline & & Total & 522.000 & 584.980 & 559.500 & 564.000 & 457.000 & 581.442 & 493.000 & $\begin{array}{l}725.980 \\
\cdot\end{array}$ & 488.000 & 774.455 & $\begin{array}{l}494.000 \\
.\end{array}$ & 839.925 & 562.500 & 925.400 & $\begin{array}{l}662.000 \\
+\end{array}$ & $\begin{array}{c}1.085 .800 \\
\cdot\end{array}$ \\
\hline & \multirow{4}{*}{ 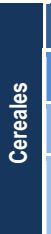 } & Maiz & 415.000 & 348.000 & 314.000 & 244.500 & 302.000 & 830.360 & 331.000 & 749.100 & 367.000 & 1.135 .500 & 365.200 & 1.012 .700 & 382.000 & 1.390 .100 & 405.000 & 978.350 \\
\hline & & Sorgo & 103.000 & 254.640 & 82.000 & 151.750 & 61.000 & 185.385 & 54.000 & 140.075 & 53.000 & 170.775 & 54.000 & 167.940 & 40.500 & 124.000 & 54.000 & 164.350 \\
\hline & & Trigo & 140.500 & 178.500 & 230.000 & 252.150 & 278.000 & 176.352 & 176.000 & 307.750 & 121.000 & 182.825 & 128.000 & 263.600 & 156.000 & 356.145 & 150.000 & 148.200 \\
\hline & & Total & $\begin{aligned} & 658.500 \\
+ & (41.276)\end{aligned}$ & $\begin{array}{l}7810140 \\
+\end{array}$ & $\begin{array}{c}626.000 \\
+(42700)\end{array}$ & $\begin{array}{r}648.400 \\
+(45.180)\end{array}$ & $\begin{array}{l}641.000 \\
+\end{array}$ & $\begin{array}{c}1.192 .097 \\
+\end{array}$ & $\begin{aligned} & 561.000 \\
+ & (14.980)\end{aligned}$ & $\begin{array}{r}1.196 .925 \\
+(18.272)\end{array}$ & $\begin{array}{l}541.000 \\
+\end{array}$ & $\begin{array}{c}1.484 .100 \\
+\end{array}$ & $\begin{array}{l}547.200 \\
+\end{array}$ & $\begin{array}{l}1.444 .240 \\
+\end{array}$ & $\begin{array}{l}578.500 \\
+\end{array}$ & $\begin{array}{c}1.870 .245 \\
+\end{array}$ & 609.000 & $\begin{array}{c}1.290 .900 \\
+\end{array}$ \\
\hline
\end{tabular}


Cuadro 2. Resultados (continuación)

\begin{tabular}{|c|c|c|c|c|c|c|c|c|c|c|c|c|c|c|c|c|c|c|}
\hline \multirow[b]{2}{*}{ Departamento } & \multicolumn{2}{|r|}{ Años } & \multicolumn{2}{|c|}{ 1996/97 } & \multicolumn{2}{|c|}{ 1997/98 } & \multicolumn{2}{|c|}{ 1998/99 } & \multicolumn{2}{|c|}{ 1999/00 } & \multicolumn{2}{|c|}{ 2000/01 } & \multicolumn{2}{|c|}{ 2001/02 } & \multicolumn{2}{|c|}{ 2002/03 } & \multicolumn{2}{|c|}{ 2003/04 } \\
\hline & & Granos & $\begin{array}{c}\text { Superficie } \\
\text { sembrada } \\
\text { (ha) }\end{array}$ & $\begin{array}{l}\text { Producción } \\
\text { (t) }\end{array}$ & $\begin{array}{l}\text { Superficie } \\
\text { sembrada } \\
\text { (ha) }\end{array}$ & $\begin{array}{c}\text { Producción } \\
\text { (t) }\end{array}$ & $\begin{array}{c}\text { Superficie } \\
\text { sembrada } \\
\text { (ha) }\end{array}$ & $\begin{array}{c}\text { Producción } \\
\text { (t) }\end{array}$ & $\begin{array}{c}\text { Superficie } \\
\text { sembrada } \\
\text { (ha) }\end{array}$ & $\begin{array}{l}\text { Producción } \\
\text { (t) }\end{array}$ & $\begin{array}{c}\text { Superficie } \\
\text { sembrada } \\
\text { (ha) }\end{array}$ & $\begin{array}{l}\text { Producción } \\
\text { (t) }\end{array}$ & $\begin{array}{c}\text { Superficie } \\
\text { sembrada } \\
\text { (ha) }\end{array}$ & $\begin{array}{l}\text { Producción } \\
\text { (t) }\end{array}$ & $\begin{array}{c}\text { Superficie } \\
\text { sembrada } \\
\text { (ha) }\end{array}$ & $\begin{array}{l}\text { Producción } \\
\text { (t) }\end{array}$ & $\begin{array}{l}\text { Superficie } \\
\text { sembrada } \\
\text { (ha) }\end{array}$ & $\begin{array}{l}\text { Producción } \\
\text { (t) }\end{array}$ \\
\hline \multirow{8}{*}{$\begin{array}{l}\text { Provincia de } \\
\text { Córdoba }\end{array}$} & \multirow{4}{*}{ 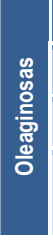 } & Soja & 1.596 .700 & 1.937 .650 & 1.833 .650 & 5.316 .192 & 1.946 .950 & 3.862 .141 & 2.497 .065 & 6.382 .060 & 2.966 .000 & 7.274 .628 & 3.213 .350 & 8.311 .742 & 3.633 .000 & 9.092 .363 & 3.933 .850 & 8.276 .196 \\
\hline & & Girasol & 397.120 & 487.662 & 466.600 & 643.016 & 516.700 & 821.224 & 502.800 & 881.080 & 319.400 & 650.378 & 265.680 & 599.340 & 250.300 & 568.646 & 115.850 & 210.715 \\
\hline & & Maní & 311.650 & 261.319 & 402.900 & 405.670 & 342.600 & 369.077 & 217.300 & 395.030 & 250.300 & 427.260 & 216.300 & 397.182 & 159.900 & 243.250 & 151.400 & 258.450 \\
\hline & & Total & $\begin{array}{c}2.305 .470 \\
+\end{array}$ & $\begin{array}{c}2.686 .631 \\
-\end{array}$ & $\begin{array}{l}2.703 .150 \\
+\end{array}$ & $\begin{array}{l}6.664 .878 \\
+\end{array}$ & $\begin{array}{l}2.806 .250 \\
+\end{array}$ & $\begin{array}{c}5.052 .442 \\
-\end{array}$ & $\begin{array}{c}3.217 .165 \\
+\end{array}$ & $\begin{array}{c}7.658 .170 \\
-\end{array}$ & $\begin{array}{c}3.535 .700 \\
+\end{array}$ & $\begin{array}{c}8.352 .266 \\
+\end{array}$ & $\begin{array}{c}3.695 .330 \\
+\end{array}$ & $\begin{array}{l}9.308 .267 \\
+\end{array}$ & $\begin{array}{c}4.043 .200 \\
+\end{array}$ & $\begin{array}{l}9.904 .259 \\
+\end{array}$ & $\begin{array}{l}4.201 .100 \\
+\end{array}$ & $\begin{array}{l}8.745 .361 \\
+\end{array}$ \\
\hline & \multirow{4}{*}{ 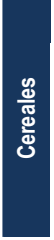 } & Maiz & 927.100 & 1.757 .239 & 895.100 & 4.276 .125 & 775.100 & 3.022 .150 & 899.600 & 5.008 .414 & 906.700 & 4.893.173 & 922.300 & 5.592 .870 & 960.180 & 6.491 .939 & 657.280 & 3.741 .112 \\
\hline & & Sorgo & 285.100 & 783.010 & 366.300 & 1.701 .927 & 333.100 & 1.129 .788 & 309.100 & 1.468 .648 & 242.950 & 1.299 .370 & 193.250 & 1.078 .620 & 175.550 & 987.975 & 144.350 & 645.525 \\
\hline & & Trigo & 618.750 & 794.025 & 395.150 & 535.567 & 561.150 & 1.015 .080 & 751.350 & 1.678 .880 & 854.700 & 1.901 .600 & 1.074 .100 & 2.235 .300 & 896.520 & 1.655 .892 & 959.700 & 1.851 .640 \\
\hline & & Total & $\begin{array}{c}1.830 .950 \\
+\end{array}$ & $\begin{array}{l}3.334 .274 \\
+\end{array}$ & $\begin{array}{c}1.656 .550 \\
.\end{array}$ & $\begin{array}{c}6.513 .619 \\
-\end{array}$ & $\begin{array}{c}1.669 .350 \\
.\end{array}$ & $\begin{array}{l}5.167 .018 \\
+\end{array}$ & $\begin{array}{c}1.940 .050 \\
-\end{array}$ & $\begin{array}{l}8.155 .942 \\
+\end{array}$ & $\begin{array}{c}2.004 .350 \\
-\end{array}$ & $\begin{array}{c}8.094 .143 \\
.\end{array}$ & $\begin{array}{c}2.189 .652 \\
-\end{array}$ & $\begin{array}{c}8.906 .790 \\
-\end{array}$ & $\begin{array}{c}2.032 .250 \\
-\end{array}$ & $\begin{array}{c}9.135 .806 \\
.\end{array}$ & $\begin{array}{c}1.761 .330 \\
.\end{array}$ & $\begin{array}{c}6.238 .277 \\
-\end{array}$ \\
\hline \multirow{8}{*}{ General Roca } & \multirow{4}{*}{ 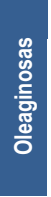 } & Soja & 6.000 & 7.800 & 10.000 & 12.000 & 20.000 & 42.300 & 25.000 & 40.205 & 52.000 & 112.320 & 53.000 & 125.388 & 62.000 & 166.860 & 66.900 & 113.730 \\
\hline & & Girasol & 125.000 & 153.750 & 165.000 & 224.000 & 185.000 & 280.500 & 180.000 & 302.526 & 130.000 & 260.000 & 120.000 & 288.000 & 103.000 & 235.520 & 50.000 & 90.000 \\
\hline & & Maní & - & - & - & - & - & - & - & - & 8.000 & 25.600 & 12.000 & 19.200 & 10.000 & 15.000 & 15.000 & 25.500 \\
\hline & & Total & 131.000 & 161.550 & 265.000 & 236.000 & 205.000 & 322.800 & 205.000 & 342.731 & 190.000 & 397.920 & 185.000 & 432.588 & 176.000 & 417.380 & 131.900 & 229.230 \\
\hline & \multirow{4}{*}{ 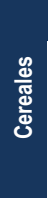 } & Maiz & 40.000 & 80.000 & 40.000 & 82.500 & 32.000 & 75.196 & 40.000 & 144.000 & 55.000 & 240.000 & 35.000 & 122.400 & 35.000 & 205.200 & 21.000 & 111.300 \\
\hline & & Sorgo & 20.000 & 60.000 & 75.000 & 55.500 & 18.000 & 51.305 & 16.000 & 72.000 & 14.000 & 70.000 & 6.000 & 20.400 & 4.500 & 27.000 & 5.500 & 25.850 \\
\hline & & Trigo & 68.000 & 66.000 & 60.000 & 126.000 & 40.000 & 76.464 & 42.000 & 78.000 & 45.000 & 97.500 & 70.000 & 138.000 & 70.000 & 140.000 & 57.000 & 62.100 \\
\hline & & Total & 128.000 & 206.000 & 175.000 & 264.000 & 90.000 & 202.965 & 98.000 & 254.000 & 114.000 & 407.500 & 111.000 & 280.800 & 109.500 & 372.200 & 83.500 & 199.250 \\
\hline \multirow[t]{8}{*}{ Juárez Celman } & \multirow{4}{*}{ 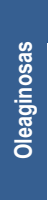 } & Soja & 88.000 & 91.200 & 88.000 & 242.200 & 88.000 & 146.124 & 135.000 & 337.500 & 170.000 & 275.400 & 204.000 & 418.200 & 255.000 & 459.000 & 300.000 & 720.000 \\
\hline & & Girasol & 37.500 & 37.125 & 35.500 & 55.250 & 39.000 & 67.118 & 42.000 & 70.875 & 22.050 & 39.690 & 20.000 & 36.000 & 20.800 & 39.520 & 6.000 & 11.400 \\
\hline & & Mani & 109.000 & 83.700 & 128.600 & 195.690 & 109.000 & 108.936 & 68.000 & 132.600 & 48.100 & 67.340 & 37.000 & 61.050 & 28.700 & 39.480 & 23.000 & 37.950 \\
\hline & & Total & 234.500 & 212.025 & 252.100 & 493.140 & 236.000 & 322.178 & 245.000 & 540.975 & 240.150 & 382.430 & 261.000 & 515.250 & 304.500 & 538.000 & 329.000 & 769.350 \\
\hline & \multirow{4}{*}{ 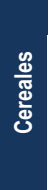 } & Maiz & 113.000 & 124.300 & 97.000 & 423.360 & 52.500 & 279.180 & 87.000 & 478.500 & 94.000 & 423.000 & 98.000 & 509.600 & 84.000 & 570.500 & 30.000 & 150.000 \\
\hline & & Sorgo & 30.000 & 36.800 & 18.000 & 81.360 & 18.000 & 78.300 & 18.000 & 99.000 & 18.000 & 81.000 & 16.000 & 30.000 & 16.200 & 97.200 & 12.000 & 60.000 \\
\hline & & Trigo & 35.000 & 30.765 & 11.250 & 5.850 & 22.000 & 41.140 & 24.200 & 41.420 & 39.000 & 85.000 & 46.800 & 88.800 & 42.120 & 56.192 & 45.000 & 43.500 \\
\hline & & Total & 176.000 & 191.865 & 126.250 & 510.570 & 92.500 & 398.620 & 129.200 & 618.920 & 151.000 & 589.000 & 160.800 & 628.400 & 142.320 & 723.892 & 87.000 & 253.500 \\
\hline
\end{tabular}


Cuadro 2. Resultados (continuación)

\begin{tabular}{|c|c|c|c|c|c|c|c|c|c|c|c|c|c|c|c|c|c|c|}
\hline \multirow[b]{2}{*}{ Departamento } & \multirow{2}{*}{\multicolumn{2}{|c|}{$\begin{array}{l}\text { Años } \\
\text { Granos }\end{array}$}} & \multicolumn{2}{|c|}{ 1996/97 } & \multicolumn{2}{|c|}{ 1997/98 } & \multicolumn{2}{|c|}{ 1998/99 } & \multicolumn{2}{|c|}{$1999 / 00$} & \multicolumn{2}{|c|}{$2000 / 01$} & \multicolumn{2}{|c|}{$2001 / 02$} & \multicolumn{2}{|c|}{$2002 / 03$} & \multicolumn{2}{|c|}{$2003 / 04$} \\
\hline & & & $\begin{array}{l}\text { Superficie } \\
\text { sembrada } \\
\text { (ha) }\end{array}$ & $\begin{array}{l}\text { Producción } \\
\text { (t) }\end{array}$ & $\begin{array}{l}\text { Superficie } \\
\text { sembrada } \\
\text { (ha) }\end{array}$ & $\begin{array}{c}\text { Producción } \\
\text { (t) }\end{array}$ & $\begin{array}{l}\text { Superficie } \\
\text { sembrada } \\
\text { (ha) }\end{array}$ & \begin{tabular}{|c|} 
Producción \\
(t)
\end{tabular} & $\begin{array}{l}\text { Superficie } \\
\text { sembrada } \\
\text { (ha) }\end{array}$ & $\begin{array}{l}\text { Producción } \\
\text { (t) }\end{array}$ & $\begin{array}{c}\text { Superficie } \\
\text { sembrada } \\
\text { (ha) }\end{array}$ & $\begin{array}{l}\text { Producción } \\
\text { (t) }\end{array}$ & $\begin{array}{l}\text { Superficie } \\
\text { sembrada } \\
\text { (ha) }\end{array}$ & $\begin{array}{l}\text { Producción } \\
\text { (t) }\end{array}$ & $\begin{array}{l}\text { Superficie } \\
\text { sembrada } \\
\text { (ha) }\end{array}$ & $\begin{array}{l}\text { Producción } \\
\text { (t) }\end{array}$ & $\begin{array}{c}\text { Superficie } \\
\text { sembrada } \\
\text { (ha) }\end{array}$ & $\begin{array}{l}\text { Producción } \\
\text { (t) }\end{array}$ \\
\hline \multirow{8}{*}{$\begin{array}{l}\text { Presidente } \\
\text { Roque Sáenz } \\
\text { Peña }\end{array}$} & \multirow{4}{*}{ 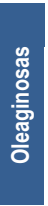 } & Soja & 36.000 & 41.340 & 43.000 & 64.655 & 47.000 & 67.895 & 62.000 & 126.880 & 76.000 & 153.000 & 68.000 & 171.870 & 73.000 & 193.053 & 88.000 & 149.600 \\
\hline & & Girasol & 78.000 & 121.600 & 95.000 & 96.380 & 100.000 & 105.950 & 110.000 & 192.774 & 83.000 & 188.600 & 65.000 & 156.000 & 62.000 & 141.450 & 33.000 & 59.400 \\
\hline & & Maní & - & - & 3.500 & 5.400 & 2.000 & 2.660 & 1.800 & 2.380 & 9.000 & 11.340 & 8.000 & 13.440 & 5.500 & 10.450 & 10.000 & 17.000 \\
\hline & & Total & 114.000 & 162.940 & 141.500 & 166.435 & 149.000 & 176.505 & 173.800 & 322.034 & 168.000 & 352.940 & 181.000 & 341.310 & 140.500 & 344.953 & 131.000 & 226.000 \\
\hline & \multirow{4}{*}{ 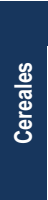 } & Maíz & 20.000 & 24.000 & 22.000 & 83.700 & 25.000 & 83.720 & 30.000 & 97.920 & 32.000 & 103.700 & 20.000 & 67.500 & 22.000 & 136.000 & 9.000 & 44.100 \\
\hline & & Sorgo & 5.000 & 7.800 & 5.000 & 22.000 & 5.000 & 17.200 & 2.500 & 9.000 & 1.500 & 5.600 & 500 & 1.700 & 500 & 3.250 & 500 & 2.400 \\
\hline & & Trigo & 85.000 & 94.800 & 68.000 & 103.620 & 38.000 & 88.800 & 39.000 & 71.400 & 40.000 & 80.300 & 46.000 & 86.400 & 42.000 & 88.200 & 45.000 & 37.500 \\
\hline & & Total & 110.000 & 126.600 & 95.000 & 209.320 & 68.000 & 189.720 & 71.500 & 178.320 & 73.500 & 189.600 & 66.500 & 155.600 & 64.500 & 227.450 & 54.500 & 84.000 \\
\hline \multirow{8}{*}{ Rio Cuarto } & \multirow{4}{*}{ 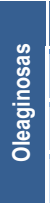 } & Soja & 108.000 & 93.150 & 105.000 & 279.885 & 137.000 & 284.745 & 153.000 & 376.250 & 198.000 & 329.300 & 235.000 & 601.600 & 271.000 & 525.000 & 410.000 & 922.500 \\
\hline & & Girasol & 96.000 & 99.592 & 117.000 & 177.603 & 123.500 & 250.950 & 115.000 & 202.500 & 50.000 & 95.000 & 43.000 & 86.000 & 49.000 & 122.500 & 15.000 & 30.000 \\
\hline & & Mani & 85.000 & 44.625 & 121.000 & 196.988 & 77.000 & 92.130 & 50.000 & 100.000 & 78.000 & 117.000 & 71.000 & 129.300 & 55.000 & 88.000 & 55.000 & 90.750 \\
\hline & & Total & 289.000 & 237.367 & 343.000 & 654.476 & 337.500 & 627.825 & 318.000 & 678.750 & 326.000 & 541.300 & 349.000 & 816.900 & 375.000 & 735.500 & 480.000 & 1.043 .250 \\
\hline & \multirow{4}{*}{ 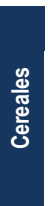 } & Maiz & 338.000 & 277.836 & 295.000 & 1.344 .905 & 248.000 & 1.116 .000 & 290.000 & 1.586 .750 & 320.000 & 1.595 .000 & 355.000 & 1.963 .150 & 314.000 & 1.977 .600 & 98.000 & 529.200 \\
\hline & & Sorgo & 12.000 & 18.000 & 22.500 & 98.775 & 24.000 & 91.200 & 25.000 & 112.500 & 20.000 & 110.000 & 22.000 & 120.120 & 23.000 & 149.500 & 15.000 & 75.000 \\
\hline & & Trigo & 62.000 & 22.950 & 23.500 & 28.788 & 29.000 & 46.200 & 42.000 & 64.000 & 42.000 & 79.800 & 52.000 & 82.800 & 48.000 & 68.800 & 45.000 & 30.000 \\
\hline & & Total & 412.000 & 318.786 & 341.000 & 1.472 .468 & 301.000 & 1.253 .400 & 357.000 & 1.763 .250 & 382.000 & 1.784 .800 & 429.000 & 2.166 .070 & 385.000 & 2.195 .900 & 158.000 & 634.200 \\
\hline \multirow{8}{*}{$\begin{array}{l}\text { Sumatoria de los } \\
\text { cuatro } \\
\text { departamentos }\end{array}$} & \multirow{4}{*}{ 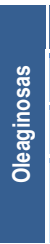 } & Soja & 238.000 & 233.490 & 246.000 & 844.740 & 292.000 & 541.064 & 375.000 & 880.835 & 496.000 & 870.020 & 560.000 & 1.317 .058 & 661.000 & 1.343 .913 & 864.900 & 1.905 .830 \\
\hline & & Girasol & 336.500 & 412.067 & 412.500 & 553.233 & 447.500 & 704.518 & 447.000 & 768.675 & 285.050 & 583.290 & 248.000 & 566.000 & 234.800 & 538.990 & 104.000 & 190.800 \\
\hline & & Maní & 194.000 & 128.325 & 253.100 & 398.078 & 188.000 & 203.726 & 119.800 & 234.980 & 143.100 & 221.280 & 128.000 & 222.990 & 99.200 & 152.930 & 103.000 & 171.200 \\
\hline & & Total & 768.500 & 773.882 & $\begin{array}{l}911.600 \\
+\end{array}$ & $\begin{array}{c}1.796 .051 \\
.\end{array}$ & $\begin{array}{l}927.500 \\
+\end{array}$ & 1.449 .308 & $\begin{array}{l}941.800 \\
+\end{array}$ & $\begin{array}{c}1.884 .490 \\
\cdot\end{array}$ & $\begin{array}{l}924.150 \\
+\end{array}$ & $\begin{array}{c}1.674 .590 \\
\cdot\end{array}$ & $\begin{array}{l}936.000 \\
+\end{array}$ & $\begin{array}{c}2.106 .048 \\
.\end{array}$ & $\begin{array}{l}995.000 \\
+\end{array}$ & $\begin{array}{c}2.035 .833 \\
.\end{array}$ & $\begin{array}{c}1.071 .900 \\
+\end{array}$ & $\begin{array}{l}2.267 .830 \\
+\end{array}$ \\
\hline & \multirow{4}{*}{ 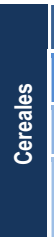 } & Maiz & 511.000 & 506.1136 & 454.000 & 1.344 .905 & 387.500 & 1.554 .096 & 447.000 & 2.307 .170 & 462.000 & 2.178 .700 & 508.000 & 2.662 .650 & 455.000 & 2.889 .300 & 158.000 & 834.600 \\
\hline & & Sorgo & 67.000 & 122.600 & 70.500 & 257.635 & 35.000 & 238.005 & 61.500 & 292.500 & 49.500 & 255.600 & 44.500 & 222.220 & 44.200 & 276.950 & 33.000 & 163.250 \\
\hline & & Trigo & 250.000 & 214.515 & 162.750 & 264.258 & 129.000 & 252.604 & 147.200 & 254.820 & 172.000 & 355.100 & 214.800 & 356.000 & 202.120 & 353.192 & 192.000 & 173.100 \\
\hline & & Total & $\begin{array}{r}828.000 \\
+(11.500)\end{array}$ & $\begin{aligned} & 843.251 \\
+ & (10.700)\end{aligned}$ & $\begin{aligned} & 687.250 \\
+ & (10.700)\end{aligned}$ & $\begin{array}{c}1.866 .798 \\
+\end{array}$ & $\begin{array}{l}581.500 \\
-\end{array}$ & $\begin{array}{c}2.044 .705 \\
+\end{array}$ & $\begin{array}{l}655.700 \\
-\end{array}$ & $\begin{array}{l}2.854 .490 \\
+\end{array}$ & $\begin{array}{l}683.500 \\
-(34.500)\end{array}$ & $\begin{array}{l}2.789 .400 \\
+(63.700)\end{array}$ & $\begin{array}{l}767.300 \\
-\end{array}$ & $\begin{array}{l}3.280 .870 \\
+\end{array}$ & $\begin{array}{l}701.320 \\
-(9.482)\end{array}$ & $\begin{array}{c}3.519 .442 \\
+\end{array}$ & $\begin{array}{l}383.000 \\
.\end{array}$ & $\begin{array}{c}1.170 .950 \\
.\end{array}$ \\
\hline
\end{tabular}




\section{Cuadro 2. Resultados (continuación)}

\begin{tabular}{|c|c|c|c|c|c|c|c|c|c|c|c|c|c|c|}
\hline \multirow[b]{2}{*}{ Departamento } & \multirow{2}{*}{\multicolumn{2}{|c|}{$\begin{array}{l}\text { Años } \\
\text { Granos }\end{array}$}} & \multicolumn{2}{|c|}{$2004 / 05$} & \multicolumn{2}{|c|}{$2005 / 06$} & \multicolumn{2}{|c|}{$2006 / 07$} & \multicolumn{2}{|c|}{$2007 / 08$} & \multicolumn{2}{|c|}{ 2008/09 } & \multicolumn{2}{|c|}{$2009 / 10$} \\
\hline & & & $\begin{array}{c}\text { Superficie } \\
\text { sembrada } \\
\text { (ha) }\end{array}$ & $\begin{array}{l}\text { Producción } \\
\text { (t) }\end{array}$ & $\begin{array}{l}\text { Superficie } \\
\text { sembrada } \\
\text { (ha) }\end{array}$ & \begin{tabular}{|} 
Producción \\
(t)
\end{tabular} & $\begin{array}{c}\text { Superficie } \\
\text { sembrada } \\
\text { (ha) }\end{array}$ & $\begin{array}{c}\text { Producción } \\
\text { (t) }\end{array}$ & $\begin{array}{l}\text { Superficie } \\
\text { sembrada } \\
\text { (ha) }\end{array}$ & $\begin{array}{l}\text { Producción } \\
\text { (t) }\end{array}$ & $\begin{array}{c}\text { Superficie } \\
\text { sembrada } \\
\text { (ha) }\end{array}$ & $\begin{array}{l}\text { Producción } \\
\text { (t) }\end{array}$ & $\begin{array}{l}\text { Superficie } \\
\text { sembrada } \\
\text { (ha) }\end{array}$ & $\begin{array}{l}\text { Producción } \\
\text { (t) }\end{array}$ \\
\hline \multirow{8}{*}{$\begin{array}{l}\text { Provincia de } \\
\text { Córdoba }\end{array}$} & \multirow{4}{*}{ 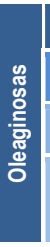 } & Soja & 3.714 .500 & 10.613 .013 & 4.221 .400 & 10.040 .395 & 4.323 .900 & 13.078.365 & 4.527 .200 & 11.462 .525 & 4.951 .900 & 10.690 .925 & 5.149 .550 & 14.036 .800 \\
\hline & & Girasol & 103.300 & 246.603 & 128.400 & 211.205 & 108.300 & 172.135 & 126.650 & 262.760 & 90.000 & 160.550 & 68.150 & 101.155 \\
\hline & & Maní & 197.000 & 453.397 & 149.900 & 335.000 & 219.550 & 482.070 & 202.450 & 449.309 & 219.100 & 476.780 & 180.800 & 441.220 \\
\hline & & Total & $\begin{array}{c}4.014 .800 \\
+\end{array}$ & $\begin{array}{c}11.313 .013 \\
+\end{array}$ & $\begin{array}{l}4.499 .700 \\
+\end{array}$ & $\begin{array}{l}10.586 .600 \\
+\end{array}$ & $\begin{array}{l}4.651 .750 \\
+\end{array}$ & $\begin{array}{c}13.732 .570 \\
+\end{array}$ & $\begin{array}{l}4.856 .300 \\
+\end{array}$ & $\begin{array}{c}12.174 .594 \\
+\end{array}$ & $\begin{array}{l}5.261 .000 \\
+\end{array}$ & $\begin{array}{c}11.328 .255 \\
+\end{array}$ & $\begin{array}{c}5.398 .500 \\
+\end{array}$ & $\begin{array}{l}14.579 .175 \\
+\end{array}$ \\
\hline & \multirow{4}{*}{ 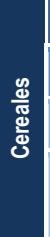 } & Maiz & 950.030 & 7.031 .547 & 927.600 & 4.696 .679 & 1.074 .600 & 8.177 .648 & 1.282 .900 & 7.162 .940 & 1.114 .500 & 6.158 .620 & 968.300 & 6.446 .340 \\
\hline & & Sorgo & 170.150 & 917.917 & 173.350 & 861.813 & 240.100 & 827.563 & 210.500 & 948.430 & 190.000 & 858.130 & 242.750 & 1.190 .960 \\
\hline & & Trigo & 1.013 .700 & 1.991 .610 & 736.900 & 1.055 .445 & 575.900 & 1.055 .445 & 1.041 .000 & 2.944 .660 & 643.200 & 910.005 & 200.950 & 239.230 \\
\hline & & Total & $\begin{array}{c}2.133 .880 \\
-\end{array}$ & $\begin{array}{c}9.941 .074 \\
-\end{array}$ & $\begin{array}{c}1.837 .850 \\
.\end{array}$ & $\begin{array}{c}6.613 .937 \\
-\end{array}$ & $\begin{array}{c}1.890 .600 \\
.\end{array}$ & 10.555 .656 & $\begin{array}{c}2.534 .400 \\
-\end{array}$ & $\begin{array}{c}11.056 .030 \\
-\end{array}$ & 1.947 .700 & $\begin{array}{c}7.926 .755 \\
-\end{array}$ & $\begin{array}{c}1.412 .000 \\
.\end{array}$ & $\begin{array}{c}7.876 .530 \\
-\end{array}$ \\
\hline \multirow{8}{*}{ General Roca } & \multirow{4}{*}{ 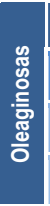 } & Soja & 80.000 & 288.000 & 128.000 & 271.400 & 140.000 & 426.250 & 138.000 & 558.800 & 360.000 & 626.400 & 385.000 & 1.116 .500 \\
\hline & & Girasol & 42.250 & 109.850 & 50.000 & 74.700 & 33.000 & 43.890 & 41.000 & 77.900 & 19.000 & 32.870 & 20.000 & 20.400 \\
\hline & & Maní & 19.000 & 43.700 & 22.000 & 44.400 & 76.000 & 167.200 & 56.000 & 123.200 & 60.000 & 150.000 & 42.000 & 117.600 \\
\hline & & Total & 141.250 & 441.550 & 200.000 & 390.500 & 249.000 & 637.340 & 235.000 & 759.900 & 439.000 & 809.270 & 447.000 & 1.254 .500 \\
\hline & \multirow{4}{*}{ 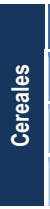 } & Maiz & 25.000 & 308.000 & 65.000 & 204.000 & 88.000 & 566.168 & 120.000 & 700.000 & 123.000 & 738.000 & 115.000 & 999.000 \\
\hline & & Sorgo & 5.000 & 23.500 & 5.500 & 30.250 & - & - & - & - & - & - & - & - \\
\hline & & Trigo & 60.000 & 108.000 & 38.000 & 54.910 & 38.000 & 54.910 & 46.500 & 145.860 & 70.000 & 100.750 & 23.000 & 16.650 \\
\hline & & Total & 90.000 & 439.500 & 108.500 & 289.160 & 126.000 & 621.078 & 166.500 & 845.860 & 193.000 & 838.750 & 138.000 & 1.015 .650 \\
\hline \multirow[t]{8}{*}{ Juárez Celman } & \multirow{4}{*}{ 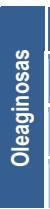 } & Soja & 280.000 & 896.000 & 320.000 & 758.400 & 363.000 & 1.089 .000 & 380.000 & 1.026 .000 & 371.000 & 686.350 & 388.000 & 846.560 \\
\hline & & Girasol & 7.000 & 14.700 & 8.000 & 14.130 & 6.000 & 9.600 & 4.000 & 7.200 & 9.000 & 18.000 & 8.100 & 15.390 \\
\hline & & Maní & 35.000 & 80.500 & 28.000 & 64.400 & 30.000 & 60.000 & 16.000 & 36.800 & 20.000 & 34.000 & 21.000 & 48.300 \\
\hline & & Total & 322.000 & 991.200 & 356.000 & 836.930 & 399.000 & 1.158 .600 & 400.000 & 1.070 .000 & 400.000 & 738.350 & 417.100 & 910.250 \\
\hline & \multirow{4}{*}{ 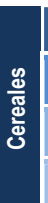 } & Maiz & 60.000 & 462.000 & 40.000 & 216.000 & 55.000 & 357.500 & 75.000 & 425.000 & 42.000 & 205.800 & 41.000 & 204.880 \\
\hline & & Sorgo & 12.000 & 72.000 & 12.000 & 68.400 & 10.000 & 67.400 & 7.200 & 42.480 & 13.000 & 63.700 & 16.000 & 83.200 \\
\hline & & Trigo & 54.000 & 124.200 & 18.000 & 20.250 & 27.000 & 20.250 & 30.000 & 72.000 & 36.800 & 33.800 & 18.000 & 11.250 \\
\hline & & Total & 126.000 & 658.200 & 70.000 & 304.650 & 92.000 & 445.150 & 112.200 & 539.480 & 91.800 & 303.300 & 75.000 & 299.330 \\
\hline
\end{tabular}




\section{Cuadro 2. Resultados (continuación)}

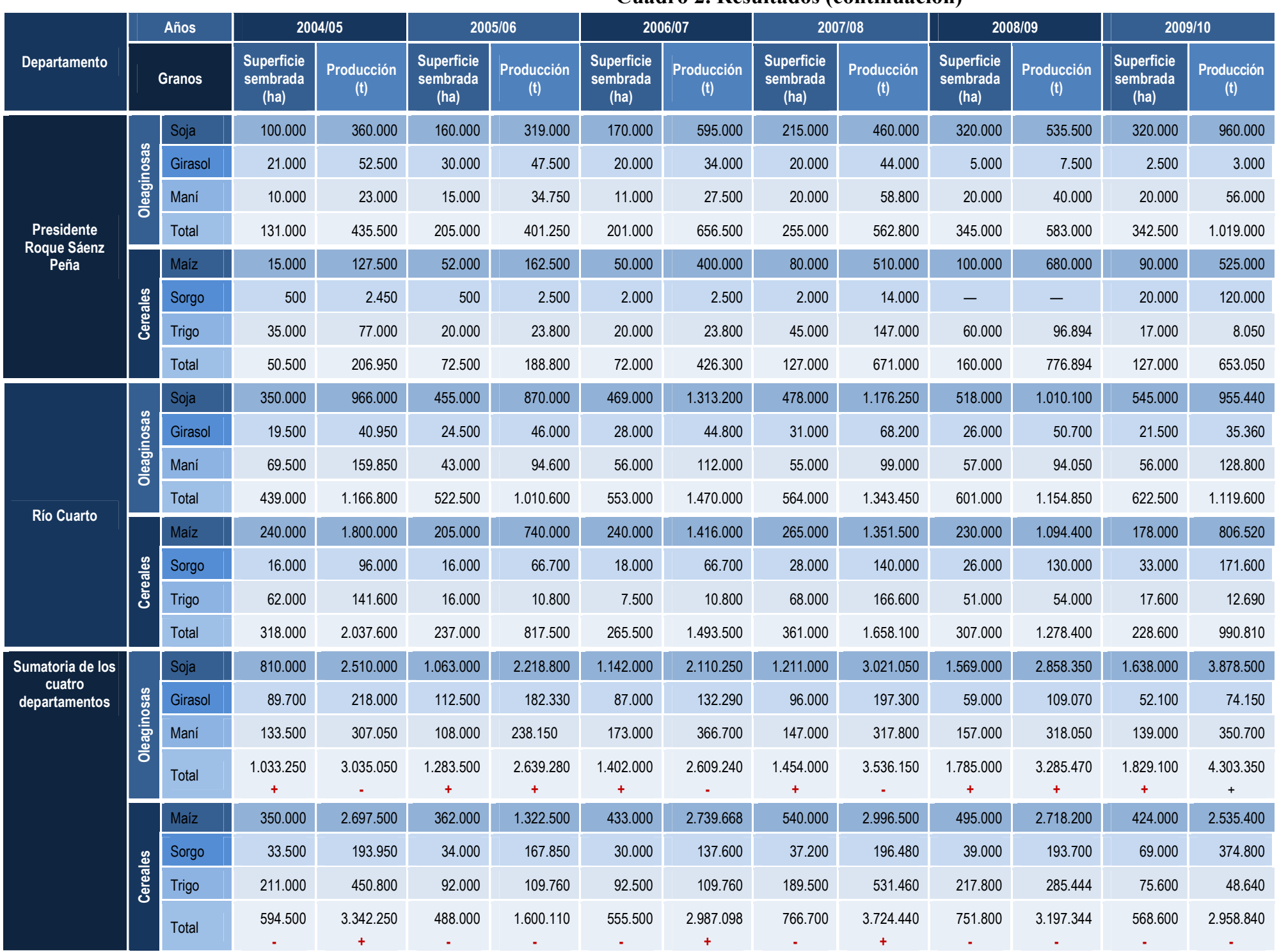

Fuente: Elaboración propia en base a los resultados provistos por UPSIIA, del Ministerio de Agricultura, Ganadería y Alimentos de la provincia de Córdoba. 


\section{ANEXO 3}

Dos ejemplos de cartografía digital empleada para la delimitación de las localidades con sus respectivas zonas rurales de influencia (programa Arvius) 


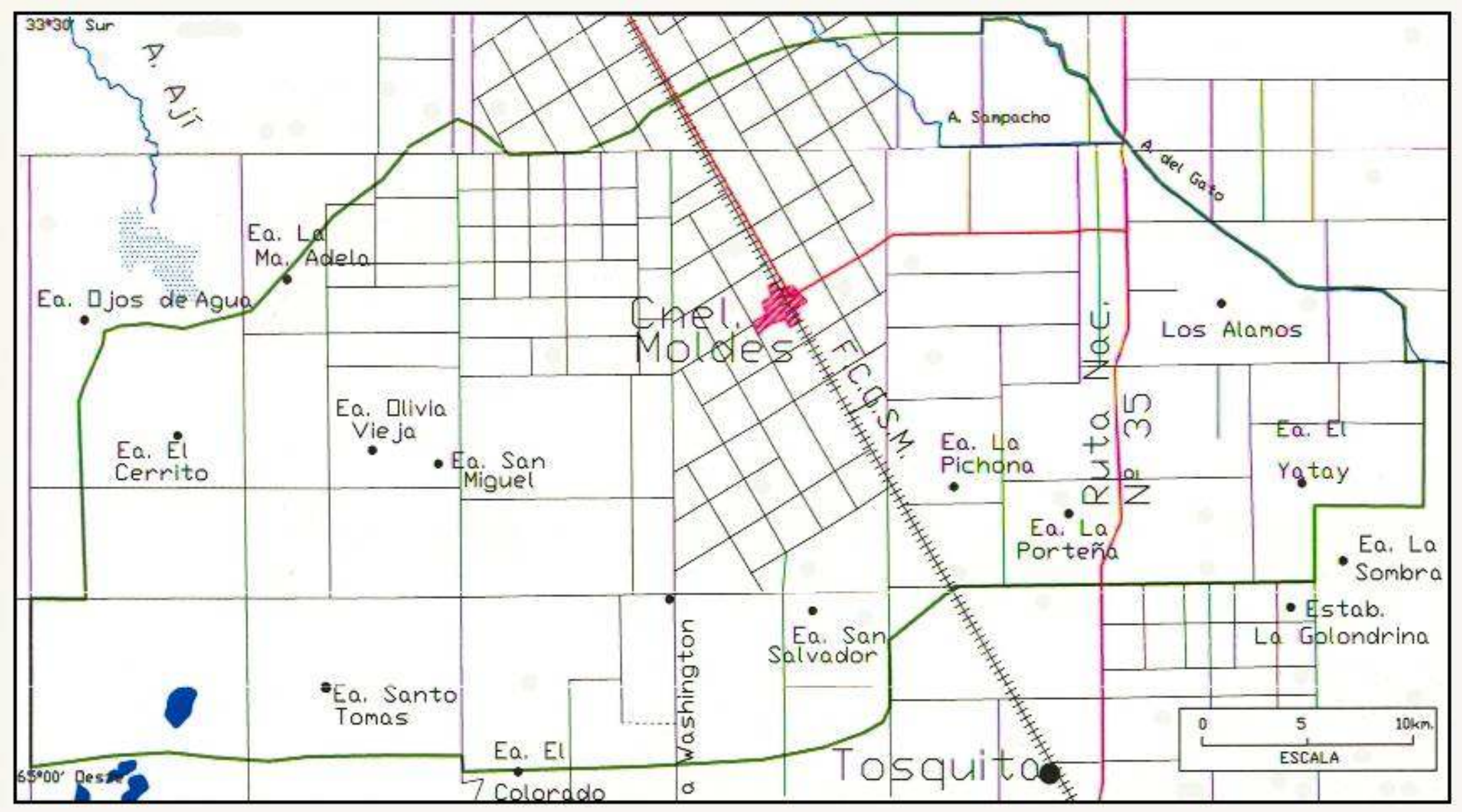

Elaborado por la Lic. Marcela Montero

Mapa $\mathrm{N}^{\mathrm{o}}$ 1. Coronel Moldes y su zona rural de influencia. 


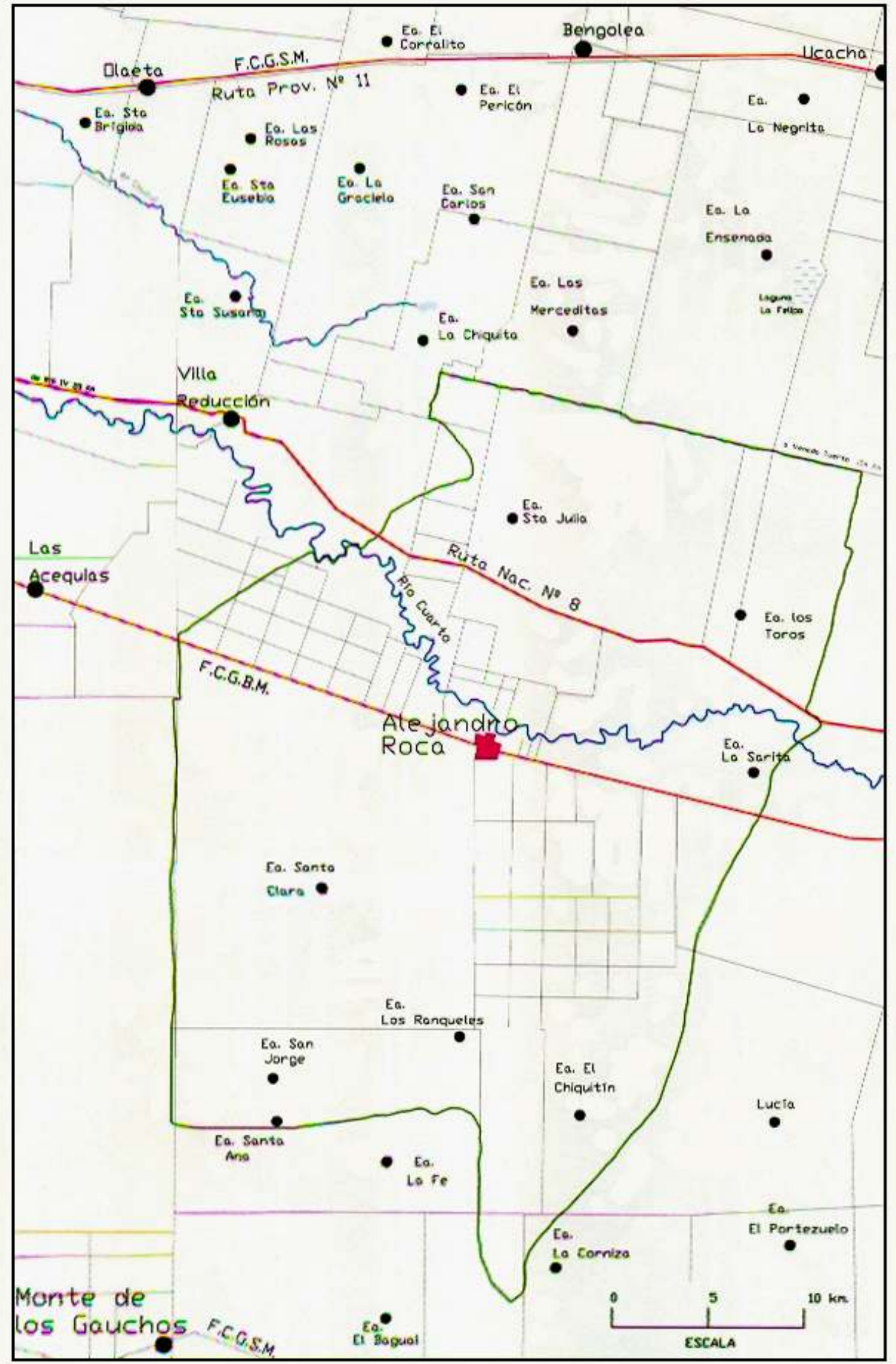

Elaborado por la Lic. Marcela Montero

Mapa $\mathrm{N}^{\mathrm{o}}$ 2. Alejandro Roca y su zona rural de influencia. 